\title{
Free movement of civil judgments in the European Union and the right to a fair trial
}

Monique Hazelhorst 
Free movement of civil judgments in the European Union and the right to a fair trial

Het vrij verkeer van civiele vonnissen binnen de Europese Unie en het recht op een eerlijk proces

Proefschrift

ter verkrijging van de graad van doctor aan de

Erasmus Universiteit Rotterdam

op gezag van de

rector magnificus

Prof. dr. H.A.P. Pols

en volgens besluit van het College van Promoties.

De openbare verdediging zal plaatsvinden op

donderdag 13 oktober 2016 om 13:30 uur

door

Monique Ingrid Hazelhorst

Geboren te Leiden

Erasmus University Rotterdam

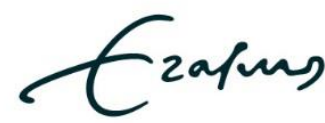


Promotiecommissie

Promotoren:

Prof. dr. X.E. Kramer

Prof. dr. K.A.M. Henrard

Overige leden:

Prof. dr. M. Requejo Isidro

Prof. dr. R. A. Lawson

Prof. dr. F. Amtenbrink 
This research was made possible with the support of the Netherlands Organisation for Scientific Research (NWO) within its Innovational Research Incentives Scheme (VIDI).

(c) Monique Hazelhorst, 2016. 


\section{Table of Contents}

Free movement of civil judgments in the European Union and the right to a fair trial ............ 1

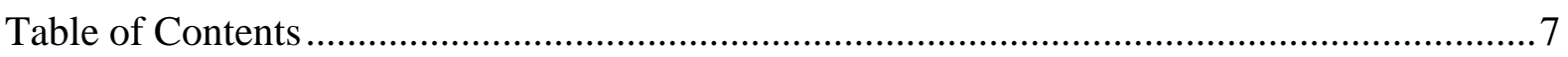

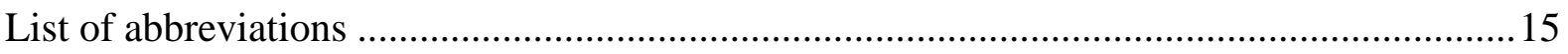

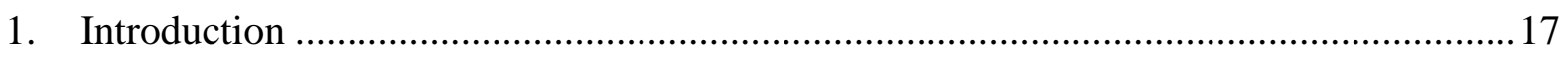

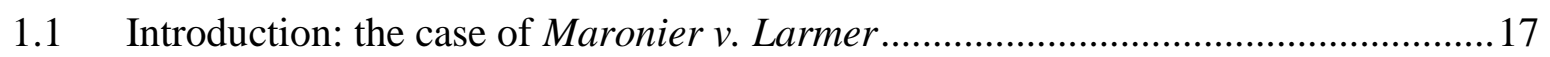

1.2 Background: free movement of judgments in the European Union........................... 18

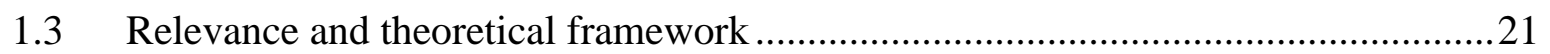

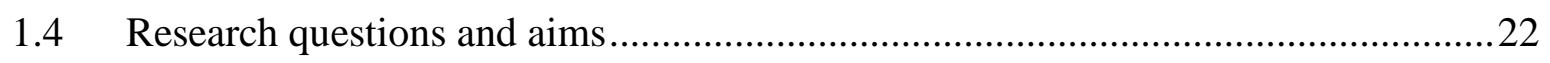

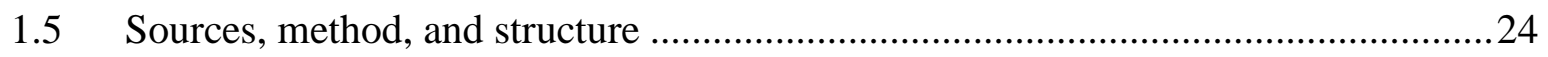

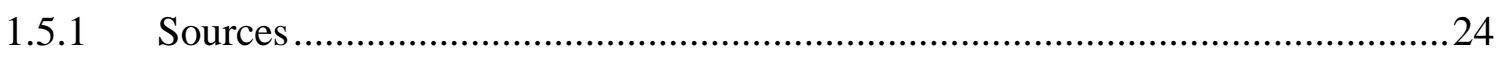

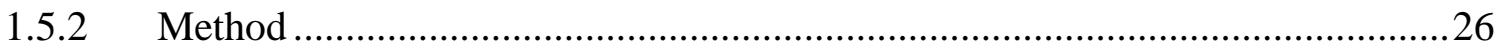

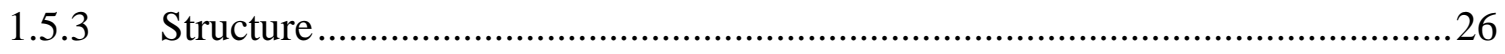

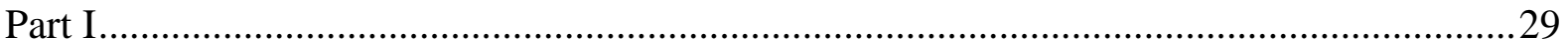

2. The evolution of free movement of civil judgments in the European Union ...................31

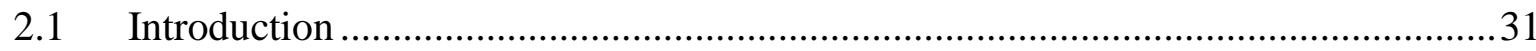

2.2 Free movement of civil judgments in the EU: historical and political background..32

2.2.1 Free movement of judgments and the internal market..................................... 32

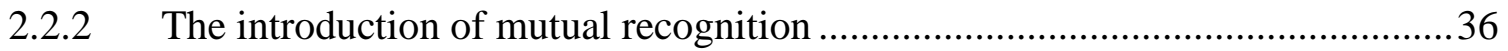

2.2.3 The role of mutual recognition and mutual trust ............................................ 41

2.2.4 Practical arguments for increased free movement .........................................45

2.2.4.1 Recognition and enforcement under Brussels I in practice ...........................45

2.2.4.2 Recognition and enforcement under other instruments in practice ................48

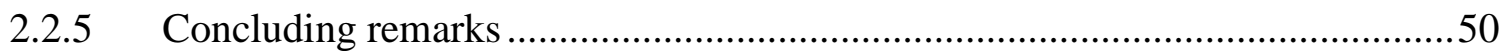

2.3 Recognition and enforcement under current EU legislation ..................................50

2.3.1 Features of recognition and enforcement in EU civil justice cooperation ..........51

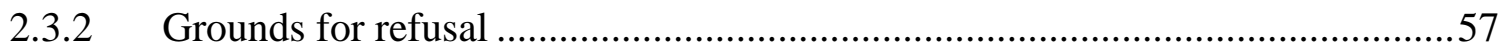

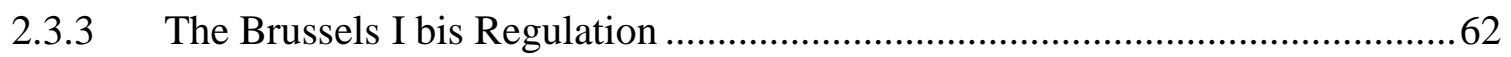

2.3.4 Complete free movement of judgments: the Maintenance Regulation...............64

2.3.5 Automatic enforcement with minimum standards under the Brussels II bis

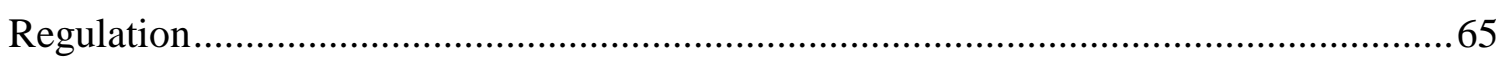

2.3.6 Automatic enforcement with minimum standards under the European

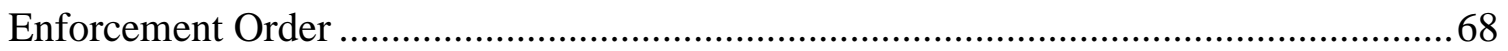


2.3.7 Automatic enforcement on the basis of common rules in the uniform procedures 70

2.3.8 Interim conclusion: the significance of the reforms for fundamental rights

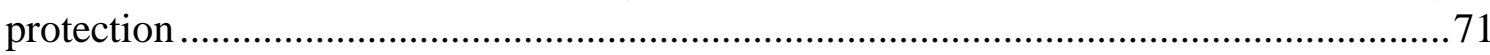

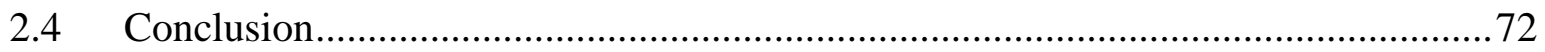

3. Protection of fundamental rights by EU instruments on cross-border recognition and

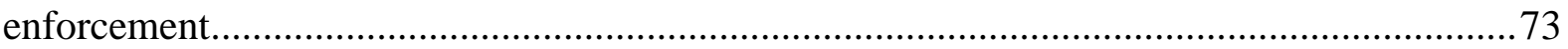

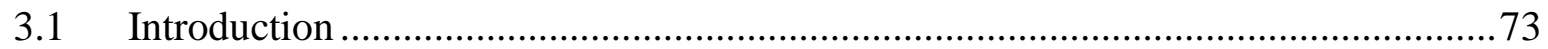

3.2 The role of the public policy exception in the protection of fundamental rights .......74

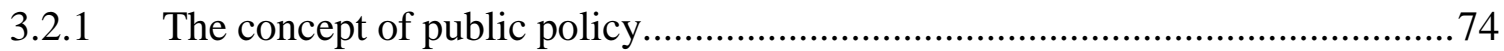

3.2.2 Public policy and the European Convention on Human Rights ........................ 76

3.2.3 The inclusion of a public policy exception in instruments of EU civil procedure 78

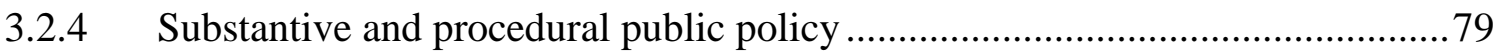

3.2.5 Interpretation by the Court of Justice of the European Union .......................... 81

3.2.6 Application of the public policy exception in European Union instruments by

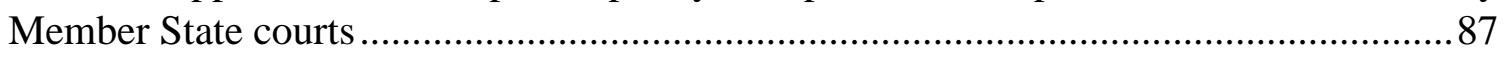

3.2.7 Conclusion: the value of the public policy exception ...................................... 94

3.3 The role of other grounds for refusal in the protection of fundamental rights ..........97

3.3.1 The protection of the defendant in default proceedings.................................... 97

3.3.2 Special jurisdiction (Article 35 Brussels I, 45(1)(e) Brussels I bis) ................ 101

3.3.3 Hearing of the child (23(b) Brussels II bis) or other interested person (23(d)

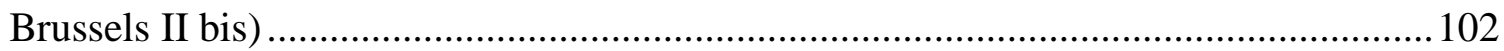

3.4 The protective function of control by the Member State addressed ....................... 103

3.4.1 The value of a cross-border check .............................................................. 103

3.4.2 Replacement of refusal grounds with minimum standards ............................. 105

3.4.3 Alternative remedies: appeal to the European Court of Human Rights............ 108

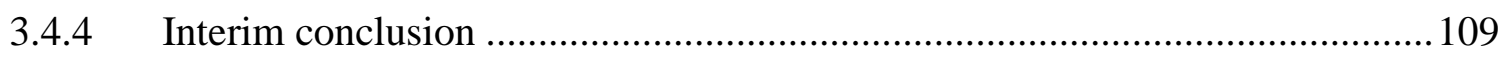

3.5 Fundamental rights protection in the absence of refusal grounds: the Zarraga case 110

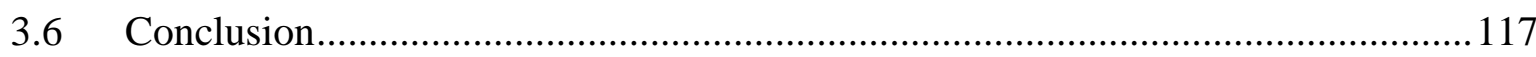

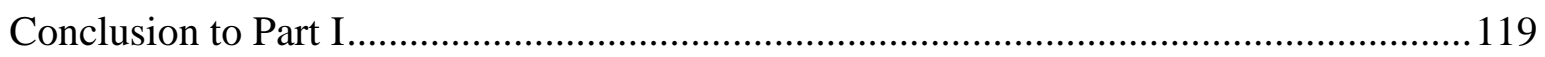

A. European Union legislation increasingly allows for complete free movement of judgments ..... 119

B. Refusal of enforcement is effective as a remedy for fundamental rights violations 120

C. Mutual trust does not make cross-border checks obsolete 
D. Conclusion: complete free movement of civil judgments is a fundamental rights question

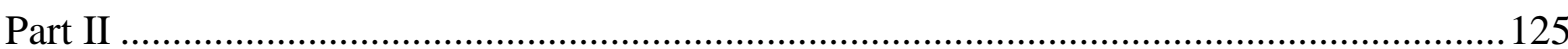

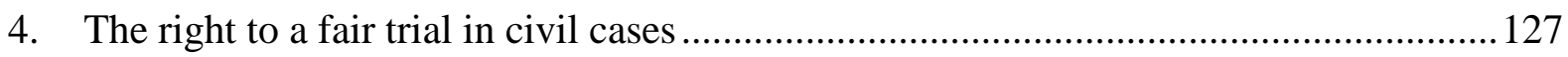

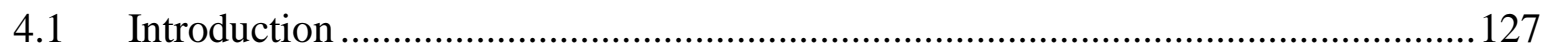

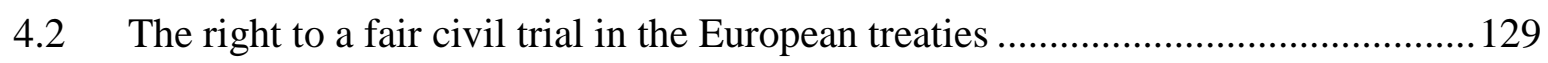

4.2.1 Article 6(1) of the European Convention on Human Rights ............................... 129

4.2.2 EU law and Article 47 of the EU Charter on Fundamental Rights................... 132

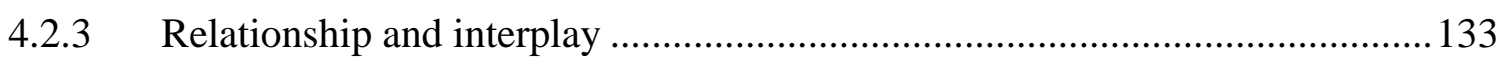

4.2.4 Structure, internal connections, and interpretation ....................................... 134

4.3 The right to a fair civil trial in the case law of the European courts ...................... 135

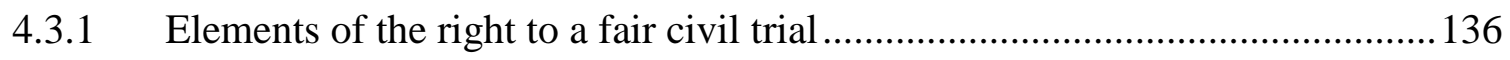

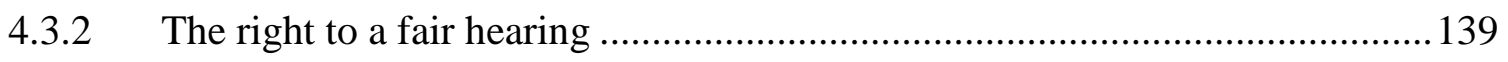

4.3.3 Right to a public trial and public pronouncement of the judgment .................156

4.3.4 The right to adjudication by an impartial and independent tribunal ................157

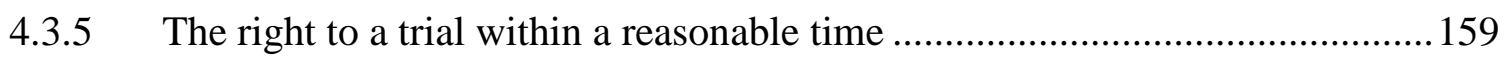

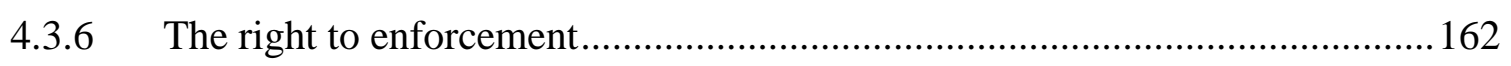

4.3.7 Consequences of a failure to observe the right to a fair trial ........................... 164

4.4 Theoretical foundations for the right to a fair trial in civil cases ........................... 167

4.4.1 Introduction: the need to delve further into the right to a fair trial .................. 167

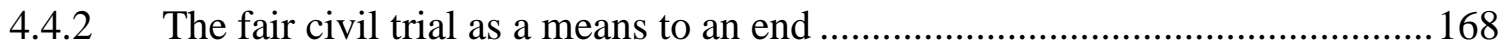

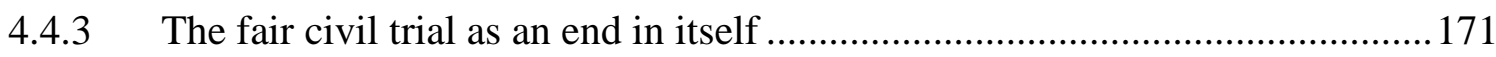

4.4.4 Is it possible to distinguish a 'core' and a 'periphery' within Article 6(1)? .... 174

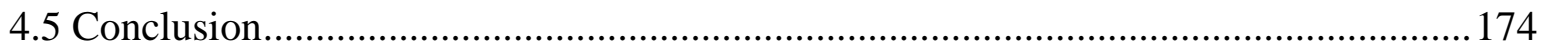

5 Free movement of judgments and the European Convention on Human Rights ........... 177

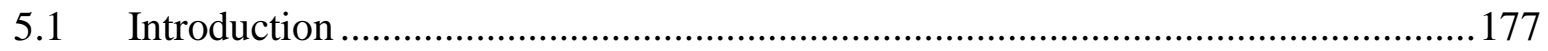

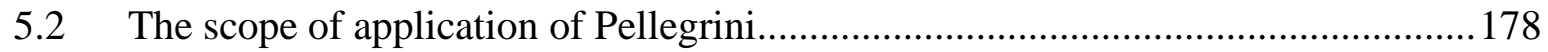

5.2.1 Application of Pellegrini to situations where both states are party to the ECHR 178

5.2.2 Application of Pellegrini to situations governed by EU law 181

5.3 A different frame of reference for intra-European Union situations: the Bosphorus test 182

5.3.1 Review by the ECtHR of matters relating to EU law prior to Bosphorus ........ 182

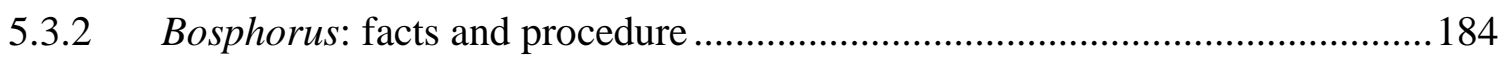

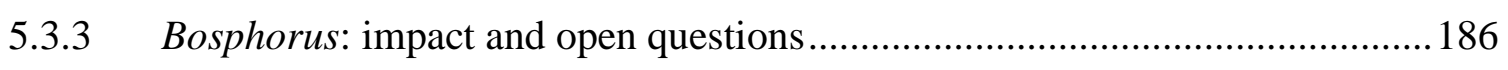

5.4 Applying Bosphorus to free movement of civil judgments: the Povse decision .... 190 
5.4.1 Povse: background to the decision 190

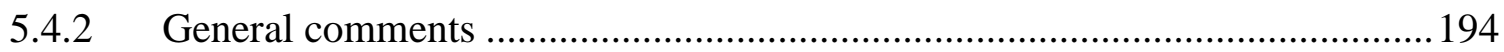

5.4.3 The presumption of equivalent protection: abstract or concrete? ....................198

5.4.4 Equivalent protection: the importance of the preliminary ruling mechanism .200

5.4.5 The matter of discretion and the applicability of Povse to Regulations which

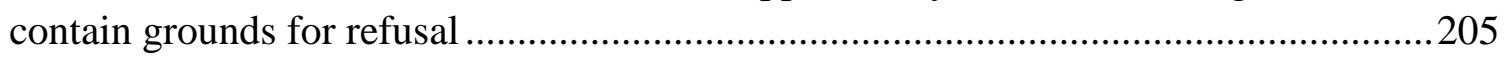

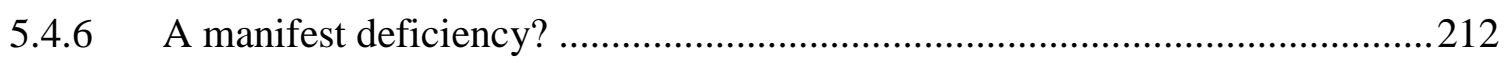

5.5 The Bosphorus doctrine after European Union accession to the European Convention

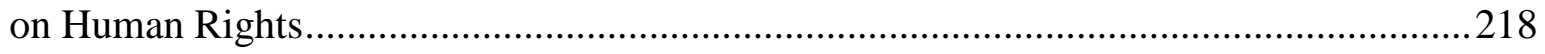

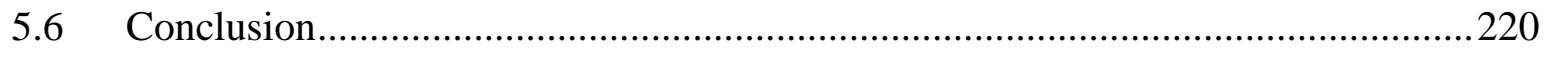

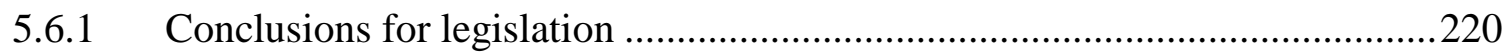

5.6.2 Conclusions for enforcing courts or authorities..........................................222

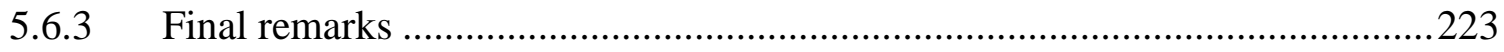

6 Free movement of civil judgments and European Union fundamental rights law .........225

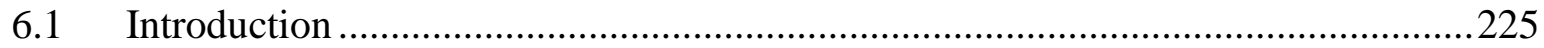

6.2 Protection of fundamental rights in the European Union legal order ...................226

6.2.1 The position of fundamental rights in EU law .............................................226

6.2.2 The Member States courts' task in the protection of EU CFR rights .............2229

6.2.3 The role of the CJEU in the protection of EU fundamental rights .................231

6.2.4 Conclusion: the system of fundamental rights protection in the EU ..............234

6.3 'Systemic deficiencies' in fundamental rights protection: N.S. and M.E. and others 234

6.3.1 The rule: mutual recognition entails a presumption that fundamental rights are

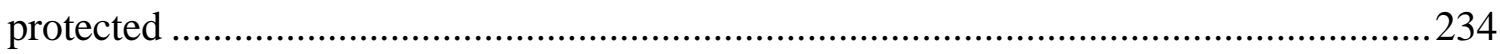

6.3.2 The exception: presumption can be rebutted in case of systemic deficiencies 236

6.3.3 Can this exception be applied in the field of civil procedure?........................240

6.4 The Court of Justice of the European Union's Melloni decision: Member State

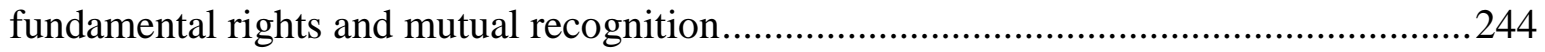

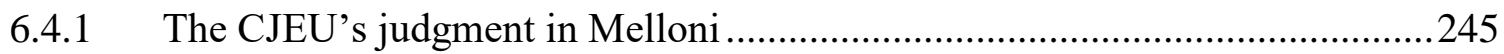

6.4.2 Application of the Melloni doctrine to EU civil procedure law ......................249

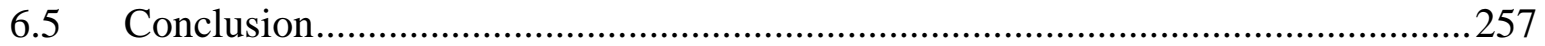

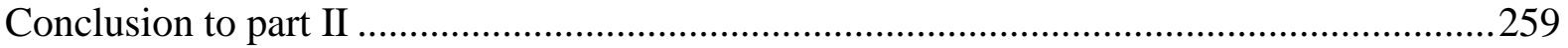

A. The right to a fair trial requires effective protection, also within the European Union

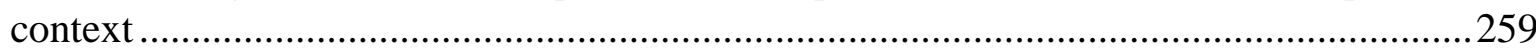

B. The ECtHR has limited jurisdiction to review the application of EU legislation ...260

C. The European Union has committed itself to protecting fundamental rights .........260 
D. Absolute mutual trust is incompatible with effective fundamental rights protection 261

E. The European legislature is uniquely placed to address cross-border fundamental rights

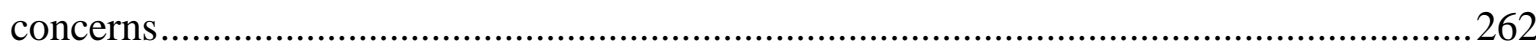

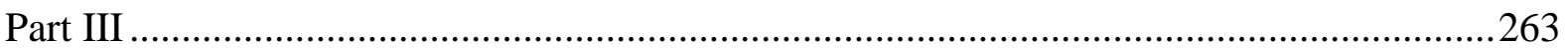

7 Towards an 'emergency brake' in instruments of EU civil procedure ..........................265

7.1 Introduction: the need for an emergency brake....................................................265

7.2 The nature of the emergency brake: procedural public policy or fair trial ............267

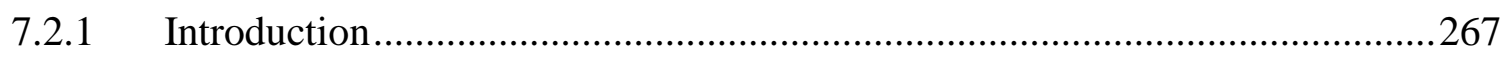

7.2.2 The right to a fair trial as a fundamental principle..........................................2 270

7.2.3 The suitability of the right to a fair trial as a yardstick for refusing enforcement 271

7.2.4 Are procedural public policy and fair trial identical in scope? ......................2278

7.2.5 Substantive public policy and fundamental rights other than fair trial............285

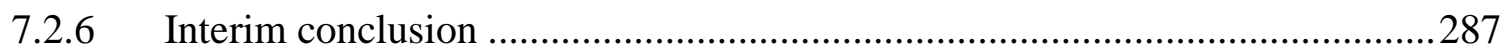

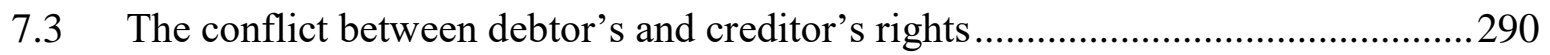

7.3.1 Guidance of the ECtHR for solving conflicts ................................................291

7.3.2 Methods for resolving conflicts between fundamental rights ..........................291

7.3.3 Whether the exercise of the right is made utterly impossible ..........................297

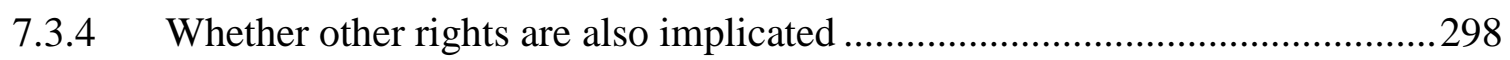

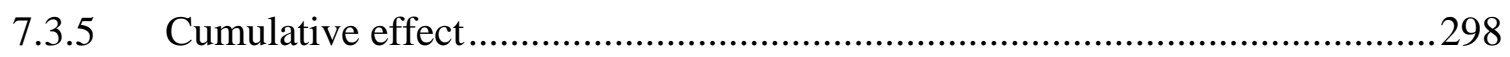

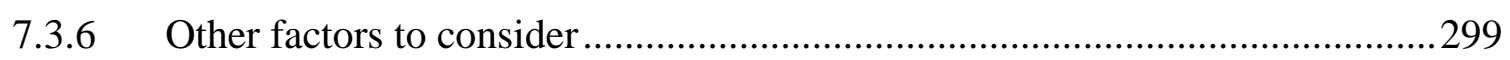

7.3.7 Application to conflicts between specific elements of fair trial .........................301

7.3.8 Conclusion: the threshold for refusing recognition or enforcement .................314

7.4 Protection of the defaulting defendant and the special jurisdiction grounds ..........315

7.5 The need for an 'emergency brake' for return and access orders ............................317

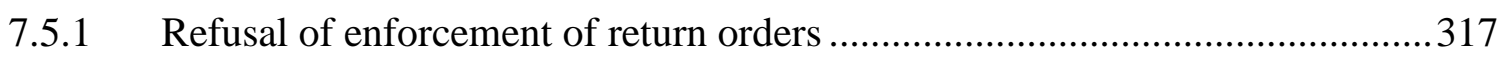

7.5.2 Automatic enforcement of judgments granting rights of access .......................319

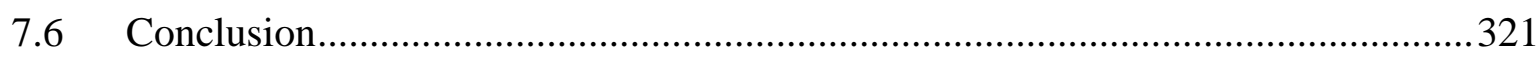

8 Facilitating enforcement of civil judgments across European Union Member States ...323

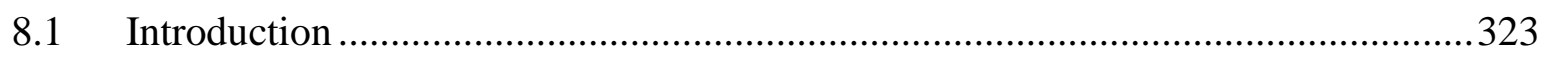

8.2 How to organize judgment import in European Union Regulations ........................324

8.2.1 Requirements that can be derived from ECtHR case law ................................326

8.2.2 Implications for the design of the procedure for obtaining permission for

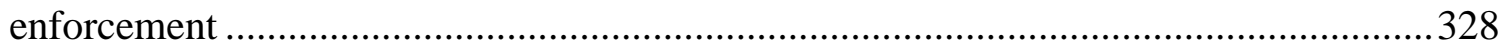


8.2.3 Other recommendations for the design of an effective enforcement procedure 330

8.2.4 Assessment: how should judgment import or export be organized? ................331

8.2.5 Conclusion on judgment export in Brussels I bis ...........................................336

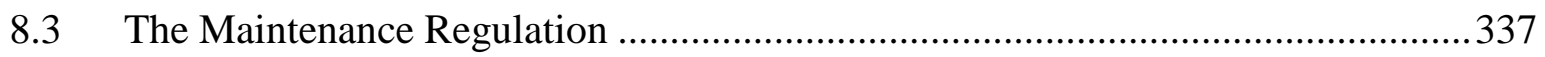

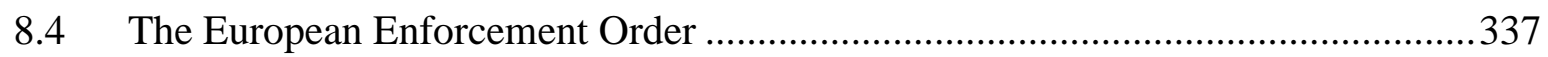

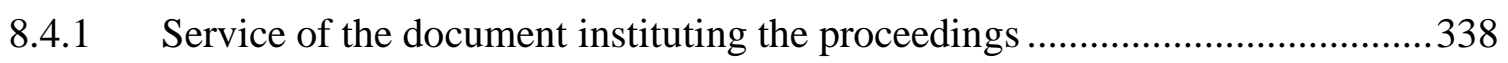

8.4.2 Impartiality of the judge who issues the EEO certificate .................................343

8.4.3 Right to a fair hearing before a judgment is declared enforceable ...................350

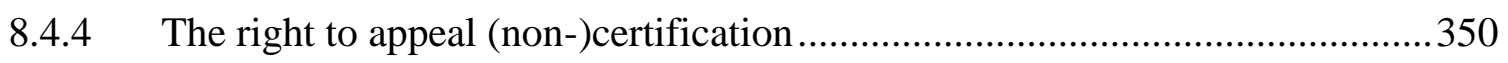

8.4.5 Conclusion on the European Enforcement Order ........................................... 353

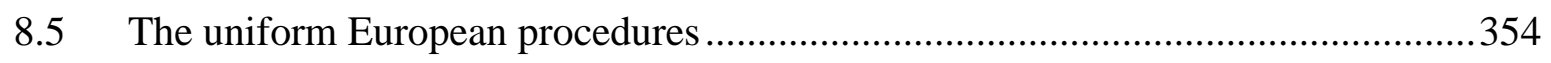

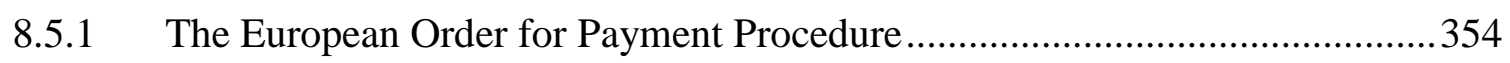

8.5.2 The European Small Claims Procedure ............................................................ 358

8.5.3 The uniform procedures and the need for grounds for refusal..........................368

8.6 Enforcement of return orders and access rights under Brussels II bis .....................371

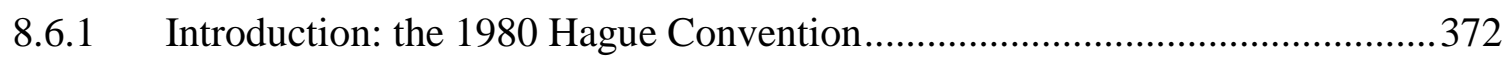

8.6.2 Reforms achieved by the Brussels II bis Regulation and controversy..............375

8.6.3 How should enforcement of return orders be organized? .................................. 377

8.6.4 Conclusion: cross-border enforcement of return order and access rights .........381

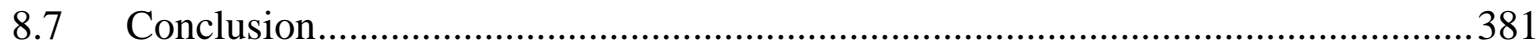

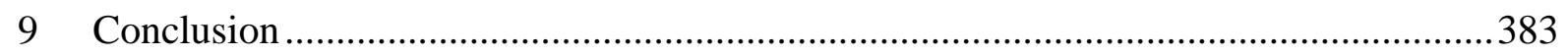

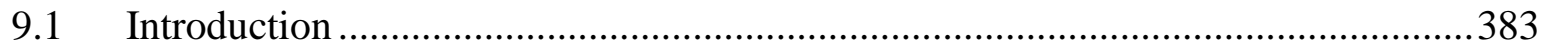

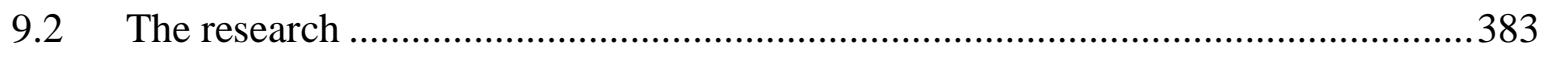

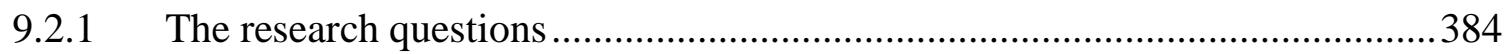

9.2.2 Summary of the findings and answers to the research questions......................384

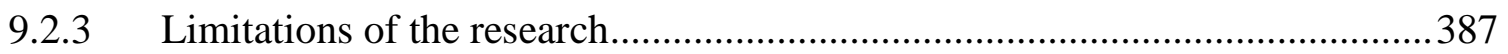

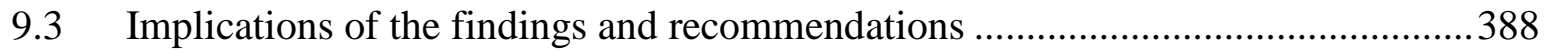

9.3.1 Implications for academic and political debate ............................................388

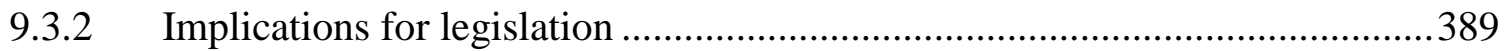

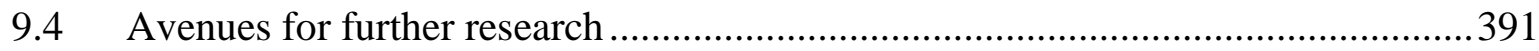

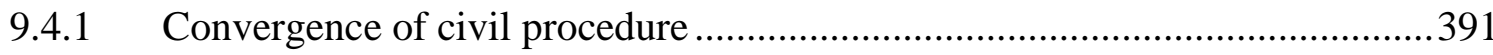

9.4.2 Best practices in the application of EU civil procedure law .............................393

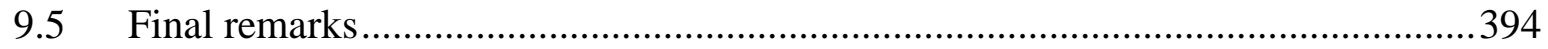

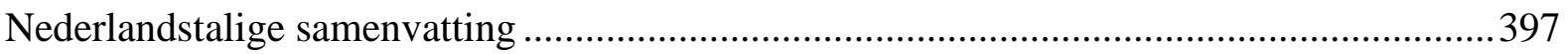


Bibliography 403

List of cases

Judgments of the Court of Justice of the European Union. .428

Opinions of the Court of Justice of the European Union 432

Judgments of the Civil Service Tribunal. 432

Judgments of the General Court 432

Advocate Generals' Opinions 432

Judgments and decisions of the European Court of Human Rights. 432

Decisions of the European Commission of Human Rights .438

National case law 439

The Netherlands 439

England and Wales 440

France 440

Germany .440

Italy 440

Portugal. .441

Finland 441

Sweden 441

Greece. 441

Spain 441

Overview of legislation. 442

Treaties 442

European Union Regulations .443

European Union Directives 444

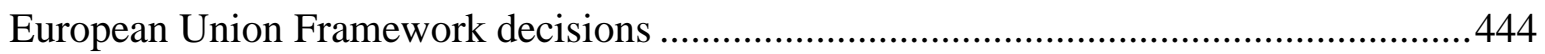

European Commission preparatory documents, proposals, green papers, reports............ 445

European Council proposals and policy programmes................................................. 447

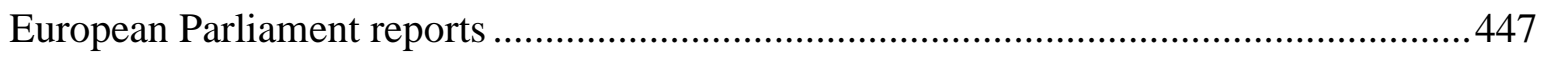

European Economic and Social Committee Opinions ................................................... 448

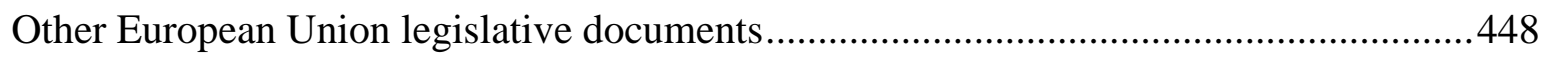

Council of Europe recommendations and guidelines................................................... 448

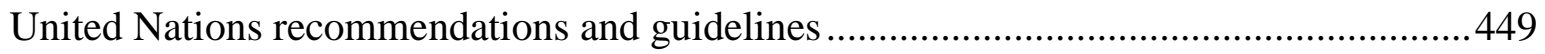

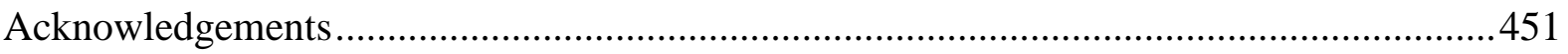




\section{List of abbreviations}

\begin{tabular}{|c|c|}
\hline$A-G$ & Advocate-General \\
\hline $\mathrm{BGH}$ & Bundesgerichtshof \\
\hline CEAS & Common European Asylum System \\
\hline CJEU & Court of Justice of the European Union \\
\hline $\mathrm{CoE}$ & Council of Europe \\
\hline Dec. & Decision on admissibility \\
\hline EAW & European Arrest Warrant \\
\hline $\mathrm{EC}$ & European Community \\
\hline \multirow[t]{2}{*}{ ECHR } & European Convention for the Protection of Human Rights and Fundamental \\
\hline & Freedoms \\
\hline ECLI & European Case Law Identifier \\
\hline ECtHR & European Court of Human Rights \\
\hline EEC & European Economic Community \\
\hline EEO & European Enforcement Order for uncontested claims \\
\hline EFTA & European Free Trade Association \\
\hline EOP & European Order for Payment \\
\hline ESCP & European Small Claims Procedure \\
\hline EU & European Union \\
\hline EU CFR & European Union Charter of Fundamental Rights \\
\hline EUR & European Euro \\
\hline FD EAW & Framework Decision on the European Arrest Warrant \\
\hline GC & Grand Chamber \\
\hline $\mathrm{OGH}$ & Oberlandesgericht \\
\hline OJ & Official Journal of the European Union \\
\hline PPU & Procédure préjudicielle d'urgence \\
\hline TEU & Treaty on European Union \\
\hline TFEU & Treaty on the Functioning of the European Union \\
\hline UK & United Kingdom \\
\hline UN & United Nations \\
\hline
\end{tabular}


UNHCR

FRF

United Nations High Commissioner for Refugees

French Francs 


\section{Introduction}

\subsection{Introduction: the case of Maronier v. Larmer}

Mr. Larmer was a dentist practicing in Rotterdam, the Netherlands. In 1984, one of his clients, Mr. Maronier, claimed damages of EUR 26,800 from Mr. Larmer, in respect of the treatment he had received from him. After an exchange of pleadings and statements, in 1986 the proceedings were stayed for a period of twelve years. After this period Mr. Maronier instructed his lawyers to pursue the case. In the meantime, however, Mr. Larmer had moved to England, leaving his address with the Rotterdam City Hall and the Dutch Association of Dentists. His lawyer, who had not been informed of the new address, stated that he had not been in contact with Mr. Larmer for a number of years and that according to his information Mr. Larmer was living in England. Whether the lawyer explicitly withdrew from the case is unclear.

Despite recognizing that Mr. Larmer was not represented in law, and recording Mr. Larmer as living in Rotterdam, the Rotterdam District Court nevertheless delivered judgment on 31 December 1999 and awarded Mr. Maronier damages to the sum of EUR 33,000. ${ }^{1}$ Not having been served with any of the documents, Mr. Larmer only found out about the reactivation of the procedure when enforcement measures were taken against him in England. At that point, there was no way for him to appeal the judgment. Given that he had submitted a statement before the proceedings were stayed, the judgment was not a default judgment, and he was therefore not able to invoke the remedy of opposition (or verzet under Dutch law). The only option open to him was therefore to oppose enforcement of the judgment in England. ${ }^{2}$

The case of Maronier $v$. Larmer shows the conflict inherent in cross-border enforcement of civil judgments. In an integrated European Union (EU), as people and businesses move across borders, many legal relationships involve cross-border elements. Economic activity within the internal market is only possible when businesses and consumers are able to rely on the effective functioning of the civil justice system to resolve any disputes resulting from that activity. ${ }^{3}$ Cooperation between Member States in the field of civil justice, and in particular rules facilitating the cross-border recognition and enforcement of judgments, are essential in this regard.

At the same time, the case of Maronier v. Larmer illustrates the difficulty of effectively safeguarding the defendant's right to be heard in a cross-border case. Such difficulty can be caused by differences in the procedural law of Member States, a lack of information such as to the defendant's whereabouts, or simple mistakes in the application of the law. The question is whether, and how, EU legislation on cross-border recognition and enforcement of civil judgments should effectively safeguard the parties' rights to a fair trial. This question involves a balancing between, on one hand, a judgment creditor's right to enforcement of a civil

\footnotetext{
${ }^{1}$ Not published; Kramer (2003) p. 16.

${ }^{2}$ Court of Appeal, Maronier v. Larmer, [2002] EWCA Civ 774. See Beaumont and Johnston (2010b) p. 255.

${ }^{3}$ Jenard (1979) p. 3.
} 
judgment, and on the other hand, protection of the judgment debtor's right to a fair trial, including his right to be heard.

\subsection{Background: free movement of judgments in the European Union}

Since the inception of the EU, the European legislature has strived to achieve effective mechanisms for recognition and enforcement of civil judgments between Member States. The 1957 Treaty establishing a European Economic Community (EEC) already required Member States to enter into negotiations in order to simplify the formalities attached to the recognition and enforcement of civil judgments. ${ }^{4}$ Prior to, and apart from, the European integration process, states already made provisions in national law for the recognition and enforcement of judgments from other states, and concluded treaties. The European integration process gave great impetus to the development of rules on this matter. For a long time, EU legislation balanced judgment creditors' with judgment debtors' rights by combining a harmonized procedure for requesting a declaration of enforceability in the Member State of enforcement (exequatur) with limited grounds for refusal of recognition and enforcement. ${ }^{5}$ These grounds for refusal included the public policy exception, ${ }^{6}$ which enabled a court in the Member State of enforcement to refuse recognition or enforcement if that would be contrary to, inter alia, that Member State's public policy, and a ground for protecting the defaulting defendant. ${ }^{7}$

With the inclusion in the 1997 Treaty of Amsterdam of a legal basis for EU legislative action in the field of judicial cooperation in civil cases, ${ }^{8} \mathrm{EU}$ law on recognition and enforcement, and civil justice cooperation as a whole, underwent what may be termed a paradigm shift. Whereas historically states saw the recognition and enforcement of foreign judgments as an exercise of state sovereignty and an act of comity towards the other state, ${ }^{9}$ in the EU it has become increasingly automatic and governed by harmonized European rules.

What spurred on this development is the goal, expressed at the 1999 the European Council of Tampere, of creating a 'European Area of Freedom, Security and Justice'. ${ }^{10}$ The conclusions from this meeting, the 'Tampere Conclusions', proposed a number of far-reaching measures to

\footnotetext{
${ }^{4}$ Article 220, Treaty Establishing the European Economic Community, Rome 1957, OJ 25 March 1957.

${ }^{5}$ Convention on jurisdiction and the enforcement of judgments in civil and commercial matters, done at Lugano on 16 September 1988; Convention of 27 September 1968 on Jurisdiction and the Recognition and Enforcement of Judgments in Civil and Commercial Matters, Brussels.

${ }^{6}$ Article 34(1) Brussels I Regulation.

${ }^{7}$ Article 34(2) Brussels I Regulation.

${ }^{8}$ Article 65, Treaty Establishing the European Community (Amsterdam consolidated version) OJ C340/173, 1997. Under the current Treaty on the Functioning of the European Union (TFEU) judicial cooperation in civil matters is based on Title V (articles 67-89) of Part III. With the entry into force of the Lisbon Treaty in 2009 the European Union has replaced and succeeded the European Community.

${ }^{9}$ Not all authors agree that this paradigm is no longer valid in the EU framework: Lopez de Tejada argues that abolition of exequatur is unwise mainly because it would remove Member States' control powers to check whether judgments conform to domestic standards. Lopez de Tejada (2013) p. 115-117.

10 Tampere European Council, 15-16 October 1999, Presidency Conclusions.
} 
achieve this goal, many of which affected civil justice, but also criminal justice and asylum and migration law.

The most influential idea arising from the Tampere Conclusions was the introduction of the principle of mutual recognition as a cornerstone for cooperation in these areas of law. Mutual recognition is a legislative concept, originally developed in the context of free movement of goods, ${ }^{11}$ which requires Member States to recognize or otherwise give effect to judicial decisions, official documents, and other 'products' from fellow Member States. The underlying notion is that of mutual trust of Member States in each other's legal systems. Though there is no uniformly accepted definition of mutual trust, it seems to require Member States to presume that, because those decisions and other documents emanate from a fellow EU Member State, they comply with norms and principles (such as fundamental rights) that are common to all Member States. Those common standards, which are laid down in primary or secondary EU legislation, thus obviate the need for grounds for refusal of recognition such as public policy.

Mutual recognition thus presupposes mutual trust, though whether this trust indeed exists or whether the European legislature merely assumes it exists is a matter of debate. In any case, where mutual recognition has been implemented, the absence of mutual trust in a concrete case is no legitimate reason for Member States to refuse recognition. Mutual trust should therefore be seen as an objectified form of trust. It has proved controversial: the fact that all EU Member States are signatories to the European Convention on Human Rights (ECHR) does not justify the conclusion that fundamental rights are therefore at all times respected. ${ }^{12}$ It has consequently been argued that mutual trust should only give rise to a rebuttable presumption that this is always the case. ${ }^{13}$

The European Council of Tampere's adoption of mutual recognition as the cornerstone of justice cooperation proved fruitful. The 2004 The Hague Programme, ${ }^{14}$ the 2010 Stockholm Programme, ${ }^{15}$ and the Civil Justice Agenda for $2020,{ }^{16}$ all proposed measures for the implementation of this concept.

For the field of civil justice, the introduction of mutual recognition launched a legislative effort with the aim of simplifying or altogether abolishing the existing procedures for cross-border

${ }^{11}$ CJEU Case 120/78 Rewe-Zentral AG v Bundesmonopolverwaltung für Branntwein, ECLI:EU:C:1979:42, para. 14; also known as Cassis de Dijon.

${ }^{12}$ Statistical data show that, in the period 1959-2011, the ECtHR delivered a total of 3672 judgments in which a violation of Article 6 was found (still excluding complaints about the length of proceedings) making it the most violated provision of the ECHR. See Table of Violations 1959-2011 at http://www.echr.coe.int/ECHR/EN/Header/Reports+and+Statistics/Statistics/Statistical+data/.

${ }^{13}$ Kramer (2011b) p. 217.

${ }^{14}$ European Council, The Hague Programme: Strengthening Freedom, Security and Justice in the European Union, 2005, OJ C 53/01.

${ }^{15}$ European Council, The Stockholm Programme - an open and secure Europe serving and protecting citizens, OJ C/115/10, 2010.

${ }^{16}$ European Commission, The EU Justice Agenda for 2020. Strengthening Trust, Mobility and Growth within the Union, COM(2014) 144 final, 2014. 
recognition and enforcement. ${ }^{17}$ This move towards simplification has resulted in the removal of formal requirements for enforcement in another Member State (exequatur) of judgments falling within the scope of the Brussels I bis Regulation, which is to say most civil and commercial judgments. ${ }^{18}$ For some categories of judgments, it has also, more controversially, ${ }^{19}$ resulted in the abolition of the grounds of refusal of enforcement and recognition that were previously available. In this category, the European Enforcement Order Regulation allows the court that handed down the judgment to provide a certificate, which renders the judgment automatically enforceable throughout the Union, without any possibility of opposing its enforcement. ${ }^{20}$ The European Small Claims Regulation ${ }^{21}$ and the European Order for Payment Procedure $^{22}$ are uniform European procedures that yield decisions that are likewise automatically enforceable throughout the Union. The Maintenance Regulation has abolished prerequisites for enforcement altogether. ${ }^{23}$ Finally, the Brussels II bis Regulation on family matters has abolished any possibility for Member States to refuse enforcement of judgments from other Member States ordering the return of a child that was wrongly removed across borders from his or her state of habitual residence. ${ }^{24}$ This same regime applies to judgments concerning access rights. ${ }^{25}$

The simplification or abolition of procedural steps necessary to enforce or recognize a judgment across borders has a profound impact on the protection of fundamental rights. On one hand, simplification of the procedure for cross-border enforcement improves parties' confidence in the rule of law and allows the judgment creditor to exercise his right to enforcement, which both Article 6 of the ECHR and Article 47 of the EU Charter of Fundamental Rights (EU CFR) guarantee. On the other hand, safeguards, such as grounds for refusal of enforcement, are necessary to protect the debtor's right to a fair trial under those same provisions. The European Court of Human Rights (ECtHR) supervises, within the limits of its jurisdiction, ${ }^{26}$ the conformity of the application of EU legislation with the ECHR.

\footnotetext{
${ }^{17}$ Kramer (2011b) p. 209.

${ }^{18}$ Regulation (EU) of the European Parliament and of the Council of 12 December 2012 No 1215/2012 on jurisdiction and the recognition and enforcement of judgments in civil and commercial matters, OJ L 351/1. This Regulation is a recast of Regulation 44/2001 (the Brussels I Regulation).

19 See among others Cuniberti and Rueda (2011); Van der Grinten (2006); Beaumont and Johnston (2010b); Oberhammer (2010); Frąckowiak-Adamska (2015); Lopez de Tejada (2013); Schack (2011); Timmer (2013).

${ }^{20}$ European Enforcement Order Regulation, Article 5.

${ }^{21}$ Regulation (EC) No 861/2007 of the European Parliament and the Council of 11 July 2007 establishing a European Small Claims Procedure, OJ L 199/1.

${ }^{22}$ Regulation (EC) No 1896/2006 of the European Parliament and the Council of 12 December 2006 creating a European Order for Payment Procedure, OJ L 399/1.

23 Council Regulation (EC) 4/2009 of 18 December 2009 on jurisdiction, applicable law, recognition and enforcement of decisions and cooperation in matters relating to maintenance obligations, OJ L7/1.

${ }^{24}$ Council Regulation (EC) 2201/2003 of 27 November 2003 concerning jurisdiction and recognition and enforcement of judgments in matrimonial matters and matters of parental responsibility, OJ L 338/1, Article 42. ${ }^{25}$ Ibid., Article 41.

${ }^{26}$ Since the European Union is as of yet not a member of the Council of Europe and not a signatory to the ECHR, the ECtHR considers it has no jurisdiction to review actions of the EU as an organisation. The ECtHR however does entertain applications against the EU's Member States, such as in ECtHR Andreasen v. the United Kingdom and 26 other Member States of the European Union (dec)., appl. no. 28827/11, 31 March 2015; see 5.4.6. It also
} 
This research considers what consequences abolition of such safeguards has for the protection of both parties' rights to a fair trial, and how an EU regime for cross-border enforcement and recognition of civil judgments should be organized in order to effectively protect those rights.

\subsection{Relevance and theoretical framework}

The questions submitted above merit examination for three reasons: timeliness, the controversial nature of the topic, and its relevance for EU law as a whole.

Firstly, as the previous section described, a great variety of mechanisms for recognition and enforcement currently exists in European Regulations, some of which, such as the European Enforcement Order (EEO), are entirely unprecedented. Given that it has now been around ten years since the entry into force of these instruments, it is possible and necessary to evaluate whether they have achieved their stated aims of simplifying cross-border enforcement while respecting the rights of defendants.

Secondly, the reforms in this field have proved controversial. The idea of abolishing exequatur and the accompanying refusal grounds, while being presented as progress, was severely criticized by some. ${ }^{27}$ With the knowledge that is currently available on the functioning of the various mechanisms, it is possible to evaluate whether that criticism has proven to be justified.

Thirdly, the topic of free movement of judgments represents certain larger developments in EU law. The EU increasingly presents itself as a fundamental rights organization, ${ }^{28}$ the most important exponent being the adoption of the EU CFR. In light of this development, careful analysis of EU legislation on its conformity with fundamental rights such as the right to a fair trial becomes all the more relevant. ${ }^{29}$ The EU's responsibilities under the ECHR and the (lack of) jurisdiction of the ECtHR to review the application of EU legislation is also highly relevant in this regard. ${ }^{30}$ The operation of civil justice regulations provides a unique perspective on this highly topical matter: the ECtHR's approach to cases involving mutual recognition of civil judgments highlights the difficulties with this concept and with the relationship between the ECHR and EU law more generally.

The topic of mutual recognition of judgments also raises profound questions about the nature of European integration and the role of fundamental rights in that respect. Though mutual

reviews actions of EU Member States where they act in the implementation of their obligations under EU law, though this review is limited where States have no discretion; see ECtHR Bosphorus Hava Yollari Turizm ve Ticaret Anonim Sirketi v. Ireland, Application no. 45036/98, 30 June 2005, ECHR 2005-VI, discussed in detail in Chapter 5.

${ }^{27}$ Supra note 19.

${ }^{28}$ Article 2 of the Treaty on European Union proclaims that 'the Union is founded on the values of respect to human dignity, freedom, democracy, equality, the rule of law and respect for human rights'. Article 6(1) provides that the Charter shall have the same legal value of the Treaties, whereas Article 6(3) provides that 'fundamental rights $[. .$.$] shall constitute general principles of the Union's law'.$

${ }^{29}$ See Sanna (2011).

${ }^{30}$ Charter of Fundamental Rights of the European Union, 2000, OJ C 364/01. 
recognition can work in various ways, it often involves the reduction or abolition of discretionary powers of the Member State where enforcement of a judicial decision is requested. This has raised the question what Member States should do when they believe the enforcement of a decision is contrary to (national or European) standards of fundamental rights. This question proved especially difficult in the field of European asylum law, where it led to the much discussed M.S.S. judgment of the ECtHR, ${ }^{31}$ and the subsequent N.S. and M.E. and Others judgment from the CJEU, ${ }^{32}$ in which the latter ruled that mutual recognition should, under very strict circumstances, give way to fundamental rights concerns. How legally and politically sensitive the relationship between mutual recognition and fundamental rights has become is also demonstrated by the fact that the CJEU saw accession of the EU to the ECHR as a potential threat to the functioning of mutual recognition, and partly for this reason advised against the 2014 Draft Accession Agreement. ${ }^{33}$ The question of whether fundamental rights may override mutual recognition has also arisen in relation to the European Arrest Warrant. ${ }^{34}$ Whereas the problems associated with mutual recognition are different in criminal law and in asylum law than in civil law, due to the difference in subject matter, they stem from the same development. Since this thesis aims to develop a principled view on the relationship between fundamental rights and mutual recognition, it needs to take into account the problems associated with that relationship in fields other than civil law, and consider whether similar solutions may be useful for these fields. The proposed solutions are therefore of interest not just for actors in the field of civil justice, but for those in other areas of law as well.

\section{$1.4 \quad$ Research questions and aims}

As stated above, this research takes as a starting point that there is a tension between the EU concept of mutual trust on one hand, and ECHR-guaranteed fundamental rights on the other. The parameters identified above together give rise to the following research questions:

Which are the requirements imposed by the right to a fair trial (as laid down in Article 6(1) ECHR and Article 47 EU CFR) on the free movement of civil judgments in crossborder cases within the $E U$, and how can the right to a fair trial be effectively safeguarded in this context?

These research questions can be divided into the following sub questions:

1. How does the (previously) existing mechanism for recognition and enforcement protect, and what consequences does its abolition or simplification have for the protection of, the right to a fair trial in cross-border cases?

2. Which requirements can be derived from Article 6(1) ECHR and Article 47 EU CFR that are relevant to the civil trial, including the enforcement stage?

\footnotetext{
${ }^{31}$ European Court of Human Rights, Case of M.S.S. v. Belgium and Greece, Application No. 30696/09, 21 January 2011.

${ }^{32}$ CJEU Joined Cases C-411/10 and C-493/10, N.S. and M.E. and others.

${ }^{33}$ Opinion 2/13 of the Court (Full Court) of 18 December 2014, ECLI:EU:C:2014:2454.

${ }^{34}$ CJEU Case C-399/11 Stefano Melloni v. Ministerio Fiscal, ECLI:EU:C:2013:107; CJEU Case C-396/11

Ciprian Vasile Radu, ECLI:EU:C:2013:39.
} 
3. To what extent does the ECHR require a mechanism that allows the Member State where enforcement is sought to refuse such recognition or enforcement in case of a violation of the right to a fair trial, and what preconditions does it impose on its abolition?

4. To what extent does the EU legal order require a mechanism that allows the Member State where enforcement is sought to refuse such recognition or enforcement in case of a violation of the right to a fair trial, and what preconditions does it impose on its abolition?

5. If a mechanism for the refusal of recognition and enforcement is found to be necessary, what criterion should national judges apply?

6. Which procedural safeguards should EU legislation concerning the recognition and enforcement contain in order to guarantee the effective protection of right to a fair trial in cross-border cases?

The aim of this thesis can be described as defining the parameters arising out of the case law and doctrine on the cross-border effect of the right to a fair trial that need to be considered if a political decision is taken on how to further facilitate free movement of civil judgments within the EU.

This thesis focuses on the right to a fair trial as laid down in Article 6 ECHR and Article 47 EU CFR. It does not focus on other fundamental rights. The reason for this is that procedural fairness is the most important aspect of public policy, as it is most often invoked. Procedural fairness has also been the subject of CJEU and ECtHR case law, unlike substantive public policy. This focus does not preclude acknowledging that other fundamental rights could also be of importance in this context; it is simply not possible to include all potentially relevant fundamental rights in this research project, though they are considered in the context of child abduction cases. This thesis may therefore serve as a starting point for further discussion on whether standards could also be derived from other fundamental rights, which are also relevant to the abolition of exequatur.

This research has as its explicit aim to discuss the cross-border recognition and enforcement of civil judgments from the perspective of fundamental rights. It does not explore whether free movement of civil judgments is feasible or desirable politically or economically. Another limitation is that this research does not consider whether it is legitimately possible to weigh the protection of fundamental rights against considerations of efficiency, such as the potential costs and benefits of the abolition of certain safeguards, or against other considerations of societal interest. This research has as its starting point that the right to a fair trial should be protected effectively in all proceedings falling within its scope. Since both the EU and its Member States have committed themselves to protecting fundamental rights, limitations on that protection are only allowed in so far as the fundamental rights framework allows for those limitations. Whereas, for example, the right to privacy in Article 8(1) ECHR can be legitimately limited provided certain conditions are fulfilled, the right to a fair trial does not contain an explicit limitation clause. ${ }^{35}$ It is therefore not possible to legitimately discuss in what cases interference with the right to a fair trial should be allowed. Whether such an outcome is acceptable as

${ }^{35}$ See for a general overview of the topic Koch (2008). 
'collateral damage' of the abolition of safeguards that may be seen as obstacles to enforcement is a political question; but this research would maintain that even politically, such a trade-off could not legitimately be considered, given that within the EU's political framework, fundamental rights are considered to be among its founding principles.

\subsection{Sources, method, and structure}

It follows from the aims cited above that this research project is analytic and evaluative in character. It seeks to identify, on the basis of existing case law and other sources, the parameters that define to what extent the right to a fair trial needs to be guaranteed in a context of interstate cooperation. It evaluates these parameters in order to draw the conclusions needed to answer this question.

\subsubsection{Sources}

This thesis can be classified as a classic doctrinal legal research project. Its primary sources are the legislation that the introduction referred to: the instruments of EU private international law and civil procedure, primarily the Brussels I Regulation (recast); the Treaty on European Union (TEU) and the Treaty on the Functioning of the European Union (TFEU); the EU CFR; and the ECHR.

For the interpretation of EU legislation, this thesis looks at legislative history. This history is found in preparatory documents such as policy documents, reports and early drafts, as well as case law from the Court of Justice of the European Union (CJEU). For the EU CFR, an important means of interpretation, though not binding, are the Explanations relating to the Charter. ${ }^{36}$

As for case law, the database of the European Fundamental Rights Agency (FRA) was of great help for CJEU cases. ${ }^{37}$ Otherwise, case law was found in the EU's Eur-lex database by using Regulation numbers (e.g., '805/2004') or certain keywords ('fundamental rights', 'rights of the defence', et cetera). ${ }^{38}$ Dutch case law was found through the Dutch case law repository, ${ }^{39}$ by searching for the relevant Regulations (e.g., '805/2004'). The Dutch journal Nederlands Internationaal Privaatrecht, published by the Asser Institute, was also a good source of case law and accompanying notes. ${ }^{40}$ For other EU Member States, case law was found either

\footnotetext{
${ }^{36}$ Explanations relating to the Charter of Fundamental Rights, OJ C 303/17, 2007.

${ }^{37} \mathrm{http}$ ://fra.europa.eu/en/case-law-database.

$38 \mathrm{http} / / /$ eur-lex.europa.eu; also accessed through http://curia.europa.eu.

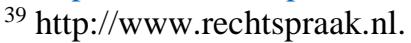

${ }^{40}$ Nederlands Internationaal Privaatrecht (NIPR) http://www.nipr-online.eu/.
} 
through the literature and reports cited above, or through journals such as IPRax (for German case law). ${ }^{41}$

For the ECHR, legislative history plays a less significant role, since it was recognized at the outset that the Convention should be a 'living instrument'. Therefore, the primary source of interpretation is the case law from the ECtHR itself. Since the body of case law on Article 6 is enormous, the selection of case law was mainly (but of course not exclusively) guided by the following sources: the $\mathrm{PhD}$ thesis Artikel 6 EVRM en het civiele proces (Article 6 ECHR and the civil trial) by P. Smits; ${ }^{42}$ handbooks by Janis et al. ${ }^{43}$ Harris et al. ${ }^{44}$ Van Dijk and Van Hoof; ${ }^{45}$ Rainey et al.; ${ }^{46}$ and Leanza and Pridal. ${ }^{47}$ The implementation handbooks ${ }^{48}$ and case law guide ${ }^{49}$ published by the Council of Europe were also valuable sources. Finally, to collect a representative sample of the ECtHR's most important recent judgments on Article 6, a collection was made of all judgments on Article 6 in civil cases published in the 2005 to 2015 editions of the case law journal European Human Rights Cases. The literature used as an aide to interpretation is cited in the footnotes and in the bibliography.

As for citation, this thesis refers to European Case Law Identifier (ECLI) numbers for Dutch case law and CJEU case law. ${ }^{50}$ For the ECtHR, the citation refers to the application number, names of the parties, and the year of publication in the ECtHR's Reports of Judgments and Decisions, including a volume number where available. ${ }^{51}$ Where a judgment was published in a journal, this is also included. For case law from other EU Member States, the mode of citation that is usual in the Member State of origin of that judgment is applied. ${ }^{52}$

Save for exceptional cases, case law and literature research was concluded on 1 February 2016. This means that the ECtHR Grand Chamber's important judgment in Avotins v. Latvia ${ }^{53}$, which is very relevant to EU Member States' obligations under the ECHR, could not be taken into

\footnotetext{
${ }^{41}$ Praxis des Internationalen Privat- und Verfahrensrechts (IPRax) http://www.iprax.de/.

${ }^{42}$ Smits (2008).

43 Janis et al. (2008).

${ }^{44}$ Harris et al. (2014).

${ }^{45}$ Van Dijk et al. (2006).

46 Rainey et al. (2014)

${ }^{47}$ Leanza and Pridal (2014).

${ }^{48}$ Mole and Harby (2006); Vitkausas and Dikov (2012).

${ }^{49}$ Council of Europe/European Court of Human Rights, Guide to Article 6. Right to a fair trial (civil limb) Council of Europe 2013, available at http://www.echr.coe.int.

50 E.g. Rechtbank Den Haag 23-12-2008, ECLI:NL:RBSGR:2008:BG9144; CJEU Case C-399/11 Stefano Melloni v. Ministerio Fiscal, ECLI:EU:C:2013:107. See the notice on 'Method of citing the case-law of the Court of Justice of the European Union on the basis of the ECLI (European Case-Law Identifier)' on the CJEU's website (http://curia.europa.eu).

${ }^{51}$ E.g. (European Court of Human Rights, Case of M.S.S. v. Belgium and Greece, Application No. 30696/09, 21 January 2011.). See the Court's Note explaining the mode of citation and how to refer to the judgments and decisions of the Court (old and new) (October 2013).

${ }^{52}$ For the UK, citations refer to the law report the case was published in, e.g. Maronier v. Larmer, [2002] EWCA Civ 774. For France and other Member States, citations include the court that delivered the judgment, the date, and the case number, e.g. CA Colmar 25 March 2004, No 02/04955; OLG Celle, 30 September 2010, 18 UF 67/10 (Germany).

${ }^{53}$ ECtHR Avotins v. Latvia [GC], appl. no. 17502/07, 23 May 2016.
} 
consideration. The Chamber judgment in this case is discussed in Chapter 5. The reader should be aware that some of that Chapter's observations are affected by the Grand Chamber ruling.

\subsubsection{Method}

It was stated that this thesis constitutes a classic doctrinal legal research project. This means that it studies law as a normative system. ${ }^{54}$ Its aim is to examine whether EU legislation that facilitates recognition and enforcement of civil judgments is consistent with the hierarchically superior norms of European fundamental rights law. The starting point is that fundamental rights, being one of the stated general principles of EU law and, through their membership in the Council of Europe $(\mathrm{CoE})$, binding on all EU Member States, are the supreme guiding principles for EU legislative action. This does not only mean that EU legislation should prevent fundamental rights violations from occurring in its implementation. The EU's stated adherence to fundamental rights, and its unique position as a legislature capable of making rules on crossborder situations, has created a responsibility for the EU to make rules that protect fundamental rights effectively. The aim of this research is therefore not simply to identify whether the existing EU legislation (potentially) leads to fundamental rights violations, but also to propose amendments or adaptations that may help to protect fundamental rights more effectively. This research is therefore not just about identifying the 'bare minimum' standards that EU legislation should comply with.

\subsubsection{Structure}

In order to achieve this aim, this research is structured as follows. Part I (Chapters 2 and 3) outlines the history, legislative function and practical use of EU legislation on recognition and enforcement, up to and including the move towards reform. Next, it analyses the way in which the exequatur has functioned as a means of protection against fundamental rights violations in cross-border cases, and explains what consequences its abolition will likely have (or in some instances has already had) on fundamental rights protection. This analysis uses case law, which was collected in the manner described above under 'Sources'. Empirical evidence on the functioning of the EU Regulations is also a valuable source here, particularly the 2007 Heidelberg Report on the functioning of the Brussels I Regulation, ${ }^{55}$ the 2011 Report on the functioning of the public policy exception, ${ }^{56}$ and recent reports on the functioning of other regulations. This research uses the empirical data gathered in these reports throughout, in order to show what problems are encountered but also to show the scale of those problems. Though it is not an explicit aim of this project, it does take data on the functioning of the regulations into account, where possible, to see how any proposed adaptations will affect the efficiency of the regulations' functioning as a whole. Primarily, however, this research focuses on the

\footnotetext{
${ }^{54}$ Van Hoecke (2011).

${ }^{55}$ Hess, Pfeiffer and Schlosser (2007).

${ }^{56}$ Hess and Pfeiffer (2011).
} 
positions of the individual litigants as protected by the right to a fair trial. The conclusions from this analysis are presented as a conclusion to Part I and used as guidelines for Part 2.

Part 2 (Chapters 4, 5, and 6) constructs a normative framework on the basis of the ECHR and EU fundamental rights law. Chapter 4 discusses the requirements that can be derived from the right to a fair trial (Art. 6(1) ECHR, Art. 47 EU CFR). It discusses both ECtHR and CJEU case law to identify the existing standard; it is after all possible that the CJEU has developed, in its application of Article 47 EU CFR, more precise standards than those that can be derived from the ECtHR's case law. The Chapter also contains a discussion of the aims and values that underlie the right to a fair trial; this analysis serves, partly, to determine the relative weight of elements of the right to a fair trial in case of a conflict. This discussion looks at the history of the right to a fair trial and its purpose and function within the larger corpus of fundamental rights in Europe. Its conclusions are supported by insights from legal philosophy.

Apart from this identification of norms, it is also necessary to establish how the responsibility for protecting these norms is organized in the multi-level legal system of the EU. Chapters 5 and 6 analyse legislation, but particularly focus on case law, to establish exactly how these responsibilities are divided between the EU as an organization and its Member States, according to (respectively) the CJEU and the ECtHR. The aim is to answer sub-questions 4, 5 and 6.

Part 3, Chapters 7 and 8, contains a synthesis of the findings of Part 2. Its purpose is to interpret the findings and to offer a perspective on how the findings apply to the larger area of EU law of civil procedure. As stated above, the aim is to propose amendments or adaptations that may help to protect fundamental rights effectively. 
Part I 


\section{The evolution of free movement of civil judgments in the European Union}

\subsection{Introduction}

In an integrated legal order such as the European Union (EU), free movement of civil judgments is essential to enabling cross-border trade and to ensuring legal certainty. In order to achieve free movement, EU legislation long since facilitated the recognition and enforcement of civil judgments delivered in one Member State in another Member State. This legislation has evolved radically over the past decades. Since the Tampere European Council of 1999 made mutual recognition a principle of civil justice cooperation, the EU legislature made it a priority to simplify cross-border recognition and enforcement as much as possible and to remove potential obstacles. This Chapter outlines the evolution within the EU of the rules facilitating recognition and enforcement of civil judgments and shows the changes that have an impact on the protection of both parties' right to a fair trial.

This Chapter starts by placing the development of mechanisms for recognition and enforcement in the broader context of legislation in the field of judicial cooperation in civil matters (Section 2.2). It shows that whereas legislation on civil justice cooperation was originally motivated by the internal market rationale, aimed at facilitating trade, the objective of creating a true European area of freedom, security, and justice, and the introduction of mutual recognition, meant that civil justice cooperation became more ideologically motivated. Justice has become increasingly accessible to all types of litigants, and the recognition and enforcement of civil judgments is now seen not simply as the fulfilment of a legal obligation but as an expression of trust among Member States. This ideology led to the gradual abolition of obstacles to complete free movement of civil judgments, as Chapter 1.1.3 explains.

Section 2.3 goes on to discuss how recognition and enforcement are currently organized under EU legislation in the field of civil justice. It shows that the mechanism obtaining permission for enforcement is characterized by a strict separation into what is called judgment import, the simplified and nearly automatic procedure for obtaining a declaration of enforceability (exequatur), and what is called judgment inspection, the opportunity to challenge the recognition or enforcement on appeal on the basis of a limited number of grounds for refusal. After these general observations, the Chapter considers how this mechanism is laid down in a number of instruments: the Brussels I bis Regulation (the recast Brussels I Regulation), the Brussels II bis Regulation, the Insolvency Regulation and the Succession Regulation. It also discusses the two uniform European Procedures, the European Small Claims Procedure (ESCP) and the European Order for Payment Procedure (EOP), as well as the European Enforcement Order for uncontested claims (EEO). It discusses to what extent these instruments achieved complete free movement of judgments in their respective fields. The discussion of the existing 
legislation provides a basis for Chapter 3, which examines the consequences of the abolition of obstacles to free movement of civil judgments for the protection of the right to a fair trial.

\subsection{Free movement of civil judgments in the EU: historical and political background}

\subsubsection{Free movement of judgments and the internal market}

Free movement of civil judgments means that parties are able to invoke a judgment in a civil case in a state other than the state where it was delivered. This requires that recognition of the judgment is possible, and that enforcement of the judgment is facilitated. Recognition of a foreign judgment means that its legal effects may be relied on. An example of this may be where a judgment from one state establishes that the seizure of goods was unlawful, and is invoked to claim damages for the unlawful seizure in another state. ${ }^{1}$ Enforcement means that the judgment creditor may take measures, assisted by an enforcement authority such as a bailiff if necessary, to ensure that he indeed receives what the judgment awarded him: for example by attaching a bank account. In this research, free movement of judgments refers to the facilitation, to the greatest extent possible, of cross-border recognition and enforcement, by EU legislation. Complete free movement means that judgments are recognized and can be enforced across borders without the interested parties needing to surmount any procedural obstacles.

Free movement of civil judgments across national borders is essential to fostering international trade and to facilitating the free movement of persons across borders. It is especially important in the EU, an internal market in which goods, people and capital move freely across its Member States. Early on, it was realized that international trade within the Union would be greatly aided if the rights arising out of legal relationships concluded across borders could be adequately recognized and enforced throughout the Union. If a judgment resulting from a trade conflict could not be recognized or enforced over a debtor's assets in another Member State, this would greatly discourage parties from entering into cross-border trade relationships. Effective mechanisms for cross-border recognition and enforcement are therefore a prerequisite for international trade. The benefits of securing cross-border recognition and enforcement are not limited to the interests of the parties involved. As summed up by Michaels:

Parties are interested in transnational legal certainty and in avoiding repeated litigation and conflicting decisions; the general public has an interest in avoiding resources spent on re-litigation and in international decisional harmonies; and States have a common interest in promoting inter-State transactions. ${ }^{2}$

\footnotetext{
${ }^{1}$ CJEU Case C-681/13 Diageo Brands v Simiramida-04 EOOD ECLI:EU:C:2015:471.

${ }^{2}$ Michaels (2009) para. 1.
} 
Facilitating cross-border recognition and enforcement of judgments resulting from civil and commercial cases has therefore long been on the European legislative agenda. The founding Treaty on the European Economic Community (EEC Treaty) already contained a provision requiring the Member States to enter into negotiations in order to "simplify formalities governing the reciprocal recognition and enforcement of judgments of courts or tribunals and of arbitration awards."3

In 1959 the Commission of the European Economic Community invited the then six Member States to enter into such negotiations. In its letter, it stated that:

[A] true internal market between the six States will be achieved only if adequate legal protection can be secured. The economic life of the Community may be subject to disturbances and difficulties unless it is possible, where necessary by judicial means, to ensure the recognition and enforcement of the various rights arising from the existence of a multiplicity of legal relationships. As jurisdiction in both civil and commercial matters is derived from the sovereignty of Member States, and since the effect of judicial acts is confined to each national territory, legal protection and, hence, legal certainty in the common market are essentially dependent on the adoption by the Member States of a satisfactory solution to the problem of recognition and enforcement of judgments. ${ }^{4}$

The Member States entered into such negotiations, which resulted in the first EU instrument regulating jurisdiction, recognition and enforcement: the Convention on Jurisdiction and the Enforcement of Judgments in Civil and Commercial Matters, ${ }^{5}$ or the 'Brussels Convention', signed by the then six Member States of the European Economic Community (EEC) on 27 September $1968 .{ }^{6}$ The Brussels Convention applied to most types of civil and commercial matters, excepting family matters, insolvency proceedings, social security, and arbitration. The introduction of rules on jurisdiction is understandable considering that jurisdiction of the court of origin is a common prerequisite for recognition and enforcement in many national legal systems. $^{7}$

One of the most important elements of the Convention was the introduction of a common procedure for obtaining a declaration of enforceability (exequatur), in the Member State where

\footnotetext{
3 Treaty Establishing the European Economic Community, Rome 1957, OJ 25 March 1957, Article 220.

${ }^{4}$ Jenard (1979) p. 3.

${ }^{5}$ Convention of 27 September 1968 on Jurisdiction and the Recognition and Enforcement of Judgments in Civil and Commercial Matters, done at Brussels on 27 September 1968 ('Brussels Convention').

${ }^{6}$ The Lugano Convention extends the Brussels regime to three EFTA Member States: Switzerland, Norway and Iceland. Convention on jurisdiction and the enforcement of judgments in civil and commercial matters, done at Lugano on 16 September 1988.

${ }^{7}$ For example France (Rosner (2004) p. 233); Germany (section 328(1) Zivilprozessordnung) Switzerland (Article 26 Federal Statute on Private International Law).
} 
enforcement was sought, of the judgments falling within its scope. The introduction of this procedure was important because it greatly reduced the procedural steps interested parties would need to take in order to have their judgments enforced in other EU Member States. Prior to the introduction of this common procedure, recognition and enforcement of foreign judgments was either governed by national procedural law - and therefore different in each state - or governed by bi-or multilateral treaties. ${ }^{8}$ In some states enforcement of foreign judgments was very difficult, if not almost impossible, necessitating complicated procedural steps. What was revolutionary about the newly introduced regime for recognition and enforcement was that it guaranteed, to the furthest extent possible, the recognition and enforcement of judgments, and created a simple and uniform procedure for obtaining recognition. All judgments were recognized automatically, ${ }^{9}$ which meant that the effects of the judgment could be relied on in all EU Member States without any procedural steps being necessary. As for enforcement, the Convention provided for both 'judgment import' and 'judgment inspection'. In order to enforce a judgment from one Member State in another Member State a declaration of enforceability had to be obtained: the exequatur. ${ }^{10}$ The exequatur effectively imported the foreign judgment into the legal order of the Member State where enforcement was sought.

The Brussels Convention balanced this simple procedure for cross-border enforcement, which greatly benefited judgment creditors, with protection for judgment debtors: it allowed Member States to refuse recognition or enforcement if one of a number of specific refusal grounds applied (judgment inspection). The introduction of common refusal grounds became a standard feature of EU legislation in the field, as they provided protection of the debtor's (and other interested parties') rights, while also being narrowly defined and thus providing clarity on the grounds on which recognition or enforcement could be refused. The Brussels Convention authorized Member States to refuse recognition or enforcement if such recognition or enforcement would be 'contrary to public policy in the State in which recognition is sought' (Art. 27(1)). The concept of public policy or ordre public, which is discussed in detail further on, ${ }^{11}$ encompasses principles that are deemed to be of fundamental importance in the legal order of the Member State where enforcement is sought. As the next Chapter shows, the public policy exception has proved instrumental in protecting the debtor's right to a fair trial.

The debtor's procedural rights were also protected by the another ground for refusal, improper service in default proceedings. Recognition or enforcement could be refused where the judgment was given in default of appearance, if the defendant was not duly served with the document that instituted the proceedings, or with an equivalent document, in sufficient time to

\footnotetext{
${ }^{8}$ Of course this is still the case for judgments falling outside the scope of European Union legislation. See for an historical overview Berglund (2009).

${ }^{9}$ Article 26, Brussels Convention.

${ }^{10}$ Article 31, Brussels Convention.

${ }^{11}$ Chapter 3.2.
} 
enable him to arrange for his defence (Art. 27(2)). Recognition or enforcement could also be refused for judgments that were irreconcilable with a judgment given in a dispute between the same parties in the State in which recognition was sought, or a judgment given in a third state, provided it involved the same cause of action and the same parties and fulfilled the conditions necessary for its recognition in the state addressed (Arts. 27(3) and (5)). ${ }^{12}$

The early Treaties on the European (Economic) Community did not give the European Community (EC) the capacity to pass legislation on free movement of judgments, which is why the first instrument within the context of the EU was a convention concluded by its Member States. This changed with the 1993 Treaty of Maastricht, which created the first legal basis for the European institutions to legislate in this field under Title VI of the Treaty on European Union. The 1997 Treaty of Amsterdam then moved this legal basis to Title IV of the EC Treaty. ${ }^{13}$ This enabled the EC to pass legislation on these matters if necessary to guarantee free movement, and firmly entrenched judicial cooperation in the framework of the internal market. It also meant that legislation on cooperation in the field of civil justice could now take the form of EC regulations.

For the cross-border recognition and enforcement of judgments, this meant that the Brussels Convention was replaced by a regulation. On 1 March 2002, Regulation 44/2001 on Jurisdiction and the Recognition and Enforcement of Judgments in Civil and Commercial Matters, or the 'Brussels I Regulation', entered into force. ${ }^{14}$ This regulation simplified the procedure for obtaining an exequatur: whereas under the Brussels Convention the court in the Member State where enforcement was requested could review the grounds for refusal at the judgment import stage, before it issued a declaration of enforceability, under the Brussels I Regulation this review was no longer possible. ${ }^{15}$ This meant that a declaration of enforceability would be issued after a check of only formal requirements. The party against whom enforcement was sought would then have to take the initiative to invoke the refusal grounds, in either an application for refusal of the declaration of enforceability, or incidentally in another

12 Article 27(4) is not discussed here because it was removed when the Convention became a Regulation and therefore was not a factor in the discussion on the abolition of refusal grounds. Article 27(4) allowed recognition or enforcement to be refused if the court of the State of origin, in order to arrive at its judgment, has decided a preliminary question concerning the status or legal capacity of natural persons, rights in property arising out of a matrimonial relationship, wills or succession in a way that conflicts with a rule of the private international law of the State in which the recognition is sought, unless the same result would have been reached by the application of the rules of private international law of that State.

${ }^{13}$ Under the current Treaty on the Functioning of the European Union (TFEU) judicial cooperation in civil matters is based on Title V (articles 67-89) of Part III (Consolidated version of the Treaty on the Functioning of the European Union OJ C 83/47). With the adoption of the Lisbon Treaty in 2009 the European Union has replaced and succeeded the European Community.

14 Council Regulation (EC) No 44/2001 of 22 December 2000 on Jurisdiction and the Recognition and Enforcement of Judgments, OJ L 12/1 (the 'Brussels I Regulation').

${ }^{15}$ Article 41, first sentence, Brussels I Regulation. 
procedure. ${ }^{16}$ The Brussels I Regulation thus clearly distinguished between a judgment import and a judgment inspection stage.

Furthermore, two of the grounds for refusal were limited: the Brussels I Regulation codified the limitation on public policy ${ }^{17}$ introduced by the Court of Justice of the European Union (CJEU) in its case law. ${ }^{18}$ Recognition or enforcement could now only be refused in case of a 'manifest' incompatibility with public policy. The Brussels I Regulation also limited the application of the ground for refusal of undue service upon the defendant in case of a default judgment ${ }^{19}$ so that it no longer applied in cases where the defendant did not lodge an appeal even though he was able to do so. This increased legal certainty for the creditor. ${ }^{20}$

The creation of a Europe without internal borders did not just facilitate cross-border trade, but also the movement of individuals (such as workers and students), families and property. This meant that the recognition of other legal claims across borders became increasingly important. The harmonized procedure for recognition and enforcement devised in the Brussels system was therefore transposed (with some specifics) to a number of instruments in specific areas of civil justice. Most of these are found in the area of family law. The mechanism for recognition and enforcement of the Brussels system thus became a standard feature of EU instruments on civil justice cooperation. However, the introduction of mutual recognition in 1999 brought about radical reforms of this mechanism.

\subsubsection{The introduction of mutual recognition}

The development of EU policies on judicial cooperation gathered momentum with the introduction of the 'Area of Freedom, Security and Justice'. Created by the 1992 Maastricht Treaty, this policy area encompasses police and judicial cooperation in criminal matters as well as judicial cooperation in civil matters. It became more prominent after the Treaty of Amsterdam intensified cooperation in criminal matters within the Third Pillar (Justice and Home Affairs), increasing openness and accountability, ${ }^{21}$ while cooperation in civil matters was moved to the Community pillar entirely. The area of freedom, security and justice was the topic of the 1999 European Council in Tampere. In its Conclusions, ${ }^{22}$ the Presidency of the European Council introduced the principle of mutual recognition as the cornerstone for

\footnotetext{
${ }^{16}$ Article 43 Brussels I Regulation.

${ }^{17}$ Article 34(1) Brussels I Regulation.

${ }^{18}$ See in more detail Chapter 3.2.5.

${ }^{19}$ Article 34 (2) of the Brussels I Regulation, Article 27(1) of the Brussels Convention.

${ }^{20}$ See Chapter 3.3.1.

${ }^{21}$ Craig and De Bùrca (2015) p. 966.

${ }^{22}$ Tampere European Council, 15-16 October 1999, Presidency Conclusions (the 'Tampere Conclusions').
} 
cooperation in this area. ${ }^{23}$ The implementation of mutual recognition meant that intermediate steps necessary for the enforcement of judgments across borders would need to be reduced. ${ }^{24}$ The introduction of this principle therefore led to a new policy goal: the abolition of the requirement for an exequatur and reform of the grounds for refusal, for all types of civil cases.

The implementation of this plan started in 2004 with the adoption of the EEO. ${ }^{25}$ The EEO regulation authorizes the court of origin of a judgment resulting from an uncontested claim to certify the judgment as an EEO. This Order is then enforceable throughout the EU without an exequatur being required and without any possibility for refusing its recognition or enforcement. The regulation applies only to uncontested claims and is intended to reduce the delay and expenses associated with the need for an exequatur. ${ }^{26}$

The EEO paved the way for two unprecedented uniform European procedures: the European Order for Payment Procedure (EOP), ${ }^{27}$ and the European Small Claims Procedure (ESCP). ${ }^{28}$ These instruments do not require an exequatur, but result in decisions that are immediately enforceable throughout the EU. Instead of refusal grounds, they contain minimum standards that are intended to safeguard the procedural rights of the debtors. All three instruments are available only in civil or commercial matters that have cross-border implications. Their purpose, according to their recitals, is to increase speed and reduce costs in cross-border litigation. While the EEO and EOP seek to facilitate commercial litigation, the ESCP is primarily aimed at consumer cases.

Having achieved complete free movement of judgments in these three instruments, the European legislature pursued this goal for the Brussels I Regulation. As opposed to the three instruments discussed above, which are optional and have a limited scope, the Brussels I Regulation applies to most civil judgments and is mandatory. The proposed abolition of exequatur and refusal grounds under this instrument therefore met with more resistance than the introduction of the three optional instruments.

The proposal for reform of Brussels I was buttressed by the finding of the 2007 Heidelberg Report $^{29}$ that the exequatur procedure of the Brussels I Regulation had functioned quite efficiently, given that in $90 \%$ of cases a declaration of enforceability was granted and that it

\footnotetext{
${ }^{23}$ Tampere Conclusions, para. 33. See Storskrubb (2016). See in general on the topic of mutual recognition Janssens (2013); Thunberg Schunke (2013); Ouwerkerk (2011); Thomas (2013).

${ }^{24}$ See section 2.2 .3 of this Chapter.

${ }^{25}$ Regulation (EC) No 805/2004 of the European Parliament and of the Council of 21 April 2004 creating a European Enforcement Order for uncontested claims, OJ L 134/15 (the 'EEO Regulation').

${ }^{26}$ Recital 9, EEO Regulation.

${ }^{27}$ Regulation (EC) No 1896/2006 of the European Parliament and the Council of 12 December 2006 creating a European Order for Payment Procedure, OJ L 399/1 (the 'EOP Regulation'). See section 2.3.7.

${ }^{28}$ Regulation (EC) No 861/2007 of the European Parliament and the Council of 11 July 2007 establishing a European Small Claims Procedure, OJ L 199/1 (the 'ESCP Regulation'). See section 2.3.7.

${ }^{29}$ Hess, Pfeiffer and Schlosser (2007) p. 221. The findings of this report are discussed in more detail in section 2.2.4.1.
} 
was seldom challenged successfully. The European Commission, in its 2009 Green Paper on the Review of Brussels I, ${ }^{30}$ concluded on the basis of these numbers that abolition of exequatur for all civil and commercial matters would be feasible. In 2010 the Commission therefore submitted a proposal for a recast ${ }^{31}$ of the Brussels I Regulation in which the exequatur was abolished. The grounds for refusal would be narrowed, and their application redistributed among the Member State of origin and the Member State of enforcement. The public policy exception was to be replaced with a more narrow reference to 'fundamental principles underlying the right to a fair trial'. The 2010 Proposal also entailed a redistribution of the authority to apply refusal grounds between the Member State of origin and the Member State of enforcement: the ground for refusal of undue service upon the defendant in case of a default judgment (Art. 34 (2) of Brussels I) would be applicable only in the Member State of origin. ${ }^{32}$

The 2010 Commission Proposal provoked much discussion on the value of the exequatur and the grounds for refusal. From the reactions to the 2009 Green Paper, it was clear that abolition of the exequatur was generally supported, but that reform or abolition of the refusal grounds was not. ${ }^{33}$ The recast Regulation 1215/2012, ${ }^{34}$ which entered into force on 10 January 2015, ${ }^{35}$ indeed abolished the exequatur as it existed under Brussels I. All that is needed for enforcement today is a certificate issued by the court of origin, but this only serves to provide information to the enforcement authorities and does not as such constitute an enforceable title. The grounds for refusal however remain intact. ${ }^{36}$

The introduction of mutual recognition also had a profound impact in the field of family law. Regulation 2201/2003 (the Brussels II bis Regulation), ${ }^{37}$ which facilitates the recognition and

${ }^{30}$ Green Paper on the Review of Council Regulation (EC) No 44/2001 on jurisdiction and the recognition and enforcement of judgments in civil and commercial matters, COM(2009) 175 final.

${ }^{31}$ Recasting is a legislative technique that involves bringing together in a single new act a legislative act and all the amendments made to it. The new act passes through the full legislative process and repeals all the acts being recast. Apart from codification, recasting involves new substantive changes, as amendments are made to the original act during preparation of the recast text. See http://ec.europa.eu/dgs/legal_service/recasting_en.htm, last visited 06 March 2016.

${ }^{32}$ See Zilinsky (2011) para. 2.3.

33 Oberhammer (2010); see the contributions to the consultation on the 2009 Green Paper on the review of Regulation 44/2001, available at http://ec.europa.eu/justice/news/consulting_public/news_consulting_0002_en.htm, from Austria; Belgium; Bulgaria; Denmark; Finland; Germany; less clearly, Greece; Latvia; Lithuania; Malta; Slovenia; and the UK.

${ }^{34}$ Regulation (EU) No 1215/2012 of the European Parliament and of the Council of 12 December 2012 on Jurisdiction and the Recognition and Enforcement of Judgments in Civil and Commercial Matters (recast) OJ L 351/1 (the 'Brussels Ibis Regulation').

${ }^{35}$ In accordance with its decision to implement it Regulation 1215/2012 will also be applicable in Denmark.: Agreement between the European Community and the Kingdom of Denmark on jurisdiction and the recognition and enforcement of judgments in civil and commercial matters, OJ L 79/4, 31 March 2013.

${ }^{36}$ See under 2.3.3.2.

37 Council Regulation (EC) 2201/2003 of 27 November 2003 concerning jurisdiction and recognition and enforcement of judgments in matrimonial matters and matters of parental responsibility, OJ L 338/1 (the 'Brussels IIbis Regulation'. This instrument replaced Regulation 1347/2000, or the Brussels II Regulation, which was the first piece of EC legislation in the field of private international law in family matters (other than maintenance) and 
enforcement of judgments in matrimonial matters and matters of parental responsibility, allowed for complete free movement of judgments ordering the return of a child in order to simplify and speed up the return of a child in cases of abduction. ${ }^{38}$ An exequatur is still required for custody orders. ${ }^{39}$ A 2014 report by the European Commission expressed a clear intention to pursue the further abolition of exequatur for judgments in the field of family law. ${ }^{40}$

The 2009 Maintenance Regulation also abolished exequatur and refusal grounds for maintenance orders. ${ }^{41}$ According to the proposal for the regulation, the reasons for proposing abolition of exequatur were 1) simplifying the citizen's life, 2) strengthening legal certainty, and 3 ) ensuring effectiveness and continuity of recovery. ${ }^{42}$

The recast Insolvency Regulation ${ }^{43}$ allows for enforcement of judgments opening insolvency proceedings by incorporating the mechanism of the Brussels I bis Regulation. ${ }^{44}$ Exequatur has therefore been abolished for these types of judgments. The recast Insolvency Regulation includes one refusal ground (the public policy exception). ${ }^{45}$

The 2012 Regulation on Wills and Succession ${ }^{46}$ still contains an exequatur procedure for decisions in matters relating to succession (Chapter IV); as do two proposals ${ }^{47}$ for regulations

was therefore considered a landmark (see (Stone, 2006) p. 384; Council Regulation (EC) No 1347/2000 of 29 May 2000 on jurisdiction and the recognition and enforcement of judgments in matrimonial matters and in matters of parental responsibility for children of both spouses, OJ L 160/19.

38 Regulation 2201/2003, Recital 17. See also Jänterä-Jareborg, (2003) p. 205; see on the free movement of judgments in these matters section 2.3.5.

${ }^{39}$ Regulation 2201/2003, Articles 21-52.

${ }^{40}$ Report from the Commission to the European Parliament, the Council and the European Economic and Social Committee on the application of Council Regulation (EC) No 2201/2003 concerning jurisdiction and the recognition and enforcement of judgements in matrimonial matters and the matters of parental responsibility, repealing Regulation (EC) No 1347/2000, COM(2014) 225 final, p. 10-11.

${ }^{41}$ Council Regulation (EC) 4/2009 of 18 December 2009 on jurisdiction, applicable law, recognition and enforcement of decisions and cooperation in matters relating to maintenance obligations, OJ L7/1 (the 'Maintenance Regulation').

${ }^{42}$ See Proposal for a Council Regulation on jurisdiction, applicable law, recognition and enforcement of decisions and cooperation in matters relating to maintenance obligations, $\operatorname{COM}(2005) 649$ final, p. 4-6.

${ }^{43}$ Regulation (EC) No 1346/2000 on Insolvency Proceedings, OJ L 160/1.

${ }^{44}$ Article 32 of Regulation (EU) 2015/... of the European Parliament and of the Council of 20 May 2015 on insolvency proceedings (recast) 2012/0360 (COD) LEX 1607, PE-CONS 31/15 (not yet published in the Official Journal) ('recast Insolvency Regulation').

${ }^{45}$ Article 33 of the recast Insolvency Regulation.

${ }^{46}$ Regulation (EU) No 650/2012 of the European Parliament and of the Council of 4 July 2012 on jurisdiction, applicable law, recognition and enforcement of decisions and acceptance and enforcement of authentic instruments in matters of succession and on the creation of a European Certificate of Succession.

${ }^{47}$ These two Proposals were not adopted after a failure to reach political agreement. Instead, in March 2016 the European Commission adopted a proposal for a Council decision authorising enhanced cooperation on these topics. European Commission, Proposal for a Council Decision authorising enhanced cooperation in the area of jurisdiction, applicable law and the recognition and enforcement of decisions on the property regimes of international couples, covering both matters of matrimonial property regimes and the property consequences of registered partnerships, $\operatorname{COM}(2016) 108$ final. 
on matrimonial property ${ }^{48}$ and property consequences of registered partnerships. ${ }^{49}$ In the text of these proposals, the Commission points out that an exequatur procedure is deemed necessary because the proposals are a first step in the harmonization of property regimes resulting from marriage or registered partnerships ${ }^{50}$ but that abolition will become an option once these instruments have been evaluated. ${ }^{51}$

The latest instrument based on mutual recognition is the European Account Preservation Order (EAPO) ${ }^{52}$ It is an instrument that allows creditors to preserve the amount owed in a debtor's bank account. The EAPO exists as an alternative to national procedures for cross-border cases. It is an ex parte procedure, which means the debtor is not notified of the application for the EAPO. The EAPO can be requested from a court in the Member State that has jurisdiction over the substance of the matter (Art. 6(1)) or, where a judgment has already been obtained, from the court in the Member State that issued the judgment (Art. 6(3)). This court shall issue the EAPO when the creditor has submitted sufficient evidence to satisfy the court that there is an urgent need for a protective measure in the form of a preservation order because there is a real risk that, without such a measure, the subsequent enforcement of the creditor's claim against the debtor will be impeded or made substantially more difficult (Art. 7(1)). When the EAPO has been issued, it is recognized and enforceable in all other Member States without the need for a declaration of enforceability (Art. 22). There are no grounds for refusal of recognition or enforcement in the Member State addressed, though the debtor may apply to the court of origin of the EAPO, which may revoke or modify it when the conditions set out in the regulation are not met; for instance, where the Order was not served on him within 14 days of the preservation of his account or accounts (Art. 33(1)).

The EAPO facilitates cross-border debt recovery by offering a uniform instrument for account preservation. However, the EAPO is not a (final) judgment, but rather a protective measure that is issued ex parte, without the defendant being summoned to appear. Under Brussels I bis, such measures are already excluded from the scope of the regime for recognition and enforcement, and therefore also from the scope of the refusal grounds. ${ }^{53}$ The innovation of the

\footnotetext{
${ }^{48}$ Proposal for a Council Regulation on jurisdiction, applicable law, recognition and enforcement of decisions in matters of matrimonial property regimes, COM (2011) 126 final.

${ }^{49}$ Proposal for a Council Regulation on jurisdiction, applicable law, recognition and enforcement of decisions regarding the property consequences of registered partnerships, COM (2011) 127 final.

${ }^{50}$ Proposal for a Council Regulation on jurisdiction, applicable law, recognition and enforcement of decisions in matters of matrimonial property regimes, COM (2011) 126 final, para. 5.4; Proposal for a Council Regulation on jurisdiction, applicable law, recognition and enforcement of decisions regarding the property consequences of registered partnerships, COM (2011) 127 final, para. 5.4.

51 The European Parliament was of the opinion that the exequatur procedure should indeed be retained for these procedures given their complexity. (European Parliament, Report on the proposal for a Council regulation on jurisdiction, applicable law and the recognition and enforcement of decisions in matters of matrimonial property regimes (COM(2011)0126 - C7-0093/2011 - 2011/0059(CNS)) Committee on Legal Affairs, rapporteur: Alexandra Thein, Explanatory statement.

${ }^{52}$ Regulation (EU) No 655/2014 of the European Parliament and of the Council of 15 May 2014 establishing a European Account Preservation Order procedure to facilitate cross-border debt recovery in civil and commercial matters, OJ L 189/59.

53 Article 2(a) Brussels Ibis Regulation. See CJEU Case 125/79 Denilauler $v$ SNC Couchet Frères, ECLI:EU:C:1980:130; see further under 2.3.1.1.
} 
EAPO is therefore primarily that it provides a uniform and automatically enforceable provisional measure, not that it contains no refusal grounds. Since it does not facilitate the recognition and enforcement of judgments, it is outside the scope of this research. The EAPO is however another example of the simplification of cross-border litigation in civil cases pursued by the European legislature and therefore worth mentioning.

To conclude, considering the amount of legislation that has recently been adopted in this field, it seems safe to say that the simplification of the regime for cross-border recognition and enforcement of civil judgments in the EU will remain a legislative priority for the future.

\subsubsection{The role of mutual recognition and mutual trust}

Under current legislation on civil justice cooperation within the EU, free movement of judgments is based on the principle of mutual recognition, which in turn presupposes mutual trust. In order to understand how these principles function, it is necessary to define them and explain how they have shaped the development of legislation in the field of civil justice.

There is no widely accepted definition of mutual trust as of yet, ${ }^{54}$ but it generally refers to the confidence Member States have, or should have, in the functioning of each other's legal systems. It is a matter for discussion whether mutual trust in fact exists between the Member States, or whether it is assumed to exist in order for EU legislation to function effectively. It is also a matter for discussion whether mutual trust implies a blanket presumption that a fellow Member State's legal system functions adequately or whether Member States are entitled to review, in specific cases, whether that trust is justified. These questions were the subject of a number of highly important CJEU and ECtHR judgments, that are discussed in Part II of this thesis. ${ }^{55}$

Mutual recognition can be seen as the practical application of mutual trust: if one Member State trusts another, then it should recognize judicial decisions and other acts of the other Member State without second-guessing whether it conforms to its own national standards. Mutual recognition presupposes and is based on mutual trust. Mutual recognition is a well-established mode of cooperation within the European Union, ${ }^{56}$ and was first introduced by the CJEU in its seminal judgment Cassis de Dijon. ${ }^{57}$ In this judgment, which concerned the free movement of goods between Member States, the CJEU ruled that goods lawfully marketed in one Member State should, in principle, be admitted to the market of any other Member State. ${ }^{58}$ This principle makes sense from the internal market perspective: it would be incompatible with the idea of an

\footnotetext{
${ }^{54}$ Andersson (2005).

${ }^{55}$ Chapters 5.4.5 and 6.3.3.

${ }^{56}$ See for a discussion on how mutual recognition was 'transferred' to the justice context Storskrubb (2016).

57 CJEU Case C-120/78 Rewe-Zentral AG v Bundesmonopolverwaltung für Branntwein ECLI:EU:C:1979:42 (Cassis de Dijon) para. 14.

${ }^{58}$ Craig and De Bùrca (2015) p. 674 onwards.
} 
internal market if States were free to prevent goods from being brought to market within their territory by imposing their own requirements on top of those the product had already fulfilled in the Member State of origin. Put rather superficially, mutual recognition reduces the need for extensive harmonization of, for instance, product standards, though in practice a certain level of harmonization has always been achieved to mediate the consequences of mutual recognition. ${ }^{59}$

In the context of free movement of civil judgments, the concept of trust in another state's legal system was as such not new. ${ }^{60}$ The 1968 Brussels Convention's regime, with common and narrowly defined grounds for refusal, was also based on the premise that differences between Member States' civil procedure law should not, in principle, be an obstacle to recognition and enforcement of judgments (though the concept of 'mutual trust' was as such not used). The Member State where recognition or enforcement was sought did however retain the authority to refuse recognition or enforcement, and a declaration of enforceability still needed to be obtained from that Member State. The purpose of the introduction of mutual recognition was, as is explained below, intended to increasingly simplify this regime, to the extent where the Member State where recognition or enforcement is sought retains no discretionary power at all.

The 1999 Tampere European Council introduced mutual trust and mutual recognition as leading principles within the context of the creation of an area of freedom, security and justice. The Maastricht Treaty of 1992 first introduced the objective of creating such an area. It intended to provide Member States with a framework through which they could cooperate in certain politically sensitive areas: immigration, asylum, border controls, police and judicial cooperation in criminal matters, and judicial cooperation in civil matters. As these policy areas were considered politically sensitive and closely connected to national sovereignty, the Maastricht Treaty created a 'pillar' structure in which these issues were separated from the supranational Community decision-making process; it devised a structure that was more intergovernmental, with almost no - or a much reduced - role for the Community institutions. ${ }^{61}$ The Treaty of Amsterdam of 1997, however, moved judicial cooperation in civil matters to the Community Pillar. This change was significant, because it not only greatly reduced the obstacles for decision-making on these matters, but it also shows that these issues were no longer considered particularly sensitive. Yet, the legislative developments in this area were still very much governed by economic objectives. In 1998, the European Commission still proclaimed that:

full abolition of the registration (exequatur) procedure is inconceivable, if only because of the wide procedural divergences between Member States as regards enforcement. ${ }^{62}$

\footnotetext{
${ }^{59}$ Storskrubb (2016) p. 301.

${ }^{60}$ See Weller (2015) p. 73.

${ }^{61}$ Craig and De Bùrca (2015) p. 965.

${ }^{62}$ Commission Communication to the Council and the European Parliament 'Towards Greater Efficiency in Obtaining and Enforcing Judgments in the European Union', COM(97) 609 final, OJ 1998, C 33/3.
} 
The 1999 Tampere European Council shifted focus from mere economic rationales to the creation of an area of freedom, security and justice. Its Conclusions first articulated the role of the principle of mutual recognition in the creation of such an area. Though this document does not use the term "mutual trust", it starts by referring to values common to all Member States:

From its very beginning European integration has been firmly rooted in a shared commitment to freedom based on human rights, democratic institutions and the rule of law. These common values have proved necessary for securing peace and developing prosperity in the European Union. They will also serve as a cornerstone for the enlarging Union.

It then goes on to state that while the primary goal of the Union, the creation of an internal market, has already been achieved, the freedom this internal market grants the EU citizens can only be exercised effectively if there is also a genuine area of justice, in which people can approach courts and judicial authorities in other Member States as easily as in their own. For civil justice, this meant that citizens should not be prevented from exercising their rights due to incompatibility or complexity of legal or administrative systems in the Member States. In order to facilitate the protection of such rights and the cooperation between judicial authorities, the Tampere Council:

endorse[d] the principle of mutual recognition which, in its view, should become the cornerstone of judicial co-operation in both civil and criminal matters within the Union. ${ }^{63}$

The Council then went on to state what this would mean specifically:

34. In civil matters the European Council calls upon the Commission to make a proposal for further reduction of the intermediate measures which are still required to enable the recognition and enforcement of a decision or judgement in the requested State. As a first step these intermediate procedures should be abolished for titles in respect of small consumer or commercial claims and for certain judgements in the field of family litigation (e.g. on maintenance claims and visiting rights). Such decisions would be automatically recognised throughout the Union without any intermediate proceedings or grounds for refusal of enforcement. This could be accompanied by the setting of minimum standards on specific aspects of civil procedural law.

The principle of mutual recognition is thus used as a basis to call for the 'further reduction' of intermediate measures for the recognition and enforcement of judgments - though it is not further explained why this principle is deemed appropriate in this context. More importantly, however, the Tampere Conclusions refer to the "reduction" of "intermediate measures", but it is not clear what exactly this means.

On the matter of mutual trust, the European Commission made quite clear that it assumed this to be at an appropriate level to proceed with the introduction of mutual recognition in the field

63 Tampere Conclusions, para. 33. 
of civil justice. It made this most explicit in its first proposal for the Recast Brussels I Regulation. In its Explanatory Memorandum, it stated that:

Today, judicial cooperation and the level of trust among Member States has reached a degree of maturity which permits the move towards a simpler, less costly, and more automatic system of circulation of judgments. ${ }^{64}$

In the 2000 Draft Programme of Measures for implementation of the principle of mutual recognition of decisions in civil and commercial matters, ${ }^{65}$ the European Council presented a number of explicit legislative objectives. First, in the chapter entitled 'Degrees of mutual recognition' the Programme explains the 'state of play'. It refers to the (then) existing 1968 Brussels Convention as the 'first degree' of mutual recognition (containing a harmonized and simplified exequatur procedure) and to the (then) proposed Brussels I Regulation as the 'second degree', containing a 'streamlined' exequatur procedure. It then goes on to formulate goals and proposals for the enhancement of mutual recognition. In a rather technical-sounding section entitled "First series of measures: further streamlining of intermediate measures and strengthening the effects in the requested State of judgments made in the State of origin" it mentions the following measures for such streamlining: "Limiting the reasons which can be given for challenging recognition or enforcement of a foreign judgment (for example, removal of the test of public policy, taking account of cases in which this reason is currently used by the Member States' courts)." It also removes all doubt as to the long-term goal (called 'second series of measures') of these efforts: "Abolition, pure and simple, of any checks on the foreign judgment by courts in the requested country". 66

Two more recent Council Programmes, the 2004 Hague Programme and the 2010 Stockholm Programme, expand the line of reasoning of the Tampere Conclusions by placing cooperation on the basis of mutual trust (now explicitly stated) and mutual recognition within the framework of the protection of fundamental rights. Both documents start with an affirmation of the Union's commitment to protecting fundamental rights, pointing out the introduction of the EU CFR and its intention to accede to the ECHR. The effective enforcement of rights is also placed in this context: the Stockholm Programme states in a section entitled "Promoting citizenship and fundamental rights" that "Citizens of the Union and other persons must be able to exercise their specific rights to the fullest extent within, and even, where relevant, outside

${ }^{64}$ Explanatory Memorandum, Proposal for a Regulation of the European Parliament and of the Council on jurisdiction and the recognition and enforcement of judgments in civil and commercial matters (Recast) $\operatorname{COM(2010)~} 748$ final, p. 6.

${ }^{65}$ Council Programme of measures to implement the principle of mutual recognition of decisions in civil and commercial matters, OJ 2001, C 12/1.

${ }^{66}$ Council Programme of measures to implement the principle of mutual recognition of decisions in civil and commercial matters, OJ 2001, C 12/1, 5 sub A(2)(b). 
the Union." ${ }^{\prime 67}$ It then reaffirms that mutual recognition facilitates cooperation between authorities and the judicial protection of individual rights. ${ }^{68} \mathrm{Next}$, in the section entitled "Furthering the implementation of mutual recognition" the Council states, "the process of abolishing all intermediate measures (the exequatur), should be continued".

This shift of focus is telling: instead of being a fundamental, yet pragmatic market-oriented measure to promote efficiency of cross-border trade, mutual recognition seems to have now taken on a normative value: it is necessary for the protection of fundamental rights, as differences in national procedures prevent Union citizens from exercising their rights effectively. Fundamental rights protection is thus presented as a reason for the introduction of mutual recognition. The question, of course, is whether legislation based on absolute mutual recognition which presupposes mutual trust between the Member States, especially when it does so by abolishing cross-border checks, is indeed the best way of protecting fundamental rights, or if it is even compatible with fundamental rights. This is because the cross-border checks that some Regulations abolished in favour of absolute mutual recognition protect the rights of the judgment debtor. These questions are central to the following Chapters. Chapter 6 in particular examines whether the European legislature takes its commitment to fundamental rights seriously when it introduces legislation that abolishes grounds for refusal and relies on absolute mutual recognition.

\subsubsection{Practical arguments for increased free movement}

\subsubsection{Recognition and enforcement under Brussels I in practice}

It was already touched upon above that the European Commission took the successful practical application of the exequatur procedure of Brussels I as a sign that the time was ripe to abolish it. The empirical data the Commission based its conclusion on were gathered in the 2007 Report on the Application of Brussels I in the Member States, commonly referred to as the Heidelberg Report. ${ }^{69}$ This Report was prepared in order to evaluate the application of the Brussels I Regulation as provided by its Article 73. The data were gathered through questionnaires and interviews with stakeholders engaged in European cross-border litigation: lawyers, judges and businessmen as well as organizations representing consumers. ${ }^{70}$ The data were collected from

\footnotetext{
${ }^{67}$ European Council, The Stockholm Programme - an open and secure Europe serving and protecting citizens, OJ C/115/10. 2010 (the 'Stockholm Programme').

${ }^{68}$ Stockholm Programme, p. 11.

${ }^{69}$ Hess, Pfeiffer and Schlosser (2007). The paragraph numbers cited refer to Study JLS/C4/2005/03, published in September 2007, available on http://ec.europa.eu/civiljustice/news/docs/study_application_brussels_1_en.pdf. The Report was also published in book form, with some additions Hess, Pfeiffer and Schlosser (2008).

${ }^{70}$ Hess, Pfeiffer and Schlosser (2007) para. 4.
} 
the (then) 24 EU Member States, although, as the authors admit, this proved difficult in the Member States that had only joined the EU in 2004, as not much practice could be reported. ${ }^{71}$ Nevertheless, its empirical findings on the operation of the Regulation in practice are of considerable value.

On the matter of the exequatur procedure, the conclusions were predominantly positive. The authors concluded that, as a rule, exequatur proceedings operated efficiently. The most influential of the Report's conclusions on the matter of exequatur is probably the statistic that the great majority, more than $90 \%$ (and often 100\%) of decisions on the declaration of enforceability were ultimately successful. ${ }^{72}$ The procedure for obtaining a declaration of enforceability was found to be "characterized by speed and simplicity". In most Member States, the creditor could access the competent authorities without representation by a lawyer, and the review by the court of enforcement was restricted to formalities: the court would only review its territorial competence, the authenticity of the decision, the existence of a civil or commercial matter and the regularity of the required certificate. ${ }^{73}$

The average time for obtaining a declaration of enforceability was deemed to be "fairly short", even though the data show that the time periods differed considerably between the Member States (from 7 days to 4 months on average) and that even within Member States the margins were wide (Greece reported a time period of 10 days to 7 months) ${ }^{74}$ Another point of concern was the costs of the declaration of enforceability. In practice, most Member States levied costs, and the ways in which these were calculated differed considerably. The authors also highlighted the costs incurred by the representation by a lawyer as an obstacle: even though legal representation is not required by the regulation, practice shows that creditors appoint a lawyer because they are not sufficiently informed about the foreign procedural law. These findings led the authors to conclude that the situation was "unsatisfactory and even problematic with respect to the guarantee of due process". ${ }^{75}$

Another influential finding was that the great majority of decisions were not appealed: the percentage of appeals was found to be "between $1 \%$ and $5 \%$ of all decisions". ${ }^{76}$ Appeal procedures were found to be handled efficiently, though the duration of appeal procedures could differ considerably. ${ }^{77}$ On the question of which grounds for refusal were most applied, the report found that though the "insufficient service in default procedures" provision of Article 34(2) was most important, its practical impact had been reduced after it was amended with the introduction of the Brussels I Regulation. The report concluded that national courts generally

\footnotetext{
${ }^{71}$ Hess, Pfeiffer and Schlosser (2007) para. 5.

${ }^{72}$ Hess, Pfeiffer and Schlosser (2007) para. 52.

${ }^{73}$ Hess, Pfeiffer and Schlosser (2007) para. 505.

${ }^{74}$ Hess, Pfeiffer and Schlosser (2007) para. 514. See for an interpretation Timmer (2013) p. 145.

${ }^{75}$ Hess, Pfeiffer and Schlosser (2007) para. 525.

${ }^{76}$ Hess, Pfeiffer and Schlosser (2007) para. 506. This corresponds with the figure found by Muller and Cuniberti (2013) see below.

${ }^{77}$ Hess, Pfeiffer and Schlosser (2007) para. 576.
} 
only allow an objection on this ground in exceptional cases and that judges were in general rather favourable towards the recognition of European judgments and the granting of declarations of enforceability. ${ }^{78}$ Little use was also made of the provisions concerning irreconcilability (Arts. 34(3) and (4)). The report concluded that this was likely because the provisions on pendency of Articles 27-30 of Brussels I were generally respected, limiting the risk of irreconcilable judgments. The Report drew a similar conclusion with regard to Article 35 , which concerns review of jurisdiction of the court of origin. This was found to be of little practical importance - because the court of enforcement would be bound by the findings of fact of the court of origin - and because it was not in line with mutual trust, the authors of the report suggested its removal. ${ }^{79}$

The report was more nuanced on the public policy exception. It concluded that the public policy exception was often invoked, but rarely successfully. ${ }^{80}$ At the same time, the reporters pointed out that public policy is of great value from a legal-political perspective,${ }^{81}$ and that even though they are rare, there are still constellations in the European judicial area in which the application of the public policy exception is needed in order to adequately protect the rights of the defendant. ${ }^{82}$

The Heidelberg Report thus reported favourably on the exequatur procedure as it functioned under the Brussels I Regulation. It showed its efficiency, but also pointed to the divergence in the time periods and costs incurred between the Member States. It also quite clearly looked for ways to limit the grounds for refusal, though it was quite nuanced on the value of the public policy exception.

In 2013, Muller and Cuniberti published an empirical study on the functioning of the exequatur procedure in the so-called Grande Région, which encompasses Luxembourg and parts of France, Germany, and Belgium and within which economic and cultural relations are strong. The researchers point out that many people working in Luxembourg live within other parts of the region, so that the existence of borders has become almost irrelevant. ${ }^{83}$ This makes research into the practice of cross-border enforcement of judgments in this region especially interesting.

By providing empirical data on the functioning of the exequatur procedure in a number of courts in the Grande Région, the researchers intended to add to the debate on whether the economic benefits of abolishing the exequatur would outweigh the risks posed to fundamental

\footnotetext{
${ }^{78}$ Hess, Pfeiffer and Schlosser (2007) para. 541.

${ }^{79}$ Hess, Pfeiffer and Schlosser (2007) p. 252. This view is also taken by Arenas Garcia (2010) p. 365 and Dickinson (2011) p. 10.

${ }^{80}$ Hess, Pfeiffer and Schlosser (2007) p. 244. The statistical data gathered by Hess c.s. in their 2011 study on the application of the public policy exception in EU instruments of private international and procedural law appear to reinforce this conclusion. Hess and Pfeiffer (2011) p. 49-50, 94, 103, 119, 134, 138, 145.

${ }^{81}$ Hess, Pfeiffer and Schlosser (2007) para. 543.

${ }^{82}$ Hess, Pfeiffer and Schlosser (2007) para. 544.

${ }^{83}$ Muller and Cuniberti (2013) p. 3.
} 
rights protection. ${ }^{84}$ Their conclusions, based on data concerning costs, duration and success rate of the exequatur, are strongly in favour of its abolition. The researchers conclude that since the great majority of claims submitted for exequatur do not exceed EUR10,000 and are therefore relatively low, legal costs associated with the exequatur are likely prohibitive in many cases. ${ }^{85}$ On top of this, they conclude that since only in a small percentage of cases an appeal is brought, and that it is rarely successful, "the value of the exequatur procedure is statistically very weak". ${ }^{86}$ This is exacerbated by the fact that exequatur proceedings result in delays for the judgment creditor.

The researchers thus provide some strong critique of the costs and delays associated with the exequatur procedure. Their statistical evidence on the success rate of appeals is also remarkable, though without knowing in which cases an appeal was successful and why, it is difficult to draw substantiated conclusions as to the exequatur's value for the protection of fundamental rights - something the researchers acknowledge with the qualification "statistically". In order to draw conclusions as to whether the exequatur protects fundamental rights it is necessary to distinguish between different types of cases and degrees of fundamental rights infringements, as Cuniberti concluded in an earlier article. ${ }^{87}$ This problem is further considered below.

The Heidelberg Report and the statistics gathered by Cuniberti and Muller lead to the conclusion that even if the exequatur procedure functions efficiently, and even in a region in which courts are presumably accustomed to dealing with these proceedings, the costs and delays associated with obtaining a declaration of enforceability are considerable. It is therefore no surprise that the European Commission has strongly emphasized the economic case for the abolition of exequatur. In its Impact Assessment, the Commission suggested that the overall annual cost exequatur proceedings in the EU amounts to approximately EUR 48 million and that this is a deterrent to cross-border trade. ${ }^{88}$

It is more difficult, however, to draw conclusions from the statistical data as to the reform of grounds for refusal. The authors of the Heidelberg Report argue in favour of abolition of the review of jurisdiction, on the basis that it is statistically almost irrelevant, but more importantly because it does not comport with mutual trust. On the public policy exception, both reports are undecided. Though the data show that the public policy exception is rarely used successfully, both groups of researchers point out that statistics are of little use here and that the public policy exception has a primarily legal-political value.

\subsubsection{Recognition and enforcement under other instruments in practice}

\footnotetext{
${ }^{84}$ Muller and Cuniberti (2013) p. 3.

${ }^{85}$ Muller and Cuniberti (2013) p. 12.

${ }^{86}$ Muller and Cuniberti (2013) p. 13

${ }^{87}$ Cuniberti (2012) p. 575-6.

${ }^{88}$ Dickinson (2012) p. 140.
} 
The Brussels II bis abolished exequatur and refusal grounds for decisions ordering the return of a child and those ordering access to a child. For decisions on divorce, legal separation or marriage annulment, and on parental responsibility, refusal grounds still apply and an exequatur is needed for judgments on parental responsibility. A 2015 evaluation of the Regulation found that the existence of these intermediate procedures "hindered smooth enforcement" and that the safeguards, particularly those protecting the best interests of the child, were not necessarily effective because they were not being applied by courts but by administrative personnel. ${ }^{89}$ The divergence in Member State practice concerning the hearing of the child proved created problems at the enforcement stage, because a failure to hear the child is a ground for refusal of enforcement. ${ }^{90}$ However, further on, the Study states: "the (automatic) recognition of judgments in matrimonial matters and cases of parental responsibility functions well in practice". ${ }^{91}$ Apparently, some decisions on parental responsibility were never enforced due to practical obstacles during enforcement procedures, such as delays caused by lack of resources. ${ }^{92}$ Practical obstacles to the enforcement of child return orders, which should be enforced automatically, were also reported..$^{93}$ The problems with the automatic enforcement of child return orders are discussed in more detail in Chapter 3 , particularly in Chapter 3.5. It is clear that the abolition of exequatur for judgments within the scope of the Brussels II bis Regulation remains a priority. In a 2014 report, the European Commission stated that the fact that certain categories of judgments do not benefit from the abolition of exequatur leads to complex, lengthy and costly procedures, and to inconsistencies in application. ${ }^{94}$ The Commission did point out that, particularly in parental responsibility matters, there was great divergence in the interpretation of the public policy exception. ${ }^{95}$ It also acknowledged the varying interpretations of the child's right to be heard. However, the Commission recommended extending the abolition of exequatur, in combination with the appropriate safeguards to take the place of these refusal grounds. ${ }^{96}$ A proposal for amendment of the Brussels II bis Regulation is being prepared. ${ }^{97}$

The Insolvency Regulation was evaluated and the corresponding report published in $2012 .{ }^{98}$ This report did not, however, cover recognition extensively. This was decided because the Regulation "already provides for the maximum solution that can be achieved in this context,

\footnotetext{
${ }^{89}$ Study on the assessment of the Brussels IIbis Regulation (2015) p. 35.

${ }^{90}$ Study on the assessment of the Brussels IIbis Regulation (2015) p. 34. See also p. 43-44 of the Study.

${ }^{91}$ Study on the assessment of the Brussels IIbis Regulation (2015) p. 36.

${ }^{92}$ Study on the assessment of the Brussels IIbis Regulation (2015) p. 35-36.

${ }^{93}$ Study on the assessment of the Brussels IIbis Regulation (2015) p. 36.

${ }^{94}$ Report from the Commission to the European Parliament, the Council and the European Economic and Social Committee on the application of Council Regulation (EC) No 2201/2003 concerning jurisdiction and the recognition and enforcement of judgements in matrimonial matters and the matters of parental responsibility, repealing Regulation (EC) No 1347/2000, COM(2014) 225 final, p. 10.

95 Ibid., p. 10.

${ }^{96}$ Ibid., p. 10-11.

${ }^{97}$ See on this proposal De Boer, Th. M. (2015) and Scott (2015).

${ }^{98}$ Hess, Oberhammer and Schlosser (2013).
} 
i.e. a direct recognition of foreign proceedings without intermediate steps" and because the reporters were not aware of any problems calling for fundamental changes. ${ }^{99}$ Some problems were reported, mainly to do with a lack of information on foreign proceedings and publication of decisions opening the proceedings ${ }^{100}$ and uncertainty as to the distinction between liquidation and reorganization proceedings. ${ }^{101}$ The report also found that the public policy was rarely raised successfully to prevent the recognition of insolvency proceedings, and that the guiding principles of the CJEU were generally applied. ${ }^{102}$

No statistical evidence is yet available on the functioning of the exequatur procedure in the Regulation on Wills and Succession, because this Regulation has only applied since 2015 and will only be evaluated in $2025 .^{103}$

\subsubsection{Concluding remarks}

Free movement of judgments is essential to guaranteeing legal certainty, which in turn fosters international trade and encourages free movement of businesses and people across borders within the EU. To facilitate free movement of judgments, the 1968 Brussels Convention and the 2001 Brussels Regulation, as well as a number of other instruments, contained a mechanism consisting of a uniform procedure for obtaining an exequatur, combined with refusal grounds that the Member State of enforcement could apply. This mechanism, which aimed at combining efficiency for the judgment creditor with protection of the debtor's rights, was found to have functioned quite satisfactorily by the 2007 Heidelberg Report.

The introduction of mutual recognition to the field of justice cooperation within the EU marks what may be termed a paradigm shift in the manner cross-border enforcement is organized in EU legislation. Mutual recognition, which is based on the assumption that sufficient mutual trust exists between the EU Member States as regards the quality of their legal system, has led to the gradual abolition of the exequatur but also, more controversially, to reform or abolition of refusal grounds. The following section explains how these changes were incorporated into current EU legislation on recognition and enforcement of civil judgments.

\subsection{Recognition and enforcement under current EU legislation}

\footnotetext{
${ }^{99}$ Hess, Pfeiffer and Schlosser (2007); Hess, Oberhammer and Schlosser (2013) p. 384.

${ }^{100}$ Hess, Oberhammer and Schlosser (2013) p. 385.

${ }^{101}$ Hess, Oberhammer and Schlosser (2013) p. 384.

102 Hess, Oberhammer and Schlosser (2013) p. 393.

${ }^{103}$ Regulation (EU) No 650/2012 of the European Parliament and of the Council of 4 July 2012 on jurisdiction, applicable law, recognition and enforcement of decisions and acceptance and enforcement of authentic instruments in matters of succession and on the creation of a European Certificate of Succession, Article 82.
} 


\subsubsection{Features of recognition and enforcement in EU civil justice cooperation}

\subsubsection{Definitions}

First, the scope of the following discussion needs to be determined. The instruments discussed in this research all facilitate the recognition and enforcement of judgments, namely, judicial decisions that have been, or have been capable of being, the subject of an inquiry in adversarial proceedings. This is to say that they have to be the outcome of a trial or procedure in which both parties appeared or were capable of appearing. The discussion does not include the recognition or enforcement of provisional or protective measures issued ex parte, where the defendant is not summoned to appear. It is important to establish this, since not only do such measures fall outside the scope of the Brussels I bis Regulation, ${ }^{104}$ the ECtHR also held that for such rules it may not be possible to comply immediately with all the requirements of Article 6(1) ECHR, lest their effectiveness be impaired. ${ }^{105}$ Article 6(1) may therefore not apply in the same way to these ex parte measures, and they would need a separate discussion. This research is limited to the recognition and enforcement of judgments and decisions that fall within the scope of the regulations discussed. It is important to note that with regard to the Brussels I bis Regulation, this also includes judgments delivered by default, ${ }^{106}$ i.e., judgments where the defendant had the opportunity to appear, but chose not to. Such judgments are often given without a full hearing on or examination of the merits and may not contain any reasoning at the national level; yet this does not exclude them from the scope of the Regulation. Included in its scope are also provisional and protective measures that were issued with notice to the defendant, ${ }^{107}$ and judgments such as payment orders that are initially issued ex parte but can be opposed by the defendant. ${ }^{108}$ Judgments need not be res judicata or final and conclusive, though Article 33 of Brussels I bis requires that the judgment is enforceable in the Member State of origin.

\subsubsection{Judgment import and judgment inspection}

The EU mechanism of cross-border enforcement of judgments is characterized by a distinction between two elements: judgment import and judgment inspection. The distinction between these two elements has been a standard feature of the European instruments on recognition and

\footnotetext{
${ }^{104}$ Recital 33, Brussels Ibis Regulation; CJEU Denilauler v SNC Couchet Frères, para. 13; Franq (2016) p. 9798.

${ }^{105}$ ECtHR Micallef v. Malta [GC] appl. no. 17056/06 ECHR 2009-V, para. 85.

${ }^{106}$ Case C-619/10 Trade Agency Ltd v Seramico Investments Ltd ECLI:EU:C:2012:531.

${ }^{107}$ Recital 33, Brussels Ibis Regulation.

${ }^{108}$ Case 166/80 Peter Klomps v Karl Michel ECLI:EU:C:1981:137.
} 
enforcement since the 1968 Brussels Convention. It is important to distinguish between these two elements and to discuss their functions separately, since both are important with a view to safeguarding the involved parties' rights and interests. ${ }^{109}$ It is shown that the formal aspect of the mechanism (judgment import) is instrumental in this regard, but that the abolition of the grounds for refusal, or judgment inspection, has proved controversial. The preceding discussion showed that the introduction of mutual recognition aimed, on one hand, to abolish the exequatur or declaration of enforceability (judgment import); and on the other hand, to abolish or narrow the refusal grounds (judgment inspection). In policy documents, the distinction between these two goals was not always clear from the start. ${ }^{110}$

The judgment import function of the mechanism for cross-border enforcement exists to allow the foreign decision to be accepted in the forum. This aspect or function of the procedure serves merely a formal goal, which is to import the foreign decision, so that it can be enforced. The judgment inspection is substantive: it offers the possibility to invoke grounds of refusal and thus inspect the decision's conformity with certain important values such as public policy.

The import function is most clearly important to legal practice: it would be incompatible with the principle of legal certainty, the principle of res judicata and the substantive rights of the judgment debtor if a decision obtained as a result of a lengthy legal procedure would have no effect across state borders. ${ }^{111}$ The EU regualations therefore provide a means of transferring a foreign judgment to the state where enforcement is sought. Under the Brussels Convention and the Brussels I Regulation, this procedural aspect consisted of obtaining a declaration of enforceability from the competent court in the Member State of enforcement. The term 'judgment import' also signifies the import of a foreign judgment as it stands; this as opposed to mechanisms where a new procedure needs to be started which results in a national title, as is, for example, the case in the Netherlands ${ }^{112}$ and England ${ }^{113}$ (for judgments that do not fall within the scope of one of the EU Regulations or another international instrument).

The second function of the mechanisms for cross-border recognition and enforcement is the judgment inspection function. It refers to the fact that a mechanism for cross-border enforcement provides an opportunity to inspect whether the decision meets certain important requirements. These are not merely formal requirements, such as whether the decision can

109 This distinction is widely accepted in literature (see for instance Oberhammer (2010) p. 197-198) but not always made in practice. See on this issue Oberhammer (2010); Dickinson (2010) p. 255; Beaumont and Johnston (2010a) p. 105.

${ }^{110}$ For instance, the 2000 Draft Programme (discussed under 2.2.3) advocates the 'abolition, pure and simple, of any checks on the foreign judgment by courts in the requested country', which later turned out to mean only the abolition of the formal check of the exequatur, not the refusal grounds.

${ }^{111}$ Michaels (2009) para. 1.

${ }^{112}$ Article 431 of the Dutch Code of Civil Procedure states that (in the absence of any international treaty or law) judgments given by foreign courts may not be enforced, and that the matters may be brought before a Dutch judge. See Van der Grinten (2006) p. 72.

${ }^{113}$ Hartley (2015) p. 397. 
indeed be qualified as a judgment, but principles of fundamental value. ${ }^{114}$ Many European states that have an exequatur procedure for example require that the court of origin had jurisdiction, ${ }^{115}$ that the judgment does not infringe its national public policy, ${ }^{116}$ and that it does not conflict with an earlier proceeding started in that state. ${ }^{117}$

In the European regime, this second function is operationalized in a limited number of grounds for refusal, which are explained below. The grounds for refusal are narrowly and exhaustively defined and must be applied restrictively. Nevertheless, the grounds of refusal are an important tool in the hands of the judgment debtor. Refusal of enforcement means that the judgment creditor is no longer able to take measures to enforce compliance by the judgment debtor with the judgment. This means that the judgment has essentially become without legal consequence in the Member State where enforcement is sought. On what grounds recognition and enforcement may be refused therefore has great significance, discussed in Section 2.2.2 onwards.

The EU Regulations on cross-border recognition and enforcement are characterized by a separation between the two functions: the procedure consists of a simplified, nearly automatic stage in which a declaration of enforceability is obtained (judgment import); and a second stage, in which the grounds for refusal may be examined if the judgment debtor chooses to invoke them (judgment inspection). Some, like Brussels I, abolish only the judgment import procedure, while others abolish both judgment import and judgment inspection, such as Brussels II bis (for certain decisions), the EEO Regulation and the uniform procedures.

\subsubsection{Recognition and enforcement}

A second feature of the EU instruments is the distinction between recognition and enforcement. Recognition means accepting the determination of rights and obligations made by the court of origin; ${ }^{118}$ in other words, accepting its legal effects. The parties may then invoke it, either by taking steps to enforce it, or raising it in another procedure. For example, a judgment granting a divorce may be used in order to obtain a maintenance order in a separate procedure.

Enforcement presupposes recognition, but goes a step further: it allows the judgment creditor to take action in order to make sure that the debtor obeys the order of the court of origin. ${ }^{119}$ It implies that steps of an official nature are taken to ensure that the judgment is complied with,

\footnotetext{
114 Rosner (2004) p. 253-254.

${ }^{115}$ For example France Rosner (2004) p. 233; Germany (section 328(1) Zivilprozessordnung) Switzerland (article 26 Federal Statute on Private International Law).

${ }^{116}$ For example France Rosner (2004) p. 239-246, Germany (section 328(4) Zivilprozessordnung) Switzerland (articles 27(1) and 27(2) Federal Statute on Private International Law).

${ }^{117}$ France: Rosner (2004) p. 250-252; Germany (article 328(1) subparagraph 3 Zivilprozessordnung); Switzerland (article 27(2) subparagraph (c) Federal Statute on Private International Law).

${ }^{118}$ Hartley (2015) p. 349.

${ }^{119}$ Hartley (2015) p. 350.
} 
whether that means that something should be done (such as the payment of a sum of money or the performance of a contract) or not be done (such as in the case of injunctions preventing the commission of an act which would constitute a tort or breach of contract). Enforcement is governed by the domestic law of the state in which enforcement is sought, meaning that only those measures that are provided for in domestic law (such as seizure of goods or the attachment of bank accounts) may be taken. ${ }^{120}$ It is clear that enforcement matters most to monetary judgments, though judgments in other areas of law may also require action from enforcement authorities, such as judgments ordering the return of a child.

Recognition and enforcement are separated under the European instruments discussed below: recognition of judgments within the remit of these instruments is entirely automatic, while for enforcement the exequatur procedure needs to be followed in order to obtain a declaration of enforceability. It must be noted that while the European instruments all contain a section on 'enforcement', they do not in fact harmonize enforcement procedures. What is meant is therefore only the procedure for obtaining permission for enforcement of condemnatory judgments - exequatur. Declaratory and constitutive judgments that fall within the scope of the European instruments are by their nature automatically recognized across the EU. However, the regulations that contain refusal grounds, such as Brussels I bis, do allow recognition to be refused (see below).

\subsubsection{Application of the refusal grounds and its consequences}

Under the Brussels regime, invoking the refusal grounds has increasingly become the responsibility of the judgment debtor or another interested party. Article 34 of the Brussels Convention of 1968 allowed the court to refuse to issue a declaration of enforceability when one of the refusal grounds of Article 27 applied. Refusal grounds could therefore be applied at the judgment import stage.

Under Brussels I bis and Brussels I, examination of refusal grounds (judgment inspection) only takes place in the second instance. Under Brussels I, the court requested to issue a declaration of enforceability is expressly prohibited from applying the refusal grounds during that first stage of the proceedings (Art. 41). Examination of the refusal grounds may only happen in the second instance, when the judgment debtor applies for refusal of recognition or enforcement. ${ }^{121}$ Under Brussels I bis, the refusal grounds can only be considered "on the application of any interested party". ${ }^{122}$ The interested party must therefore take the initiative to invoke one of the

\footnotetext{
${ }^{120}$ That enforcement procedures vary among Member States is shown by Andenas, Hess and Oberhammer (2005). That this divergence may constitute a bottleneck for effective cross-border enforcement even in the presence of a harmonized exequatur procedure is signaled by Jänterä-Jareborg (2003) p. 205.

121 The question remains whether, even though the refusal grounds may only be applied on the application of an interested party, a court is allowed or required to apply the refusal grounds of his own motion, for instance where it considers that a refusal ground other than the one expressly invoked also applies. It appears from the wording that the court may do so, since Article 45 implies that enforcement or recognition must be refused if one of the grounds applies. See Franq (2016) p. 871.

${ }^{122}$ The Brussels Ibis Regulation does not define the scope of the class of persons who may be considered an 'interested party'. See Fitchen (2015) p. 437-440.
} 
grounds. The burden of proving that the particular ground applies lies with the party who applies for refusal. Under Brussels I bis, judgment import has therefore become entirely automatic (though the requirement of a certificate could be seen as a form of judgment export), while judgment inspection takes place at the second instance.

The refusal grounds can be invoked by applying for refusal of recognition or enforcement (Art. 46). According to Article 47, the application shall be submitted by the court that the Member State of enforcement has designated to hear such applications. The decision on the application for refusal may be appealed by either party (Art. 49). The decision on appeal may then be contested only if the Member State where enforcement is sought has appointed a court to hear such contestations (Art. 50). The refusal grounds can also be invoked by applying for a preemptive declaration that no refusal grounds apply (Art. 36(2)); this possibility may be used by a judgment creditor seeking to ascertain that enforcement of the judgment will not at a later stage be contested.

The refusal grounds can also be raised incidentally during court proceedings. An example of the latter situation is the recent case of Diageo v. Simiramida, ${ }^{123}$ in which Simiramida claimed damages in the Netherlands from Diageo on the basis of a Bulgarian judgment that established that Diageo had wrongfully seized goods belonging to Simiramida. Diageo invoked the public policy exception against recognition of the Bulgarian judgment, stating that the judgment was contrary to EU law (though this appeal was unsuccessful). Since recognition of a judgment means that the determination of rights and obligations by the court of origin is accepted, refusal of recognition means that this determination is no longer accepted as having legal merit by the court deciding in the second procedure. This means that certain claims may have to be relitigated, to the expense of the parties involved.

Article 22(1) of the ESCP Regulation and Article 22(1) of the EOP Regulation both provide that enforcement shall be refused upon application by the defendant by the Member State of enforcement if the judgment is irreconcilable with another decision, as specified in the Articles.

Articles 22 and 23 of the Brussels II bis Regulation however can be applied at the first stage of enforcement proceedings. Article 28(1) requires a declaration of enforceability for judgments concerning parental responsibility, to be issued in the Member State of enforcement. Article 31(2) allows the court to refuse the application for a declaration of enforceability on the basis of one of the grounds of Articles 22 and 23. In the case of judgments concerning divorce, legal separation or marriage annulment, refusal of recognition is most likely to take place incidentally, when the judgment is invoked in another procedure, for instance to claim alimony.

The grounds for refusal are harmonized, strictly defined in the respective legal instruments, and restrictively applied, removing the possibility of arbitrary refusal of recognition or enforcement and reducing the chance that a judgment may not be invoked, increasing legal

${ }^{123}$ Case C 681/13 Diageo Brands v Simiramida-04 EOOD ECLI:EU:C:2015:471; see Hazelhorst (2016). 
certainty. The refusal grounds are thus limitative and must be interpreted restrictively. This means that a court may not use any of the grounds for a purpose for which it is not intended. Lack of jurisdiction of the court of origin is not a ground for refusal under any of the regulations and some even explicitly forbid it, save in certain exceptional cases. ${ }^{124}$

Review of a foreign judgment on the merits is also prohibited. ${ }^{125}$ If it were not, the recognition and enforcement regime would make little sense, since if a court in the State addressed were allowed to review a case on the merits, this would amount to deciding the case anew. Not only would this undermine the efficiency of the regime, it would also amount to the court in the State addressed putting its decision above that of the court of origin, which is incompatible with the underlying idea of mutual trust. ${ }^{126}$ The prohibition of review on the merits means that a court must accept the findings of fact made by the court of origin, but also the findings of law: the court of the Member State addressed may not substitute its own discretion for that of the court of origin. ${ }^{127}$ An appeal for refusal of recognition or enforcement is not in any way an appeal on the merits. This means that the court addressed must not question the validity or correctness of the original decision, the substantive or legal soundness of the conclusions, or whether the correct substantive law was applied. ${ }^{128}$

Notwithstanding these qualifications, the grounds for refusal are obligatory, which means that recognition or enforcement must be denied if one of them is found to apply. ${ }^{129}$

Refusal of enforcement means that the judgment creditor is no longer able to take measures to ensure compliance by the judgment debtor with the judgment. This means that the judgment has essentially become without legal consequence in the Member State where enforcement is sought. It must be emphasized that refusal of recognition or enforcement does not affect the validity of the judgment as such: it remains valid in the Member State where it was delivered. It may still be invoked in other states, though there is of course the possibility that another state will also deny recognition or enforcement on the same ground, unless it upholds a different interpretation of the refusal ground, which may happen with public policy (see below). However, it is clear that refusal of recognition or enforcement has radical consequences for the judgment creditor. Unless the debtor has assets in another state, which may very well not be the case with many non-international businesses and consumers, enforcement of the judgment may have become impossible. This goes against the principle of res judicata and renders the exercise of the debtor's right to enforcement utterly impossible. This explains why refusal of recognition or enforcement is only a proportional sanction in the most serious of cases, for

\footnotetext{
124 Article 45(3) Brussels Ibis Regulation.

125 Article 52, Brussels Ibis Regulation; Article 22(2) ESCP Regulation; Article 22(2) EOP Regulation; Article 21(2) EEO Regulation; Article 26, Brussels IIbis Regulation; Article 41, Succession Regulation.

${ }^{126}$ Mankowski (2016) p. 964; he posits that "the judiciary in the Member States is deemed equivalent and equally apt to decide cases which assertion in turn vastly disposes of a necessity for review and control. Whereas control freaks and Leninists might go berserk, European ideology demands so", citing the dictum attributed to Lenin: "Trust is good, but control is better".

${ }^{127}$ Mankowski (2016) p. 964.

${ }^{128}$ Mankowski (2016) p. 964-965.

129 This is implied by the wording of, for instance, Article 45(1) Brussels Ibis Regulation, which provides that recognition 'shall' be refused if one of the refusal grounds is found to apply.
} 
instance where the right to a fair trial was violated. The following provides an overview of the refusal grounds, whereas the following Chapter contains an extensive analysis as to how the refusal grounds have acted as a remedy for fundamental rights violations.

\subsubsection{Three 'models' of free movement of judgments}

The EU Regulations that facilitate cross-border enforcement can be divided into three 'models', according to the degree they have achieved complete free movement of judgments.

First, there are regulations that require exequatur (for certain categories of judgments in their scope) and contain grounds for refusal of recognition and enforcement. This category includes the Succession Regulation, the Brussels II bis Regulation (for judgments concerning parental responsibility), and the two proposed regulations on matrimonial property ${ }^{130}$ and property consequences of registered partnerships. ${ }^{131}$ Because these instruments still operate on the basis of this traditional model and have not reformed or abolished the refusal grounds, they fall outside the scope of this research, which is concerned with the consequences of such reforms. They are therefore not discussed in detail in this section.

The second model is the Brussels I bis Regulation, which has abolished the exequatur, instead requiring the court of origin of the judgment to issue a certificate. The grounds for refusal remain applicable. This model is discussed in Section 2.3.3.

The third model is one where both exequatur and grounds for refusal have been abolished, ${ }^{132}$ thus attaining complete free movement of judgments. Within this model there are variations. The Maintenance Regulation has abolished exequatur and all grounds for refusal completely. The Brussels II bis Regulation has abolished exequatur for judgments ordering the return of a child and those concerning access to children, but has replaced the judgment inspection function with a check of 'minimum requirements' (procedural standards) by the court of origin. The EEO operates in a similar manner, by essentially making the Member State of origin of the judgment responsible for both judgment import and judgment inspection.

An entirely new approach can be observed in the uniform European procedures, the ESCP and the EOP. These instruments can be seen as circumventing exequatur by providing alternative procedures that result in a title that is immediately enforceable throughout the EU.

\subsubsection{Grounds for refusal}

\footnotetext{
${ }^{130}$ Proposal for a Council Regulation on jurisdiction, applicable law, recognition and enforcement of decisions in matters of matrimonial property regimes, COM (2011) 126 final.

${ }^{131}$ Proposal for a Council Regulation on jurisdiction, applicable law, recognition and enforcement of decisions regarding the property consequences of registered partnerships, COM (2011) 127 final.

${ }^{132}$ Except for the refusal ground pertaining to irreconcilability, as discussed under 2.3.2.3.
} 
The exequatur procedure's purpose of guaranteeing free movement is also borne out by the fact that recognition and enforcement can only be opposed on the basis of a limited number of grounds for refusal. This section provides a brief overview of the grounds for refusal that are found in the currently existing EU instruments.

\subsubsection{Public Policy}

The first, and most contentious, ground for refusal is the public policy exception (Art. 45(1)(b) of Brussels I bis). ${ }^{133}$ This entails that recognition or enforcement may be refused if it would be manifestly contrary to the public policy (ordre public) of the Member State addressed - to those principles that are believed to be of fundamental value in the legal order of that State, including internationally recognised fundamental rights. The words 'of the Member State addressed' indicates that it is primarily the national conception of the State in which enforcement is sought which determines the content of public policy; however, the limits of this concept have been defined by the CJEU in its case law and it must be interpreted restrictively. ${ }^{134}$ The court may also not use it to review whether the court of origin had jurisdiction. ${ }^{135}$ Public policy has two elements: substantive public policy, which concerns the substance of the foreign judgment; and procedural public policy, which concerns the procedure of which the judgment is the result. Since a court may not review a foreign judgment as to its substance, ${ }^{136}$ a successful objection on the basis of substantive public policy is rare. ${ }^{137}$ Procedural public policy, however, is much more often invoked, though often unsuccessfully. ${ }^{138}$ In addition, the Brussels II bis Regulation provides that a review on the basis of public policy shall take into account the best interests of the child (Art. 23(a)).

Though Chapter 3 discusses the application of the public policy exception in instruments of EU civil procedure in detail, some information as to its role is needed here in order to understand why its (proposed) abolition has proven to be so controversial. The public policy exception is often seen as an 'emergency brake': ${ }^{139}$ due to its general formulation, it may be used, in extreme cases, against violations of fundamental principles, including fundamental rights. The primary example of such a violation is the case Krombach v. Bamberski, ${ }^{140}$ which is discussed in detail in the following Chapter.

\footnotetext{
${ }^{133}$ Article 40(a) of Regulation 650/2012; Articles 22(a) and 23(a) of the Brussels IIbis Regulation; the Insolvency Regulations and both proposed Regulations discussed earlier refer to the Brussels I Regulation.

${ }^{134}$ To be discussed in Chapter 3.2.5.

135 Article 24 of the Brussels IIbis Regulation.

${ }^{136}$ Article 52, Brussels Ibis Regulation; Article 26, Brussels IIbis Regulation.

${ }^{137}$ Franq (2016) p. 883; Hess, Pfeiffer and Schlosser (2007) para. 559.

${ }^{138}$ Hess, Pfeiffer and Schlosser (2007) para. 548.

${ }^{139}$ Kramer (2011a) p. 640.

${ }^{140}$ CJEU Case C-7/98 Dieter Krombach v André Bamberski ECLI:EU:C:2000:164.
} 


\subsubsection{Insufficient service in default proceedings}

A second ground for refusal that is found in EU instruments ${ }^{141}$ is contained in Article 45(1)(b) of the Brussels I bis Regulation. This Article concerns the position of a defendant in case the judgment was delivered by default. It aims to protect the right of the defendant to a fair hearing at the stage of recognition and enforcement. The conditions for application are rather strict. A judgment may only be refused recognition or enforcement where:

a) it was given in default of appearance; ${ }^{142}$ but,

b) only if the defendant was not served with the document which instituted the proceedings or with an equivalent document in sufficient time and in such a way as to enable him to arrange for his defence;

c) unless the defendant failed to commence proceedings to challenge the judgment when it was possible for him to do so.

Article 45(1)(b) should be read in conjunction with Article 28(2) of Brussels I, which also aims to protect the rights of the defendant in default proceedings by enabling the court to stay proceedings until it is satisfied that the defendant has received the requisite documents. Article 28(2) therefore concerns the proceedings before the court of origin, while Article 45(1)(b) provides a safety net at the court of enforcement, which explains why the latter only applies under very strict circumstances.

The document instituting the proceedings must have reached the defendant not only in sufficient time for him to prepare his defence, but also in such a way as to enable him to do so, though these two aspects are often intertwined. ${ }^{143}$ This places the focus on the actual possibility of the defendant to prepare his defence: an irregularity of service may not prohibit recognition or enforcement if it did not in fact prevent the defendant from arranging his defence.

Finally, if the defendant did not exercise his right to challenge the decision in the country of origin when he was able to do so, he loses the possibility of later raising Article 45(1)(b), or the corresponding article in other regulations, for opposing its recognition. ${ }^{144}$ The rationale

\footnotetext{
${ }^{141}$ Article 40(b) of Regulation 650/2012. Articles 22(b) and 23(c) of the Brussels IIbis Regulation are a little more lenient: recognition and enforcement may only be refused if the first two conditions apply and if the person in default has accepted the judgment unequivocally. This means that inactivity on the part of the person in default does not necessarily preclude an appeal on the basis of these articles.

142 The term 'default of appearance' is applied autonomously and independently of national procedural law. See further Franq (2016) p. 908, citing Kropholler (2005) Article 34 para. 27: "with respect to the aim of Article 45(1)(b) the defendant cannot be considered as having failed to appear as soon as he or his counsel presented arguments before the court from which it can be deduced that he has actual knowledge of the proceedings and enjoyed enough time to prepare his defence".

143 The circumstances surrounding the delivery will often determine whether the defendant had enough time to prepare: for example, if the defendant was served with a document in a foreign language a longer period of time will have been necessary. Franq (2016) p. 913.

${ }^{144}$ Except under the Brussels IIbis Regulation, see footnote 71.
} 
behind this is that it is deemed more effective if a defendant is able to challenge the decision in its country of origin, rather than at the stage of enforcement in another country, when there is only limited scope for review. ${ }^{145}$ Article 45(1)(b) thus encourages the defendant to actively exercise his rights if he is able to do so; passivity on his side to challenge the decision may later prevent him from opposing its recognition.

This ground for refusal provides protection of the procedural rights of the defendant under specific circumstances. As was explained above, the public policy exception may also be used to protect procedural rights, but only as a subsidiary to Article 45(1)(b); that is, if the conditions of Article 45(1)(b) have not been met.

\subsubsection{Irreconcilability}

A final ground for refusal common to most instruments ${ }^{146}$ is that a decision may be denied recognition or enforcement if it is irreconcilable either with:

a) a decision given in proceedings between the same parties in the Member States in which recognition is sought; ${ }^{147}$ or,

b) with an earlier decision given in another Member State or a third state in proceedings involving the same cause of action and between the same parties, provided that the earlier decision fulfills the conditions necessary for its recognition in the Member State in which recognition is sought. ${ }^{148}$

It should be noted that this ground for refusal is the only one that was not abolished by the regulations that otherwise allow for complete free movement, as enforcement of two irreconcilable decisions is simply practically impossible. As the ECJ explained, judgments are irreconcilable where they entail mutually exclusive legal consequences. ${ }^{149}$ Where the irreconcilability is between a judgment given in the Member State where enforcement is sought and one in another Member State, the judgment in the Member State of enforcement is prioritized: ${ }^{150}$ its existence precludes recognition or enforcement, even if it was delivered

${ }^{145}$ CJEU Case C-123/91 Minalmet GmbH v Brandeis Ltd ECLI:EU:C:1992:432, para. 19.

146 Article 45(1)(c) and (d) Brussels Ibis Regulation; Article 22(1) ESCP Regulation; Article 22(1) EOP Regulation; Article 21(1) EEO Regulation; Article 21(2) Maintenance Regulation; Article 40(c) Succession Regulation. Again, Regulation 2201/2003 provides an exception for judgments concerning parental responsibility: only irreconcilability with a later judgment can lead to refusal of recognition or enforcement. This shows that the Regulation accepts the inherent nature of custody orders, as being open to modification by reason of a subsequent change in circumstances. See Borràs (1998) para. 73.

147 Article 25(3) of the Insolvency Regulation 1346/2000 (there is no such ground for refusal for judgments opening proceedings); Articles 22(c) and 23(e) of the Brussels IIbis Regulation; Article 40(c) of Regulation $650 / 2012$.

${ }^{148}$ Article 25(3) of Regulation 1346/2000 (there is no such ground for refusal for judgments opening proceedings); Articles 22(d) and 23(f) of Regulation 2201/2003; Article 40(d) of Regulation 650/2012. It should be noted that 'third State' refers to a state that is not an EU Member State.

${ }^{149}$ CJEU Case C-145/86 Hoffman v Krieg ECLI:EU:C:1988:61.

${ }^{150}$ This is the situation covered by Article 45(1)(c) of Brussels Ibis and its equivalents. 
later. ${ }^{151}$ In these situations, the judgments do need to concern the same parties, though they need not be on the same cause of action. Where the irreconcilability is with a judgment delivered in another Member State or a third state, the judgments do need to concern the same cause of action. ${ }^{152}$ In these situations, priority is given to the earlier judgment.

\subsubsection{No review of jurisdiction, with some exceptions}

As a rule, the court deciding on the declaration of enforceability may not review whether or not the court of origin had jurisdiction. ${ }^{153}$ Review of jurisdiction 'through the back door' by applying the public policy exception is also not permitted. ${ }^{154}$ However, there are some exceptions. The Brussels I bis Regulation contains a number of special rules of jurisdiction that are intended to protect the weaker party in certain legal relationships, namely matters relating to insurance, consumer contracts, employment and certain exclusive jurisdiction grounds, among others those that apply to immovable property (sections 3, 4, 5 and 6 of Chapter II). A judgment may not be recognized if it does not comply with these provisions, though the court of enforcement is bound by the findings of fact of the court of origin (Art. 45(2)).

\subsubsection{Specific grounds for refusal under Brussels II bis}

Finally, the Brussels II bis Regulation contains some specific grounds for refusal of recognition of judgments concerning parental responsibility, which are necessary considering the sensitivity of these matters. Recognition may be refused if the child concerned was not heard (Art. 23(b)), except when this was not possible due to urgency; and when any person claims that the judgment infringes his or her parental responsibility, if it was given without that person having been given an opportunity to be heard (Art. 23(d)). A final ground for refusal is where the special procedure laid down in Article 56 for the placement of a child in another Member State was not followed. As discussed, no refusal grounds apply to decisions ordering the return of a child or those ordering access to a child; see for a detailed discussion 2.2.5, below.

\subsubsection{Concluding remarks}

Under the Brussels I bis Regulation and other instruments of EU civil justice cooperation, recognition or enforcement may only be refused on the basis of a limited number of grounds. Of these grounds, irreconcilability and incorrect service in default proceedings are only applicable under very specific circumstances - especially the latter has been limited in its practical value with the addition that it may not be relied upon unless the judgment debtor has done everything in his power to make himself heard. The public policy exception is the only

${ }^{151}$ CJEU Hoffman v. Krieg.

152 This is the situation covered by Article 45(1)(d) of Brussels Ibis and its equivalents.

${ }^{153}$ Article 24 of the Brussels IIbis Regulation explicitly forbids review of jurisdiction of the court of origin.

154 Article 45(3) Brussels I Regulation. This was affirmed by the CJEU in Krombach v. Bamberski, see the discussion under 3.2.5. 
ground for refusal that provides some room for interpretation, though the threshold has been set very high by the CJEU, as is discussed in the next Chapter.

The next sections discuss how the various regulations facilitate recognition and enforcement.

\subsubsection{The Brussels I bis Regulation}

The regime for recognition and enforcement under the Brussels I bis Regulation ${ }^{155}$ takes a step back from the radical 2010 Proposal. ${ }^{156}$ Brussels I bis abolishes the requirement for a declaration of enforceability, and therefore the judgment import aspect of the exequatur procedure; but the grounds for refusal, and the mechanism for invoking them, remain the same. In fact, a ground for refusal has been added, with the inclusion of a breach of the jurisdiction rules in employment cases as laid down in Section 5 of Chapter II of the Regulation, improving legal protection for employees.

\subsubsection{Steps required to achieve enforcement under Brussels I bis}

The new regime for recognition and enforcement takes place over four procedural steps. ${ }^{157}$ As under Brussels I, recognition of a judgment from one Member State in the other Member States is automatic (Art. 36(1)). Article 39 provides that "a judgment given in a Member State which is enforceable in that Member State shall be enforceable in the other Member States without any declaration of enforceability being required". To streamline the process of cross-border enforcement, Article 42 prescribes the documents that need to be submitted to the enforcement authority. It provides that, at the request of any interested party, the court of origin shall first issue a certificate (Art. 42) using the form set out in Annex I (Art. 53). The purpose of this certificate is to certify that the decision is indeed enforceable, as well as providing information as to the costs of the procedure and interest. Next, the judgment creditor must submit this certificate to the enforcement authority along with a copy of the judgment which satisfies the conditions necessary to establish its authenticity (Art. 42(2)).

According to Article 43, the certificate shall then be served on the defendant in reasonable time before the first enforcement measure, along with the judgment itself if it has not yet been served. The purpose of this provision is to inform the person against whom enforcement is

\footnotetext{
155 See for a general discussion Nielsen (2013) p. 524-528; Zilinsky (2014); Hazelhorst and Kramer (2013); Kramer (2013); Cadet (2013).

${ }^{156}$ As Section 2.2.2 discussed, the 2010 Proposal included, alongside the abolition of the exequatur a narrowing of the grounds for refusal. The public policy exception was to be replaced with a more narrow reference to 'fundamental principles underlying the right to a fair trial'. The 2010 Proposal also included a redistribution of the authority to apply refusal grounds between the Member State of origin and the Member State of enforcement: the ground for refusal of undue service upon the defendant in case of a default judgment (Article 34 (2) of Brussels I) would be applicable only in the Member State of origin.

${ }^{157}$ See for a general discussion Nielsen (2013); Beraudo (2013).
} 
sought of the enforcement of a judgment given in another Member State (Recital 32). If the defendant so requires he may request a translation of the certificate (Art. 42(3)).

It should be noted that the certificate is not comparable to an EEO, since its provision is not conditional on certain minimum requirements having been fulfilled. The certificate serves only to provide the enforcement authority in the Member State where enforcement is sought with relevant information about the judgment; it does therefore not as such constitute "permission" to enforce a judgment in another Member State. The function of the certificate is to aid communication between the court of origin and the enforcement authorities in the Member State of enforcement; it does not as such constitute an enforceable title.

Finally, the judgment creditor must present the required documents to the enforcement authority in the Member State in which enforcement is sought, which may then take measures in order to enforce the judgment. According to Article 41 of the Regulation, the law of the Member State of enforcement shall govern enforcement. This provision likely leaves room for enforcement disputes that are provided for by national law, since the provision does not substantively differ from its equivalent provision under the Brussels I Regulation. On this provision the CJEU ruled in Prism Investments that it did not exclude national enforcement disputes on grounds not included in the Regulation, despite the limitative system of grounds for refusal. ${ }^{158}$

\subsubsection{Grounds for refusal}

The grounds for refusal are laid down in Article 45, which is found in Section 3, subsection 1, entitled "Refusal of recognition". Evidently, the grounds of refusal can be invoked to oppose recognition, thus reversing the 2010 Proposal that limited the use of grounds for refusal only to the enforcement of judicial decisions.

According to Article 45(1) recognition shall be refused:

a) if such recognition is manifestly contrary to public policy (ordre public) in the Member State addressed;

b) where the judgment was given in default of appearance, if the defendant was not served with the document which instituted the proceedings or with an equivalent document in sufficient time and in such a way as to enable him to arrange for his defence, unless the defendant failed to commence proceedings to challenge the judgment when it was possible for him to do so;

c) if the judgment is irreconcilable with a judgment given between the same parties in the Member State addressed;

d) if the judgment is irreconcilable with an earlier judgment given in another Member State or in a third State involving the same cause of action and between the same parties,

${ }^{158}$ Hazelhorst and Kramer (2013). 
provided that the earlier judgment fulfils the conditions necessary for its recognition in the Member State addressed; or

e) if the judgment conflicts with:

(i) Sections 3, 4 or 5 of Chapter II where the policyholder, the insured, a beneficiary of the insurance contract, the injured party, the consumer or the employee was the defendant; or

(ii) Section 6 of Chapter II.

The grounds for refusal have thus remained the same as under the Brussels I Regulation, apart from article 45(1)(e), which has extended the categories of jurisdiction rules whose obedience is required to Section 5 of Chapter II, which includes special jurisdiction rules in employment cases and thus creates additional legal protection for employees, the weaker party that this section is designed to protect.

According to Article 46, enforcement may be refused when one of the grounds for refusal of Article 45 is found to exist. The application for refusal of enforcement shall be submitted with the court that the Member State concerned (that is, the Member State where enforcement is sought) has communicated to the European Commission as being authorized to examine such requests. As under the Brussels I Regulation, all grounds for refusal must be examined by a court - not an enforcement authority, as Article 45(2) of the 2010 Proposal would have it - in the Member State of enforcement. The division of tasks between courts in the Member State of origin and that in the Member State of enforcement as originally proposed, which was so severely criticized, has therefore been abandoned.

\subsubsection{Complete free movement of judgments: the Maintenance Regulation}

The Maintenance Regulation demonstrates the simplest approach towards the abolition of exequatur. This Regulation, which is of great practical importance, has abolished exequatur for decisions concerning maintenance obligations ${ }^{159}$ for states that have adopted the 2007 Hague Protocol to the Maintenance Convention. ${ }^{160}$ This means that for the enforcement of judgments that fall within the remit of this Regulation, declaration of enforceability is required. ${ }^{161}$ There are also no possibilities of opposing recognition or enforcement of such judgments, except in the case of irreconcilability. ${ }^{162}$ It does, however, provide for a review procedure in case the

\footnotetext{
159 Council Regulation (EC) 4/2009 of 18 December 2009 on jurisdiction, applicable law, recognition and enforcement of decisions and cooperation in matters relating to maintenance obligations, OJ L7/1 (the 'Maintenance Regulation'). According to the Proposal, the reasons for proposing abolition of exequatur were 1) simplifying the citizen's life, 2) strengthening legal certainty, and 3) ensuring effectiveness and continuity of recovery. See Proposal for a Council Regulation on jurisdiction, applicable law, recognition and enforcement of decisions and cooperation in matters relating to maintenance obligations, COM(2005) 649 final, p. 4-6.

160 Protocol of 23 November 2007 on the Law Applicable to Maintenance Obligations, concluded in the framework of The Hague Conference on Private International Law. All EU Member States and Serbia have ratified this Protocol.

${ }^{161}$ Article 17 Maintenance Regulation.

162 Article 21(2) Maintenance Regulation.
} 
defendant was not served with the document instituting the proceedings in such a manner as to allow him to prepare for his defence, or when he was prevented from doing so by reason of force majeure or other extraordinary circumstances without any fault on his part, unless he forewent his opportunity to challenge the decision (Art. 19(1)). Unlike the second-generation instruments, however, the Regulation does not contain minimum standards as to the way in which service is to be effected.

The Regulation does not, as the Brussels II bis Regulation does, require that a judgment be certified in its state of origin before it can be enforced. According to Articles 20(1) and (2) of the Maintenance Regulation, all the creditor needs to do in order to enforce a maintenance order is to submit a copy of the judgment and an extract from it which is provided by the court of origin (Annex A to the Regulation). There is therefore no control of compliance with any standards regarding service of documents or otherwise.

The Maintenance Regulation thus allows for complete free movement of decisions pertaining to maintenance. It is remarkable that all refusal grounds have been abolished for these decisions, because as Chapter 3 discusses, practice shows that the public policy exception was invoked in maintenance cases many times when these cases still fell within the remit of the Brussels I Regulation, at least once successfully. ${ }^{163}$

\subsubsection{Automatic enforcement with minimum standards under the Brussels II bis Regulation}

The Brussels II bis Regulation governs the recognition and enforcement of judgments concerning parental responsibility and those concerning divorce, legal separation or parental responsibility. Under this Regulation, recognition also does not require any special procedure (Art. 21(1)). It is, however, possible to oppose recognition under Brussels II bis (Art. 21(3)). The reason why this is possible is that recognition of the judgments that fall within the material scope of this Regulation may have far-reaching legal effects. For example, automatic recognition of a judgment granting divorce would enable an interested party to claim maintenance on the basis of that judgment. Article 28(1) requires a declaration of enforceability for judgments concerning parental responsibility. As under the Brussels I Regulation, neither the party against whom enforcement is sought, nor the child concerned, may make submissions at this stage (Art. 31(1)). Since judgments concerning divorce, separation or annulment do not require enforcement, no exequatur exists for these judgments. Finally, it should be pointed out that Brussels II bis does not contain an exequatur procedure for judgments concerning access rights (Art. 41(1)) and ordering the return of a child (Art. 42(1)). Chapter 3 discusses the practical consequences of this arrangement.

${ }^{163}$ See Chapter 3.2.6.1. 
To understand the changes brought about by the Brussels II bis Regulation, it must be considered in comparison with the 1980 Hague Convention on the Civil Aspects of International Child Abduction ${ }^{164}$ (hereinafter: the 1980 Convention), which applies in the EU alongside Brussels II bis. ${ }^{165}$ The 1980 Convention provides a uniform rule on the conditions governing the return of an abducted child. Article 12 of the 1980 Convention requires the state to which the child was abducted to order the return of the child 'forthwith'. Article 13(1) provides that that state may refuse to order the return of the child if:

a) the person, institution or other body having the care of the person of the child was not actually exercising the custody rights at the time of removal or retention, or had consented to or subsequently acquiesced in the removal or retention; or,

b) there is a grave risk that his or her return would expose the child to physical or psychological harm or otherwise place the child in an intolerable situation.

The rule is therefore that an abducted child should be returned to its state of habitual residence without any delay, unless one of the grounds for refusal applies. The defences, especially the 'grave risk defence', should be interpreted restrictively, ${ }^{166}$ in order to discourage abductors from claiming it too freely simply to gain time.

The most important innovation when compared to the 1980 Convention is the reform of the enforcement regime of judgments requiring the return of a child. As explained above, under the 1980 Convention it was the court in the state to where the child was abducted which was obliged to order the child's return (Art. 12), retaining the possibility to refuse such an order on the grounds of Article 13. Under the Brussels II bis Regulation, this system is replaced with one where the court of the Member State where the child was habitually resident should order his or her return; the Member State to where the child was abducted should then, on the basis of mutual recognition, enforce this order, without any possibility of refusing its enforcement. ${ }^{167}$ Any discretionary powers to decide on the return of the child lie with the Member State where the child was habitually resident prior to the abduction.

There are therefore no grounds in the Regulation on which the court in the Member State to where the child was abducted may refuse enforcement of a return order. It is important to note that the procedure of Articles 12 and 13 of the 1980 Convention remains applicable within the EU, but that a number of rules within Brussels II bis curtail its application. Article 11(4) of Brussels II bis provides that return may not be refused on the basis of Article 13(b) of the 1980

\footnotetext{
${ }^{164}$ Convention of 25 October 1980 on the Civil Aspects of International Child Abduction.

${ }^{165}$ Because the 1980 Convention remains in force within the EU, the following discussion on the child abduction regime in the EU refers where relevant also to that Convention. See also Article 62(2) of Brussels IIbis that provides that "The conventions mentioned in Article 60, in particular the 1980 Hague Convention, continue to produce effects between the Member States which are party thereto" unless the Brussels IIbis Regulation takes precedence.

166 Pérez-Vera (1982) para. 34.

${ }^{167}$ Article 41(1)) and 42(1) Brussels IIbis Regulation. Note that this only applies to those States that have ratified the 2007 Protocol to the Hague Convention on the law applicable to maintenance obligations: Protocol of 23 November 2007 on the Law Applicable to Maintenance Obligations.
} 
Convention if it is established that adequate arrangements have been made to secure the protection of the child after his or her return. Furthermore, a court cannot refuse to return a child unless the party that requested his or her return has been heard (Art. 11(5)). Finally, and vitally, Article 11(8) of Brussels II bis provides that a refusal by a state on the basis of Article 131980 Convention can be trumped by a subsequent judgment requiring the return of a child from the Member State with jurisdiction (i.e., the state of habitual residence of the child prior to the abduction). Such a subsequent judgment is immediately enforceable throughout the EU pursuant to Article 42(1) of the Regulation once it has been certified by the court that ordered it. To safeguard the rights of the parties involved, as well as those of the child, the court is required to check whether they were given an opportunity to be heard prior to issuing the certificate. With this arrangement, the possibilities for Member States to where a child has been abducted to refuse return are therefore severely curtailed when compared to the 1980 Convention.

According to the Explanatory Memorandum to the Proposal for this Regulation, ${ }^{168}$ the decision to abolish exequatur for return orders was made on the basis of a French initiative. ${ }^{169}$ This initiative stated as reasons that the right of a child to maintain contact with both parents after a separation must be protected, while the parent with custody must also be guaranteed that the child will return. ${ }^{170}$ While the French proposal only proposed abolition of exequatur for judgments concerning rights of access, ${ }^{171}$ the Regulation abolished it for both these judgments and those ordering the return of a child. For these judgments, no declaration of enforceability is needed: such a judgment may be enforced immediately once it has been certified as being enforceable by the judge of origin. It has rightly been pointed out that because it was only achieved for these two categories of decisions, abolition of exequatur in family law has a very limited scope, ${ }^{172}$ but as already mentioned, it is seen as a step along the way.

The certification of the judgment by the judge of origin has thus replaced the role of the declaration of enforceability for these judgments. Articles 41(2) and 42(2) contain certain minimum requirements that must be fulfilled before the judge of origin may issue a certificate. For judgments concerning rights of access, the judge must make sure that (a) if the judgment was given in default, the person defaulting was given sufficient opportunity to defend him or herself, or accepted the decision unequivocally; (b) that all parties were given the opportunity to be heard; and (c) the child was given an opportunity to be heard, unless such a hearing was considered inappropriate due to the child's age or degree of maturity. For judgments ordering

\footnotetext{
${ }^{168}$ Proposal for a Council Regulation concerning jurisdiction and the recognition and enforcement of judgments in matrimonial matters an in matters of parental responsibility repealing Regulation (EC) No 1347/2000 and amending Regulation (EC) No 44/2001 in matters relating to maintenance, COM (2002) 222 final/2, p. 2.

${ }^{169}$ Initiative of the French Republic with the view to adopting a Council Regulation on the mutual enforcement of judgments on rights of access to children, OJ C 234/7.

${ }^{170}$ Initiative of the French Republic with the view to adopting a Council Regulation on the mutual enforcement of judgments on rights of access to children, OJ C 234/7, recitals 3 and 13.

${ }^{171}$ In order to ensure the return of a child to its state of residence, the initiative proposed that the authorities in the state where the child is staying order the prompt return on the application of the parent with custody. Articles 10 and 11 ,

172 Boele-Woelki and Gonzàlez Beilfuss (2007) p. 7.
} 
the return of a child, the Regulation also requires that the child and parents were given an opportunity to be heard (Art. 42(2)(a) and (b)) and that the court has taken into account in issuing its judgment the reasons for and evidence underlying the order pursuant to Article 13 of the 1980 Hague Convention on Child Abduction.

Certification is done using standardized forms that are attached to the Regulation by way of Annexes (Annex III and IV). These certificates are very simple in that they only require the court to fill out some information such as the names and addresses of the parties concerned, and check some boxes saying that the minimum requirements have been observed.

It is therefore not the case that a judgment can be enforced immediately once it has been delivered: it is still necessary to request a certificate from the court that rendered the judgment. However, the certification mechanism differs considerably from the procedure for obtaining a declaration of enforceability. The most significant difference is of course that a certificate is issued by the court of origin. This not only removes the cross-border element of the exequatur procedure, but by leaving this responsibility with the court of origin, also the opportunity of control by a court which was not involved in the original proceedings.

Second of all, while the court of origin is required to check that the minimum requirements have been satisfied, there is no possibility for appeal if these requirements are thought to have been violated. It is thus entirely the court of origin's responsibility and prerogative to check whether they have been complied with (Art. 43(2) of the Regulation). That this arrangement should be observed strictly was confirmed by the ECJ in its judgment in Zarraga, ${ }^{173}$ which is discussed in the following Chapter.

It can be concluded that since the Regulation contains no requirement of a declaration of enforceability and no possibility to oppose enforcement in the Member State of enforcement the Brussels II bis Regulation allows for nearly complete free movement of judgments concerning rights of access and those ordering the return of a child. By introducing minimum standards that are checked by the court of origin, it has however retained some of its inspection function. The approach taken in this Regulation is therefore less radical than that chosen in the Maintenance Regulation. As Section 2.2.4.2 discussed, in its 2014 Report on Brussels II bis, the Commission recommended extending the abolition of exequatur, in combination with the appropriate safeguards to take the place of refusal grounds.

\subsubsection{Automatic enforcement with minimum standards under the European Enforcement Order}

${ }^{173}$ CJEU Case C-491/10 PPU Joseba Andoni Aguirre Zarraga v Simone Pelz ECLI:EU:C:2010:828. 
The Regulation creating the EEO was introduced in 2004. ${ }^{174}$ This Regulation seeks to facilitate the cross-border enforcement of uncontested claims. If a claim is uncontested within the meaning of this Regulation, ${ }^{175}$ the court of origin may certify its decision as an EEO provided certain minimum standards are fulfilled. The certified decision can then be enforced throughout the EU. The certification as an EEO is an administrative procedure during which the judgment debtor is not heard. By means of compensation, the Regulation contains minimum standards relating to service of documents and provision to the debtor of due information about the claim, ${ }^{176}$ which the court of origin is required to check before issuing the certificate. In essence, the EEO thus places the responsibility for judgment inspection with the court of origin of the judgment. If these minimum standards have not been complied with, such non-compliance can be cured if it is proven that the debtor has failed to challenge the judgment even though he was able to do so (Art. 18(1)). If this is not the case, the judgment certified may be reviewed in the Member State of origin if (a) the debtor was not served with the documents in such a way to allow him to arrange for his defence, or (b) he was not able to object to the claim by reason of force majeure, in either case provided that he acts promptly (Art. 19(1)).

As a judgment certified as an EEO, or a decision resulting from one of the two autonomous procedures, is immediately enforceable in all other Member States, a court or other judicial authority in the Member State of enforcement has no authority to review it in any way. All three instruments contain an article explicitly stating that exequatur has been abolished and that the decision in question "shall be recognized and enforced in the other Member States without the need for a declaration of enforceability and without any possibility of opposing its recognition". ${ }^{177}$ The regulations therefore also do not contain any of the traditional grounds for refusal such as public policy review. The only ground on which enforcement may be refused is irreconcilability with an earlier judgment in the state of enforcement, but the reason why this ground remains is less to do with ideology than with the fact that enforcing two irreconcilable judgments is a logical impossibility.

\footnotetext{
${ }^{174}$ See for a discussion of the instrument Bittman (2008); Zilinsky (2005); Zilinsky (2006).

175 According to Article 3(1) of the EEO Regulation, a claim shall be regarded as uncontested if (a) the debtor has expressly agreed to it by admission or by means of a settlement which has been approved by a court or concluded before a court in the course of proceedings; or (b) the debtor has never objected to it, in compliance with the relevant procedural requirements under the law of the Member State of origin, in the course of the court proceedings; or (c) the debtor has not appeared or been represented at a court hearing regarding that claim after having initially objected to the claim in the course of the court proceedings, provided that such conduct amounts to a tacit admission of the claim or of the facts alleged by the creditor under the law of the Member State of origin; or (d) the debtor has expressly agreed to it in an authentic instrument.

${ }^{176}$ Article 16 EEO Regulation.

${ }^{177}$ EOP Regulation, Article 19; ESCP Regulation, Article 20(1); EEO Regulation, Article 5.
} 


\subsubsection{Automatic enforcement on the basis of common rules in the uniform procedures}

The EEO for uncontested claims paved the way for two autonomous harmonized EU instruments, the EOP and the ESCP.

The EOP is aimed at swift and efficient recovery of outstanding debts "over which no legal controversy exists". ${ }^{178}$ It can be characterized as a one-step procedure or as a primarily administrative nature, since all that is required from the claimant is to fill in a number of standard forms concerning information about the claim and a description of the evidence. On the basis of the information provided, a court then issues an order for payment. While there is some uncertainty as to the extent to which the court will review the case on the merits, ${ }^{179}$ the possibility to have the application reviewed through an automatic procedure (Art. 8) appears to preclude a thorough examination of the merits. This means that an EOP can be obtained fairly easily. It is then served on the defendant, and it becomes the defendant's responsibility to oppose the order for payment if he deems it to be wrongfully granted. If no statement of opposition is lodged, the order is declared enforceable, and since the Regulation has abolished the exequatur (Art. 19), there is no possibility of opposing its enforcement in other Member States. This arrangement clearly favours the claimant, requiring the defendant to take action to oppose the Order to prevent it being enforced against him. To compensate this, the Regulation provides for a review procedure in the Member State of origin for cases in which the defendant was not served with the order in such a manner to allow him to arrange for his defence (Art. 20(1)); or when the order for payment "was clearly wrongly issued, having regard to the requirements laid down in this Regulation, or due to other exceptional circumstances". The Regulation does not further explain what "exceptional circumstances" are or when an order may be considered to have been "clearly wrongly issued". It has been pointed out that this leaves a lot of room for interpretation, ${ }^{180}$ but given the "exceptional" nature of the review, a limited application seems appropriate. ${ }^{181}$

The ESCP is the only real adversarial procedure of the three instruments and works in much the same way as corresponding procedures under national law. ${ }^{182}$ The claimant lodges his claim with the competent court in the Member State of his choosing. The claim form, which must

\footnotetext{
${ }^{178}$ EOP Regulation, Recital 6.

${ }^{179}$ Article 8 does not make clear whether the claim is to be reviewed on the merits. Recital 16 of the Regulation provides that the court reviews the claim on the basis of the information provided by the claimant, which would allow it to review prima facie the merits of the claim and inter alia to exclude any unfounded or unmeritorious claims, yet goes on to state that "the examination should not need to be carried out by a judge". This, combined with the provision in article 8 that the examination may be conducted automatically, appears to rule out a thorough examination of the merits. See Kramer (2010) p. 24.

${ }^{180}$ Kramer (2010) p. 26.

${ }^{181}$ Kramer (2007) p. 47-49 and Kramer (2009) p. 101-103.

${ }^{182}$ See for an analysis Kramer (2008a); Kramer (2008b).
} 
include a description of the evidence, is served on the defendant, who may then submit a response. After having received this response and, if necessary, after an oral hearing, the court decides on the claim. Appeal is only possible if the law of the Member State in question provides for it. As under the EOP and EEO Regulations, review is possible if the defendant can show that he was not served with the order in such a manner to allow him to arrange for his defence (Art. 18(1)). In December 2015, a regulation was adopted which widened the scope of the review procedure for the ESCP Regulation. ${ }^{183}$ This amendment is discussed in Chapter $8 .{ }^{184}$

By providing a - wholly European - alternative to existing national procedures and instruments, the ESCP, EOP and EEO Regulations adopt a new approach towards facilitating cross-border litigation and are therefore seen as "second-generation instruments". ${ }^{185}$ All three result in a title which is immediately enforceable throughout the EU, and which cannot be reviewed across borders; the authority thus lies with the court of origin. Apart from irreconcilability, all grounds for refusal have been replaced with minimum requirements that are checked by the court of origin. As no declaration of enforceability is required and no crossborder check of any kind is possible, the judgment import as well as the judgment inspection function of exequatur have been truly left behind under these instruments. The abolition of exequatur and, in particular, the abandonment of public policy review under these instruments have been criticized in literature, ${ }^{186}$ though as these objections relate more generally to the abolition of exequatur in EU legislation, they are discussed in Chapter 3.2.7 along with other criticisms on this development.

\subsubsection{Interim conclusion: the significance of the reforms for fundamental rights protection}

The previous sections have shown that it is difficult to detect a consistent approach towards the abolition of exequatur. The solutions chosen range from complete abolition of exequatur (the Maintenance Regulation) to abolition with some safeguards, checked by means of certification (Brussels II bis) to autonomous procedures, including minimum standards, which aim to replace (EEO) or circumvent (ESCP and EOP) the exequatur.

What is especially remarkable is that the EEO Regulation has as of yet still to be evaluated by the European Commission. An evaluation of the abolition of exequatur under this instrument would have provided valuable information on the practical consequences this has had. The fact that the EEO Regulation has not been evaluated is especially regrettable because this instrument was used to clear the way for the abolition of exequatur on a larger scale. The

\footnotetext{
${ }^{183}$ Regulation (EU) 2015/2421 of the European Parliament and of the Council of 16 December 2015 amending Regulation (EC) No 861/2007 establishing a European Small Claims Procedure and Regulation (EC) No 1896/2006 creating a European order for payment procedure, OJ L 341/1.

${ }^{184}$ Article 18 ESCP Regulation, as amended by Regulation 2015/2421. See Chapter 8.5.2.

${ }^{185}$ Kramer (2011a) p. 633.

${ }^{186}$ Van der Grinten (2006); Van Bochove (2007); Cuniberti (2007-2008).
} 
Maintenance Regulation, which achieved the most radical reforms, has also not yet been evaluated, though its evaluation is not due until 2016 (Art. 74).

In conclusion, the only element all instruments have in common is the abolition of cross-border control of judicial decisions (save under certain "exceptional circumstances" under the EOP Regulation). Whether this element in itself has protective value is discussed in Chapter 3.

\subsection{Conclusion}

Free movement of judgments is essential to guaranteeing legal certainty, which is important to individual litigants, but also to the European legal order as a whole. Effective cross-border enforcement of civil judgments protects not only judgment creditor's right to enforcement but also, in the greater scheme, creates faith in the efficiency of the justice system, which in turn stimulates intra-EU trade and other types of legal relationships. However, it was shown that efficiency of cross-border enforcement needs to be, and has been, combined with effective protection of debtor's procedural rights as well. The next Chapter explains in detail why such safeguards are necessary to protect debtor's rights. This Chapter showed that traditionally the grounds for refusal of recognition and enforcement acted as safeguards, but that these have been progressively abolished by the EU legislature as a result of the introduction of mutual recognition. The various regulations achieved this abolition in different ways, ranging from an abolition of exequatur combined with a retention of refusal grounds (Brussels I bis) to a complete abolition of both the exequatur and the refusal grounds (the Maintenance Regulation). The adoption of uniform European procedures, the ESCP and the EOP, but also the provisional instrument of the EAPO, shows the European legislature's innovativeness and willingness to move beyond the traditional modes of cooperation in civil justice. 


\section{Protection of fundamental rights by EU instruments on cross-border recognition and enforcement}

\subsection{Introduction}

This Chapter discusses why the simplification of the European Union (EU) regime for recognition and enforcement of civil judgments is important to the protection of the fundamental rights of EU citizens.

It starts by discussing the role of the public policy exception, which is arguably the primary tool for addressing fundamental rights violations in the context of cross-border recognition and enforcement. The previous Chapter showed that a large number of EU instruments abolished the public policy exception, ${ }^{1}$ while the Brussels I bis Regulation retained it after its proposed abolition was met with severe criticism. ${ }^{2}$ This Chapter goes deeper into the question of why the abolition of public policy was so controversial. It begins by discussing the public policy exception in its wider political and legal context (Section 3.2). It argues that the value of the public policy exception lies in its flexibility, its deference to national definitions of public policy and the fact that it protects against systemic failures. Next, the functioning of the public policy exception in instruments of EU private international law is explained to show how this protection is effected in practice.

The scope of this Chapter is wider, however, than the role of the public policy exception in the protection of fundamental rights. Section 3.3 explains how other grounds of refusal also perform this role: namely, the possibility of refusal of recognition in case of ineffective service, the review of jurisdiction in certain cases, and the requirement to hear the child and the parents included in the Brussels II bis Regulation. Recent regulations that have abolished exequatur have also abolished these grounds for refusal. Though their abolition has not proved as politically controversial as the abolition of public policy review, the role of these grounds in the protection of fundamental rights needs to be considered.

Section 3.4 discusses whether the cross-border review of civil judgment that refusal of recognition or enforcement entails is valuable in and of itself. This is an important question, because the EU instruments that abolished cross-border checks replaced them with common ('minimum') standards that are to be checked by a court in the Member State of origin of the judgment. It is discussed whether such home-state control is as effective a remedy for fundamental rights violations as refusal of enforcement by the state where recognition or enforcement is sought.

\footnotetext{
${ }^{1}$ Chapter 2.3.3 onwards.

${ }^{2}$ Chapter 2.2.2.
} 
Section 3.5 shows the relevance of this question by examining recent case law of the European Court of Justice (ECJ) and the European Court of Human Rights (ECtHR) in cases where exequatur has been abolished. The Court of Justice of the European Union's (CJEU) judgment in Zarraga shows the possible consequences for fundamental rights protection if a court in the Member State of enforcement is no longer allowed to exercise any control on a foreign judgment because refusal grounds have been abolished (in this case under the Brussels II bis Regulation).

\subsection{The role of the public policy exception in the protection of fundamental rights}

As Chapter 2 explained, the move towards complete free movement of civil judgments within the EU was met with severe criticism regarding the possible consequences for fundamental rights protection, particularly in the context of the recast of the Brussels I Regulation. These concerns primarily centered on the abolition of the public policy exception, ${ }^{3}$ because, as will be shown, the public policy exception can play a vital role in the protection of fundamental rights. ${ }^{4}$ The Brussels I bis Regulation retains a public policy exception, after a proposal to reduce its scope was met with fierce academic and political criticism. ${ }^{5}$ Many other instruments have abolished refusal grounds however, including public policy. This development has been criticized on the grounds that the public policy exception allowed Member States to refuse enforcement of judgments that constituted fundamental rights violations, and that its abolition therefore creates a risk that such judgments could circulate across the EU without any possibility to prevent them from taking effect. This section therefore shows how the public policy exception has acted as a remedy for violations of fundamental rights.

\subsubsection{The concept of public policy}

To understand the link between public policy and fundamental rights, it is first necessary to define the concept and to explore its scope. Public policy, in the context of private international law, essentially refers to the fundamental principles underlying the legal order where a foreign law or foreign decision is to take effect. Public policy is used to avoid unacceptable results (in

\footnotetext{
${ }^{3}$ See the literature discussed under 3.2.7.

${ }^{4}$ See in general Callsen (2011); Vlas (2013); Kinsch (2004); Kinsch (2011) p. 44-45; Fawcett (2007); Schilling (2012); Oster (2015); Wurmnest (2016).

${ }^{5}$ Chapter 2.2.2.
} 
the view of the local forum) that would arise from the acceptance into the legal order of a foreign decision or foreign law. ${ }^{6}$

In a recent and extensive exploration of the concept's meaning in the EU, Corthaut defines public policy as "the complex of norms at the very heart of a political entity expressing and protecting the basic options taken by that entity in respect of its political, economic, social and cultural order". 7 This definition expresses the diversity of norms and principles which public policy may encompass. Public policy is clearly a living concept, whose content may evolve according to time and place. ${ }^{8}$

What is also important is that this definition may apply to any political entity: a state quite clearly constitutes a political entity, but so does a political organisation like the EU. This means that in the multilevel and pluriform structure of EU public policy has a unique role: while it exists at the Member State level, the EU, being a political entity founded on common values, must also necessarily have its own concept of public policy. ${ }^{9}$

Public policy plays a role in the internal legal order of many states, but it also plays a role in defining relationships between states. In private international law, states may apply public policy as a ground for refusing the recognition of foreign judgments, or against the application of foreign law that is deemed contrary to public policy. When a state applies public policy in this manner, it essentially imposes its national values on acts of foreign states. This form of public policy is therefore referred to as external public policy (ordre public externe) and is much narrower than the concept of public policy that states might apply internally. ${ }^{10}$ Within the EU, external public policy has taken on a new dimension by defining the relationship between the Union and its Member States. For instance, under the Treaties, public policy is one of the grounds Member States may invoke to block the application of free movement law. ${ }^{11}$ A recent, and much discussed, example of a case where national public policy was applied to limit the free movement of services is Omega, ${ }^{12}$ in which the CJEU held that the objective of protecting human dignity was a legitimate interest which justified a restriction of the

\footnotetext{
${ }^{6}$ Gebauer (2007) no. 1. In the European Union, Article 21 of the Rome I Regulation on the law applicable to contractual obligations, and Article 26 of the Rome II Regulation on the law applicable to non-contractual obligations, allow courts to refuse the application of a provision of foreign law "only if such application is manifestly incompatible with the public policy (ordre public) of the forum". Regulation (EC) No 593/2008 of the European Parliament and of the Council of 17 June 2008 on the law applicable to contractual obligations (Rome I) OJ L 177/6; Regulation (EC) No 864/2007 of the European Parliament and of the Council of 11 July 2007 on the law applicable to non-contractual obligations (Rome II) OJ L 199/40.

${ }^{7}$ Corthaut (2012) p. 15.

${ }^{8}$ Kessedjian (2007) p. 28. See for a more in-depth discussion of the concept Chapter 7.

${ }^{9}$ Corthaut (2012) p. 16.

${ }^{10}$ Van Hoek (2001) p. 1018.

11 Kessedjian (2007) p. 28; see articles 36 (free movement of goods) 45(3) (free movement of workers) 52 (freedom of establishment and to provide services) and 65 (1) (freedom of capital) of the Treaty on the Functioning of the European Union.

${ }^{12}$ CJEU Case C-36/02 Omega Spielhallen ECLI:EU:C:2004:614.
} 
obligations imposed by EU law. In this way, principles regarded as fundamental to Germany's legal order prevented provisions of EU law from taking effect.

Fundamental principles of EU law may also come within the scope of Member State's external public policy: in Eco Swiss China Time, ${ }^{13}$ the CJEU found that the EU prohibition on cartels was so fundamental that it should prevent the enforcement in an EU Member State of a Chinese arbitral award that contravenes this prohibition. In this case, principles of EU law were deemed to be part of Member State's public policy, and as such prevented the foreign arbitral act from taking effect.

Because public policy refers only to the most fundamental principles underlying a legal order, and because of the disruptive consequences its application may have,${ }^{14}$ external public policy is normally quite closely circumscribed. It is generally accepted that it may only be applied in exceptional cases. ${ }^{15}$ At the same time, it is important to stress that when public policy is applied to refuse recognition or enforcement of a foreign judgment, it is only the recognition or enforcement of that judgment which is deemed to be contrary to public policy, not the judgment as such. ${ }^{16}$ The effects of a decision that a judgment may not be recognised or enforced therefore are therefore confined to the state where enforcement is sought; it does not purport to prevent or reverse the foreign judgment. Still, in a EU that aims to harmonise and stimulate free crossborder movement of judgments, refusal of enforcement is in principle considered undesirable, and it is therefore not surprising that the CJEU has influenced the interpretation of the principle of public policy through its case law.

\subsubsection{Public policy and the European Convention on Human Rights}

Besides being interpreted by the CJEU, the content of public policy in the European states has been influenced by international human rights law, in particular by the European Convention on Human Rights (ECHR). In fact, the ECtHR has affirmed that the "Convention [is] a constitutional instrument of European public order (ordre public)." ${ }^{17}$ In this way the ECtHR has entrenched the values embodied in the Convention more firmly into the legal orders of the signatory states, enhancing its status.

A second consequence, however, is that external public policy has also come under the influence of the ECHR. In its judgment in Drozd and Janousek v. France and Spain, the ECtHR held that signatory states could be prevented from transferring prisoners on the basis of a foreign judgment if that judgment was the result of a "flagrant denial of justice", even if that

${ }^{13}$ CJEU Case C-126/97 Eco Swiss China Time Ltd vs Benetton International NV ECLI:EU:C:1999:269, paras. 36-37.

${ }^{14}$ As explained under 2.3.1.4.

${ }^{15}$ Corthaut (2012) p. 23.

${ }^{16}$ Franq (2016) p. 882.

${ }^{17}$ ECHR Loizidou v. Turkey (preliminary objections) appl. no. 15318/89, 1995, para. 75 
judgment was rendered in a non-signatory state. ${ }^{18}$ ECHR signatory states are therefore in certain circumstances required to prevent decisions from non-signatory states from taking effect, if that effect is likely to result in violations of Convention rights. In this way, the rights protected by the ECHR became part of the ECHR signatories' ordre public externe. In Drozd and Janousek and later cases the ECtHR was not however consistent on the question whether all (potential) violations of ECHR rights should lead to a refusal by the requested state to cooperate, or whether only certain very serious violations should give rise to such an obligation. This question of the appropriate yardstick gave rise to much discussion and is examined in Chapter 7. ${ }^{19}$

In some circumstances, this obligation applies also to the enforcement of foreign civil judgments, as the ECtHR ruled in Pellegrini. ${ }^{20}$ This case concerned the recognition in Italy of a marriage annulment granted by the Ecclesiastical Court of the Vatican. The applicant in this case appealed against the permission for enforcement granted by the Italian courts on the basis that she had not been adequately informed of the proceedings in the Ecclesiastical Court, so that her right to a fair hearing under Article 6(1) ECHR had been violated. The ECtHR ruled that its task in the matter was not to examine whether the Vatican courts had acted in conformity with article 6(1) ECHR, given that the Vatican is not a signatory to the Convention. Rather, it had to examine whether the Italian court had adequately reviewed whether the applicant's rights under the Convention had been observed prior to granting permission for enforcement. The ECtHR ruled that:

In these circumstances the Court considers that the Italian courts breached their duty of satisfying themselves, before authorising enforcement of the Roman Rota's judgment, that the applicant had had a fair trial in the proceedings under canon law. (para. 47).

In this judgment, the ECtHR thus imposes on national courts a duty to verify, prior to recognizing a foreign judgment, whether the right to a fair trial was adequately protected. However, the judgment refers explicitly to judgments emanating from states that have not ratified the ECHR, in this case the Vatican. ${ }^{21}$ This requires countries that are signatories to the ECHR to apply their obligations under the ECHR to acts of foreign (non-signatory) states, effectively extending the territorial reach of the ECHR. ${ }^{22}$ Importantly, the ECtHR did not attenuate the scope of Article 6(1) in Pellegrini; namely, it did not indicate that only "flagrant" violations of Article 6(1) should lead to refusal of recognition or enforcement. ${ }^{23}$

${ }^{18}$ ECHR Drozd and Janousek v France and Spain [GC], no. 12747/87, 1992; Lush (1993); De Schutter (2006) p. 202-204. See also the earlier Soering case: ECHR Soering v. United Kingdom [GC], no. 14038/88, 1989.

${ }^{19}$ Kinsch (2004) p. 210-211; Fawcett (2007) p. 3-5; Schilling (2012). See Chapter 5.2.

${ }^{20}$ ECtHR Pellegrini v. Italy, appl. no. 30882/96 ECHR 2001-VIII.

${ }^{21}$ See Kinsch (2004) p. 228.

${ }^{22}$ Fawcett calls this the "indirect effect" of article 6 ECHR: Fawcett (2007) p. 3-5.

${ }^{23}$ ECtHR Pellegrini, para. 47. See Briggs (2005) p. 187; Cuniberti (2008) p. 33-34. 
This raises the question of whether the obligation to refuse recognition or permission for enforcement under Pellegrini is limited to judgments from non-signatory states, or whether it also applies in the intra-EU context, where all Member States are by necessity signatories to the Convention. This question was debated during the recast process of the Brussels I Regulation. ${ }^{24}$ If an obligation to refuse enforcement of judgments that in some way infringe Convention rights could be inferred from Pellegrini, then complete free movement would deprive signatory states that are also EU Member States from the only available mechanism for fulfilling that obligation. Chapter 5.2 examines the Pellegrini judgment and later case law in more detail. It shows that the ECtHR applies a different framework in cases involving the enforcement of judicial decisions from one EU Member State in another on the basis of EU legislation: the Bosphorus doctrine. Thus, in light of this later case law, Pellegrini cannot be said to give rise to an obligation for EU Member States to refuse recognition or enforcement of judgments from other EU Member States if those judgments constitute a violation of one of the Convention rights.

This finding does not refute the conclusion that the ECtHR has entrenched Convention rights into the application of external public policy by its signatory states. Though a general obligation to refuse enforcement even to judgments emanating from EU Member States cannot be derived from Pellegrini, there is no doubt that Convention rights must play a part in a national court's decision to recognize or enforce a foreign judgment, as they are contained in their national public policy. That this conclusion holds for the recognition and enforcement of judgments under European instruments of civil procedure is clear from the CJEU's judgment in Krombach v. Bamberski, discussed in detail further on.

\subsubsection{The inclusion of a public policy exception in instruments of EU civil procedure}

The foregoing discussed the concept of public policy and its function in classical private international law in general terms. The following discusses more specifically some of the features of the public policy exception as included in instruments of EU civil procedure.

With regard to the protective function of the public policy exception, it is first of all worth noting that the public policy exception may only be examined when invoked by one of the interested parties. This was different under the 1968 Brussels Convention: under the Convention, the grounds for refusal could be invoked ex officio when deciding on the application for a declaration of enforceability (the judgment import stage). Brussels I forbade the examination of refusal grounds at the judgment import stage. Since Brussels I bis abolished the judgment import stage, grounds for refusal are only examined in the second, judgment

\footnotetext{
${ }^{24}$ Schilling (2011); Kinsch (2004) p. 228.
} 
inspection stage, if one of the parties applies for refusal of recognition or enforcement. ${ }^{25}$ Under Brussels II bis, refusal of recognition does appear to be applicable ex officio, since Articles 22 and 23 of that Regulation do not require that an interested party invoke the refusal grounds. The same applies to the Succession Regulation. ${ }^{26}$

A second limitation on the use of the public policy exception was introduced when the Brussels I Regulation came to replace the Brussels Convention. Since then, recognition or enforcement may only be refused when it would be manifestly against public policy. The Brussels Convention did not contain this qualification, which codifies the CJEU's interpretation of the public policy exception in its judgment in Krombach v. Bamberski, which is discussed later on. However, since it was already concluded that public policy by definition consists only of principles that are considered to be of fundamental importance, its function as a last resort in extreme cases was already apparent. This qualification was therefore not considered to substantially reduce the scope of the public policy exception. ${ }^{27}$

Finally it should be mentioned that the public policy exception under the European instruments has a residual function: it only applies in cases where the other, more specific, grounds for refusal do not apply. ${ }^{28}$

\subsubsection{Substantive and procedural public policy}

Public policy covers both procedural and substantive issues. The former concerns the substance of the judgment of which recognition or enforcement is requested; the latter concerns the procedure leading up to the delivery of that judgment. For the purposes of this thesis, which is concerned with the protection of the right to a fair trial in cross-border situations, the abolition of procedural public policy is clearly most relevant. The content of procedural public policy in relation to the right to a fair trial is the subject of Chapter 7. The substantive aspect of public policy is however also important in view of the protection of fundamental rights other than fair trial, and it is therefore worth briefly considering its application. ${ }^{29}$

Substantive public policy may be applied in cases where the outcome is considered to be contrary to fundamental principles or mandatory provisions of the Member State of enforcement, such as where damages were awarded on a legal basis that is not recognized in

\footnotetext{
${ }^{25}$ Chapter 2.3.3.2; Article 45, Brussels Ibis Regulation; Fitchen (2015) p. 437.

${ }^{26}$ Article 40, Succession Regulation.

${ }^{27}$ Franq (2012) p. 660. This is borne out by the 1999 Proposal which states that this adverb is intended to "underscore" the exceptional nature of the public policy exception (p. 23).

${ }^{28}$ CJEU Case 145/86 Hoffman v Krieg ECLI:EU:C:1988:6.

${ }^{29}$ For instance Dickinson (2011) p. 8.
} 
the Member State addressed. ${ }^{30}$ The leading European case on this matter is the CJEU's judgment in Renault/Maxicar, ${ }^{31}$ in which the party opposing enforcement (Maxicar) held that the French law on intellectual property rights that was applied in the judgment to be enforced was contrary to Community law. The CJEU decided, reiterating the relative character of public policy, that a mere difference in the law between the Member State of origin and that of enforcement, or an alleged error in that law, does not justify recourse to public policy: it is only the result of recognition or enforcement which can be considered to be contrary to public policy, not the law as such. In this case, enforcement could therefore not be considered to be contrary to public policy. ${ }^{32}$

Substantive public policy is applied only rarely, for two reasons. First, as Franq notes, is that the legal divergences between the EU Member States are rarely strong enough to bring about a contradiction with public policy. ${ }^{33}$ The second is quite obvious: the prohibition of review as to the substance of foreign judgments limits the situations in which a court may consider a contradiction to substantive public policy, as this prohibition precludes a court from examining the accuracy of the findings of law or facts which were made by the court of origin. A court may not refuse recognition or enforcement purely on the basis that it would have arrived at a different outcome; rather, it must assess whether the enforcement of the resulting judgment as it stands would be contrary to its country's public policy. The focus is thus on the outcome of the foreign procedure, not on the way that outcome was arrived at, and the criterion is whether this outcome as such infringes national public policy.

Substantive public policy therefore only applies in exceptional situations, and those in which fundamental rights may be at stake may be even rarer. It is however very much conceivable that such a situation may arise, especially in the context of family law, areas of which are

\footnotetext{
${ }^{30}$ Hess and Pfeiffer (2011) p. 152-153, have shown that European national courts have repeatedly refused enforcement of judgments in cases where damages were awarded on legal bases which were considered against public policy in the Member States of enforcement, for instance in cases concerning liability in employment relations. Other potential sources of application of substantive public policy are cases involving the award of punitive damages: see on this matter Vanleenhove (2016). Dickinson (2011) names a number of other topics that could be considered part of substantive public policy, including matters relating to freedom of religious expression or the status or activities of religious bodies, liability for wrongful conception or "wrongful life", disputes concerning the right to life or death and other questions of medical ethics, the use of gene technology and the operation of nuclear installations (p. 8-9). Other examples, such as disputes arising from trade in organs or questions on surrogacy, are imaginable.

31 CJEU Case C-38/98 Régie nationale des usines Renault SA v Maxicar SpA and Orazio Formento ECLI:EU:C:2000:225. See also the CJEU's more recent judgment in Diageo/Simiramida:CJEU Case C-681/13 Diageo Brands v Simiramida-04 EOOD ECLI:EU:C:2015:471; Hazelhorst (2016).

32 The relationship between this judgment and Eco Swiss/Benetton, in which the CJEU decided that principles of EU law were part of public policy was seen as unclear (Franq (2012) p. 664). The difference in treatment can however at least partly be explained by the fact that Eco Swiss/Benetton concerned the recognition of an arbitral award. Since arbitration tribunals cannot request preliminary rulings from the CJEU, refusal of enforcement is sometimes the only way of addressing the error in the application of EU law, since the CJEU cannot be relied on to correct the error. Vlas (2003) no. 6.

${ }^{33}$ Franq (2016) p. 883.
} 
governed by EU Regulations such as Brussels II bis. ${ }^{34}$ It has been proposed that the recognition of divorce judgments, or those concerning marital property, pertaining to same-sex couples in states where same-sex marriage is not permitted could be considered contrary to substantive public policy. Seen from the perspective of the ECHR, in these situations a conflict with the right to family life (Art. $8 \mathrm{ECHR}$ ) could arise. Likewise, the right to family life could be at risk within the context of the enforcement of judgments ordering the return of a child or those granting access to a child. The compatibility of the enforcement of a return order under Brussels II bis with the right to family life was at issue in the ECtHR's recent decision in Povse, ${ }^{35}$ though the question whether this could conflict with public policy could not be examined, because public policy as a ground for refusal no longer exists under this Regulation.

Substantive public policy falls outside the scope of this research, which concerns the right to a fair trial. As is shown below, the right to a fair trial is for the most part encompassed by the procedural aspect of public policy. Substantive and procedural aspects may however be closely connected. For example, the recent case Diageo/Simiramida ${ }^{36}$ entailed the recognition in the Netherlands of a Bulgarian judgment. According to the party that invoked the public policy exception, the Bulgarian judgment relied on an incorrect interpretation of EU law. In the procedure it was alleged that the Bulgarian courts had knowingly misapplied EU law. ${ }^{37}$ While the CJEU in casu rejected the argument, ${ }^{38}$ the case raises the question whether a wilful mistake in the application of substantive law, which would come within the remit of the substantive aspect of public policy, can violate procedural public policy at the same time, since it denies litigants an impartial and fair examination of their case.

\subsubsection{Interpretation by the Court of Justice of the European Union}

The CJEU consistently rules that public policy must only be applied in exceptional cases, as its application restricts the attainment of one of the fundamental objectives of the EU regime: the unfettered recognition and enforcement of civil judgments across borders within the EU. ${ }^{39}$

\footnotetext{
${ }^{34}$ See for instance Kiestra (2014) p. 307-317.

${ }^{35}$ CJEU Povse v. Austria [dec.] appl. no. 3890/11 ECHR 2013; see for an extensive discussion Chapter 5.

${ }^{36}$ CJEU Case C-681/13 Diageo Brands v Simiramida-04 EOOD ECLI:EU:C:2015:471. See Hazelhorst (2016).

37 CJEU Diageo/Simiramida, para. 53. The case also raises interesting questions concerning the relationship between Member State and European Union public policy in the context of recognition and enforcement; see d'Oliveira (2015) and d'Oliveira (2014).

${ }^{38}$ CJEU Diageo/Simiramida, para. 54.

${ }^{39}$ CJEU Case C-420/07 Apostolides v. Orams ECLI:EU:C:2009:271, para. 55; CJEU Case C-145/86 Hoffman v Krieg ECLI:EU:C:1988:61, para. 21; CJEU Case C-78/95 Hendrikman and Feyen / Magenta Druck \& Verlag ECLI:EU:C:1996:380, para. 23; CJEU Case C-302/13 flyLAL-Lithuanian Airlines, ECLI EU:C:2014:2319, para. 47.
} 
While the European Regulations refer to the public policy of 'the Member State addressed', the CJEU, as discussed, restricts its application by delineating its outer limits. ${ }^{40}$

The role of the public policy exception in the protection of the right to a fair trial was addressed by the CJEU in two important judgments: Krombach v. Bamberski ${ }^{41}$ and Gambazzi ${ }^{42}$ Both judgments concern cases in which the defendants were prevented from taking part in the proceedings by national procedural rules. These judgments therefore merit a detailed discussion.

The Krombach v. Bamberski case is not only remarkable for its significance in the interpretation of the public policy concept, but also for its facts. ${ }^{43}$ The case arose out of criminal proceedings. Dr. Krombach, a German doctor, was accused of having caused the death of a girl, Mr. Bamberski's daughter, who died after Mr. Krombach gave her an injection in Germany. The German prosecutor conducted an investigation but did not prosecute Mr. Krombach for lack of evidence, after which the Criminal Court in Paris (Cour d'Assises) took up the case, basing its jurisdiction on the French nationality of the victim (a ground for jurisdiction which was itself questioned during the CJEU proceedings). Mr. Krombach, afraid of being arrested if he entered French territory, did not appear in person before the Cour d'Assises but instead sent a lawyer on his behalf. The court nevertheless held him in contempt and convicted him in absentia of voluntary manslaughter. Additionally, it also decided on a civil claim brought by Mr. Bamberski, ordering Krombach to pay him FRF 350,000 as in compensation for the loss of his daughter. It was this judgment that Bamberski sought to enforce in Germany. Krombach appealed the declaration of enforceability granted by the German court at the Bundesgerichthof (BGH), complaining that he had had no opportunity to adequately defend himself before the French court. The BGH referred the question whether recognition of the judgment would be contrary to public policy as contained in Article 27(1) of the Brussels Convention (now Article 34(1) of the Brussels I Regulation) to the CJEU.

The CJEU reiterated that the public policy exception, being an obstacle to the free movement of judgments, should only be applied in 'exceptional cases'. It went on to elaborate on what circumstances would constitute such an exceptional case. It stated that recourse to the public policy exception would only be justified if recognition or enforcement of a foreign judgment would be,

at variance to an unacceptable degree with the legal order of the State in which enforcement is sought inasmuch as it infringes a fundamental principle. In order for the

\footnotetext{
${ }^{40}$ CJEU Case C-7/98 Dieter Krombach v André Bamberski ECLI:EU:C:2000:164, para. 21, and CJEU Renault v. Maxicar, para. 26.

${ }^{41}$ CJEU Case C-7/98 Dieter Krombach v André Bamberski ECLI:EU:C:2000:164; Van Hoek (2000).

42 CJEU Case C-394/07 Marco Gambazzi v. DaimlerChrysler Canada Inc. and CIBC Mellon Trust Company ECLI:EU:C:2009:219.

${ }^{43}$ Corthaut deems them "worthy of a novel": Corthaut (2012) p. 174.
} 
prohibition of any review of the foreign judgment as to its substance to be observed, the infringement would have to constitute a manifest breach of a rule of law regarded as essential in the legal order of the State in which enforcement is sought or of a right recognized as being fundamental within that legal order. ${ }^{44}$ (Emphasis added)

The CJEU then stressed the fundamental importance of the right to a defence and made clear that its violation may lead to a refusal of recognition or enforcement of a judgment:

[the right to a defence] occupies a prominent position in the organization and conduct of a fair trial and is one of the fundamental rights deriving from the constitutional traditions of the Member States. More specifically still, the European Court of Human Rights has on several occasions ruled in cases relating to criminal proceedings that, although not absolute, the right of every person charged with an offence to be effectively defended by a lawyer, if need be one appointed by the court, is one of the fundamental elements in a fair trial and an accused person does not forfeit entitlement to such a right simply because he is not present at the hearing. (para. 38 et seq.)

For that reason, the CJEU concluded that,

a national court of a Contracting State is entitled to hold that a refusal to hear the defence of an accused person who is not present at the hearing constitutes a manifest breach of a fundamental right. (para. 40)

The public policy exception may therefore be relied upon only when recognition or enforcement would constitute a manifest breach of an essential rule of law or fundamental right. The right to a defence is such a fundamental right, and the denial of an effective defence by a lawyer as punishment for not being present at the trial can be considered a manifest breach of that right, according to the CJEU. On the basis of its preliminary ruling the BGH therefore denied recognition of the French judgment. ${ }^{45}$

The CJEU's ruling in Krombach thus removes any doubt as to the public policy exception's relevance for fundamental rights protection. It makes clear that infringements of fundamental procedural rights may come within the remit of public policy, something that had previously been doubted, because Article 27(2) Brussels Convention (now Article 45(1)(b) Brussels I bis) already provided protection for procedural mistakes. ${ }^{46}$ Yet Krombach makes abundantly clear that the ground for refusal contained in that article, which only concerns situations in which the defendant was not adequately informed of the trial and did not use his right to appeal, only provides protection in a very narrow category of situations, which does not include Krombach. The defendant in this case was perfectly aware of the trial taking place and had sent a lawyer

\footnotetext{
${ }^{44}$ CJEU Krombach, para. 37.

${ }^{45}$ With the refusal to enforce the French civil judgment, the case of Krombach v. Bamberski was far from over; according to various media, Mr Bamberski took the drastic measure of kidnapping Mr Krombach and delivering him to French justice. See for an update Cuniberti, 'Dr Krombach's Final (?) Contribution to the European Judicial Area', http://conflictoflaws.net/2009/dr-krombachs-final-contribution-to-the-european-judicial-area/, 21 October 2009.

${ }^{46}$ Muir Watt (2001) p. 550.
} 
to defend him, yet was actively prevented from taking part in his trial by French procedural law.

What is also striking is that the CJEU in Krombach explicitly refers to the ECtHR's case law as a means of identifying which rights are considered fundamental and when their infringement can be seen as manifest so that it should lead to refusal of recognition or enforcement. The connection between public policy and fundamental rights as protected by the ECHR is therefore recognized also by the CJEU.

Not all procedural irregularities may be contrary to public policy, however. In Gambazzi, the CJEU explained what factors may count against the application of the public policy exception. This case originated from the Stolzenberg litigation concerning widespread fraud against Canadian pension funds and other trustees. One of the defendants was Mr. Gambazzi, a Swiss resident. The UK High Court of Justice delivered several orders against Mr. Gambazzi, including a freezing order (which restrained him from dealing with his funds) and a disclosure order (which instructed him to disclose some information concerning his assets and certain documents). Mr. Gambazzi did not comply with these orders, despite the High Court having made an order to exclude him from the further proceedings (debarment) unless he complied (the 'unless order'). Finally, the High Court considered him to be in contempt of court and excluded him from the hearing, after which he was ordered via judgment by default to pay substantial damages. When enforcement of the judgment was sought in Italy, he appealed on the basis that his right to a defence had been violated by his exclusion from the proceedings.

In its judgment, the CJEU was a little more nuanced than in its earlier judgment in Krombach, though it arrived at the same conclusion. It stated that the right to a defence occupies a 'prominent' position in the organisation and conduct of a fair trial and is laid down in the ECHR as well as the constitutional traditions of the Member States. However, it also stated that,

It should [...] be borne in mind that fundamental rights, such as respect for the rights of the defence, do not constitute unfettered prerogatives and may be subject to restrictions. However, such restrictions must in fact correspond to the objectives of public interest pursued by the measure in question and must not constitute, with regard to the aim pursued, a manifest or disproportionate breach of the rights thus guaranteed. ${ }^{47}$

While in Krombach the CJEU focused on the adequate protection of the right to a defence through the application of public policy, in Gambazzi it added weight to the other side of the balance, by distinguishing a number of factors that may justifiably restrict the rights of the defence. It stated that it is for the national court that decides on recognition or enforceability to investigate whether the defendant can be said to have enjoyed a fair trial, having regard to the proceedings as a whole in light of all relevant circumstances. The CJEU went on to state:

Following completion of such verification, it is for the national court to carry out a balancing exercise with regard to those various factors in order to assess whether, in

${ }^{47}$ CJEU Gambazzi, para. 29. 
the light of the objective of the efficient administration of justice pursued by the High Court, the exclusion of Mr Gambazzi from the proceedings appears to be a manifest and disproportionate infringement of his right to be heard. (para. 47)

The CJEU then provided some guidance for the national court to decide on the acceptability of the various orders that had been made against Mr. Gambazzi. The CJEU has been criticized for 'stating the obvious' and not assessing whether the debarment order in fact infringed Article 6 ECHR, instead deferring to the national court, ${ }^{48}$ whereas in Krombach it was more explicit. Others have pointed out that in Krombach the CJEU had access to directly relevant ECHR case law, whereas in Gambazzi it would have had to make its own autonomous interpretation, which is problematic from an institutional point of view. ${ }^{49}$ Though the reticence of the CJEU to give a definitive answer in this case is understandable from this point of view, it is nevertheless difficult not to see the debarment order as a violation of Mr. Gambazzi's right to a fair trial. The similarities with Krombach v. Bamberski are after all striking: in both cases, the defendants were prevented from taking part in their own trial, thereby denying them the essential guarantee of access to justice. While Mr. Gambazzi was able to prevent the debarment order from being applied by complying with the order to disclose assets and evidence, it is not clear why this should lead to a different conclusion than the one reached in Krombach v. Bamberski. The sanction, a complete exclusion from the trial, is simply entirely disproportionate to the aim pursued. ${ }^{50}$

While the CJEU concluded that the debarment order made by the UK High Court could indeed be a deciding factor in assessing the applicability of the public policy clause (para. 48), the focus of its analysis has shifted to the 'balancing act' to be performed by the national court, which needs to take into account both the importance of the protection of rights of the defence as well as objectives of public interest which may justify a restriction of those rights. The public policy exception therefore in effect provides a margin of appreciation for the national court. The Italian court finally used this margin of appreciation to decide that, in light of all circumstances of the case, Mr. Gambazzi had in fact been given, and exercised, the opportunity to be heard, so that the English debarment order was not a manifest and disproportionate breach of his rights to a defence.

To conclude, both these cases show that the public policy exception may be used to refuse recognition or enforcement, but only in the most extreme of cases. While the Krombach judgment laid down the - very high - threshold to be crossed, the Gambazzi judgment additionally identifies a number of factors that may count against it being justified. Still, in both cases the CJEU stresses the 'prominence' of the right to a defence, which is embodied in the ECHR as well as Member States' constitutional traditions, showing the link between public

\footnotetext{
${ }^{48}$ Beaumont and Johnston (2010b) p. 256.

${ }^{49}$ Van Bochove (2009) p. 300.

${ }^{50}$ Andrews (2007) p. 42. See for a more detailed discussion 4.3.2.2.
} 
policy and fundamental rights that was also recognized by the ECtHR in its case law. The public policy exception may only be applied when recognition or enforcement would constitute a 'manifest breach' of such a fundamental right. It is therefore up to the national court to decide not just whether a breach occurred, but whether, in light of all relevant circumstances, this breach can be considered manifest.

The role of the 'manifest' requirement is not entirely clear. The word 'manifest' means 'easily visible' or 'easy to understand or recognise' ${ }^{51}$ It appears therefore to apply to the visibility or obviousness of the breach, not (directly) to its seriousness. The requirement that the breach be obvious is understandable, since a rigorous review of the proceedings before the court of origin would be at odds with the prohibition on substantive review of the foreign judgment. ${ }^{52}$ Because the prohibition on review on the substance has always been a feature of the EU regime on recognition and enforcement, it has been doubted whether the addition of the 'manifest' qualification by the 2001 Brussels I Regulation really added anything. It was clear from the start that the prohibition of review on the substance requires that only obvious breaches of a fundamental principle could lead to a refusal of enforcement. ${ }^{53}$

Still, it is not immediately clear which violations of procedural rights could come within the scope of the public policy exception. If it is accepted that the right to a fair trial is as such a fundamental principle and therefore part of public policy, then manifest violations of the right to a fair trial should lead to a refusal of recognition or enforcement, if requested. However, if the justification for the 'manifest' requirement is the prohibition of review on the substance, then it is difficult to see why it should apply to a review of the procedure in the Member State of origin. As Chapter 2.3.1.4 explained, the prohibition of review on the substance refers to the findings of fact and law made by the court of origin. A thorough review of the procedure would certainly diminish the expediency of the regime for recognition and enforcement, slowing down the procedure and undermining mutual trust, and consequentially affecting the creditor's right to enforcement. This is perhaps a more convincing explanation for the 'manifest' requirement for procedural violations than the prohibition of review on the substance. The fact remains however that it is not clear from the CJEU's case law when a breach can be considered manifest, though it should be concluded that 'manifest' refers to the obviousness of the violation, not its seriousness (though in most cases a serious violation is also obvious). While the breaches that occurred in Krombach v. Bamberski and Gambazzi were certainly both obvious and serious, it can be questioned whether other obvious violations of the right to a fair trial, such as a clear transgression of the reasonable time requirement, should also come within the remit of procedural public policy. Aside from the 'manifest' requirement, does the concept of public policy have an inherent 'threshold' that the breach be sufficiently serious? Or does the concept of public policy itself provide that threshold, that is to say, should only certain fundamental elements of the right to a fair trial come within its scope, so that the right to a trial

\footnotetext{
${ }^{51}$ Merriam-Webster Dictionary; Oxford Dictionary of English.

${ }^{52}$ Cuniberti (2008) p. 34.

${ }^{53}$ Franq (2016) p. 881.
} 
within a reasonable time is excluded? These are difficult questions, which Chapter 7 examines in detail.

To conclude, the public policy exception protects the right to a fair trial because this right falls within the category of fundamental principles that public policy encompasses. There is one important caveat to the conclusion that the public policy exception may be used to protect the right to a fair trial, which is that even though article 6 ECHR is used to define the content of the public policy exception, it is still applied only indirectly. If recognition or enforcement is refused, this should be done on the basis of 45(1)(a) of the Brussels I bis Regulation or a corresponding provision. Nowhere in its case law does the CJEU suggest that without the existence of a public policy exception in the applicable European Regulation a judgment could be refused recognition simply for being contrary to Article $6 .{ }^{54}$ What would happen if this ground for refusal were not available is left open.

\subsubsection{Application of the public policy exception in European Union instruments by Member State courts}

The application of the public policy exception in the European Regulations was evaluated by Hess and Pfeiffer in their 2011 Report for the European Parliament. The Report comprises of statistical data as well as an analysis of national case law on the public policy exception gathered in national reports from a representative number of Member States. It encompasses a number of the most pertinent EU Regulations that contain a public policy clause, including the Brussels I and Brussels II bis Regulations and the Insolvency Regulation. It also includes the Maintenance Regulation, despite the fact that it contains no public policy clause, for the purpose of scrutinizing the practical impacts of abolishing exequatur clauses. Likewise it also discusses the judgments for which exequatur has been abolished under the Brussels II bis Regulation. ${ }^{55}$

The Report gives valuable information about the role of the public policy exception for the protection of fundamental rights. Most of the relevant CJEU and national case law on public policy concerns Article 34(1) of the Brussels I Regulation, which is understandable given that it is the instrument with the greatest practical importance. For this reason, it is given special attention in the Report. ${ }^{56}$ However, the CJEU case law on Article 34(1) also applies to other public policy provisions. ${ }^{57}$ The following analysis also incorporates case law from the Netherlands that was decided after the Report was published. ${ }^{58}$

\footnotetext{
${ }^{54}$ Cuniberti (2008) p. 33.

${ }^{55}$ Hess and Pfeiffer (2011) p. 17.

56 The Report does not concern the application of public policy under the Brussels Ibis Regulation, since this was not in force yet at the time the Report was prepared. There are as of yet no statistics or case law available as to the operation of public policy under Brussels Ibis.

${ }^{57}$ See Eurofood, in which the findings of Krombach are seen by the CJEU as "transposable" to the interpretation of article 26 of the Insolvency Regulation.CJEU Case C-341/04 Eurofood IFSC Ltd ECLI:EU:C:2006:281, para. 62-64.

${ }^{58}$ For more information on the methodology see Introduction (Chapter 1.5).
} 


\subsubsection{The Brussels I Regulation}

Concerning the Brussels I Regulation, the 2011 Report reinforces the general assumption that the use of substantive public policy is very limited, though there are examples of it having been successfully invoked. In total, the number of cases where public policy was successfully invoked run from zero to five in each of the Member States for which data is available. The public policy exception is applied only rarely, but one of the instances where it is applied is where serious violations of the right to a fair trial have occurred.

The 2011 Report shows that the situations in which it is applied are very diverse. The following categories are distinguished: ${ }^{59}$ instances of procedural fraud; a judgment given without reasons; insufficient or even misleading information about the defence in the court of origin; violation of the rights of defence (language barriers); and unacceptably high litigation costs.

So what caused the national courts to rule that a foreign judgment violated procedural public policy? In the first category, cases where the foreign procedural law as such was found to be problematic, courts have ruled that time limits for service of a claim form or for the preparation of a defence were prohibitively short; or that the rules concerning service of documents, translations and deadlines were lacking. ${ }^{60}$ Some of the national reports however stated that the courts of those Member States would refrain from criticizing foreign procedural law, but rather focus on the specific procedure at hand (see the UK response to question (c)). ${ }^{61}$

The application of public policy in the second category is naturally very casuistic, but some examples are worth mentioning. The first is a judgment from a Dutch court where recognition of a German judgment was refused because it was not adequately motivated (though this was later overturned by the Dutch Supreme Court, since the violation of fair trial was not considered manifest). ${ }^{62}$ A French court also refused recognition on this basis. ${ }^{63}$ A second category of cases concerns incorrect, late, or absent delivery of documents or other procedural irregularities, leaving one party unable to adequately defend himself. ${ }^{64}$ In one German case, recognition was

\footnotetext{
${ }^{59}$ Hess and Pfeiffer (2011) p. 65-67.

${ }^{60}$ Italy: Corte d'appello Milan, September 29, 1978, Jure id: 38703; Corte d'Appello Naples, February 20, 1982, Trans-Atlantica s.p.a./Soc. Vertom Shipping and Trading Corporation B.V., Rivista di diritto internazionale private e processuale 1983; Supreme Court of Portugal (Suprema Tribunal de Justica) Ac STJ pf 22 September 2005, available at http://www.dgsi.pt. Hess and Pfeiffer (2011) p. 58.

${ }^{61}$ Hess and Pfeiffer (2011) p. 60-61.

${ }^{62}$ Netherlands: Hoge Raad 18 March 2011, ECLI:NL:HR:2011:BP0003.

${ }^{63}$ France: CA Colmar 25 March 2004, No 02/04955. That recognition of a judgment lacking reasons should be considered contrary to public policy was already argued by Cuniberti: Cuniberti (2008).

${ }^{64}$ France: Ca Versailles, 5 July 2006, No 05/04718; Ca Versailles, 21 december 2006, No 06/03801, Ca Reims, 7 May 2007, No 06/01161.
} 
refused because the applicant was only notified of the proceedings against her when enforcement measures were being taken. ${ }^{65}$

The 2011 Report does not make explicit in what types of cases public policy was invoked, but some Member States report a relatively high incidence of it being invoked in maintenance cases. ${ }^{66}$ Germany reports fifteen instances of public policy being invoked in maintenance cases, while Austria, Sweden and the Netherlands also report such cases. Though it appears most of these cases involved substantive public policy (often an assessment of the amount of maintenance awarded), ${ }^{67}$ a striking example, where the appeal to public policy was upheld, is found in German case law. This case concerned the enforcement in Germany of a Polish judgment. The Polish court had established the defendant's paternity of the child on the basis of testimony of the child's grandmother; she had told the court that her daughter, the child's mother, had told her the defendant was the child's father. Though the defendant denied this, the Polish court established his paternity on the basis of the grandmother's testimony. The defendant's offer of paying for and submitting a paternity test was rejected by the Polish court, because such a test was not possible in Poland, and it would have to be done in Germany (even though this would have been possible by applying the Evidence Regulation). ${ }^{68}$ The German BGH refused enforcement of the final Polish judgment, which ordered the defendant to pay DM 500 per month to the mother. It held that it was contrary to German public policy that the defendant's paternity had been determined on the basis of what amounted to hearsay evidence, without an expert opinion. ${ }^{69}$ That one of the few instances identified by the 2011 Report where public policy was successfully invoked involves a maintenance case is remarkable considering that the 2009 Maintenance Regulation has since abolished the public policy exception as well as all other grounds for refusal for such cases. ${ }^{70}$

Another striking example of a case where procedural public policy was applied is Maronier $v$. Larmer, in which a Dutch judgment was deemed contrary to public policy by an English court. It provides a good illustration of how simple mistakes or carelessness may result in a serious violation of the rights of defence, and as such has been much discussed. ${ }^{71}$

The facts of the case were simple. Mr. Larmer, the respondent in this appeal case, practiced as a denist in Rotterdam, Netherlands. In 1984 one of his patients, Mr. Maronier, claimed damages of EUR 26,800 from Mr. Larmer, in respect of the treatment he had received from him. After

\footnotetext{
${ }^{65}$ Germany: OLG Zweibrücken 10.05.2005, 3 W 165/04.

${ }^{66}$ Prior to the entry into force of the Maintenance Regulation (Regulation 4/2009) judgments on maintenance fell within the scope of the Brussels I Regulation, which is why they were subject to the public policy exception under this instrument. Since the entry into force of the Maintenance Regulation, maintenance judgment are excluded from the scope of the Brussels I and Ibis Regulations.

${ }^{67}$ The Netherlands: Hoge Raad 3 March 2006, ECLI:NL:HR:2006:AU8179.

${ }^{68}$ Siehr (2013) p. 535.

${ }^{69}$ Germany: BGH 26.8.2009, XII ZB 169/07; see for a discussion Siehr (2013) p. 533 onwards.

${ }^{70}$ Chapter 2.3.4.

${ }^{71}$ Court of Appeal, 29 March 2002, Unanimous opinion by Lord Philips MR - Maronier v. Larmer; Kramer (2003). This case was not reported on the Dutch case law repositories, which is not surprising because it was considered a simple default judgment containing no reasoning and therefore probably not suitable for publication. See also Beaumont and Johnston (2010b) p. 255; Franq (2016) p. 896-897.
} 
an exchange of pleadings and statements in 1986 the proceedings were stayed for a period of twelve years. After this period Mr Maronier instructed his lawyers to pursue the case. $\mathrm{Mr}$ Larmer had moved to England in the meantime, leaving his address with the Rotterdam City Hall and the Dutch Association of Dentists. His lawyer, who had not been informed of the new address, stated that he had not had contact with Mr Larmer for a number of years and that according to his information Mr Larmer was living in England. Whether the lawyer explicitly withdrew from the case is unclear.

Despite recognizing that Mr Larmer was not represented in law, and (inaccurately) recording Mr Larmer as living in Rotterdam, the Rotterdam District Court nevertheless delivered judgment on 31 December 1999 and awarded Mr Maronier damages of EUR 33,000. Not having been served with any of the documents pertaining to the reactivation of the case $\mathrm{Mr}$ Larmer only found out about the reactivation of the procedure when enforcement measures were taken against him in England. Given that he had submitted a statement before the proceedings were stayed, the judgment was not a default judgment, and he was therefore not able to invoke the remedy of opposition (or verzet under Dutch law). He applied to the English court for refusal of enforcement on grounds of public policy.

On appeal, Mr Maronier's lawyer argued, along the lines of the CJEU's judgment in Solo Kleinmotoren, ${ }^{72}$ that the purpose of the system of recognition and enforcement of the (then) Brussels Convention was to facilitate to the greatest extent possible the free movement of judgments. This objective would be frustrated if courts were required to carry out a detailed review of whether the procedures that resulted in the judgment had complied with Article 6 ECHR. While the Court of Appeals sympathised with this view, it also stated that while courts should apply a strong presumption that the procedures of other signatories to the ECHR are compliant with the ECHR, this presumption cannot be irrebuttable. The Court goes on to conclude, on the basis of the CJEU's judgments in Hendrikman v. Magenta Druck ${ }^{73}$ and Krombach v. Bamberski, that the right of a defendant putting his case to court is fundamental to a fair trial, and that in such cases enforcement can be refused on the basis of the public policy exception.

Maronier $v$. Larmer provides a perfect example of a case where the safeguards that were in place to guarantee a fair hearing of both parties quite simply failed. It should also be noted that even though the conditions of Article 34(2) Brussels I (Art. 45(1)(b)) were satisfied (since the defendant was properly served with the document instituting the proceedings and was therefore in theory able to defend himself and invoke his right to appeal), the defendant nevertheless did not receive a fair trial. ${ }^{74}$

The English Court of Appeal also concisely formulated the dilemma national judges are faced with when deciding whether to refuse enforcement: they must operate under an assumption that the court of origin adequately protected the right to a fair trial, which prevents them from

\footnotetext{
${ }^{72}$ CJEU Case C-414/92 Solo Kleinmotoren GmbH v Emilio Boch ECLI:EU:C:1994:221.

${ }^{73}$ CJEU Case C-78/95 Hendrikman and Feyen / Magenta Druck \& Verlag ECLI:EU:C:1996:380.

${ }^{74}$ Franq (2016) p. 896.
} 
conducting a detailed review of the foreign procedure; yet this assumption may not be irrebuttable, and courts must therefore be vigilant about spotting circumstances that may rebut it. The Court of Appeal is clearly mindful of this dilemma, as it is quite careful to distinguish its own conclusion that Mr Larmer had not received a fair trial from its observations on the conduct of the Dutch courts or Dutch procedural law ("nothing that we have said should be taken as a criticism of the Rotterdam District Court or the procedure that it was applying"). It recognized that the circumstances of this case are unusual and therefore concludes that the public policy exception should be applied.

A conclusion that can be found in the 2011 Report, ${ }^{75}$ but which is also borne out by the Court of Appeal in Maronier v. Larmer, is that courts generally use Article 6 ECHR in their assessment of whether procedural public policy is applicable.

Finally, a special category of cases where public policy is relevant is mentioned: cases involving procedural fraud. Procedural fraud can be committed either by the parties (for example by falsifying signatures on documents used in the court proceedings) or by the court, for example by taking a bribe. The European instruments do not contain a separate refusal ground for cases involving procedural fraud. English courts have held that procedural fraud is encompassed by public policy, though only if there is no remedy in the country where the judgment was obtained, ${ }^{76}$ a condition that appears to be shared by Dutch courts ${ }^{77}$ but not German courts. ${ }^{78}$ In the common law tradition, for example under English law, procedural fraud constitutes a separate ground for refusal of enforcement. ${ }^{79}$ The 2011 Report showed that the public policy exception was invoked in cases involving fraud in at least eight instances, ${ }^{80}$ though it appears that none of these were successful. ${ }^{81}$ The 2007 Heidelberg Report states that "the main practical problems relate to the allegation of procedural fraud", ${ }^{82}$ referring to a Greek and an English case in which enforcement was refused because procedural fraud was detected ${ }^{83}$ Procedural fraud is a complicated issue, since while it is certainly unfair to allow a judgment obtained by fraud to circulate freely, procedural fraud does not appear to be covered

\footnotetext{
${ }^{75}$ Hess and Pfeiffer (2011) p. 155.

${ }^{76}$ Hartley (2015) p. 373.

77 E.g. Rechtbank Dordrecht 24 May 2006, ECLI:NL:RBDOR:2006:AX2008; the Dutch court rejected the argument that the alleged fraud should lead to a refusal of enforcement because it had already had an opportunity to address the fraud before the courts in Belgium, where the judgment originated.

${ }^{78}$ Hess, Pfeiffer and Schlosser (2007) para. 552.

${ }^{79}$ Hartley (2015) p. 410.

${ }^{80}$ The Netherlands: Rechtbank Dordrecht, 24 May 2006, Nr. 60725/HA ZA 05-2282; Slovenia (Hess and Pfeiffer 2001, p. 61); Germany (at least 6 cases, Hess and Pfeiffer 2011, p. 65).

${ }^{81}$ None of the German cases where the public policy exception was applied concern fraud (OLG Zweibrücken 10 May 2005, 3 W 165/04 and BGH 26 August 2009, XII ZB 169/07; Hess and Pfeiffer 2011, p. 58); the Dutch case was also unsuccessful for the reasons explained above with regard to Rechtbank Dordrecht 24 May 2006, ECLI:NL:RBDOR:2006:AX2008. See also Hess, Pfeiffer, Schlosser (2007) para. 546.

${ }^{82}$ Hess, Pfeiffer and Schlosser (2007) para. 548.

${ }^{83}$ Hess, Pfeiffer and Schlosser (2007) paras. 549 and 551.
} 
by the right to a fair trial. Chapter 7 discusses the consequences of this conclusion in more detail.

All in all, the Heidelberg Report concluded that the public policy exception was considered of great value from a legal-political perspective. It also concluded that, though rare, there are still constellations in the European judicial area in which the application of the public policy exception is needed in order to adequately protect the rights of the defendant. ${ }^{84}$ "In this respect", the Heidelberg Report concluded, "Article 34(1) JR still permits a residual control which can be exercised by the Member State of enforcement in extreme cases. [...] Seen from this perspective, it would be difficult to delete this provision entirely without any substitute". It pointed out, however, that what matters for a judgment debtor is not the recourse to public policy, but the availability of effective remedies. As a result it concluded that a further reduction of the public policy exception seemed possible, "if Community law provides for efficient means of redress in the Member State of origin or in the enforcement proceedings of the Member State addressed." ${ }^{85}$

\subsubsection{The Brussels II bis Regulation}

According to the 2011 Report by Hess and Pfeiffer on the interpretation of the public policy exception, there is very little pertinent case law pertaining to the use of the public policy exception in the recognition of divorce judgments. The general conclusions that national judges make a distinction between procedural and substantive public policy, and that provisions of the ECHR are relevant for determining their scope, are also applicable here.

As to judgments on parental responsibility, the 2011 Report also shows little relevant case law, though it must be noted that there are no statistics available for the majority of the respondent states, and that - as the Report underlines - the available statistics should be read with caution as they may also include case law on return orders. ${ }^{86}$

Yet, there are still some pertinent findings. An important conclusion is that the reference in Article 23(a) of the Brussels II bis Regulation to the 'best interests of the child' appears to create an increased relevance of the public policy exception (though there is some disagreement as to whether these are separate principles, or whether the best interests of the child are part of public policy). ${ }^{87}$ The best interests of the child have both a procedural and a substantive aspect.

\footnotetext{
${ }^{84}$ Hess, Pfeiffer and Schlosser (2007) para. 544.

${ }^{85}$ Hess, Pfeiffer and Schlosser (2007) para. 562.

${ }^{86}$ Hess, Pfeiffer (2011) p. 156.

${ }^{87}$ Hess, Pfeiffer (2011) p. 113-115.
} 
From the case law analysis, it appears that enforcement had been refused on the basis of procedural public policy because the child had not been heard. ${ }^{88}$ Substantive public policy is invoked when it is argued that enforcement of a judgment would harm the child's best interests in a wider sense, for example when the child's attachment to his or her parents has not been adequately assessed, ${ }^{89}$ or when a risk of physical harm to the child is alleged. ${ }^{90}$ Both procedural and substantive public policy are therefore relevant. The report shows that in determining the content of these concepts, courts refer to ECHR provisions, especially Article 8 (the right to respect for family life) and Article 6. The report also concludes that Member States often refer to case law on Article 34(1) Brussels I in this regard.

Interestingly, the report also comments on the mutual recognition of return orders under Articles 40 and 42 of the Brussels II bis Regulation, despite this being outside the scope of the report. The conclusions of the report on this matter are discussed in Section 3.5, below.

\subsubsection{The Insolvency Regulation}

The 2011 Report cites very little case law on the application of the public policy exception in the context of the Insolvency Regulation. It shows that while the exception is often invoked, its application is usually denied. The courts recognize the exceptional character of the public policy exception and apply it narrowly. It appears that the distinction between procedural and substantive public policy is also present here. Procedural public policy relates to the debtor's and creditor's rights to be heard ${ }^{91}$ and to appeal, ${ }^{92}$ while substantive public policy relates to preferential treatment of certain claims above others. ${ }^{93}$ The report notes that the narrow application of the exception in insolvency cases can be attributed to the special character of these cases: non-recognition of a judgment opening insolvency proceedings in one of the Member States where assets are located will automatically result in the creditors located in that Member State being at a disadvantage over other creditors, which infringes the principle that all creditors must be treated equally. Secondly, the refusal of recognition of a judgment opening

\footnotetext{
${ }^{88}$ Germany: OLG Celle, 30 September 2010, 18 UF 67/10; Helsinki CoA 13-05-2009 S 09/357. See also a Dutch judgment in a case where procedural fraud was alleged, Rb Den Haag 23-12-2008, ECLI:NL:RBSGR:2008:BG9144.

${ }^{89}$ Portugal: Lisbon Court of Appeal, 20 January 2009, RP 10097/2008-7, N. 4-6.

${ }^{90}$ Netherlands: Rb Den Haag 10-4-2009, ECLI:NL:RBSGR:2009:BJ1995.

${ }^{91}$ Netherlands, Rb Haarlem, 7 September 2010, Nr. F. 172470; Germany: Amsgericht Düsseldorf 07 April 2004 , 502 IN 124/03; Amtsgericht Nürnberg 15 August 2006, 8004 IN 1326; Amtsgericht Düsseldorf 12 March 2004 , 502 IN 126/03; Amtsgericht Deggendorf 12 February 2007, 1 IK 255/03; Amtsgericht Düsseldorf 6 June 2003, 502 IN 126/03; Landesarbeitsgericht Hessen 14 December 2010, 13 Sa 969/10.

92 Netherlands, Rb Haarlem, 7 September 2010, Nr. F. 172470.

${ }^{93}$ UK: Re Stojevic v Official Receiver, [2007] BPIR 141. Also Hess, Oberhammer and Schlosser (2013) p. 123.
} 
insolvency proceedings could affect a large number of creditors, and therefore be much more disruptive than the refusal to enforce a judgment that involves only two parties.

Case law from the CJEU shows a similarly restrained approach. In Eurofood, ${ }^{94}$ the CJEU was asked whether a Member State could refuse recognition of insolvency proceedings on the basis of public policy if procedural rules had been disregarded. Eurofood was a company based in Ireland, which was wholly owned by Italian-based Parmalat. Insolvency proceedings were started against Eurofood in Ireland and a provisional liquidator was appointed. Insolvency proceedings were however also started in Italy, the Italian court ruling that it had jurisdiction since Eurofood's main centre of activities was in Italy. An application for a declaration that Eurofood was insolvent was lodged with the Parma District Court in Italy, and a hearing was scheduled, of which the Irish provisional liquidator was informed only a few days beforehand. He also did not receive certain necessary documents. Ireland sought to refuse recognition of the insolvency proceedings in Italy because of these procedural irregularities. In its judgment, the CJEU first referred to the Krombach case, which it deemed 'transposable' to the interpretation of Article 26 of the Insolvency Regulation. The CJEU ruled that while the right of creditors and their representatives to participate in accordance with the equality of arms principle is of particular importance, restrictions are possible, but "any restriction on the exercise of that right must be duly justified and surrounded by procedural guarantees ensuring that persons concerned by such proceedings actually have the opportunity to challenge the measures adopted in urgency". ${ }^{95}$ It stated explicitly that a national court should not substitute its own rules regarding the right to an oral hearing, but should assess whether the proceedings on a whole gave the provisional liquidator sufficient opportunity to be heard.

The CJEU did not in this judgment go so far as to explicitly state a right of creditors to be heard in all phases of the procedure; rather it stateed that the right to be heard can be limited, albeit only for good reasons and only if the parties have the opportunity to challenge any adopted measures. Bariatti points out that under these rules it is possible for a judgment opening insolvency proceedings to be rendered after a hearing held in private, without all creditors being present. $^{96}$

This judgment does however show that the right to a fair trial is relevant in insolvency proceedings, with the CJEU explicitly citing the Krombach judgment and referring to the ECHR. The Report by Hess and Pfeiffer has shown that national courts interpret the public policy exception in the same way. ${ }^{97}$

\subsubsection{Conclusion: the value of the public policy exception}

\footnotetext{
${ }^{94}$ CJEU Case C-341/04 Eurofood IFSC Ltd, [2006] I-3813. See Bariatti (2009); Beale (2006); Barlowski (2012); Hess, Oberhammer, and Schlosser (2013).

${ }^{95}$ CJEU Eurofood, para. 66.

${ }^{96}$ Bariatti (2009) p. 644.

${ }^{97}$ Sweden: Göta Hovrätt case Ö 3222-07; Svea Hovrätt case Ö 4988-08.
} 
There is no doubt that the public policy exception, in its procedural as well as its substantive dimension, can plays a vital role in the protection of fundamental rights. Both the ECtHR and the CJEU have affirmed that fundamental rights, especially those laid down in the ECHR, must be an essential constitutive of the public policy of European states and of the EU itself. The CJEU has explicitly made the link with the Convention, in particular Article 6, in its case law in Krombach v. Bamberski and Gambazzi. National courts also reportedly apply Convention provisions in their assessment whether public policy is applicable.

The cited case law also justifies the conclusion that the public policy exception is mainly important for the protection of procedural rights; it has been stated that procedural issues form 'the crux' of Article 34(1) of Brussels I. ${ }^{98}$ The experience with public policy exceptions under other regulations also bears this out. First of all, it is established that courts apply these provisions analogously with Article 34(1) of Brussels I; secondly, the 2011 Report has shown a great number and diversity of procedural issues which are covered by the exception, in particular the right to be heard of affected parties.

On the other hand, the public policy exception is inherently very limited in its application. Public policy refers to principles that are of fundamental importance in the legal order of the state concerned, and this definition in itself implies that it may only be applied in exceptional situations. EU and national case law bears this out: it has been repeatedly affirmed that courts may not refuse enforcement simply because a foreign judgment does not conform, substantively or procedurally, to national rules; the threshold is much higher, in that enforcement would constitute a manifest violation of public policy. Public policy is there to act as a safety valve in extreme cases, such as where a national rule of procedural law completely precludes a defendant from making himself heard (Krombach) or where guarantees offered by national procedural law simply failed, whether through malicious intent (fraud) or oversight (Maronier v. Larmer).

These cases also show why sometimes control by a state other than the one that delivered the judgment is the only available remedy. Mr Krombach could not have been expected to seek a remedy against his judgment in France, because he was at risk of being arrested there. The French rule of procedure that forbade him to appear in the civil procedure, which was intended to prevent the accused of avoiding justice in this way, was exactly what triggered the application of the public policy exception in his case. Mr Larmer could also not have been expected to invoke a remedy against his judgment in the Netherlands, since what gave rise to the application of public policy was the fact that he was not informed of the reinstituted proceedings against him. By the time he became aware of the existence of the judgment, the time for appeal had expired. If no review at the enforcement stage in England had been

\footnotetext{
${ }^{98}$ Beaumont and Johnston state that procedural issues are the crux of Article 34(1) and that its content essentially corresponds to Article 6 ECHR: Beaumont and Johnston (2010b) p. 261.
} 
available, he would have had no effective remedy. ${ }^{99}$ The same goes for the (unnamed) presumed father in the German/Polish maintenance case, whose paternity had been accepted on the basis of little to no evidence: the case shows that the defendant's attempt to submit conclusive evidence in the Polish courts was refused. It seemed clear that a judgment based on such questionable evidence did not merit enforcement. ${ }^{100}$ In this regard it is especially concerning that public policy was abolished for maintenance judgments, even though the 2011 Report showed that the exception was clearly necessary for these types of cases.

It is clear that the public policy exception has proven to act as a remedy for violations of fundamental rights in cases where no other remedy was available. The 2007 Heidelberg Report and the 2011 Report on the application of public policy show that it has done so in only very few cases. For the Brussels I Regulation, the number of successful appeals is in the single digits, and for the other regulations, the number is even lower. It may be concluded from these figures that in a purely statistical sense, the role of the public policy exception in the protection of fundamental rights is rather limited. Yet, this research suggests that, if anything, the small number of successful appeals to public policy does not show that the refusal grounds are irrelevant: it rather confirms the exceptional nature of public policy.

The abolition of public policy as a refusal ground was severely criticized. They point to the existence of cases such as those discussed in this section to show that refusal of enforcement is sometimes the only adequate remedy. ${ }^{101}$ It was pointed out that a check in a Member State other than that which issued the judgment is sometimes necessary to detect a violation. ${ }^{102}$ This is not only because it may be practically or legally impossible for parties to seek remedies in the Member State of origin, ${ }^{103}$ but also because it may simply not be realistic to expect Member States to disqualify their own law. ${ }^{104}$ Overall, it is acknowledged that an 'emergency brake' such as the public policy exception is sometimes indispensable to remedy severe breaches of procedural standards. ${ }^{105}$ The 2007 Heidelberg Report also concludes that a residual control of foreign titles is clearly still needed. All in all, the value of the public policy exception in the protection of fundamental rights appears to be widely recognized. ${ }^{106}$

The question remains whether a public policy exception, as it currently exists under Brussels I bis, is the only possible 'emergency brake'. This question has three aspects. Firstly, the

\footnotetext{
${ }^{99}$ See also Beaumont and Johnston (2010b) p. 264.

${ }^{100}$ Schlosser (2010). p. 103.

${ }^{101}$ Schlosser (2010) p. 103; Beaumont and Johnston (2010b) p. 264.

${ }^{102}$ Cuniberti and Rueda (2011) p. 293.

${ }^{103}$ As in Krombach v. Bamberski and Maronier v. Larmer, discussed above; Beaumont and Johnston (2010) p. 264.

${ }^{104}$ Cuniberti and Rueda (2011) p. 301; Muir Watt (2001) p. 549; Kramer (2011a) p. 640; Schack (2011) p. 7.

105 Oberhammer (2010) p. 202; Cuniberti and Rueda (2011) p. 293; Beaumont and Johnston (2010b) p. 264; De Cristofaro (2011) p. 452; Schlosser (2010) p. 103; Schack (2011) p. 6; Timmer (2013) p. 131; Kramer (2011a) p. 640.

106 Apart from the other literature cited in this section, see Oster (2015); Frąckowiak-Adamska (2015); Vlas (2013).
} 
European legislature has considered it possible to replace the refusal grounds, including public policy, with 'minimum standards', for instance in the European Enforcement Order (EEO), European Small Claims Procedure (ESCP), and European Order for Payment (EOP) Regulations. The idea is that such common procedural standards obviate the need for grounds of refusal that can be applied by the Member State of enforcement. Whether minimum standards can indeed adequately replace refusal grounds has been questioned, ${ }^{107}$ and is discussed below. ${ }^{108}$

The second aspect is whether it is possible to replace 'public policy', with its national (i.e., domestic) connotations, with a reference to common (to all EU Member States) norms, such as the right to a fair trial. This was proposed both by academics, ${ }^{109}$ and by the European legislature. Chapter 7 discusses the concept of public policy vis-à-vis the right to a fair trial in great detail and aims to answer the question whether they are indeed interchangeable. The fundamental question here is whether public policy should be seen as embodying principles common to all EU Member States, such as fundamental rights, or whether Member States should still be able to apply their own definition of the concept. ${ }^{110}$

The third fundamental aspect is which court or institution should provide the emergency brake. As discussed, the 2010 Proposal for the recast Brussels I Regulation proposed to transfer some of the refusal grounds to the Member State of origin. Some authors proposed a similar arrangement. ${ }^{111}$ However, the discussion of the application of public policy already shows that sometimes review in the Member State of enforcement is the only way of detecting a violation. This preliminary conclusion is discussed in more detail below. ${ }^{112}$

\subsection{The role of other grounds for refusal in the protection of fundamental rights}

\subsubsection{The protection of the defendant in default proceedings}

Article 45(1)(b) of the Brussels I bis Regulation (formerly 34(2) of the Brussels I Regulation) and Articles 22(b) and 23(c) of the Brussels II bis Regulation all provide protection for defendants in cases where a judgment was delivered by default. As such, this provision is the

\footnotetext{
${ }^{107}$ Cuniberti and Rueda (2011) p. 296-302.

108 Section 3.4.2.

${ }^{109}$ Oberhammer (2010) p. 202.

${ }^{110}$ E.g. Beaumont and Johnston (2010a) p. 110.

${ }^{111}$ Oberhammer (2010) p. 202.

112 Section 3.4.1.
} 
only one aiming specifically at protecting the defendant, ${ }^{113}$ whereas the public policy exception has a subsidiary character. ${ }^{114}$

The provision protects defendants who do not appear at proceedings instigated against them. Such default proceedings allow courts to issue a judgment even if a defendant is absent from the proceedings. This benefits the claimant, who is able to obtain an enforceable title and does not have to suffer the consequences of a defendant's inactivity. It also obviously creates a risk for the defendant of being faced with a judgment that is the result of proceedings he did not know about. For this reason, national and EU legislation provide that a default judgment can only be delivered (or declared enforceable) if it is shown that the defendant was served with documents instituting the proceedings in an appropriate way. ${ }^{115}$ Effective service, in such a manner and in sufficient time for the defendant to arrange for his defence, is however not always achieved, especially in cross-border cases. For this reason, the Brussels I bis Regulation provides additional protection, in the form of a refusal ground that can be invoked in the Member State of enforcement.

This provision has proved very practically important. The 2007 Heidelberg Report concluded that the Article was "the most important provision for objecting to the recognition of a foreign judgment". ${ }^{116}$ The Heidelberg Report does not provide statistics as to the application of the provision, but reports at least several cases in which it was invoked successfully. ${ }^{117}$ Dutch case law also provides at least one example of its application. ${ }^{118}$

Article 45(1)(b) is formulated in such a way as to motivate the defaulting defendant to take action: the provision cannot be invoked if the defendant failed to take action against the judgment in the Member State of origin when it was possible for him to do so. This amendment, introduced by the Brussels I Regulation in 2001, significantly reduced the scope of the provision. ${ }^{119}$ Its introduction meant that the defendant could no longer profit from inactivity. He has to show that he invoked all possible means to challenge the judgment when he was able to do so; the protection of Article 45(1)(b) only applies when the defendant was unable to challenge the judgment, for reasons outside his control, i.e., where he was unaware of the proceedings, or where service was effected too late or in such a way as to prevent him from preparing for his defence. The amendment to this provision of the 2001 Regulation thus increased the burden on the defendant.

\footnotetext{
${ }^{113}$ Franq (2016) p. 902. CJEU Case C-228/81 Pendy Plastic Products BV v Pluspunkt Handelsgesllschaft GmbH, ECLI:EU:C:1982:276, para. 13.

${ }^{114}$ The Jenard Report formulates the purpose of the as follows: "Where judgment is given abroad in default of appearance, the Convention affords the defendant double protection". Jenard (1979) p. 44.

${ }^{115}$ Fitchen (2015) p. 451; EEO Regulation, Articles 13 and 14. The ESCP and EOP Regulations similarly contain rules on service.

${ }^{116}$ Hess, Pfeiffer, Schlosser (2007) para. 539.

${ }^{117}$ Hess, Pfeiffer, Schlosser (2007) paras. 540-541.

118 Rechtbank Haarlem 25 April 2008, ECLI:NL:RBHAA:2008:BD0602.

${ }^{119}$ Hess, Pfeiffer, Schlosser (2007) para. 539.
} 
The elements of the provision are all defined functionally, and allow for an interpretation specific to the circumstances of the case: what is decisive is what the defendant needed to arrange for his defence in terms of time and information in the case at hand. What is important is that the documents served contain sufficient information, and were served in sufficient time, for the defendant to understand the subject-matter and grounds of the claim and be aware of the proceedings, not that it conformed to certain formal requirements. In the cross-border context, this is especially important, since acquiring legal advice about a dispute taking place under foreign law in a foreign language may take considerable time and effort.

The question of what it means to 'appear' in a meaningful sense has also come up in CJEU case law. In Hendrikman, it ruled that a mere 'technical' appearance of a party by reason of the appointment of lawyers on her behalf by the court did not suffice. ${ }^{120}$ The CJEU confirmed this in its recent judgment in $A v B$ and others. ${ }^{121}$ In Sonntag, the CJEU rejected the defendant's argument that he had not wanted to appear in the civil aspect of the proceedings, even though he had appointed and instructed legal representatives to act on his behalf in the criminal aspect of the proceedings. ${ }^{122}$

The requirement of sufficient time is similarly casuistic: it must be determined by the court seized with recognition, on the basis of all factual and legal circumstances of the case, and independently of the law of the state where recognition is sought and the opinion of the adjudicating court. ${ }^{123}$ The conditions of the delivery of the document are likewise interpreted: if the documents are in a foreign language, more time will be allowed to the defendant to prepare for his defence. ${ }^{124}$

In short, this provision is intended to protect the defendant's right to 'have his day in court' (albeit in writing and not in person), by providing a remedy in cases where he did not appear because he was not properly informed of the proceedings. This applies under the condition that he acted in good faith and did everything in his power to make himself heard when he had the opportunity. Because of this last requirement the scope of application of this provision is rather limited; the discussion of the Maronier $v$. Larmer judgment (above) has shown that the public policy exception may still be necessary as a subsidiary means of protection.

${ }^{120}$ CJEU Case C-78/95 Hendrikman and Feyen / Magenta Druck \& Verlag, ECLI:EU:C:1996:380.

${ }^{121}$ CJEU Case C-112/13 A v B and Others ECLI:EU:C:2014:2195, paras. 55-58. CJEU Case C-112/13 A $v$ B and Others ECLI:EU:C:2014:2195, paras. 55-58. In Hypotečni Banka the CJEU clarified that it should be possible to bring proceedings against a defendant whose domicile is unknown by the appointment of a guardian $a d$ litem or another court-appointed representative, but that such an arrangement should be seen as a judgment by default against which Article 45(1)(b) can be invoked. CJEU Case C-327/10 Hypoteční banka a.s. v Udo Mike Lindner ECLI:EU:C:2011:745, para. 53-54.

122 CJEU Case C-172/91 Volker Sonntag v Hans Waidmann ECLI:EU:C:1993:144., para. 39.

${ }^{123}$ CJEU Case 228/81 Pendy Plastic Products BV v Pluspunkt Handelsgesellschaft GmbH ECLI:EU:C:1982:276, para. 13.

${ }^{124}$ Franq (2012) p. 685. 
It is concluded that Article 45(1)(b) and its equivalents are specifically designed to protect the right to a defence at the enforcement stage, even if these provisions were greatly limited in scope when the obligation for the defendant to take action was introduced. The application of this provision is very case-specific and leaves it to a national judge to appreciate the relevant factual and legal circumstances to decide whether it is indeed applicable; for that reason it is difficult to extract from the relevant case law any hard and fast rules as to its application.

The CJEU's judgment in ASML however gives a good indication of how the provision is intended to protect the rights of the defence. ${ }^{125}$ In this case, SEMIS, the defendant in the original proceedings, appealed against the declaration of enforceability that had been served on it on the grounds that it had not been served with the default judgment, so it had not been able to apply for a review of the default judgment. ASML, the original claimant, argued that SEMIS could not invoke Article 34(2) because it had been aware of the original proceedings. SEMIS had received a summons, albeit after the hearing had taken place.

The CJEU was asked to answer the question whether (then) Article 34(2) required that a judgment should have been duly served on the defendant, or whether it is sufficient that the defendant was aware of its existence at the stage of enforcement proceedings. The CJEU makes very clear that the purpose of the provision is to ensure that the rights of defence are effectively respected (para. 20), and that these rights may not be undermined by the considerations of mutual trust on which the Regulation is based (para. 24). It also invokes ECtHR case law to show that the rights of defence require special protection, and that it has been found that knowledge of a judgment's contents is vital to allow a defendant to exercise their right to an appeal (para. 28). ${ }^{126}$ The Court states that because it is knowledge of the content of the judgment which is required, a mere procedural irregularity does not suffice to give rise to Article 34(2) (paras. 36 and 47); yet it answers the preliminary question by ruling that knowledge of the contents can only be acquired if the judgment was served on him in sufficient time to arrange for his defence before the court of origin (para. 39). It is not sufficient that the defendant was merely aware of the existence of the judgment.

The CJEU decided in favour of the original defendant; yet what is more important is that it affirms that the purpose of Article 45(1)(b) is to protect the defendant's right to a defence, citing ECtHR case law to interpret it. It also echoes the application of Article 6(1) ECHR by the ECtHR by stating that the application of the provision is dependent on whether the defendant effectively, not just formally, received a fair trial. The purpose and function of the provision in the protection of the defendant's right under Article 6(1) ECHR are thus clear.

${ }^{125}$ Case C-283/05 ASML Netherlands BV v Semiconductor Industry Services GmbH (SEMIS), ECLI:EU:C:2006:787.

${ }^{126}$ ECtHR Hadjianastassiou v Greece of 16 December 1992, ECHR. Series A. no 252, para. 29 to 37. 


\subsubsection{Special jurisdiction (Article 35 Brussels I, 45(1)(e) Brussels I bis)}

A good case can be made that the exclusive jurisdiction grounds encompassed in sections 3, 4 and 6 of the Brussels I Regulation also protect the right to a fair trial of the weaker parties that are favoured by the jurisdiction clauses. It may be remembered that the 2010 Proposal for the Recast Brussels I Regulation originally sought to abolish this ground for refusal; ${ }^{127}$ the Brussels I bis Regulation instead expanded the categories of jurisdiction grounds that fall within the scope of the provision. ${ }^{128}$

Article 45(1)(e) of the Brussels I bis Regulation provides that enforcement may be refused of judgments that violate the jurisdiction rules of sections 3, 4, 5 or 6 of Chapter II of the Regulation. These sections all contain rules that derivate from the general rule that a defendant be sued in the State where he is domiciled. Section 3 concerns insurance contracts and provides that an insurer may be sued by a policyholder, the insured, or a beneficiary in the Member State where the plaintiff is domiciled. The purpose of this rule is to protect the weaker parties (the policyholder, the insured, a beneficiary, or an injured party) by allowing them to start a procedure in their own domicile under their own legal system. ${ }^{129}$ Conversely, the dominant party has no choice under the provisions but to bring proceedings in the Member State of the weaker party's domicile. The review of these jurisdiction grounds is an exception to the general rule that the jurisdiction of the foreign court is not reviewed, ${ }^{130}$ but with good reason: it would constitute too heavy a burden for the consumer to contest jurisdiction in a foreign court. ${ }^{131}$ The Brussels I bis Regulation has however made application of the provision dependent on it being invoked by an interested party; under Brussels I bis, the prevailing opinion was that the provision needed to be applied ex officio. ${ }^{132}$

As stated, the special jurisdiction grounds aim to preserve procedural fairness by protecting the weaker party to a dispute. Section 3 of Chapter II allows a policy holder to bring proceedings against an insurer in the claimant's own domicile (Art. 11(1)(b)). Section 4 protects the consumer in consumer contracts by giving the consumer a choice to sue the professional party of the contract either in the professional party's domicile or in the consumer's own domicile, while providing that the professional party may only sue the consumer in the consumer's domicile. ${ }^{133}$ Section 5 provides greater protection for employees by providing that they may sue their employer not just in the Member State where they are domiciled but also in a Member State where they have a branch, agency or establishment; or in the courts of a Member State

\footnotetext{
${ }^{127}$ See Dickinson (2011) p. 7.

128 The scope now includes Section 5 of Chapter II of the Regulation, which concerns employment cases.

${ }^{129}$ Heiss (2016) p. 407; Mankowski and Nielsen (2016) p. 443; Esplugues Mota and Palao Moreno (2016) p. 539.

${ }^{130}$ Article 45(3) Brussels Ibis Regulation.

${ }^{131}$ Kramer (2011b) p. 216.

132 Fitchen (2015) p. 474; Franq (2012) p. 391.

${ }^{133}$ Article 18(1) and (2) Brussels Ibis Regulation.
} 
where the plaintiff habitually carries out his work. ${ }^{134}$ Finally, section 6 provides for exclusive jurisdiction, among other things in cases concerning immovable property for the courts of the Member State where that property is situated (Art. 24(1)). ${ }^{135}$ While the latter provision has a very practical purpose (it being logical for the court that is most closely connected to the subject matter to decide on conflicts relating to it), it by the same token protects procedural fairness.

The possibility to refuse enforcement in cases where these rules were incorrectly applied is a departure from the principle that jurisdiction of the court of origin is not reviewed at the enforcement stage. The fact that these exceptions are made is indicative of the importance attached to them.

\subsubsection{Hearing of the child (23(b) Brussels II bis) or other interested person (23(d) Brussels II bis)}

The Brussels II bis Regulation contains two special grounds for refusal, which protect the right to the parties involved to be heard. The function of these provisions in the protection of procedural rights of interested parties is quite obvious: both provisions explicitly require that someone (the child, or a person claiming that his or her parental responsibility would be infringed, respectively) are given a fair hearing, which is an essential constitutive of the right to a fair trial.

Article 23(b), which refers to the child's right to be heard, implements Article 12 of the UN Convention of the Rights of the Child of $1989 .{ }^{136}$ This article requires that "the child who is capable of forming his or her own views is afforded the right to express those views freely in all matters affecting the child, the views of the child being given due weight in accordance with the age and maturity of the child". It also requires that "for this purpose, the child shall in particular be provided the opportunity to be heard in any judicial and administrative proceedings affecting the child, either directly, or through a representative or an appropriate body, in a manner consistent with the procedural rules of national law". Recognition or

\footnotetext{
${ }^{134}$ Article 21(1)(a) and (b).

135 The other sections of this Article confer exclusive jurisdiction: a) in proceedings which have as their object the validity of the constitution, the nullity or the dissolution of companies or other legal persons or associations of natural or legal persons, or the validity of the decisions of their organs, on the courts of the Member State in which the company, legal person or association has its seat (Article 24(2)); b) in proceedings which have as their object the validity of entries in public registers, on the courts of the Member State in which the register is kept (Article $24(3)$ ); c) in proceedings concerned with the registration or validity of patents, trade marks, designs, or other similar rights required to be deposited or registered, irrespective of whether the issue is raised by way of an action or as a defence, on the courts of the Member State in which the deposit or registration has been applied for, has taken place or is under the terms of an instrument of the Union or an international convention deemed to have taken place (Article 24(4)); and d) in proceedings concerned with the enforcement of judgments, on the courts of the Member State in which the judgment has been or is to be enforced (Article 24(5)).

${ }^{136}$ Borràs (1998) para. 73; UN Convention of the Rights of the Child, 1989.
} 
enforcement of a foreign judgment relating to parental responsibility must be refused if: (1) the child has not been heard; provided that, (2) the child was capable of forming his or her own views at the time of the decision; and, (3) there was no case of urgency. ${ }^{137}$

EU Member States have differing practices when it comes to hearing children in proceedings that concern them. It was foreseen when the Brussels II bis Regulation was adopted that these divergences would create problems at the enforcement stage. ${ }^{138}$ The 2015 Study on the assessment of the Brussels II bis Regulation shows that such divergences have indeed created problems at the enforcement stage: distrust between Member States on this matter has led to refusals of enforcement where the Regulation allows it. ${ }^{139}$ It has proven especially difficult to organise a hearing of the child if the abducting parent does not cooperate. ${ }^{140}$ Given that such divergences exist, it can be doubted whether the condition that the child be heard prior to issuing the certificate of Article 42(2)(a) is at all effective. Unfortunately, the 2015 Study does not provide conclusions as to whether the requirement of Article 42(2)(a) serves its purpose.

\subsection{The protective function of control by the Member State addressed}

\subsubsection{The value of a cross-border check}

The previous sections showed the role of the various grounds of refusal contained in the existing regulations in the protection of the right to a fair trial. This role is quite selfexplanatory: the grounds for refusal discussed are all clearly intended to provide protection for the judgment debtor in some way. The existence of certain grounds for refusal which may be invoked at the recognition and enforcement stage is therefore one of the ways in which the exequatur procedure protects the right to a fair trial.

At the same time the grounds for refusal are all embedded in the framework of the regulations of which they are part, even if some of them can be found across different legal instruments. It is important to take a more abstract view on the question of how the exequatur procedure protects fair trial, one that is not bound up with the technical issues pertaining to each separate piece of legislation: this book intends to discuss the fundamental rights consequences of the abolition of exequatur as a legal phenomenon, not the specific consequences this would have for each separate legal field.

137 This qualification is found in the Hague Convention on Parental Responsibility and Protection of Children, Article 23(b); see also Siehr (2012) p. 282.

${ }^{138}$ Kruger (2011) p. 37.

${ }^{139}$ Study on the assessment of the Brussels IIbis Regulation (2015) p. 43.

${ }^{140}$ Study on the assessment of the Brussels IIbis Regulation (2015) p. 48. 
The question is therefore whether the cross-border character of the review mechanism provided by the refusal grounds provides some protective value in and of itself. Is the cross-border control inherently protective of fair trial rights, or can a check in the country of origin of a judgment really replace the exequatur as it exists now?

It is submitted that in the cases discussed, the fact that review was carried out by a court in a Member State other than where the judgment was delivered was certainly necessary to address the problems that occurred. There is little doubt that the mechanism for recognition and enforcement as originally implemented by the EU regulations is intended, and effectively enables Member States, to ensure that foreign judgments conform to European fundamental rights, given that these are by necessity a constitutive of their public policy. ${ }^{141}$ It is incontestable that this mechanism serves a protective (judgment inspection) as well as a procedural (judgment import) function: ${ }^{142}$ the refusal of recognition or enforcement acts as a remedy to fundamental rights violations by limiting the effects of those violations to the jurisdiction where they were committed.

There is also no question that the exequatur fulfils this function also in practice. The Maronier v. Larmer case offers a striking example of a procedural irregularity that had clearly gone unchecked in the Member State where it occurred, ${ }^{143}$ while Krombach has shown that an external perspective was the only way of calling into question the fairness of the French contumax procedure. ${ }^{144}$ It has been pointed out that in none of the cases which are discussed in this Chapter did the courts of the Member State of origin question whether the application of their national law was in any way incompatible with the right to a fair trial. ${ }^{145}$ This implies that in some cases review by a foreign court may be the only way to detect a fundamental rights violation. ${ }^{146}$

This Chapter already raised the question whether this protection may be organized in some other way. It was discussed in the context of the public policy exception that the 2010 Proposal for a recast Brussels I Regulation moved control over the application of the provision that protects the defaulting defendant (now Article 45(1)(b) of Brussels I bis) to the Member State of origin of the judgment. ${ }^{147}$ This arrangement was criticized in various ways. It was seen as illogical that a defendant should need to rely on the review mechanisms in the Member State that had failed to protect his right to a fair trial in the main proceedings. ${ }^{148}$ This, it appears, is a fundamental objection to the abolition of cross-border control. As the analysis of the CJEU's case law on public policy shows, in some cases the Member State of origin cannot be expected

\footnotetext{
${ }^{141}$ See under 3.2.2, above, and the discussion in Chapter 7.2.2.

142 See Section 2.3.1.2.

${ }^{143}$ Kramer (2003) expresses surprise that the case was allowed to progress in this way, even if Dutch procedural law technically allowed it, and states that "maybe, hopefully, under the new procedural rules a case like this would not have slipped through". Kramer (2003) p. 18.

${ }^{144}$ Muir Watt (2001) p. 551.

${ }^{145}$ De Cristofaro (2011) p. 452; Kramer (2011a) p. 639-640; Cuniberti and Rueda (2011) p. 301.

${ }^{146}$ Muir Watt (2001) p. 551.

${ }^{147}$ Article 45, 2010 Proposal; see in general Dickinson (2011) p. 8-10; Layton (2011) p. 5-8. Something similar was proposed by Oberhammer (2010) p. 202.

${ }^{148}$ Layton (2011) p. 6-7.
} 
to adequately review the application of its own laws; but more importantly, the litigants should not be required to rely on such review in a legal system that has failed to observe a fundamental right. This is also one of the objections against the mechanism of the EEO, which is discussed in Chapter 8.4.

\subsubsection{Replacement of refusal grounds with minimum standards}

It has been discussed that some of the regulations that have abolished refusal grounds (the ESCP, EOP, EEO, Brussels II bis, and Maintenance Regulation) have replaced the grounds for refusal with minimum standards. These minimum standards take different forms.

Under the EEO Regulation, the minimum standards apply to service of the documents instituting the proceedings. The EEO Regulation requires the court asked to certify a judgment as an EEO to check whether the documents instituting the proceedings were served on the debtor in accordance with minimum standards on service, which are enumerated in Articles 13 and 14 of the Regulation. Additionally, the Regulation provides that if service was effected by a method that is less certain to be effective (service without proof of receipt by the debtor), a judgment may only be certified as an EEO if the debtor is able to apply for review of the judgment in the Member State of origin (Art. 19). ${ }^{149}$ The underlying idea is that if the requested court, which may be the court that issued the judgment itself, checks that these minimum requirements were observed, this prevents judgments that do not respect the rights of the defendant from being declared enforceable.

The Brussels II bis Regulation contains a similar mechanism for judgments concerning access to a child (Art. 41) or the return of a child (Art. 42). ${ }^{150}$ The minimum requirements should be checked by the judge in the Member State of origin prior to issuing a certificate that renders the judgment automatically enforceable throughout the EU. For judgments concerning rights of access, the judge must make sure that: (a) if the judgment was given in default, the person defaulting was given sufficient opportunity to defend him or herself, or accepted the decision unequivocally; (b) that all parties were given the opportunity to be heard; and, (c) the child was given an opportunity to be heard, unless such a hearing was considered inappropriate due to the child's age or degree of maturity. For judgments ordering the return of a child, the Regulation also requires that the child and parents were given an opportunity to be heard (Art. 42(2)(a) and (b)) and that the court has taken into account in issuing its judgment the reasons for and evidence underlying the order pursuant to Article 13 of the 1980 Hague Convention on Child Abduction.

The EOP and ESCP Regulations also contain minimum standards, but these function differently. Rather than requirements that a judgment must fulfil before it is allowed to

\footnotetext{
149 The Maintenance Regulation contains a similar provision: Article 19.

${ }^{150}$ Chapter 2.3.5. See for a discussion of the effectiveness of this arrangement Chapter 8.6.3.
} 
circulate, in the EOP and ESCP Regulations, the minimum standards can be invoked to apply for a review of the decision. ${ }^{151}$ The Maintenance Regulation contains a similar review procedure. ${ }^{152}$ This review procedure can be invoked by the debtor if the minimum standards were not observed and he was consequentially not adequately informed of the proceedings taking place against them. Its use is however limited to cases where service was effected in a manner without proof of receipt. ${ }^{153}$

These minimum standards can be seen as a new remedy to replace the application for refusal of recognition or enforcement. The added value of minimum standards has however been questioned for various reasons, which are discussed in turn.

For one, as was already stated above, the fact that these standards are introduced, together with a review mechanism, shows that the European legislature believes that even in the absence of a check in the Member State of enforcement, some remedy for the protection of fundamental rights is necessary. Other existing remedies against the violation of fundamental rights, for example those available under national procedural law, are clearly not considered sufficient. ${ }^{154}$ This is somewhat incongruous with the principle underlying the instruments, which is mutual trust.

Apart from these inconsistencies, the minimum standards and accompanying review mechanism were also criticized as to their substance. ${ }^{155}$ While the minimum standards in each specific regulation are discussed below, some criticisms apply to the idea of minimum standards in general. Cuniberti and Rueda rightly ask why the minimum requirements, especially the review procedure, are limited to only one aspect of the right to a fair trial: the right to receive prior notice. ${ }^{156}$ For the EEO and EOP Regulations, this is understandable because these procedures are in principle conducted without an appearance by the defendant. The right to, for example, an oral hearing only comes into play when the defendant enters an appearance, which in the context of an EOP he may very well not do. The right to effective service is pivotal to these procedures because this allows the defendant to decide whether or not to appear, which is why it is not strange that it was singled out.

For the ESCP procedure, however, the question is appropriate. The scope of application of Article 6 ECHR, which safeguards the right to a fair trial, to civil cases is much wider: it encompasses the right to an impartial and independent judge, the right to a fair hearing, the

\footnotetext{
${ }^{151}$ Article 20, EOP Regulation; Article 18, ESCP Regulation. Regulation (EU) 2015/2421 widened the scope of this review procedure for the ESCP Regulation, in order to address the lacuna identified by the CJEU in its judgment in eco cosmetics/Raiffeisenbank; see 8.5.1.

152 Article 19(1) Maintenance Regulation.

${ }^{153}$ As provided for by Article 14 of the EEO Regulation; Article 18(1)(a) ESCP Regulation, Article 20(1)(a) EOP Regulation.

${ }^{154}$ Cuniberti and Rueda (2011) p. 298.

${ }^{155}$ E.g. Cuniberti and Rueda (2011); Stadler (2004a); Kramer (2008a); Zilinsky (2006); Ptak (2014).

${ }^{156}$ Cuniberti and Rueda (2011), p. 298.
} 
right to equality of arms, the right to a reasoned judgment within a reasonable time, and so forth. The authors question why the European legislature chose only one of the many procedural rights as worthy of protection by means of minimum standards, and point out that this seems to imply that some procedural rights are more fundamental than others. They raise the question whether in this way the European legislature has tried to disconnect its own definition of fundamental rights from that of the ECtHR, and whether this is wise to cherrypick some rights and protections and neglect others. ${ }^{157}$ Finally, the CJEU's judgment in eco cosmetics/Raiffeisenbank ${ }^{158}$ shows that the minimum standards on service and the review procedure currently contained in the EOP Regulation have proved insufficient to prevent or address certain failures to effect service.

Yet perhaps the real problem with the concept of minimum standards, even if coupled with a review mechanism, is not how they are formulated, but the simple fact that they cannot be a replacement for the exequatur because they miss the - arguably vital - cross-border element. The Zarraga judgment, discussed in Section 3.5, below, is an example of a case where the capability of the minimum requirement that the child be heard to prevent an infringement of the child's rights under Article 42(2) Brussels II bis was questioned.

Another fundamental problem, it is submitted, is the 'closed' nature of the minimum requirements when compared with the 'open' nature of the refusal grounds. As Chapter 2.2 explained, one of the valuable aspects of the public policy exception is its open nature. It can be applied in a wide variety of cases, thereby acknowledging that it is impossible to foresee in advance the types of procedural mistakes that may occur. The protection of the defendant in default proceedings is similarly open to interpretation, requiring the court to assess retrospectively whether the defendant was actually able to effectively prepare for his defence. By contrast, the minimum requirements of, for example, the EEO Regulation rely on the assumption that if these requirements were complied with, the defendant knew that proceedings were taking place and took a conscious decision not to appear. A case such as Maronier v. Larmer shows that service having been effected in accordance with the appropriate rules does not mean that the defendant knew about the proceedings. The mechanism whereby refusal grounds are replaced with an exhaustive and narrowly defined list of minimum requirements removes the potential for case-by-case review which proved essential in a case such as Maronier v. Larmer. It also places a great deal of trust in the legislature, who must foresee the potential problems that might arise and provide remedies for them. The case of eco cosmetics/Raiffeisenbank, discussed further on, shows that such trust may not always be justified. ${ }^{159}$

There are therefore some significant doubts as to whether the exequatur can adequately be replaced with minimum standards to be checked in the court of enforcement. These doubts

157 Cuniberti and Rueda (2011) p. 298-300.

158 CJEU eco cosmetics/Raiffeisenbank; see under 8.5.1.

${ }^{159}$ Joined cases C-119/13 and C-120/13 eco cosmetics GmbH \& Co. KG v Virginie Laetitia Barbara Dupuy and Raiffeisenbank St. Georgen reg. Gen. mbH v Tetyana Bonchyk ECLI:EU:C:2014:2144. See under 8.5.1. 
concern both the minimum requirements included in the various regulations as well as the mechanism per se.

\subsubsection{Alternative remedies: appeal to the European Court of Human Rights}

Arguably, an alternative to refusal of cross-border enforcement would be for a judgment debtor to pursue an action against the Member State where the judgment originated before the ECtHR, if the procedural remedies available in that state would have been insufficient (which, as discussed above, they typically are in these cases). This of course conforms to the starting point of the ECHR that each signatory state is responsible for violations committed within its jurisdiction. Academics have however criticized the idea that an appeal to the ECtHR could adequately replace refusal of enforcement or recognition as a remedy. ${ }^{160}$ They point out that an appeal to the ECtHR would at best only result in a finding that the Member State concerned had violated one of the Convention rights, perhaps combined with a "just satisfaction" (damages). ${ }^{161}$ The ECtHR cannot in any way cancel the original judgment from which the violation resulted; the judgment will therefore remain in force and continue to produce legal effects, which is exactly what refusal of recognition or enforcement is intended to prevent. The following Chapter also explains that the ECtHR itself requires that violations of ECHR rights are remedied by the state that committed them; recourse to the ECtHR is only a last resort. The EU, being the legislature in the field of civil justice cooperation, is therefore still under an obligation to provide for adequate remedies in legislation, even if recourse to the ECtHR is available. As Chapter 5 explains, it is in itself highly doubtful that EU citizens would even have recourse to the ECtHR in matters governed by EU legislation.

Additionally, Cuniberti and Rueda point to the reluctance of the ECtHR to become actively engaged in certain cases with an EU law element. They cite as an example the decision of the ECtHR in the previously discussed Gambazzi case that an application brought by Mr Gambazzi against the United Kingdom in this case was manifestly ill-founded. ${ }^{162}$ However, since the ECtHR's decision on admissibility has not been published, it is impossible to know exactly why the ECtHR considered the application manifestly ill-founded. ${ }^{163}$ It is however certainly

\footnotetext{
${ }^{160}$ Cuniberti and Rueda (2011); De Cristofaro (2011).

161 Cuniberti and Rueda (2011) p. 295.

162 Kuipers (2010) p. 44; Cuniberti (2010) p. 8.

${ }^{163}$ The admissibility decision was not published in the ECtHR's reports or its online database. In response to a request by the author of this research, the ECtHR's registry confirmed that 'The case GAMBAZZI v. the United Kingdom has been declared inadmissible on the date of 09/01/2003.The Court does not give any justifications regarding an inadmissibility on a case. The HUDOC database provides access to the case-law of the Court (Grand Chamber, Chamber and Committee judgments, decisions, communicated cases, advisory opinions and legal summaries from the Case-Law Information Note), the European Commission of Human Rights (decisions and reports) and the Committee of Ministers (resolutions). Therefore, this case cannot be found in HUDOC and decisions are only sent to the applicants or their representatives.'
} 
true that in the absence of ECtHR rulings on this matter the CJEU provides the more specific interpretation on this point.

Finally, and most importantly, it must be emphasized that the availability of recourse to the ECtHR does not eliminate the need for effective remedies at the national level. Recourse to the ECtHR is a last resort. Article 13 of the ECHR requires that violations of the rights it protects are effectively remedied at the national level; a failure to provide an adequate remedy in itself gives rise to a violation. With regard to Article 6, the ECHR requires that procedural irregularities are in principle remedied within the procedure itself, while a failure to observe the reasonable time requirement may be remedied with monetary compensation. ${ }^{164}$ Leaving aside the difficulties associated with holding an EU Member State responsible for violations of the ECHR committed in the implementation of EU legislation (discussed in detail in Chapter 5), the fact that recourse to the ECtHR is possible in no way means that EU or national legislation no longer needs to provide adequate remedies. On the contrary: effective remedies must always be available. As for the EU as an intitution, Article $47 \mathrm{EU}$ CFR requires that anyone whose rights and freedoms guaranteed by EU law are violated has the right to an effective remedy before a tribunal in compliance with the conditions laid down in that Article.

\subsubsection{Interim conclusion}

There is no doubt that the exequatur provides an additional means of protection in cases where the person against whom enforcement is sought has not received a fair trial. Practice has shown that courts are generally reluctant to be very critical of their own procedural rules, and therefore unlikely to rule that a judgment from their country is contrary to public policy. In the context of the public policy exception, this is in fact logically impossible, because public policy despite being closely circumscribed by the CJEU - necessarily refers to the public policy of the state where enforcement is sought.

However, the protective value of the exequatur is not subject to debate. Even proponents of abolition recognize that the exequatur provides an additional check. The problem lies in the question whether this check is necessary in an EU where all Member States are expected to protect fundamental rights adequately. From the point of view of the judgment debtor, more protection will always seem better; but a balance needs to be struck between the debtor's right to a defence, and the creditor's right to access to justice, which includes having his judgment enforced. In this regard, it is submitted that there is at least one category of fundamental rights violations for which a cross-border check is necessary: those that are a result of corruption in the state of origin. Instances of corruption can never completely be prevented, and it is unlikely that they would be detected through self-examination; moreover, the judgment debtor can no longer be expected to have trust in the legal system in which they occurred. ${ }^{165}$

${ }^{164}$ See Chapter 4.3.7.2.

${ }^{165}$ Stadler (2004b) p. 8 . 
Exequatur therefore certainly provides a layer of procedural protection, but whether it is indispensable has been questioned. From a purely legal perspective, it may not be; the debate about its value has therefore mostly been conducted in either very pragmatic or very idealistic terms. The following analysis of what happens when it is absent hopefully provides some clarity.

\subsection{Fundamental rights protection in the absence of refusal grounds: the Zarraga case}

This section discusses the CJEU's Zarraga judgment, ${ }^{166}$ as it illustrates very well what the consequences of automatic enforcement without any refusal grounds may be. The Zarraga decision (also sometimes referred to as Aguirre v. Pelz) provides insight into what the abolition of exequatur means in practice. This judgment is a preliminary ruling on a question referred by the German Oberlandesgericht Celle. The Oberlandesgericht had been asked to enforce a judgment delivered by the Spanish Juzgado de Primera Instancia e Instrucción No 5. The judgment concerned the return of a child (Andrea) to her father in Spain.

Andrea's parents, Joseba Andoni Aguirre Zarraga (from Spain) and Simone Pelz (from Germany) married in 1998 and lived in Sondika, Spain. Their daughter Andrea was born on 31 January 2000. Mr Zarraga and Ms Pelz separated in 2007. On 12 May 2008, Mr Zarraga was awarded provisional rights of custody over Andrea, with Ms Pelz being granted access rights. Ms Pelz moved to her home country of Germany in June 2008, and Andrea spent the summer holidays there; but when the holidays ended she did not return to her father in Spain.

Mr Zarraga requested provisional measures from the Juzgado de Primera Instancia e Instrucción No 5 de Bilbao. This court handed down a judgment on 15 October 2008, in which it considered that Andrea had been living with her mother in breach of its judgment of 12 May 2008, and subsequently imposed provisional measures including prohibiting Andrea from leaving Spanish territory with her mother or anyone close to her mother.

Next the Juzgado de Primera Instancia e Instrucción No 5 de Bilbao continued the proceedings relating to custody over Andrea. The court considered that it was necessary to obtain both a fresh expert report and to hear Andrea and subsequently fixed dates for both in Bilbao. However - and this is the crux of the matter before the CJEU - the Bilbao court refused both Ms Pelz's application that she and her daughter be permitted to leave Spanish territory after the expert report and Andrea's hearing, as well as Ms Pelz's request that Andrea be heard via video conference. Ms Pelz and Andrea therefore attended on neither of those dates, and on 16 December 2009, the Juzgado de Primera Instancia e Instrucción No 5 de Bilbao awarded sole rights of custody in respect of Andrea to her father. An appeal by Ms Pelz, which included a request that Andrea be heard, was refused.

${ }^{166}$ CJEU Case C-491/10 PPU Joseba Andoni Aguirre Zarraga v Simone Pelz ECLI:EU:C:2010:828. 
Mr Zarraga subsequently took action to have his daughter returned to him. First, on 30 January 2009 , he brought an application for the return of his daughter on the basis of the 1980 Hague Convention. That application was first upheld by the Amtsgericht Celle, but subsequently refused on appeal by the Oberlandesgericht Celle by decision of 1 July 2009. It dismissed Mr Zarraga's application on the basis of Article 13(b) of the Hague Convention, which prohibits the return of a child if this would entail a "grave risk" that the child would be exposed to physical or psychological harm. The Oberlandesgericht based its decision in particular on the fact that, when Andrea was heard by that court, she had shown to be resolutely opposed to returning to Spain and had categorically refused to do so. The Oberlandesgericht found that Andrea's opinion should be taken into account based on both her age and her maturity.

In a second set of proceedings, Mr Zarraga obtained a certificate pursuant to Article 42 of Regulation 2201/2003 from the Juzgado de Primera Instancia No 5 de Bilbao, on the basis of the judgment of 16 December 2009. The Amtsgericht Celle was asked to enforce this judgment, but refused on the ground that the Spanish court had not heard Andrea prior to delivering its judgment. Mr Zarraga appealed against this decision before the Oberlandesgericht Celle and requested enforcement of the Spanish judgment.

The Oberlandesgericht Celle then turned to the CJEU for clarification on the powers, if any, it enjoyed to refuse enforcement. The Oberlandesgericht made two observations: first, that the Juzgado de Primera Instancia e Instrucción No 5 de Bilbao did not obtain Andrea's current views and was therefore unable to take into account those views in its 2009 judgment; and second, that the efforts made by the Spanish court to hear Andrea were insufficient to satisfy the requirements of Article 24(1) of the EU Charter of Fundamental Rights (EU CFR).

Consequently, the Oberlandesgericht wondered whether it could be held to enforce a certificate of which the contents were 'manifestly inaccurate', given that it stated that Andrea had been heard, whereas she was not. It asked the CJEU, essentially, whether it could refuse enforcement of the Spanish judgment on the basis of one of two grounds: that the judgment contained a 'serious infringement of fundamental rights', or that it was 'manifestly inaccurate'.

The questions posed by the Oberlandesgericht and the answers provided by the CJEU boil down to the following two issues. Firstly, they concern an interpretation of the Brussels II bis Regulation to ascertain whether there is any discretion left to the enforcing court to refuse enforcement, on either of the two grounds named above. Secondly, they concern the interpretation of the obligation to check whether the child was given an opportunity to be heard, as laid down in Article 42(2) of the Brussels II bis Regulation. 
The CJEU already addressed the first problem in two earlier preliminary rulings: Povse ${ }^{167}$ and Rinau. ${ }^{168}$ Both of these preliminary rulings concerned the court of enforcement's powers of review under the Regulation. In Rinau, but more explicitly in Povse, the CJEU gave a strict interpretation of the system of jurisdiction introduced by the Brussels II bis Regulation which can be summed up as follows: the Regulation, and in particular the provisions concerning the enforcement of return orders, are based on the principle of mutual trust of Member States in one another, ${ }^{169}$ meaning that grounds for refusal should be kept to a minimum. The system of jurisdiction has resulted in a clear division of tasks between the court of origin and the court of enforcement. In this system, only the former is entitled to hear all appeals and applications pertaining to the child's return, while the latter is simply obliged to enforce any decisions handed down by the court of origin without any powers of review. Essentially, the abolition of exequatur including grounds for review is exactly what it looks like: the courts of the Member State where enforcement is sought have no discretion to refuse enforcement, no matter what the circumstances are.

What distinguishes Zarraga from the Rinau and Povse judgments is the issue of when the alleged interference with fundamental rights occurred. Rinau concerned the more technical question of whether the fact that the judgment was subsequently overturned could lead to refusal of enforcement; Povse concerned the possible (future) consequences of enforcement for the concerned parties' family life. Zarraga, by contrast, concerns a case where the fundamental rights interference (whether it was a violation is discussed further on) was already apparent at the time when the judgment was handed down, and therefore obvious to the court responsible for enforcement. It is therefore a case in which, arguably, enforcement would previously have been refused under the public policy exception, and for that reason it demonstrates very well the consequences of abolition of this refusal ground.

Even so, the CJEU's answer to the first problem was, if anything, more explicit than the ones it gave in Rinau and Povse. After reaffirming that the principle of mutual trust forms the basis of the Regulation, and after reiterating the division of tasks achieved by the Regulation, the CJEU states:

52 [Mutual trust and the clear division of jurisdiction] are the principles which must guide the interpretation of the first subparagraph of Article 42(2) of Regulation No 2201/2003, which provides that the court of the Member State of origin is to issue the certificate referred to in paragraph 1 of that article only if the child was given the opportunity to be heard, unless a hearing has been considered inappropriate having regard to the child's age or degree of maturity (Art. 42(2)(a)), if the parties were given the opportunity to be heard (Art. 42(2)(b)) and if that court has in handing down its

167 CJEU Case C-211/10 PPU, Doris Povse v Maura Alpago, ECLI:EU:C:2010:400, not to be confused with ECtHR Povse v. Austria (dec.) no. 3890/11, ECHR 2013.

${ }^{168}$ CJEU Case C-195/08 PPU Inga Rinau, [2008] ECLI:EU:C:1998:608.

${ }^{169}$ CJEU Povse para. 40. 
judgment taken into account the reasons for and evidence underlying the order issued pursuant to Article 13 of the 1980 Hague Convention (Art. 42(2)(c)).

53 It must be observed at the outset that the first subparagraph of Article 42(2) of that regulation has no purpose other than to inform the courts of the Member State of origin of the minimum content required in the judgment on the basis of which the certificate provided for in Article 42(1) is to be issued.

54 Moreover, having regard to the case-law cited in paragraphs 48, 50 and 51 of this judgment, it must be held that the first subparagraph of Article 42(2) in no way empowers the court of the Member State of enforcement to review the conditions for the issue of that certificate as stated therein.

55 Such a power could undermine the effectiveness of the system set up by Regulation No 2201/2003, as described in paragraphs 44 to 51 of this judgment.

56 It follows that, where a court of a Member State issues the certificate referred to in Article 42, the court of the Member State of enforcement is obliged to enforce the judgment which is so certified, and it has no power to oppose either the recognition or the enforceability of that judgment. [Emphasis added]

The CJEU interpreted the Regulation very strictly: the absence of refusal grounds means, quite simply, that enforcement cannot, under any circumstances, be refused. According to the CJEU, this reasoning is bolstered by an a contrario interpretation of the refusal grounds incorporated in the Regulation for other categories of judgments: the fact that these exist for certain judgments, but not for return orders, means that they were deliberately excluded (para. 57). This reasoning is entirely in line with what could be expected on the basis of the two earlier judgments.

Perhaps remarkably, therefore, the CJEU continued to examine whether Article 42(2) of the Regulation, which requires that the court of origin satisfies itself that the child was given an opportunity to be heard prior to certifying the return order as enforceable, gives rise to an absolute duty to hear the child, and whether this was respected. One could ask why the Court considered this analysis necessary, given that it had already concluded that a possible violation of the child's right to be heard could not play any part in the decision to enforce the resulting judgment anyway. Perhaps we should therefore see this part of the CJEU's ruling as a signal that it took the German court's complaint seriously, and used the opportunity to clarify how Article 42(2) should be interpreted. The CJEU began by stating that Article 42(2) should be interpreted in the light of Article 24 of the EU CFR. It went on to state that

62 In that regard, it must first be observed that it is clear from Article 24 of that charter and from Article 42(2)(a) of Regulation No 2201/2003 that those provisions refer not to the hearing of the child per se, but to the child's having the opportunity to be heard. 
This interpretation of Article 24 of the EU CFR appears to be in line with Article 12 of the UN Convention on the Rights of the Child, which was the basis for Article 24. ${ }^{170}$ Article 12(2) of the UN Convention provides that "the child shall in particular be provided the opportunity to be heard in any judicial and administrative proceedings affecting the child", which according to the Implementation Handbook "implies an active obligation on the State to offer the child the opportunity to be heard, although, [...] it is important to emphasize that there is no requirement that the child express views." 171

There is therefore no obligation to hear the child, only to actively provide it with the opportunity to be heard. However, the right of the child to be heard in procedures such as these, which greatly affect him or her, is protected by the UN Convention and - accordingly - the Charter for a very important reason: ${ }^{172}$ to allow the child to participate in procedures which concern him or her, to respect his or her autonomy, and to prevent the child being pressured or influenced by other parties. ${ }^{173}$ This element seems especially important in cases where the parents have separated, as was the case in Zarraga, because in such cases both parents clearly have opposing interests, which do not necessarily correspond to those of the child.

It is submitted that it is at least questionable whether the Spanish court fulfilled this "active obligation", given that it rejected two of Ms Pelz's requests that were aimed at facilitating the hearing of Andrea, including a request that she be heard through videoconferencing. It is not difficult to understand that Ms Pelz did not want to take Andrea to Spain to be heard by the court, if no guarantee could be given that they would be allowed to leave together.

It can therefore be argued, even if the CJEU did not arrive at this conclusion, that the Spanish court was certainly capable of doing more to allow Andrea to make her views heard, ${ }^{174}$ and moreover, that Andrea's views were of central importance to the decision whether or not to order her return, given that both parents clearly had opposing interests. The CJEU recognizes that a court may use "all means available to it under national law as well as the specific instruments of international judicial cooperation" to obtain a child's views, and that a "genuine and effective opportunity" must be provided to the child to express those views.

\footnotetext{
${ }^{170}$ Explanations relating to the Charter of Fundamental Rights, OJ C 303/17, p. 25 (relating to Article 24 of the Charter).

${ }^{171}$ Hodgkin and Newell (2007) p. 155-156.

172 The UN Committee has even recognized the right of the child to be heard as one of four "general principles" of the Convention, which according to the General Comments of the Committee on that article "highlights the fact that this article establishes not only a right in itself, but should also be considered in the interpretation and implementation of all other rights." The right of the child to be heard is therefore clearly of central importance to protecting the child's autonomy. United Nations Committee on the Rights of the Child, Convention on the Rights of the Child. General Comment No. 12: the right of the child to be heard. 2009, p. 3. See also Kruger (2011) p. 37-39; Chapter 7.5.3.

${ }^{173}$ United Nations Committee on the Rights of the Child, Convention on the Rights of the Child. General Comment No. 12: the right of the child to be heard, 2009.

${ }^{174}$ Beaumont and Walker (2011) 244-245.
} 
Furthermore, no pressing reasons seem to have been given as to why Ms Pelz's requests which would have facilitated Andrea's hearing were rejected, even though the Spanish court was clearly allowed to use all available means to obtain her views. Hearing Andrea would have been even more important considering that she had expressed a clear wish not to return to Spain when she was heard by the Oberlandesgericht.

The fact that the CJEU offers its interpretation of the right of the child to be heard at length in its preliminary ruling, even though this interpretation could not influence the outcome of the enforcement proceedings either way, may be taken as a sign that it at least takes the German court's complaint very seriously. This is also clear from the fact that the CJEU did not accept Advocate General Bot's conclusion that Spain was not obliged to hear Andrea because the German court deciding on the first application for Andrea's return had already done so. ${ }^{175}$ This result shows a belief that each court is in principle obliged to obtain its own information concerning the child's views, especially considering that these may change over time. ${ }^{176}$

It has therefore been observed that Zarraga demonstrates the "near-absolute rule" of mutual trust in the area of judicial cooperation in civil matters, ${ }^{177}$ which has in Zarraga been interpreted to the detriment of fundamental rights. ${ }^{178}$ For that reason commentators have concluded that the system of certification under Article 42 has shifted the balance too far in favour of the court of origin, and that it is unfortunate that the CJEU did not use the opportunity to correct it. ${ }^{179}$

Another question is what, if any, is the added value of incorporating a minimum requirement that the child be given an opportunity to be heard in a regulation, if this requirement cannot be invoked in any way by the parties it seeks to protect. Article 42(2)(a) of the Brussels II bis Regulation requires a court to ensure that the child was given an opportunity to be heard prior to certifying the order as enforceable. Zarraga shows this provision does not provide the child any procedural opportunities to invoke the protection of this provision for the child - even though it is the party whose rights this provision intends to protect. Article 43(2) explicitly prohibits an appeal against the issuing of a certificate by the court of origin, while Zarraga excludes any possibility of invoking the minimum requirements in the member state of enforcement. ${ }^{180}$ This raises the question what the practical added value is of the incorporation

\footnotetext{
${ }^{175}$ View of Advocate General Bot, delivered on 7 December 2010, Case C-491/10 PPU, Joseba Andoni Aguirre Zarraga v. Simone Pelz, para. 95 et seq.

${ }^{176}$ De Boer, Th. M. (2011) p. 4644; Holliday (2012) p. 130.

177 Peers (2011) p. 693.

${ }^{178}$ Holliday (2012) p. 132.

${ }^{179}$ Beaumont and Walker (2011) p. 245.

180 The CJEU does note that an appeal against the custody decision of the Juzgado de Primera Instancia e Instrucción No 5 de Bilbao was still pending with the Audiencia Provincial de Biskaya, so a procedural remedy is still open to Ms Pelz and her daughter, which may eventually lead to a review before the Constitutional Court. However, while the appeal on the merits of the custody decision was indeed still pending, the Audiencia Provincial had already explicitly refused a request that Andrea be heard on appeal. Whether this possibility would eventually
} 
of minimum requirements such as those contained in Article 42(2) of Brussels II bis. If they are intended to impel the court that delivered the return order to exercise self-examination, then the experience of Krombach, Maronier v. Larmer and Gambazzi may show this to be illusory, given that in none of these cases the court of origin considered itself to be at fault. ${ }^{181}$ Given this conclusion, do the minimum requirements of Articles 41(2) and 42(2) really add anything of value, or do they merely exist to pay lip-service to the EU's commitment to fundamental rights? From the viewpoint of the parties concerned they probably do not add anything practical; yet the examination of the Povse decision of the ECtHR in the following Chapter will make clear why they may nevertheless play a role in the ECtHR's assessment. ${ }^{182}$ Practice has also shown that the divergence in interpretation regarding the hearing of children between the Member States are so large that this creates problems at the enforcement stage. ${ }^{183}$ The 2015 Study on the Evaluation of the Brussels II bis Regulation concluded that the differing interpretations gave rise to reservations and refusals to enforce (where this was allowed by the Regulation), which undermines "legal certainty and predictability for citizens". ${ }^{184}$

The conclusion must be that Zarraga illustrates the consequences for the protection of fundamental rights when exequatur is abolished: a judgment that previously would have been rightfully refused is now considered enforceable. Any discretion the court of enforcement would previously have enjoyed is removed; together, Rinau, Povse and Zarraga cover a range of factors, from technical to fundamental, which can no longer lead to refusal of enforcement. The likelihood of an exception being allowed in the future is therefore slim.

As discussed, ${ }^{185}$ the authors of the 2011 Report on the Interpretation of the Public Policy Exception commented on the application of the automatic enforcement mechanism of articles 41 and 42 of Brussels II bis. Citing Zarraga as a "prominent, but typical" example, the reporters stated that the application of these provisions has been "difficult":

For national courts, ordering the return of a (minor) child (even against his or her will) to the Member State of its former habitual residence appears problematic. Normally, the emotional conflict between the parents strongly affects the child who becomes entrapped in a difficult situation. Deciding upon such issues is a challenging situation for the courts of EU Member States confronted with highly emotional situations. Taking these concerns into account, it comes as no surprise that the ECJ has been repeatedly requested by national courts on the interpretation of Regulation (EC) No 2201/2003. ${ }^{186}$

provide Andrea with an opportunity to be heard is therefore unclear, since the Spanish courts are clearly of the opinion that they have already satisfied their legal obligation by inviting her to a hearing which she did not attend.

${ }^{181}$ See under 3.4.1.

182 Chapter 5.4.3.

${ }^{183}$ Study on the assessment of the Brussels IIbis Regulation (2015) p. 43 onwards; see Chapter 7.5 below.

${ }^{184}$ Study on the assessment of the Brussels IIbis Regulation (2015) p. 29.

${ }^{185}$ Chapter 3.2.6.2.

${ }^{186}$ Hess and Pfeiffer (2011) p. 159. 
The researchers conclude later on that given the difficult and emotionally charged situations families are confronted with, many find it hard to accept the preference of a foreign judge, leading them to instigate "satellite litigation" in the Member State of enforcement. "This practice", according to the researchers, "demonstrates that the abolition of review proceedings - at least in sensitive areas of law - should be carried out with great caution". ${ }^{187}$

\subsection{Conclusion}

This Chapter demonstrated how EU legislation on civil justice cooperation has generally proved to protect fundamental rights. Its protective function is most apparent in the existence of grounds for refusal. The public policy exception, the protection of defendants in default cases, and the right of the child to be heard are the clearest examples, and it has been shown that they contribute also in practice to the protection of fundamental rights. The special jurisdiction rules are more tangentially connected but are also clearly intended to provide protection for a weaker party.

Section 3.4 demonstrated that the value of the regime for cross-border recognition and enforcement introduced by the Brussels Convention lies not just in these specific grounds for refusal. In fact, grounds for refusal have changed over time, and may be interpreted differently in different contexts. This means that it is very difficult to replace them with common minimum standards, as these cannot possibly be drafted in such a manner as to cover the wide variety of potential problems that have in the past led to the application of the public policy exception or other grounds for refusal.

It was also proposed that cross-border review provides a remedy that cannot be replaced by a check against minimum standards in the Member State of origin of the judgment. Cases such as Maronier v. Larmer and the Polish paternity case show that even when adequate procedural safeguards are in place, they are not always respected, and that only an independent observer may be capable of noticing that a violation occurred. It is submitted that it can never be assumed that all Member States always protect procedural rights adequately, it is a task for the EU legislature to provide for adequate remedies. Since refusal of recognition or enforcement on the basis of common refusal grounds has proved an effective remedy in the past, it is difficult to defend the abolition of this mechanism. Many commentators have expressed their belief that to prioritise free movement over fundamental rights protection is fundamentally wrong, ${ }^{188}$ or at least unwise in the current political situation, where differences in language, legal culture

\footnotetext{
${ }^{187}$ Hess and Pfeiffer (2011), p. 162.

${ }^{188}$ De Cristofaro (2011) p. 451; Beaumont and Johnston (2010a) p. 106; Muir Watt (2001) p. 554; Cuniberti and Rueda (2011) p. 312; Kramer (2011a) p. 640.
} 
and national procedural law are simply too great to allow exequatur to be abolished. ${ }^{189}$ Crossborder checks sometimes simply remain necessary to address fundamental rights violations. ${ }^{190}$

${ }^{189}$ Stadler (2004b) p. 7.

${ }^{190}$ Hess (2012) p. 1103; Kramer (2011b) p. 230. 


\section{Conclusion to Part I}

Chapters 2 and 3 discussed how European Union (EU) legislation on free movement of civil judgments evolved and what potential consequences the developments in this field have for the protection of the fundamental rights of EU citizens and businesses. This conclusion presents the most pertinent findings from the two Chapters, and explains why these support the conclusion that complete free movement of civil judgments is a potential problem from a fundamental rights perspective.

\section{A. European Union legislation increasingly allows for complete free movement of judgments}

Chapter 2 showed the evolution of free movement of civil judgments in EU legislation. It explained that the cross-border recognition and enforcement of judgments in civil and commercial cases has been within the purview of the EU for a long time due to its importance to the realisation of the internal market. ${ }^{1}$ Since the creation of an express legal basis in the EU's founding Treaties, but especially as a result of the introduction of mutual recognition by the 1999 Conclusions of Tampere, ${ }^{2}$ the EU legislature's objective became much more ambitious than it was previously: to remove all legal obstacles to the recognition or enforcement of judgments across borders within the EU. This objective led to both the abolition of formal requirements for cross-border enforcement in some instruments (judgment import, or the exequatur) and the abolition of grounds for refusal (judgment inspection). The latter removed all possibilities for the Member State where recognition or enforcement was sought to exercise control. This was despite the fact that the 2007 Heidelberg Report concluded that the existing procedure for cross-border enforcement of Brussels I functioned quite effectively, with over $90 \%$ of judgments being enforced without difficulty, ${ }^{3}$ and that the refusal grounds were only rarely applied. ${ }^{4}$

Currently, the Maintenance Regulation ${ }^{5}$ and the two uniform procedures (the European Small Claims Procedure (ESCP) and the European Order for Payment Procedure (EOP) $)^{6}$ have abolished both judgment import and judgment inspection. Judgments falling within the scope of (or resulting from) one of these Regulations can therefore be enforced automatically throughout the EU, and there are no possibilities for the Member State addressed to refuse recognition or enforcement.

\footnotetext{
${ }^{1}$ Chapter 2.2.1.

${ }^{2}$ Chapters 2.2.2 and 2.2.3.

${ }^{3}$ Chapter 2.2.4.

${ }^{4}$ Chapter 2.2.4.1; the 2011 Report on the application of the public policy exception, discussed in Chapter 3.2.6, supports this conclusion with regard to the public policy exception.

${ }^{5}$ Chapter 2.3.4.

${ }^{6}$ Chapter 2.3.7.
} 
The European Enforcement Order for Uncontested Claims (EEO) ${ }^{7}$ and the Brussels II bis Regulation ${ }^{8}$ replaced the judgment inspection previously provided by refusal grounds with minimum standards that need to be fulfilled before a judgment is declared enforceable. The responsibility to check whether they are fulfilled lies with the court in the Member State of origin of the judgment. The new Brussels I bis Regulation retained the grounds for refusal ${ }^{9}$ after a proposal to reform them was met with academic and political criticism. ${ }^{10}$ Apart from Brussels I bis, the Insolvency Regulation and the Succession Regulation still contain refusal grounds, although this may change. ${ }^{11}$

To conclude, the abolition of both formal and substantive checks on the cross-border recognition and enforcement of judgments in civil cases is a clear priority for the EU legislature, which has so far been achieved for a considerable number of Regulations in all fields of civil law.

\section{B. Refusal of enforcement is effective as a remedy for fundamental rights violations}

Chapter 2 showed that the substantive checks on cross-border recognition and enforcement have been shown to act as a remedy for violations of the right to a fair trial. Grounds for refusal - the public policy exception, the protection of the defaulting defendant, and the requirement that the child or parents be heard of the Brussels II bis Regulation - enabled courts in the requested Member State to identify fundamental rights violations and to remedy them by preventing the judgment from taking effect. Both the Heidelberg Report (2007) and the Report on the functioning of the public policy exception (2011) demonstrated that the public policy exception was and is applied by national courts in order to address procedural defects and, comparatively rarely, substantive issues. ${ }^{12}$ Most of the cases in which public policy was invoked successfully, as reported in the 2011 Report on the public policy exception, concerned the Brussels I Regulation. Cases such as Krombach v. Bamberski, ${ }^{13}$ Maronier v. Larmer,${ }^{14}$ and the small, yet considerable, number of national cases ${ }^{15}$ cited in both the Heidelberg Report and the Report on the public policy exception show that procedural defects occur from time to time. They can be the result of an unacceptable rule of procedure (Krombach) or of an incorrect application of rules that may, in principle, be considered adequate (Maronier v. Larmer). The

\footnotetext{
${ }^{7}$ Chapter 2.3.6.

${ }^{8}$ Chapter 2.3.5.

${ }^{9}$ Chapter 2.3.3.2

${ }^{10}$ Chapter 2.2.2.

${ }^{11}$ Chapter 2.2.2.

${ }^{12}$ Chapter 3.2.6.

${ }^{13}$ Chapter 3.2.5.

${ }^{14}$ Chapter 3.2.6.

${ }^{15}$ Chapter 3.2.6.
} 
number of cases is 'small, yet considerable', because it must be stressed that the fact that a safeguard such as the public policy exception is applied only rarely does not mean it is unimportant or that it can be done away with. It should not be forgotten that public policy is an 'emergency brake', only to be applied in the most extreme of cases; the fact that there are cases that are sufficiently serious to warrant its application is itself telling. The fact that they occurred at all, even if there were only few, should therefore be cause for concern for the European legislature.

Chapter 2 also concluded that in cases such as Krombach v. Bamberski, Maronier v. Larmer and the Polish/German paternity case ${ }^{16}$ the cross-border check by means of refusal of enforcement was necessary to address the violation that occurred. This is not only because the parties affected were unable to invoke a remedy in the Member State of origin, but also because it is highly doubtful whether courts in the Member State of origin are capable of disqualifying their own legislation and practice. It is submitted that the value of a cross-border check is precisely to address the application of rules that may be legal in the Member State of origin, but that are unacceptable when regarded objectively. ${ }^{17}$

The 2011 Report also discussed, as this research has done, ${ }^{18}$ the 'difficult' application of mutual recognition of judgments concerning access and return of children. In the absence of refusal ground such as public policy, national courts are clearly hesitant to apply mutual trust. This research has argued that their reluctance can be justified. Especially in the sensitive context of the return of abducted children, adequate safeguards need to be in place to ensure that the interests of all parties, but primarily that of the child, are taken into consideration. The case of Zarraga shows that minimum requirements in the Member State of origin cannot adequately replace a public policy (or similar) exception in the Member State of enforcement. ${ }^{19}$

\section{Mutual trust does not make cross-border checks obsolete}

The European Commission contended in its proposal for a recast Brussels I Regulation that "the level of trust among Member States has reached a degree of maturity which permits the move towards a simpler, less costly, and more automatic system of circulation of judgments". ${ }^{20}$ It is submitted that even if this is true, it cannot justify the complete abolition of cross-border checks. The question is not whether mutual trust exists: it is not contested that EU legislation on recognition and enforcement is based on mutual trust and that Member State courts apply the provisions in conformity with this principle. ${ }^{21}$ The 2007 Heidelberg Report showed that the refusal grounds were applied restrictively and only in a small number of cases, and therefore

\footnotetext{
${ }^{16}$ Chapter 3.2.6.

${ }^{17}$ Chapter 3.4.1.

${ }^{18}$ Chapter 3.5.

${ }^{19}$ Chapter 3.4.2.

${ }^{20}$ Chapter 2.2.2.

${ }^{21}$ Chapter 2.2.3.
} 
do not considerably reduce efficiency. The question is rather whether mutual trust can be assumed to exist, and be justified, at all times. Chapter 3 showed that serious problems simply sometimes occur. When these are detected and remedied, this is not an expression of distrust, but rather an incidental rebuttal of the strong presumption that trust is justified. Even the existence of common minimum standards, as in the EEO, ESCP and EOP Regulations, cannot prevent occasional misunderstandings or misapplications of these rules that could lead to a rebuttal of trust in a concrete case. It is therefore submitted that in some cases refusal of recognition or enforcement by the requested Member State may be the only way of remedying a serious violation of a fundamental rights. This is especially so in situations where the judgment debtor cannot be expected to put his trust in the effectiveness of the justice system of the Member State of origin, for example where the judgment was delivered as a result of bribery or other forms of corruption. ${ }^{22}$

\section{Conclusion: complete free movement of civil judgments is a fundamental rights question}

Complete free movement of civil judgments, obtained by a reduction in checks pertaining to cross-border recognition and enforcement, is problematic from a fundamental rights perspective because these checks were shown to both detect and remedy violations of fundamental rights. For that reason alone, free movement of civil judgments is a topic that merits close examination from a fundamental rights perspective. The following three Chapters provide such an examination: Chapter 4 shows which obligations flow from the right to a fair trial in civil cases, while Chapters 5 and 6 explore who is responsible for fulfilling these obligations in the multilevel legal order of the EU.

This is not, however, the only question pertaining to the protection of the right to a fair trial raised by the EU legislation on free movement of judgments. The EOP and ESCP Regulations aim to provide complete and uniform European civil procedures. For these procedures, fundamental rights problems do not only result from the abolition of refusal grounds, but also from the fact that they aim to create simple and efficient procedures; whether this quest for efficiency has come at the expense of procedural fairness is a question that merits examination. ${ }^{23}$ The EEO Regulation likewise raises questions as to its conformity with the right to a fair trial that go beyond the mere abolition of refusal grounds. ${ }^{24}$

The abolition of cross-border checks also raises questions regarding the obligations of the EU's Member States to protect fundamental rights. Under regulations such as those named above, Member States are required to trust that decisions from other EU Member States conform to fundamental norms; they are not allowed to check whether these norms have actually been observed. This raises questions with regard to the Member States' responsibilities under the European Convention on Human Rights, since as Chapter 2 discussed, the ECtHR has considered the Convention rights to be part of states' ordre public externe, obligating them to

\footnotetext{
${ }^{22}$ Chapter 7.1.

${ }^{23}$ Chapter 8.5.

${ }^{24}$ Chapter 8.4.
} 
refuse enforcement of foreign judgments. The question is whether this obligation exists where EU legislation requires Member States to enforce each other's decisions on the basis of trust.

Finally, it should be emphasised that abolition of obstacles to cross-border enforcement of judgments does not only create risks that violations of fair trial might go unchecked; it also potentially greatly benefits judgment creditors and therefore contributes to the effective protection of their right to enforcement, which is also part of the right to a fair trial. The question is therefore not only how to safeguard debtor's rights in the context of cross-border enforcement, but also how to ensure that creditors can effectively exercise their right to enforcement. In the following Chapters, the question is therefore not only how fundamental rights limit free movement of judgments, but also how fundamental rights create a positive obligation to facilitate free movement of judgments. 
Part II 


\section{The right to a fair trial in civil cases}

\subsection{Introduction}

The previous Chapter introduced the move towards complete free movement of civil judgments as a development that raises profound questions concerning the protection of fundamental rights. It was discussed that safeguards such as grounds for refusal are increasingly being abolished. This means that judgments that are the result of unfair civil proceedings, which previously would have been caught by these refusal grounds, may now be immediately enforced and recognised throughout the European Union (EU). To show why this is a potential problem, it is necessary to understand why it is important to safeguard the right to a fair trial in civil procedures, and what this entails. This Chapter shows which requirements the right to a fair trial, as protected by both the European Convention on Human Rights (ECHR) and in the EU fundamental rights framework, imposes on the civil trial. ${ }^{1}$ It specifically explores how the right to a fair trial informs the enforcement stage of the civil trial, and what this means for a legal regime on cross-border recognition and enforcement.

The goal of this exploration is threefold. First, it provides a context in which to place the cases that were presented in the introduction and the previous Chapter as examples of violations of the right to a fair trial that should be remedied through the application of refusal grounds. This Chapter aims to show why the violations that occurred in those cases were sufficiently serious to trigger the application of those grounds.

The second goal of this Chapter is to provide a framework for the following chapters by looking at the structure and character of the right to a fair trial, and the principles underlying it. This is especially important with a view to exploring in what cases refusal of recognition or enforcement is an appropriate remedy. It was previously discussed that the public policy exception should only be applied in exceptional cases, as should the protection of the defaulting defendant. This Chapter aims to provide a basis for distinguishing between violations of the right to a fair trial that can only be remedied by the application of a refusal grounds, and those that can be remedied in other ways. It also makes it possible to explore where the concepts of public policy and the right to a fair trial overlap, and where they do not.

Third, this Chapter serves the very practical purpose of providing an overview of the case law that the European courts have handed down concerning the right to a fair trial. This case law provides specific interpretations of the right to a fair trial that are of great importance with regard to the design of legislation intended to prevent violations from occurring. Chapter 7 uses

\footnotetext{
${ }^{1}$ This Chapter only discusses what an enforcement procedure should look like, based on the ECtHR's and CJEU's case law on the right to a fair trial. Whether the ECHR requires a form of cross-border judgment inspection at all is discussed in Chapter 5.
} 
the identified standards to evaluate the existing safeguards in the current regulations and to provide suggestions on how these could be improved.

The structure of this Chapter is as follows. Section 4.2 presents the primary sources for the right to a fair trial in Europe: Article 6(1) of the ECHR and Article 47 of the EU Charter of Fundamental Rights (EU CFR). This Article is a codification of the Court of Justice of the European Union's (CJEU) case law in which it developed the right to a fair trial as a general principle of EU law, so this case law remains applicable. Article 47 of the EU CFR is, by virtue of Article 52(3) of the EU CFR, directly connected to Article 6(1) and its interpretation; this connection is explained in Section 4.2.3. Section 4.2.4 then discusses in general terms how the right to a fair trial has been applied; in particular, to what extent it is considered absolute and whether a margin of appreciation applies.

Section 4.3 discusses the elements of the right to a fair trial and how they apply to civil cases. The elements of the right to a fair trial are examined in turn and it is shown how the CJEU and European Court of Human Rights (ECtHR) apply these elements in their case law. The case law from the CJEU and the ECtHR are discussed together, since for the purposes of EU legislation they are equally relevant.

Section 4.4 then is an attempt to understand the principles behind the fair civil trial as it has been developed in the Western constitutional tradition. The purpose of this section is to understand better why the civil trial took on its current form. It is argued that the civil trial, with its emphasis on equality between the parties and adversity, and presided over by an independent and impartial judge, serves a dual purpose. On one hand, it allows parties to protect or exercise their subjective rights under civil law; in order to achieve this objective, the civil trial facilitates a fair outcome that is true to the facts. ${ }^{2}$ At the same time, the fair trial as guaranteed by Articles 6(1) ECHR and 47 EU CFR is arguably an expression of the principle of human dignity, in which each party to a conflict should be treated as having a good faith position worth taking into consideration. ${ }^{3}$

This exploration of the principles behind the fair civil trial serves as a framework for following chapters, in which it is used to provide some insight into what elements of the right to a fair trial require more protection, in the specific context of cross-border recognition and enforcement of judgments, than others. It should be noted that these principles are not intended as a general theory on the hierarchy of elements of the right to a fair trial or as a comment on the courts' case law. Rather, it is an attempt to understand the function of certain elements of the right to a fair trial and the consequences of disregarding them. These conclusions are then used in Chapter 7 to show how conflicts between these elements may be resolved, and in Chapter 8 to reflect on the best way to incorporate these elements into legislation.

\footnotetext{
${ }^{2}$ See 4.4.2.

${ }^{3}$ See under 4.4.3.
} 


\subsection{The right to a fair civil trial in the European treaties}

\subsubsection{Article 6(1) of the European Convention on Human Rights}

The European Convention on Human Rights is the primary source of fundamental rights in Europe. ${ }^{4}$ All EU Member States are Contracting Parties to the ECHR; its ratification is a prerequisite for joining the Union. Furthermore, Article 2 of the Treaty on European Union (TEU) expresses that the EU is founded on, among others, respect for human rights, while Article 6 TEU provides that fundamental rights as guaranteed by the ECHR shall constitute general principles of the EU. As is further explained below, the CJEU has consistently drawn on the ECHR and the ECtHR's case law in cases involving fundamental rights. The EU CFR has, by virtue of Article 52(3), effectively made the ECHR's sunstantive provisions directly binding on the EU institutions and its Member States when they implement EU law, at least in so far as its provisions correspond to those of the ECHR. While the EU CFR is therefore the primary reference point when considering the compatibility of EU legislation with fundamental rights, its corresponding provisions are interpreted in accordance with the ECHR.

Within the ECHR, Article 6 holds a prominent place, because of its importance in a democratic society and as a central element of the rule of law. ${ }^{5}$ Its practical importance is also considerable: Article 6 has attracted more applications and resulted in more judgments than any other right. ${ }^{6}$

Only its first section applies to the civil trial; sections 2 and 3 contain specific guarantees for the criminal trial. Article 6(1) reads as follows:

\section{Article 6}

\section{Right to a fair trial}

1. In the determination of his civil rights and obligations or of any criminal charge against him, everyone is entitled to a fair and public hearing within a reasonable time by an independent and impartial tribunal established by law. Judgment shall be pronounced publicly but the press and public may be excluded from all or part of the trial in the interests of morals, public order or national security in a democratic society, where the interests of juveniles or the protection of the private life of the parties so require, or to the extent strictly necessary in the opinion of the court in special circumstances where publicity would prejudice the interests of justice.

\footnotetext{
${ }^{4}$ The Convention's territorial scope is wider than the European Union, as it applies in all countries that are members of the Council of Europe. Currently, the Council of Europe has 47 Member States, that are all Contracting Parties to the Convention. See http://echr.coe.int/en/web/human-rights-convention.

${ }^{5}$ Rainey et al. (2014) p. 247; Janis et al. (2008) p. 719.

${ }^{6}$ Harris et al. (2014) p. 370; Grotian (1994).
} 


\section{A. Scope of application}

The scope of this Article includes all civil rights and obligations, which may be taken to mean all rights and obligations that apply in the relation between private persons (though relations between private persons and public institutions are not entirely excluded). It also applies in civil matters only where there is a dispute between private parties whose intended outcome is the determination of those civil rights and obligations. It appears evident that Article $6(1)$ covers ordinary civil litigation between private individuals, such as those arising out of tort, contract, and family law. ${ }^{7}$ The requirement of a 'dispute' is derived from the French text of the Convention, which uses the word 'contestation' instead of 'determination'. ${ }^{8}$ The dispute must be one that lends itself to judicial resolution: for example, the ECtHR once ruled that an examination aimed at assessing the candidate's competence as an accountant did not come within the scope of Article 6, because the examination was more akin to school or university examining than judging. ${ }^{9}$ There must therefore be some sort of legal question that may be resolved through a judicial procedure for Article 6 to be applicable. The dispute must also be 'genuine and serious', i.e., there must be something at stake for the applicant. ${ }^{10}$ Moreover, the decision resulting from the procedure must be directly decisive for the civil rights and obligations concerned.

It can be assumed that Article 6 in principle applies to all matters that come within the material scope of the Regulations discussed in this research. ${ }^{11}$ The Brussels I bis, II bis, Insolvency, European Order for Payment (EOP), European Small Claims Procedure (ESCP) and European Enforcement Order for uncontested claims (EEO) Regulations all apply to civil matters, while Brussels I bis explicitly excludes certain administrative disputes ${ }^{12}$ and all regulations exclude disputes against the State. ${ }^{13}$

It can also be assumed that most of the procedures that benefit from the application of the regulations can also be considered disputes. Brussels I bis regulates the recognition and enforcement of 'judgments', which as Chapter 2 explained, only applies to judicial decisions which have been, or were capable of being, the result of an inquiry in adversarial proceedings. ${ }^{14}$ It seems likely that all judgments that fit this definition will also be deemed to concern the

\footnotetext{
${ }^{7}$ Rainey et al. (2014) p. 252. 'Civil rights and obligations' is an autonomous concept, though in König v. Germany the ECtHR ruled that a right's classification under domestic law can be relevant: ECtHR König $v$. Germany, appl. no. 6232/73 ECHR A27, para. 89.

${ }^{8}$ ECtHR Benthem v. Netherlands appl. no. 5548/80 ECHR A97.

${ }^{9}$ ECtHR Van Marle v. The Netherlands, appl. nos. 8543/79 8674/79 8675/79 8685/79, ECHR A101.

${ }^{10}$ ECtHR Kienast v. Austria appl. no. 23379/94, 23 January 2003.

${ }^{11}$ See also 2.3.1.1.

${ }^{12}$ Article 1(1) Brussels Ibis Regulation.

${ }^{13}$ Article 2(1) EEO Regulation; Article 2(1) EOP Regulation; Article 2(1) ESCP Regulation; Article 1(1) Brussels Ibis Regulation; Article 1(1) Brussels IIbis Regulation.

${ }^{14}$ Chapter 2.3.1.1; CJEU Case 125/79 Denilauler v SNC Couchet Frères, ECLI:EU:C:1980:130.
} 
'determination of civil rights and obligations'. It is also clear from the ECtHR's case law that the matters covered by the Brussels II bis Regulation (divorce, separation, marriage annulment, and parental responsibility) can be considered civil rights and obligations for the purpose of Article 6(1). ${ }^{15}$ Finally, there can be no question that the procedures of the ESCP and EOP Regulations, ${ }^{16}$ which are designed to result in a judgment determining the rights and obligations of parties vis-à-vis each other, should in their entirety conform to Article 6(1).

B. Stages of proceedings covered by Article 6(1)

While all disputes covered by the Regulations can therefore be regarded 'determinations of civil rights and obligations' within the meaning of Article 6(1), a more difficult question is whether enforcement proceedings, and in particular exequatur proceedings, should conform to Article 6(1). Article 6(1) applies from the moment court proceedings are instituted (normally when a writ of summons is served), ${ }^{17}$ and prescribes the manner in which judgments should be handed down and motivated. It is not clear from the wording of Article 6(1) whether it applies to procedural steps that are taken after the judgment has been delivered.

The ECtHR however ruled in the landmark case of Hornsby v. Greece that Article 6 also applies to the execution of judgments. According to the ECtHR, the 'right to a court' would be 'illusory' if the final judgment were allowed to remain inoperative to the detriment of one of the parties, and that this would contravene the principles underlying the ECHR. ${ }^{18}$ The extent to which the right to enforcement is protected under Article 6 is extensively discussed in 4.3.6 below.

Exequatur proceedings, meaning proceedings in which a court decides whether a foreign judgment should be allowed to be enforced, have also been ruled to come within the remit of Article 6. In McDonald v. France, ${ }^{19}$ the ECtHR first accepted that a refusal to enforce a foreign judgment could amount to a violation of Article 6(1), though it did not find a violation in that case. In ECtHR Saccoccia v. Greece,${ }^{20}$ the ECtHR ruled that the proceedings for obtaining an exequatur should in their entirety conform to Article 6(1).

\footnotetext{
${ }^{15}$ See for example ECtHR Airey v. Ireland appl. no. 6289/73 ECHR A32, on separation, and ECtHR Mizzi v. Malta, appl. no. 26111/02, ECHR 2006-I, on paternity.

16 The European Order for Payment (EOP) Procedure is in principle a one-sided procedure that does not require the appearance of the defendant (Chapter 2.3.7). It should nevertheless be considered as a 'dispute' within the scope of Article 6(1) ECHR, since the procedure clearly determines the civil rights and obligations of the claimant and defendant vis à vis each other. The ECtHR has ruled that a procedure cannot be regarded as a dispute when it is non-contentious and unilateral and does not involve opposing parties (ECtHR Alaverdyan v. Armenia (dec.) appl. no. 4523/04, 24 August 2010) but this is clearly not the case in an application for an EOP. That the presence of the defendant is not required to issue an EOP does not negate its status as a dispute.

${ }^{17}$ E.g. ECtHR Guincho v. Portugal 8990/80 ECHR A81.

${ }^{18}$ ECtHR Hornsby v. Greece appl. no. 18357/91 ECHR 1997-II.

${ }^{19}$ ECtHR McDonald v. France [dec.] appl. no. 18648/04, 29 April 2008.

${ }^{20}$ ECtHR Saccoccia v. Austria, appl. no. 69917/01, 18 December 2008.
} 
The mechanisms for recognition and enforcement contained in these regulations, including the EEO, should therefore conform to Article 6(1) ECHR. Section 8.4, below, explores the implications of this conclusion in greater detail.

\subsubsection{EU law and Article 47 of the EU Charter on Fundamental Rights}

The second relevant source of the right to a fair trial for EU legislation is to be found within EU law itself: Article 47 of the EU CFR and the case law of the CJEU. ${ }^{21}$

Article 47 reads as follows:

Article 47

\section{Right to an effective remedy and to a fair trial}

Everyone whose rights and freedoms guaranteed by the law of the Union are violated has the right to an effective remedy before a tribunal in compliance with the conditions laid down in this Article.

Everyone is entitled to a fair and public hearing within a reasonable time by an independent and impartial tribunal previously established by law. Everyone shall have the possibility of being advised, defended and represented.

Legal aid shall be made available to those who lack sufficient resources in so far as such aid is necessary to ensure effective access to justice.

Since the wording of Article 6(1) ECHR is identical to the second paragraph of Article 47 EU CFR, it can be concluded that it corresponds to that Article, which is confirmed by the Explanations to the EU CFR. ${ }^{22}$ According to Article 52(3) of the EU CFR, this means that it shall be interpreted in the same way as Article 6(1) ECHR (see below). A clear difference is that the scope of Article 47 is not limited to the determination of civil rights or obligations, or of a criminal charge. This limitation is absent from the Article, which means that administrative disputes are also included in its scope. For the purpose of civil proceedings however, Article 47 corresponds to Article 6(1), though the CJEU may provide more extensive protection in its case law (see below).

\footnotetext{
${ }^{21}$ The status of the EU CFR in the wider EU fundamental rights framework is discussed in Chapter 6.2; the following concerns only Article 47.

${ }^{22}$ Explanations relating to the EU Charter of Fundamental Rights, OJ C 303/17, 2007. These Explanations do not as such have the status of law, but they are a valuable tool of interpretation intended to clarify the provisions of the EU CFR.
} 
Notably, Article 47 expressly provides a right to legal aid. Article 6(1) does not explicitly refer to the right to legal aid, but the ECtHR accepted in its judgment in Airey ${ }^{23}$ that Article 6(1) includes a right to legal aid in certain circumstances as part of the right to access to justice. The final sentence of Article 47 of the EU CFR is, according to the Explanations, a codification of that judgment. ${ }^{24}$

\subsubsection{Relationship and interplay}

Since the second sentence of Article 47 therefore corresponds to Article 6(1) ECHR, it must be interpreted in the same way. Article 52(3) of the EU CFR provides the following on EU CFR rights that correspond to ECHR rights:

In so far as this EU CFR contains rights which correspond to rights guaranteed by the Convention for the Protection of Human Rights and Fundamental Freedoms, the meaning and scope of those rights shall be the same as those laid down by the said Convention. This provision shall not prevent Union law providing more extensive protection.

The Explanations to the EU CFR confirm that Article 47 indeed corresponds to Article 6(1) and needs to be interpreted accordingly:

Article 52(3) is intended to ensure the necessary consistency between the EU CFR and the ECHR by establishing the rule that, in so far as the rights in the present EU CFR also correspond to rights guaranteed by the ECHR, the meaning and scope of those rights, including authorised limitations, are the same as those laid down by the ECHR.

[...] Article 47(2) and (3) corresponds to Article 6(1) of the ECHR, but the limitation to the determination of civil rights and obligations or criminal charges does not apply as regards Union law and its implementation.

The combined consequence of these provisions is essentially that Article 6(1) ECHR has become directly binding on the EU and its Member States when they apply EU law, ${ }^{25}$ though the Union is free to provide more extensive protection. ${ }^{26}$ The previous section concluded that the legal instruments on judicial cooperation that are in force within the EU must conform to Article 6(1) ECHR. They clearly must also conform to Article 47 of the EU CFR. Since Article 52(3) of the EU CFR allows the Union to provide more extensive protection, the implications of both articles for the regulations on civil justice cooperation must be considered together in

\footnotetext{
${ }^{23}$ ECtHR Airey v. Ireland.

${ }^{24}$ Explanations to the EU CFR, p. 30.

${ }^{25}$ Article 51(1) EU CFR; see for a discussion of its scope Chapter 6.2.2.

${ }^{26}$ Explanations to the EU CFR, p. 33; Heringa and Verhey (2001) p. 17.
} 
order to conclude which provides the most extensive protection. Section 3 provides an overview of the most important case law from both the CJEU and ECtHR on the right to a fair trial that is of relevance to the civil trial.

\subsubsection{Structure, internal connections, and interpretation}

Before going into detail, it is useful to briefly discuss the interpretation guidelines with regard to the right to a fair trial. According to the ECtHR,

In a democratic society within the meaning of the Convention, the right to a fair administration of justice holds such a prominent place that a restrictive interpretation of Article 6(1) would not correspond to the aim and purpose of that provision. ${ }^{27}$

As opposed to other rights laid down in the ECHR, Article 6(1) has been applied extensively by the ECtHR. It is only to a limited extent subject to what is called the 'margin of appreciation doctrine', by which the ECtHR determines to what extent the States Parties may legitimately restrict the exercise of ECHR rights. ${ }^{28}$

Such a margin is not considered to play a significant role in the application of Article $6 .{ }^{29}$ The reason for this is that the application of Article 6 does not, unlike other ECHR rights, allow limitations on grounds of public safety, health, morals or other grounds relating to morals and values that differ across Member States. In relation to these grounds for limitation, the argument is made that States are better placed to decide whether limitations are justified, and that the ECtHR should therefore only carry out a marginal review. ${ }^{30}$ With regard to Article 6, the 'better placed' argument does not apply, since as a judicial authority, the ECtHR is in a good position to review a national procedure for its compatibility with Article 6. Consequently, the ECtHR stated from the outset, in its judgment in Delcourt, ${ }^{31}$ that Article 6 does not lend itself to a restrictive interpretation. However, certain elements of the right to a fair trial may be subject to a certain degree of discretion: the ECtHR has accepted that in particular the right to access to a court (which is not explicitly included in Article 6(1)) may be restricted, though only if certain conditions are met. ${ }^{32}$ Similarly the ECtHR has acknowledged a certain discretion as regards the degree to which judgments must contain reasoning. ${ }^{33}$

\footnotetext{
${ }^{27}$ ECtHR Delcourt v. Belgium appl. no. 2689/65 ECHR A11, para. 25.

${ }^{28}$ See for a discussion Chapter 7.2.3.2.

${ }^{29}$ Gerards (2011) p. 185-190; Legg (2012) p. 210.

${ }^{30}$ ECtHR Handyside v. UK, appl. no. 5493/72 ECHR A24 para. 48; see Chapter 6.2.3.

${ }^{31}$ ECtHR Delcourt v. Belgium, appl. no. 2689/65 ECHR A11, para. 25.

${ }^{32}$ ECtHR Ashingdane v. UK appl. no. 8225/78 ECHR A93.

${ }^{33}$ See section 4.3.2.7.
} 
The Contracting States are also accorded considerable leeway as to the manner in which they guarantee a fair trial. It has been argued that in this regard the rules of Article 6(1) are as much obligations of result as of conduct, with national courts being allowed whatever particular rules they choose as long as the end result can be considered fair. ${ }^{34}$ Consequently the ECtHR bases its assessment of a trial's fairness on the proceedings in their entirety. The 'extensiveness' of its assessment is expressed in the fact that the trial must always be fair: since there are no grounds for limitation and no margin of appreciation, it is never acceptable to grant a less than fair trial; and what is 'fair' in a given case is decided by the ECtHR.

What is 'fair' may differ according to the circumstances of the case. When the ECtHR is called upon to review whether a procedure was fair, it will look at the trial in its entirety. ${ }^{35}$ There are few procedural defects that will conflict with a fair trial to such an extent that an opinion can be given about the fairness of the trial irrespective of the further course of the proceedings. One example may be national legislation that completely prevents a person from being effectively defended $^{36}$. In most cases it will be possible for procedural defects to be effectively repaired at a later stage of the trial, for example during appeal, so that the procedure as a whole can be considered fair. ${ }^{37}$ This approach means that there is not one correct way of conducting a fair civil trial. The ECtHR has avoided giving an enumeration of criteria in the abstract by which the fairness of a procedure can be assessed. ${ }^{38}$ This means that Contracting States are free to shape the civil trial in such a way as they consider appropriate, and that the ECtHR will assess on a case-by-case basis whether the requirements of a fair trial were met.

There is also no hierarchy between the elements of the right to a fair trial; in principle, a failure to observe any of the elements may result in a finding that Article 6(1) was violated. Section 4.4 of this Chapter and Chapter 7.3 further discuss the question of hierarchy in the context of conflicts between elements of Article 6(1). ${ }^{39}$

\subsection{The right to a fair civil trial in the case law of the European courts}

\footnotetext{
${ }^{34}$ Harris et al. (2014) p. 371; ECtHR Schenk v. Switzerland appl. no. 10862/84 ECHR A140; ECtHR De Cubber v. Belgium (merits) appl. no. 9186/80 ECHR A124-B, para. 35.

${ }^{35}$ ECtHR Barberà, Messegué and Jabardo v. Spain, appl. no. 10590/83 ECHR A146; ECtHR Kostovski v. The Netherlands (merits) appl. no. 11454/85 A166.

${ }^{36}$ See under 4.3.2.2.

${ }^{37}$ Mole and Harby (2006) p. 6.

${ }^{38}$ Van Dijk and Viering (2006) p. 579; Smits (2008) p. 99.

${ }^{39}$ Section 4.4 of this Chapter explores whether it is possible to distinguish a 'core' and a 'periphery' within Article 6(1); Chapter 7.3.2.1 explores whether such a distinction may help determine when refusal of recognition or enforcement is an appropriate remedy.
} 


\subsubsection{Elements of the right to a fair civil trial}

The following discusses the elements of Article 6(1) one by one.${ }^{40}$ For each element of Article 6(1), its implications for the civil trial is discussed, using the ECtHR's and the CJEU's case law as a guide to interpretation. To what extent any of the elements leave a margin of appreciation to the domestic legal systems is also considered.

After having discussed how the ECtHR has applied each element, the same is done for the CJEU. It was discussed above that the EU CFR allows for EU law to provide more extensive fundamental rights protection than required by the ECHR. This means that whichever of the two systems provides the more extensive protection should be considered the standard that EU legislation in the field of civil justice should adhere to. It is often difficult to speak of 'more extensive' protection. This is because sometimes a case has come before one of the courts, where the other court has not yet had an opportunity to rule on the same matter. In such cases it is perhaps more appropriate to speak of a more specific, rather than a more extensive, interpretation. An example is the rights of defaulting defendants; whereas there is no ECtHR case law explicitly dealing with this matter, the CJEU has been able to rule on it several times due to the existence of EU legislation that includes rules on the protection of defaulting defendants. ${ }^{41}$

Selection of case law

As stated before, the right to a fair trial has been acknowledged as a general principle of EU law in the CJEU's case law for a long time. However, owing to the limitations to the CJEU's jurisdiction, which extends only to those cases that fall within the scope of EU law, the right to a fair trial was initially developed as ancillary to other substantive or material questions of EU law. This is illustrated by cases such as Les Verts ${ }^{42}$ and Factortame,${ }^{43}$ in which the CJEU held that substantive rights provided by EU law must always be enforceable before a national court, which in turn may require that effective remedies are implemented at the national level. This line of case law was built on in $D E B,{ }^{44}$ discussed below, which provided that legal aid must be made available in the Member States to litigants who seek to enforce rights emanating from EU law before the national courts. In a similar vein, the CJEU ruled that in case of uncertainties regarding the application of EU law, access to national courts, and in particular the CJEU, must

\footnotetext{
40 There are different ways of presenting these aspects and the interrelations between them: for example, sometimes the right to a reasoned judgment is presented as part of the right to a fair hearing (e.g. Van Dijk and Viering (2006) p. 430) sometimes as an element in its own right (Leanza and Pridal (2014)).

${ }^{41}$ See under 4.3.2.3.

42 CJEU Case 294/83 Les Verts ECLI:EU:C:1986:166.

${ }^{43}$ CJEU Joined Cases C-46/93 and C-48/93 Brasserie du Pecheur and Factortame ECLI:EU:C:1996:79.

${ }^{44}$ CJEU Case C-279/09 DEB ECLI:EU:C:2010:811.
} 
be guaranteed. ${ }^{45}$ Likewise, the effective enforcement of EU rights at the national level requires a right to be heard ${ }^{46}$ and a right to access to documents. ${ }^{47}$

Not surprisingly, there is a lot of case law concerning the right to a fair trial to be found in the field of competition law, where the European Commission has the authority to impose fines on undertakings found to have taken part in a cartel or to have abused their dominant position. The procedural rights of these undertakings in proceedings before the CJEU and the General Court have been subject to litigation in numerous cases, which has yielded rulings on such matters as the right to be heard, ${ }^{48}$ the right not to incriminate oneself (nemo tenetur) and the right to a judgment within a reasonable time. ${ }^{49}$

The cited case law shows that the notion of a right to a fair trial is firmly established in the CJEU's case law. However, as mentioned earlier, the development of that notion has primarily taken place in the field of administrative law (the EU CFR contains a separate codification of the right to a fair trial in administrative cases - Article 41). It is not immediately certain that rights which have been developed to govern the vertical relationship between administrative authorities and their subjects are also applicable in the horizontal situation between two private parties, especially given that the procedural rights in administrative cases have been codified separately in Article 41 EU CFR (the right to good administration). However, it is submitted that it is possible to deduce from the CJEU's case law rules that are also relevant to the civil trial. This is because the CJEU has often framed certain rights as expressions of general principles of the EU, which may be applied more broadly than the specific case in which they were pronounced. There is however also a large number of cases where the applicability to the civil trial is immediately clear. The following section discusses the cases in which, is it submitted, the CJEU gave an interpretation of the right to a fair trial that should be taken into account in the context of future EU legislation in the field of civil procedure.

Since the EU CFR entered into force the EU courts primarily apply Article 47 of the EU CFR and use ECtHR case law to interpret this provision. ${ }^{50}$ However, the EU CFR is explicitly not intended to replace the fundamental rights jurisprudence of the CJEU that was delivered prior

\footnotetext{
${ }^{45}$ CJEU Case 77/83 CILFIT, ECLI:EU:C:1984:91.

${ }^{46}$ CJEU Case C-135/92 Fiskano, ECLI:EU:C:1994:267; CJEU Case C-32/95 P Lisrestal, ECLI:EU:C:1996:402.

${ }^{47}$ GC Case T-23/99 LR af, ECLI:EU:T:2002:75; Joined cases T-10/92, T-11/92, T-12/92 and T-15/92

Cimenteries CBR and others $v$. Commission ECLI:EU:T:1992:123.

${ }^{48}$ CJEU Case 17-74 Transoceanic Marine Paint Association, ECLI:EU:C:1974:106; CJEU Joined Cases 46/87 and 227/88 Hoechst, ECLI:EU:C:1989:337; CJEU Case 107-76 Hoffman-la Roche, ECLI:EU:C:1977:89.

${ }^{49}$ Famously, in Baustahlgewebe the CJEU for the first time ruled that the European Commission had failed to respect the reasonable time requirement and annulled the Commission decision in that case; CJEU Case 185/95 P Baustahlgewebe, ECLI:EU:C:1998:608.

${ }^{50}$ CJEU Case C-199/11 Otis, ECLI:EU:C:2012:684, para. 47.
} 
to the EU CFR entering into force. ${ }^{51}$ This means that older CJEU case law remains relevant. The following sections therefore contain, where relevant, both pre- and post-EU CFR case law.

Another note on the selection of case law must be made: the following is intended to give an overview of case law that is most relevant for civil cases. A large number of ECtHR judgments on Article 6(1) concern criminal cases. ${ }^{52}$ As for the EU, there is, of course, a wealth of case law on the procedural rights of undertakings who are the subject of an investigation by the European Commission under the EU competition rules or on whom a fine has been imposed. ${ }^{53}$ Likewise, there is a great deal of case law dealing with the procedural rights of accused persons in criminal cases and in asylum cases, ${ }^{54}$ on judicial review in cases involving EU external relations policy, ${ }^{55}$ on rights of employees of EU institutions, ${ }^{56}$ and so on.

For the purposes of the following analysis, a selection has been made of the case law that is most relevant to civil justice. It has been well documented that certain elements of the right to a fair trial are interpreted differently in civil cases then they are in criminal cases. For example, in criminal cases the ECtHR nearly always requires a hearing in the presence of the accused, whereas this is not generally necessary in civil cases. ${ }^{57}$

All this means that even though Articles 6(1) and 47 provide the same requirements for both civil and criminal cases, the way in which these requirements can be fulfilled may differ according to the type of case. ${ }^{58}$ This is a direct consequence of the notion of 'fairness', which forms the cornerstone of these provisions: what is needed to achieve fairness is dependent on the circumstances of the case. Because one of the stated goals of this analysis is not to give a comprehensive overview of all ECtHR and CJEU case law on the principle of a fair trial, but to identify the standard that EU legislation on civil justice must comply with, only those cases have been selected that are most relevant to civil cases. This Chapter does therefore not contain a comprehensive discussion of the right to a fair trial as it applies in competition cases or other types of cases outside the scope of this research. Where there is no CJEU judgment on a specific

\footnotetext{
${ }^{51}$ Article 53 of the Charter provides that "nothing in the Charter shall be interpreted as restricting or adversely affecting human rights and fundamental freedoms as recognised [...] by Union law'.

${ }^{52}$ CJEU Case C 396/11 Ciprian Vasile Radu, ECLI:EU:C:2013:39; CJEU Case C 399/11 Stefano Melloni v. Ministerio Fiscal, ECLI:EU:C:2013:107.

${ }^{53}$ See e.g. Kowalyk-Bańczyk (2015).

${ }^{54}$ Case C-562/13 Centre public d'action sociale d'Ottignies-Louvain-La-Neuve v Moussa Abdida, ECLI:EU:C:2014:2453; CJEU Case C-249/13 Khaled Boudjlida v Préfet des Pyrénées-Atlantiques, ECLI:EU:C:2014:2431.

${ }^{55}$ Cases C-402 and 415/05 P Yassin Abdullah Kadi and Al Barakaat International Foundation v Council and Commission ECLI:EU:C:2008:461 (Kadi I); Case T-85/09 Kadi v Commission and Council

ECLI:EU:T:2010:418 (Kadi II) and Case C-584/10 Commission v Kadi ECLI:EU:C:2013:518 (Kadi II).

${ }^{56}$ See for an overview Gattinara (2015).

${ }^{57}$ Harris et al. (2014) p. 410.

${ }^{58}$ It is however important to note that Article 6(1) itself does not, in principle, distinguish between civil and criminal cases, and that the elements of Article 6(1) therefore all apply to both types of proceedings, though their implementation may differ: see Rozakis (2004) p. 97.
} 
element of the right to a fair trial that emanates from a civil case, judgments from other types of cases are analysed and interpreted by analogy in so far as possible.

\subsubsection{The right to a fair hearing}

\subsubsection{The right to access to a court}

ECtHR

Though Article 6(1) does not explicitly guarantee it, the ECtHR acknowledged that access to a court is an essential prerequisite of the right to a fair trial, and may therefore be inferred from the Article ${ }^{59}$ The right to access to a court includes the right to commence civil proceedings; ${ }^{60}$ however, it is difficult to imagine this becoming a problem at the stage where enforcement is sought, because presumably where a judgment was given, the creditor must have had access to a court. However, the right to access to a court also applies to the defendant, who derives from it a right to participate effectively in the proceedings. This means that a lack of access may become an issue at the enforcement stage, where a judgment debtor claims that though he was aware of the proceedings instituted against him, he was prevented from participating, for example because he was wrongfully refused legal aid. ${ }^{61}$ This happened in Steel and Morris $v$. $U K,{ }^{62}$ where the fast-food chain McDonald's brought a claim for defamation against two Greenpeace campaigners and was awarded a total of $£ 76,000$ against them. The defendants had no legal representation and were therefore placed at a considerable disadvantage compared to their opponent. The ECtHR ruled that the United Kingdom had infringed Article 6(1) by refusing them legal aid.

An implication of the right to access to a court is also that court fees may not be disproportionately high. According to the ECtHR, the amount of the charges by the state for taking a case to court must be related to the particular circumstances, including the applicant's ability to pay. ${ }^{63}$ It is imaginable that a judgment debtor may oppose enforcement of a judgment

\footnotetext{
${ }^{59}$ ECtHR Golder v. UK, appl. no. 4451/70 ECHR A18. See Francioni (2007).

${ }^{60}$ ECtHR Airey $v$, Ireland, supra note 14.

${ }^{61}$ Other situations are imaginable, for example where the defendant was barred from participating due to excessive formality; see for example ECtHR Sergey Smirnov v. Russia, appl. no. 14085/04, in which the applicant was not allowed to bring a case because he could not provide a residential address, though he could provide a correspondence address.

${ }^{62}$ ECtHR Steel and Morris v. UK, appl. no. 68416/01 ECHR 2005-II.

${ }^{63}$ ECtHR Weissman v. Romania, appl. no. 63945/00 ECHR 2006-VII, para. 37.
} 
where he was, by virtue of losing the case, condemned to pay the creditor's costs. This question is considered in more detail in Chapter 7.2.4.4.

The right to access to a court also has implications for the way documents should be filed. In Lawyer Partners A.S. v. Slovakia, ${ }^{64}$ the Slovakian court had refused to allow the applicant to digitally submit his dossiers, instead requiring him to file the printed documents, which would amount to 43,800,000 pages in total. The ECtHR ruled that since in this case electronic submission of the files was the only way for the applicant to present his cases to the court in an effective manner, the refusal to receive the electronic files amounted to a violation of Article 6(1) ECHR. The court took into account the fact that Slovakian law allowed for the electronic filing of documents; the court's objection that its computers were not capable of processing the volume of documents was therefore no longer valid. ${ }^{65}$ This aspect of the right to access is especially relevant with regard to the functioning of the ESCP and EOP, which allow the procedure to be conducted digitally.

CJEU

As Section 4.2.2 above discussed, the CJEU since long requires that substantive rights provided by EU law must always be enforceable before a national court (see cases such as Les Verts ${ }^{66}$ and Factortame ${ }^{67}$ ), which in turn may require that effective remedies are implemented at the national level. In $D E B$, the CJEU ruled that legal aid must be made available in the Member States to litigants who seek to enforce rights emanating from EU law before the national courts. ${ }^{68}$ In a similar vein, the CJEU ruled that access to national courts, and in particular the CJEU in case of uncertainties regarding the application of EU law, must be guaranteed. ${ }^{69}$ Another iteration of the right to access to a court can be found in the obligation of Member State courts to request a preliminary ruling from the CJEU; the ECtHR has confirmed that a refusal to request such a ruling may amount to an unacceptable limitation of the right to access to a court. ${ }^{70}$

\subsubsection{The right to a fair hearing}

\footnotetext{
${ }^{64}$ ECtHR Lawyers Partners A.S. v. Slovakia, appl. no. 54252/07 ECHR 2009.

${ }^{65}$ ECtHR Lawyers Partners A.S. v. Slovakia, para. 54.

${ }^{66}$ CJEU Case C-294/83 Les Verts, ECLI:EU:C:1986:166.

${ }^{67}$ CJEU Joined Cases C-46/93 and C-48/93 Brasserie du Pecheur and Factortame.

${ }^{68}$ CJEU Case C-279/09 DEB, ECLI:EU:C:2010:811.

${ }^{69}$ CJEU Case 77/83 CILFIT, ECLI:EU:C:1984:91.

${ }^{70}$ ECtHR Dhahbi v. Italy appl. no. 17120/09, 8 April, 2014, para. 33.
} 
The right to a fair hearing can be seen as the overarching notion behind Article 6(1). Compliance with specific rights set out in the Article is not sufficient to guarantee a fair trial: there is an overarching requirement that the proceedings as a whole should be fair. ${ }^{71}$ This requirement serves not only the interests of the parties but also the general interest in a fair administration of justice. ${ }^{72}$

The requirement of fairness implies that the parties to the conflict must be given sufficient and adequate opportunity to present their views on both the legal and factual aspects of the case. ${ }^{73}$ 'Hearing' does not only refer to the hearing in person or oral hearing, but to the proceedings as a whole; it can therefore be equated with the notion of 'trial' ${ }^{74}$

The ECtHR has applied the requirement as a residual guarantee, providing an opportunity for adding particular rights that are not explicitly mentioned in Article 6(1). In its case law the ECtHR has distinguished a number of more specific aspects of the right to a fair hearing. These include the right to adversarial proceedings and the principle of equality of arms, which are discussed below. ${ }^{75}$ Other elements of a fair hearing are inter alia a right to be adequately informed of the proceedings, the right to an oral hearing (if necessary, and if need be in person) ${ }^{76}$ and the right to an adequately reasoned judgment. ${ }^{77}$

Aside from these specific aspects, the ECtHR has abstained from providing a list of guarantees that must be complied with in order to provide a fair hearing; rather, the hearing in its entirety should be fair. However, some guarantees are so essential that without them a trial most likely can no longer be considered fair. An example is the right to be defended by a lawyer, during the trial and/or at the oral hearing. In Poitrimol v. France the ECtHR ruled that this right is so fundamental to a fair trial that refusing legal assistance can under no circumstances be considered a proportionate sanction for failing to appear in person at a hearing. ${ }^{78}$ Depriving a litigant from the opportunity to be effectively defended during the trial can thus by itself constitute a violation of the right to a fair trial. It is this case law that the CJEU relied on when

${ }^{71}$ ECtHR Ankerl v. Switzerland appl. no. 17748/91 ECHR 1996-V para. 38; Centro Europa 7 S.R.L. and Di Stefano v. Italy appl. no. 38433/09 ECHR 2012 para. 197; Harris et al. (2014) p. 409, Smits (2008) p. 99, Rainey et al. (2014) p. 263.

${ }^{72}$ ECtHR Nideröst-Huber v. Switzerland appl. no. 18990/91 ECHR 1997-I, para. 30.

${ }^{73}$ See the European Commission of Human Rights in, among others, X v. Belgium, appl. no. 7450/46, D.R. 9 p. 108; Bricmont v. Belgium appl. no. 9938/82 D.R. 48 p. 28.

${ }^{74}$ Van Dijk and Viering (2006) p. 578.

${ }^{75}$ See under 4.3.2.4 and 4.3.2.5, respectively.

${ }^{76}$ Smits (2008) p. 113; Van Dijk and Viering (2006) p. 589-590. ECtHR Helmers v. Sweden, appl. no. 11826/85 ECHR A212-A; discussed below under 4.3.2.6.

${ }^{77}$ See under 4.3.2.7.

${ }^{78}$ ECtHR Poitromol v. France appl. no. 14032/88 ECHR A277-A, para. 34. 
concluding in Krombach v. Bamberski that the exclusion of Mr Krombach, as a sanction for failing to appear in person, should be considered contrary to public policy. ${ }^{79}$

While there is therefore no abstract definition of what constitutes a fair hearing, the following can be said in general about the requirement of fairness. It provides parties with a right to present all observations and evidence that they consider relevant to their case, and places on courts a "duty to conduct a proper examination of the submissions, arguments and evidence adduced by the parties, without prejudice to its assessments whether they are relevant to its decision". ${ }^{80}$ It also involves a duty for the court to communicate, on its own initiative, all documents that it has at its disposal, so that parties are given an effective opportunity to comment on all available information. ${ }^{81}$ Litigants should be able to exercise their right to a fair hearing effectively. For example, in H. v. Belgium, a disbarred avocat (attorney) sought readmission to the bar. The ECtHR ruled that Article 6(1) was breached because the procedure that needed to be followed to achieve such readmission were unclear and that there were no precise rules governing the situations in which such readmission would be allowed. Moreover, the applicant in that case did not have a right to challenge the decision on his request to be readmitted. Together, these circumstances made for a trial that was, as a whole, unfair. ${ }^{82}$

CJEU

The right to a fair hearing has been recognized by the CJEU, albeit formulated in various ways (notably 'respect for the rights of the defence' or the 'right to effective judicial protection'). There are a number of important rulings of the CJEU on this aspect, some of which provide specific interpretations of the right to a fair hearing that are relevant to the civil trial. In some cases, these interpretations are in fact more specific than the existing case law of the ECtHR.

The right to be heard in cases where a decision will be taken that might affect a litigant has been developed in competition cases, but it is derived from a more general principle that the rights of the defence should be respected, which is a "fundamental principle of Community law", as the CJEU ruled in Michelin. ${ }^{83}$ According to the Court, respect for the rights of the defence includes that the person concerned must have been enabled to express his views effectively. ${ }^{84}$ While this case law pertains to administrative proceedings, its underlying

\footnotetext{
${ }^{79}$ CJEU Case C-7/98 Dieter Krombach v André Bamberski ECLI:EU:C:2000:164, para. 39.

${ }^{80}$ ECtHR Kraska v. Switzerland appl. no. 13942/88 ECHR A254-B (see Van Dijk p. 578-9). See also Van der Hurk v. Netherlands, appl. no. 16034/90 ECHR A288 para. 59; ECtHR Perez v. France appl. no. 47287/99 ECHR 2004-I para. 80; and ECtHR Dombo Beheer B.V. v. the Netherlands, appl. no. 14448/88 ECHR A274 para. 33 in fine.

${ }^{81}$ ECtHR Kerojärvi v. Finland appl. no. 17506/90 ECHR A322 para. 42; ECtHR Göç v. Turkey appl. no. 36590/97 ECHR 2002-V para. 57.

${ }^{82}$ ECtHR H. v. Belgium appl. no. 8950/80 ECHR A127-B para. 53.

${ }^{83}$ CJEU Case C-322-81 Michelin ECLI:EU:C:1983:313, building in turn on CJEU Case 17-74 Transoceanic Marine Paint Association ECLI:EU:C:1974:106 para. 15.

${ }^{84}$ CJEU Michelin, para. 8.
} 
principles can be applied to civil cases as well, considering how they were conceived by the CJEU as fundamental principles of EU law. CJEU case law certainly supports the existence of the right to a fair hearing, in the sense of having an effective opportunity to make one's views known, in civil cases.

That this is true is evident from the CJEU's case law on the application of the European instruments of civil procedure. As discussed in Chapter 3.2.5, the CJEU held in Krombach v. Bamberski that a national rule which prevented a person from being effectively defended at trial simply because he was not present at the hearing could be considered incompatible with the right to a fair trial. ${ }^{85}$ The CJEU even effectively set aside a Protocol to the Brussels Convention that allowed such rules for certain offenses. It cited the judgments in Lisrestal and Fiskano $^{86}$ (which are administrative cases) to conclude that the fundamental principle of EU law that a fair trial must be guaranteed "in all proceedings initiated against a person which are liable to culminate in a measure adversely affecting that person" prohibited such a rule. ${ }^{87} \mathrm{In}$ this case the CJEU quite closely followed the guidance of the ECtHR. ${ }^{88}$

In Gambazzi, the CJEU was asked to consider whether an English 'debarment order' (which forbade the defendant from being included in the further proceedings if he refused to cooperate) infringed the right to a fair trial. It may be recalled that in that judgment the CJEU allowed the national court to decide that such a debarment order could be considered contrary to public policy, only providing some factors that a national court might take into consideration. ${ }^{89}$ As such, the CJEU allowed a national court to declare a debarment order contrary to the right to a fair trial, though it did not take a definitive position on this matter. Perhaps this was because there was no ECtHR case law available to the CJEU at that point which could have influenced the decision either way. ${ }^{90}$ Yet even in the absence of such case law, it is clear that a debarment order is an extreme measure that may render a party completely incapable of taking part in the proceedings in any way whatsoever. Though measures that coerce the parties to litigation into cooperation and discourage abuse of process may be compatible with the right to a fair trial, a complete debarment would deprive the affected party completely of his right to access to a court. While it was discussed that the right to access to a court may be subject to limitations, these must not only serve a legitimate goal, but must also be proportionate. It is possible to apply measures with a view to encouraging a party to participate in the proceedings that do not deprive him of his right to access. ${ }^{91}$ Furthermore, whereas such coercive measures are perhaps

\footnotetext{
${ }^{85}$ Case C-7/98 Dieter Krombach v André Bamberski ECLI:EU:C:2000:164.

${ }^{86}$ CJEU Case C-32/95 P Lisrestal ECLI:EU:C:1996:402; CJEU Case C-135/92 Fiskano ECLI:EU:C:1994:267.

${ }^{87}$ CJEU Krombach v. Bamberski, para. 42. See further Chapter 3.2.5.

${ }^{88}$ CJEU Krombach v. Bamberski para. 39.

${ }^{89}$ CJEU Case C-394/07 Marco Gambazzi v. DaimlerChrysler Canada Inc. and CIBC Mellon Trust Company ECLI:EU:C:2009:219 para. 47; see for a discussion Chapter 3.2.5.

90 Van Bochove (2009) p. 299.

${ }^{91}$ For example a limitation of the right to appeal, as applied in ECtHR Eliazer $v$. The Netherlands, appl. no. 38055/97 ECHR 2001-X. See also Andrews (2007) p. 41-42.
} 
more easily acceptable in criminal cases where there is a strong societal interest in preventing evasion of justice, they must be applied with more reticence against a party to civil proceedings who refuses to disclose evidence. ${ }^{92}$ This research suggests that application of the public policy exception and refusal of enforcement of the judgment against Mr Gambazzi would have been justified. ${ }^{93}$

It has also been argued that on this point the CJEU provided a more extensive, or at least more specific, interpretation of the right to a fair hearing. Before pursuing his case in Luxembourg, Mr Gambazzi filed an application with the ECtHR against the United Kingdom, which was declared inadmissible for being manifestly ill-founded. ${ }^{94}$ Some authors have concluded from this that the CJEU provided more extensive protection of the right to a fair trial than the ECtHR in this case, ${ }^{95}$ though because the ECtHR's decision on admissibility has not been published, it is impossible to know exactly why the ECtHR considered the application manifestly illfounded. It is however certainly true that in the absence of ECtHR rulings on this matter the CJEU provides the more specific interpretation on this point.

A matter which has not yet come before the ECtHR, but which the CJEU has extensively considered, is the implications of the right to a fair hearing for cases in which a defendant does not appear. Many of these judgments are also relevant with regard to the right to effective service. ${ }^{96}$ In ASML, the CJEU ruled provides that a defendant can only be considered capable of defending himself when he is aware of the contents of a default judgment rendered against him; it is not sufficient that he was aware that the proceedings had commenced. ${ }^{97}$ The CJEU based this ruling on a judgment from the ECtHR that concerned a criminal case. With its ruling in ASML the CJEU therefore extended the protection provided by the ECtHR to the civil trial.

In Trade Agency the CJEU again ruled on the question of default judgments, this time in relation to the right to a reasoned judgment. ${ }^{98}$ In that judgment the CJEU first ruled that when a defendant challenges the enforcement of a judgment on the basis that he was not served with the document instituting the proceedings, so that a judgment was delivered against him in default, the court deciding on the enforceability is entitled to review whether this is supported by evidence. ${ }^{99}$ This interpretation of Article 34(2) Brussels I Regulation (now Article 45(1)(b) Brussels I bis Regulation) favours the defendant, because it ensures that when he invokes the

\footnotetext{
92 Andrews (2007) p. 41.

93 Though the Italian court did allow enforcement: Corte d'appello di Milano (court of appeal, Milan) Section I, 14 December 2010, reported at http://conflictoflaws.net/2011/gambazzi-looses-in-milan/ (last visited 27/01/2016).

${ }^{94}$ See the discussion in Chapter 3.4.3.

${ }^{95}$ Kuipers (2010) p. 44; Cuniberti (2010) p. 8. See Chapter 2.4.3.

${ }^{96}$ See Chapter 4.3.2.3.

${ }^{97}$ CJEU Case C-283/05 ASML Netherlands BV v Semiconductor Industry Services GmbH (SEMIS) ECLI:EU:C:2006:787, para. 36. See Section 3.3.1.

${ }^{98}$ Case C-619/10 Trade Agency Ltd v Seramico Investments Ltd ECLI:EU:C:2012:531.

${ }^{99}$ CJEU Trade Agency Ltd v Seramico Investments, paras. 26-46.
} 
protection of this Article by stating that he was not properly served, the court deciding on enforceability must satisfy itself that this is indeed the case, and cannot simply rely on the assessment made by the court of origin. The CJEU applied the right to a fair trial to reach this conclusion, stating that the objective of facilitating cross-border enforcement "cannot be attained by undermining in any way the right to a fair hearing". ${ }^{100}$ In Apostolides v. Orams the CJEU however emphasized that the protection provided by Article 34(2) of Brussels I can only be relied upon when the defendant was unable to challenge the judgment; in other words, it may not be relied upon when the defendant had some other opportunity to challenge a defective service. $^{101}$

Also on the topic of default judgments, the CJEU ruled in Hendrikman that a defendant who had not been represented during the proceedings should benefit from the protection of Article 34(2) Brussels I, even if the court originally thought they had been represented by a lawyer who later turned out not to be authorized to represent the defendant. ${ }^{102}$ Again, in other words this means that defendants must enjoy a real and effective opportunity to defend themselves, and that a national court must ascertain whether they did so. Equally importantly, in Hendrikman the CJEU ruled that "the proper time for the defendant to have an opportunity to defend himself is the time at which proceedings are commenced"; ${ }^{103}$ the availability of a remedy against a judgment rendered in default which has already become enforceable "cannot constitute an equally effective alternative to defending proceedings before judgment is given". ${ }^{104}$ As illustrated by the earlier judgment in Minalmet $v$. Brandeis, once a judgment has become enforceable, the only options open to the defendant are generally a suspension of enforcement, which is usually difficult to obtain, so that the defendant's possibilities to defend himself are diminished. ${ }^{105}$ For this reason the CJEU considered that the defendant should in principle be entitled to defend himself at the initial stage of proceedings.

In a more recent judgment, $A$ v. $B$ and others, the CJEU ruled that under the Brussels I Regulation, defendants are entitled to contest the jurisdiction of the court seised of their case. To this end, they must have entered an appearance in person. It is not sufficient that a courtappointed representative entered an appearance on behalf of the defendant, since jurisdiction is based on the defendant's domicile, and it is therefore necessary that the defendant himself enters an appearance. ${ }^{106}$ As the CJEU points out in this judgment, if a court-appointed guardian was to be allowed to enter an appearance on behalf of the defendant, this would deprive the

${ }^{100}$ CJEU ASML v. SEMIS, para. 24.

${ }^{101}$ CJEU Case C-420/07 Apostolides v. Orams, ECLI:EU:C:2009:271, para. 77.

102 CJEU Case C-78/95 Hendrikman and Feyen / Magenta Druck \& Verlag, ECLI:EU:C:1996:380. See Chapter 3.3.1.

${ }^{103}$ CJEU Hendrikman, para.

${ }^{104}$ Ibid., para.

105 CJEU Case C-123/91 Minalmet GmbH v Brandeis Ltd ECLI:EU:C:1992:432, para. 20.

${ }^{106}$ CJEU Case C-112/13 Av B and Others ECLI:EU:C:2014:2195, paras. 55-58. 
defendant of his opportunity to challenge recognition of the judgment on the basis that judgment was delivered against him by default. ${ }^{107}$ This provides additional protection to the defendant within the system of EU civil justice regulations.

\subsubsection{The right to effective service}

ECtHR

The right to a fair hearing also includes a right to effective service. The ECtHR has acknowledged in Beer $v$. Austria that a lack of service prevents a party from being informed of and reacting to an appeal brought by the other party. ${ }^{108}$ The ECtHR explicitly stated in this judgment that "what is at stake is the litigants' confidence in the workings of justice, which is based on, inter alia, the knowledge that they have had the opportunity to express their views on every document in the file". ${ }^{109}$ Without effective service, this cannot be achieved. Article 6(1) ECHR does not prescribe one method of service. The question is rather whether an individual's right to access to justice has been denied in a specific case. The ECtHR's case law provides that authorities must show that they acted with diligence in ensuring that persons are informed of any court proceedings against them. ${ }^{110}$ The Court has consistently reviewed whether authorities took all the necessary steps to ensure the documents reached the person concerned. ${ }^{111}$ This may involve searching for his address, ${ }^{112}$ or publishing a notification in mass media. ${ }^{113}$ Documents must also be sent in sufficient time to allow defendants to attend the hearing. ${ }^{114}$ Sending a letter to the defendant without proof of delivery has not been considered sufficient. ${ }^{115}$ The fact that a defendant is aware of the proceedings taking place is also no substitute for service. ${ }^{116}$ On the other hand, defendants are expected to be reasonably diligent, for example by ensuring access to their mail. ${ }^{117}$

\footnotetext{
${ }^{107}$ CJEU $A v B$ and Others, para. 60.

${ }^{108}$ ECtHR Beer v. Austria appl. no. 30428/96, 6 February 2001.

${ }^{109}$ ECtHR Beer v. Austria, para. 18; see also ECtHR Nideröst-Huber, para. 29; and ECtHR Kenzie Global Limited Ltd. B. Republic of Moldova, appl. no. 287/07, para. 18.

${ }^{110}$ E.g. ECtHR Colozza v. Italy, appl. no. 9024/80 ECHR A89, para. 28.

${ }^{111}$ ECtHR Petroff v. Finland, appl. no. 31021/06, 3 November 2009 para. 22.

${ }^{112}$ ECtHR Dilipak and Karakaya v. Turkey Application nos. 7942/05 24838/05 ECHR 2014, para. 83.

${ }^{113}$ ECtHR Zavodnik v. Slovenia Application No. 36261/08 ECHR 2013, paras. 79-81.

${ }^{114}$ ECtHR Yakovlev v. Russia, appl. no. 72701/01, 15 March 2005.

${ }^{115}$ ECtHR Godorozea v. Moldova Application No. 17023/05 ECHR 2009, para. 31; Russu v. Moldova, appl. no. 7413/05, para. 23-28; ECtHR Bucuria v. Moldova, appl. no. 10758/05, 5 January 2010, para. 22-24.

${ }^{116}$ ECtHR F.C.B. v. Italy, appl. no. 12151/86 ECHR A208-B, para. 33.

${ }^{117}$ ECtHR Hennings v. Germany, appl. no. 12129/86 ECHR A251-A.
} 
The right to effective service has arguably been more extensively developed in EU law. The European instruments on civil procedure place great emphasis on the importance of effective service as a precondition for the enforcement of judgments, especially those delivered in default of the defendant.

To this end, the Brussels I bis Regulation and the other Regulations enable courts to refuse enforcement or recognition of a judgment if it was given in default of appearance, if the defendant he is able to show that there was a defect in service which rendered him incapable of defending himself effectively. The EEO Regulations operate on a similar basis. Moreover, the right to effective service is protected by the existence of the Service Regulation, ${ }^{118}$ and specific rules on service in the EOP and ESCP Regulations.

The right to effective service is therefore recognized in EU law, and its importance has been confirmed by the CJEU in its judgments in Trade Agency ${ }^{119}$ and Hendrikman. ${ }^{120}$ The CJEU in these two cases specified that the right to effective service includes a duty for the requested court applying the previously mentioned refusal ground to satisfy itself, if necessary on the basis of evidence, that service was indeed effected. Furthermore, in Hypotečni Banka, the CJEU ruled that a court may continue proceedings if it is not clear that the defendant is aware of the proceedings. This is only allowed, however, "if all necessary steps have been taken to ensure that the defendant can defend his interests. To that end, the court seised of the matter must be satisfied that all investigations required by the principles of diligence and good faith have been undertaken to trace the defendant". ${ }^{121}$

With these judgments the CJEU emphasizes that parties should be able to exercise their right to a fair hearing effectively. The court at issue should review whether the defendant was able to exercise his right in view of all the circumstances of the case. This contrasts with the very formal interpretation of this clause by the ECtHR in Avotins v. Latvia. ${ }^{122}$

To conclude, both the ECHR and EU law recognize the right to a fair hearing. Both the CJEU and ECtHR apply an open-ended definition of the notion of fairness, with both courts emphasizing that what matters is that participants in a procedure must be able to express their views effectively, and that it is for the courts to ensure that this happens in each case. It also

\footnotetext{
${ }^{118}$ See for an interpretation of the right to effective service under this Regulation C-14/07 Ingenieurbüro Michael Weiss und Partner GbR v Industrie- und Handelskammer Berlin ECLI:EU:C:2008:264; CJEU Case C443/03 Götz Leffler v Berlin Chemie AG ECLI:EU:C:2005:665 (the recipient of documents instituting proceedings may not refuse those documents because they are not in the language of the Member State addressed); CJEU Case C-473/04 Plumex v Young Sports NV ECLI:EU:C:2006:96 (no hierarchy between the methods of service provided for in the Regulation).

${ }^{119}$ CJEU Case C-619/10 Trade Agency Ltd v Seramico Investments Ltd, ECLI:EU:C:2012:531.

${ }^{120}$ CJEU Hendrikman.

${ }^{121}$ CJEU Case C-327/10 Hypoteční banka a.s. v Udo Mike Lindner, ECLI:EU:C:2011:745, para. 52. See also CJEU Case C-292/10 Gv Cornelius de Visser, ECLI:EU:C:2012:142, para. 60.

${ }^{122}$ ECtHR Avotins v. Latvia, appl. no. 17502/07, 25 February 2014. This case was referred to the Grand Chamber and is currently under consideration. See for a discussion Requejo Isidro (2015).
} 
appears that on some points the CJEU has provided more specific protection than the ECtHR. In particular, EU law provides more extensive rules on effective service than the ECtHR has been able to provide. With its Gambazzi ruling the CJEU has provided more specific guidance than the ECtHR on the matter of the exclusion of parties from the proceedings as a coercive measure.

\subsubsection{The right to adversarial proceedings}

ECtHR

The right to a fair hearing includes a right to adversarial proceedings, which the ECtHR has defined as follows:

The right to an adversarial trial means the opportunity for the parties to have knowledge of and comment on the observations filed or evidence adduced by the other party. ${ }^{123}$

This consideration from the ECtHR's judgment in Ruiz-Mateos can be considered settled case law, as it has been utilized in many subsequent judgments. ${ }^{124}$ Parties should be able to exercise this right in a satisfactory manner: a party to the proceedings should have an effective opportunity to familiarise himself with the evidence before the court, as well as the possibility to comment on its existence, contents and authenticity in an appropriate form and within an appropriate time, if need be, in a written form and in advance. ${ }^{125}$ It is for the parties themselves to decide whether evidence produced or statements provided by a witness requires their comment. ${ }^{126}$ It also means that parties must be allowed to present any evidence that they feel is necessary to substantiate their claim. ${ }^{127}$ Furthermore, a court must, of its own initiative, communicate to the parties all information in its possession, ${ }^{128}$ whether it influences the court's decision or not. ${ }^{129}$

${ }^{123}$ ECtHR Ruiz-Mateos v. Spain appl. no. 12952/87 ECHR A262; see for a discussion Van Dijk and Viering (2006) p. 584-589; Leanza and Pridal (2014) p. 126-128; Harris et al. (2014) p. 416-418.

${ }^{124}$ Smits (2008) p. 116.

${ }^{125}$ ECtHR Krcmar and others $v$ Czech Republic, appl. no. 35376/97, 3 March 2000, para. 42; see also Immeuble Groupe Kosser v. France, appl. no. 38748/97, para. 26; McMichael v. UK, appl. no. 16424/90 ECHR A307-B para. 80; Vallauri v. Italy appl. no. 39128/05 para. 71.

${ }^{126}$ ECtHR Nideröst-Huber, p. 22; ECtHR Zagrebacka banka v. Croatia appl. no. 39544/05 para. 203.

${ }^{127}$ ECtHR Clinique des Acacias and others v. France appl. Nos. 65399/01 65405/01 65407/01 65406/01, 13 October 2005, para. 37.

${ }^{128}$ ECtHR Kerojärvi v. Finland appl. no. 17506/90 ECHR A322 para. 42; ECtHR Goç v. Turkey para. 57.

${ }^{129}$ ECtHR Nideröst-Huber, para. 27. 
On this point, the CJEU's judgment in Varec is relevant. ${ }^{130}$ In that case, the CJEU was asked to rule whether the right to a fair trial permitted that a contracting authority could keep certain information from their adversary in a procedure for reasons of fair competition. The CJEU acknowledged that the principle of adversarial proceedings is an important aspect of the right to a fair trial, though it may be balanced against other considerations. According to the Court, the principle includes:

[A]s a rule, that the parties have a right to a process of inspecting and commenting on the evidence and observations submitted to the court. However, in some cases it may be necessary for certain information to be withheld from the parties in order to preserve the fundamental rights of a third party or to safeguard an important public interest. ${ }^{131}$

Having established this, the Court further addressed some of the factors that may be taken into account in the balancing act, which the court seized of the procedure must perform. ${ }^{132}$ In this regard it followed quite closely the case law of the ECtHR. ${ }^{133}$ The CJEU further developed the principle in its Unitrading judgment. In Unitrading, it ruled that the right to an adversarial trial was not infringed because a third party who had been asked to provide evidence would not disclose additional and commercially sensitive information to support its evidence. The CJEU ruled that this did not make for an unfair trial given that the court which had to examine the evidence also did not have access to that information. ${ }^{134}$

\subsubsection{The principle of equality of arms}

ECtHR

The right to an adversarial trial is closely connected to the principle of equality of arms. ${ }^{135}$ The difference is that the principle of equality of arms requires that both parties are treated equally,

\footnotetext{
${ }^{130}$ CJEU Case C-450/06 Varec SA v Belgian State ECLI:EU:C:2008:91.

${ }^{131}$ CJEU Varec para. 47.

132 CJEU Varec paras. 48-54.

${ }^{133}$ Rowe and Davis v The United Kingdom [GC] no 28901/95, ECHR 2000-II, para.61; V v Finland no 40412/98, para.75; Edwards and Lewis v. UK, nos. 39647/98 40461/98 ECHR 2004-X.

${ }^{134}$ Case C-437/13Unitrading ECLI:EU:C:2014:2318, para. 23-24.

${ }^{135}$ See for a discussion of the principle Van Dijk and Viering (2006) p. 580-584; Janis et al. (2008) p. 792-816;

Harris et al. (2014) p. 413-416; Rainey et al. (2014) 263-264.
} 
while the right to an adversarial trial requires access to all relevant information whether the other party has access to it or not. ${ }^{136}$

The principle of equality of arms implies, with regard to civil cases,

[T]hat each party must be afforded a reasonable opportunity to present his case including his evidence - under conditions that do not place him at a substantial disadvantage vis-à-vis his opponent. ${ }^{137}$

Dombo Beheer, the case from which this consideration was taken, concerned the opportunities provided to both parties to summon witnesses. This case centred on the question of whether a certain agreement had been concluded between the applicant company and its bank. The bank had been allowed to summon the person who had represented the bank during the meeting. However, the applicant company had not been allowed to summon the person who had represented the company during the meeting, because this person was identified by the court with the bank itself. This, the ECtHR ruled, placed the company "at a substantial disadvantage" vis-à-vis the bank during the proceedings. Another example is Feldbrugge, in which the ECtHR ruled that there had been a violation of Article 6 because the person concerned had not been able to comment on two reports of medical experts, which were of decisive importance for the outcome of the proceedings. ${ }^{138}$ Not all limitations on the right to summon witnesses amount to a violation of the equality of arms. In Ankerl, the ECtHR ruled that Mr Ankerl's right to equality of arms had not been violated as a result of the court's refusal to allow his wife to give evidence. As is the case in many legal systems, spouses were not allowed to testify under national law, and so her testimony could not have influenced the outcome of the proceedings. The court did have access to other evidence rather than just the witness statements in this case. ${ }^{139}$

The ECtHR's interpretations of both elements show that what matters is that both parties are treated fairly and equally. This entails that both parties are allowed to summon witnesses, ${ }^{140}$

136 The difference between the two elements is illustrated by the Krcmar judgment of the ECtHR: in this case, neither of the parties had been able to comment on evidence gathered by the court itself. This was deemed a violation of the right to an adversarial trial. However, because neither of the parties had been able to comment, they had been treated equally, so there was no violation of equality of arms; ECtHR Krcmar; Mole and Harby (2006) p. 49. See also ECtHR Nideröst-Huber.

${ }^{137}$ ECtHR Dombo Beheer, para. 88.

${ }^{138}$ ECtHR Feldbrugge v Netherlands (merits) appl. no. 8562/79, ECHR A99. See also ECtHR 44962/98 ECHR 2003-V; ECtHR Platakou v. Greece appl. no. 38460/97 ECHR 2001-I; ECtHR Apeh Uldozotteinek Szovetsege and others v. Hungary, appl. no. 32367/96 ECHR 2000-X; ECtHR K.H. and others v. Slovakia appl. no. 32881/04 ECHR 2009-II.

${ }^{139}$ ECtHR Ankerl v. Switzerland, appl. no. 17748/91 ECHR 1996-V.

140 Though Article 6(2) which explicitly guarantees a right to call witnesses, applies only to criminal cases, the ECtHR has found it to have a 'certain relevance' outside criminal cases. Courts do have more discretion in civil cases in this respect, though of course the proceedings as a whole, including the manner in which evidence was gathered, should be fair: ECtHR Dombo Beheer, para. 32. 
are given the time and opportunity to comment on evidence that has been submitted by the other party, ${ }^{141}$ and that documents are served on them in a timely manner. ${ }^{142}$ It is also not necessary for a party to prove that he or she suffered actual prejudice; the inequality in itself may give rise to a violation of Article 6(1). ${ }^{143}$ There are no "hard and fast rules" on this point: all depends on the circumstances of the case. ${ }^{144}$

CJEU

The CJEU has also recognised the importance of the principle of equality of arms. In Eurofood, the CJEU was asked to decide whether the alleged unfairness of the procedure leading up to the opening of insolvency proceedings could trigger the application of the public policy clause. It held that "in the context of insolvency proceedings, the right of creditors or their representatives to participate in accordance with the equality of arms principle is of particular importance." 145 For that reason, it allowed the national court to apply the public policy exception if it was convinced that a fair hearing had not been granted in the state where insolvency proceedings were opened.

\subsubsection{The right to be present at the trial/right to an oral hearing}

ECtHR

According to the ECtHR, an oral, and public, hearing constitutes a fundamental principle of Article 6(1). That said, the obligation to hold a hearing is not absolute. In Jussila v. Finland the ECtHR ruled that:

There may be proceedings in which an oral hearing may not be required: for example where there are no issues of credibility or contested facts which necessitate a hearing and the courts may fairly and reasonably decide the case on the basis of the parties' submissions and other written material. ${ }^{146}$

\footnotetext{
${ }^{141}$ ECtHR Dombo Beheer.

${ }^{142}$ ECtHR Beer v. Austria, para. 19.

${ }^{143}$ ECtHR A.B. v. Slovakia appl. no. 41784/98, 4 March 2003.

${ }^{144}$ Smits (2008) p. 117.

${ }^{145}$ CJEU Case C-341/04 Eurofood IFSC Ltd, ECLI:EU:C:2006:281, para. 66.

${ }^{146}$ ECtHR Jussila v. Finland (merits) appl. no. 73053/01 ECHR 2006-XIV, para. 41.
} 
In earlier case law, the ECtHR recognised a right to an oral hearing in at least one instance, unless 'exceptional circumstances' allowed a national court to dispense with an oral hearing. ${ }^{147}$ In Jussila, the ECtHR clarified this stance by ruling that whether an oral hearing may be dispensed with essentially comes down to the nature of the issues to be decided by the competent national court, not to the frequency of such situations. ${ }^{148}$ It does not mean that a refusal to hold an oral hearing may be justified only in rare cases, and regard may be had to considerations of "efficiency and economy". ${ }^{149}$ However, litigants may always request a hearing on the grounds that the case presents special features; the state may refuse such a request after proper consideration of it. ${ }^{150}$ In Miller $v$. Sweden, the ECtHR considered that certain social security cases are better dealt with in writing due to the technical nature of such disputes, ${ }^{151}$ while in Schuler-Zgraggen v. Austria the privacy of the applicant in a case of a medical nature was also found to be a reason for dealing with the dispute in writing. ${ }^{152}$

In some, but not all, civil trials, a fair hearing also requires that the litigant should be present in person. The ECtHR has held that in civil cases it is only necessary for the litigant to be present where "personal character and manner of life" of the party concerned are relevant for the decision, ${ }^{153}$ or where the case involves an assessment of the applicant's 'conduct'. ${ }^{154}$ For example, in the Helmers case, the ECtHR ruled that in light of the seriousness of what was at stake - the applicant's professional reputation and career - the court should have conducted a direct assessment of the evidence given in person by the applicant. ${ }^{155}$

The right to be present at the trial as well as the right to an oral hearing can be waived, provided that the waiver is made "of his own free will, either expressly or tacitly", is "established in an equivocal manner", is "attended by minimum safeguards commensurate to its importance", and "does not run counter to any important public interest". ${ }^{156}$ Article 6(1) does not therefore exclude the possibility of delivering a judgment by default. In such cases safeguards need to be in place to ensure that the person in question has been adequately summoned. ${ }^{157}$ Non-

\footnotetext{
${ }^{147}$ ECtHR Fischer v Austria, appl. no. 33382/96, 17 January 2002; ECtHR Salomonsson v Sweden, appl. no. 38978/97, 12 November 2002; ECtHR Martinie v France [GC], 58675/00 ECHR 2006-VI; ECtHR Miller v Sweden appl. no. 55853/00, 8 February 2005, para. 29.

${ }^{148}$ ECtHR v. Finland (merits) para. 42.

${ }^{149}$ ECtHR Schuler-Zgraggen v. Austria, appl. no. 14518/89, 31 January 1995.

${ }^{150}$ ECtHR Martinie v France [GC].

${ }^{151}$ ECtHR Miller v Sweden, para. 29; see also ECtHR Döry v Sweden, appl. no. 28394/95, 12 November 2002, para. 43.

${ }^{152}$ ECtHR Schuler-Zgraggen v. Austria, para. 58.

${ }^{153}$ European Commission on Human Rights, X. v. Sweden (dec.) appl. no. 434/58. The presence of the litigant has also been required in child access cases $(X v$. Sweden $)$ and in some commercial cases: European

Commission on Human Rights $X . v$. Germany (dec.) appl. no. 1169/61.

${ }^{154}$ ECtHR Muyldermans v. Belgium appl. no. 12217/86 ECHR A214-A.

${ }^{155}$ ECtHR Helmers, para. 36-39. See also ECtHR Göç v. Turkey; ECtHR Lorenzetti v Italy appl. no. 32075/09, 10 April 2012; ECtHR Khuzhin v. Russia appl. no. 13470/02; ECtHR Salomonsson v. Sweden.

${ }^{156}$ ECtHR Sejdovic v Italy appl. no. 56581/00 ECHR 2006-II.

${ }^{157}$ See for a discussion of the ECHR and EU framework on the right to effective service 4.3.2.3.
} 
appearance of a litigant, provided he has the required knowledge of the case, may thus constitute a waiver, though non-appearance in itself may not. ${ }^{158}$ In criminal cases the ECtHR has examined whether the procedure by which a person was summoned to appear was adequate, if it is not clear whether he was aware of the proceedings taking place against him; ${ }^{159}$ though no such case law exists for civil cases. ${ }^{160}$

CJEU

In Eurofood, the CJEU was asked to rule on the recognition of a judgment opening insolvency proceedings which had been given without the creditor having been present at the hearing. The CJEU ruled (without giving a definitive answer) that the right to be present at a hearing is not absolute; it did however hold that "though the specific detailed rules concerning the right to be heard may vary according to the urgency for a ruling to be given, any restriction on the exercise of that right must be duly justified and surrounded by procedural guarantees ensuring that persons concerned by such proceedings actually have the opportunity to challenge the measures adopted in urgency". ${ }^{161}$ With this ruling the CJEU appears to follow quite closely the line of the ECtHR, which also allows for restrictions on the right to a hearing but requires that the state should justify the restrictions.

\subsubsection{The right to a reasoned judgment}

ECtHR

Though it is not explicitly included in Article 6(1), the ECtHR has derived from the right to a fair trial an obligation for courts to provide sufficient reasons for their decisions. ${ }^{162}$ According to the ECtHR, courts must "indicate with sufficient clarity the grounds on which they base their decision". ${ }^{163}$ The justification for this obligation seems mainly to lie in the interests of the parties. ${ }^{164}$ An adequately reasoned decision allows parties to see whether they have indeed been given a fair hearing. It also enables them to make effective use of the possibilities for appeal. ${ }^{165}$

\footnotetext{
${ }^{158}$ ECtHR Godlevskiy v Russia appl. no. 14888/03, 23 October 2008; ECtHR Hermi v. Italy appl. no. 18114/02 ECHR 2006-XII.

${ }^{159}$ Van Dijk and Viering (2006) p. 591.

${ }^{160}$ Smits (2008) p. 109.

${ }^{161}$ CJEU Case C-341/04 Eurofood IFSC Ltd, ECLI:EU:C:2006:281, para. 66.

162 ECtHR H. v. Belgium.

${ }^{163}$ ECtHR Hadjanastassiou v. Greece appl. no. 12945/87 ECHR A252.

${ }^{164}$ Smits (2008) p. 146.

${ }^{165}$ ECtHR Hirvisaari v. Finland, appl. no. 49684/99, 27 September 2001 para. 30 in fine.
} 
The ECtHR has furthermore acknowledged the interest of the public in a democratic society in knowing the reasons for judicial decisions given in the name of the public. ${ }^{166}$

The domestic court is required to provide a justification for its actions, though it has a certain margin of appreciation in when choosing arguments and admitting evidence. ${ }^{167}$ It is not required to give a detailed answer to every argument. ${ }^{168}$ However, submissions that would have been decisive for the outcome of the case, had they been accepted, may require a 'specific and express reply' by the court. For example, it is not enough for a court to merely state that a party had been grossly negligent without citing evidence for that statement. ${ }^{169}$ The extent to which a judgment should be motivated is therefore determined by what the parties need to exercise the right to an effective remedy. ${ }^{170}$

There also appears to exist a certain margin of discretion for the States in this regard. In Ruiz Torija v. Spain, the ECtHR ruled that in the assessment whether a judgment has been sufficiently reasoned, what matters is not only the nature of the decision and the submissions that a litigant may have brought before the court, but also "the differences that may existing in the Contracting States with regard to statutory provisions, customary rules, legal opinion and drafting of judgments." "171 This implies that the extent to which a judgment is motivated will also be compared to what is customary in the State where it was rendered. This 'relativity' of the obligation to provide an adequately reasoned judgment may become a problem in the context of cross-border enforcement. ${ }^{172}$

CJEU

In Trade Agency, ${ }^{173}$ the CJEU was asked whether a national court would be allowed to refuse enforcement of a judgment because it did not contain reasons. The CJEU allowed the national court to do so, but only if, after an overall assessment of the proceedings and in the light of all the relevant circumstances, the judgment was considered "a manifest and disproportionate breach of the defendant's right to a fair trial". ${ }^{174}$ The CJEU therefore does not consider a judgment that does not contain reasons an infringement of the right to a fair trial per se: it depends on the circumstances of the case. Here it is difficult to compare the standards set by the CJEU with those provided by the ECtHR. It was discussed above that the ECtHR requires courts to motivate their judgment to the degree necessary to ensure parties are able to invoke any available remedies effectively. In doing so it has not however provided a clear lower limit.

\footnotetext{
${ }^{166}$ ECtHR Tatishvili v. Russia, appl. no. 1509/02, ECHR 2007-I.

${ }^{167}$ ECtHR Suominen v. Finland, appl. no. 37801/97, 1 July 2003.

${ }^{168}$ ECtHR Van der Hurk v. Netherlands, para. 61; Garcia Ruiz v. Spain [GC], appl. no. 30544/96, ECHR 1999-I para. 26; ECtHR Jahnke and Lenoble v. France (déc.) 40490/98, ECHR 2000-IX; Perez v. France [GC], appl. no. 47287/99, ECHR 2004-I, para. 81.

${ }^{169}$ ECtHR Georgiadis v Greece, appl. no. 21522/93, ECHR 1997-III.

${ }^{170}$ ECtHR Suominen v. Finland, para. 38-39.

${ }^{171}$ ECtHR Ruiz Torija v. Spain, appl. no. 18390/91 ECHR A303-A, para. 29.

${ }^{172}$ Chapter 7.3.2.3.

${ }^{173}$ Case C-619/10 Trade Agency Ltd v Seramico Investments Ltd ECLI:EU:C:2012:531.

${ }^{174}$ CJEU Trade Agency Ltd v Seramico Investments, para. 62.
} 
The question of the compatibility of judgments lacking reasons with European fundamental rights is discussed in detail in Chapter 7.3.7.3. To conclude, while the right to a reasoned judgment is recognized within the EU legal system, the standards set are not clearly different from those emanating from the ECtHR's case law.

\subsubsection{The principle of legal certainty and consistency}

The ECtHR has also found violations for failures to observe the principle of legal certainty. This principle as applied by the ECtHR requires that judgments are final, and that they cannot be reversed, ${ }^{175}$ unless necessary to address "circumstances of a substantial and compelling character." 176 The principle of legal certainty thus protects res judicata.

Additionally, the ECtHR has derived from Article 6(1) a kind of right to consistent adjudication: a protection against conflicting court decisions. Though it has been derived from the right to a reasoned judgment, the ECtHR has also emphasized its link with the principle of legal certainty. The leading case is Albu and Others v. Romania, in which the Court developed a number of principles for dealing with conflicting court decisions. ${ }^{177}$ Though it is not for the Court to deal with errors of fact and law, and although it acknowledges that irregularities are a necessary element of each justice system, the Court may nevertheless find a violation if "profound and long-standing differences"178 exist within the case law of the domestic courts. In such cases it will review "whether the domestic law provides for machinery for overcoming these inconsistencies, whether that machinery has been applied and, if appropriate, to what effect". ${ }^{179}$ If such machinery has been applied insufficiently, this may lead to a violation of Article 6(1). For example, a violation was found in Borovská and Ferrai v. Slovakia. ${ }^{180}$ In this case the Court found "profound and long-standing differences" in the way courts decided whether or not to grant an easement in respect to land owned by the applicants. These decisions were based on a piece of legislation aimed at reforming Slovakian property rights in order to remedy the expropriation of property during the socialist regime. According to the Court, this piece of legislation was "rather fundamental" and was part of a "transformation of the respondent State's legal and constitutional systems, which has been in force for about two decades". The Court then concluded that "even assuming that the domestic law provides for machinery for overcoming the impugned inconsistencies and that that machinery has been applied, it cannot be said to have had any consolidating effect." ${ }^{\prime 181}$

\footnotetext{
${ }^{175}$ ECtHR Brumarescu v. Romania, 28342/95 ECHR 2001-I; ECtHR Esertas v. Lithuania, appl. no. 50208/06.

${ }^{176}$ ECtHR Pravednaya v. Russia, appl. no. 69529/01, 18 November 2004; Nikitin v. Russia appl. no. 50178/99 ECHR 2004-VIII.

${ }^{177}$ ECtHR Albu and others v. Romania, appl. no. 34796/09 and 63 other cases, 10/05/2012.

${ }^{178}$ ECtHR Albu and others v. Romania, para. 34.

179 Ibid.

${ }^{180}$ ECtHR Borovská and Ferrai v. Slovakia, appl. no. 48554/10, 25 November 2014.

${ }^{181}$ ECtHR Borovská and Ferrai v. Slovakia, para. 67.
} 


\subsubsection{Right to a public trial and public pronouncement of the judgment}

ECtHR

As the ECtHR itself put it, "justice must not only be done, it must also be seen to be done." 182 The right to a public trial contributes to a fair hearing because it increases transparency for the litigants and consequently increases both their and the general public's confidence in the courts. ${ }^{183}$ The right to a public hearing requires that when an oral hearing take place (see on that topic 4.3.2.6, above), the hearing is held in public. ${ }^{184}$ Article 6(1) also requires that the judgment be pronounced publicly. Both elements are discussed in this section.

The publicity of the hearing is essential to guarantee the trial's fairness: the ECtHR has found that "given the possible detrimental effects that the lack of a public hearing could have on the fairness of the proceedings, the absence of publicity could not in any event be remedied by anything other than a complete re-hearing before the appellate court" ${ }^{\prime 185}$. A private hearing behind closed doors is therefore almost by definition incompatible with Article 6(1), unless one of the grounds for limitation applies, which are exhaustively listed in the Article. The restrictions may only be applied proportionately in response to a pressing social need. ${ }^{186}$ The ECtHR has not allowed states a margin of appreciation on this point; rather it has consistently made its own assessment of the necessity and proportionality of any restrictions. ${ }^{187}$

Examples of cases in which a restriction of the right to a public hearing may be allowed in civil cases is where it is required to protect the privacy of those involved. For example, in divorce proceedings or hearings concerning the residence of children following a divorce, privacy might be necessary to allow people to express themselves freely on highly personal and sensitive issues. ${ }^{188}$ There are cases in which a hearing in public could even amount to a violation of the right to a fair hearing or the right to privacy (Art. 8 ECHR), for example where

\footnotetext{
${ }^{182}$ ECtHR Delcourt v. Belgium, para. 31.

${ }^{183}$ ECtHR Malhous v. Czech Republic [GC],33071/96, ECHR 2000-XII.

${ }^{184}$ Given the fact that the word 'hearing' in Article 6(1) has been taken to refer to the entire trial, it has been questioned whether the 'right to a public hearing' also requires that all aspects of the trial, including the documents submitted by the parties, should be open to the public. Though the inference is justified, there is no ECtHR case law which affirms this viewpoint. Smits (2008) p. 167-170.

${ }^{185}$ ECtHR Riepan v. Austria, appl. no. 35115/97, ECHR 2000-XII, para. 40.

${ }^{186}$ Harris et al. (2014) p. 434.

${ }^{187}$ Harris et al. (2014) p. 434

${ }^{188}$ ECtHR $B$ and $P$ v. $U K$, appl. nos. 36337/97 35974/97 ECHR 2001-III; ECtHR $X v U K$, appl. no. 7366/76, 2 Digest 452 (1977); see also European Commission on Human Rights, Guenoun v. France [dec.] 13562/88, D.R. No. 66, p. 184, and Imberechts v. Belgium [dec.] 15561/89 D.R. No 69, p. 314 on medical disciplinary proceedings in which the privacy of patients constituted a legitimate ground on which to limit publicity.
} 
the youthful age of the accused in a criminal case necessitates protection from the press. ${ }^{189}$ It can be concluded that if a hearing is held, it should be public, unless there are particularly pressing circumstances that mean that a public hearing could harm the rights or interests of those involved.

The right to public pronouncement of the judgment is somewhat less absolute and more subject to interpretation. The wording of this element suggests that the judgment should be read out in public, but other ways exist of rendering a judgment public that are compatible with Article 6(1); some flexibility is applied. For civil cases, the judgment in Ryakiv Burdakov v. Russia is relevant; in this case the Court found a violation because only the operative part of the judgment was read out, with no opportunities for finding out the reasons. ${ }^{190}$ It may also be incompatible with Article 6(1) if in such cases the full judgment is available, but only to those whose rights and interests were affected by the judgment. ${ }^{191}$ This means that a litigant can suffer a violation of Article 6(1) of the judgment was not made available to the public, even if he himself had access to the full judgment. ${ }^{192}$ The requirement of publicity may also be fulfilled when the full judgment is deposited in the court registry ${ }^{193}$ or where the judgment concerns the upholding of a lower court's judgment which itself was pronounced publicly. ${ }^{194}$

CJEU

There currently appears to be no case law from the CJEU dealing specifically with the right to a public hearing.

\subsubsection{The right to adjudication by an impartial and independent tribunal}

ECtHR

Article 6(1) guarantees a fair trial by an "independent and impartial tribunal established by law". Independence and impartiality of the judiciary are closely interlinked. Independence refers primarily to the independence from the executive and legislative powers ${ }^{195}$ but also vis-

\footnotetext{
${ }^{189}$ ECtHR V. v. United Kingdom [GC], appl. no. 24888/94, ECHR 1999-IX.

${ }^{190}$ ECtHR Biryukov v. Russia, 14810/02 ECHR 2008-I, para. 45.

${ }^{191}$ ECtHR Malmberg and Others v. Russia, appl. Nos. 23045/05 21236/09 17759/10 48402/10, 15 January 2015 para. 55; however, such restrictions may be acceptable in sensitive cases (for example those involving the residence of children) provided there is some way for the public to gain insight into how courts deal with such cases: see ECtHR B and P v. UK, para. 47 (no violation) and Moser v. Austria, appl. no. 12643/02, para. 102103 (violation).

192 ECtHR Biryukov v. Russia.

${ }^{193}$ ECtHR Pretto v. Italy, appl. no. 7984/77 ECHR A71, para. 27-28.

${ }^{194}$ ECtHR Axen v. Germany, appl. no. 8273/78 ECHR A72, para. 32.

${ }^{195}$ ECtHR Beaumartin v. France, appl. no. 15287/89 ECHR A296-B, para.38; ECtHR Ringeisen v. Austria, appl. no. 2614/65 ECHR A13; ECtHR Procola v. Luxembourg, appl. no. 14570/89 ECHR A326.
} 
à-vis the parties. ${ }^{196}$ To guarantee an independent tribunal, there must be organisational safeguards, for example on the manner of appointment of judges and their term of office, ${ }^{197}$ and protection against outside pressures. ${ }^{198}$ Tribunals must also give the appearance of independence: circumstances giving rise to legitimate doubts about a judicial body's independence can also lead to a violation on this point. ${ }^{199}$

Impartiality denotes the absence of prejudice or bias on the part of the judge. This prejudice and bias may be both apparent from the personal conviction and behaviour of the judge himself (subjective test) but also from the existence of objective factors that may give rise to doubt as to the impartiality of the judicial body (objective test) ${ }^{200}$ It seems clear that impartiality and independence will be absent when the judge is shown to have been corrupt, for example when he or she has taken a bribe. Whether a judge or a judicial body can be considered impartial and independence requires a careful assessment of the facts of the case: it is decided on a case by case basis and it must be shown that there were concerns as to one of these requirements in the particular case at hand. ${ }^{201}$

Such concerns may arise from personal connections between the judge and the parties. In Micallef $v$. Malta there was a lack of objective impartiality because one of the judges hearing the case was a family member of one of the advocates of the applicant's opponent. ${ }^{202}$ Prior involvement of one or more judges in the case in some form may also be problematic. In Aslaner $v$. Turkey, there was a lack of impartiality because three judges (out of a chamber of 31) had previously been involved in the case; they could therefore be considered biased. ${ }^{203}$ However, it is not in itself incompatible with the right to an impartial tribunal if judges are involved in a case in multiple stages of the proceedings: what matters is the degree of their involvement. According to the ECtHR, the mere fact that a judge has already taken pre-trial decisions cannot by itself be regarded as justifying concerns about his impartiality; likewise, the fact that the judge has detailed knowledge of the case file does not entail any prejudice on his part that would prevent his being regarded as impartial when the decision on the merits is taken. ${ }^{204}$

${ }^{196}$ ECtHR Sramek v. Austria, 8790/79 ECHR A84 para. 42.

${ }^{197}$ ECtHR Agrokompleks v. Ukraine (merits) appl. no. 23465/03; Campbell and Fell v. UK, appl. Nos. 7819/77 7878/77 ECHR A80.

${ }^{198}$ ECtHR Engel v Netherlands (merits) appl. nos. 5100/71 5101/71 5102/71 5354/72 5370/72 ECHR A22.

${ }^{199}$ ECtHR Findlay v. UK, appl. no. 22107/93 ECHR 1997-I.

${ }^{200}$ ECtHR Kyprianou v. Cyprus [GC], 73797/01 ECHR 2005-XIII, para. 118; ECtHR Gautrin and Others v. France, appl. Nos. 21257/93 21258/93 21259/93 21260/93, ECHR 1998-III, para. 58.

201 Ibid.

${ }^{202}$ Micallef v. Malta [GC], appl. no. 17056/06 ECHR 2009-V, para. 93.

${ }^{203}$ ECtHR Aslaner v. Turkey, appl. no. 36073/04, 4 March 2014 para. 35.

${ }^{204}$ ECtHR Morel v. France, appl. no. 34130/96 ECHR 2000-VI, para. 45; see also ECtHR Ökten v. Turkey, appl. no. 22347/07. 
Doubts may also arise when a judge has made pronouncements about the case in the press, ${ }^{205}$ where he or she has a personal interest in the outcome, ${ }^{206}$ or where the rules on allocation of cases between judges are capable of being abused. ${ }^{207}$

CJEU

The CJEU has dealt with the right to an impartial tribunal in several cases. In Chronopost and La Post v. UFEX and Others, ${ }^{208}$ a case concerning state aid, the appellant (Chronopost) complained that the Chamber of the Court of First Instance which had ruled on its application had not been impartial, because two of the judges sitting in the Chamber had been involved (as President and Judge-Rapporteur) in a related case (in which its subsidiary was involved). The CJEU considered that the right to an impartial tribunal constitutes the "cornerstone" of the right to a fair trial, which is a general principle of EU law. ${ }^{209}$ However, the Court ruled on the basis of ECtHR case law that it is not in itself incompatible with the objective of impartiality if judges are involved in multiple stages of the proceedings. ${ }^{210}$ It is up to the parties to present objective arguments that give rise to legitimate doubts about their impartiality; according to the Court, Chronopost failed to do so. The CJEU later applied the same approach in Gorostiago Atxandalabaso v. European Parliament. ${ }^{211}$ In this case, a former member of the European Parliament appealed against a decision on the repayment of improperly reimbursed expenses. In this case too the Court came to the conclusion that the appellant had failed to show arguments giving rise to legitimate doubts concerning the judges' impartiality. ${ }^{212}$

\subsubsection{The right to a trial within a reasonable time}

ECtHR

Article 6(1) provides parties with a right to a trial within a reasonable time. This element protects the litigants from having to wait an excessively long time for a decision in their case. Excessive delays jeopardize the credibility and effectiveness of the trial. ${ }^{213}$ The ECtHR found more violations of the reasonable time requirement than of all other elements of Article 6(1)

\footnotetext{
${ }^{205}$ ECtHR Buscemi v. Italy 29569/95 ECHR 1999-VI.

${ }^{206}$ ECtHR Sigurdsson v. Iceland, appl. no. 39731/98 ECHR 2003-IV; ECtHR D. v. Ireland, appl. no. 26499/02; Demicoli v. Malta, appl. no. 13057/87 ECHR A210.

${ }^{207}$ ECtHR DMD Group v. Slovakia, appl. no. 19334/03.

${ }^{208}$ Joined Cases C-341/06 P and C-342/06 P Chronopost and La Poste v UFEX and Others ECLI:EU:C:2008:375.

${ }^{209}$ CJEU Chronopost and La Poste v UFEX and Others, para. 46.

${ }^{210}$ CJEU Chronopost and La Poste v UFEX and Others, para. 59.

${ }^{211}$ General Court Case T-146/04, Gorostiaga Atxandalabaso v. European Parliament, ECLI:EU:T:2005:584.

${ }^{212}$ General Court Gorostiaga Atxandalabaso v. European Parliament, para. 46-49.

${ }^{213}$ ECtHR Stögmüller v Austria appl. No 1602/62 ECHR A9; ECtHR H. v France appl. no. 10073/82 ECHR A162-A.
} 
combined, ${ }^{214}$ and failures to observe the requirement are the cause of $26 \%$ of all applications to the ECtHR. ${ }^{215}$

What constitutes a 'reasonable time' within which a trial should be conducted varies according to the circumstances. ${ }^{216}$ According to the ECtHR, the following factors need to be taken into account: the complexity of the case; the conduct of the applicant and of the relevant authorities; and what was at stake for the applicant in the dispute. ${ }^{217}$ These factors have in turn been fleshed out in case law. The complexity of the case may lie in the facts or in the law. ${ }^{218}$ It may for instance relate to the number of parties involved in the case,${ }^{219}$ or the complexity of obtaining evidence. ${ }^{220}$ The conduct of the applicant may be relevant in assessing the reasonableness of the period it took for the case to be resolved, though parties cannot be blamed for making full use of the procedural remedies available to them. ${ }^{221}$ They only need to show diligence in carrying out the procedural steps required of them and to refrain from using delaying tactics. ${ }^{222}$ Although the domestic authorities cannot be held responsible for the conduct of a defendant, the delaying tactics used by one of the parties do not absolve the authorities from their duty to ensure that the proceedings are conducted within a reasonable time. ${ }^{223}$

On the other hand, the applicants' behaviour constitutes an objective fact that cannot be attributed to the respondent State and which must be taken into account for the purpose of determining whether or not the reasonable time referred to in Article 6(1) has been exceeded. ${ }^{224}$ A delay in the proceedings that is primarily caused by the applicant's own conduct may therefore lead to the conclusion that the time it took to resolve the case was not unreasonable. ${ }^{225}$

214 The ECtHR's Table of Violations 1959-2011 shows that in this period the length of proceedings had resulted in 4810 violations, more than any other Article of the ECHR; other elements of the right to a fair trial combined were found to have been violated 3672 times.

215 The European Court of Human Rights, 50 Years of Activity: Some Facts and Figures, p. 6, available at http://www.echr.coe.int/Documents/Facts_Figures_1959_2009_ENG.pdf.

${ }^{216}$ See for an overview e.g. Mole and Harby (2006) p. 24-28; Lawson and Teuben (2004) p. 161; Édel (2007) p. 34 onwards.

${ }^{217}$ ECtHR Comingersol S.A. v Portugal [GC] 35382/97 ECHR 2000-IV; ECtHR Frydlender v France appl. no. 30979/96 ECHR 2000-VII; ECtHR Sürmerli v. Germany appl. no. 75529/01 ECHR 2006-VII.

${ }^{218}$ ECtHR Katte Klitsche de la Grange v. Italy, appl. no. 12539/86 ECHR A293-B, para. 55; ECtHR

Papachelas v. Greece [GC], appl. no. 31423/96 ECHR 1999-II, para. 39.

${ }^{219}$ ECtHR H. v. the United Kingdom 9580/81 ECHR A120, para. 72.

${ }^{220}$ ECtHR Humen v. Poland [GC], appl. no. 26614/95, 15 September 1999 para. 63.

${ }^{221}$ ECtHR Erkner and Hofauer v. Austria, appl. no.no. 9616/81 ECHR A117, para. 68.

${ }^{222}$ ECtHR Unión Alimentaria Sanders S.A. v. Spain, appl. no. 11681/85 ECHR A157, para. 35.

${ }^{223}$ ECtHR Mincheva v. Bulgaria, appl. no. 21558/03, 2 September 2010 para. 68.

${ }^{224}$ ECtHR Poiss v. Austria, appl. no. 9816/82 ECHR A117 para. 57; Wiesinger v. Austria, appl. no. 11796/85

ECHR A213 para. 57; ECtHR Humen v. Poland [GC], para. 66.

${ }^{225}$ ECtHR Vernillo v. France, appl. no. 11889/85 ECHR A198; Janis et al. (2008) p. 819. 
What is at stake for the applicant also plays an important role. For example, employment cases $^{226}$ and cases concerning custody over a child ${ }^{227}$ require a speedy resolution.

What constitutes a reasonable time within a given case therefore depends greatly on the circumstances; a period of time which is deemed excessive in a relatively simple case may be considered reasonable for a more complicated case. Still, the reasonable time requirement is the element of Article 6(1) that is most often violated; so often in fact that violations of this element are counted separately from violations of other elements of Article $6 .{ }^{228}$ The ECtHR has also ruled on the consequences that should be attached to a failure to observe the requirement: states should provide for an effective remedy which parties can use to either achieve an acceleration of the procedure or (in any case) to obtain monetary compensation for the delay. ${ }^{229}$

\section{CJEU}

In Baustahlgewebe the CJEU recognized, albeit in an administrative (competition) procedure that the right to a fair process within a reasonable time exists as a general principle of EU law, and held the General Court accountable for exceeding it. ${ }^{230}$ It ruled that proceedings of a considerable length may be considered reasonable in the light of the circumstances specific to each case, in particular the importance of the case for the person concerned, its complexity and the conduct of the applicant and of the competent authorities. It based this approach on a number of judgments from the ECtHR. ${ }^{231}$ The CJEU's judgment in Der Grüne Punkt is also remarkable. Firstly, because it is the first judgment in which the procedure before the General Court was found to have exceeded a reasonable period which did not concern a competition case. Secondly, because the CJEU explained what the consequences under EU law should be of a failure to observe the reasonable time requirement. Whereas in competition cases an exceedance of the reasonable time requirement may result in a lowering of an imposed fine, in other cases the affected party may commence an action for compensation against the EU itself. ${ }^{232}$ This corresponds to the measures required by the ECtHR as discussed above.

${ }^{226}$ ECtHR Vocaturo v. Italy, appl. no. 11891/85 ECHR A206-C, para. 17.

${ }^{227}$ ECtHR Hokkanen v. Finland, appl. no. 19823/92 ECHR A299-A, para. 72; ECtHR Niederböster v. Germany, appl. no. 39547/98 ECHR 2003-IV, para. 39.

${ }^{228}$ ECHR, Violations by article and by state 1959-2011, 31 December 2011, available at http://www.echr.coe.int.

${ }^{229}$ ECtHR Kudla v. Poland, appl. no. 30210/96 ECHR 2000-XI; ECtHR Mifsud, appl. no. 57220/00 ECHR 2002-VIII.

${ }^{230}$ CJEU Baustahlgewebe, para. 21. Since then the CJEU has found more violations of the reasonable time requirement in competition cases, for instance in C-385/07 P Der Grüne Punkt - Duales System Deutschland $\mathrm{GmbH} v$ Commission of the European Communities ECLI:EU:C:2009:456.

${ }^{231}$ Ibid, para. 29.

${ }^{232}$ CJEU Der Grüne Punkt para. 195. 
Because the conclusion whether the reasonable time requirement has been respected is dependent on a number of factors, it cannot be said that the CJEU was more lenient or more stringent in this judgment than the ECtHR would have been. It can, however, be concluded that in its approach and the factors it took into account the CJEU essentially followed the ECtHR.

\subsubsection{The right to enforcement}

ECtHR

The scope of right to a fair trial does not end with the pronouncement of the judgment. In Hornsby v. Greece, the ECtHR ruled that Article 6(1) also encompasses a right to enforcement of a judicial decision. ${ }^{233}$ According to the ECtHR, the right to access to a court "that right would be illusory if a Contracting State's domestic legal system allowed a final, binding judicial decision to remain inoperative to the detriment of one party". ${ }^{234}$ In McDonald $v$. France, the ECtHR then extended this reasoning to the enforcement of foreign decisions. In this case, Mr McDonald requested an exequatur in France of a divorce granted in America. The ECtHR acknowledged that enforcement of foreign decisions could come within the scope of Article 6(1); yet it declared the application inadmissible, because the reason that France had refused enforcement was that the applicant had committed fraud. According to ECtHR case law, no one can complain about a situation to which they themselves had contributed. ${ }^{235}$ Also on the question of enforcement of foreign decision, in Négrépontis-Giannisis v. Greece the Court derived from Article 6(1) a right to enforcement of a foreign judgement. It ruled that though Greece had significant margin of appreciation in the application of the requirement that the judgment should not violate Greek ordre public, it should nevertheless not apply that condition in an arbitrary or disproportionate manner. The Court ruled that the principle of proportionality had not been respected and that there had therefore been a violation of Article 6(1). ${ }^{236}$ Finally, in Saccoccia $v$. Austria the ECtHR ruled that the proceedings for obtaining an exequatur should also in their entirety conform to the requirements of Article 6(1). ${ }^{237}$

Aside from these judgments on the right to enforcement of foreign decisions, there is a great deal of case law on the compatibility of national enforcement proceedings with Article 6(1). As in Hornsby v. Greece, the ECtHR generally derives the right to enforcement from the right to access to a court, though it is not entirely consistent on this point. ${ }^{238}$ Article 6(1) imposes on

\footnotetext{
${ }^{233}$ See for a discussion Kiestra (2014) p. 203-216; Kinsch (2014); Kodek (2005).

${ }^{234}$ ECtHR Hornsby v. Greece, para. 40; see also ECtHR Marinkovic v Serbia, appl. no. 5353/11, 22 October 2013.

${ }^{235}$ ECtHR McDonald v. France.

${ }^{236}$ ECtHR Négrépontis-Giannisis (merits) appl. no. 56759/08, 3 May 2011, para. 91.

${ }^{237}$ ECtHR Saccoccia v. Greece.

${ }^{238}$ Kiestra (2014) p. 204.
} 
states a positive obligation to have an effective system in place for the enforcement of judgments. ${ }^{239}$ The ECtHR will review whether the assistance provided by the state's authorities have been adequate and sufficient. ${ }^{240}$ There are, however, certain limitations to the right to enforcement. Firstly, a state cannot be held responsible if enforcement is impossible due to the debtor's lack of funds. Secondly, the right to enforcement does not preclude the existence of statutory limitation periods, though the nature of such measures and the manner in which they are applied must be compatible with the Convention. ${ }^{241}$ Also, the judgment creditor may be expected to take action. ${ }^{242}$ Finally, authorities are provided some margin of appreciation where enforcement could disturb the public order or where rights of others are involved. For example, in Sud Est Réalisations, ${ }^{243}$ and in Cofinfo, ${ }^{244}$ the applicants claimed that the authorities had violated their right to enforcement by failing to take measures to (forcibly) evict residents from properties belonging to the applicants. The Court ruled that in such cases authorities are granted a reasonable time period in order to achieve an acceptable solution (for example rehousing residents elsewhere). However, after such a period has elapsed, all necessary measures must be taken to enforce the decision. A continued inactivity on the part of the authorities may amount to a violation of Article 6(1).

It may be derived from the preceding case law that the right to enforcement does not entail an absolute right to obtain what was awarded by the decision; rather, the ECtHR reviews whether the authorities acted adequately and sufficiently. As the ECtHR ruled in Sanglier v. France, the right to access to a court does not oblige a state to have every civil judgment executed, whatever the circumstances. ${ }^{245}$ Where enforcement cannot be obtained due to circumstances beyond the control of the authorities, this cannot be attributed to the state. Finally, the ECtHR has recommended specific measures to guarantee enforcement decisions in a timely manner; see under 4.3.7.2, below.

CJEU

Obviously, EU citizens enjoy a right to enforcement across the Union of judicial decisions by virtue of the extensive EU legislation in this field, which the preceding Chapter discussed in depth. It should perhaps be repeated that the regulations do not prescribe the actual enforcement proceedings as these are governed by Member States' legislation. If the EU Member State where enforcement was sought would fail to take adequate measures to obtain enforcement, the creditor could therefore still file an application against that state with the ECtHR. If the application concerned a failure to provide permission for enforcement, which should have been provided on the basis of one of the regulations, the ECtHR may also have jurisdiction

\footnotetext{
${ }^{239}$ ECtHR Matrakas and others v. Poland and Greece, appl. no. 47268/06, 7 November 2013.

${ }^{240}$ ECtHR Románczyk v. France, 7618/05, 18 November 2010.

${ }^{241}$ ECtHR Vrbica v. Croatia appl. no. 32540/05, 1 April 2014, para. 66.

${ }^{242}$ ECtHR Scollo v. Italy 19133/91 ECHR A315-C, para. 44; ECtHR Fuklev v. Ukraine appl. no. 71186/01, 7 June 2005.

${ }^{243}$ ECtHR Sud Est Réalisations v. France, appl. no. 6722/05, 2 December 2010.

${ }^{244}$ ECtHR Société Cofinfo v. France, appl. no. 23516/08, 12 October 2010.

${ }^{245}$ ECtHR Sanglier v. France appl. no. 50342/99, 27 May 2003, para. 39.
} 
depending on whether the obligation was absolute or whether there were grounds for refusal. The complicated matter of EU Member State responsibility under the ECHR for carrying out their obligations under EU law are extensively discussed in Chapters 3 and 4.

\subsubsection{Consequences of a failure to observe the right to a fair trial}

This research concerns the appropriate remedies in for a failure to observe the right to a fair trial that should be available in EU legislation on cooperation in civil justice. It is therefore useful to see what remedies have been considered appropriate in such cases by the European courts.

\subsubsection{General}

The most obvious consequence of a violation of Article 6(1) is that the affected litigant may file an application with the ECtHR, which, if it is well-founded, will find that a violation has occurred and may award just compensation under Article 41 ECHR. The enforcement of ECtHR judgments is monitored by the Committee of Ministers, which may recommend measures such as changes in domestic legislation. ${ }^{246}$ The finding of a violation by the ECtHR does not as such invalidate the domestic judgment or otherwise influence the legal position of the parties at the domestic level.

At the national level, Article 13 ECHR provides that states are under an obligation to provide an effective remedy for a violation of one of the Convention rights. However, as is explained below, Article 13 has not been applied to cases falling within the scope of Article 6. Of course, where a national court finds that a procedural irregularity has occurred before the remedies at the national level have been exhausted, it may be repaired at a later stage of the proceedings: for example, if a hearing was denied in the first instance, it may be granted at the appeal stage, which means the proceedings as a whole have been fair. A violation is then avoided and a remedy unnecessary.

Within the multi-layered EU legal system, things are more complicated. The first paragraph of Article 47 of the EU CFR guarantees that, echoing Article 13 ECHR, an effective remedy before a court shall be available to those whose rights under the EU CFR have been infringed. Yet, the question remains of who should provide this remedy and what it should consist of. In principle, Member States are responsible for exercising their obligations under EU law in such a way that they do not infringe fundamental rights. ${ }^{247}$ Violations of EU CFR rights should therefore be addressed at the Member State level when they result from Member State actions.

\footnotetext{
246 Article 46 ECHR.

${ }^{247}$ CJEU Case C-101/01 Criminal proceedings against Bodil Lindqvist, ECLI:EU:C:2003:596, para. 87.
} 
If Member States believe that there is no way of complying with their EU CFR obligations without having to set aside EU legislation, they must first seek a preliminary ruling from the CJEU, ${ }^{248}$ which can declare legislation that does not comply with fundamental rights invalid. ${ }^{249}$ Where the actions of EU institutions, such as the European Commission, are deemed to be in violation of the EU CFR, recourse can be had to the General Court of the Court of Justice, within the limits of their jurisdiction as defined by Articles 251 to 281 TFEU. ${ }^{250}$

Both the ECHR and the EU CFR therefore require an effective remedy for a violation of Article 6(1) ECHR, and Article 47 EU CFR. Since the first paragraph of Article 47 EU CFR corresponds to Article 13 ECHR, the ECtHR's case law on that article must be looked at for guidance. In general, the ECtHR has ruled that remedies should be "effective in practice as well as in law" 251 and should either prevent violations or their continuation, or provide "adequate redress for any violation that has already occurred". ${ }^{252}$ There no case law on what constitutes an effective remedy for a violation of Article 6(1). ${ }^{253}$ The reason for this is that Article 6(1) was for a long time seen as a lex specialis of Article 13, in which the requirements of Article 13 were absorbed. Violations of Article 6(1) therefore did not require a separate consideration of Article 13. The exceptions are violations of the reasonable time requirement and violations resulting from failures to enforce judgments (see below); for these cases, Article 13 does require specific remedies.

\subsubsection{Remedies for violations of the reasonable time requirement}

Both within the EU and the Council of Europe, specific remedies have been developed or recommended for dealing with violations of the reasonable time requirement. ${ }^{254}$ In Kudla $v$. Poland, the ECtHR ruled that Article 13 imposes on states an obligation to provide remedies specifically for addressing the excessive length of proceedings, by which a litigant can either achieve an acceleration of the procedure (thus preventing a violation of the reasonable time requirement) or obtain compensation. According to the Court, these must be provided at the

\footnotetext{
${ }^{248}$ CJEU Case C-77/83 CILFIT ECLI:EU:C:1984:91; see also specifically on Article 47 A v. B and others, in which the CJEU ruled that the right of domestic courts to refer questions for a preliminary ruling may not be limited by a national rule which authorises the national constitutional court to generally strike down legislation deemed to be contrary to Article 47. CJEU Case C-112/13 Av B and Others ECLI:EU:C:2014:2195.

${ }^{249}$ CJEU Joined Cases C-92/09 and C-93/09 Volker und Schecke ECLI:EU:C:2010:662. This is an exclusive competence of the CJEU: CJEU Case C-314/85 Foto-Frost ECLI:EU:C:1987:452.

${ }^{250}$ Article 47 of the EU CFR is explicitly not intended to change the system of judicial review within the EU: Explanations on Article 47.

${ }^{251}$ ECtHR Kudla v. Poland, para. 157.

252 ECtHR Kudla v. Poland paras. 157-8.

253 The Guide to good practice in respect of domestic remedies, adopted by the Council of Europe's Committee of Ministers, also does not contain specific remedies for violations of Article 6(1).

${ }^{254}$ Chapter 7.3 discusses when refusal of enforcement can be considered appropriate as a remedy.
} 
national level, as states are better placed than the ECtHR to deal with such complaints. ${ }^{255}$ Additionally, the Venice Commission (an advisory body to the Council of Europe) undertook a study that assessed the effectiveness of remedies that states offer in their national law to address excessive length of proceedings. The study shows that many states offer both preventative remedies, aimed at acceleration of the proceedings, and compensatory remedies. Compensation can take such forms as pecuniary compensation, disciplinary sanctions to the dilatory judge, or exemption of legal costs..$^{256}$

As addressed above, the CJEU has also considered what remedies should be available within the EU framework for a failure to comply with the reasonable time requirement. In Der Grüne Punkt, the CJEU ruled that where EU institutions exceed the reasonable time, the affected party may commence an action for compensation against the EU. ${ }^{257}$ Most likely, the CJEU would consider that when Member States fail to observe the reasonable time requirement in their application of EU law, they must provide remedies at the national level.

It can be concluded that appeals and other procedural remedies are generally not considered appropriate remedies for exceeding the reasonable time requirement. The ECtHR has expressed a preference for measures that prevent violations from occurring and addresses the root cause of the problem, instead of requiring the affected litigant to pursue even further procedures to obtain compensation. ${ }^{258}$

\subsubsection{Remedies for violations of the obligation to enforce}

Finally, specific remedies have been recommended for failures to enforce national judgments. As was concluded earlier, a failure to enforce a judgment can amount to a violation of Article 6(1). As an example, in Nesevski v. FYR Macedonia, ${ }^{259}$ the applicant had successfully submitted a claim against a school which had rejected his application for a teaching job, hiring someone unqualified instead. The Supreme Court upheld the applicant's appeal, but the school then appealed to halt the enforcement proceedings and reappointed the unqualified candidate. The ECtHR ruled that the Macedonian authorities' failure to enforce the Supreme Court judgment amounted to a violation of Article 6(1). The respondent government then argued that the applicant did not suffer a lack of effective remedies because he was able to start a fresh civil action against the decision to reappoint the unsuitable candidate. The ECtHR ruled that

\footnotetext{
255 ECtHR Kudla v Poland, para. 154-155.

${ }^{256}$ Venice Commission (2007) para. 69-78. The Report also mentions assumption of a decision in the applicant's favour as a sanction, but this applies only in administrative cases: see para. 79 .

${ }^{257}$ CJEU Der Grüne Punkt, para. 195.

${ }^{258}$ ECtHR Sürmerli v. Germany, para. 100.

${ }^{259}$ ECtHR Nesevski v. FYR Macedonia, appl. no. 14438/03, 24 April 2008. See also Burdov v. Russia, appl. no. 59498/00 ECHR 2002-III; ECtHR Gerasimov v. Russia, appl. no. 29920/05, 1 July 2014; ECtHR Nosov v. Russia appl. no. 9117/04 and 10441/04, 20 February 2014.
} 
this could not amount to an effective remedy, because the applicant had already successfully gone down this route yet been denied enforcement of the resulting judgment.

Clearly, where a judgment has already been obtained but enforcement is denied, the possibility to litigate even further is not an effective remedy. ${ }^{260}$ For that reason the Committee of Ministers proposes in its aforementioned Guide to good practice in respect of domestic remedies that remedies that expeditious enforcement, thus preventing a violation, is to be preferred. ${ }^{261}$ There are clear parallels with the problem of excessive length of proceedings, which is why similar remedies are recommended. ${ }^{262}$

\subsection{Theoretical foundations for the right to a fair trial in civil cases}

\subsubsection{Introduction: the need to delve further into the right to a fair trial}

The following sections aim to take the discussion of the values underlying the fair civil trial further. The purpose of this discussion is to provide a framework for Chapter 7, which aims to create guidelines for the application of refusal grounds. It can be derived from the preceding discussion that when a court applies the public policy exception, it essentially has to decide whether the (alleged) violation of the right to a fair trial suffered by the person who invokes the exception is sufficiently serious to justify that the judgment creditor is no longer able to exercise his right to enforcement. This is a difficult choice for the judge to make. Essentially, what will happen is that the judgment creditor suffers the consequences of the State's failure to protect his counterparty's right to a fair trial. A refusal to recognise or enforce a foreign judgment renders the exercise of the creditor's right to enforcement completely impossible.

This makes the refusal of enforcement or recognition much more impactful than other available remedies. The person who claims to have suffered a violation of his right to a fair trial can also file an application with the ECtHR against the State where the litigation took place, but this can only result in the finding of a violation. This will not invalidate the original domestic judgment and therefore will not hinder enforcement. Alternatively, a remedy might be available under national law, such as recourse against the judgment in the state where it was rendered, or an enforcement dispute in the state of enforcement. None of these remedies however have the effect of rendering enforcement completely impossible. An appeal against the judgment does not prohibit enforcement, though it may result in a new judgment that overturns the

\footnotetext{
${ }^{260}$ See also ECtHR Garcia Mateos v. Spain, appl. no. 38285/09, para. 48, in which the ECtHR considered that a constitutional complaint (recurso de amparo) was not effective, because it was not capable of providing the applicant with the appropriate remedy, which should have involved restoring her rights in full.

${ }^{261}$ Council of Europe Guide to good practice in respect of domestic remedies p. 39.

${ }^{262}$ Council of Europe Guide to good practice in respect of domestic remedies p. 40-41.
} 
previous one; however, this is a possibility in any civil litigation. Enforcement disputes may have the effect of prohibiting enforcement, but strict conditions usually apply, and they are generally not intended for addressing procedural irregularities, even if they are serious. ${ }^{263}$

The possibility of refusing enforcement or recognition is therefore a uniquely radical sanction, and it follows that its application is only justified in exceptional cases. In order to decide whether it should be applied in a particular situation, the judge has to examine whether the violation suffered by the judgment debtor outweighs the consequences for the creditor. A considerable body of literature exists on the problem of resolving conflicts between fundamental rights. It is generally proposed that when resolving such conflicts, regard should be had to such considerations as whether the element at issue forms the 'core' or the 'periphery' of the right as such. ${ }^{264}$ To assess which elements of the right to a fair trial could, when violated, supersede the right to enforcement, it is important to analyse what role the elements of Articles 6(1) ECHR and 47 EU CFR play in achieving a fair trial. How essential is it whether a judgment is adequately reasoned, or whether the trial was concluded within a reasonable time? Conversely, is it appropriate if a judgment creditor is allowed to enforce the judgment he obtained, even if it was obtained unfairly? In order to answer such questions, it may be helpful to explore why the fair civil trial is as it is: if we know what goals the fair civil trial is intended to achieve, it is also possible to determine which elements are essential to achieving those goals, and which are not. The following sections discuss two goals, or sets of goals, of the civil trial: on one hand, the goal of allowing litigants to protect or acquire private law positions, and to establish the truth to make that possible (means to an end); and on the other, the goal of protecting the dignity of the litigants by taking them seriously (end in itself).

It should be stressed that the following sections are not an attempt to provide an interpretation of 'the civil trial' in a general sense, but of the civil trial as protected by Article 6(1) ECHR and 47 EU CFR. There are many possible ways to design a civil trial, and ideas as to what it should look like may vary across time and place. The following sections therefore only concern the perception of the fair trial that is embodied in Articles 6(1) ECHR and 47 EU CFR, as demonstrated by the European courts' case law.

\subsubsection{The fair civil trial as a means to an end}

Though 'fairness' in the context of Articles 6(1) ECHR/47 EU CFR refers only to procedural fairness, there can be no doubt that the manner in which a fair trial is to be organised is intended to contribute to the substantive fairness of the outcome as well. This section argues that many

\footnotetext{
${ }^{263}$ In the Netherlands, enforcement may only be refused in a domestic enforcement dispute if enforcement would amount to an abuse of rights by the creditor, for example where the debtor would be made homeless through eviction from his home, where the judgment is manifestly legally or factually wrong, or where there has been a significant change in the circumstances after the delivery of the judgment. See Hoge Raad 22 April 1983, Ritzen v. Hoekstra. ECLI:NL:HR:1983:AG4575.

${ }^{264}$ Brems (2005) p. 303-304; Sullivan (1991-1992) p. 821-823.
} 
elements of a fair trial contribute not just to the fairness of the proceedings, but also to the fairness of the outcome. The following are therefore goal-oriented, or consequentialist, views on the civil trial as protected by Articles 6(1) and 47.

\subsubsection{The civil trial as a means of protecting or acquiring rights}

In many ways, the right to a fair trial is an auxiliary fundamental right, in the sense that it contributes to protecting other fundamental rights or the values embodied in them. For example, Van Kempen, in his inaugural lecture on positive obligations, argues that the right to a fair trial is 'dependent' on the infringement of another fundamental right. ${ }^{265}$ In criminal cases, the accused should be granted a fair trial to compensate for the (potential) infringements of his right to liberty and privacy he may suffer during or after the trial. Analogously, it can be argued that private parties have a right to a fair trial in order to protect their fundamental rights in so far as they give rise to claims under civil law. For example, many claims under civil law could be seen as expressions of the right to property (such as a claim for compensation arising out of damage to one's property), the right to privacy (defamation), the right to family life (custody of or access to children); and more examples are imaginable, especially under the EU CFR. ${ }^{266}$ The only problem is that fundamental rights protected by the ECHR and the EU CFR do not create obligations for private parties but are addressed to the State. Van Kempen argues that a right to a fair trial in civil cases can therefore not directly be derived not from the provisions themselves, but that it is possible to derive them from the principles underlying those provisions. $^{267}$

Robert Alexy's theory on constitutional rights ${ }^{268}$ offers a more direct way of linking fundamental rights to the right to a fair civil trial. According to Alexy, subjective rights emanating from civil law are a means of guaranteeing constitutional (fundamental) rights. ${ }^{269}$ After all, there can be no right to property (under the constitution or under the ECHR) without the legal institution of 'property', its acquisition, and its relinquishment. Likewise, the right to marry is meaningless if the law does not provide for ways in which to attain a married status. The same argument can be made for the right to privacy, the right to family life, and so on. According to Alexy, "there is a subjective right to the validity of those private law norms which are necessary to make possible what the constitutional right guarantees."270 Procedures, particularly the civil trial, are thus necessary to protect, exercise or enforce these subjective rights. ${ }^{271}$

\subsubsection{The importance of uncovering the truth}

\footnotetext{
265 Van Kempen (2008).

266 Van Kempen (2008) p. 16.

${ }^{267}$ Ibid., p. 21-24.

${ }^{268}$ Alexy (2002).

${ }^{269}$ Alexy (2002) p. 325.

${ }^{270}$ Alexy (2002) p. 326.

${ }^{271}$ Ibid.
} 
The foregoing provides a justification for the existence of a fair trial in civil cases: it serves to enable parties to either protect or acquire subjective rights under civil law. But what implications does it have for the manner in which that trial should be organised? It can be argued that in order to determine whether the litigants in fact legally enjoy the rights they claim (whether they are indeed entitled to ownership, compensation for damage, etc.), it must first be determined what the factual and legal situation is which provides the basis for their claim. If the facts have not been established, it is impossible for the judge to accurately apply the law to the facts. A judgment that is based on an incorrect presentation of the facts cannot be just; a fair trial should therefore serve to uncover the truth.

Though the ECtHR and CJEU have not stated this in so many words, the importance of uncovering the truth does seem to be one of the underlying notions of Articles 6(1) and 47. As has been described, Article 6(1) ECHR/47 EU CFR places great emphasis on the notion of an adversarial trial, in which litigants are able to see and comment on all evidence and arguments presented. ${ }^{272}$ They should also be able to do so in equal measure (equality of arms). Clearly, a fair trial is one that facilitates a dialectic: a process of assertion and refutation. This idea has close similarities to Karl Popper's theory of scientific rationality, which proposes that the truth is most likely to emerge if each side of the conflict attempts to prove its case, while the other attempts to refute the arguments and evidence presented. ${ }^{273}$ If a trial is conducted in this way, it is most likely that all aspects of the matter are presented. It can be argued that the impartiality and independence of the judge also contribute to finding the truth: only an objective and neutral observer would be able to see clearly the picture that emerged from the debate between the parties. If a judge were biased, the dialectic process would essentially be disturbed.

Though the ECtHR does not explicitly refer to uncovering the truth as a purpose of the fair trial, its case law does provide innumerable examples that support this notion. As stated above, the principles of an adversarial trial and of equality of arms are conducive to uncovering the truth. The ECtHR's case law on these principles offers many examples of cases that demonstrate this connection. Though Article 6(1) does not oblige parties to a civil trial to submit evidence to support their claim and thus prove its truthfulness, it does allow parties to present all evidence they consider necessary, ${ }^{274}$ and to familiarise themselves with, and comment on, all evidence presented by their opponent. ${ }^{275}$ It also places a duty on judges to examine all evidence, ${ }^{276}$ to craft their judgments on the basis of what has been presented, ${ }^{277}$ and if necessary to explain why they considered certain arguments or allegations unfounded or

\footnotetext{
${ }^{272}$ See on the connection between the adversarial trial and establishing the truth De Bock (2011) p. 66-67.

${ }^{273}$ Luban (1988) p. 69, referring to Popper (1963).

${ }^{274}$ ECtHR Clinique des Acacias, para. 37.

${ }^{275}$ ECtHR Krcmar and others $v$ Czech Republic, para. 42; see also Immeuble Groupe Kosser v. France, para.

26; McMichael v. UK, para. 80; ECtHR Vallauri v. Italy, para. 71.

${ }^{276}$ Harris et al (2014) p. 429.

${ }^{277}$ ECtHR H. v. Belgium.
} 
unacceptable. ${ }^{278}$ The ECtHR has found violations in cases where courts completely ignored important evidence, ${ }^{279}$ or did not refer to the facts as established by a lower court. ${ }^{280}$ The right to an oral hearing is also a clear example of the truth-finding purpose of the fair civil trial: as the ECtHR has emphasised, an oral hearing can be necessary for establishing the truth regarding the certain claims, especially those concerning a person's personal life ${ }^{281}$ or conduct. $^{282}$

One may ask whether all these guarantees actually contribute to uncovering the (objective) truth. For instance, Luban has argued that a trial modelled on the adversarial principle allows parties to advance arguments they know to be untrue and then use procedural rules to exclude probative evidence. ${ }^{283}$ A trial conducted in that manner therefore only produces the parties' version of the truth (the subjective truth), which may not be what really happened (the objective truth). However, what seems important here is not whether a trial conducted along the lines of Article 6(1) ECHR/47 EU CFR produces a judgment that most closely resembles the objective truth. What matters is that establishing the truth is clearly one of the objectives behind the fair trial as proscribed, whatever 'truth' may mean in that context. It can therefore be concluded that when certain elements of the right to a fair trial have been violated, it can be doubted, within the framework of Article 6(1), whether the judgment accurately reflects the facts of the case, and therefore also whether its application of the law to those facts was correct. Of course, it needs to be examined in each case whether the violation committed was great enough to cast substantial doubt on the accuracy of the judgment.

\subsubsection{The fair civil trial as an end in itself}

Though some have argued to the contrary, ${ }^{284}$ it can be argued that the fair civil trial has a purpose in and of itself, apart from uncovering the truth or protecting parties' rights under civil law (the nonconsequentialist view). This section proposes that the fair trial as protected by Articles 6(1) ECHR and 47 EU CFR also has an intrinsic value: it protects the litigant's right to human dignity by treating him with respect, and in so doing increases his sense of procedural justice. The following sections explain why this should be seen as an independent objective of the civil trial.

\footnotetext{
${ }^{278}$ ECtHR Georgiadis v Greece appl. no. 21522/93 ECHR 1997-III.

${ }^{279}$ ECtHR Khamidov v. Russia appl. no. 72118/01, 15 November 2007, para. 174.

${ }^{280}$ ECtHR Andelkovic v. Serbia, appl. no. 1401/08, 9 April 2013, para. 27.

${ }^{281}$ See section 4.3.2.6.

${ }^{282}$ ECtHR Muyldermans v. Belgium.

${ }^{283}$ Luban (1988) p. 69.

${ }^{284}$ Ten Kate (1983); De Bock (2011) p. 65.
} 


\subsubsection{The civil trial and human dignity}

The connection between the civil trial and human dignity was elaborated upon by David Luban in Legal Ethics and Human Dignity. ${ }^{285}$ In this book, Luban advocates an understanding of human dignity that can be summed up as follows: to respect human dignity is to take a person seriously. ${ }^{286}$ This involves treating his views, however subjective, as credible until proven otherwise, assuming him to be acting in good faith, and not humiliating him. According to Luban,

society respects our human dignity by provisionally treating the positions we maintain in legal disputes (criminal or civil) as good faith positions, even when they are not. Respect for human dignity demands that only after a trial can it be concluded that we were not arguing in good faith. The legal system must therefore allow us to articulate our view of the facts and the law in court: that is why we have an adversary system in which parties present their own cases, rather than, say, on official inquiry into the matter conducted by the State. ${ }^{287}$

The fact that the civil trial facilitates the presentation by both parties of their subjective views shows that the trial is more than a way of attaining legal justice, or of establishing the truth in a 'wholehearted dialectic of refutation and discussion' similar to Karl Popper's theory of scientific rationality. While the result of the trial - the judgment - is, at least in the ideal situation, based on the objective truth and a fair representation of the parties' substantive rights (therefore attaining legal if not also moral justice), the process leading up to that result leaves room for the expression of the parties' subjective viewpoints.

\subsubsection{The civil trial and procedural justice}

Research in the field of social psychology has also confirmed that the civil trial serves not only to allocate legal rights and obligations, but also has intrinsic value to the participants. Studies show that participants more easily accept the outcome of a procedure if it is perceived as fair. ${ }^{288}$ A fair procedure is one that allows parties,

\footnotetext{
${ }^{285}$ Luban (2009).

${ }^{286}$ The concept of human dignity has been given extensive attention in legal philosophy and within the context of fundamental rights. It has been defined in various ways according to its context. Though this is not the place for an extensive discussion on its various meanings, it can be said that most definitions emphasize the autonomy of the person. Dignity is an intrinsic value or quality that each person possesses by virtue of being a human, that acknowledges his consciousness, freedom, and responsibility and allows him to be the bearer of legal rights and obligations. See Rendtorff and Kemp (2000) p. 31-32.

${ }^{287}$ Luban (1988) p. 85.

${ }^{288}$ Klaming and Giesen (2008) p. 4.
} 
to present their case, in which the decision-maker is unbiased and neutral and relies on accurate information when deriving an outcome. Furthermore, the decision-maker needs to be consistent and to consider ethical and moral standards. The individual using a procedure should have the right to correct statements and to appeal against an unfavourable decision. ${ }^{289}$

As is readily apparent from this statement, these 'indicators' of procedural justice largely correspond to the requirements of Articles 6(1) ECHR and 47 EU CFR. ${ }^{290}$ It was also shown that parties value the opportunity to comment on all arguments and evidence submitted, even if those do not influence the decision, thus reinforcing the conclusion that the outcome is not all that matters.

\subsubsection{Nonconsequentialist views in the case law of the ECtHR}

The ECtHR's case law shows that a fair trial should allow parties to present their subjective version of events. This is reflected most clearly in the Court's finding that parties should have the opportunity to comment on all arguments and evidence submitted, even if that evidence has not been decisive for the outcome of the case. ${ }^{291}$ It is also reflected in the principle that it is up to the parties, not the court, to decide what evidence to present and whether to comment on evidence presented. ${ }^{292}$ The principle of equality of arms can also be seen as an expression of the litigant's dignity, in the sense that it does not merely serve a fair outcome of the case. The ECtHR ruled that the inequality in itself may constitute a violation of Article 6(1), even if the party concerned did not suffer actual prejudice. ${ }^{293}$ So, while the outcome of the proceedings may still be fair, a lack of equality in the procedure may also by itself give rise to a violation.

The ECtHR's case law also produces some arguments to the contrary. The civil trial as understood by the ECtHR does not in every case facilitate the subjective wishes and desires of the parties. For example, courts may reject a party's request for an oral hearing; such a denial will only constitute a violation of the party's rights under Article 6(1) if an oral hearing was required to establish certain facts. ${ }^{294}$ One may argue that an oral hearing increases a party's sense of procedural justice because it provides him with an additional opportunity to present his views. However, the ECtHR clearly does not consider this objective paramount, as it allows states to refuse a request for an oral hearing for reasons of 'efficiency and economy'; instead it applies an objective test concerning the necessity of a hearing for deciding the case ${ }^{295}$ Here, the goal-oriented (consequentialist) view on the civil trial arguably outweighs the nonconsequentialist view: not every feature of the civil trial that may increase a litigant's sense of procedural justice is in fact necessary to conduct a fair civil trial.

\footnotetext{
${ }^{289}$ Klaming and Giesen (2008) p. 7.

${ }^{290}$ Klaming and Giesen (2008) p. 7.

${ }^{291}$ ECtHR Nideröst-Huber, para. 27.

${ }^{292}$ EctHR Nideröst-Huber p. 22; ECtHR Zagrebacka banka v. Croatia, para. 203.

${ }^{293}$ ECtHR A.B. v. Slovakia.

${ }^{294}$ ECtHR Schuler-Zgraggen v. Austria.

${ }^{295}$ ECtHR Schuler-Zgraggen v. Austria. See under 4.3.2.6.
} 


\subsubsection{Is it possible to distinguish a 'core' and a 'periphery' within Article 6(1)?}

The preceding sections presented consequentialist and nonconsequentialist interpretations of the civil trial as distinct, but in reality the two sets of objectives are connected and mutually reinforcing. It is clear that many of the factors that increase parties' sense of procedural justice $^{296}$ also contribute to an outcome that correctly reflects the facts of the case and is therefore likely to be just. ${ }^{297}$ Procedure and outcome are often inseparable and mutually reinforcing. The principles of an adversarial trial, independence and impartiality of the judge, the right to reasons, and the requirement of publicity can all be seen as both contributing to a fair outcome and to the parties' (subjective) sense of justice.

In some cases one objective overrides the other, for example in the case of oral hearings discussed above. Another possible example is found in the ECtHR's case law on the right to a reasoned judgment: perhaps the litigant's sense of procedural justice would be increased if judges answered every argument presented, but this is not necessary to satisfy the requirements of Article 6(1). ${ }^{298}$ Conversely, the nonconsequentialist view takes precedence over the consequentialist view where the ECtHR finds a violation in the unequal treatment of parties even if they did not suffer actual prejudice, or where parties were denied the opportunity to comment on a piece of evidence even if that did not influence the decision.

Does this exploration provide some way of solving conflicts between elements of the right to a fair trial? The introduction to Section 4.4.1 stated that one way of solving conflicts is to assess what elements of a right belong to the 'core' of that right and which belong to the 'periphery'. Can some aspects of the right to a fair trial be seen as more 'essential' than others? It transpires from the preceding analysis that this is hardly possible. As previously stated, all elements of Article 6(1) contribute to the trial's fairness. Moreover, it was shown that the fair trial serves different purposes: it serves to protect litigants' legal rights, but it also serves the inherent purpose of providing procedural justice. Some elements of Article 6(1) may be peripheral to one of those objectives, but essential to the other. On the other hand, perhaps in the specific context of the decision as to whether refusal of enforcement or recognition of a foreign judgment is an appropriate remedy, a judge could take into account what objective of the trial is at issue. This is discussed further in Chapter 7.

\subsection{Conclusion}

\footnotetext{
${ }^{296}$ As cited under 4.4.3.2.

${ }^{297}$ See also De Bock, p. 67, who speaks of the 'procedural value' of establishing the truth: the parties' sense of procedural justice is increased if the judge is seen to carry out a careful investigation into the facts.

${ }^{298}$ ECtHR Van der Hurk v. Netherlands, para. 61; Garcia Ruiz v. Spain [GC], para. 26; Jahnke and Lenoble v. France (déc.); Perez v. France [GC], para. 81.
} 
This Chapter aimed to provide three things. First, it has provided a context in which to place the judgments that were discussed in the preceding Chapters as examples of the application of the public policy exception. This Chapter demonstrated why the procedural irregularities in Krombach, Gambazzi, Maronier v. Larmer, Eurofood, Trade Agency, and so on could amount to violations of Articles 6(1) ECHR or 47 EU CFR, and why, consequently, application of the public policy exception was justified. Chapter 7 discusses in depth why indeed in these types of cases application of that exception is the appropriate remedy.

Second, this Chapter aimed to provide a basis for discussing which of the elements of Article $6(1)$ could or should trigger the application of a refusal ground, and under what circumstances. Section 4 found that it is difficult to determine a 'core' of the right to a fair trial, but instead suggested that one should look at the objectives that the fair trial is intended to fulfil. In determining how a violation of the right to a fair trial should be remedied, it should be considered which element has been violated, and which objective has by consequence become unattainable. Chapter 7 uses the findings of that section to discuss when application of the public policy exception might be appropriate.

Third, this Chapter aimed to provide an overview of the ECtHR's and CJEU's case law on the right to a fair trial in so far as it applies to civil cases, in order to assess what legislation is needed to safeguard it. In particular, this Chapter aimed to establish two things: firstly, whether the CJEU's or the ECtHR's case law provided more specific standards with regard to each element; and secondly, whether a margin of appreciation applies. These elements also play a part in Chapters 7 and 8. 


\section{Free movement of judgments and the European Convention on Human Rights}

\subsection{Introduction}

This Chapter discusses whether and how free movement of judgments within the European Union (EU) is limited by the EU Member States' obligations as Contracting Parties to the European Convention on Human Rights (ECHR). Chapter 3 discussed that in Pellegrini the European Court of Human Rights (ECtHR) required ECHR Contracting Parties to check whether foreign judgments conformed to the standards of the ECHR (see Section 5.2). The question this Chapter addresses is whether this obligation also applies in situations where the recognition or enforcement of judgments is governed by EU legislation. The difficulty here is that while EU Member States must respect the rights contained in the ECHR, they may have little or no discretion when they implement EU legislation. This situation raises the question how the fact that EU law governs Member States' actions relates to their individual responsibility under the ECHR.

An analysis of ECtHR case law shows that the frame of reference differs according to whether the Member State enjoys discretion in their decision to enforce a judgment from another Member State. If no discretion remains for the Member States, the ECtHR applies what is called the 'Bosphorus doctrine'. In its Bosphorus judgment, the ECtHR held that when Member States do no more than fulfil their obligations under EU law, they are presumed to act in accordance with the ECHR, provided that they enjoy no discretion, and that no 'manifest deficiency' is apparent (Section 5.3). ${ }^{1}$ In its Povse decision, the ECtHR clarified that this frame of reference also applies in the context of cross-border enforcement in the absence of refusal grounds (Section 5.4). However, the Bosphorus doctrine, and in particular its application to cross-border situations, raises a number of important questions. This Chapter analyses the Povse decision against the background of the Bosphorus judgment and other rulings in which the doctrine was applied. This Chapter concludes that while the Povse decision leaves a number of matters unclear, it nevertheless provides valuable guidance for future legislation which facilitates free movement. The Chapter concludes with the preconditions Povse imposes on free movement of civil judgments.

The previous Chapter discussed that the grounds for refusal confer on the enforcing court discretionary powers to refuse enforcement. According to the ECtHR in Cantoni and Avotins ${ }^{2}$,

\footnotetext{
${ }^{1}$ Chapter 6 discusses in detail how the CJEU interpreted this element in its case law, and what its implications are for civil justice cooperation. See Chapter 6.3.

${ }^{2}$ As case law research for this research was concluded on 1 February 2016, Grand Chamber's important judgment in Avotins v. Latvia could not be taken into consideration. This judgment is very relevant to EU Member States' obligations under the ECHR. The reader should be aware that some of that Chapter's observations are affected by the Grand Chamber ruling. ECtHR Avotins v. Latvia [GC], appl. no. 17502/07, 23 May 2016.
} 
in such cases Member States are considered to be acting of their own accord, and so in these situations Member States' actions are subject to full scrutiny by the ECtHR (Section 5.4.5).

Finally, the EU's accession to the ECHR has long been on the political agenda. Such accession would radically alter the framework discussed in this Chapter, as the EU would then become accountable under the ECHR, as would its Member States when they apply EU legislation. Yet, in light of the Court of Justice of the European Union's (CJEU) negative Opinion as to the compatibility of the recent Accession Agreement with the autonomy of the EU's legal order it is questionable when, if ever, accession will happen. This Chapter briefly discusses the CJEU's Opinion, since it illustrates the sensitivity of the question whether mutual recognition of judicial decisions within the EU is compatible with fundamental rights (Section 5.5).

\subsection{The scope of application of Pellegrini}

\subsubsection{Application of Pellegrini to situations where both states are party to the ECHR}

To reiterate, in Pellegrini the ECtHR imposed on national courts a duty to verify, prior to recognizing a foreign judgment, whether the right to a fair trial was adequately protected. ${ }^{3}$ In doing so it entrenched the ECHR into the external public policy of the Contracting Parties to the ECHR. Since Pellegrini concerned the recognition by a Contracting Party to the ECHR (Italy) of a judgment from a third state (the Vatican), the question remains as to whether it applies where both states are ECHR Contracting Parties.

This question was debated in the negotiations leading to the recast Brussels I Regulation. If an obligation to refuse enforcement of judgments which in some way infringe Convention rights could be inferred from Pellegrini, then complete free movement of judgments, with no possibility to refuse recognition or enforcement, would deprive signatory states who are also EU Member States from the procedural mechanism allowing them to fulfil that obligation. Abolition of refusal grounds would therefore be problematic in view of protection of Convention Rights. ${ }^{4}$

Literature is divided on the question of Pellegrini's scope of application. Some authors have argued that Pellegrini does not give rise to an obligation for Contracting Parties to review judgments from other contracting states but that this is optional. ${ }^{5}$ Another argument is that an obligation to review Convention compliance for the enforcing state is of little added value when

\footnotetext{
${ }^{3}$ See section 5.2 .

${ }^{4}$ Kramer (2011b) p. 220.

${ }^{5}$ Stein (2004) p. 187; Hess (2001) p. 394; Kinsch (2004) p. 228.
} 
the state of origin is also accountable to the ECtHR. ${ }^{6}$ Some argue that Pellegrini only applies when no remedies remain in the state of origin of the judgment: refusal of enforcement is in no way an alternative to an available appeal in the home state, and that the available local remedies must first have been exhausted. ${ }^{7}$

On the other hand, it has been argued that if there were no obligation for the enforcing court to refuse enforcement from another signatory state, this would allow judgments that are contrary to the Convention to be enforced. This would be at odds with an obligation to refuse enforcement of judgments that emanate from states that are not even signatories to the Convention. ${ }^{8}$ Moreover, while the Pellegrini judgment concerned a third-state judgment, the ECtHR did not explicitly exclude judgments from Contracting Parties from its scope. Some therefore consider it arguable that the ECHR's obligation to refuse enforcement extends also to signatory states. ${ }^{9}$

In light of later case law, however, it appears that the ECtHR did intend Pellegrini to be applicable only to judgments emanating from third states. The next sections of this Chapter discuss the Bosphorus judgment, which concerns the responsibilities of states under the ECHR when they act in the implementation of EU law. In this judgment, the ECtHR considered that

Pellegrini is distinguishable: the State responsibility issue raised by the enforcement of a judgment not of a Contracting Party to the Convention [...] is not comparable to compliance with a legal obligation emanating from an international organisation to which Contracting Parties have transferred part of their sovereignty. ${ }^{10}$ (emphasis added)

With this statement, the Court retrospectively frames the problem as one raised by the enforcement of a judgment from a third state that is not a Contracting Party to the ECHR though as was explained earlier, some commentators considered this obvious from Pellegrini itself.

Strictly speaking, this does not exclude the possibility that Pellegrini may be applicable to intra-ECHR situations; the ECtHR did not explicitly exclude intra-ECHR situations, which is understandable, given that the case at hand did not require it to do so. The Court would have

\footnotetext{
${ }^{6}$ Christians (2004) p. 119.

${ }^{7}$ Schilling (2011) p. 35.

${ }^{8}$ Costa (2002) p. 475; Fawcett (2007) p. 43. See also Judge Matscher's Concurring Opinion in Drozd and Janousek $v$. France and Spain, in which he holds that "Thus, for example, a State may violate Articles 3 and/or 6 (art. 3, art. 6) of the Convention by ordering a person to be extradited or deported to a country, whether or not a member State of the Convention, where he runs a real risk of suffering treatment contrary to those provisions of the Convention" (emphasis added). ECtHR Drozd and Janousek v France and Spain [GC], no. 12747/87, ECHR 1992.

${ }^{9}$ Van Bochove (2007) p. 337; Kramberger Skerl (2011) p. 470.

${ }^{10}$ ECtHR, Bosphorus Hava Yollari Turizm ve Ticaret Anonim Sirketi v. Ireland, appl. no. 45036/98, ECHR 2005-VI.
} 
gone beyond the legal questions it was asked to decide upon if it had made explicit in which situations its findings would not apply.

However, there is one other ECtHR judgment that deals with cross-border enforcement of civil judgments between ECHR Contracting Parties: Lindberg v. Sweden. ${ }^{11}$ In that case, $\mathrm{Mr}$ Lindberg, a Norwegian national residing in Sweden, had been found liable for defamation in Norway and ordered to pay compensation. The judgment creditors sought enforcement of this judgment against Mr Lindberg in Sweden. Mr Lindberg held that Sweden's failure to refuse enforcement to this judgment on his request amounted to a violation of his right to freedom of expression (Art. 10 ECHR) and his right to an effective remedy (Art. 13 ECHR). The ECHR declared his application against Sweden inadmissible because Mr Lindberg had, and availed himself of, the opportunity to challenge the judgment before the Norwegian court and, when that proved unsatisfactory, bring an application against Norway in Strasbourg. According to the ECtHR,

A contrary approach would give an applicant the undue possibility of having reopened matters already finally settled, at the risk of upsetting the coherence of the division of roles between national review bodies and the European Court, making up the system of collective enforcement under the Convention. ${ }^{12}$ (emphasis added)

The ECtHR considers the fact that the applicant was able to pursue an application against Norway, a Contracting State to the ECHR, a reason to declare his complaint against Sweden inadmissible. It did not however exclude the possibility that a Contracting Party might be found to have violated the ECHR by enforcing a judgment from another Member State; it did review the Swedish enforcement procedure, ruling that there were no compelling reasons against enforcement. ${ }^{13}$ It declared itself satisfied that the Swedish courts reviewed the substance of the applicant's complaint against the requested enforcement of the Norwegian judgment, to a sufficient degree to provide him an effective remedy for the purposes of Article 13 of the Convention. ${ }^{14}$ For those reasons, the Court did not deem it necessary to determine what standard should apply ${ }^{15}$ where the enforcing State as well as the State whose court gave the contested decision is a Contracting Party to the Convention and where the subject-matter is one

\footnotetext{
${ }^{11}$ ECtHR Lindberg v. Sweden [dec.], appl. no. 48198/99, 15 January 2004.

${ }^{12}$ ECtHR Lindberg v. Sweden, para. 1 (under '(b) The Court's assessment').

${ }^{13}$ ECtHR Lindberg v. Sweden, para. 1 (under '(b) The Court's assessment').

${ }^{14}$ ECtHR Lindberg v. Sweden, para. 1 (under '(b) The Court's assessment').

15 The matter of which standard should be applied in the context of judicial cooperation between states has repeatedly come before the ECtHR. In Drozd and Janousek v. France and Spain [GC], appl. no. 12747/87, ECHR 1992, the ECtHR ruled that enforcement of foreign decisions (in that case an arrest warrant pertaining to the execution of a prison sentence by a judgment in a criminal case) should be refused if the foreign proceedings constituted a "flagrant denial of justice" (para. 110). While this qualification is absent from Pellegrini, the ECtHR indicated in Lindberg that this was not deliberate (ECtHR Lindberg v. Sweden, para. 1 (under '(b) The Court's assessment'). From these judgments it can be concluded that very serious infringements of the right to a fair trial in the foreign proceedings should therefore lead to non-enforcement. See for an analysis Kiestra (2014) p. 252; Schilling (2012) p. 566 onwards; Oster (2015) p. 561-565.
} 
of substance (i.e., here, the freedom of expression) rather than procedure. ${ }^{16}$ As for matters of procedure, it referred to Pellegrini. ${ }^{17}$

Lindberg v. Sweden indicates that it is possible for a Contracting State to the ECHR to violate the ECHR by enforcing a judgment from another Contracting Party. The threshold for finding a violation is likely to be high, since the ECtHR aims to protect the coherence of the enforcement system under the ECHR, which entails that a remedy must first be sought in the State of origin of the judgment (the 'local remedy rule'). ${ }^{18}$

\subsubsection{Application of Pellegrini to situations governed by EU law}

When the two states involved are both not only ECHR Contracting Parties, but also EU Member States applying EU law, another layer of complexity is added. Within the EU, recognition and enforcement of civil judgments are governed by EU Regulations, which either contain an exequatur or require automatic enforcement where exequatur has been abolished. The question is therefore not whether the ECHR requires cross-border control as regards the enforcement of judgments among ECHR Contracting Parties, but whether it does so in situations where the enforcement is governed by EU law. In this context, the ECtHR has shown to take a different approach from that which it adopted in Pellegrini. Its conclusions in Pellegrini are still largely based on the principle of individual responsibility of each signatory state for the protection of its subjects: it follows from this principle quite logically that a signatory state may not avoid responsibility by claiming that it is simply 'importing' a faulty foreign judgment.

In the intra-EU context, the situation is different in this regard in that the interactions between Member States are no longer ruled by classic principles of international law, but by obligations imposed on them by a supranational organization: the EU. With their accession to the EU, Member States effectively transferred a degree of sovereignty to the Union. Whether or not there is an exequatur, refusal grounds or any other kind of discretion left to them to decide on the enforceability of judgments emanating from other EU Member States is from that moment no longer exclusively up to them. It may be recalled from Chapter 2 that judicial cooperation in civil matters has been an EU competence since the Treaty of Amsterdam, which entered into force in 1999.

The ECtHR has therefore examined the question of the abolition of the exequatur and refusal grounds in EU law from a different angle by applying the by now well-established Bosphorus doctrine. In its recent Povse decision, the Court applied the Bosphorus doctrine to decide that the abolition of exequatur and refusal grounds under the Brussels II bis Regulation was, under certain conditions, compatible with the ECHR. This decision and its implications are examined in detail in this Chapter.

\footnotetext{
${ }^{16}$ ECtHR Lindberg v. Sweden, para. 1 (under '(b) The Court's assessment').

${ }^{17}$ ECtHR Lindberg v. Sweden, para. 1 (under '(b) The Court's assessment').

${ }^{18}$ Kiestra (2014) p. 277.
} 


\subsection{A different frame of reference for intra-European Union situations: the Bosphorus test}

\subsubsection{Review by the ECtHR of matters relating to EU law prior to Bosphorus}

Prior to Bosphorus, the ECtHR's competence to review matters relating to EU law had already been the subject of several rulings. The foundation for the ECtHR's approach can be found in $M \& C o$ v. Federal Republic of Germany, a decision of the (now defunct) European Commission on Human Rights delivered in $1990 .{ }^{19}$ This case concerned the imposition by the European Commission of a fine for a violation of (then) Article 85(1) European Community (EC) Treaty (the prohibition on cartels, now Article 101 Treaty on the Functioning of the European Union (TFEU)). The respondent State held that it could not be held responsible for this action of a EC institution. The Commission held that

[T]he Convention does not prohibit a Member State from transferring powers to international organisations. Nonetheless, The Commission recalls that "if a State contracts treaty obligations and subsequently concludes another international agreement which disables it from performing its obligations under the first treaty it will be answerable for any resulting breach of its obligations under the earlier treaty [...]." The Commission considers that a transfer of powers does not necessarily exclude a State's responsibility under the Convention with regard to the exercise of the transferred powers. Otherwise the guarantees of the Convention could wantonly be limited or excluded and thus be deprived of their peremptory character. The object and purpose of the Convention as an instrument for the protection of individual human beings requires that its provisions be interpreted and applied so as to make its safeguards practical and effective. Therefore the transfer of powers to an international organisation is not incompatible with the Convention provided that within that organisation fundamental rights will receive an equivalent protection.

In this decision, the Commission for the first time expressed the notion of equivalent protection. The idea is that individual states should not be held accountable under the Convention for actions that are performed either by or in the context of an international organisation, provided that the organisation itself protects fundamental rights in a manner that is considered 'equivalent' to that of the Convention. To hold Member States responsible under the ECHR

\footnotetext{
${ }^{19}$ European Commission of Human Rights, $M \&$ Co. v. Federal Republic of Germany (dec.) appl. no. 13258/87, D.R. No. 64 p. 138.
} 
for carrying out obligations resulting from their membership of international organisations would be at odds with the principle of pacta sunt servanda, as well as with the growing importance of international cooperation and the need to secure the proper functioning of international organisations. ${ }^{20}$ However, Member States could not escape responsibility for safeguarding fundamental rights simply by transferring powers to an international organisation: the ECtHR requires that the international organisation itself provides protection that is equivalent - though not identical - to that provided by the Convention. ${ }^{21}$

In $M . \& C o$. , the Commission went on to analyse the different ways in which the (then) EC protected fundamental rights and came to the conclusion that both the substantive guarantees, as well as the procedural protection offered by the CJEU through its preliminary ruling mechanism, could be considered equivalent to the protection offered by the ECHR.

An important reason for the ECtHR to consider the EU system 'equivalent' to that of the Convention is the availability of a form of procedural protection, namely a preliminary ruling, within the EU system. This was affirmed by the ECtHR in Matthews v. United Kingdom. ${ }^{22}$ The ECtHR was asked to rule whether the United Kingdom's (UK) failure to organise European Parliament elections in Gibraltar amounted to a violation of Article 3(1) ECHR. At issue was whether the UK could be held responsible for this failure under the ECHR, given that it was a Council Decision (and the accompanying Act) which provided that the elections should only be organised in the United Kingdom. The Act had the status of a Treaty. The violation was, the UK government argued, therefore a direct result of EU primary legislation.

In its judgment, the ECtHR found that the Act was concluded on the basis of the European Ecconomic Community (EEC) Treaty. It could, the ECtHR found, not be challenged before the European Court of Justice "for the very reason that it is not a "normal" act of the Community, but is a treaty within the Community legal order". ${ }^{23}$ For this reason, the UK itself remained responsible ratione materiae under Article 1 of the ECHR for the consequences of the Act. The Commission consequently found that the UK had indeed violated Article 3(1).

Matthews affirmed that what is decisive for the question of accountability of states for applying EU law is whether the specific piece of legislation can be reviewed within the EU legal system. In its reasoning, the Court distinguished between primary law, such as the Council Decision that was at issue in Matthews, and secondary law ("normal acts of the Community"). International treaties should be considered as primary law, freely entered into by the contracting parties; for this reason, they cannot be challenged before the European Court of Justice, unlike secondary EU law. It appears from the judgment that the lack of legal protection against primary law offered within the EU system is the reason for the ECtHR to hold the UK

\footnotetext{
${ }^{20}$ ECtHR Bosphorus, para. 150.

${ }^{21}$ ECtHR Bosphorus, para. 152.

${ }^{22}$ ECtHR Matthews v. United Kingdom [GC], appl. no. 24833/94, ECHR 1999-I.

${ }^{23}$ ECtHR Matthews v. United Kingdom [GC], para. 33.
} 
responsible: if the UK could not be held accountable, no legal recourse would be available to the applicant, neither in the EU system nor under the ECHR. ${ }^{24}$ This conclusion is however not explicit from the judgment, and confusion on this point remained.

\subsubsection{Bosphorus: facts and procedure}

The ECtHR's Bosphorus judgment is important because it clarified the Court's approach regarding Member State responsibility for acts of secondary EU law. ${ }^{25}$ Moreover, it affirmed that the availability of judicial review within the EU system itself was indeed the decisive factor. In Bosphorus, the Court explicitly enumerated the conditions under which a state could be exempt from responsibility under the ECHR. This approach is often referred to as the 'Bosphorus test'.

At issue in Bosphorus was the impoundment of an aircraft by the Irish authorities on the basis of an EC Regulation. The aircraft was leased by the Turkish company Bosphorus Hava Yollari Turizm ve Ticaret Anonim Sirketi, but it was owned by a Yugoslav company. At the time, the United Nations (UN) Security Council had adopted a Resolution ordering sanctions against Yugoslavia. The Resolution was implemented in the EC through the EC Regulation, which of course had direct effect in Ireland's legal order, unlike the UN Resolution. The Turkish company claimed that the impoundment of the aircraft was a violation of their right to free enjoyment of property, guaranteed by Article 1 of the First Protocol to the ECHR. The matter reached the Irish Supreme Court, which asked preliminary questions to the CJEU. In its judgment, ${ }^{26}$ the CJEU considered the compatibility of the sanction with the right to property, though it did not refer to the ECHR, only to its own case law on the matter. ${ }^{27}$ The CJEU concluded that the impounding of the aircraft was not disproportionate or inappropriate with regard to the aim of the measure. ${ }^{28}$ The Turkish company next brought their case to the ECtHR.

First, the ECtHR affirmed that the impoundment of the aircraft fell within the jurisdiction of the Irish State; apparently, for this finding it did not matter that Ireland's actions were based on EU (at the time EC) law, and the applicant was justified in bringing its case against Ireland. The Court also quite quickly established that the impoundment constituted an interference with the company's right to free enjoyment of their property.

\footnotetext{
${ }^{24}$ This narrow reading of Matthews was suggested by Lenaerts: Lenaerts (2000) p. 575.

25 The narrow reading suggested by Lenaerts was thus affirmed; see Douglas-Scott (2006a) p. 249, and Hinarejos Parga (2006) p. 255.

${ }^{26}$ CJEU Case C-84/95, Bosphorus Hava Yollari Turizm ve Ticaret AS v. Minister for Transport, Energy and Communications, Ireland and the Attorney General, ECLI:EU:C:1996:312.

${ }^{27}$ CJEU Bosphorus, para. 21.

${ }^{28}$ Ibid., para. 26.
} 
Next, the ECtHR examined whether this interference was justified. The Court started by stating that the fulfilment of obligations resulting from a state's membership to an international organisation can be considered a "legitimate interest of considerable weight". ${ }^{29}$ Whether this legitimate interest could justify the interference with property rights was made dependent on whether the Court could review Ireland's actions (even though the Court had already established jurisdiction over the matter) ${ }^{30}$ The Court started by reaffirming the principle expressed in Matthews: that while the Convention does not prohibit states from transferring their sovereign powers to international organisations, they nevertheless remain responsible for safeguarding the rights laid down in the Convention. ${ }^{31}$ Incidentally, this is what distinguishes it from Pellegrini, according to the Court. With the citation quoted under 5.2.1, above, the Court stated that the questions raised by the enforcement of judgments from third states is "not comparable" to the transfer of competences to an international organisation. ${ }^{32}$

The Court then formulated the presumption of Convention compliance. This entails that state action taken in compliance with legal obligations emanating from their membership to international organisations is compatible with their obligations under the Convention, but only as long as the relevant organisation is considered to protect fundamental rights in a manner that is at least equivalent to that for which the Convention provides. If the organisation is considered to provide such equivalent protection, the state in question will be presumed to have acted in conformity with the Convention provided it had no discretion (the 'presumption of Convention compliance'). This presumption may however be rebutted if, in the circumstances of a particular case, the protection of Convention rights was manifestly deficient.

The Bosphorus test therefore consists of three elements: 1) the organisation in question must protect fundamental rights, both materially and procedurally, to an equivalent degree; 2) the state must have had no discretion in the matter (i.e., done no more than implement legal obligations flowing from its membership of the organisation; and 3) there is no apparent 'manifest deficiency' in the protection of Convention rights in the circumstances of a particular case.

The Court addressed these three elements in turn. First, it established that the EU, as an organisation, adequately protects fundamental rights. What mattered, according to the ECtHR, is not whether fundamental rights protection is identical, but whether it can be considered comparable to that provided by the Convention, because to require identical protection would "run counter to the interest of international cooperation pursued" (para. 155). The Court stated that "any such finding of equivalence could not be final and would be susceptible to review in the light of any relevant change in fundamental rights protection". ${ }^{33}$ Yet further on in the

\footnotetext{
${ }^{29}$ ECtHR Bosphorus, para. 150.

${ }^{30}$ Besselink notes in this regard that "what the ECtHR granted with one hand, it took away with the other"; Besselink (2008) p. 298.

${ }^{31}$ ECtHR Bosphorus, para. 152-154.

${ }^{32}$ According to the Court, "the State responsibility issue raised by the enforcement of a judgment not of a Contracting Party to the Convention is not comparable to compliance with a legal obligation emanating from and international organisation to which Contracting Parties have transferred part of the sovereignty", para. 157.

${ }^{33}$ ECtHR Bosphorus, para. 155.
} 
judgment, the Court applied a rather abstract analysis in finding 'equivalence'. It considered not whether the regulation at issue adequately protected fundamental rights, but whether the Community as an organisation does so. In a relatively brief segment, it first referred to the CJEU's case law, which incorporated fundamental rights into the general principles of Community law and indicated the ECHR as having "special significance" as a source of such rights. Furthermore, the Treaty of Amsterdam affirmed the Union's adherence to fundamental rights by introducing Article 6(1) Treaty on European Union (TEU), and the EU Charter of Fundamental Rights (EU CFR) (although at the time not binding) is 'substantially inspired' by the Convention (para. 159). The abstract and general nature of this analysis proved controversial: see Section 5.3.3, below.

Next, the Court analysed the mechanisms of control that are available to ensure the observance of fundamental rights. It acknowledged that individuals have limited standing before the European Court of Justice (para. 162), but it found that it is essentially through the national courts that individuals are protected against their Member States or other individuals for a breach of Community law. The CJEU exercises supervision through the mechanism of preliminary rulings. The Court acknowledged that preliminary rulings are limited to answering the interpretative or validity questions posed by the national courts, but that they are nevertheless often determinative of the final outcome of the proceedings (para. 164).

Consequently, the Court found that the protection of fundamental rights by EC law could be said to have been equivalent at the relevant time. Without any further analysis, the Court then found that Ireland had done no more than implement legal obligations flowing from its EC membership (para. 165), satisfying the "no discretion" requirement. It concluded that the presumption therefore arose that Ireland acted in conformity with the Convention.

In a final paragraph, the Court then found that there was no dysfunction in of the mechanisms of control of Convention rights in the particular case. It simply referred to "the nature of the interference, the general interest pursued by the impoundment and by the sanctions regime and to the ruling of the ECJ [European Court of Justice] [...] with which the [Irish] Supreme Court was obliged to comply" (para. 166). Unanimously, the Court then found that no violation of Article 1 of Protocol no. 1 to the ECHR had occurred.

\subsubsection{Bosphorus: impact and open questions}

The impact of Bosphorus is considerable. With this judgment, the ECtHR redefined the constitutional framework of Europe, by accommodating the autonomous legal order of the EU without relinquishing control over the application of Convention standards, and providing an incentive for the CJEU to incorporate those standards into its case law. ${ }^{34}$ What Bosphorus does, in essence, is to give rise to a presumption that states acted in conformity with the ECHR when

\footnotetext{
${ }^{34}$ Costello (2006) p. 91.
} 
EU law obliges them to act in a certain way. This presumption is conditional, because it only applies when three conditions are fulfilled. The first is that the organisation in question provides equivalent protection. The second is that the state may not have had any discretion in the fulfilment of the obligations imposed on it by EU law. Together, these two factors give rise to a presumption of Convention compliance (also sometimes called the "presumption of equivalent protection', ${ }^{35}$ though the ECtHR does not use this term). The third is that must be no evidence of a 'manifest deficiency' in the protection in a certain case that may rebut the presumption. These three conditions are examined at three stages (the 'equivalence' stage, the 'discretion' stage, and the 'rebuttal' stage).

Some of the elements of this test were already controversial at the moment it was announced. While the finding that no violation had occurred was unanimous, seven of the seventeen judges that made up the Grand Chamber submitted concurring opinions, six of them, including President Rozakis, together (the "Rozakis opinion"), while judge Ress submitted his own concurring opinion. This section does not aim to give a comprehensive overview of all the arguments raised in these opinions and in the literature, ${ }^{36}$ but highlights some aspects that proved to be problematic when applied in the Povse case. Since the main goal of this Chapter is to offer an interpretation of the decision in that case, the purpose of this section is to explain those aspects in more detail.

A contentious point was whether the judgment gave rise to a blanket presumption that EU law protects fundamental rights to an equivalent degree, or whether this should be checked on a case-by-case basis; and whether such a check should be abstract or concrete. While the Court emphasized, as cited, that "any such finding of equivalence could not be final and would be susceptible to review in the light of any relevant change in fundamental rights protection", and that in Bosphorus the protection was found to be sufficient "at the relevant time", its subsequent analysis was rather short and general in nature, and paid no attention to the relevant secondary legislation. ${ }^{37}$ The authors of the Rozakis opinion stated in this regard that they were "not entirely convinced by the approach that was adopted in order to establish that such protection existed in the instant case". ${ }^{38}$ They recalled the limited standing of the individual before the CJEU and pointed out that the protection offered by the preliminary ruling mechanism "is not of the same nature and does not replace the external, a posteriori supervision of the European Court of Human Rights, carried out following an individual application". ${ }^{39}$ This means that the ECtHR cannot apply a blanket presumption that fundamental rights are adequately safeguarded within the EU legal system, and that it must check in each instance whether the protection afforded was sufficient. The authors stated that

\footnotetext{
${ }^{35}$ Besselink (2008) p. 300.

${ }^{36}$ See for comments on this judgment among others Douglas-Scott (2006a); Peers (2006); Hinarejos Parga (2006); Besselink (2008); Costello (2006); Lock (2010a); Eckes (2007); Lawson (2010).

${ }^{37}$ See for criticism on the ECtHR's approach in this regard also Douglas-Scott (2006a) p. 250-251; Costello (2006) p. 103; Lawson (2010) p. 234.

38 Joint concurring opinion of Judges Rozakis, Tulkens, Traja, Botoucharova, Zagrebelsky and Garlicki, para. 3.

${ }^{39} \mathrm{Ibid}$., para. 3. This proved to be a controversial aspect of the Povse decision; see further under 5.4.4).
} 
For the Court to leave to the Community's judicial system the task of ensuring "equivalent protection", without retaining a means of verifying on a case-by-case basis that that protection is indeed "equivalent", would be tantamount to consenting tacitly to substitution, in the field of Community law, of Convention standards by a Community standard which might be inspired by Convention standards but whose equivalence with the latter would no longer be subject to authorised scrutiny.

The critique offered in the Rozakis opinion thus boils down to two points: firstly, that the preliminary ruling mechanism cannot offer individual applicants the same degree of protection that recourse to the ECtHR can; ${ }^{40}$ and secondly, that for this reason it needs to be examined in each individual case whether the applicant's rights were adequately protected by the EU system. ${ }^{41}$ Judge Ress, in his opinion, added to this criticism that this examination should not only be conducted on a case-by-case basis, but should also involve an assessment of whether the protection of the fundamental right at issue was substantively equivalent in the concrete case. According to Judge Ress, the Court should not just look at the formal and procedural mechanisms for fundamental rights protection, but should also examine whether the protection of the relevant right was in concreto equivalent. This element is discussed with regard to the Povse decision under Section 5.4.3, below.

Another important unanswered question raised in the Rozakis opinion, but examined in more detail by Judge Ress, is what exactly a "manifest deficiency" in protection would entail. The presumption of Convention compliance may only be rebutted if such a manifest deficiency is found to exist, so it is important to know precisely what this means. Judge Ress, in his concurring opinion, submits that this would occur if: 1) the CJEU had no jurisdiction, as was the case at the time for second- and third-pillar EU law; 2) when the CJEU has been too restrictive in its interpretation of individual access to it; or 3) when there has been an obvious misinterpretation or misapplication by the European Court of Justice of the guarantees of the Convention right. Essentially, a 'manifest deficiency' thus refers to either a lack of jurisdiction of the CJEU, or a wrongful decision of the CJEU; Ress does not discuss whether a manifest deficiency could be found in the relevant secondary legislation, or in the procedural protection available at the national level.

A second problematic aspect of the "manifest deficiency" criterion is whether it would result in a double standard for cases that fall within the remit of EU law. On this the authors of the concurring opinions disagree: the Rozakis opinion states that "the criterion [...] appears to

\footnotetext{
${ }^{40}$ These worries are shared by Peers (2006) p. 454, while Eckes cites a diversity of sources which have expressed their concerns on this point: Eckes (2007) p. 56-57.

${ }^{41}$ See on this ambiguity also Eckes (2007) p. 62-63.
} 
establish a relatively low threshold, which is in marked contrast to the supervision generally carried out under the European Convention on Human Rights". ${ }^{2}$

Finally, the judgment left unanswered when, exactly, a Member State would be found to have done no more than implement obligations emanating from its EU Membership. ${ }^{43}$ When does the Member State have enough discretion for it to be considered responsible under the ECHR? This aspect proved to be problematic in MSS v. Belgium and Greece, which is discussed below. ${ }^{44}$ This case is important not just for this reason, however, but also because it gave rise to the CJEU's judgment in N.S. and M.E. and others. In this judgment the CJEU allowed a Member State to deviate from the obligations imposed on it by mutual recognition. ${ }^{45}$ In the Povse case, the element of discretion did not prove problematic, because the free movement of judgments was absolute for return orders within the remit of the Brussels II bis Regulation; yet this test may yield different results for Regulations that facilitate free movement in different ways. It is therefore important to analyse precisely how much discretion a Member State should have in order to be considered responsible by the ECtHR in order to establish the impact of the Povse decision.

In conclusion, Bosphorus shows that when faced with the question of Member States' responsibilities towards the ECHR when they act under EU law, it will apply a substantively different approach than it did in the Pellegrini case. The lesson from Pellegrini seemed to be that Contracting Parties cannot escape their responsibilities under the ECHR by importing judgments from non-Contracting Parties. As was explained in the previous section, ${ }^{46}$ a dispute remained as to whether this would also apply between Contracting Parties. Bosphorus confirmed by Povse - provides the answer for situations where the states concerned are also EU Member States acting in the implementation of EU law: Pellegrini does not apply to these situations.

According to the Court, therefore, Pellegrini is only considered relevant in situations where Contracting Parties enforce judgments or sentences from outside ECHR territory. When both states concerned are EU Member States enforcing a judgment under an EU Regulation, then the Bosphorus test is used to establish responsibility.

\footnotetext{
${ }^{42}$ Costello also calls the standard required to rebut the presumption "worryingly high" (Costello (2006) p 102) while Eckes suspects that the high threshold is intended to address the Court's workload, and that it does not provide full Convention protection: Eckes (2007) p. 64. See further under 5.4.6.

${ }^{43}$ Peers (2006) p. 452-453.

${ }^{44}$ See under 4.4.5.

${ }^{45}$ The significance of this judgment for cross-border enforcement is examined at length in 6.3.

${ }^{46}$ Chapter 3.2.
} 


\subsection{Applying Bosphorus to free movement of civil judgments: the Povse decision}

The Povse decision ${ }^{47}$ is of great significance, because it affirms that the ECtHR will apply the Bosphorus test also to the context of cross-border enforcement of judgments on the basis of EU Regulations. ${ }^{48}$ The case concerned the application of Article 42 of the Brussels II bis Regulation, which allows judgments ordering the return of an abducted child to be enforced without exequatur and without any grounds for refusal being available. ${ }^{49}$ Before exploring in depth the conditions under which it allows the abolition these safeguards, the facts and procedure are discussed.

\subsubsection{Povse: background to the decision}

\subsubsection{Facts and procedure in the Member States}

The two applicants in this case, Sofia Povse (S.P.) and Doris Povse (D.P.), are daughter and mother, respectively. S.P. was born in Italy in 2006 as the daughter of D.P. and M.A., an Italian national. The family lived together in the city of Vittorio Veneto. The relationship between Doris Povse and M.A. deteriorated and on 4 February 2008, M.A. requested the Venice Youth Court (tribunale per I minorenni di Venezie) to award him sole custody of his daughter. It also appears that the Venice Youth Court issued a travel ban in respect of the child on 8 February 2008. On the same day, however, D.P. took her daughter to Austria, of which Doris Povse is a national, where they took up residence with D.P.'s parents. On 23 May 2008 the Venice Youth Court lifted the travel ban, granted preliminary joint custody to both parents, and authorized the child's residence with her mother in Austria. M.A. was granted access rights in a neutral location twice a month. M.A. exercised his access rights, until, in June 2009, he declared that he would no longer visit his daughter, and indeed did not do so.

From this moment onwards, a legal battle over custody and the return of the child ensued. Doris Povse, now living in Austria with her daughter, obtained an interim injunction against M.A. from the Judenburg District Court (Austria), prohibiting M.A. from contacting her and her daughter. She also obtained a judgment awarding her sole custody from the same court, which based its jurisdiction on Article 15(5) of the Brussels II bis Regulation (8 March 2010).

In the meantime, M.A. had applied to the Venice Youth Court (Italy) for his daughter's return (9 April 2009). In its judgment of 10 July 2009, the court granted this request. On 21 July 2009,

\footnotetext{
${ }^{47}$ ECtHR Povse v. Austria [dec.], appl. no. 3890/11, ECHR 2013; see Cuniberti (2014), Hazelhorst (2014).

${ }^{48}$ In his comment on the Bosphorus judgment, Peers already foresaw the relevance of that judgment to crossborder enforcement: Peers (2006) p. 453.

${ }^{49}$ See Chapter 2.
} 
the Venice Youth Court issued a certificate of enforceability under Article 42 of the Regulation, and on 22 September, M.A. requested the enforcement of the return order. The Leoben District Court (Austria) attempted to refuse enforcement, but this decision was quashed by the Leoben Regional Court, which found that there was no room to refuse enforcement given that the Italian court had declared the order enforceable, and that the Italian court had jurisdiction because Italy was the child's habitual residence immediately prior to her removal. ${ }^{50}$ The matter reached the Austrian Supreme Court, which requested a preliminary ruling from the CJEU.

\subsubsection{The CJEU preliminary ruling}

The Austrian Supreme Court posed five questions to the CJEU. ${ }^{51}$ The first of these questions was whether the Austrian courts could be deemed to have jurisdiction under Article 10(b)(iv) of the Regulation. The second question was whether for a return order to be enforceable, it is necessary under Article 11(8) of the Regulation that the court ordering the return has already decided on custody. Questions four and five ${ }^{52}$ asked whether enforcement can be refused on the basis of either of two grounds: (1) that a subsequent judgment from the Member State of enforcement awarded custody to the abducting parent, (2) there was a change of circumstances after the delivery of the return order, which means that its enforcement would result in a violation of fundamental rights.

Without analyzing in depth the answer to each question, the general line of reasoning of the Court is the same as that in the Zarraga judgment. ${ }^{53}$ The CJEU firmly stated that the Brussels II bis Regulation, and in particular the provisions concerning the enforcement of return orders, are based on the principle of mutual trust of Member States in one another (para. 40), meaning that grounds for refusal should be kept to a minimum. This meant, for the Court, that questions four and five must be answered in the negative. Secondly, the Regulation has introduced a system in which the court of the Member State where the child was habitually resident before its removal (in this case Italy) has jurisdiction, meaning that this court is entitled to hear all appeals and applications pertaining to its return (para. 41). This is the basis for answering questions one and four in the negative and for affirming that jurisdiction lies with the Italian courts. Question two is also answered negatively. Following the reasoning of the CJEU, the Brussels II bis Regulation therefore grants no discretion to Austria in enforcing the Italian court's return order.

\subsubsection{Continuation of the proceedings and application to the ECtHR}

\footnotetext{
${ }^{50}$ On the basis of Art. 10 of the Brussels IIbis Regulation.

${ }^{51}$ CJEU Case C-211/10 PPU Doris Povse v. Mauro Alpago, ECLI:EU:C:2010:400. See section 5.4.

${ }^{52}$ Since question three is not answered by the CJEU, because it is dependent on an affirmative answer to the first two questions, it is not discussed here.

${ }^{53}$ CJEU Case C-491/10 PPU Joseba Andoni Aguirre Zarraga v. Simone Pelz, ECLI:EU:C:2010:828. See 3.5.
} 
On the basis of the preliminary ruling, the Austrian Supreme Court dismissed D.P.'s appeal and preparations were made to enforce the return order.

Next, in a second set of proceedings, on 23 November 2011 the Venice Youth Court awarded M.A. sole custody of his daughter. It withdrew Doris Povse's custody rights as granted in its judgment of 23 May 2008 and ordered her to return the child to Italy.

M.A. notified the Leoben District Court of the Venice Youth Court's judgment and, on 19 March 2012, submitted a certificate of enforceability. Despite D.P.'s appeals - and after a change of address by Doris Povse and Sofia Povse - on 15 June 2012 the Wiener Neustadt District Court ordered Doris Povse to hand over Sofia to her father, stating that enforcement measures would be taken if she failed to comply. It was this final decision of the Wiener Neustadt District Court to enforce the Venice Youth Court's judgment of 23 November, which was the subject of the application to the Human Rights Court.

A final footnote to the story is that at the time the decision was delivered, two sets of criminal proceedings against Doris Povse were pending before the Treviso Court (Italy), one for removing a minor and failing to comply with court orders and one for child abduction. This was used as an argument during the proceedings, as the removal of Sofia to Italy would in effect separate her completely from her mother, since her mother could not visit her in Italy for fear of being arrested.

\subsubsection{The decision of the ECtHR}

The Doris and Sofia Povse attempted to hold Austria accountable before the ECtHR for the enforcement of the contested return order. They complained that the enforcement of the return order would violate their right to respect for their family life as protected by Article 8 of the Convention. In particular, they argued that the Austrian courts had simply ordered the enforcement of the Italian return order without examining their argument that Sofia's return to Italy would constitute a serious threat to her well-being, and would in effect permanently separate mother and daughter. Notwithstanding the reasoning of the CJEU in its preliminary ruling, the applicants stated that the Austrian courts' failure to acknowledge these matters resulted in a violation of Article 8 of the Convention.

In its assessment, the Court first established that there had been an interference with the applicants' right to respect for their family life under Article 8 of the Convention. This was not in dispute (paras. 70-71). The second element of the assessment, whether the infringement was in accordance with the law, was also clear: the decisions of the Austrian court ordering enforcement were in accordance with Article 42 of the Brussels II bis Regulation (para. 72). This in itself constituted the required legitimate aim; ${ }^{54}$ moreover, the enforcement of the return

\footnotetext{
${ }^{54}$ Compliance with EU law by a contracting party constitutes a legitimate general-interest objective; ECtHR Michaud v. France, appl. no. 12323/11, ECHR 2012-VI, para. 100; ECtHR Bosphorus, paras. 150-151.
} 
order also protected the right of the father to have access to his child and is therefore also a legitimate aim as required by paragraph 2 of Article 8 of the Convention (para. 73).

The Court then turned to the question whether the interference was necessary. Given that the respondent government submitted that the Austrian courts had simply fulfilled the obligations flowing from Austria's membership of the EU by applying relevant provisions of the Brussels II bis Regulation as explained by the CJEU, the Court examined this question by applying the Bosphorus test, discussed above.

For the first element, the Court established whether the international organization, the EU, could be said to protect fundamental rights to an adequate degree. This question had already been examined and answered in the affirmative in its previous judgments in Bosphorus and Michaud ${ }^{55}$ so the Court swiftly concluded that the requirement of equivalence was fulfilled (para. 77). The Court also examined whether the EU legislative act in question - the Brussels II bis Regulation - protects fundamental rights. Further on, it also noted that the Regulation requires the court that orders a child's return to hear all parties and to examine the evidence. Perhaps a little confusingly, however, the Court only examined this element in the part of the decision where it looked whether the court of enforcement enjoyed discretion, so that the precise implications of this finding are doubtful (see further under 5.4.3, below).

Next, the Court reiterated the importance of the preliminary ruling mechanism in the EU system of fundamental rights protection, and pointed out that the Austrian Supreme Court had "duly made use of the control mechanism provided for in European Union law" (paras. 80-81). This distinguished the case from Michaud, in which the Court found that the presumption did not apply because no preliminary ruling had been requested and the control mechanism had not been fully brought into play (para. 83).

On the basis of these three determinations, the Court concluded that the presumption of Convention compliance was applicable.

In examining the second element of the Bosphorus test, the Court concluded from a brief examination of the rules on the enforcement of return decisions laid down by the Brussels II bis Regulation that the Austrian courts had no discretion in ordering the enforcement. It deferred to the CJEU's preliminary ruling for affirmation of this finding (para. 81), and found that the second condition of the Bosphorus test was fulfilled (para. 82).

Having concluded that a presumption of compliance applied, the Court turned to the third element of the Bosphorus test to ask whether there were circumstances that could rebut the presumption. The applicants argued that they had been deprived of the protection of their Convention rights because the CJEU did not examine the alleged violation of those rights. The Court rejected this argument (para. 84). It reiterated the principle, expressed by the CJEU in its

\footnotetext{
${ }^{55}$ ECtHR Michaud, paras. 102-104.
} 
preliminary ruling, that the Brussels II bis Regulation has introduced a strict division of tasks between the courts of the Member State of origin and those of the court of enforcement. Any objections to the judgment in question should be brought before the court of origin, in this case the Venice Youth Court, which would be accountable to the ECtHR. ${ }^{56}$ Given that the applicants did not appeal against the return order before this court, but argued their case instead before the Austrian courts, the Court decided that there had been no dysfunction in this control mechanism. In essence, the ECtHR applied the "local remedy rule", which provides that refusal of enforcement is only an option when the perceived injustice can no longer be remedied in the state of origin. ${ }^{57}$ This also means that the CJEU was only called upon to rule on the interpretation of the Brussels II bis Convention and that there was no basis for it to examine the Austrian courts' decision and whether or not it infringed the applicant's Convention rights.

In the end, the ECtHR concluded that the mechanism for the protection of Convention rights had not failed. Austria, which did no more than to fulfil its obligations under Brussels II bis, could therefore be presumed to have acted in accordance with the Convention. As such, the Court ruled, the application was manifestly ill-founded and had to be rejected.

\subsubsection{General comments}

The importance of the Povse decision for the compatibility of free movement of civil judgments with the ECHR should not be underestimated. Though there are some reservations concerning its impact, it is nevertheless significant simply for the fact that it affirmed that the ECtHR will apply the Bosphorus doctrine to the context of cross-border cooperation in civil justice cases under EU law.

Before it is examined what lessons can be derived from Povse, some preliminary remarks should be made. Firstly, and importantly, Povse is a decision on admissibility, which by necessity carries less weight than a judgment on the merits, especially a Grand Chamber judgment. On the other hand, there is no clear distinction between cases that are found to be manifestly ill-founded at the admissibility stage, and those which are considered on the merits but where no violation is found. The Court admits as much in its own Guide on Admissibility: "the reasons given for the inadmissibility decision in such a case will be identical or similar to those which the Court would adopt in a judgment on the merits concluding that there had been no violation". ${ }^{58}$ It cannot therefore be concluded that a decision on admissibility in which an application is found to be manifestly ill-founded is of less value than a judgment on the merits.

\footnotetext{
${ }^{56}$ Reiterating its judgment in ECtHR Šneersone and Kampanella v. Italy, appl. no. 14737/09, 12 July 2011.

57 This argument is referred to as the "local remedy rule": see Kiestra (2014) p. 301. See ECtHR Lindberg: the refusal of recognition may not be used as an alternative for remedy in the country of origin. See under 5.2.1.

${ }^{58}$ European Court of Human Rights, Practical Guide on Admissibility Criteria, 2011, (available at http://www.echr.coe.int) para. 370; see Gerards (2014) p. 8.
} 
Also, the Povse decision was taken by a chamber of 7 judges, rather than a committee of three judges or a single judge, indicating its significance. At the same time, for the individual applicant, the difference between an admissibility decision and a judgment is significant, because after a decision, no referral to the Grand Chamber is available. ${ }^{59}$ The Court, being aware of this procedural constraint, must therefore be convinced that the application has no chance of succeeding in order for it to dismiss it on grounds of admissibility. This may be a signal that the Court considers the Bosphorus line of case law by now so well-established that cases which satisfy the Bosphorus test can now be declared inadmissible at an early stage ${ }^{60}$ though it is of course impossible to know exactly why the Court chose to dismiss the case on grounds of admissibility, instead of on the merits, in this particular case.

A remarkable, and potentially problematic, aspect of Povse is that it applies the Bosphorus doctrine to the context of cross-border cooperation under EU law. Whereas Bosphorus concerned the straightforward situation of a Member State implementing EU law, another layer of complexity is added in these cross-border situations. In these cases the obligation imposed on Member States is not simply to apply EU law, but to recognize, on the basis of EU law, a decision from another Member State. By applying the Bosphorus test to this type of case, the ECtHR recognizes that cooperation on the basis of mutual recognition is an essential component of the EU legal order, and accepts that it imposes nondiscretionary obligations on the Member States. In fact, a precedent was already set in M.S.S. v. Belgium and Greece (discussed below), though in that case the presumption of Convention compliance was found not to apply because the Member State in question enjoyed discretionary powers. ${ }^{61}$ Both M.S.S. and Povse make no mention of any doubts as to the applicability of Bosphorus to these situations, so it appears that the ECtHR considers this matter uncontroversial.

The application of the Bosphorus test to 'indirect' situations (where Member States cooperate with each other on the basis of EU law) as opposed to 'direct' situations (where Member States simply act in the implementation of EU law) does however raise some difficult questions.

Firstly, as will be discussed in more detail further on, the Court has applied the requirement that a preliminary ruling be requested in a confusing, perhaps even inconsistent manner, when compared to Bosphorus and the later ruling in Michaud. This inconsistency arguably gives rise to a hierarchy between direct and indirect violations (see Section 5.4.4, below).

Secondly, there is the question what circumstances would give rise to a 'manifest deficiency' in the cross-border context. ${ }^{62}$ The Court's analysis seems to imply that a deficiency in the available procedural remedies in the state of origin - Italy - could also be seen as a manifest deficiency. However, the explanation of this concept offered by Judge Ress in his concurring opinion to Bosphorus, and the Bosphorus judgment itself, do not support this. Rather, the

\footnotetext{
${ }^{59}$ Article 43(1) ECHR.

60 This conclusion is also supported by the Court's decision on admissibility in Biret, which was also declared inadmissible after a very brief consideration of the Bosphorus test. ECtHR La Société Établissements Biret et Cie S.A. et la Société Biret International c. 15 Etats [dec.], appl. no. 13762/04.

${ }^{61}$ ECtHR, Case of M.S.S. v. Belgium and Greece, appl. no. 30696/09, ECHR 2011-I.

62 The broader problem of the definition of "manifest deficiency" is explored in Chapter 5.4.6.
} 
concept of 'manifest deficiency' seems to apply to a deficiency in the EU system itself, such as the unavailability of a preliminary ruling. On the other hand, it is difficult to see how the procedural protection available in the state of origin could not be considered part of the EU system for fundamental rights protection. The Brussels II bis Regulation has devised a system whereby jurisdiction over the return of a child lies exclusively with the court of the state in which the child was habitually resident. It is therefore this court that is entitled to hear all appeals and applications pertaining to the child's return. Under this system, procedural protection is thus concentrated with the court of origin. This system was affirmed in the CJEU's preliminary rulings in Povse, Rinau, and Zarraga, and the ECtHR clearly sanctions it in its Povse decision. It points towards the wording of Article 42 of Brussels II bis, and to the CJEU's ruling, for confirmation. Moreover, the ECtHR considers that this system was not manifestly deficient because there was procedural protection available in Italy in the present case. This cannot lead to a different conclusion than that the procedural remedies available in Italy are part of the EU system for the protection of fundamental rights. If so, logically, if in Povse a serious deficiency in Italy's judicial system was found, this would have led to the conclusion that the EU system for the protection of fundamental rights protection was manifestly deficient, which would cause the presumption of Convention compliance to be rebutted. If this had happened, Austria could have been held accountable for a deficiency in Italy's judicial system.

This shows the problem with applying the Bosphorus doctrine to the cross-border situation. In Bosphorus the situation was quite clear: the state applying EU law was also responsible for providing procedural protection against that application of EU law through its own courts with the assistance of the CJEU if necessary. In cross-border cases, the enforcing state essentially has to rely on the procedural protection granted in the state of origin; its own courts cannot provide protection because it has no jurisdiction in the matter. Essentially, the elements of the Bosphorus test, which are intended to apply to one individual state, are in the context of the complete free movement of judgments divided across two Member States: the member state of origin provides procedural protection (fulfilling the 'equivalence' requirement), while the member state of enforcement fulfils the requirement of non-discretion.

A strict application of Bosphorus could lead to the enforcing state being held responsible for violations committed by the state of origin, even though the state of enforcement has no say in the matter whatsoever. The ECtHR clearly wanted to avoid this conclusion.

This might explain the somewhat twisted logic the ECtHR applies in the decision when it comes to Austria's duty to request a preliminary ruling. The Court appears less strict on this point than it was in previous case law. As is explained in Section 5.4.4 below, the only explanation for this inconsistency is that it wanted to avoid giving any indication that the enforcing state could be held accountable. It also explains the confusing manner in which the Court addresses the existence of minimum requirements for certification in Article 42 of Brussels II bis in paragraph 80 of its decision. This element of protection is discussed at the 'discretion' stage of the Bosphorus test, even though, strictly speaking, these minimum requirements have no bearing on the discretion left to the enforcing court.

It is therefore submitted that the ECtHR's Povse decision is best understood as an expression of both the presumption of ECHR compliance offered by the Bosphorus doctrine, as well as 
the "local remedy rule" which is found in the ECHR itself, ${ }^{63}$ but also in international law. ${ }^{64}$ In fact, although the ECtHR does not cite it in Povse, the ECtHR itself had already applied this local remedy rule in its decision in Lindberg v. Sweden. ${ }^{65}$

This segment of the ECtHR's reasoning provides a much more satisfying explanation for the Court's approach in Povse. It is not only the nature of the law that is applied by the Austrian court (being EU law) that exonerates it under the ECHR, but also the fact that remedies were available in the state of origin. If these were not sufficient, the applicants would have been able to file an application against Italy. The ECtHR has shown in Šneersone and Kampanella v. Italy that it will indeed hold the state of origin accountable for a violation resulting from a wrongfully granted return order. ${ }^{66}$

The overarching conclusion of all this must be that, whatever its underlying motivations, the ECtHR in Povse clearly wanted to avoid the possibility that the enforcing state could be held accountable for enforcing judgments in a situation where it had no discretion, i.e., where the exequatur and refusal grounds have been abolished. Though there are some conditions, the following discussion of various elements of the Court's analysis shows that these in fact do not seem likely to become a problem in the future. It can therefore be stated that the ECtHR has sanctioned the automatic enforcement of access and return orders as it was accomplished in Brussels II bis.

To understand the impact of Povse, its outcome should be contrasted with the ECtHR's case law on the enforcement of child return orders that are not based on the Brussels II bis Regulation, but on the 1980 Convention on the Civil Aspects of International Child Abduction (the 1980 Convention). ${ }^{67}$ This Convention, which in the European Union applies alongside the Brussels II bis Regulation, also contains a mechanism for the cross-border enforcement of return orders. However, contrary to the Brussels II bis Regulation, it allows for refusal of enforcement if return of the child would constitute a grave risk to his or her physical or psychological health and safety (Article 13). The ECtHR requires courts that are to decide on the enforceability of the return order to exercise the discretion granted by this provision in accordance with their obligations under Article 8 ECHR. To fulfil these obligations, courts are required to "genuinely take into account $[. .$.$] the factors capable of constituting an exception$ to the child's immediate return" 68 and to "take a decision that is sufficiently reasoned on this point, in order to enable the [ECtHR] to verify that those questions have been effectively examined" 69 . In other words, where courts have the possibility to refuse enforcement of a return order, a failure to carefully consider whether there are reasons for doing so may result in a violation of Article 8 ECHR. The fact that courts operating on the basis of Article 42(1) of the

\footnotetext{
${ }^{63}$ Art. 35(1) ECHR. See Kiestra (2014) p. 301.

${ }^{64}$ See Amerasinghe (2004); Kiestra (2014) p. 301.

${ }^{65}$ ECtHR Lindberg v. Sweden; see the discussion under 5.2.1.

${ }^{66}$ ECtHR Šneersone and Kampanella v. Italy.

${ }^{67}$ See in more detail under 8.6.1.1.

${ }^{68}$ ECtHR X. v. Latvia para. 106. See Beaumont, Trimmings et al. (2015) p. 43.

${ }^{69}$ Ibid.
} 
Brussels II bis Regulation are not at risk of violating the ECHR when they apply this provision shows that EU law is clearly treated differently in this regard. In the context of the 1980 Convention, the ECtHR requires courts to abide by the ECHR when they apply its provisions; for the EU instrument, they are under no such obligation.

\subsubsection{The presumption of equivalent protection: abstract or concrete?}

It was already noted above that the ECtHR paid attention to the fundamental rights protection offered by Regulation 2201/2003 in its Povse decision. It may be recalled that the Bosphorus judgment was criticized for looking at the EU mechanism for fundamental rights protection in a very general manner. The ECtHR did not examine the EC Regulation that was at issue to see whether it materially offered the same protection as the ECHR would have done. Instead, it looked only at the more general ways in which the EU has affirmed its adherence to fundamental rights, and to the procedural framework available (the national courts, supplemented by the preliminary ruling mechanism). In Povse, the ECtHR also paid attention to the Regulation at issue, implying a more concrete appraisal; but it did in a slightly confusing manner.

The ECtHR started with the general assessment of the EU system for fundamental rights protection that it first gave in Bosphorus. In Povse, it sufficed with literally citing the summary it gave of the relevant case law in its judgment in Michaud, without adding to it. It stated that "[the Court] has already found that the protection of fundamental rights afforded by the European Union is in principle equivalent to that of the Convention system as regards both the substantive guarantees offered and the mechanisms controlling their observance". So far the reasoning is therefore equally abstract as it was in the earlier case law.

Next, the Court analysed whether Austria had any discretion in the application of EU law. It first established that the wording of Article 42 Brussels II bis leaves no room for discretion by the enforcing court. Next, however, the Court stated the following:

In this connection, the Court notes that under Article 42(2) of the Brussels [II bis] Regulation, the court ordering a child's return under Article 11(8) of the Regulation shall issue a certificate of enforceability only if the parties have been heard, as well as the child - if appropriate in view of its age and maturity - and if the reasons for and the evidence underlying a previous refusal of return under Article 13 of the Hague Convention have been taken into account. In other words, in a context like the present one, the court ordering the return has to have made an assessment of the question whether the return will entail a grave risk for the child (para. 80).

The words "in this connection" seem to imply that the finding that the Regulation contains requirements that are to be checked in the Member State of origin is somehow connected with the matter of discretion of the court of enforcement. But the ECtHR had already concluded this simply by looking at the wording of Article 42(1). Moreover, it is unclear why the Court needs to look at the obligations imposed on the court of origin in order to draw conclusions as to the discretion left to the court of enforcement - unless it is to show that there was no need for any 
discretion to refuse enforcement, because the court of origin had already performed the control that the Austrian courts wished to exert.

If this is conclusion is correct, then it shows that the Court does indeed pay attention to the fundamental rights protection incorporated into the Regulation at issue, albeit in a roundabout way - not at the 'equivalence' stage of the Bosphorus test, but at the 'discretion' stage. ${ }^{70}$ It should be mentioned that the Court follows this paragraph with the statement that the Austrian courts "duly made use" of the preliminary ruling mechanism. Though this is then used to affirm that Austria had no discretion (because this was the conclusion of the preliminary ruling), the message of these paragraphs is clearly that there was nothing wrong with the fundamental rights protection offered by the EU system in this particular case. Austria could indeed not refuse enforcement on the basis that the applicants' right to respect for their family life would be harmed, but there are other safeguards in the Regulation that prevent that from happening; moreover, the Austrian courts requested a preliminary ruling and therefore did everything in their power. Together, these circumstances allow the presumption of Convention compliance to apply.

Without trying to read too much into it, it appears that the Court gave weight to the existence of procedural safeguards (minimum requirements) in the Brussels II bis Regulation. It may be recalled that the added value and practical importance of minimum requirements was doubted in legal literature. ${ }^{71}$ The fact that the Court nevertheless looks positively at the existence of minimum requirements is a sign that they are valuable after all; they are a signal that fundamental rights protection has been adequately taken care of in the relevant piece of legislation.

It cannot however be concluded that the abstract analysis of the EU's protection mechanism has been replaced with a more concrete one. The Court is careful not to examine the safeguards of the Regulation at the stage where it establishes the equivalence of the EU's protection mechanism, but at the second stage, which concerns the discretion left to the Member State. Even though this looks confusing, the reason might be that the Court did not want to disregard the legislative efforts made to safeguard fundamental rights in the absence of refusal grounds, but also did not want to give the signal that it now required additional evidence to consider the protection offered by the EU as equivalent to the Convention. This would constitute a break with all the Court's earlier case law, which it was careful to cite nearly word for word (paras. 76-77). Also, it has already been concluded under Section 5.4.2 that the Court wanted to avoid giving any indication of criticizing the free movement of judgments achieved by the Brussels II bis Regulation.

For the purposes of legislation, the conclusion must therefore be that minimum requirements are certainly seen as having added value for the protection of fundamental rights. They are not

\footnotetext{
70 This in itself could also be seen as a sign that the ECtHR does not want to question the "equivalence" of the protection provided by the system introduced by Brussels IIbis; see under 5.4.2.

${ }^{71}$ See 3.4.2 above.
} 
necessary to fulfil the condition of equivalence, but the Court does see them as a signal that in the absence of cross-border control fundamental rights are nevertheless adequately protected.

It must be noted however that the Court makes no mention of the fact that the minimum requirements of Article 42(2) cannot be invoked by any of the parties which the article is intended to protect. While it seems possible to conclude that the Court does not consider this a problem, it must be remembered that Article 42(2) was not examined in detail in this decision, because the obligations of the court which declared the return order in the Member State of origin were not at issue. Rather, Article 42(2) was used as an additional argument in favour of the finding that the absence of discretion on the part of the enforcing court was not problematic. Perhaps not too much should be read into the fact that the Court refrained from commenting on this aspect.

\subsubsection{Equivalent protection: the importance of the preliminary ruling mechanism}

In Povse, the Court continued with the line of reasoning it established in Bosphorus that the procedural protection of fundamental rights within the EU is offered primarily through the Member States' courts, complemented by the preliminary ruling mechanism. The ECtHR has consistently emphasized that it considers the preliminary ruling an essential component of the control mechanism provided for in EU law. Indeed it found in Michaud that if a national court refrained from requesting a preliminary ruling, this would mean that the protection offered by EU law could not be considered equivalent to that of the Convention. However, when the various judgments are examined in turn, the Court's inconsistency in the standards it applies is shown.

Starting with Bosphorus, it was already stated that in this case the Court considered it sufficient that the Irish Supreme Court requested a preliminary ruling, though the CJEU did not apply ECHR case law in its examination, but only its own case law on the right to free enjoyment of property. ${ }^{72}$ Nevertheless, it is clear that the CJEU considered in some detail the question whether the impoundment of the aircraft constituted an infringement of Bosphorus' right to free enjoyment of property, in the light of the specific circumstances of the case.

A subsequent decision of the ECtHR implied that a preliminary ruling is not always necessary. In Cooperative des Agriculteurs de Mayenne v. France ${ }^{73}$ the Court found that there was no deficiency in the EU mechanism for the protection of fundamental rights, even though no preliminary ruling had been requested. As the Court remained entirely silent on the matter in its decision, there is no way of knowing why the Court did not consider a preliminary ruling

\footnotetext{
${ }^{72}$ ECtHR Bosphorus para. 21.

${ }^{73}$ ECtHR, Cooperative des Agriculteurs de Mayenne et la Cooperative Laitière Maine-Anjou v. France [dec.], no. 16931/04, ECHR 2006-XV.
} 
necessary in this case. However, the Court repeatedly referred to a decision of the (now abolished) European Commission on Human Rights in Procola v. Luxembourg, ${ }^{74}$ in which the matter at hand - the compatibility of a levy for exceeding milk quotas with the right to free enjoyment of property - had already been examined. The Court stated that in Mayenne that "the Convention institutions have already had occasion to stress the public interest of curbing milk production," describing the policy to that effect as "in the public interest, given that it is aimed at stabilising the market". ${ }^{75}$ This reasoning implies that a preliminary ruling may not be necessary when the fundamental rights concern at issue was already dealt with in earlier case law; in other words, the simple absence of a preliminary ruling is not enough to conclude that the protection offered by the EU was deficient. This makes sense, given that the ECtHR stressed that, within the EU system, protection is primarily offered through the national courts, while the CJEU has a complementary role. ${ }^{76}$ To declare that the protection offered was inadequate simply because of the lack of reference alone would be overly formalistic and disregard whether the Convention rights at issue were substantively respected.

In Michaud ${ }^{77}$ the ECtHR did find that the presumption of Convention compliance did not apply because the national court had failed to request a preliminary ruling, and it showed itself to be quite stringent. Michaud concerned the application by France of two EU Directives aimed at preventing the use of the financial system for money laundering. The French National Bar Council adopted a number of regulations designed to implement these Directives, which included among other things a duty to report suspicious activity. A Parisian lawyer applied to the Conseil d'Etat to have these regulations set aside. He argued that the obligation to report suspicions was incompatible with Article 8 of the ECHR as it jeopardized legal professional privilege and attorney-client confidentiality. He also asked that the Conseil d'Etat request a preliminary ruling from the CJEU on the question whether the "declaration of suspicion of criminal offence" was in conformity with Article 6 TEU and Article 8 of the ECHR. The Conseil d'Etat however refused to refer the matter to the CJEU.

The Belgian Constitutional Court did, however, refer a question to the CJEU. This question concerned the conformity of the obligation to report suspicious activity with Article 6 ECHR (the right to a fair trial), since clients would no longer be able to rely on attorney-client confidentiality. The CJEU ruled that this obligation did not jeopardize the right to a fair trial of the clients, since the obligation to report suspicions only applied only where lawyers were helping their clients to carry out certain financial or real estate transactions, not in contexts relating to any judicial proceedings. ${ }^{78}$

In Michaud, the respondent government, France, then argued that it had acted in the application of EU law and that the presumption of Convention compliance was applicable. According to

\footnotetext{
${ }^{74}$ European Commission on Human Rights, Procola v. Luxembourg [dec.], no. 14570/89.

${ }^{75}$ ECtHR, Cooperative des Agriculteurs de Mayenne et la Cooperative Laitière Maine-Anjou v. France [dec.].

${ }^{76}$ See Lock (2010a) p. 540.

${ }^{77}$ ECtHR Michaud v. France.

${ }^{78}$ CJEU C-305/05 Ordre des barreaux francophones et germanophone and Others $v$. Conseil des Ministres, ECLI:EU:C:2007:383.
} 
France the ECtHR had given the EU human rights protection system "a certificate of conventionality" in terms of both its substantive as its procedural guarantees (para. 73), so that there was no deficiency in the protection system. It also held that Advocate General Poiares Maduro had in his conclusions in Ordre des barreaux francophone et Germanophone and Others v. Conseil des Ministres concluded that the Directives respected client confidentiality not just in respect of Article 6 but also of Article 8 .

The ECtHR however ruled that the French Conseil d'Etat should nevertheless have requested a preliminary ruling on the matter of the compatibility of the reporting obligations with Article 8 ECHR. It stated that the fact that a preliminary ruling of the CJEU already existed was not sufficient because this concerned a different question:

The Court observes that in its judgment in the case of Ordre des barreaux francophone et Germanophone and Others [...] the Court of Justice examined the compatibility of the obligation for lawyers to report suspicions only in respect of the requirements of the right to a fair trial within the meaning of Article 6 of the Convention. In so doing, it ruled solely on the rights of the lawyer's client. The question is different, however, when approached from the angle of Article 8 of the Convention: here the issue is not just the rights of the lawyer's client under this provision, but also the rights of the lawyer himself [...] (para. 114).

The ECtHR therefore found that the question of the compatibility of the obligation to report with Article 8 ECHR should have been referred to the CJEU by the Conseil d'Etat, because it concerned a matter that had not been addressed by the CJEU. Because the Conseil d'Etat did not do so, it had ruled: "without the full potential of the relevant international machinery for supervising fundamental rights - in principle equivalent to that of the Convention - having been deployed. In the light of that choice and the importance of what is at stake, the presumption of equivalent protection does not apply" (para. 115).

From these three judgments, Bosphorus, Mayenne, and Michaud, the following rule can be derived. The preliminary ruling mechanism forms an essential, ${ }^{79}$ yet complementary, element of the EU mechanism for the protection of fundamental rights; the primary control is exercised by the national courts. This means that if a national court did not request a preliminary ruling, even though this was necessary, this will mean that the presumption that the EU system provided equivalent protection was not applicable (Michaud). A preliminary ruling may not be necessary when the matter has already been dealt with in an earlier ECtHR (or European

\footnotetext{
${ }^{79}$ Apart from the case law cited here, there are numerous other judgments in which the ECtHR affirmed importance of the the preliminary ruling mechanism. In Pafitis, it ruled that a delay resulting from a request for a preliminary ruling could not result in a violation of the reasonable time requirement of Article 6(1) ECHR: ECtHR Pafitis and Others v. Greece, appl. no. 20323/93, ECHR 1998-I, para. 95. Recently the Court ruled that a failure to motivate why no preliminary ruling had been requested could in itself constitute a violation of article 6(1): ECtHR Dhahbi v. Italy, appl. no. 17120/09, para. 33. See on the obligation to refer preliminary questions also ECtHR Vergauwen and others v. Belgium, appl. no. 4832/04, 4 April 2012.
} 
Commission on Human Rights) decision or judgment (Mayenne), but this ruling needs to concern the same Convention right that is at issue (Michaud). Finally, the preliminary ruling is also used as evidence as to whether any discretion is left to the Member State (Bosphorus). ${ }^{80}$

The Court's decision in Povse however does not appear to be consistent with these rules. The Court begins its examination by distinguishing Povse from Michaud: the difference, it states, is that in Michaud the control mechanism had not been fully brought into play, because in that case the Conseil d'Etat had refused to request a preliminary ruling (para. 83). This had caused the presumption of equivalent protection to be rebutted. ${ }^{81}$ The Court then goes on to examine whether the presumption of Convention compliance could also be rebutted in Povse.

In this regard, the applicants claimed - citing Bosphorus - that the presumption had been rebutted because the preliminary ruling of the CJEU in their case did not deal with the alleged violation of their Convention rights. On the basis of the ECtHR's ruling in Michaud, it would be expected that this would indeed constitute a ground to consider the presumption rebutted (or inapplicable). However, the ECtHR states that the Brussels II bis Regulation, in contrast to the Regulation at issue in Bosphorus, does not constitute a direct basis for the alleged violation; rather, the Court seems to be saying, if the Brussels II bis Regulation gave rise to a violation, this would be the responsibility of the state of origin (Italy), because its courts had jurisdiction under the Brussels II bis Regulation. According to the ECtHR:

The CJEU was called upon to interpret the Brussels [II bis] Regulation and to clarify the scope of jurisdiction of the Italian courts on the one hand and the Austrian courts on the other. It follows that the present case differs from the Bosphorus case in that the CJEU was not required to rule on the alleged violation of the applicant's fundamental rights. $^{82}$

It is difficult to interpret what exactly the reason is for the difference between the Court's findings in Michaud and Povse. Two alternative, or perhaps cumulative, explanations can be derived from the text of the Povse decision. The first is that it appears that the Court considers the "indirect" nature of the alleged violation in Povse to be of importance. ${ }^{83}$ The line of reasoning is that the Brussels II bis Regulation gave the Italian courts exclusive jurisdiction. That means that if Brussels II bis resulted in a violation, it would be Italy that would need to answer for it, either before the CJEU or before the ECtHR. Therefore, it does not matter that the CJEU's preliminary ruling did not concern the alleged fundamental rights violation at issue, because Austria would not have been responsible anyway. The problems with this reasoning could be, firstly, that this distinction between direct and indirect violations was entirely unforeseeable from earlier case law. Moreover, this reasoning seems to disregard the lessons of Michaud and Mayenne about the purpose of preliminary rulings: they should not be

\footnotetext{
${ }^{80}$ See Costello (2006) p. 110.

${ }^{81}$ Though, confusingly, in the Michaud judgment itself it stated that the presumption had been found not to apply - which is different from saying it did apply but was rebutted, because this would imply a manifest deficiency. See ECtHR Michaud, para. 115.

${ }^{82}$ ECtHR Povse, para. 85.

${ }^{83}$ Cuniberti (2014) para. 23.
} 
requested simply to satisfy a procedural requirement, but to clarify an important legal question. It would certainly have been worthwhile to hear the CJEU's views on the compatibility of the abolition of refusal grounds with the Convention, regardless of whether Austria would then be held responsible. Perhaps, though it is nowhere explicitly mentioned, the fact that the CJEU had delivered a preliminary ruling in Zarraga in which it explicitly excluded all possibilities of discretion for the enforcing court played a role here. The ECtHR may have felt that to impose on national courts the obligation to refer for a preliminary ruling in matters which had already been clarified by the CJEU would not be opportune. If so, it would have been preferable if the Court had made this explicit. ${ }^{84}$

Finally, if it is accepted that Austria did not need to request a preliminary ruling at all, it is a mystery why the Court on numerous occasions affirms that Austria "duly" made use of the control mechanism, which seems to imply an obligation ("duly" is synonymous with "rightly" or "properly").

A second possible reading of the Court's reasoning is the following: the Court states that the difference with Bosphorus is that that case concerned a regulation which provided a "direct basis" for the impoundment of the aircraft (and therefore for the violation), whereas the Brussels II bis Regulation needed to be interpreted. The Court states that in Povse the CJEU was "called upon" only to interpret the Regulation, so that "it follows [...] that the CJEU was not required to rule on the alleged violation of the applicant's fundamental rights." Taken literally, this seems to imply that the CJEU did not have to rule on the alleged violations simply because it was not asked to do so. In Bosphorus, the question of conformity with the ECHR could be asked directly because there was no disagreement over the matter of responsibility; in Povse, this matter was not clear, so it is logical that the referring court would ask for an interpretation rather than a direct assessment of the compatibility with the ECHR.

If this interpretation of the ECtHR's reasoning is correct, then the ECtHR has offered a very formalistic and potentially dangerous reformulation of the rules as explained above. It implies that the CJEU is only required to rule on compatibility of rules of EU law with the Convention if the referring court explicitly asks for it. The argument that the Austrian court was not required to ask about ECHR compatibility because the Regulation first required clarification is not convincing, as referring courts frequently ask multiple, sometimes cumulative, preliminary questions: the reference from the Austrian Supreme Court in Povse is itself an example. If the ECtHR indeed tries to say that it is no problem that the CJEU did not rule on the compatibility question because it was not asked to, then this is a dangerous precedent. It would mean that referring courts could easily dodge the question of whether they acted in conformity with the Convention and still be granted immunity under the Bosphorus test simply by requesting a preliminary ruling on the interpretation of the piece of legislation at issue while avoiding the question of ECHR compatibility. Because this conclusion is at odds with the holdings of both

${ }^{84}$ Cuniberti (2014) para. 47. 
Michaud and Mayenne, it is assumed that this is simply an unfortunate formulation on the ECtHR's part.

Povse thus leaves us with uncertainty as to the circumstances in which a national court is required to ask preliminary questions in order to satisfy the requirements of the Bosphorus test. In general, the rules enumerated above appear to apply, with one of two possible exceptions: (1) the national court does not need to make a reference if it is not directly responsible, or (2) it does not need to make a reference if the issue has been dealt with in previous CJEU case law. Both exceptions, however, are only implicit in the Povse decision. It could even be derived from Povse that national courts have a duty to refer, but that it does not matter whether their questions concerned the alleged violations. All in all, Povse has done little to clarify the obligations imposed on national courts. It seems that a request for a preliminary ruling is still an attractive option, even if it is not technically required. ${ }^{85}$

If none of the conclusions offered above appear very satisfying, a simpler one is available: the ECtHR was simply reluctant to find fault with the system of the Brussels II bis Regulation and the free movement of judgments. If it had been very stringent in its assessment of the preliminary ruling requested by Austria, it would have had to conclude that the presumption of Convention compliance did not apply, and that Austria could, theoretically, be held accountable if a violation was found. To avoid this, the ECtHR was forced to conclude, even in a manner inconsistent with its own earlier case law, that the Austrian courts satisfied the preliminary ruling requirement. Once again, the conclusion drawn in Section 5.4.2 that the ECtHR clearly wanted to sanction the free movement of judgments as achieved under Brussels II bis is reaffirmed.

\subsubsection{The matter of discretion and the applicability of Povse to Regulations which contain grounds for refusal}

It has been shown extensively that the presumption of Convention compliance that allows a state to avoid accountability under the ECHR only applies when that State had no discretion in the implementation of the relevant piece of EU legislation. Former President of the ECtHR Luzius Wildhaber clarified this in a speech given shortly after Bosphorus was delivered. According to him the 'equivalent protection' doctrine only applies if the State "does no more than implement legal obligations flowing from its membership of the organisation. [The State] would be fully responsible under the Convention for all acts falling outside its strict international legal obligations." 86

\footnotetext{
${ }^{85}$ Costello (2006) p. 120.

${ }^{86}$ Wildhaber, "The Coordination of the Protection of Fundamental Rights in Europe", Address by the President of the European Court of Human Rights, Geneva, 8 September 2005; cited by Costello (2006) p. 100.
} 
That the presumption of Convention compliance only applies in cases where the state in question had no choice in the way it fulfilled its obligations is clear from the case law. In Bosphorus, the ECtHR thoroughly investigated the relevant legislation ${ }^{87}$ to reach the conclusion that the Irish authorities had not exercised discretion. ${ }^{88}$ The subsequent case law presents a mixed picture on this point: sometimes the Court looks at the relevant legislation to reach its conclusion, ${ }^{89}$ sometimes it does not mention the question of discretion at all. ${ }^{90}$

In Povse, the ECtHR needed few words to conclude that Article 42 of the Brussels II bis Regulation left no discretion to the Member State where enforcement is sought (para. 79). It also referred to the CJEU's preliminary ruling which affirmed that the courts of the requested state could not review the merits of the return order, nor refuse enforcement on the ground that the return would entail a grave risk for the child (para. 81). This does not seem controversial: the CJEU had indeed already affirmed that Brussels II bis left no room for refusal of enforcement on any grounds, as the recognition and enforcement of return orders under this Regulation is based on the principle of mutual trust, which means that refusal grounds should be kept "to a minimum". ${ }^{91}$ This is also the central argument of the CJEU's ruling in Zarraga. ${ }^{92}$ The ECtHR's conclusion that Austria had no discretion is therefore correct.

The lesson for the larger context of the abolition of exequatur and refusal grounds is therefore that Member States that are required to enforce a judgment under an EU Regulation which allows complete free movement will not be held accountable by the ECtHR for the consequences of that enforcement, provided that they indeed had no discretion in this regard. This is an important conclusion, because it means that instruments such as the Brussels I bis Regulation, which still contains grounds for refusal, will not benefit from this exception. To illustrate this point, it is worth looking at the ECtHR's judgment in M.S.S. v. Belgium and Greece, in which the Court found that the presumption of Convention compliance did not apply because the state in question, Belgium, would have been able to refuse to carry out its obligation on the basis of the so-called "sovereignty clause".

M.S.S. v. Belgium and Greece is a case about the Common European Asylum System, which like the free movement of civil judgments is an outcome of the 1999 European Council meeting in Tampere. ${ }^{93}$ As such, it is also based on the principles of mutual trust and the presumption of compliance of all Member States with fundamental rights. The asylum system is based on the rule that asylum seekers can submit an asylum application in only one of the European Member States; which Member State is responsible for examining their request is determined according

${ }^{87}$ ECtHR Bosphorus, para. 143-148.

${ }^{88}$ Ibid., para. 148.

${ }^{89}$ ECtHR Mayenne.

${ }^{90}$ ECtHR Biret; Lock (2010a) p. 544.

${ }^{91}$ CJEU Povse para. 40.

${ }^{92}$ CJEU Zarraga, para. 46.

${ }^{93}$ ECtHR MSS v Belgium and Greece, appl. no. 30696/09 ECHR 2011-I; see Bossuyt (2011) Clayton (2011). 
to criteria laid down in the Dublin II Regulation (Arts. 5-14). ${ }^{94}$ The Regulation also states that when an asylum seeker lodges an application in a Member State that is not responsible for examining it under the Regulation, this Member State is required to transfer the person back to the Member State that is responsible (Art. 17). The latter State would then be required to take the asylum seeker back. There is however one exception, the so-called "sovereignty clause" of Article 3(2), which gives Member States the possibility of accepting responsibility for applications for which they are not responsible under the Regulation.

Mr M.S.S., the applicant in this case, had fled Afghanistan, and finally arrived in Belgium, where he applied for asylum. However, it transpired that he had first entered the EU in Greece and had been registered there. Belgium was therefore obliged under the Dublin II Regulation to transfer him back to Greece. M.S.S. appealed against the decision that ordered his transfer on the grounds that in Greece he would likely be detained under terrible conditions, facing ill treatment. This appeal was denied, and M.S.S. brought an application against Belgium, alleging that with his expulsion Belgium had violated Articles 2 and 3 ECHR.

The M.S.S. case concerns the same problem as Povse: the accountability of Contracting Parties for "indirect" violations; violations that took place in another state (also a Contracting Party), but for which they are indirectly responsible because they exposed the victim to those violations. The difference is, of course, that in Povse the indirect violation consists of importing a foreign judgment that somehow violates Convention rights, while in cases such as M.S.S. the indirect violation consists of transferring the victim to a state where he is likely to suffer ill treatment. The Court had already developed a body of case law on the latter situation in the context of extradition of criminal suspects to (non-Contracting party/third) states where they would likely suffer inhumane treatment. ${ }^{95}$ It had also extended this reasoning to situations where a person was extradited from one Contracting Party to another, with the purpose of eventually extraditing him to a third state where he would suffer ill treatment. ${ }^{96}$

The question in M.S.S. was then whether the same also applied in intra-EU situations, where the state responsible for ill-treatment was also an EU Member State. The ECtHR first applied the Bosphorus test. Having found that the EU system in principle offered equivalent protection to that of the Convention, the Court next examined the matter of discretion. It found that

[...] Article $3 \S 2$ of the Dublin Regulation provides that, by derogation from the general rule set forth in article $3 \S 1$, each Member State may examine an application for asylum lodged with it by a third-country national, even if such examination is not its responsibility under the criteria laid down in the Regulation. This is the so-called

\footnotetext{
${ }^{94}$ Council Regulation (EC) No 343/2003 of 18 February 2003 establishing the criteria and mechanisms for determining the Member State responsible for examining an asylum application lodged in one of the Member States by a third-country national, OJ L 50/01 (the 'Dublin II Regulation'). This Regulation has since been repealed by the recast Regulation (EU) No 604/2013 of the European Parliament and of the Council of 26 June 2013 establishing the criteria and mechanisms for determining the Member State responsible for examining an application for international protection lodged in one of the Member States by a third-country national or a stateless person, OJ L 180/31 (the "Dublin III Regulation").

${ }^{95}$ ECtHR Drozd and Janousek $v$ France and Spain [GC], no. 12747/87, ECHR 1992.

${ }^{96}$ ECtHR, T.I. v. United Kingdom [dec.], no. 43844/98, ECHR 2000-III.
} 
"sovereignty" clause. In such a case the Member State concerned becomes the Member State responsible for the purposes of the Regulation and takes on the obligations associated with that responsibility.

The Court concludes that, under the Regulation, the Belgian authorities could have refrained from transferring the applicant if they had considered that the receiving country, namely Greece, was not fulfilling its obligations under the Convention. Consequently, the Court considers that the impugned measure taken by the Belgian authorities did not strictly fall within Belgium's international legal obligations. Accordingly, the presumption of equivalent protection does not apply in this case. [emphasis added].

The Court then went on to apply the principles of the T.I. and subsequent K.R.S. judgment ${ }^{97}$ to the case (paras. 341-359). It found that in light of all the available information about the human rights situation in Greece, submitted by, among others, the UNHCR and the Council of Europe Commissioner for Human Rights, the Belgian authorities knew or ought to have known about the harms to which he at risk of suffering, and should have considered them. The fact that they had not, while they had the means to refuse to transfer him, gave rise to a violation of Article 3 of the ECHR (para. 361).

The approach adopted by the Court in M.S.S. therefore conforms to the proclamation of former President Wildhaber: that the presumption of Convention compliance would only apply if states had no discretion. It is not enough if they did not exercise discretion; if they had the opportunity to do so, this means that the presumption does not apply, regardless of whether discretion was in fact exercised or not.

It follows from Povse that those Regulations which have abolished exequatur and refusal grounds will be covered by the immunity - at least as far as the element of discretion is concerned. In Povse, the ECtHR came to the conclusion that the Austrian courts were not capable of exercising discretion simply on the basis of the wording of Article 42 of the Brussels II bis Regulation:

the decision ordering the enforcement of the Venice youth Court's judgment were based on Article 42 of the Brussels [II bis] Regulation, which provides that a certified judgment ordering a child's return under Article 11(8) of the Regulation "shall be recognised and enforceable in another Member State without the need for a declaration of enforceability and without any possibility of opposing its recognition." That provision leaves no discretion to the courts of the State of enforcement. (para. 79)

The other regulations for which exequatur and refusal grounds have been abolished all contain the same phrasing: "shall be recognised and enforceable in another Member State without the

${ }^{97}$ ECtHR K.R.S. v. United Kingdom appl. no. 32733/08 02/12/2008. 
need for a declaration of enforceability and without any possibility of opposing its recognition". ${ }^{98}$ It is therefore to be expected that these regulations shall be treated in the same way by the ECtHR. ${ }^{99}$

The matter becomes a little more complicated when it comes to regulations that still contain a complete exequatur procedure including refusal grounds, such as the Brussels II bis Regulation as concerns judgments on parental responsibility, or those that require no declaration of enforceability but do contain grounds for refusal, such as Brussels I bis.

Under the Brussels I Regulation, courts had no discretion to refuse enforcement at the first (judgment import) stage; ${ }^{100}$ this was clear from the wording of Article 41. It is also obvious that courts do not have any discretion at this stage under Brussels I bis, since the requirement of a declaration of enforceability has been abolished. ${ }^{101}$ A state could therefore not be held accountable under the Convention for violating Convention rights by granting a declaration of enforceability at this first stage, because it had no powers to refuse the declaration. However, it is difficult to imagine such a situation arising. If a person lodges an application with the ECtHR against a state for a violation resulting from wrongfully granted permission for enforcement, then he or she will need to have exhausted the available local remedies lest their application be declared inadmissible. Such an applicant will therefore have to make use of the procedure provided for in these regulations by which he or she can apply for refusal of enforcement on the basis of the grounds for refusal. Therefore, while the national court indeed enjoys no discretion at the first stage of the procedure for cross-border enforcement (and could therefore not be held accountable under the ECtHR for doing so), what really matters is what happens at the second (contradictory) stage of the procedure. As the Brussels II bis Regulation does allow the requested court to refuse a declaration of enforceability at the first stage (Art. 31(2)), the following also applies to that Regulation.

It is submitted that at this contradictory stage the court clearly is capable of exercising discretion in the sense of the M.S.S. judgment. In the words of the ECtHR, discretion is absent when the national authority does "no more than implement legal obligations flowing from its Membership of the organisation". Seen in the context of the judgments in which the state was considered to have no discretion, this means that the state may not have enjoyed any freedom

\footnotetext{
98 Article 20(1) of Regulation 861/2007 establishing a European Small Claims Procedure; Article 19 of Regulation 1896/2006 establishing a European Order for Payment Procedure; Article 5 of Regulation 805/2004 creating a European Enforcement Order for uncontested claims; Article 17 of Regulation 4/2009 on Maintenance obligations.

${ }^{99}$ The EEO, EOP and ESCP Regulations do allow enforcement to be refused in case of irreconcilability. Though this refusal ground has little to do with fundamental rights but rather with the impossibility of enforcing mutually exclusive judgments, it is of course possible that a case involving its application reaches the ECtHR. In such a case, the Member State concerned would not benefit from the presumption of Convention compliance, given the fact that it clearly enjoyed discretion. See Article 22, EOP Regulation; Article 21, EEO Regulation; Article 22, ESCP Regulation.

${ }^{100}$ Franq (2012) p. 651; see the discussion in Chapter 2.3.1.2.

${ }^{101}$ Article 39, Brussels Ibis Regulation.
} 
to make a decision as to how to implement their obligations. Freedom in this sense does of course not mean that there are no boundaries within which the national authorities must act, but that the relevant legal obligation leaves room for interpretation. That this is true follows from the ECtHR's judgment in Cantoni. ${ }^{102}$ This judgment shows that if EU law affords discretion - in this case the interpretation of a medical term in a directive - then the ECtHR will review how this discretion was exercised. In Bosphorus the ECtHR explicitly distinguished this judgment, stating:

It remains the case that a state would be fully responsible under the Convention for all acts falling outside its strict legal obligations. The numerous Convention cases cited by the applicant [...] confirm this. Each case (in particular, Cantoni, p. 1626, § 26) concerned a review by this Court of the exercise of State discretion for which Community law provided. ${ }^{103}$

It is concluded, both on the basis of Cantoni itself, and on the basis of the fact that the ECtHR explicitly distinguished this judgment in Bosphorus, that the relevant factor in determining whether a state was capable of exercising discretion is whether the relevant legislation left any room for interpretation. This conclusion is reinforced by the Court's finding in Povse: Article 42 simply imposes an obligation on the requested court to enforce the return order which has been certified by the court of origin, which does not leave any room for interpretation.

The wording of the grounds for refusal contained in the various regulations however do clearly leave room for interpretation by the judge who is requested to rule on their application. The notions of "public policy", 104 "in sufficient time and in such a way for him to arrange for his defence", ${ }^{105}$ and irreconcilability, ${ }^{106}$ are all capable of being interpreted differently according to the circumstances of the case, whereas the notion of public policy may also vary according to the Member State where it is invoked. If a case reaches the ECtHR in which the applicant complains that a court has wrongly granted a declaration of enforceability under, for example, Article 28 of the Brussels II bis Regulation, then the ECtHR will consider that the court in that case will have made an examination of the facts of the case and will have interpreted the relevant ground for refusal to see whether the facts can support its invocation. It is submitted that this interpretation will be seen as an exercise of discretion by the State that causes the presumption of Convention compliance to be inapplicable. This is confirmed by the ECtHR's

${ }^{102}$ ECtHR, Cantoni v. France [GC], no. 17862/91, ECHR 1996-V.

${ }^{103}$ ECtHR Bosphorus, para. 157.

${ }^{104}$ Art. 34(1) Brussels I, art. 45(1)(a) Brussels Ibis; art. 22(a) and 23(a) Brussels IIbis Regulation; art. 26 of the Insolvency Regulation.

105 Article 34(2) of the Brussels I Regulation; article 45(1)(b) of Brussels Ibis; articles 22(b) and 23(c) of Regulation Brussels IIbis.

${ }^{106}$ Articles 34(3) and (4) of Brussels I; articles 45(1)(c) and (d) of Brussels Ibis: articles 22 (c) and (d) and 23

(e) and (f) of Brussels IIbis. 
judgment in Avotins, where it reviewed whether Latvia's application of Article 34(2) of the Brussels I Regulation had been in conformity with Article 6(1) ECHR. ${ }^{107}$

It is important to emphasize however that this conclusion only establishes accountability for national courts under the Convention. It does not have any bearing on the question whether they will be found guilty of a violation. It follows from Cantoni that if a national authority has any discretion, the Court will review their conduct as it would in any other case before it: by applying the relevant Convention article to it, while keeping in mind that states enjoy a margin of discretion. The forthcoming Grand Chamber judgment in Avotins will likely provide more clarity on this matter. ${ }^{108}$

In this regard, it is interesting to ask whether a state could be found to have violated Article 6(1) of the Convention by wrongly granting permission for enforcement. Especially interesting is the question whether it could be seen as contrary to this article if the court in question failed to raise any of the grounds for refusal of its own motion. There is no agreement on this point in the literature. ${ }^{109}$ The Proposal for the Brussels I Regulation however clearly excludes any obligation for the court to do so. In this context it should also be noted that under the Brussels I bis Regulation the freedom of courts to raise grounds for refusal of their own motion seems to have been curtailed by the legislature. ${ }^{110}$ The question whether the ECtHR would find a violation in a court's failure to raise grounds of its own motion remains to be answered, though it is submitted that in the absence of any clear indications on this point, the ECtHR would be unlikely to do so.

To come back to the general question, it can be concluded that from the perspective of the Convention, national judges are certainly capable of exercising discretion when it comes to refusing recognition or enforcement under the Brussels I and Brussels I bis Regulations, and also under the other Regulations that contain grounds for refusal. It must therefore be concluded

${ }^{107}$ ECtHR Avotins v. Latvia, appl. no. 17502/07, 25 February 2014. This case has been referred to the Grand Chamber. See Requejo Isidro (2015).

${ }^{108}$ ECtHR Avotins v. Latvia; see especially the dissenting opinion by judges Ziemele, Bianku and De Gaetano, wh are of the opinion that the way the Latvian court had applied the provision may not have been compatible with EU law. According to the judges in their dissenting opinion, '[w] hile the Court is not competent to interpret EU law, we submit that it should not implicitly approve of domestic practices that may go against EU law. This is a new situation for the Court which merits very serious further reflection.' The Grand Chamber judgment is therefore eagerly awaited.

${ }^{109}$ Francq (2012) p. 650 considers it possible to derive from art. 34 Brussels I that a court may of its own motion take grounds for refusal into consideration. Layton and Mercer are of the opinion that the court is obliged to do so (Layton and Mercer (2004) para. 24.011) while Rauscher provides a very strict reading of the article and submits that grounds for refusal may only be examined on application (Leible, Mankowski and Staudinger (2006) p. 553). It is interesting to note that in a recent judgment the German Bundesgerichtshof considered itself obliged to raise grounds for refusal under the Brussels I Regulation; BGH 12 December 2007, XII ZB 240/05, paras. 23-25.

${ }^{110}$ In this regard, it appears that the legislature intended to decrease the possibility for national courts to raise refusal grounds of their own motion, by changing the wording of article 34(1) Brussels I, "A judgment shall not be recognised [if one of the grounds for refusal is found to apply]", to "On the application of the person against whom enforcement is sought, the enforcement shall be refused if one of the grounds referred to in Article 45 is found to apply" in article 46 of Brussels Ibis (emphasis added). 
that the immunity granted by Bosphorus, and by extension Povse, does not cover these Regulations.

What is important to emphasize here is that the simple abolition of the declaration of enforceability that was achieved under Brussels I bis does not appear sufficient to bring the enforcement of judgments under this Regulation within the remit of the immunity provided by Bosphorus. As explained above, the abolition of the exequatur has not changed the discretion enjoyed by courts with regard to the application of refusal grounds at the second stage. The fact that the first stage has been abolished also makes no difference from the perspective of accountability before the ECtHR, because courts did not have any discretion at this stage anyway under the previously existing procedure. Moreover, the situation where a Member State would be held accountable for failing to refuse enforcement of a judgment at the first stage would not arise, because it would mean that the applicant had not exhausted local remedies. The lack of discretion at the first stage is therefore of little practical importance.

\subsubsection{A manifest deficiency?}

The final element of the Bosphorus case law that remains to be discussed is the question of what, if anything, a manifest deficiency would look like in the context of cross-border enforcement of judgments. It was already noted that, to date, the ECtHR has not once found a manifest deficiency, so that it is unknown what circumstances will lead to such a finding. It was discussed under Section 5.3.3 that the concept as well as the standard to be applied were already subject to debate. Some have considered it "most unlikely" that the ECtHR would ever find a manifest deficiency, considering the marginal review the ECtHR conducts on this exception, ${ }^{111}$ though others consider it remarkable that it has not been found. ${ }^{112}$

The ECtHR's case law on this point provides a mixed picture, especially when it comes to the analysis of the substantive protection offered by the EU system, as opposed to the procedural protection. ${ }^{113}$ In Mayenne v. France - which was already discussed above in the context of the importance of the preliminary ruling mechanism - the ECtHR was satisfied that there had not been a manifest deficiency. ${ }^{114}$ It came to this conclusion after an analysis that, though short, considers the substantive compatibility of the contested measures (the milk quota system) with the ECHR. It refers to the European Commission on Human Rights' decision in Procola v. Others ${ }^{115}$ in which it had already been found that the milk quota system was in the public

\footnotetext{
${ }^{111}$ Besselink (2008) p. 300.

112 Lock (2010a) p. 545.

${ }^{113}$ Lock (2010a) p. 542.

${ }^{114}$ ECtHR Mayenne v. France.

${ }^{115}$ European Commission on Human Rights Procola v. Luxembourg.
} 
interest, and that its interference with Article 1 of the First Protocol to the ECHR was therefore justified:

[T]he Court reiterates that the Convention institutions have already had occasion to stress the public interest of curbing milk production, describing the policy to that effect as "in the public interest, given that it is aimed at stabilizing the market". ${ }^{116}$

The Mayenne - and underlying Procola - decisions can be seen as the exceptions to the rule that in the context of the Bosphorus test the Court generally does not review whether the EU legislation at issue substantively conforms to Convention standards. Bosphorus itself is the best example (see Section 5.3.2, above). Another example is the ECtHR's decision in Biret, ${ }^{117}$ in which the Court reiterated its finding in Bosphorus as to the equivalence of the EU's protection mechanism in general. As for any manifest deficiency in the case at hand, the Court satisfied itself with the sentence that:

It considers that the present case does not reveal any "manifest deficiency" in the protection of fundamental rights which could rebut this presumption.

It did not offer any further explanation, aside from citing "mutatis mutandis" its decision in Mayenne.

In a more recent case, Andreasen v. the United Kingdom and 26 other Member States of the European Union, ${ }^{118}$ the applicant aimed to hold the EU Member States accountable for her (allegedly) unjustified dismissal from a position at the European Commission. She challenged the decision on her dismissal before the EU Civil Service Tribunal ${ }^{119}$ (then the Court of First Instance) and, on appeal, before the General Court. ${ }^{120}$ Both courts rejected her complaints. Before the ECtHR, the applicant relied on Article 6(1) in combination with Article 13 to claim that she had been denied an effective remedy because the disciplinary proceedings were not considered by an independent tribunal that was either objectively or subjectively impartial. She also complained that the disciplinary hearings were not public, and that the jurisdiction of the Civil Service Tribunal and the General Court had been limited to the question of whether her dismissal was obviously disproportionate (para. 55). The ECtHR considered these complaints in light of the Bosphorus doctrine and its earlier decision in Perez, where it ruled that a state (Germany) could be held accountable for shortcomings in the internal appeal proceedings of the United Nations because 'manifest deficiencies' in those proceedings had been shown to exist. ${ }^{121}$ In Andreasen, it held that the 27 Member States could not be held accountable for any

\footnotetext{
${ }^{116}$ ECtHR Mayenne v. France, para. 13.

${ }^{117}$ ECtHR Biret.

${ }^{118}$ ECtHR Andreasen v. the United Kingdom and 26 other Member States of the European Union (dec)., appl. no. 28827/11, 31 March 2015.

${ }^{119}$ Case F-40/05, Marta Andreasen v Commission of the European Communities, ECLI:EU:F:2007:189.

${ }^{120}$ Case T-17/08 P, Marta Andreasen v European Commission, ECLI:EU:T:2010:374.

${ }^{121}$ ECtHR Perez v. Germany (dec.) appl. no. 15521/08, 6 January 2015.
} 
deficiencies in the EU's internal appeal proceedings, because the applicant had, unlike Mrs Perez, "not complained in a substantiated manner either that there were manifest deficiencies in the internal appeal proceedings". ${ }^{122}$ Though in Andreasen a manifest deficiency in the EU's review mechanism was not found to exist, the ECtHR's judgment in Perez provides useful insight in what kind of circumstances could indicate that a manifest deficiency exists. In Perez, the ECtHR considered the following circumstances relevant: ${ }^{123}$

a) the fact that she did not have an oral hearing at any stage of the proceedings regarding her dismissal, despite the fact that in her case there were issues of both credibility and contested facts;

b) she claimed that she had not had access to all documents submitted by the United Nations Development Programme (her employer) to the United Nations Administrative Tribunal (which has exclusive jurisdiction to employment-related disputes between the United Nations (UN) and its staff), and relied upon by the latter, in breach of her right to equality of arms;

c) that the United Nations Administrative Tribunal only had limited jurisdiction in cases concerning wrongful terminations of contracts as the Secretary-General could choose to pay compensation instead of reinstating the person who had been unlawfully dismissed;

d) that a number of the shortcomings complained of by the applicant were indeed confirmed in the report of the Redesign Panel on the United Nations system of administration of justice of July 2006, a panel of independent external experts set up by the UN Secretary-General himself.

The ECtHR however concluded that Mrs Perez had failed to exhaust all domestic (German) remedies, rendering the application inadmissible, and did not therefore go on to examine whether these circumstances indeed constituted a manifest deficiency in the internal appeal proceedings at the UN. ${ }^{124}$ Still, it stands to reason that if factors such as those enumerated here had been alleged in a substantiated manner in Andreasen, the presumption of equivalent protection could have been rebutted in that case. Because Mrs Andreasen did not allege such circumstances, the ECtHR clearly did not feel compelled to examine whether a manifest deficiency existed in casu.

The Court has on occasion offered a more thorough review of the procedural safeguards available. In Kokkelvisserij, the applicant claimed that he had suffered a violation of his right to a fair trial because he had not been allowed to respond to the Opinion of the AdvocateGeneral during the preliminary ruling proceedings before the CJEU. The ECtHR stressed that the nature of the preliminary ruling is a consultation of the CJEU by a national court, not (it seems to imply) a contradictory procedure. However, since the preliminary ruling mechanism is an essential component of the EU's procedural mechanism for safeguarding fundamental

${ }^{122}$ CJEU Andreasen v. the United Kingdom and 26 other Member States of the European Union (dec) para. 70.

${ }^{123}$ ECtHR Perez v. Germany (dec.) para. 65.

${ }^{124}$ ECtHR Perez v. Germany (dec.) para. 90. 
rights, and as such is necessary to consider that mechanism as 'equivalent' to that of the Convention, the ECtHR considers itself bound to examine whether the preliminary ruling procedure ensured equivalent protection of the applicant's rights. It then examined the circumstances of the case as well as the Rules of Procedure of the CJEU, finally coming to the conclusion that the protection afforded to the applicant was not 'manifestly deficient' because he had not had the opportunity to respond to the Advocate General. ${ }^{125}$

The intensity of the Court's review in Povse has already been discussed in detail above, so it suffices to reiterate here that the Court considered that no manifest deficiency existed in that case, because, firstly, the Austrian Supreme Court had "duly made use" of the preliminary ruling mechanism, and secondly, the applicants could have invoked their Convention rights before the Italian courts. The latter argument seems to imply that an inadequacy in Italy's procedural mechanisms could also have constituted a "manifest deficiency".

The following conclusions can be drawn. Firstly, that the Court's review of the question of whether a manifest deficiency existed is as a rule relatively marginal; and secondly, that in the majority of cases the Court's review concerned only the procedural mechanism, not the degree of substantive protection afforded by the relevant legislation or by the CJEU - even though Judge Ress opined that "an obvious misinterpretation or misapplication by the ECJ of the guarantees of the Convention right" could also be considered a manifest deficiency. Moreover, it has been concluded - and is supported by Povse - that the burden of providing proof that a manifest deficiency occurred rests in principle with the applicant. ${ }^{126}$ The Court will not examine this question of its own motion, and its analysis of factors that may contribute to a manifest deficiency is therefore limited to the evidence submitted by the applicants.

For these reasons it is not possible to say with certainty, on the basis of the case law previously cited, exactly what a manifest deficiency would entail in the context of free movement of civil judgments. However, some clues can be deduced from the case law on this point.

Firstly, it appears that the concept of "manifest deficiency" refers primarily to a deficiency in the procedural protection of fundamental rights. This is clear from the ECtHR's case law with the notable exception of Mayenne - as well as from the concurring opinion by Judge Ress. Another argument that the substantive standards of the relevant secondary legislation have no bearing on the question whether the protection is considered equivalent or manifestly deficient comes from Povse: though the ECtHR approvingly cites the minimum requirements of Article 42 of Brussels II bis, it does so at the 'discretion' stage, not at the 'equivalence' or 'rebuttal' stage. The standard of protection provided by the regulations that allow for complete free movement is therefore unlikely to be considered by the ECtHR as contributing to a 'manifest deficiency'; neither does it have any bearing on the 'equivalence' test.

${ }^{125}$ ECtHR, Coöperatieve Producentenorganisatie van de Nederlandse kokkelvisserij e.a. v. Netherlands [dec.], no. 65542/12, ECHR 2009-I, p. 21.

${ }^{126}$ Lock (2010a) p. 541. 
Secondly, if it follows that the alleged manifest deficiency is found in the procedural protection offered by the EU system, the question arises which procedural deficiencies would qualify as a manifest deficiency. It must be reiterated that according to the ECtHR, the EU system for protection consists of two elements: the national courts, complemented (if necessary, see Mayenne) by the CJEU. The following discusses under what circumstances deficiencies in national courts or the EU courts, respectively, could amount to a manifest deficiency.

In the context of the free movement of judgments, the problem is that the protection of fundamental rights under the regulations at the national level has been relegated exclusively to the courts of the Member State of origin. The courts of the member state of enforcement have no discretion and can therefore not provide protection to the individual concerned, which means that the model presented by the ECtHR in Bosphorus does not fit these situations. Strictly speaking, under the Bosphorus test, a dysfunction in the procedural framework of the member state of origin could lead to the member state of enforcement being held accountable, because one of the elements of the Bosphorus test would not have been fulfilled. Yet in Povse, the Court also pointed to the availability of redress for the applicants in Italy as an argument why no manifest deficiency existed in this case. Interpreted a contrario, this seems to mean that the unavailability or insufficiency of procedural remedies in Italy could have resulted in the finding of a manifest deficiency. On the other hand, as has been argued under Chapter 4.4.2, such a conclusion would be entirely at odds with the general message of the Court's decision in Povse. It has been demonstrated repeatedly that the ECtHR avoided giving the impression that it would ever consider an enforcing state liable for merely enforcing a judgment in the absence of any discretion. It is therefore submitted that a defect in the procedural protection offered in the state of origin would not be seen by the ECtHR as a manifest deficiency in the sense of the Bosphorus doctrine - a conclusion which is strengthened by the fact that the persons concerned could lodge an application against that state with the ECtHR if such a serious deficiency occurred. While it has been questioned whether lodging an application with the ECtHR against the state of origin would really provide an effective remedy to replace the cross-border control of refusal grounds, ${ }^{127}$ this does seem to be the approach favoured by the ECtHR. Once again, this is logical when seen in the light of the "home remedy rule" that underlies the Convention, and that the Court has previously applied. ${ }^{128}$ More importantly, it is in keeping with the deference shown by the ECtHR to the importance of cooperation within the EU and the manner in which this is achieved, which it has repeatedly shown in the judgments discussed in this Chapter. Finally, the ECtHR has shown in Šneersone and Kampanella $v$. Italy that it will indeed hold the state of origin accountable for a violation resulting from a wrongfully granted return order. ${ }^{129}$

This leaves us with the final element that could be found to be manifestly deficient: the procedural protection granted by the CJEU itself. Looking at the situations proposed by Judge Ress (see under Section 5.3.3, above) the only one that seems applicable is the possibility of

${ }^{127}$ Cuniberti and Rueda (2011); De Cristofaro (2011).

${ }^{128}$ ECtHR Lindberg; see 5.2

${ }^{129}$ ECtHR Šneersone and Kampanella v. Italy. 
an obvious misinterpretation or misapplication by the CJEU of the guarantees of the Convention right. So, if the court in the Member State of enforcement had requested a preliminary ruling, which had resulted in an obvious misinterpretation or misapplication by the CJEU of the Convention right at issue, then that could result in a finding of a manifest deficiency. However, it was shown that the ECtHR is not clear on whether the courts of the Member State of enforcement would in fact be required to request a preliminary ruling; in fact, it was suggested under Section 5.4.4 that this inconsistency exists precisely because the ECtHR wanted to avoid the impression that the enforcing court could lose its immunity by not requesting a ruling. To rebut the presumption of Convention compliance would therefore entail a request for a preliminary ruling by the enforcing court - which it is not clearly obliged to request, and whose contents do not even need to consider the possible infringement of a Convention right, according to Povse - which would then nevertheless result in an obvious misinterpretation by the CJEU of the Convention right at issue. Such a situation is difficult to envisage, but theoretically it could lead to the enforcing court being held accountable. However, while it is difficult to predict exactly how the ECtHR would resolve this particular legal puzzle, this research suggests that its insistence on avoiding responsibility of Austria in Povse, seen in the light of all its earlier case law as cited in this Chapter, makes it very unlikely that it would decide otherwise in a future case. Once again, this shows the difficulty with applying the Bosphorus approach to the cross-border context.

The conclusion of the foregoing must be as follows. The message from Povse is that the ECtHR would be very reluctant to find fault with the system for fundamental rights protection as it is devised by the Brussels II bis Regulation. It has shown that it finds the division of tasks, whereby procedural protection is concentrated with the court of origin, while the court of enforcement has a purely executive function, is in conformity with the Convention. The court of enforcement is exempted from responsibility under the CJEU because it is implementing EU law, and because it has no discretion. The only thing which could upset this balance is if there would be a manifest deficiency in the sense of an obvious misinterpretation of a Convention right by the CJEU in a preliminary ruling requested by the court of enforcement. This is a theoretical possibility, made even more unlikely by the fact that it is questionable whether the court of enforcement has a duty to request a preliminary ruling at all. It is difficult to imagine the ECtHR holding the court of enforcement accountable as a result of a deficiency in a preliminary ruling which it was not even required to request. This is reinforced by the general impression that the ECtHR performs a very marginal review of the circumstances that could give rise to a manifest deficiency in each particular case, as well as the fact that the burden of proof lies with the applicant. This research finds that Besselink's conclusion that the ECtHR would be very unlikely to find a manifest deficiency seems convincing. ${ }^{130}$ The concept of 'manifest deficiency' should perhaps be seen as an insurance against a theoretical dramatic future decrease in the EU's adherence to fundamental rights, the proverbial 'emergency brake'

${ }^{130}$ Besselink (2008) p. 300. 
without which there would be a blanket presumption that the EU will always protect fundamental rights adequately; rather than a realistic, legally testable concept.

\subsection{The Bosphorus doctrine after European Union accession to the European Convention on Human Rights}

As explained, the Bosphorus doctrine arose from the ECtHR's limited ability to review state actions flowing from their membership in the EU. As discussed in the context of Matthews, the ECtHR recognised that it would be difficult for states to reconcile their membership of international organisations such as the EU with their obligations under the ECHR. The Bosphorus doctrine is the ECtHR's way of reconciling these two interests. Essentially, however, the Bosphorus doctrine stemmed from the ECtHR's inability to review the compatibility of EU legislation with the ECHR. The ECtHR acknowledged that, because the EU was not a party to the ECHR, individuals had no recourse to the ECtHR if their fundamental rights had been violated as a result of the application of EU law. It therefore invented the 'equivalence test' to establish whether fundamental rights were adequately protected within the EU legal system, which in turn is a precondition for the presumption of Convention compliance conferred on Member States when they apply EU law.

This compromise would have been resolved by the accession of the EU to the ECHR, which has been on the agenda since $1994 .{ }^{131}$ At that time, an opinion from the CJEU on the legality of such accession (Opinion 2/94) found that the EU lacked the legal capacity to accede. With the Treaty of Lisbon, the TEU was amended to include Article 6(2):

The Union shall accede to the European Convention for the Protection of Human Rights and Fundamental Freedoms. Such accession shall not affect the Union's competences as defined in the Treaties.

The EU and the Council of Europe reached a Draft Accession Agreement, ${ }^{132}$ which again was scrutinised by the CJEU. In Opinion 2/13, ${ }^{133}$ the CJEU declared the Draft Accession Agreement incompatible with the EU's constitutional framework. Extensive discussion of the Opinion can be found elsewhere. ${ }^{134}$ For the context of civil justice cooperation, it is noteworthy

\footnotetext{
${ }^{131}$ See for a discussion Jacqué (2011).

${ }^{132}$ Draft revised agreement on the accession of the European Union to the Convention for the Protection of Fundamental Rights and Freedoms, 47+1(2013)008rev2, available at http://www.coe.int/t/dghl/standardsetting/hrpolicy/Accession/Working_documents_en.asp. See Gragl (2014); Lock (2012); Lock (2010b); Raba (2013).

${ }^{133}$ Opinion 2/13 of the Court (Full Court) of 18 December 2014, ECLI:EU:C:2014:2454.

${ }^{134}$ Barnard, C., Opinion 2/13 on EU accession to the ECHR: looking for the silver lining?, 16-02-2015, at http://www.eulawanalysis.blogspot.nl (last accessed 29/01/2016); Krommendijk, Beijer and Van Rossem (2015); Buyse, CJEU Rules: Draft Agreement on EU Accession to ECHR Incompatible with EU Law, 20-122014, at http://www.echrblog.blogspot.com (last accessed 29-01-2016).
} 
that one of the reasons for the incompatibility was the perceived risk that accession would undermine the functioning of mutual recognition.

The CJEU observed that the functioning of many instruments of EU law (including those on civil justice cooperation) rely on the existence and application of common fundamental rights standards, which Member States may not override on the basis of their own constitutional fundamental rights standards. This means that when fundamental rights standards are exclusively governed by EU law, Member States may not apply their own higher standards instead, as that would negatively affect the effectiveness of those instruments. The CJEU observed that Article 53 of the ECHR allows its Contracting Parties to apply higher standards than provided for in the ECHR; the ECHR contains only minimum standards. This, according to the CJEU, could potentially jeopardize the primacy of EU fundamental rights standards and thereby diminish EU legislation's effectiveness (para. 189).

The Court also observed that the principle of mutual trust prohibits EU Member States from checking, when implementing EU legislation, whether other EU Member States in fact protected fundamental rights. The CJEU expressed concern that mutual trust would be undermined if the EU was to be treated as every other Contracting Party after accession: it would disregard that in cases of mutual recognition, states' relations between each other are governed by EU law, to the exclusion of every other law. According to the CJEU, the ECHR could potentially require EU Member States to check each other's observance of fundamental rights, thereby undermining cooperation on the basis of mutual trust (para. 194).

It is interesting to observe that the balance between mutual recognition and Member States' fundamental rights obligations is such a sensitive issue that the risk of it being upset by the EU's accession was found to be a reason to advise against accession. It is doubtful whether the CJEU's objections are valid. ${ }^{135}$ For one, Article 53 ECHR only allows Contracting Parties to apply higher standards than those proscribed by the ECHR; it never obliges them to apply such standards. The CJEU's first argument seems therefore to be based on a misinterpretation of Article 53. Secondly, if indeed the ECtHR were to find certain instances of the operation of mutual recognition incompatible with provisions of the ECHR, then this is simply inherent to the external control that accession is intended to achieve. If the EU accedes, it is with the purpose of opening itself up to external scrutiny as to EU actions' compatibility with fundamental rights. It is incompatible with that purpose to require that the risk that certain instruments may be found incompatible with the ECHR is excluded from the outset. It is clear from this element of Opinion 2/13 that the CJEU is not prepared to jeopardise the functioning of mutual recognition in any way. In fact, it has been questioned whether after Opinion 2/13, and the case law on which it relies, the ECtHR can still hold that the EU offers 'equivalent protection' to the ECHR, given its near-absolute application of mutual recognition. ${ }^{136}$

\footnotetext{
${ }^{135}$ See also Krommendijk, Beijer and Van Rossem (2015) paras. 7-11.

136 Mole (2016).
} 


\subsection{Conclusion}

The conclusions of the ECtHR's application of the Bosphorus test in Povse should be drawn separately for two different actors. First, it is considered what conditions Povse imposes on EU regulations that seek to facilitate free movement of civil judgments. Secondly, Povse also imposes obligations on national courts or authorities asked to enforce a judgment on the basis on one of these regulations.

\subsubsection{Conclusions for legislation}

For any future legislative initiatives that seek to facilitate free movement of judgments, the message seems simple: the abolition of exequatur and of refusal grounds, whereby the enforcing Member State loses all discretion to evaluate the enforcement with regard to the protection of Convention rights, is allowed by the ECHR. This conclusion is based on two arguments: firstly, the abolition of exequatur and refusal grounds in the view of the ECtHR merely means that the responsibility to observe fundamental rights is concentrated with the court of origin of the judgment, remedied if necessary by recourse to the ECtHR; this means that the absence of cross-border control is unproblematic. Secondly, the abolition of exequatur is allowed because it is achieved within the framework of the EU, which as an organisation adequately protects fundamental rights; and also because the enforcing state has absolutely no discretion where exequatur and refusal grounds are completely abolished. Additionally, it can be inferred from the decision that the existence of minimum requirements is an additional guarantee, in the view of the ECtHR, that fundamental rights are adequately protected.

The conclusions for legislation are the following. First, while the enforcing state may be exempt from scrutiny, the responsibility lies with the court of origin. This means that the procedures in the state of origin, up to and including the certification for enforcement, are subject to scrutiny by the ECtHR. That the ECtHR will indeed carry out such scrutiny is exemplified by the Šneersone and Kampanella judgment. Essentially, the state of origin will be held accountable by the ECtHR for any violations committed in the context of the application of an EU Regulation where it applies any discretion. While Šneersone and Kampanella shows the consequences of this conclusion for the Brussels II bis Regulation, it also needs to be considered what this means for the 'second-generation' instruments of the European Small Claims Procedure (ESCP), European Order for Payment (EOP), and European Enforcement Order for uncontested claims (EEO) Regulations.

Essentially, the ESCP and EOP Regulations are intended to function in the same way as equivalent national procedures. The authorities in the Member State which has jurisdiction are therefore responsible for safeguarding the procedural rights of the parties in the same way as they would be if the procedure were entirely governed by national law; as the ECtHR decided in Cantoni, where there is discretion the ECtHR will review the state's conduct in accordance with the ECHR. Aside from the ECtHR's case law, this conclusion is also supported by the 
Recitals to the ESCP Regulation, which affirm that the "court or tribunal should respect the right to a fair trial and the principle of an adversarial process". ${ }^{137}$ Moreover, these Regulations quite clearly require the relevant court or tribunal to make a great number of discretionary decisions, the most obvious of which is the decision to issue a EOP or to deliver a judgment as the result of a ESCP.

For the EEO, the conclusion is essentially the same: responsibility before the ECtHR lies with the courts of the Member State which has jurisdiction, because the Regulation requires the court or tribunal to decide on such things as whether the claim for which an EEO is requested is indeed uncontested (Art. 6 of the EEO Regulation), or whether the minimum requirements of Chapter III of that Regulation have been complied with.

The consequence of these conclusions is that when Regulations abolish exequatur and refusal grounds, and therefore in essence concentrate the responsibility with the state of origin of the decision or judgment, the procedures on the basis of which this state reaches its decision or judgment should themselves conform to the ECHR. This is not an especially surprising conclusion, and the European legislature was clearly aware of it: the three Regulations each pledge adherence to fundamental rights in their Recitals, and they contain procedural guarantees in their operative clauses. Whether these guarantees are indeed sufficient to satisfy the ECtHR can only really be proven if they become the subject of an application before the ECtHR against the Member State who applied them. In any case, it is clear that this Member State will be responsible under the ECHR.

Conversely, if it is the intention of the European legislature to concentrate responsibility with the state of origin, while shielding the state of enforcement from having to answer to the ECtHR, then it is necessary that no discretion be left to the enforcing state. As was explained in Section 5.4.5, the existing Regulations appear to fulfil this requirement. The legislature is therefore well advised to apply the same formula to future Regulations that seek to facilitate free movement.

As to the Court's review of the specific guarantees offered in the Regulations at issue, the picture is unclear. On one hand, case law shows that the ECtHR generally has trust in the guarantees offered in the EU system as such, without looking specifically at the legislation in question. Strictly speaking, for the presumption of compliance of Bosphorus to apply, it is not necessary that the Regulation in question contains adequate safeguards (though of course this does matter with regard to the responsibilities of the court of origin, see above). However, in Povse the ECtHR does point to the minimum requirements of Article 42 of Brussels II bis, presumably to substantiate its finding that the abolition of exequatur and refusal grounds is not problematic with regard to the ECHR. While it only referred to this at the "discretion" stage of its examination (see Section 5.4.3, above), this could nevertheless be seen as a sign that the ECtHR considers the existence of minimum requirements if not a precondition for the abolition of exequatur and refusal grounds, then at least a sign that fundamental rights are properly

${ }^{137}$ ESCP Recital 9; such an affirmation of absent from the EOP Regulation. 
protected. The legislature could therefore be well-advised to include in any future Regulations minimum standards which need to be examined prior to certification, such as Article 42 of the Brussels II bis Regulation or those contained in Chapter III of the EEO Regulation. It should be noted, however, that these minimum standards perform a different function to those incorporated into the ESCP and EOP Regulations. While under the Brussels II bis Regulation and the EEO Regulation, the minimum standards need to be checked after the delivery of the judgment but prior to certification of the judgment as enforceable, under the ESCP and EOP Regulations they do not circumscribe the permission for enforcement, but the procedure as a whole. However, if the ECtHR applies the same approach when it is faced with a question concerning the responsibility of the enforcing Member State under the ESCP or EOP as it did for the Brussels II bis Regulation, it stands to reason that it would also look favourably on the inclusion of procedural safeguards. To sum up, while the Povse decision does not give rise to a requirement that minimum standards be incorporated into the Regulations, the inclusion of minimum standards is nevertheless advisable.

What is also important to emphasize here is that the ECtHR did not consider it a problem that the guarantees of Article 42 of Brussels II bis could not be invoked by the parties concerned. It is merely the existence of the requirements that is of importance for the finding that the enforcing state enjoys immunity. From the perspective of the state of enforcement, the justiciability of the minimum standards is therefore of no concern - though it is for the state of origin.

In essence, what the ECtHR said in Povse is the mirror image of what it said in Šneersone and Kampanella. Where a regulation allows complete free movement, it is the state of origin which is held accountable (Šneersone and Kampanella); the enforcing state is exempted from accountability (Povse). This means that the European legislature should be very careful to abolish exequatur and refusal grounds completely, with no discretion for the state of enforcement, while at the same time making sure that the regulation at issue provide the state of origin with sufficient means to ensure that a fair trial is conducted.

\subsubsection{Conclusions for enforcing courts or authorities}

For the court or authority responsible for enforcement in the absence of exequatur or refusal grounds, the most troublesome element of the Court's conclusions in Povse is surely whether, and if so how, it should refer preliminary questions to the CJEU. Up until Povse, the ECtHR was quite clear on this point: ${ }^{138}$ where a CJEU ruling was considered necessary, a state whose courts nevertheless failed to request such a ruling would be held responsible under the ECHR, because it would have acted "without the full potential of the relevant international machinery for supervising fundamental rights - in principle equivalent to that of the Convention - having

\footnotetext{
${ }^{138}$ See under 5.4.3.
} 
been deployed". ${ }^{139}$ Povse however muddled the waters. It seemed to imply that the Austrian court was indeed required to refer preliminary questions, ${ }^{140}$ yet did not consider it a problem that those questions did not concern the fundamental rights questions. With Povse, the ECtHR has therefore left national enforcing authorities with a great deal of uncertainty as to their obligations. However, the message of Povse is also clearly that the ECtHR approves of the abolition of exequatur and refusal grounds, and it clearly avoided giving any indication that the enforcing state could be held liable. Perhaps the ECtHR's insistence that the Austrian Supreme Court "duly" made use of the preliminary ruling mechanism should therefore not so much be seen as an affirmation of Austria's obligation, but as a compliment for the trouble the Austrian Supreme Court took in referring preliminary questions despite not being obliged to.

It should also be emphasised that, whatever the legal basis for it, recognition or enforcement of a judgment that violates ECHR rights in principle constitutes a separate violation under the ECHR. This follows from Pellegrini and from Avotins (for intra-EU situations). This conclusion however also follows from the principles underlying the ECHR, which is that each Contracting State bears responsibility to protect fundamental rights 'to everyone within their jurisdiction' (Art. 1). Even in situations where the obligation to recognise or enforce a foreign judgment flows from EU legislation, the state where recognition or enforcement is sought is not passive; a decision is always necessary to import a foreign judgment into the legal order. The State addressed is not a passive 'accessory' to the violation that already occurred. ${ }^{141}$ Povsetype cases, where any discretion to decide on the recognition or enforcement of foreign judgments has been removed from the Member State addressed, are the exception.

\subsubsection{Final remarks}

Without repeating what has already been said, the Povse decision is an example of the remarkable degree of deference with which the ECtHR treats the application of the law of the EU by its Member States. This is exemplified by the very general and abstract test it deploys for declaring the EU's system of fundamental rights protection equivalent to that of the Convention. In fact, Povse shows how this assessment has become nearly automatic: the ECtHR merely cited previous case law, pointing to its finding in those previous cases that the EU system was previously considered equivalent, and left it at that. Furthermore, the ECtHR's deference is also shown in its efforts to avoid the impression that the immunity of the enforcing state could ever be rebutted: especially the inconsistent application of the preliminary ruling requirement and the illogical discussion of the minimum requirements should be mentioned here. Both elements of the Court's reasoning only really make sense when seen as an attempt to avoid criticizing the abolition of exequatur and refusal grounds and implying the accountability of the enforcing state in that context.

\footnotetext{
${ }^{139}$ ECtHR Michaud.

${ }^{140}$ See under 5.4.4.

${ }^{141}$ See Vonken (1993) p. 172; Oster (2015) p. 564.
} 
The only real mystery remains when, if ever, a manifest deficiency would be considered to have occurred. The ECtHR has so far never found a manifest deficiency to exist, and that it has never positively defined the concept in its case law. We are therefore left with the authoritative, but non-binding, concurring opinion of Judge Ress on this point, as well as with a number of rulings in which the ECtHR gave some indications as to what is not considered a manifest deficiency. Even more complicated is the question of what a manifest deficiency would entail in the cross-border context. It seems very unlikely that a manifest deficiency will be found in the cross-border context, because that would lead to the enforcing state being held accountable, which is a conclusion the ECtHR clearly wanted to avoid. Unfortunately, therefore, we are not closer to discovering what a manifest deficiency would entail; though perhaps this should read "fortunately", since the finding of a manifest deficiency would mean a grave defect in the system of protection of fundamental rights within the EU had occurred.

Finally, it is as of yet unclear what precisely the consequences of the EU's accession to the ECHR will be, if ever it accedes. There are two elements to this question which are of particular importance: the division of responsibilities between the Member States and the Union, particularly when those Member States act under the principle of mutual recognition; and secondly, the level of scrutiny that the EU's legislation will be subject to. 


\section{Free movement of civil judgments and European Union fundamental rights law}

\subsection{Introduction}

The previous Chapter analysed to what extent the European Convention on Human Rights (ECHR) places limitations on the application of European Union (EU) law and on mutual recognition in particular. It showed that EU Member States are required to respect the ECHR when they apply EU law, and that they are presumed to have acted in compliance with the ECHR if they have no discretion in this regard, which is often the case in the context of mutual recognition.

This Chapter analyses the different ways in which EU fundamental rights law circumscribes the free movement of judgments. Where Chapter 4 focused on the Court of Justice of the European Union's (CJEU) interpretation of the right to a fair trial as it applies to civil cases, this Chapter looks at the bigger picture of the EU's constitutional and procedural fundamental rights framework. Its scope is therefore wider than the specific context of civil justice cooperation.

First, this Chapter discusses how EU fundamental rights law may constrain the powers of the European legislature and the application of EU legislation (Section 6.2). It looks at the function of fundamental rights in the EU legal order, including the application of the Charter of Fundamental Rights of the European Union (EU CFR) ${ }^{1}$ by the CJEU. It is shown that the EU has expressed a clear commitment to the protection of fundamental rights, and that the CJEU has repeatedly held the institutions accountable for this commitment by reviewing the conformity of EU legislation with fundamental rights. This has happened in the context of mutual recognition, such as in the NS and ME and Others judgment where the CJEU held that concerns as to the fundamental rights situation in one Member State could limit the application of mutual recognition. Section 6.3 discusses this case and its implications for civil justice cooperation. It shows that while the EU has expressed a clear commitment to fundamental rights, it can be questioned whether fundamental rights have in fact so far acted as a constraint on EU legislative and executive action, especially in the context of mutual recognition.

At the same time, EU fundamental rights are not merely capable of constraining the application of EU legislation: fundamental rights standards are also used as a way of ensuring EU legislation's effectiveness and as a tool to further implement mutual recognition. The CJEU's judgment in Melloni shows that where fundamental rights standards have been harmonised in secondary legislation, Member States may not impose higher national fundamental rights

\footnotetext{
${ }^{1}$ Charter of Fundamental Rights of the European Union, OJ C 326/391, 2012.
} 
standards to the detriment of the legislation's effectiveness. Since EU civil justice regulations often contain harmonised fundamental rights standards, the Melloni judgment is highly relevant. Section 6.4 discusses the implications of this judgment for mutual recognition in the field of civil justice. It is concluded that, where fundamental rights standards in EU legislation are intended to be maximum standards, the EU legislature has a responsibility to ensure that these standards are sufficient to safeguard EU citizens' fundamental rights.

\subsection{Protection of fundamental rights in the European Union legal order}

This section discusses how fundamental rights gradually became part of the EU legal order, a process that culminated in the adoption of the EU CFR. With the elevation of the EU CFR to the level of the Treaties in 2009, fundamental rights gained a central role in the EU legal order, and conformity with fundamental rights is now a clear condition for the legality of EU measures. The following sections further explain how fundamental rights play a role in the application of EU law. Section 6.2.1 discusses the substantive aspect of this question. Sections 6.2.2 and 6.2.3, respectively, discuss how fundamental rights should be protected by the EU's multi-level judicial system, which comprises the Member States' courts as well as the EU judicial institutions.

\subsubsection{The position of fundamental rights in EU law}

Originally, the constitutional treaties of the EU contained no provisions for the protection of fundamental rights. However, the CJEU developed an unwritten catalogue of fundamental rights in its case law. ${ }^{2}$ As such, fundamental rights became part of what are called the general principles of EU law. ${ }^{3}$

The CJEU laid the foundation for this development with its judgment in Internationale Handelsgesellschaft, in which the CJEU accepted that while national fundamental rights could not override Community law, fundamental rights nevertheless formed an integral part of the general principles of law protected by the Court of Justice. ${ }^{4}$ In later case law, the CJEU emphasized that it would draw inspiration from the national constitutional traditions of the

\footnotetext{
${ }^{2}$ Craig and de Bùrca (2015) 384-390; Lawson (2005) p. 232-234; Douglas-Scott (2006b).

${ }^{3}$ Apart from fundamental rights, these encompass such principles as proportionality, subsidiarity, effectiveness (and/or loyal cooperation) and national procedural autonomy. See among others Tridimas (2006); Bernitz, Nergelius and Cardner (2008); Ehlers (2007).

${ }^{4}$ Case 11-70 Internationale Handelsgesellschaft mbH v Einfuhr- und Vorratsstelle für Getreide und Futtermittel ECLI:EU:C:1970:114.
} 
Member States, international human rights treaties, ${ }^{5}$ and the ECHR. ${ }^{6}$ In Stauder, it confirmed that these rights could be binding on the Member States if they acted in the implementation of EU law. ${ }^{7}$ Initially, fundamental rights, and the right to a fair trial in particular, can be said to have played an instrumental role to the effective implementation of EU law and to have facilitated integration. For example, in Johnston, the CJEU developed the idea of an EU right to effective judicial protection, but did so as an aspect of the effective application of EU law. ${ }^{8}$ The CJEU did, however, affirm that the right to effective judicial review constituted a general principle of law recognized in the constitutional traditions common to the Member States and in the ECHR that must therefore be taken into consideration in Community law. ${ }^{9}$ Building on that ruling, in Heylens, the CJEU proclaimed that such judicial control encompassed a duty for institutions applying EU law to give reasons for their decisions, to allow the person concerned to defend himself. ${ }^{10}$

Early on, the CJEU began to refer to the ECHR as an additional basis for its fundamental rights pronouncements. In Nold, it affirmed its "special status" as a source of inspiration for its fundamental rights jurisprudence. ${ }^{11}$ It first directly cited the ECHR in Rutili, ${ }^{12}$ and it has continued to do so ever since. However, it treated the ECHR as a source of inspiration, rather than as a binding source of law, giving its own autonomous interpretation to certain fundamental rights in order to safeguard the goals and values of the EU. This resulted in divergent interpretations of certain rights, for example on the right to remain silent, ${ }^{13}$ and the right to privacy of business premises, ${ }^{14}$ both in competition cases.

The special status of the ECHR in EU law was affirmed by the inclusion of Article 6(3) in the Treaty on European Union (TEU) by the Treaty of Lisbon. This Article provides that "fundamental rights, as guaranteed by the European Convention of Human Rights and Fundamental Freedoms [...] shall constitute general principles of the Union's law." This

\footnotetext{
${ }^{5}$ CJEU Case 43-75 Defrenne, ECLI:EU:C:1976:56.

${ }^{6}$ See, eg, Case 4/73 Nold v Commission, ECLI:EU:C:1974:51; Case 44/79 Hauer v Land Rheinland-Pfalz, ECLI:EU:C:1979:290; Case C-235/99 The Queen v Secretary of State for the Home Department, ex p Kondova ECLI:EU:C:2001:489; Case C-25/02 Rinke v Arztekammer Hamburg ECLI:EU:C:2003:435; Cases C-465/00, 138 and 139/01 Rechsnungshof $v$ Österreichischer Rundfunk and others, ECLI:EU:C:2003:294.

${ }^{7}$ CJEU Case 29-69 Stauder ECLI:EU:C:1969:57.

${ }^{8}$ CJEU Case 222-84 Johnston ECLI:EU:C:1986:206, para. 19.

${ }^{9}$ CJEU Johnston para. 18.

${ }^{10}$ CJEU Case 222/86 Heylens, ECLI:EU:C:1987:442 para. 15

${ }^{11}$ CJEU Case 4/73 Nold v Commission, ECLI:EU:C:1974:51.

12 CJEU Case 36-75 Rutili, ECLI:EU:C:1975:137.

${ }^{13}$ Compare the CJEU's judgment in Case C-374/87 Orkem, ECLI:EU:C:1989:387, with the ECtHR's ruling in Saunders v. United Kingdom, 19187/91 ECHR 1996-VI. See Callewaert (2009) p. 775.

${ }^{14}$ Compare the CJEU's judgment in Joined Cases 46/87 and 227/88 Hoechst, ECLI:EU:C:1989:337, with that of the ECtHR in Niemietz v. Germany, appl. no. 13710/88; however, the CJEU has now revised its provision (see CJEU Case C-94/00 Roquette Frères, ECLI:EU:C:2002:603).
} 
provision has clarified the position of the ECHR in the EU legal order. The influence of the ECHR and the case law from the ECtHR has however been radically altered by the EU CFR.

The EU CFR changed the system of fundamental rights protection within the EU by codifying all these developments. It entered into force in 2001, but was only elevated to the same legal status as the Treaties with the ratification of the Treaty of Lisbon in 2009. ${ }^{15}$ The implications of the EU CFR have inspired a wealth of literature. ${ }^{16}$

With their inclusion in the EU CFR, and by virtue of Article 6(1) TEU, fundamental rights became part of EU primary law. The EU CFR is intended to codify - though not replace - those fundamental rights that were already developed as general principles of EU law. ${ }^{17}$ With the EU CFR, the EU has a clear canon of fundamental rights that apply within its legal order. Equally importantly, Article 52(3) of the EU CFR essentially incorporated the ECHR into the EU legal order by providing that those CFR rights that correspond to ECHR rights shall be interpreted in the same way as those ECHR rights (though EU law may provide more extensive protection). It therefore also clarified the scope and interpretation of fundamental rights in the EU.

The EU CFR is now the primary source of reference for fundamental rights for EU institutions. ${ }^{18}$ In Otis, the CJEU ruled that since Article 47 of the EU CFR secures protection of the right to a fair trial within the EU, it needed to refer only to that Article. ${ }^{19}$ In such cases, the CJEU will however refer to ECtHR case law in order to ensure that the level of protection it provides is commensurate to that provided by the ECHR.

As to the scope of the protection provided by the EU CFR, Article 51 provides that the EU CFR is binding both on the Union's institutions and on its Member States when they implement EU law. The term "implementing" in that Article is to be understood as "acting within the scope of Union law", ${ }^{20}$ and is intended as a codification of the CJEU's judgments in Wachauf, ${ }^{21}$ $E R T,{ }^{22}$ and Annibaldi. ${ }^{23}$ Though the limits of the scope of EU law are debated, there is no doubt that it includes all situations in which a Member State applies EU legislation, in which it

\footnotetext{
${ }^{15}$ See for a discussion of the consequences of the Lisbon Treaty for the application and interpretation of the EU CFR Iglesias Sanchez (2012); Leczykiewicz (2010).

${ }^{16}$ Among many others De Vries, Bernitz, Weatherill (2013); Di Federico (2011); Trybus and Rubini (eds.)

(2012); O’Brien and Koltermann (2013); Peers, Hervey et al. (2016).

${ }^{17}$ EU Charter of Fundamental Rights, Recital 5.

${ }^{18}$ Borowski speaks of a "pragmatic preference", Borowski (2012) 217; De Visser (2014) p. 42; European

Commission, Report on the application of the EU Charter of Fundamental Rights, 2012, COM/2013/0271 final, para. 2.3.

${ }^{19}$ CJEU Case C-199/11 Otis, ECLI:EU:C:2012:684, para. 47.

${ }^{20}$ Explanations relating to the EU Charter of Fundamental Rights, OJ C 303/17, 2007, p. 32.

${ }^{21}$ Case C-5/88 Hubert Wachaufv Bundesamt für Ernährung und Forstwirtschaft, ECLI:EU:C:1989:321.

${ }^{22}$ C-260/89 Elliniki Radiophonia Tiléorassi AE and Panellinia Omospondia Syllogon Prossopikou v Dimotiki

Etairia Pliroforissis and Sotirios Kouvelas and Nicolaos Avdellas and others (ERT v DEP)

ECLI:EU:C:1991:254.

${ }^{23}$ C-309/96 Daniele Annibaldiv Sindaco del Comune di Guidonia and Presidente Regione Lazio, ECLI:EU:C:1997:631
} 
effectively acts as an agent of the Union. ${ }^{24}$ The foregoing leads to the conclusion that when Member States apply one of the regulations in the field of civil procedure, they are bound to respect the EU CFR. Situations cannot exist which are covered by EU law without the fundamental rights of the EU CFR being applicable, as the CJEU affirmed in Akerberg Fransson. ${ }^{25}$

\subsubsection{The Member States courts' task in the protection of EU CFR rights}

It is clear that fundamental rights have achieved constitutional status in the EU. This means that Member States are required to respect EU fundamental rights, including the EU CFR, when they apply EU legislation. ${ }^{26}$ How Member State courts should do this in practice depends on the degree of discretion that the provision of secondary EU law leaves to the Member State. When there is no discretion, the only way for a national court to avoid having to apply the provision in such a way as to harm EU fundamental rights would be to declare it inapplicable or invalid. When there is discretion, CJEU case law shows that it is for the national court to interpret the provision in such a way as to avoid results that are incompatible with fundamental rights. ${ }^{27}$ The CJEU has ruled that when Member States have discretion under EU law, they should respect the EU CFR, but it is their responsibility to interpret and if necessary set aside national norms in such a way as to ensure effective application of EU law, including the EU CFR. As the Court ruled in Akerberg Fransson: ${ }^{28}$

45 As regards, next, the conclusions to be drawn by a national court from a conflict between provisions of domestic law and rights guaranteed by the EU CFR, it is settled case-law that a national court which is called upon, within the exercise of its jurisdiction, to apply provisions of European Union law is under a duty to give full effect to those provisions, if necessary refusing of its own motion to apply any conflicting provision of national legislation, even if adopted subsequently, and it is not necessary for the court to request or await the prior setting aside of such a provision by legislative or other constitutional means.

The Court added that a Member State court may in such cases, if necessary, request clarification from the CJEU as to the interpretation of the provision of EU law at issue. ${ }^{29}$

As for the first situation, the following must be considered. It is a well-established doctrine of EU law that only the CJEU may declare Union law invalid for reasons of incompatibility with some other legal principle; national courts may not do so. ${ }^{30}$ It was already discussed that many

\footnotetext{
${ }^{24}$ Besselink (2001) p. 77.

${ }^{25}$ CJEU Case C-617/10 ̊kklagaren v. Hans Åkerberg Fransson, ECLI:EU:C:2013:280, para. 21.

${ }^{26}$ CJEU Åkerberg Fransson.

${ }^{27}$ CJEU Case C-101/01 Criminal proceedings against Bodil Lindqvist, ECLI:EU:C:2003:596.

${ }^{28}$ See for comments Fierstra (2014); Fontanelli (2013); Hancox (2013); Veenbrink and De Waele (2013); Swarcz (2014).

${ }^{29}$ CJEU A kerberg Fransson, para. 47.

${ }^{30}$ Craig and De Bùrca (2015) p 475-6; CJEU Case 314/85 Foto-Frost, ECLI:EU:C:1987:452, para. 15.
} 
instruments of EU legislation in the field of civil procedure leave no discretion to the national authorities; the enforcement of return orders under Articles 41 and 42 of Brussels II bis or of judgments rendered under the European Small Claims Procedure (ESCP) or European Order for Payment (EOP) Regulations are good examples. In such cases, if a national court believed that enforcement would be contrary to a fundamental right (whatever its source), the only way for that court to refuse enforcement would be to find EU law inapplicable or invalid, because there would be no room to interpret the rules in accordance with fundamental rights. This, however, is an exclusive competence of the CJEU. In its Foto-Frost judgment, the CJEU held that, "where the validity of a Community act is challenged before a national court the power to declare the act invalid must also be reserved to the Court of Justice." 11

While it is therefore possible that EU legislation on the enforcement of judgments could be contrary to EU fundamental rights, national courts would not have the power to declare such legislation invalid. ${ }^{32}$ Again, if there is no discretion and therefore no room for the court to interpret the obligations arising out of this legislation in accordance with fundamental rights, ${ }^{33}$ this means that courts must make a preliminary reference to the CJEU to receive a ruling on the validity of EU legislation. This is especially important when it comes to the automatic enforcement (without refusal grounds) provided for in the ESCP, EOP, European Enforcement Order for uncontested claims (EEO), Maintenance, and Brussels II bis Regulations. A national court may not by itself decide not to invalidate such legislation for reasons of nonconformity with the EU CFR. ${ }^{34}$

In practice it may be difficult for courts to distinguish where EU legislation requires them to take measures to protect fundamental rights. It is not always obvious where EU legislation allows Member States discretion and where it does not. For the context of free movement of civil judgments, this is shown by the eco cosmetics/Raiffeisenbank case. ${ }^{35}$ This case deals with the consequences that should be attached to a failure to serve an EOP on the debtor. The EOP Regulation is an instrument that relies heavily on the uniform application of harmonised procedural standards in order to safeguard its effectiveness. It contains very few remedies, one of which is review where an EOP was served in the correct manner, but too late for the

\footnotetext{
${ }^{31}$ CJEU Foto-Frost para. 17.

32 It has nevertheless been questioned whether Member State courts should be given this power: Leczykiewicz (2010); Sarmiento, R., (2013).

${ }^{33}$ Where there is room for interpretation, it is for the authorities and courts of the Member States not only to interpret their national law in a manner consistent with Directive 95/46 but also to make sure they do not rely on an interpretation of it which would be in conflict with the fundamental rights protected by the Community legal order; CJEU Lindqvist, para. 87.

${ }^{34}$ The only exception to this rule is that the CJEU has allowed national courts to temporarily suspend the application of EU legislation during the preliminary ruling procedure, but only under certain conditions: CJEU Joined Cases C-134/88 and C-92/89 Zuckerfabrik, ECLI:EU:C:1991:65, para. 33.

${ }^{35}$ CJEU Joined cases C-119/13 and C-120/13 eco cosmetics GmbH \& Co. KG v Virginie Laetitia Barbara Dupuy and Raiffeisenbank St. Georgen reg. Gen. mbH v Tetyana Bonchyk, ECLI:EU:C:2014:2144. See also 8.5.1.
} 
defendant to object to it. ${ }^{36}$ In eco cosmetics/Raiffeisenbank, the EOP had not been served on the debtor at all. The referring court asked whether it could apply the remedy of review by analogy. The CJEU however ruled that review would be an inappropriate remedy, since an EOP that was never served on the defendant should not have become enforceable at all; it could not therefore be reviewed but should be seen as invalid. ${ }^{37}$ According to the CJEU it would be incompatible with the rights of the defence (it did not refer to the EU CFR). In such a case, the Member State must provide a remedy under national law.

What is difficult here is that the EOP Regulation, like the ECSP Regulation, is intended to provide a complete procedure for cross-border debt recovery, which is applied uniformly across the Member States. It contained no remedies for cases where an EOP was not served on the defendant, which was a clear legal vacuum created by the European legislature. ${ }^{38}$ With its judgment in eco cosmetics/Raiffeisenbank, the CJEU places on Member States the responsibility to fill these kinds of gaps in EU legislation where necessary for the protection of the right to a fair trial. It is not surprising however that the referring court did not foresee this and instead asked whether it could apply a remedy already present in the Regulation by analogy. Because the effectiveness of the EOP relies largely on its uniform application, this suggests that the Regulation contains a closed system of legal remedies, which clearly it does not. Even a uniform Regulation such as the EOP, which relies heavily on harmonised norms and appears to leave little discretion to the Member States, may thus at times require Member State courts to supplement its fundamental rights protection. The distinction between situations where Member States enjoy discretion, and in which they are responsible for application of EU law in conformity with fundamental rights, and situations in which they are not, is therefore not as clear-cut as it may seem.

\subsubsection{The role of the CJEU in the protection of EU fundamental rights}

The obligation for national courts and authorities to respect the EU CFR rights means that, when they are faced with a choice between applying provisions of secondary EU law and thereby infringing EU CFR rights, or disregard EU law, they must first seek a preliminary ruling from the CJEU, which will then review the provision's compatibility with the EU CFR. This is illustrated by the case of Volker and Schecke. ${ }^{39}$ In this case the Court ruled that Member States' obligations to publish information about the beneficiaries of agricultural subsidies were

\footnotetext{
${ }^{36}$ Article 20(1) EOP Regulation.

${ }^{37}$ CJEU eco cosmetics/Raiffeisenbank, para. 48.

${ }^{38}$ View of Advocate General Bot, delivered on 9 April 2014, Joined Cases C 119/13 to C 121/13 eco cosmetics GmbH \& Co. KG (C 119/13) v Virginie Laetitia Barbara Dupuy, Raiffeisenbank St. Georgen reg. Gen. mbH (C 120/13) v Tetyana Bonchyk and Rechtsanwaltskanzlei CMS Hasche Sigle, Partnerschaftsgesellschaft (C 121/13) v Xceed Holding Ltd, ECLI:EU:C:2014:248, para. 45.

${ }^{39}$ CJEU Case C-172/91 Volker Sonntag v Hans Waidmann, ECLI:EU:C:1993:144.
} 
incompatible with the right to privacy of those beneficiaries, as protected by Article 8 of the EU CFR. The case is illustrative of the framework for fundamental rights protection that the EU CFR created. The rules in question very specifically prescribed the information that needed to be published by the Member States, and therefore left no discretion. The referring national court, being of the opinion that the rules regarding publication breached the right to privacy, had no room for interpretation, and therefore requested a preliminary ruling from the CJEU to confirm this view. The CJEU decided that the rules indeed interfered with the right to privacy in a disproportional way, and declared the rules invalid. ${ }^{40}$

The CJEU has therefore clearly shown itself to be prepared to review secondary EU legislation as to its compatibility with the EU CFR. ${ }^{41}$ This is encouraging, because European citizens will need to rely on the protection provided by the CJEU when they challenge EU legislation that leaves no discretion to the Member State that applied it.

The roles of the CJEU and the Member State courts as regards the protection of EU CFR rights are therefore complementary. ${ }^{42}$ It has always been an important feature of the judicial system of the EU that national courts essentially become EU courts when they apply EU law, a task in which they are supervised and supported by the CJEU. National courts are bound, by virtue of the obligation of loyalty laid down in Article 4(3) TEU, to give full effect to EU law, which includes the EU CFR.

It was discussed before that a large number of the instruments of EU civil procedure law are designed to limit the discretion of the Member States, relying on mutual recognition, in order to achieve greater efficiency in cross-border litigation. It can therefore be concluded that, for this category of legislation, the CJEU is the primary protector of fundamental rights, as national courts have little discretion. The case of Volker and Schecke shows that the CJEU is certainly prepared to review secondary EU legislation and declare it incompatible with the EU CFR. In principle, therefore, it is possible that the CJEU will stand in the way of the application of EU legislation in the field of civil procedure and the cross-border enforcement of judgments as well.

There are two caveats to this conclusion. The first is that while the CJEU has certainly proved itself to be critical as to the compatibility of EU law with fundamental rights (as illustrated by

\footnotetext{
${ }^{40}$ CJEU Joined Cases C-92/09 and C-93/09 Volker und Schecke, ECLI:EU:C:2010:662, paras. 86-88.

${ }^{41}$ See also Case C-236/09 Association Belge de Consommateurs Test-Achats ECLI:EU:C:2011:100; De Visser, (2014) p. 42. More recently, the CJEU also declared invalid a Commission decision (Case C-362/14 Maximillian Schrems v Data Protection Commissioner, ECLI:EU:C:2015:650) as well as the Data Retention Directive (Joined Cases C-293/12 and C-594/12 Digital Rights Ireland and Seitlinger and Others, ECLI:EU:C:2014:238). See, critically, Chalmers and Trotter (2016) p. 9.

42 Barents (2010) p. 715.
} 
Volker and Schecke and the case law discussed in Chapter 4.3) it has not always been critical enough, at least not in the view of certain commentators. ${ }^{43}$

The second caveat is that while the CJEU has reviewed secondary EU law, it has so far only once allowed Member States to refrain from applying EU law and to refuse mutual recognition on the basis of concerns about the actual fundamental rights situation in a certain Member State. This happened in the case of N.S. and M.E. and others, which is discussed in the next section. Mutual recognition, and the mutual trust in each other's legal systems Member States are required to have, are therefore almost absolute in the view of the CJEU. In other words, if fundamental rights concerns are not caused by the EU legislation itself, but by the actual fundamental rights situation in the Member State of origin, then the CJEU has proved itself to be very strict: only in exceptional circumstances are Member States allowed to disregard the obligations imposed on them by EU law. This position has become more nuanced with the recent judgment in Aranyosi and Căldăraru, ${ }^{44}$ which concerns the European Arrest Warrant (EAW).

These points can be illustrated by Zarraga, discussed in Chapter 3. Though the CJEU was asked in Zarraga to rule on the compatibility of the rules for enforcement of return orders with Article 24 of the EU CFR (regarding the child's right to be heard), the Court showed restraint in its assessment, essentially ruling in favour of mutual trust and automatic enforcement. As discussed in Chapter 3.5, the CJEU applied a very formal logic. It found that since Article 42(2) of the Brussels II bis Regulation required the court in the Member State of origin of a judgment ordering the return of a child to ascertain whether the child had been given an opportunity to be heard, the protection granted by the secondary EU law in question was sufficient. The CJEU did not consider the question whether the protection granted by this provision was in fact effective, and did not grant the court in the Member State of enforcement any leeway to refuse enforcement for that reason. ${ }^{45}$

The conclusion is that the review conducted by the CJEU of the fundamental rights protection granted by secondary EU legislation was very formal in this case. More importantly however, this case shows that the compatibility of EU legislation with fundamental rights is not the only issue. Sometimes the legislation will in principle conform to fundamental rights standards, but it will be the actual application in the Member State of that legislation which is the issue. In such cases nothing can be achieved by the Member State of enforcement, as Zarraga shows. Peers was therefore right to conclude that the rule of mutual recognition is "near-absolute". ${ }^{4}$

\footnotetext{
${ }^{43}$ See e.g. the reactions to the CJEU's judgment in Advocaten voor de Wereld, which was about the European Arrest Warrant. The CJEU quite quickly dispensed with the argument that this was contrary to the principle of legality of criminal offences and penalties, in a reasoning which has been called "disappointing in its brevity" (Raulus (2012) p. 194) "very laconic" (Albi (2010) p. 42) and as making "little effort to engage with its national counterparts” (Sarmiento, D. (2008)). CJEU Case C-303/05 Advocaten voor de WereldVZW v Leden van de Ministerraad, ECLI:EU:C:2007:261.

${ }^{44}$ Joined Cases C-404/15 and C-659/15 PPU Pál Aranyosi and Robert Căldăraru ECLI:EU:C:2016:198.

${ }^{45}$ See under 3.5.

${ }^{46}$ Peers (2011) p. 693.
} 
The N.S. and M.E. and others and Aranyosi and Căldăraru cases discussed in Section 6.3, below, show that exceptions to mutual recognition are only possible in very serious circumstances.

\subsubsection{Conclusion: the system of fundamental rights protection in the EU}

The previous sections considered whether fundamental rights in some way limit the free movement of judgments within the EU. It was concluded that the EU CFR certainly allows the CJEU to exercise control over the compatibility of EU legislation with fundamental rights, but that the CJEU has done so only to an extent. While it has acted as a fundamental rights court in the cases of Volker und Schecke and Test-Achats, the Zarraga case presents a different picture, perhaps because it concerned the compatibility of mutual recognition with fundamental rights. The following sections show that the compatibility of mutual recognition with fundamental rights has been problematic for the CJEU, and that it has been reticent in its examination of this issue. It is not at this point entirely clear what the reason is for this reticence. A possible explanation is that the instruments in these fields tend to be the result of complicated and intense negotiations, which is certainly true for the EAW and the Brussels II bis Regulations, and the CJEU might not consider itself to be in a position to harshly criticize a complicated political compromise. This explanation is certainly supported by the CJEU's judgment in Melloni, discussed in Section 6.4, in which the CJEU considered the existence of a "European consensus" as a reason not to allow national courts to apply national constitutional principles that diverge from this consensus. In this judgment, it also only briefly discussed the conformity of the legislation at issue with the ECHR, and did not even address the question whether it would be opportune for the EU to provide more extensive protection. It can be argued that the CJEU was prepared to find fault with the system of remedies of the EOP Regulation in eco cosmetics/Raiffeisenbank, but this case concerned a clear gap in fundamental rights protection and may therefore be an anomaly.

\section{3 'Systemic deficiencies' in fundamental rights protection: N.S. and M.E. and others}

\subsubsection{The rule: mutual recognition entails a presumption that fundamental rights are protected}

It has been repeatedly shown that secondary EU legislation based on the principle of mutual recognition requires and supposes mutual trust between the Member States. This mutual trust obliges Member States to work on the presumption that their fellow Member States adequately uphold fundamental rights or other standards. In many legal instruments, this trust is not blind but is based on common (minimum) standards incorporated into the legislative instrument concerned. 
This phenomenon and its implications for fundamental rights have been much debated, especially in the areas of criminal law, asylum law, and migration law. ${ }^{47}$ Many have doubted whether it is wise to expect Member States to rely on such a presumption and to abolish checks at the national level, especially when this is done in the name of creating a European Area of Freedom, Security and Justice. ${ }^{48}$ It is not surprising that the implementation of mutual recognition has been especially controversial in the areas mentioned, since in these areas the risk of interference with individual fundamental rights is considerable: criminal law essentailly regulates the exercise of State power against an individual, and the rights and freedoms enjoyed by that individual against State intervention. ${ }^{49}$ In the fields of criminal, migration and asylum law, the introduction of the principle of mutual recognition and underlying assumption of trust has raised cause for concern, and the question of how to reconcile mutual recognition with fundamental rights has been the subject of much research and debate. ${ }^{50}$

The trust Member States should have that fundamental rights are adequately protected throughout the EU is an essential prerequisite of mutual recognition. From policy documents such as the 2010 Stockholm Programme it is clear that the purpose of mutual trust is efficiency in the cooperation between Member States. ${ }^{51}$ The idea is that if Member States are able to trust that judicial systems and other fundamental rights safeguards are of equal and adequate quality throughout the Union, this reduces the need for intermediate checks, increasing efficiency. It is also stressed in the policy documents that mutual trust needs to be built by increasing exchange of information and cooperation between legal systems and judicial authorities, ${ }^{52}$ but also by creating common norms, such as the rules on strengthening the procedural rights of suspected or accused persons in criminal proceedings which were being developed at the time. $^{53}$

The regulations resulting from the implementation of mutual recognition in the various fields all work on the principle that mutual trust between the Member States is justified and respected. The discussion of the Zarraga, CJEU Povse, and Rinau cases ${ }^{54}$ all show that the enforcing Member States in those situations were expected by the regulations to rely on mutual trust and not substitute their own assessment of the fundamental rights situation for that of the State of origin. The CJEU's ruling in Melloni, discussed in detail below, shows that the same is true for

\footnotetext{
${ }^{47}$ E.g. Thunberg Schunke (2013); Battjes et al. (2011).

${ }^{48}$ Peers (2011).

${ }^{49}$ Mitsilegas (2006) p. 1280.

${ }^{50}$ Battjes et al. (2011) p. 6; Thunberg Schunke (2013); Ouwerkerk (2011).

${ }^{51}$ Stockholm Programme, para. 1.2.1.

${ }^{52}$ Stockholm Programme, p. 13-14; The Hague Programme para. 3.2.

${ }^{53}$ Stockholm Programme para. 2.4; in 2009 the European Council adopted a "Roadmap" on procedural rights in criminal proceedings (11457/09, DROIPEN 53, COPEN 120) which in turn formed the basis for Directives on translation (2010/64/EU) and the right to information (2012/13/EU).

${ }^{54}$ See Chapter 5.4.1.2.
} 
the EAW in the field of criminal law. In the field of asylum law, the Dublin II Regulation ${ }^{55}$ and the recast Dublin III Regulation ${ }^{56}$ operate on the same principle. These Regulations create a Common European Asylum System (CEAS) by laying down rules that determine which Member State is responsible for examining an asylum application. The principle of mutual recognition as implemented by that Regulation entailed that when asylum seekers make their way to another Member State, this state should send them back to the Member State that is responsible for examining the asylum application on the basis of the Regulation. Mutual trust in the context of the Dublin system entails that all Member States are expected to treat asylum seekers and examine their applications in conformity with the relevant rules of national, EU and international law. ${ }^{57}$

In the context of the CEAS, however, it has been decided that this mutual trust cannot be absolute. According to the CJEU, there should be a possibility to rebut the presumption that fundamental rights are respected in the Member State to which the asylum seeker is to be returned, when there is evidence that this is clearly not the case. This exception is the result of the CJEU's ruling in N.S. and M.E. and others, and is the consequence of the ECtHR's judgment in M.S.S. v. Belgium and Greece, which was discussed in the preceding Chapter. The following section analyses the CJEU judgment. ${ }^{58}$ It is considered what implications N.S. and M.E. and others has for the functioning of mutual recognition in the field of civil justice.

\subsubsection{The exception: presumption can be rebutted in case of systemic deficiencies}

In M.S.S. v. Belgium and Greece, the ECtHR had found that Belgium violated Article 3 of the ECHR, the prohibition on torture. The ECtHR decided that Belgium could be held accountable because even though it had acted in the application of EU law, it had nevertheless enjoyed discretion under the "humanitarian clause" (Art. 3(2) of the Dublin II Regulation). It then decided that Belgium had violated Article 3 ECHR because it had not used this clause to prevent the forced return of M.S.S. to Greece (the Member State responsible for examining his asylum application) because it was well known at the time that the conditions to which asylum seekers were subjected in Greece were incompatible with that Article. ${ }^{59}$

\footnotetext{
${ }^{55}$ Council Regulation (EC) No. 343/2003 of 18 February 2003 establishing the criteria and mechanisms for determining the Member State responsible for examining an asylum application lodged in one of the Member States by a third-country national, OJ L 50/01, the "Dublin II Regulation".

${ }^{56}$ Regulation (EU) No 604/2013 of the European Parliament and of the Council of 26 June 2013 establishing the criteria and mechanisms for determining the Member State responsible for examining an application for international protection lodged in one of the Member States by a third-country national or a stateless person, OJ L 180/31 (the "Dublin III Regulation').

${ }^{57}$ See Battjes et al. (2011) p. 9.

${ }^{58}$ For more information on the preceding ECtHR judgment in M.S.S. v. Belgium and Greece, see Chapter 5.4.5.

${ }^{59}$ See for a comprehensive discussion of the M.S.S. v. Belgium and Greece judgment Chapter 5.4.5.
} 
With this judgment, the ECtHR clearly puts the principle of mutual trust underlying the CEAS under pressure. As a result of this judgment, there are situations in which a Member State may not rely on mutual trust, but should make an assessment of the risks the asylum seeker will be subjected to in the Member State to which he should be returned. This judgment was expected to have major repercussions for the CEAS and other fields of law in which mutual trust plays an important role, and the CJEU's interpretation of the judgment was eagerly awaited. ${ }^{60}$

The CJEU was able to give its interpretation in N.S. and M.E. and Others. ${ }^{61}$ The judgment concerns two joined cases. In the first, N.S., an Afghan national, challenged the decision of the Secretary of State of the United Kingdom (UK) to return him to Greece, which was responsible under the Dublin II Regulation for examining his asylum applications. The case of M.E. and others concerned five persons who challenged a similar decision of the Irish authorities to return them to Greece. All the persons involved argued that the UK and Ireland, as transferring Member States, should refrain from transferring them to Greece because of the risks they would be subjected to in that country. The UK and Irish courts asked the CJEU whether they were obliged to make an assessment of the compliance of Greece with the fundamental rights and provisions of EU asylum law, and what the consequences of a finding of non-conformity should be.

The CJEU started its answer of these questions by stressing that the CEAS was based on the full and inclusive application of international and European rules ${ }^{62}$ that guarantee that no person should be sent back to a place where they would be persecuted. It also cited its own judgment in Lindqvist, mentioned above, to emphasize that Member States must, when they apply secondary EU legislation, make sure that they do not rely on an interpretation of that legislation which is contrary to fundamental rights. ${ }^{63}$

Next, the CJEU discussed the issue of mutual trust. It started by stating that the CEAS was "conceived in a context making it possible to assume that all participating States [...] observe fundamental rights, and that Member States can have confidence in each other in that regard." The EU legislature, according to the Court, was therefore able to use this principle of "mutual confidence" in legislation, in such a way as to speed up and simplify the handling of asylum applications within the EU. Nevertheless, the CJEU stated:

[I]t is not inconceivable that that system may, in practice, experience major operational problems in a given Member State, meaning that there is a substantial risk that asylum seekers may, when transferred to that Member State, be treated in a manner incompatible with their fundamental rights. (para. 81)

The CJEU then stated that not every minor infringement of the Regulations by the responsible Member State should have as a consequence that the asylum seeker could not be transferred to

\footnotetext{
${ }^{60}$ Den Heijer (2012) p. 1736.

${ }^{61}$ CJEU Joined Cases C-411/10 and C-493/10, N.S. and M.E. and others, ECLI:EU:C:2011:865.

62 Along with the Dublin II Regulation, Directives 2003/9, 2004/83 and 2005/85 contained minimum standards intended to protect the rights of asylum seekers.

${ }^{63} \mathrm{CJEU}$ Lindqvist; see Chapter 5.2.
} 
that State, as that would deprive the Regulation of its substance and endanger the realisation of its goal. However, the CJEU stated:

By contrast, if there are substantial grounds for believing that there are systemic flaws in the asylum system and reception conditions for asylum applicants in the Member State responsible, resulting in inhuman or degrading treatment, within the meaning of article 4 of the EU CFR, of asylum seekers transferred to the territory of that Member State, the transfer would be incompatible with that provision. (para. 86) (emphasis added)

The CJEU thus ruled that only "systemic flaws in the asylum system and reception conditions", as opposed to "the slightest infringement" of the Directives, could result in mutual trust not being justified and in an obligation for the transferring Member State not to transfer the asylum seeker to the State experiencing those systemic flaws. The CJEU considered it proven that Greece experienced such systemic deficiencies, and that the information available about those deficiencies, as cited by the ECtHR in M.S.S., enabled the transferring States to evaluate the risks to which the asylum seekers would be exposed. According to the Court, Member States may not transfer asylum seekers to another Member State when they

cannot be unaware that systemic deficiencies in the asylum procedure and in the reception conditions of asylum seekers in that Member State amount to substantial grounds for believing that the asylum seeker would face a real risk of being subjected to inhuman or degrading treatment within the meaning of Article 4 of the EU CFR. (para. 94) (emphasis added)

The CJEU concluded by stating that the CEAS could not be applied on the basis of a conclusive presumption that the asylum seeker's fundamental rights will be observed in the Member State to which he is to be transferred. Such a conclusive presumption "could itself be regarded as undermining the safeguards which are intended to ensure compliance with fundamental rights by the European Union and its Member States" (para. 100).

The conclusion of the Court is clear: while mutual trust is required for the effective functioning of the regulation establishing the CEAS, it cannot result in a conclusive and non-rebuttable presumption that fundamental rights are protected everywhere. However, the threshold for rebuttal is very high: it is only justified when "systemic deficiencies" give rise to "substantial grounds" for believing that the asylum seeker would be exposed to a "real risk".

The N.S. judgment is remarkable for acknowledging that mutual trust cannot be assumed in all circumstances: it must be based on real information as to the actual situation in the Member States. The CJEU acknowledges this by stating that the CEAS was "conceived in a context making it possible to assume that all Member States observe fundamental rights" (para. 78). It also clearly recognises that this context may change, and that circumstances in the Member States may in practice make it impossible to rely on mutual trust. The repercussions of this 
finding for the CEAS, and for other areas of EU law where mutual recognition may conflict with fundamental rights, has been acknowledged. ${ }^{64}$

In its recent judgment in Aranyosi and Căldăraru, ${ }^{65}$ the CJEU ruled that exceptions to mutual recognition should also be made in the context of the EAW. In the two cases leading to the judgment, the referring courts asked whether the execution of a EAW can be refused when the detention conditions in the Member State that requested the execution are incompatible with fundamental rights, in particular the prohibition on inhuman or degrading treatment or punishment (Art. 3 ECHR/Art. 4 CFR). The Framework Decision on the EAW (FD EAW) contains a strict and closed system of grounds for refusal, which does not include a possibility to refuse enforcement on the basis of concerns as to the fundamental rights situation in the requesting Member State. ${ }^{66}$ Citing its Opinion $2 / 13,{ }^{67}$ which in turn referred to N.S. and M.E. and others, the CJEU ruled that "limitations of the principles of mutual recognition and mutual trust between Member States can be made 'in exceptional circumstances"' (para. 82). The CJEU then acknowledged that the prohibition on inhuman or degrading treatment or punishment is absolute and cannot be derogated from (para. 85). According to the CJEU,

It follows that, where the judicial authority of the executing Member State is in possession of evidence of a real risk of inhuman or degrading treatment of individuals detained in the issuing Member State, having regard to the standard of protection of fundamental rights guaranteed by EU law and, in particular, by Article 4 of the Charter [...], that judicial authority is bound to assess the existence of that risk when it is called upon to decide on the surrender to the authorities of the issuing Member State of the individual sought by a European arrest warrant. The consequence of the execution of such a warrant must not be that that individual suffers inhuman or degrading treatment. (emphasis added) (para. 88).

The CJEU then gave a number of quite specific guidelines regarding how the court should proceed in such cases. Initially the court should determine, on the basis of "objective, reliable, specific and properly updated" information, that there is a "real risk" of the individual concerned being subjected to unacceptable detention conditions (para. 92). The court must then "assess whether there are substantial grounds to believe that the individual concerned will be exposed to that risk" (para. 92). Interestingly, the CJEU added that:

the mere existence of evidence that there are deficiencies, which may be systemic or generalised, or which may affect certain groups of people, or which may affect certain places of detention, with respect to detention conditions in the issuing Member State does not necessarily imply that, in a specific case, the individual concerned will be

\footnotetext{
${ }^{64}$ Den Heijer (2012) p. 1736; Billing (2012); Brouwer (2013). The "systemic flaws" exception was incorporated into the recast Dublin Regulation: Dublin III Regulation, Article 3(2).

${ }^{65}$ Joined Cases C-404/15 and C-659/15 PPU Pál Aranyosi and Robert Căldăraru ECLI:EU:C:2016:198.

${ }^{66}$ See the discussion on CJEU Melloni under 6.4.

${ }^{67}$ Opinion 2/13 of the Court (Full Court) of 18 December 2014, ECLI:EU:C:2014:2454.
} 
subject to inhuman or degrading treatment in the event that he is surrendered to the authorities of that Member State (para. 93).

It seems that, unlike in N.S. and M.E. and others, the CJEU does not require that deficiencies be "systemic". What matters is the real risk to the individual concerned.

The CJEU's finding of an exception to mutual recognition in the field of criminal justice is remarkable, especially considering its earlier strict stance in Melloni, discussed below. It is commendable that the CJEU recognised that deficiencies in fundamental rights protection should be able to justify an exception to mutual recognition where one does not already exist in legislation. The question now is whether the approach developed by the CJEU in N.S. and M.E. and others and Aranyosi and Căldăraru can be applied to civil cases.

\subsubsection{Can this exception be applied in the field of civil procedure?}

The question now is what, if any, repercussions the judgments discussed have for the field of civil procedure. This requires an appraisal of the function of mutual trust in the different areas and the consequences if that mutual trust were considered to be rebuttable. In this regard, it is helpful that such an appraisal has already been made for the field of EU criminal law, in which some important aspects have already been identified.

\subsubsection{Goal and function of mutual trust and the conditions for rebuttal}

It was discussed above that the goal of mutual trust in the context of the CEAS is to promote efficiency", 68 facilitating cooperation between Member States, and by doing so, discouraging asylum seekers from submitting applications in multiple states. It allows Member States to transfer asylum seekers to the Member State responsible under the Regulation, on the basis of a presumption that they will be treated in accordance with all relevant rules. If such a presumption were not possible, the Member State could be compelled to make, in each case, make an assessment of the risks the asylum seeker may be exposed to in the future, ${ }^{69}$ which would reduce efficiency. Various studies into the function of mutual trust in the field of criminal law conclude that this is similar: mutual trust allows Member States to extradite persons for whom a EAW has been issued without on the basis of mutual recognition, though there are a number of refusal grounds. ${ }^{70}$ It is clear that in both situations mutual trust primarily concerns the risks that the person concerned (the asylum seeker, or accused or convicted person in criminal cases) will be exposed to in the future. The EAW intends to achieve "the arrest and surrender by another Member State of a requested person, for the purposes of conducting a criminal prosecution or executing a custodial sentence or detention order" (Art. 1(1)). The

\footnotetext{
${ }^{68}$ Stockholm Programme (2010) p. 5.

${ }^{69}$ As discussed, the ECtHR has ruled that in cases where asylum seekers are transferred to third (non-ECHR) states, the ECHR imposes an obligation on Contracting States not to expel a person to a country where substantial grounds have been shown for believing that he would face a real risk of being subjected to treatment contrary to Article 3; see among others ECtHR T.I. v. United Kingdom [dec.] 43844/98 ECHR 2000-III.

${ }^{70}$ Art. 1(2) EAW FD; Refusal grounds art. 3 and 4.
} 
execution of an EAW therefore exposes the requested person to a future criminal prosecution or a detention, during which he may be subject to fundamental rights risks. Likewise, the obligation to transfer an asylum seeker back to the Member State responsible for his asylum application exposes the asylum seeker to the circumstances that exist in that Member State with regard to the reception and treatment of asylum seekers.

The assessment of the conditions that persons will be subjected to in future is a difficult task, which is why it is more efficient for judicial authorities to rely on a presumption that these will be in accordance with fundamental rights. It is presumably for this reason that the CJEU has in $N . S$. set a high standard for the presumption to be rebutted: this is only the case where a judicial authority "cannot be unaware" of "systemic deficiencies" which amount to "substantial grounds for believing that there is a real risk". It has been argued that the "cannot be unaware" notion reflects the permissibility of a presumption that fundamental rights are complied with, which can only be rebutted when there is clear and publicly available evidence to the contrary. ${ }^{71}$ The presumption is kept intact, because a national judicial authority does not need to conduct its own investigation into the situation in the other Member State; the deficiencies in that Member State must be sufficiently widespread and well-documented that such information is already available. In Aranyosi and Căldăraru, the CJEU did not use the phrase "cannot be unaware". It is not entirely clear from that judgment whether executing authorities are obligated to carry out research as to the detention conditions in a Member State prior to transferring an individual there. The judgment implies that only "where the judicial authority of the executing Member State is in possession of evidence or a real risk", the authority should research whether it is likely that the individual will be exposed to the risk (para. 88). However, the CJEU also states that "to that end, the executing judicial authority must rely on information that is objective, reliable, specific, and properly updated" (para. 89), and names a number of sources that can be used, such as judgments of the ECtHR. This implies an obligation for the executing authority to keep itself informed on the detention situations in fellow EU Member States, at least to a level sufficient to allow it to identify a potential risk.

It does appear from both judgments that the problems with detention conditions should be widespread and well reported. This will likely not be the case where only individual and isolated incidents have occurred. This high standard is also encompassed in the notion of "systemic deficiencies", which points towards deficiencies that are widespread and serious. ${ }^{72}$ Moreover, these circumstances must amount to a "substantial grounds for believing that there is a real risk" for the person concerned, which should be interpreted as a foreseeable and serious risk. ${ }^{73}$

The question now is what the function of mutual trust is in the field of civil procedure and how it is applied. As was discussed at length in Chapters 2 and 3, the implementation of mutual recognition in this field has taken the shape of the progressive abolition of intermediate checks

\footnotetext{
${ }^{71}$ Costello (2012) p. 89.

${ }^{72}$ Costello (2012) p. 89.

${ }^{73}$ Costello (2012) p. 90.
} 
on the enforcement of judgments from other Member States. Mutual trust in this context means that judicial authorities in the Member States must assume that judgments from other Member States conform to the relevant law, including fundamental rights, and that they may not refuse to enforce them or otherwise exercise control if they feel that this is not the case. The goal here, again, is efficiency: it is more efficient for the judgment creditor (or other beneficiary) if they can have their judgment enforced throughout the Union without having to go through further procedural hurdles.

While the goal of mutual trust is therefore the same, there is an important difference between the function of mutual trust between the different fields. As discussed above, in the fields of criminal and asylum law mutual trust exempts the judicial authority from having to make a prospective analysis of the future risks to which the person concerned will likely be subjected. This requires not only detailed knowledge of the situation in the Member State where he is to be sent to, but also an assessment of the risks that these will pose to the person concerned. The lesson from the N.S. and Aranyosi and Căldăraru judgments is therefore, that a national judicial authority cannot be expected to make such an assessment unless the evidence is publicly available and there are substantial grounds for believing that the person will be subjected to serious risks.

In the field of civil procedure, the task of the national judge is different. If they were not able to rely on mutual trust, they would have to examine in a particular case whether fundamental rights were complied with in the Member State of origin of the judgment. While this would certainly reduce efficiency if it needed to be done in each case, the burden placed on the judge need not be as heavy in an individual case. This is because, when a judgment is presented to him for enforcement, he is dealing with an isolated case, in which the individual risk to the parties does not need to be proven, and in which the fundamental rights infringement, if it happened, should be relatively easy to identify. More importantly however, in cases where the enforcement of a judgment is requested, the judgment has already been delivered and the fundamental rights infringement therefore has already occurred. ${ }^{74}$ We are therefore not dealing with a prospective assessment of a future risk that a person may encounter, but with an infringement that has already occurred and which should be obvious from the judgment itself or the case file.

\subsubsection{Evidentiary standard: "cannot be unaware"}

It is therefore submitted that the exception to mutual trust that the CJEU has made in the N.S. case should also be applicable in the area of civil procedure and to the cross-border enforcement of judgments, but that the evidentiary standard can potentially be lower. The efficiency loss that is caused by requiring a judge to assess, retrospectively, whether an infringement occurred in a particular case is not as great as that which would be caused by requiring a judge to prospectively assess the potential risks to which an asylum seeker would be subjected. This is

\footnotetext{
${ }^{74}$ See on this point also Corthaut (2012) p. 186.
} 
because evidence will be already available to the judge, because an individual risk does not need to be proven, and because the assessment concerns an infringement that has already occurred, not a future risk.

\subsubsection{Threshold: "systemic deficiencies" giving rise to a "real risk"}

The next question is what the threshold would be for considering mutual trust to be rebutted. In the N.S. judgment the CJEU required "systemic deficiencies" or "major operational problems" to exist, though it appears to nuance this somewhat in Aranyosi and Căldăraru. Firstly, as has been argued elsewhere, this notion does not appear in the ECtHR's M.S.S. judgment, and would therefore, if it were seen as an additional threshold, not be incompatible with the interpretation of Article 3 ECHR in that case. Since the EU CFR binds the EU to the ECtHR's interpretation of this right, such an additional threshold would not be allowed. It has therefore been argued that the "systemic" element should not be seen as an additional hurdle. This seems justified, since, apart from the fact that the ECtHR judgment does not allow it, for the individual it does not matter whether he is the victim of a systemic or an isolated deficiency. It is therefore submitted that the threshold cannot lie at systemic failures, but at such a level that allows for isolated incidents to refute mutual trust, yet does not encompass every minor transgression. It in fact appears that the 'systemic' threshold may be incompatible with the ECtHR's recent judgment in Tarakhel v. Switzerland. ${ }^{75}$ In this important case, it decided that Switzerland could not under the Dublin system send back asylum seekers to Italy, where they were first registered. In this case the ECtHR found that the fact that Italy could not give assurances that accommodation would be available for all members of the family concerned together in itself constituted a violation of Article 3 EHCR ${ }^{76}$ It also explicitly stated, "the current situation in Italy can in no way be compared to the situation in Greece at the time of the M.S.S. judgment". ${ }^{77}$ On the face of it, this constitutes a lowering of the threshold of 'systemic deficiencies'. 78

Finally, the question should be asked if it matters that N.S. concerned the prohibition on torture (Arts. 3 ECHR/4 CFR), a right that is considered notstandsfest, in the sense that it may under no circumstances be interfered with (Art. 15 ECHR). It is also absolute - Article 3 ECHR contains no limitation clauses. ${ }^{79}$ It is possible that infringements of the right to a fair trial, which is considered to leave a greater margin of appreciation to the parties to the $\mathrm{ECHR},{ }^{80}$ might not be considered as serious and capable of precluding mutual trust as (possible) infringements of

\footnotetext{
${ }^{75}$ ECtHR Tarakhel v. Switzerland [GC], appl. no. 29217/12, ECHR 2014.

${ }^{76}$ ECtHR Tarakhel v. Switzerland, para. 22.

${ }^{77}$ ECtHR Tarakhel v. Switzerland, para. 114.

${ }^{78}$ See for an analysis Peers, S., Tarakhel $v$ Switzerland: Another nail in the coffin of the Dublin system?, http://www.eulawanalysis.blogspot.com, 5 November 2014 (last accesed 4 May 2016).

${ }^{79}$ Gerards (2011) p. 103.

${ }^{80} \operatorname{Legg}(2012)$ p. 210.
} 
the prohibition on torture. Here, there are two counterarguments. The first is that the ECHR does not establish a hierarchy of rights, and that therefore not one right can be considered more "important" than the other. The second is that, as articulated by the CJEU itself in N.S., it cannot be accepted that mutual trust, which is intended to facilitate the respect for fundamental rights within a European Area of Freedom, Security and Justice, could itself undermine those fundamental rights. ${ }^{81}$ It should not, in that context, matter which fundamental rights are at issue; if the EU is founded on a respect for fundamental rights, this should encompass all fundamental rights. It is submitted that this is especially unacceptable when, as is the case in the context of enforcement of judgments, the infringement will already have occurred and should be clearly identifiable.

\subsubsection{Conclusion}

The cases of M.S. and N.E. and others and Aranyosi and Căldăraru show that mutual trust is not always justified. Fundamental rights violations simply occur, even in an EU where all Member States have ratified the ECHR. This is a reality that cannot be ignored. It is correct that in N.S. and M.E. and others, the CJEU created an exception to the rule that mutual recognition is absolute. This thesis has repeatedly argued that deficiencies in fundamental rights protection may occur in the field of civil justice just as they may in the field of asylum law. For that reason, the preceding sections have argued that the exception created in N.S. and M.E. and others and Aranyosi and Căldăraru should also be available for civil justice cases.

The preceding sections however argued that the yardstick the CJEU developed, that the deficiencies should be systemic, is understandable for fields of law where mutual trust applies prospectively, such as asylum law. In civil justice however mutual trust applies retrospectively, to proceedings that have already taken place. This means that an exception to the rule of mutual trust is all the more necessary and acceptable from the viewpoint of efficiency, since the judge in a civil case is not required to prospectively assess possible risks and in so doing make a statement about the fundamental rights situation in another Member State. Rather, they can decide, in an individual case and on the basis of the evidence already available in the judgment and the case file, whether an infringement has occurred. This means that the requirement of "systemic" deficiencies does not need to apply. Chapter 7.3 further develops the threshold that should be applied and the way in which this should be operationalised.

\subsection{The Court of Justice of the European Union's Melloni decision: Member State fundamental rights and mutual recognition}

${ }^{81}$ CJEU N.S. and M.E. and others, para. 100. 
The previous section showed that concerns about the practice of fundamental rights protection in a Member State can, in exceptional circumstances, act as an obstacle to mutual recognition and may therefore restrict the free movement of judgments. This section looks at a final category of fundamental rights norms that exist within the EU: the rights guaranteed by the Member States' constitutions. ${ }^{82}$

Member States' constitutions have an important role in the multi-layered legal order that is the EU. The CJEU has ensured this by citing "the constitutional traditions common to the Member States" as a source of inspiration for the general principles of EU law. ${ }^{83}$ The EU CFR acknowledges the importance of the Member States' constitutions in Article 53. This Article provides that

Nothing in this EU CFR shall be interpreted as restricting or adversely affecting human rights and fundamental freedoms as recognised [...] by the Member States' constitutions.

When the EU CFR entered into force in 2001, the meaning of this provision was already subject to discussion. It was considered that a literal interpretation of this provision would entail that if a Member States' constitution provided a higher standard than the EU CFR, this higher standard should prevail, meaning essentially that Member States' constitutions could stand in the way of an EU decision or policy. Such a literal interpretation was considered a threat to the primacy of EU law. ${ }^{84}$ The Explanations provide little clarity, merely stating that the provision is intended to maintain the level of protection afforded "within their respective scope" by EU law, national law, and international law.

Since then, the CJEU has been given the opportunity to rule on the matter in the Melloni case, and expanded on its reasoning in Akerberg Fransson. Together, the judgments provide an interpretation of Article 53 that is guided by the principle of effectiveness of EU law.

\subsubsection{The CJEU's judgment in Melloni}

\subsubsection{The questions posed to the CJEU}

The Melloni case ${ }^{85}$ concerned the execution of an EAW issued by an Italian court for the execution of a sentence imposed on Mr Melloni, an Italian national, for bankruptcy fraud. $\mathrm{Mr}$ Melloni was arrested in Spain, and the court authorised his surrender to the Italian authorities.

\footnotetext{
${ }^{82}$ See Craig and de Bùrca (2015) p. 388-390, who explain that the CJEU has proved itself reluctant to ascribe too much importance to Member States' conceptions of fundamental rights.

${ }^{83}$ Case 11-70 Internationale Handelsgesellschaft mbH $v$ Einfuhr- und Vorratsstelle für Getreide und

Futtermittel, ECLI:EU:C:1970:114, para. 4.

${ }^{84}$ Heringa and Verhey (2001) p. 18.

${ }^{85}$ See for a discussion N. de Boer (2013); De Visser (2013); Veldt-Foglia (2013).
} 
Mr Melloni sought to challenge the surrender by filing a recurso de amparo (petition for constitutional protection) against the order before the Tribunal Constitucional (Constitutional Court). His argument was essentially that he had been convicted without him being present (in absentia), though he had been represented by two lawyers. Mr Melloni contended that Italian law prevented him from appealing the sentence imposed in absentia, which amounted to a violation of his right to a fair trial. He submitted therefore that the execution of the EAW should be made subject to the condition that an appeal against the findings of guilt in the original judgment would be available. ${ }^{86}$ The Spanish Constitutional Court requested a preliminary ruling from the CJEU, asking whether it could refuse to execute the EAW requesting the surrender of Mr Melloni.

It identified three possible grounds for such a refusal: firstly, it asked whether the FD EAW (as amended $)^{87}$ allowed a refusal of execution on these grounds, or whether it should be seen as exhaustively governing the conditions in which execution may be refused. Secondly, it asked whether the Framework Decision could be considered compatible with the right to a fair trial and the rights of the defence as laid down in Articles 47 and 48(2) of the EU CFR. Finally, it asked whether, if the Framework Decision was indeed found to be in breach of the right to a fair trial, the national court would be allowed on the basis of Article 53 of the EU CFR to make the execution of an EAW dependent on the conviction being open to review in the requesting State, "thus affording those rights a greater level of protection than that deriving from European Union law, in order to avoid an interpretation which restricts or adversely affects a fundamental right recognised by the constitution of the first-mentioned Member State." 88

As already discussed under Section 6.3.2, the EAW is based on the principle of mutual recognition. This is expressed in, among other things, the limited number of grounds for refusal to execute the EAW contained in the FD EAW. Moreover, the Article of that Framework Decision that dealt with convictions in absentia had been replaced with new rules contained in Framework Decision 2009/299, which sought to clarify the circumstances in which the execution of an EAW rendered for the purpose of executing a sentence imposed in absentia could legitimately be refused. These circumstances were laid down in Article 4a(1) of Framework Decision 2009/299, which states that an executing judicial authority "may also

\footnotetext{
${ }^{86}$ This argument had already been examined by the Spanish Constitutional Court in a case from 2009, whose facts were virtually the same. In that case the Constitutional Court ruled the execution of the EAW to be unconstitutional, an outcome which was at the time criticized as being in conflict with EU law. Spanish Constitutional Court, judgment of 28 September 2009, STC 199/2009, para. 3. Apart from its significance for EU law, the Melloni case is therefore also remarkable for the fact that this time around the Spanish Constitutional Court recognized the potential conflict and, for the first time in its existence, requested a preliminary ruling; see Torres Pérez (2012) p. 108-109.

${ }^{87}$ Council Framework Decision 2002/584/JHA on the European arrest warrant and the surrender procedures between Member States, OJ L 190/001, as amended by Council Framework Decision 2009/299/JHA of 26 February 2009 amending Framework Decisions 2002/584/JHA, 2005/214/JHA, 2006/783/JHA, 2008/909/JHA and 2008/947/JHA, thereby enhancing the procedural rights of persons and fostering the application of the principle of mutual recognition to decisions rendered in the absence of the person concerned at the trial, OJ L $81 / 24$.

${ }^{88}$ CJEU Melloni para. 26.
} 
refuse to execute the European Arrest Warrant issued for the purpose of executing a custodial sentence or a detention order if the person concerned did not appear in person at the trial resulting in the decision [...]" (emphasis added) unless one of the circumstances enumerated in the rest of the provision applies, which pertain to the provision of information to the person concerned. Essentially, the provision lists a number of situations in which the person concerned can be assumed to have known about the trial, and his being absent can therefore be seen as a choice. Only when these circumstances do not apply may the execution of the EAW be refused. In this way, the provision limits the circumstances in which the execution of an EAW may be refused.

6.4.1.2 The CJEU's reasoning: does the secondary legislation express a European consensus?

The CJEU concluded that the FD EAW portrayed a European consensus as to the appropriate level of fundamental rights protection. It analysed the FD EAW and the amending acts to establish that these indeed reflected such a consensus. It reiterated that the FD EAW is based on the principle of mutual recognition and that this entails that the grounds for non-execution are limited and exhaustively governed by the FD EAW and its amending acts (paras. 35-46). It looked at the wording of the provisions and the objectives of the Framework Decision, as expressed in its recitals. On the basis of these elements, it came to the conclusion, answering the Spanish Constitutional Court's first question, that the FD EAW intended to exhaustively govern the conditions in which the execution of an EAW could be refused where a sentence had been imposed in absentia.

The CJEU then examined the Spanish Court's second question, coming to the conclusion that the FD EAW were in conformity with the ECtHR's case law on this point. With regard to the third question, the CJEU came to the conclusion that an interpretation of Article 53 of the EU CFR that allowed a national court to refuse execution on the basis of national constitutional rights would be unacceptable, as it would undermine the principle of primacy of EU law. It stated that the legislature had clearly intended to exhaustively harmonise the grounds for nonexecution in the FD EAW and its amending acts (as already concluded with regard to the first question), and that the those conditions reflected "the consensus reached by all the Member States regarding the scope to be given under EU law to the procedural rights enjoyed by persons convicted in absentia." Allowing a Member State to apply Article 53 of the EU CFR in such a way as to allow it to apply national norms over and above those laid down in the FD EAW would "undermine the principles of mutual trust and recognition [...] by casting doubt on the uniformity of the standard of protection of fundamental rights as defined in that framework decision"(para. 63).

Whether or not Member States are allowed to apply national constitutional standards when they interpret EU secondary legislation is therefore dependent on the degree of harmonisation of fundamental rights standards that the legislation has sought to achieve: the European consensus. That this is so is confirmed by the CJEU itself in Akerberg Fransson. In that 
judgment, the CJEU was asked to rule on the conformity of national legislation (which implemented EU law, but had not been designed for that purpose) with the EU CFR. The CJEU ruled as follows:

[...] where a court of a Member State is called upon to review whether fundamental rights are complied with by a national provision or measure which, in a situation where action of the Member States is not entirely determined by European Union law, implements the latter for the purposes of Article 51(1) of the EU CFR, national authorities and courts remain free to apply national standards of protection of fundamental rights, provided that the level of protection provided for by the EU CFR, as interpreted by the Court, and the primacy, unity and effectiveness of European Union law are not thereby compromised. (para. 29) (emphasis added)

The primary requirement seems to be the presence of a consensus reached at the European level regarding the level of fundamental rights protection to be provided, which in this case was obvious from the provision's legislative history. On this point the Court accepted the approach proposed by Advocate-General (A-G) Bot in his Opinion in Melloni. Paragraphs 124 to 128 of this Opinion further clarify the distinction.

According to A-G Bot in his Opinion in Melloni, it is necessary to differentiate between situations where "there is a definition at the European level of the degree of protection which must be afforded to a fundamental right", and situations in which there is no such European definition. A-G Bot links this to the objectives of the EU action concerned. According to him, the definition of a European level of protection

reflects a balance between the need to ensure the effectiveness of European Union action and the need to provide adequate protection for fundamental rights. In that situation, it is clear that, if a Member State were to invoke, a posteriori, the retention of its higher level of protection, the effect would be to upset the balance achieved by the European Union legislature and therefore to jeopardise the application of European Union law. (para. 125).

What is necessary is therefore that the level of fundamental rights protection has been determined at the European level with the purpose of ensuring the effective application of EU law. The qualification of "a posteriori" makes clear that the time for Member States to oppose such a European determination on the basis of national principles is during the legislative process, when the European consensus is being reached; not at the stage of application.

\subsubsection{Effectiveness as the decisive factor}

The lesson to be drawn from the CJEU's Melloni judgment is that Member States' national fundamental rights standards cannot be applied to the detriment of the effectiveness of EU legislation. When EU secondary legislation contains a European consensus as to the appropriate level of fundamental rights protection, Member States are not allowed to apply higher national standards. To do so would diminish the effectiveness of that legislation. 
Whether application of national fundamental rights standards would diminish the legislation's effectiveness depends in part on the level of discretion that Member States enjoy in the application of that legislation. Where standards are exhaustively harmonised, application of national standards is more likely to render implementation of the legislation less effective. Regulations in the field of judicial cooperation, both in criminal and civil justice, often rely on a high degree of harmonisation of standards in order to facilitate mutual recognition. The FD EAW had been amended with the purpose of avoiding any uncertainty as to the conditions that could be attached to non-execution of an EAW. It is understandable from the perspective of effectiveness that Member States should not be allowed to apply higher national standards. This would be different in cases where EU legislation leaves a lot of room for implementation or interpretation, such as in the case of Directives. This is clear from the CJEU's pronouncement in Akerberg Fransson cited above: where action of the Member States is not entirely determined by EU law, national authorities and courts remain free to apply national standards of protection of fundamental rights.

\subsubsection{Conclusions}

Melloni is an important judgment because it shows that fundamental rights standards in EU legislation are, unless explicitly stated otherwise, maximum standards. This is highly relevant to the field of EU civil procedure law, because the Regulations in this field often rely on harmonised standards in order to facilitate mutual trust. Melloni shows that Member State courts' room for applying national, even constitutional, standards is very much limited by the principle of effectiveness.

Another equally important lesson is that, if fundamental rights standards in EU secondary legislation are to be maximum standards, they must be sufficient to protect those fundamental rights effectively. This places a great deal of trust in the legislature - perhaps too much. ${ }^{89}$

\subsubsection{Application of the Melloni doctrine to EU civil procedure law}

The following sections seek to ascertain what the repercussions are of the Melloni judgment for the application of EU civil procedure law. The preceding analysis showed that whether the wording, scheme and purpose of the Regulations in that field can be said to express a European consensus is vital, and it is therefore necessary to analyse the Regulations discussed in this book against background. However, since the text of the Regulations was already discussed in detail in Chapters 2 and 3, the following sections refer back to those Chapters where appropriate.

${ }^{89}$ See Besselink (2014). 
It has been discussed that most EU Regulations in the field of civil justice rely on mutual recognition combined with common minimum standards. Some Regulations leave considerably more leeway to the Member States in their application and implementation than others. As the previous analysis of Melloni showed, the level of discretion left to the Member States largely determines whether they have any room to apply national fundamental rights standards. As Chapter 2 made clear, the Regulations that have abolished exequatur and refusal grounds rely heavily on harmonized standards of fundamental rights protection, whereas others do not. For the former category, application of national fundamental rights standards would probably sooner impart their effectiveness than for the latter category. The following discusses these two categories separately.

\subsubsection{Application to Regulations which contain grounds for refusal}

There is no doubt that the principle of effectiveness governs the application of the refusal grounds contained in the European regulations. The CJEU consistently rules that refusal grounds must be applied restrictively so as not to render the objective of those regulations, effective cross-border enforcement, completely unattainable. ${ }^{90}$ In Prism Investments it also clarified that the refusal grounds are limitative. ${ }^{91}$

At the same time, both the public policy exception (Art. 45(1)(a) of Brussels I bis) and the protection for the defaulting debtor (Art. 45(1)(b)) explicitly leave room for interpretation. While the CJEU has restricted the application of the public policy exception to "manifest" breaches of "fundamental" principles, ${ }^{92}$ and linked the principle of public policy to the rights laid down in the ECHR, ${ }^{93}$ it remains up to the Member States court to determine whether enforcement or recognition would in a given case be contrary to public policy. As for the protection of the defaulting defendant, it should be interpreted strictly, ${ }^{94}$ but it is still up to the Member State court whether the defendant was left with 'sufficient time to enable him to arrange for his defence'.

It is clear that together, these grounds for refusal are intended to be limitative: the CJEU has confirmed that they do not overlap and that the public policy exception has a residual function. ${ }^{95}$ Applying the Melloni test, this means that no higher national grounds of fundamental rights protection can be applied. Article 41(2) of Brussels I bis should be interpreted correspondingly; its prohibition on the application of "incompatible" grounds should be seen as prohibiting the application of national fundamental rights standards that are

\footnotetext{
${ }^{90}$ See e.g. CJEU CJEU Case C-420/07 Apostolides v. Orams, ECLI:EU:C:2009:271, para. 55. With regard to Article 45(1)(b) which protects the defaulting debtor, see CJEU Volker Sonntag v Hans Waidmann.

${ }^{91}$ CJEU Case C-139/10 Prism Investments vs. Jaap-Anne van der Meer, ECLI:EU:C:2011:653.

${ }^{92}$ Corthaut (2012) p.15; Kessedjian (2007) p. 28.

${ }^{93}$ CJEU Krombach v. Bamberski, discussed in Chapter 2.2.5.

${ }^{94}$ CJEU Volker Sonntag v Hans Waidmann.

${ }^{95}$ Franq (2012) p. 567; CJEU Case 145/86 Hoffman v Krieg, ECLI:EU:C:1988:61; CJEU Case C -78/95

Hendrikman and Feyen / Magenta Druck \& Verlag, ECLI:EU:C:1996:380.
} 
higher than those allowed by the grounds incorporated in the Regulations. Article 41(2) must therefore be seen as primarily aimed at refusal grounds of a practical nature, such as those prohibiting seizure of certain (primary) goods or assets, the use of disproportionate enforcement measures, or set-off (as in the Prism Investments case).

\subsubsection{Regulations that abolished exequatur}

It may be recalled that complete abolition of both stages of exequatur was achieved for judgments falling within the scope of the Maintenance Regulation, some of the judgments falling within the scope of the Brussels II bis Regulation, and those resulting from the autonomous European procedures of the ESCP and the EOP. ${ }^{96}$

For all these instruments, the abolition of all possibilities of cross-border control was a conscious choice, motivated by the objective of achieving free circulation of judgments. This objective, however, has underlying motivations that pertain in turn to the protection of fundamental rights. The 1999 Tampere Conclusions already stated that "[e]nhanced mutual recognition of judicial decisions and judgments [...] would facilitate [...] and the judicial protection of individual rights", while pinpointing mutual recognition as an instrument to achieve this aim. The subsequent Stockholm Programme ${ }^{97}$ and Programme for the implementation of mutual recognition in civil matters ${ }^{98}$ subsequently pursued the abolition of the exequatur as a means of implementing mutual recognition.

The abolition of exequatur and refusal grounds in these instruments - or, in most cases, the decision not to include an exequatur procedure with grounds for refusal from the outset therefore reflects a decision on the part of the European legislature that fundamental rights would be best respected by concentrating the responsibility for their protection in the Member State of origin of the judgments. To this end, the Brussels II bis Regulation requires the court that delivered a judgment ordering the return of a child to the state where (s)he is habitually resident (in cases of child abduction) to check whether the child was given an opportunity to make his or her views known before certifying the initial judgment as enforceable. This replacement of the exequatur procedure, which gives authority to the Member State where enforcement is sought to apply grounds for refusal, with a certification procedure in the Member State of origin, can therefore be said to reflect a European consensus as to the fundamental rights standards to be applied. The same can be said of instruments where the exequatur has been abolished altogether. The European consensus required by the CJEU in

\footnotetext{
${ }^{96}$ See 2.3 .

${ }^{97}$ European Council, The Stockholm Programme - an open and secure Europe serving and protecting citizens, OJ C/115/10, 2010, p. 13.

${ }_{98}$ Council Programme of measures to implement the principle of mutual recognition of decisions in civil and commercial matters, OJ 2001, C 12/1.
} 
Melloni therefore certainly exists for these instruments. For a Member State of enforcement to try to refuse enforcement would clearly limit the free circulation of judgments that these instruments are intended to achieve and therefore diminish the effective application of EU law. That the abolition of exequatur and the shifting of protective functions away from the Member State of enforcement are absolute was confirmed by the CJEU in its Zarraga ${ }^{99}$ judgment, and subsequently sanctioned by the ECtHR in Povse. ${ }^{100}$

\subsubsection{Consequences of Melloni for the uniform instruments}

The Melloni judgment is also likely to have repercussions for the application of the ESCP and EOP. In a way, these two instruments reflect in their entirety a European consensus on the fundamental rights standards to be applied, since they are two autonomous procedures intended to provide an alternative to the existing national procedures. However, both Regulations explicitly leave a number of issues to national law. ${ }^{101}$ The following analysis explains this conclusion.

\subsubsection{The European Small Claims Procedure}

It is clear that the rules governing the ECSP are aimed at simplifying, speeding up and reducing the costs of obtaining an enforceable title, which is the stated purpose of the procedure according to its Recital 8. ${ }^{102}$ On the other hand, the ESCP Regulation does provide that the procedural law of the Member State where the procedure is conducted shall apply 'subject to the provisions of this Regulation'. In other words, where the Regulation does not explicitly provide otherwise, the procedural law of the Member State shall apply. This means that some of the provisions of the Regulation may not actually leave as much discretion to the Member States as they appear.

An example is the right to an oral hearing. The ESCP is intended to be primarily a written procedure, with an oral hearing only possible if the court considers it necessary for a fair conduct of the procedure. Clearly this leaves discretion to the national court, and as such does not completely proscribe the standards to be applied. However, if a Member State were to implement the rules of the Regulation in such a way as to require an oral hearing in every instance, this would clearly diminish the effectiveness of the procedure. It would therefore not be allowed to do so, even if the right to an oral hearing was protected by its constitution. ${ }^{103}$ This might be problematic for a Member State such as the UK, where part 27.10 of the English Civil Procedure Rules only allows for a procedure in the Small Claims Track to be concluded without a hearing "if all parties agree."

${ }^{99}$ CJEU Joseba Andoni Aguirre Zarraga v. Simone Pelz, discussed under 3.5.

${ }^{100}$ Discussed in detail in Chapter 5.

101 Article 26, EOP Regulation; Article 19, ESCP Regulation.

102 See also the Proposal, section 2.1 ("Overall objective").

${ }^{103}$ Kramer (2008a) 358. 


\subsubsection{The European Order for Payment Procedure}

It can be assumed that, analogously to the rules of the ESCP, the expression of the effectiveness principle of Melloni would also apply to the rules of conduct of the procedure contained in Article 7 of the EOP Regulation, as well as the corresponding time limits, as these could also be seen as a European standard concerning the procedural standards that should be upheld. The same is true for Article 8 of the Regulation, which authorises the court to issue an EOP when "the claim appears to be founded". Combined with Article 7(2) of the Regulation, which provides that the claimant only needs to provide "the cause of the action, including a description of the circumstances invoked as the basis of the claim and, where applicable, of the interest demanded", as well as "a description of the evidence", this means that the examination to be conducted by the court can only be very limited indeed. ${ }^{104}$ This is confirmed by the fact that Article 8 allows this examination to take the form of an automated procedure. It can be questioned whether this could prove problematic to courts in a Member State such as France, where even when claims are uncontested courts are still in principle required to examine the merits of the case. Another potential problem has been raised by the CJEU's case law itself. In Banco Espanol ${ }^{105}$ and Cofidis, ${ }^{106}$ the CJEU ruled that Member State courts must, of their own accord, apply EU rules on unfair terms on consumer contracts in national procedures. If this applies in national payment procedures, it arguably also applies in procedures for an EOP. Standards of EU consumer law may therefore require Member State courts to conduct a more thorough investigation of the merits than the EOP Regulation appears to allow. ${ }^{107}$

6.4.2.6 Application of Melloni to Regulations which contain minimum standards for certification

A final area where the application of norms could be limited by Melloni is the procedure by which judgments are checked against certain minimum standards by the court of origin before being certified as enforceable throughout the Union without any need for exequatur. ${ }^{108}$ This

\footnotetext{
${ }^{104}$ Kramer (2010) para. 3.2.2.

${ }^{105}$ Case C-618/10 Banco Español de Crédito SA v Joaquín Calderón Camino, ECLI:EU:C:2012:349.

${ }^{106}$ Case C-473/00 Cofidis SA v Jean-Louis Fredout, ECLI:EU:C:2002:705.

107 Though the European Commission, in its 2015 Report, suggests that in such cases Member State courts may choose to conduct the procedure under national law; it is questionable whether this solves the problem. Report from the European Commission to the European Parliament, the Council and the European Economic and Social Committee on the Application of Regulation (EC) 1896/2006 of the European Parliament and the Council creating a European Order for Payment Procedure, COM(2015) 495 final, p. 10-11.

${ }^{108}$ Some have doubted whether minimum requirements could provide an adequate compensation for the abolition of exequatur. Cuniberti and Rueda consider it an "alibi" for the removal of cross-border checks: Cuniberti and Rueda (2011) p. 297 et seq. More generally, it has been pointed out that it is the cross-border nature of the exequatur procedure which has a protective value and can therefore not be replaced with a check in
} 
model is to be found in the Brussels II bis Regulation, pertaining to judgments ordering the return of a child or access to a child by its parents, where the court of origin can issue such a certificate, provided that the child and the parents (in case of access) were given a chance to be heard. Its most pertinent example however is the EEO, ${ }^{109}$ an instrument which was introduced in 2005 and which allows the court in the Member State of origin of the judgment to declare any judgment falling within its scope enforceable throughout the EU, provided that the claim was uncontested ${ }^{110}$ and that the minimum requirements laid down in the Regulation are fulfilled.

The minimum requirements laid down in the EEO Regulation concern the service and provision of information to the defendant. Like the EOP Regulation, the EEO contains a large number (no fewer than 10) permissible ways in which the documents instituting the proceedings may have been served on the defendant. The wording of these articles ("one of the following methods") certainly suggests that they should be seen as exhaustive. Articles 16 and 17 governing the provision of information to the defendant are similarly prescriptive: they contain a list of facts that must have been conveyed to the debtor. There appears to be little room for a court requested to issue an EEO to diverge from these criteria. The Recitals to the Regulation serve to affirm this: Recital 13 explicitly states that "due to differences between the Member States as regards the rules of civil procedure and especially those governing the service of documents, it is necessary to lay down a specific and detailed definition of those minimum standards." The rules on service and information therefore intend to reflect a European consensus on the methods of service that are deemed acceptable.

Interestingly, as opposed to the ESCP and EOP Regulations, the EEO Regulation contains relatively generous grounds for review. Article 19(1) contains the same grounds for review as Articles 18 of the ESCP Regulation and 20 of the EOP Regulation, namely in cases where the debtor was not adequately informed and could therefore not defend himself through no fault of his own. Article 19(2) then leaves open the possibility for courts to "grant access to a review of the judgment under more generous conditions than those mentioned in paragraph 1." The Proposal makes clear that this should not be interpreted as giving the national court discretion to review an EEO on the basis of any ground whatsoever; it explicitly refers to the conditions laid down in paragraph 1 , which leads to the conclusion that courts may be more generous in allowing a review of an EEO, but only for reasons that have to do with a lack of provision of information to the debtor. ${ }^{111}$

the country of origin: De Cristofaro (2011) p. 452; Kramer (2011a) p. 640; Cuniberti and Rueda (2011) p. 301; Muir Watt (2001) p. 551.

${ }^{109}$ EEO Regulation; Krans (2005); Zilinsky (2005); See for a critical appraisal of the lack of cross-border control in this instrument Stein (2004); Zilinsky (2011).

${ }^{110}$ Article 3(1) of the Regulation clarifies when a claim can be seen as uncontested.

${ }^{111}$ See the explanation of Article 20 in the Proposal, COM/2002/0159 final. 
It is more difficult to interpret Articles 41(2)(c) and 42(2)(a) of the Brussels II bis Regulation in this respect. These articles require that a court satisfies itself, before declaring enforceable a judgment concerning the right of access of parents to their child, or the return of a child, that the child "was given an opportunity to be heard, unless a hearing was considered inappropriate having regard to his or her age or degree of maturity". These provisions are based on Article 24 of the EU CFR, which in turn is based on appears to be in line with Article 12 of the UN Convention on the Rights of the Child. ${ }^{112}$ Article 12(2) of this Convention provides that "the child shall in particular be provided the opportunity to be heard in any judicial and administrative proceedings affecting the child", which according to the Implementation Handbook "implies an active obligation on the State to offer the child the opportunity to be heard, although, [...] it is important to emphasize that there is no requirement that the child express views." $" 113$

There is therefore no obligation to hear the child, only to actively provide it with the opportunity to be heard. However, the right of the child to be heard in procedures such as these, which greatly affect him or her, is protected by the UN Convention and - accordingly - the EU CFR for a very important reason: ${ }^{114}$ to allow the child to participate in procedures which concern him or her, to respect his or her autonomy, and to prevent the child being pressured or influenced by other parties. ${ }^{115}$ These minimum standards therefore require interpretation by the court requested to certify a judgment: it must ascertain that the child had an opportunity to be heard, unless such a hearing was considered inappropriate because of the child's age or maturity. It seems strange that a court is expected to ascertain that a child was given an opportunity to be heard commensurate with his or her age and maturity, while only the court originally seized of the dispute could have made such an assessment.

Moreover, the Zarraga case discussed in Chapter 3 makes clear that what constitutes "an opportunity to be heard" is not at all easy to define: in that case the child had been summoned to appear before the Spanish court, but due to her age would have to be accompanied by her mother, who was herself at risk of being arrested for child abduction if she entered Spain. The mother's requests for a guarantee that she and her daughter would be allowed to leave together was ignored, as were her requests that her daughter be heard via videoconferencing. Nonetheless, the Spanish court ruled that the child had been given an opportunity to give her views, and declared the judgment enforceable. To conclude, there is a great deal of uncertainty as to what is needed to satisfy the requirements of Articles 41(2)(c) and 42(2)(a). Even though

\footnotetext{
${ }^{112}$ Explanations relating to the EU Charter of Fundamental Rights, OJ C 303/17, p. 25 (relating to Article 24 of the EU CFR).

${ }^{113}$ Hodgkin and Newell (2007) p. 155-156.

114 The UN Committee has even recognized the right of the child to be heard as one of four "general principles" of the Convention, which according to the General Comments of the Committee on that article "highlights the fact that this article establishes not only a right in itself, but should also be considered in the interpretation and implementation of all other rights." The right of the child to be heard is therefore clearly of central importance to protecting the child's autonomy. United Nations Committee on the Rights of the Child, Convention on the Rights of the Child. General Comment No. 12: the right of the child to be heard, 2009, p. 3.

${ }^{115}$ United Nations Committee on the Rights of the Child, Convention on the Rights of the Child. General Comment No. 12: the right of the child to be heard, 2009.
} 
they both implement a fundamental rights norm that is common to all EU Member States due to being enshrined in the EU CFR, they can therefore hardly be said to reflect a European consensus.

To conclude, the model by which a court in the Member State of origin certifies a judgment as enforceable after checking certain minimum standards can be seen as a way to provide some protection of fundamental rights, if very limited and closely circumscribed, in the absence of exequatur. Whether this model provides an adequate substitute for the cross-border control provided by the exequatur has been doubted. For one, cross-border control provides a "fresh look" which an internal control can by definition not provide. It is therefore questionable what, if anything, this mechanism provides in terms of actual protection. This is all the more true in the case of the Articles 41 and 42 of the Brussels II bis Regulation as the grounds for certification are not grounds for review; they cannot be invoked by those they are intended to protect.

\subsubsection{Final remarks}

The conclusion of the foregoing must be that the Melloni judgment closely circumscribes the way in which EU instruments of civil procedure are to be interpreted and applied. It is submitted that this could prove to be problematic for national courts and potentially creates risks for individual litigants. Melloni's message seems simple, but practice shows that it may not always be so easy to determine what consequences effectiveness has for the application of instruments that involve mutual recognition. The ESCP and EOP Regulations explicitly leave room for interpretation to Member State courts, but the preceding analysis showed that this room for interpretation is in practice limited by the effectiveness requirement. This creates potential problems where important principles of national or European law are at stake, for example the protection of consumer rights by way of ex officio application of EU directives in the context of EOP procedures.

Apart from complicating the situation for national courts, the CJEU in Melloni also gives a signal that cannot be misunderstood: primacy and effectiveness of EU legislation supersede national fundamental rights. The CJEU's more recent judgment in Aranyosi and Căldăraru ${ }^{116}$ does not change this conclusion; though in that judgment, the Court allowed an exception to the automatic enforcement of the European Arrest Warrant, it only allowed an exception on the basis of the prohibition on inhuman or degrading treatment or punishment (laid down in the ECHR and the EU CFR), not on the basis of Member States' constitutions. The CJEU in that judgment also closely circumscribed the circumstances in which this exception could be applied.

The CJEU's strict stance on mutual recognition in the context of judicial cooperation, combined with the lack of willingness of the CJEU to test the conformity of that legislation

\footnotetext{
116 Joined Cases C-404/15 and C-659/15 PPU Pál Aranyosi and Robert Căldăraru ECLI:EU:C:2016:198; see the discussion under 6.3.3.
} 
with fundamental rights itself, does little to allay the concerns and confusion which, empirical research shows, national courts experience with regard to the implementation of these provisions. This places all the more responsibility on the EU legislature to provide for effective and robust fundamental rights provisions in secondary legislation.

\subsection{Conclusion}

This Chapter asked whether EU fundamental rights law imposes restrictions on the free movement of judgments. It discussed a number of different sources of fundamental rights norms as to their impact on this process.

First, this Chapter showed that the EU has long considered itself bound by fundamental rights, first through their inclusion in the canon of general principles of EU law, and now through the EU CFR. The adoption of the EU CFR is a clear signal that the EU as an organisation is committed to protecting fundamental rights; conformity with fundamental rights norms is clearly a prerequisite for the legality of EU legislation. The CJEU has proved itself to be prepared to review EU legislation's conformity with fundamental rights, though unfortunately, this has not yet led to a revision of the near-absolute application of mutual recognition.

Secondly, this Chapter discussed the compatibility of mutual trust with fundamental rights. It explored whether defects in the actual fundamental rights protection in an EU Member State can, in a concrete case, justify an exception to the application of mutual trust. It was shown in N.S. and M.E. and others and in Aranyosi and Căldăraru that the CJEU allowed such an exception, but only in cases where widespread or systemic violations have been shown to occur. It was proposed that this threshold is not appropriate for the civil justice context, because in civil cases mutual trust functions retrospectively. Unlike in criminal or asylum cases, Member States are not required to prospectively assess the potential risk a person may be exposed to, but rather to retrospectively assess whether a violation has already occurred. In civil cases it is therefore even less defensible for EU Member States to be required to disregard violations in other EU Member States than it is in criminal or asylum cases (though the ECtHR's Tarakhel judgment casts doubt on the acceptability of the 'systemic' threshold in the latter categories of cases as well). The next Chapter proposes a new 'emergency brake' for civil cases.

Finally, this Chapter discussed the role of national constitutional fundamental rights standards in the application of EU legislation. It was shown in Melloni that the CJEU gave off a clear signal that when fundamental rights standards have been harmonised in EU secondary legislation, national standards can no longer be applied if that affects the EU legislation's effectiveness. Melloni shows that fundamental rights, in the EU, are not only a constraint on legislative or executive power: they also facilitate integration by reducing Member States' scope to apply national norms, increasing legal certainty. The Melloni judgment leads to the conclusion that the CJEU attaches great importance to the intentions of the legislature, as expressed in the wording, scheme and purpose of any legislative instrument. This is valuable 
knowledge: it means that provisions that are intended to protect procedural rights must be formulated very carefully, as they will be taken literally. A precise and clear formulation of legislative provisions of course also improves legal certainty for individual litigants and provides clarity to national courts who are charged with applying these norms. Chapter 8 discusses how the civil justice Regulations that rely on highly harmonised fundamental rights standards should be improved, in light of the fact that they are to be regarded as maximum standards. 


\section{Conclusion to part II}

The preceding Chapters analysed how the fundamental rights framework that applies in the European Union (EU) constrains the free movement of judgments in civil cases. Chapter 4 discussed the requirements flowing from the right to a fair trial as protected by Article 6(1) European Convention on Human Rights (ECHR), and EU fundamental rights law, in particular Article 47 of the EU Charter of Fundamental Rights (CFR). Chapters 5 and 6 then took a broader perspective and analysed how free movement of judgments fits into the constitutional framework of fundamental rights protection. Chapter 4 analysed the compatibility of free movement of judgments with accountability of EU Member States under the ECHR; Chapter 6 discussed the role of EU Member States in the protection of fundamental rights within the EU's own framework. The conclusions from the analysis conducted in these three Chapters are as follows.

\section{A. The right to a fair trial requires effective protection, also within the European Union context}

Chapter 4 showed that the right to a fair trial holds a prominent place within the ECHR, because of its importance in a democratic society and as a central element of the rule of law. ${ }^{1}$ The Court of Justice of the European Union (CJEU) has long acknowledged the existence of the right to a fair trial within the EU legal order. The EU CFR has explicitly linked the interpretation of the right to a fair trial in the EU context to that provided in the European Court of Human Rights's (ECtHR) case law. The CJEU's interpretation of the right to a fair trial is in some respects more specific and extensive than that provided by the ECtHR. It was also shown that the right to a fair trial applies to the enforcement stage of civil proceedings, ${ }^{2}$ and guarantees a right to enforcement. The Chapter also discussed whether some kind of hierarchy could be discerned within the right to a fair trial. While in principle all aspects of the fair trial are equally deserving of protection, it was shown that they can be distinguished according to their function in achieving a fair trial ${ }^{3}$ and according to how a failure to observe them could be remedied. ${ }^{4}$ The next Chapter explores how these factors could play a role in the decision whether or not the creditor's right to enforcement should take precedence over the violation suffered by the judgment debtor in the context of an application for refusal of recognition or enforcement.

\footnotetext{
${ }^{1}$ Chapter 4.2.

${ }^{2}$ Chapter 4.3.6.

${ }^{3}$ Chapter 4.4.

${ }^{4}$ Chapter 4.3.7.
} 


\section{B. The ECtHR has limited jurisdiction to review the application of EU legislation}

Chapter 5 showed that the ECtHR developed the Bosphorus doctrine for addressing potential fundamental rights violations that occurred due to the application of EU law. The Bosphorus line of case law is based on the premise that the EU provides 'equivalent protection' to that provided by the ECHR. In Povse, the ECtHR applied this reasoning to the free movement of civil judgments. Chapter 5 argued that Povse suffers from twisted logic due to the ECtHR not being well placed to deal with a violation involving several states. ${ }^{5}$ The ECtHR's jurisdiction is based on individual responsibility of states for violations occurring within their jurisdiction. This mechanism is not designed for addressing situations that are not only the result of obligations placed on those states by virtue of their Membership of the EU. The ECtHR's Bosphorus doctrine is difficult to apply to the cross-border context. ${ }^{6}$ The limitations of the ECtHR's jurisdiction over the application of EU law are especially problematic in the context of mutual recognition, since the ECtHR has essentially sanctioned the concentration of decision-making power in the Member State of origin, which, it is submitted, may at times be unacceptable.

\section{The European Union has committed itself to protecting fundamental rights}

It was extensively discussed that the EU has committed itself to protecting fundamental rights. ${ }^{7}$ Article 2 of the Treaty on European Union (TEU) states that the EU is 'founded on [...] respect for human rights'. Article 6 TEU affirms that the EU recognises the rights and freedoms set out in the EU CFR and that these shall have the same value as the Treaties: they are therefore primary EU law. As discussed in Chapter 4, through their incorporation into the EU CFR, the EU is indirectly bound by the rights laid down in the ECHR, and their interpretation by the ECtHR. Moreover, the EU professes itself to be, among other things, an 'area of freedom, security and justice'. In the 1999 Tampere Conclusions, the purpose of the creation of such an area is shown to be firmly rooted in the Union's commitment to fundamental rights. ${ }^{8}$ The principle of mutual recognition, whose adoption the Tampere Conclusions endorse, was therefore clearly intended to improve European citizens' access to justice and to ensure that they could exercise their rights everywhere in Europe without being hindered by borders. This commitment to the effective enjoyment of rights is reaffirmed by the later policy programmes discussed in earlier Chapters. It is submitted that it would be incongruous if the implementation of the principle of mutual recognition, which is intended to improve the legal position of European citizens, would have the side effect of allowing judgments that are the result of an unfair procedure to be enforced, especially is previously there had been a perfectly effective

\footnotetext{
${ }^{5}$ Chapter 5.4.

${ }^{6}$ Chapter 5.4.2.

${ }^{7}$ Chapter 6.2.

${ }^{8}$ Tampere Conclusions, no.1.
} 
remedy. If the EU is committed to ensuring its citizens can effectively exercise their rights, what rights can be more important than those guaranteed by the ECHR and the EU CFR?

\section{Absolute mutual trust is incompatible with effective fundamental rights protection}

Furthermore, the degree of mutual trust between the Member States that is necessary for mutual recognition to function effectively arguably does not in fact exist, and neither can those Member States be expected to rely on it. The European legislature appears to be working on the assumption that mutual trust is at a sufficient level to allow measures such as the exequatur to be abolished, but this has been doubted. ${ }^{9}$ Moreover, even the EU legislature has acknowledged that there are differences between the Member States' legal systems, both in theory and in practice, which may prove detrimental to mutual trust. ${ }^{10}$

The necessity of exceptions to mutual recognition was acknowledged in the field of asylum law by the judgments in M.S.S. v. Belgium and Greece (ECtHR) and N.S. and M.E. and others (CJEU). As discussed in Chapter 5, in N.S., the CJEU ruled that if there are 'systemic flaws' in the conditions the asylum seeker in question would be subjected to in the Member State that he would be returned to, an exception to the principle of mutual recognition would be allowed. Chapter 5 argued that a similar emergency brake is necessary in the field of civil justice cooperation, but that the 'systemic' threshold developed by the CJEU is inappropriate. ${ }^{11}$

In Melloni, the CJEU underlined the important role of harmonised standards of fundamental rights protection in EU legislation in the application of mutual recognition. It is submitted that, provided they are of sufficient quality, such harmonised standards may of course contribute greatly to the protection of fundamental rights in the context of mutual recognition. The important question however is, according to this research, what happens when these standards have proved to be insufficient, or they have been disregarded. It is submitted that the existence of harmonised standards in secondary legislation cannot be an adequate substitute for crossborder control at the enforcement stage. Cases such as Maronier v. Larmer and Zarraga show that the existence of legislative safeguards does not prevent problems occurring: rules can be disregarded, or wrongly applied. The real, and difficult, question is what happens when the

\footnotetext{
${ }^{9}$ Chapter 2.2.3.

${ }^{10}$ This is shown by the fact that Brussels Ibis includes an attempt to preclude parties from using so-called 'torpedo actions', whereby they bring a claim in a Member State where civil procedures are known to take very long (see Franzosi (1997)). Even if this Member State has no jurisdiction, the lis pendens rules of the Brussels I Regulation required that no other court could consider the matter before the court first seised declines jurisdiction. Article 31(2) of Brussels Ibis attempts to prevent this by allowing the court specified in an exclusive choice-of-court agreement to examine the case without having to wait for the court first seised to decline jurisdiction. According to Recital 22 of the Regulation, this rule has the purpose of preventing 'abusive litigation tactics'. The European legislature is therefore clearly aware that differences in the efficiency of Member States' justice systems exist and may be exploited.

${ }^{11}$ Chapter 5.3.3.
} 
existing standards have proved insufficient. In such cases, it is submitted, absolute mutual trust of Member States in each other's legal systems cannot be demanded.

To sum up, there are both practical and fundamental legal arguments to be made against requiring Member States to rely fully on mutual trust and expecting absolute mutual recognition. This has been acknowledged in the fields of EU criminal law and asylum law. It is submitted that EU civil procedure should do likewise, since, as has been discussed at length in this research, fundamental rights violations occur also in this field. The next Chapter proposes that an exception to mutual trust should be possible for extreme cases.

\section{E. The European legislature is uniquely placed to address cross- border fundamental rights concerns}

It can also be argued that the Povse decision, which applied the Bosphorus doctrine to the crossborder enforcement of judgments, does not in any way absolve the EU and its Member States from the obligation to adequately protect fundamental rights. It was shown that the Bosphorus doctrine emanates from the ECtHR's lack of jurisdiction to review Member State's actions when they apply EU law. By contrast, the EU, whose legislative authority is based precisely on the existence of the cross-border element, is perfectly placed to design a solution that adequately protects the rights of the individual litigant. It has the capability of designing instruments such as regulations which apply in each Member State in the same way and whose application can be supervised, both by the CJEU and through monitoring activities by the European political institutions. It is not hindered, as the ECtHR is, by the fact that it can only deal with one specific situation, involving one state, at a time. To conclude, Povse should be seen as a sign of encouragement, a signal that the EU must take its obligations as an organisation which respects fundamental rights seriously. In Povse, but also in the judgments preceding it, the ECtHR gave the European legislature the perfect basis for assuming a role as a fundamental rights protector in its own right, which does not interfere with the ECtHR's jurisdiction. 
Part III 


\section{Towards an 'emergency brake' in instruments of EU civil procedure}

\subsection{Introduction: the need for an emergency brake}

This Chapter proposes that European Union (EU) regulations on recognition and enforcement should retain an 'emergency brake' of the kind provided by the public policy exception: a ground for refusal of recognition or enforcement that is capable of remedying fundamental rights violations, that can be applied by the Member State where recognition or enforcement is sought (the Member State addressed). Chapters 2 and 3 showed that the refusal grounds have proven to act as a mechanism for detection and remediation of violations of the right to a fair trial and other fundamental rights. ${ }^{1}$ It was argued that in the cases where the public policy exception was applied, the violation could only have been detected through cross-border review. This is not only because in these cases the parties affected by the violations were unable to invoke a remedy in the Member State of origin, but also because Member States may not be able to critically assess and disqualify their own legal system and judicial culture. ${ }^{2}$ For this reason, many authors have previously argued in favour of such an emergency brake for exceptional cases. ${ }^{3}$ In addition to the preceding arguments, the following three reasons are offered as to why an emergency brake is indispensable, especially in the current legal and political situation.

This research proposes that, from the viewpoint of fundamental rights protection, it is unwise to abolish a safeguard that has been proven to act as an effective mechanism for highlighting fundamental rights violations and limiting their effects. ${ }^{4}$ It could be argued that the possibility of refusing enforcement is a remedy which is only available to debtors lucky enough to have assets located in a Member State other than that where the judgment was rendered. From this perspective, abolishing refusal grounds only serves to achieve equality between cross-border cases and domestic cases, in which such a remedy would not be available. Correct though this

\footnotetext{
${ }^{1}$ Chapter 3.2.7.

${ }^{2}$ Chapter 3.4.1.

${ }^{3}$ De Cristofaro concludes that the "goal of enhancing free movement on the basis of absolute mutual recognition cannot be attained to the detriment of fundamental rights"; De Cristofaro (2011) p. 451 ; Frąckowiak-Adamska (2015); Lopez de Tejada (2013); Schlosser (2010) p. 103; Oberhammer (2010) p. 202; Kramer (2011b) p. 640; Dickinson (2011) p. 8-10; Schack (2011); Vlas (2013) p. 624; Layton (2011) p 7. Contra: Hess (2001) p. 394; Stein (2004) p. 182.

${ }^{4}$ Cuniberti and Rueda (2011) p. 302.
} 
observation may be, there are two counterarguments. The first is that if one takes the view, as this research does, that the purpose of fundamental rights law is to prevent or remedy all violations, it cannot be argued that removing an effective mechanism for doing so is acceptable as 'collateral damage' of the implementation of free movement of judgments. ${ }^{5}$ Whether this is acceptable is a political decision, requiring debate as to how the balance should be struck between efficiency and fundamental rights protection.

Secondly, it can be argued that cross-border disputes, which are often conducted over a great geographical distance and where differences in language and procedural culture exist, carry a higher risk of miscommunication and misinformation, which may impact on the fairness of the trial. Partly this increased risk is acknowledged by the existence of a special refusal ground intended to protect the defaulting defendant, under Article 45(1)(b) of Brussels I bis and its equivalents. ${ }^{6}$ It was discussed that even the second-generation instruments (the European Enforcement Order for uncontested claims (EEO), European Order for Payment (EOP), and European Small Claims Procedure (ESCP) Regulations) acknowledge that cross-border service of documents may provide minimum standards for service, ${ }^{7}$ but recent case law shows that these may not prevent mistakes. ${ }^{8}$ The difficulties associated with service in cross-border cases are also demonstrated by the existence of a specific Regulation concerning the service of documents in civil and commercial matters within the EU. ${ }^{9}$

A final and important argument for keeping some kind of emergency brake is that it may be the only way of remedying judgments that are the result of corruption in the Member State of origin. Corruption within the judiciary can never be ruled out. The EU, the Council of Europe, ${ }^{10}$ and other international organisations such as the World Justice Project, ${ }^{11}$ produce regular reports concerning the independence of the judiciary in European countries. For example, the 2014 Anti-Corruption Report of the European Commission to the Parliament and the Council, which reports on corruption and the ways this is addressed in the Member States, found that, at least where corruption is concerned, judicial independence is under pressure in some Member States. Some of the country reports also highlight concerns with regard to specific Member States. ${ }^{12}$ The EU Justice Scoreboard, produced by the European Commission, in 2013

\footnotetext{
${ }^{5}$ Kramer (2011b) p. 221; De Cristofaro (2011) p. 451; Muir Watt (2001) p. 554.

${ }^{6}$ Chapter 2.3.2.2.

${ }^{7}$ See Chapters 2.3.6 and 2.3.7; Kramer (2011b) p. 226-228.

${ }^{8}$ In a recent judgment, eco cosmetics/Raiffeisenbank, the CJEU ruled that a European order for payment that was not served in accordance with those standards could not benefit from the enforcement regime of the EOP Regulation: CJEU Case C-119/13 and 120/13 eco cosmetics and Raiffeisenbank para. 483. See 8.5.1

${ }^{9}$ Regulation (EC) No 1393/2007 of the European Parliament and of the Council of 13 November 2007 on the service in the Member States of judicial and extrajudicial documents in civil or commercial matters (service of documents) and repealing Council Regulation (EC) No 1348/2000, OJ L 324/79 ('Service Regulation').

${ }^{10}$ See for example the reports of the European Commission for the Efficiency of Justice (CEPEJ) whose reports are available at http://www.coe.int/t/dghl/cooperation/cepej/evaluation/default_en.asp.

${ }^{11}$ See for example their 'Rule of Law Project', available at http://data.worldjusticeproject.org/\#.

${ }^{12}$ For example, the country report concerning Bulgaria pointed towards 'integrity challenges' concerning the nomination and selection of Constitutional Justices and 'flaws' in the Parliaments involvement in judicial
} 
showed a "rather low level of perception of judicial independence by business-end users in certain Member States". ${ }^{13}$ Given these conclusions, it cannot be assumed that judgments delivered in Europe are never the result of a procedure in which corruption was present, for instance because a judge was bribed.

As has been argued by Stadler and Kramer, enforcing a judgment that is the result of corruption may be at odds with the right to a fair trial. ${ }^{14}$ In such cases a cross-border remedy such as refusal of enforcement may be especially necessary because an available remedy in the Member State of origin is hardly satisfactory in such cases. As Stadler puts it, "it goes very far to expect a debtor in such cases to once again put his trust in the justice system of the state where the judgment was rendered and to invoke a remedy there". ${ }^{15}$ The necessity of a crossborder check in cases of corruption is illustrated by the Yukos Oil vs. Rosneft case, discussed below. ${ }^{16}$

To conclude, this research considers that there are sufficient arguments for maintaining an emergency brake in EU instruments that facilitate cross-border recognition and enforcement. This Chapter discusses what such an emergency brake should look like. It is considered whether it is preferable, with a view to protecting the right to a fair trial, to retain a public policy exception, or to replace this with an explicit reference to fair trial (Section 7.2). Section 7.3 provides guidelines for the application of such an emergency brake. Section 7.4 discusses the need for other more specific refusal grounds, such as the protection for the defaulting defendant provided by Article 45(1)(b) of the Brussels I bis Regulation. Section 7.5 discusses the specific context of judgments ordering the return of the child or access to a child.

\subsection{The nature of the emergency brake: procedural public policy or fair trial}

\subsubsection{Introduction}

\footnotetext{
appointments (p. 9) while the report on Hungary highlights some serious concerns regarding such matters as the premature termination of the mandate of the former president of the Supreme Court, extensive powers attributed to the President of the National Judicial council (an administrative body) to transfer cases (p. 4-5). European Commission, EU Anti-Corruption Report 2014, country reports of Bulgaria and Hungary, available at

${ }^{13}$ European Commission, The EU Justice Scoreboard, COM(2013) 160 final, p. 21.

${ }^{14}$ Kramer (2012) p. 129; Stadler (2004b) p. 8.

${ }^{15}$ Stadler (2004b) p. 8.

${ }^{16}$ See under 7.3.7.6.
} 
The previous section made a case for the retention of some kind of refusal ground in EU legislation on recognition and enforcement that should be capable of remedying fundamental rights violations. This section addresses what that refusal ground should look like.

As described in Chapter 2, in 2010 the European Commission in 2010 proposed to replace the public policy exception of the Brussels I Regulation with a much narrower refusal ground. ${ }^{17}$ It was proposed that a defendant would be able to contest a judgment's recognition or enforcement in the Member State where it was sought when such recognition or enforcement "would not be permitted by the fundamental principles underlying the right to a fair trial."18 The 2010 Proposal did not explain in detail the reasons for replacing the public policy exception with this much narrower refusal ground.

As discussed, this proposed limitation prompted much criticism from the European Parliament and individual commentators. ${ }^{19}$ The criticism focused mostly on the political implications of replacing public policy with a narrow reference to a fair trial. The European Parliament's Report stated that the public policy exception was necessary for Member States to safeguard their fundamental values. ${ }^{20}$ It was also stated that the European Commission had not made a convincing case for including only the procedural aspect of public policy, thereby abolishing substantive public policy. ${ }^{21}$ Eventually, the public policy exception in Brussels I bis remained substantively as it was in Brussels I.

What was not explicitly addressed during the discussions was the fundamental question of the difference between a public policy exception and a more narrow reference to fundamental principles underlying the right to a fair trial. Chapter 3 discussed that public policy certainly encompasses fundamental rights, as confirmed by the Court of Justice of the European Union (CJEU) in Krombach v. Bamberski. ${ }^{22}$ Yet, as a concept it is wider, and it should therefore be carefully considered whether there is a benefit from the viewpoint of fundamental rights to having this open-ended concept incorporated into legislation. The goal here is to ascertain whether the public policy exception provides advantages over a reference to fair trial. The value of public policy is traditionally seen as mainly political, allowing States an opportunity to protect national values; it is assumed that public policy could be done away with if it is accepted that Member States share common values. ${ }^{23}$ This Chapter questions that assumption.

\footnotetext{
${ }^{17}$ Chapter 2.2.2.

${ }^{18}$ Proposal for a Regulation of the European Parliament and of the Council on jurisdiction and the recognition and enforcement of judgments in civil and commercial matters (Recast) COM(2010) 748 final (2010 Proposal).

${ }^{19}$ Layton (2011) p. 7; Dickinson (2011) p. 8-9; Nielsen (2012) p. 592-593; Kramer (2011a) p. 640; Cuniberti and Rueda (2011) p. 312-315.

${ }^{20}$ European Parliament, Draft Report on the proposal for a regulation of the European Parliament and of the Council on jurisdiction and the recognition and enforcement of judgments in civil and commercial matters (recast) (COM(2010)0748 - C7-0433/2010 - 2010/0383(COD)) 28 June 2011, p. 26-27.

${ }^{21}$ Layton (2011) p. 7; Dickinson (2011) p. 8-9.

${ }^{22}$ Chapter 3.2.5.

${ }^{23}$ E.g. Frąckowiak-Adamska (2015) p. 25.
} 
As this book concerns the role of the right to a fair trial in the context of recognition and enforcement, this chapter focuses primarily on the right to a fair trial as protected by Article 6(1) European Convention of Human Rights (ECHR) and 47 EU Convention on Fundamental Rights (EU CFR). The question that is asked is whether, for the purposes of protecting the right to a fair trial in the cross-border context, the public policy exception could be adequately replaced with a reference to the right to a fair trial. The chapter therefore compares the current situation, in which some regulations allow recognition or enforcement to be refused where it would be incompatible with public policy, with a hypothetical situation in which recognition or enforcement could be refused where it would be incompatible with Article 6(1) ECHR or 47 EU CFR. This means that the discussion primarily concerns the procedural aspect of public policy, though the substantive aspect of public policy is not forgotten. ${ }^{24}$

The reason that the current public policy exception is compared to a situation in which the right to a fair trial would serve as a criterion for recognition and enforcement is not that these are the only two legislative options available. It would be possible, for example, to include a reference to "fundamental principles underlying the right to a fair trial" in the regulations, as the 2010 Proposal for the recast Brussels I Regulation proposed, or some other variation. ${ }^{25}$ It would however be difficult to assess what the consequences would be of replacing the public policy exception with such a refusal ground without knowing more about what would constitute such fundamental principles. The analysis would become highly theoretical and would likely not yield very useful conclusions. The right to a fair trial of Article 6(1) ECHR/ 47 EU CFR however, provides a clear reference point, and a comparison between these Articles and the public policy exception serves to clarify the particularities of the public policy exception as opposed to a fair trial. The conclusion then returns to the question whether, if the public policy exception can be replaced as a refusal ground, its replacement should be a reference to Article 6(1) specifically or a more general concept of fair trial, due process, or another criterion.

This chapter proceeds as follows. It seeks to ascertain whether a reference to the right to a fair trial can adequately replace the public policy exception by analysing its scope, character and manner of interpretation. It is shown that the fair trial is clearly a fundamental principle underlying the legal order of the EU and its Member States (Section 7.2.2). It is considered whether the nature of the right to a fair trial and its interpretation render it suitable to be used as a yardstick for the review of foreign judgments (Section 7.2.3).

Next, it is discussed what replacing public policy with the right to a fair trial would mean for the scope of this refusal ground. The next section then discusses a number of iterations of procedural public policy which would not be covered by the right to a fair trial, and which would therefore fall outside the scope of the refusal ground (Section 7.2.4). It is shown that

\footnotetext{
${ }^{24}$ Section 7.2.5.

${ }^{25}$ For instance, Article 33 of the recently adopted Insolvency Regulation refers to the Member State's "public policy, in particular its fundamental principles or the constitutional rights and liberties of the individual". Regulation (EU) 2015/... of the European Parliament and of the Council of 20 May 2015 on insolvency proceedings (recast) 2012/0360 (COD) LEX 1607, PE-CONS 31/15 (not yet published in the Official Journal).
} 
though the right to a fair trial to a large extent defines procedural public policy, the two concepts are not identical.

It must be emphasised that the discussion only concerns the relationship between fair trial and procedural public policy. The need for a substantive public policy exception is discussed separately in Section 7.2.5. Finally, a conclusion is drawn on the suitability of fair trial as a yardstick in Section 7.2.6.

\subsubsection{The right to a fair trial as a fundamental principle}

In order to assess whether there is an added value to having a public policy clause as opposed to only a reference to a fair trial, it is necessary to analyse to what extent the two concepts overlap and what the differences between them are. An immediate caveat is that, as Chapter 3.2.1 explained, public policy can be defined as "the complex of norms at the very heart of a political entity", and as such its content may vary across time and place. ${ }^{26}$ It is therefore not possible to provide a complete overview of what principles constitute public policy at a given time. It is very difficult to say a priori what the consequences would be of replacing procedural public policy with a reference to the right to a fair trial. It is shown below that the current interpretation of procedural public policy to a large extent corresponds with, or is even derived from, Article 6(1) ECHR/47 EU CFR. But this is not to say that the concepts are identical. Even the commonly accepted fundamental right to a fair trial is subject to varying interpretations that are closely related to national ideas about what constitutes a fair civil procedure, but which are all in principle compatible with Article 6(1) and the European Court of Human Rights' (ECtHR) case law on this point. An example is the right to a reasoned judgment. ${ }^{27}$ Apart from these existing discrepancies, it is well understood that public policy may evolve over time. A conclusion that currently, procedural public policy in the EU Member States to a large extent coincides with Articles 6(1) ECHR/47 EU CFR ${ }^{28}$ may not necessarily hold true in future.

There is no doubt however that in the current legal-political constellation, the right to a fair trial does constitute a fundamental principle of the legal orders of the Member States of the EU, as well as the EU as such. The inclusion of the principle of fair trial in the ECHR and in the EU CFR - which binds the EU as well as its Member States - in itself testifies to that, though fair trial has been a feature of European constitutional culture for far longer. ${ }^{29}$ There is

\footnotetext{
${ }^{26}$ Chapter 3.2.

${ }^{27}$ See 7.2.6.

${ }^{28}$ Hess and Pfeiffer (2011) p. 155.

${ }^{29}$ The right to a fair trial can be found in the Magna Carta, the charter of rights agreed between King John of England and a number of rival barons in 1215, a document which influenced the constitutional development of England, the United States and the entire modern world: Van Caenegem (1995) p. 80. It is also apparent in the maxim of audiatur et alteram pars (or audite et alteram partem), loosely translated as the principle of an adversarial trial, which was found in Roman law. See Smits (2008) p. 97.
} 
however no doubt that Article 6(1) ECHR has been adopted by national courts and that it has had a profound influence on national case law, on legislation and on legal procedural culture. ${ }^{30}$

The right to a fair trial clearly also constitutes part of the EU's public policy. For example, in Kadi the CJEU applied fundamental rights as constitutional principles of the EU, which cannot be set aside for the purposes of international cooperation:

285 It follows from all those considerations that the obligations imposed by an international agreement cannot have the effect of prejudicing the constitutional principles of the EC Treaty, which include the principle that all Community acts must respect fundamental rights, that respect constituting a condition of their lawfulness which it is for the Court to review in the framework of the complete system of legal remedies established by the Treaty. ${ }^{31}$

There can therefore be no doubt that fundamental rights, as enshrined by the ECtHR and in the Charter, are part of the public policy of the EU and (therefore) its Member States. As Chapter 3 discussed in detail, this conclusion was confirmed both by the CJEU ${ }^{32}$ and Member State courts. The 2011 Report on the Interpretation of the Public Policy Exception by Hess and Pfeiffer shows that the majority of cases where public policy was applied by courts concerned procedural public policy. ${ }^{33}$ Moreover, it was shown that in most of these cases, national courts derive the content of public policy from international fundamental rights treaties such as the ECHR, primarily Article 6 ECHR. ${ }^{34}$ Chapter 3 discussed a number of examples. ${ }^{35}$ It seems clear that procedural issues are the primary reason for invoking and applying the public policy exception, and that the content of public policy is in those cases derived from Article 6(1) $\mathrm{ECHR}^{36}{ }^{37}$

\subsubsection{The suitability of the right to a fair trial as a yardstick for refusing enforcement}

\footnotetext{
${ }^{30}$ See for the Netherlands Smits (2008) p. 19-20.

${ }^{31}$ CJEU Joined Cases C-402/05 P and C-415/05 P Kadi and Al Barakaat International Foundation $v$ Council and Commission ECLI:EU:C:2008:461, para. 285.

${ }^{32}$ CJEU Krombach v. Bamberski para. 38-39; Case C-394/07 Marco Gambazzi v. DaimlerChrysler Canada Inc. and CIBC Mellon Trust Company ECLI:EU:C:2009:219, para. 28.

${ }^{33}$ Hess and Pfeiffer (2011) p. 57-59.

${ }^{34}$ Hess and Pfeiffer (2011) p. 155.

${ }^{35}$ Chapter 3.2.6.

${ }^{36}$ Beaumont and Johnston (2010b) p. 261.

${ }^{37}$ Though the remit of substantive public policy is very limited, as shown by a case such as Diageo v. Simiramida, it may nevertheless play a role in the protection of fundamental rights (CJEU Case C 681/13 Diageo Brands $v$ Simiramida-04 EOOD ECLI:EU:C:2015:471, discussed in Chapter 3.2.4; see Hazelhorst (2016). See section 7.2.5.
} 
If the content of procedural public policy is largely derived from the right to a fair trial, does this mean that fair trial could replace procedural public policy? This section considers the nature of the right to a fair trial in order to show what the consequences of such a replacement would be. It is shown that the right to a fair trial cannot be legitimately restricted, though it is subject to inherent limitations. It is also shown that though the ECtHR applies the right to a fair trial extensively and accords Contracting States little margin of appreciation, Contracting States nevertheless enjoy discretion as to how they conduct a fair trial. It is considered whether these characteristics mean that fair trial is suitable as a criterion to apply in the context of crossborder recognition and enforcement, and what potential problems this may cause.

Chapter 3 already extensively discussed the various elements of the right to a fair trial, so this is not required here. It should be remembered that Article 6(1) includes a right to a fair and public hearing within a reasonable time by an independent and impartial tribunal established by law. The right to access to a court is inherent to the right to a fair trial. ${ }^{38}$ The element of a "fair hearing" can be further divided into such requirements as the right to an adversarial trial, the right to equality of arms, and the right to a reasoned judgment. Article 6(1) does not suggest a hierarchical relationship between the elements.

\subsubsection{Absolute character of Article 6(1) and interpretation}

It is generally accepted that the right contained in the ECHR can be divided into categories according to whether, and in what way, their exercise can be limited. There are different ways of making such distinctions; ${ }^{39}$ for the purposes of this research, it is useful to distinguish between absolute rights, qualified rights, and limited rights, in which Article 6(1) belongs to the latter category. Absolute rights are non-derogable: they contain no grounds on which they can be restricted (for instance Arts. 4(2) and (3)(c) (the prohibition on forced labour) and Art. 5 (habeas corpus)). Some of them are also 'notstandsfest', which means they cannot be derogated from even in times of war or another public emergency (Art. 15(1) and (2) ECHR). This category includes Articles 3 (the prohibition on torture), Article 4(1) (the prohibition of slavery) and Article 7 (the principle of "no punishment without law").

Qualified rights are rights that Contracting States may interfere with in order to secure certain interests, which are expressly stated in the Article. Such interests are either the needs of society as a whole (such as public health or public safety), or the rights of others. Qualified rights include the right to respect for private and family life, home and correspondence in Article 8 ECHR; freedom of thought, conscience and religion in Article 9; and freedom of expression in

\footnotetext{
${ }^{38}$ ECtHR Golder v. UK appl. no. 4451/70 ECHR A18.

${ }^{39}$ Kiestra (2014) p. 38.
} 
Article 10. In the balancing of these fundamental rights against the interests that the interference is intended to secure, Contracting Parties enjoy a margin of appreciation. ${ }^{40}$

Article 6(1) ECHR contains no limitation clauses that apply to the Article in its entirety, which means Contracting Parties may not restrict its application. The only element of Article 6(1) that can be restricted is the requirement of publicity. ${ }^{41}$ However, Article 6(1) contains inherent limitations $;{ }^{42}$ for example, the ECtHR has accepted that the right to access to a court may be limited, because this right is not expressly defined in Article 6(1). ${ }^{43}$ Article 6(1) can therefore be seen as a limited right. The difference with qualified rights such as Article 8 ECHR is that Article 6(1) does not expressly provide for these limitations and that Contracting Parties enjoy less discretion. ${ }^{44}$ It can be concluded that Article 6(1) cannot be restricted, apart from the requirement of publicity (as provided for in the Article) and the limitation inherent to the right to access to a court.

That said, the concept of fairness is always subject to interpretation. It can be derived from the foregoing that when a trial cannot be considered fair, Article 6(1) will have been violated. But what is considered fair differs depending on the circumstances of the case. When the ECtHR is called upon to review whether a procedure was fair, it will look at the trial in its entirety. ${ }^{45}$ There are few procedural defects that will conflict with fair trial to such an extent that an opinion can be given about the fairness of the trial irrespective of the further course of the proceedings. One example may be national legislation that completely prevents a person from effectively defending himself, such as the French law that prevented Mr Krombach from entering an appearance. Alternatively, it is possible that procedural defects are repaired at a later stage of the trial, for example during appeal, so that the procedure as a whole can be considered fair. ${ }^{46}$ This approach means that there is no one correct way of conducting a fair civil trial. The ECtHR has avoided giving an enumeration of criteria in the abstract by which the fairness of a procedure can be assessed. ${ }^{47}$ This means that Contracting States are free to shape the civil trial in such a way as they consider appropriate, but that the ECtHR will assess on a case-by-case basis whether the requirements of a fair trial have been met.

\subsubsection{Margin of appreciation and possibilities for restriction}

\footnotetext{
${ }^{40}$ See below.

${ }^{41}$ See 4.3.3.

${ }^{42}$ Gerards (2011) p. 108; Kiestra (2014) p. 41.

${ }^{43}$ Chapter 4.3.2.1; Arai (2001) p. 35; ECtHR Golder, para. 38.

${ }^{44}$ Arai shows that the ECtHR has over time become more stringent in its assessment whether limitations on the right to access were proportional: Arai (2001) p. 39-43.

${ }^{45}$ E.g. ECtHR Barberà, Messegué and Jabardo v. Spain, appl. no. 10590/83 ECHR A146; ECtHR Kostovski v. The Netherlands (merits) appl. no. 11454/85 A166.

${ }^{46}$ Mole and Harby (2006) p. 6; Chapter 4.2.4.

${ }^{47}$ Van Dijk and Viering (2006) p. 579; Smits (2008) p. 99.
} 
While Article 6 ECHR is therefore subject to interpretation, this does not mean that it cannot provide a clear and common benchmark for Member State courts to apply. An indication of the fundamentality of Article 6(1) is the fact that, as opposed to other rights laid down in the ECHR, it is subject to extensive interpretation by the ECtHR. As the previous section explained, the ECHR allows Contracting States to limit the exercise of certain provisions in order to secure certain interests; in this consideration, they enjoy a margin of appreciation. This doctrine is grounded in the ECtHR's consideration that national authorities may at times be 'better placed' to decide to what extent limitations on ECHR rights are necessary to protect certain values or interests. $^{48}$

Such a margin of appreciation does not play a significant role in the application of most elements of Article 6(1) ECHR, because it cannot legitimately be restricted. ${ }^{49}$ However, there are elements of Article 6(1) where a certain margin of appreciation applies. Its role is most notable with regard to the right to access to a court, which according to the ECtHR may be limited provided that the "very essence" of the right is not impaired, the limitation pursues a legitimate aim, and there must be a reasonable relationship of proportionality between the aim and the means employed. ${ }^{50}$ The ECtHR also accorded Contracting Parties a margin of appreciation with regard to the admissibility of evidence, where it considered that domestic courts are better placed to decide on such matters. ${ }^{51}$ Contracting States also have a margin of appreciation with regard to the right to a public hearing and the public pronouncement of the judgment, because Contracting Parties may limit this right in the interests of morals, public order or national security. They enjoy a margin of discretion in this regard, though how wide this margin is depends on the aim the restriction of publicity is intended to achieve. ${ }^{52}$ Chapter 4 also discussed that the ECtHR leaves some discretion to Contracting Parties concerning the extent to which judgments contain reasoning, ${ }^{53}$ when deciding whether a judgment was adequately motivated, it takes into consideration what the national practice is in that regard. This is however only one of the factors the ECtHR takes into account when deciding whether the motivation is adequate. The ECtHR in these cases still reviews thoroughly whether the judgment was sufficiently motivated. ${ }^{54}$

${ }^{48}$ ECtHR Handyside v. $U K$, appl. no. 5493/72 ECHR A24 para. 48.

${ }^{49}$ Legg (2012) p. 210.

${ }^{50}$ ECtHR Ashingdane v. UK appl. no. 8225/78 ECHR A93; see 4.2.4.

${ }^{51}$ Arai (2001) p. 49.

${ }^{52}$ Arai (2001) p. 50; compare e.g. ECtHR Campbell and Fell v. UK appl. nos. 7819/77 7878/77 ECHR A80, para. 87 (public security) with the stricter approach in ECtHR Le Compte, Van Leuven and De Meyere v. Belgium [merits], appl. nos. 6878/75 7238/75 ECHR A43 (professional secrecy and the right to privacy of doctors and their patients).

${ }^{53}$ Chapter 4.3.2.7.

${ }^{54}$ See for example the extensive examination of the parties' arguments and submissions and whether they needed to be discussed in the judgment in ECtHR Ruiz Torija v. Spain, appl. no. 18390/91, ECHR A303-A, para. 30. 


\subsubsection{Extensive interpretation and the 'fourth instance' doctrine}

In Delcourt v. Belgium, the ECtHR ruled that Article 6(1) is subject to extensive interpretation. In its assessment whether a certain restriction was necessary for the protection of morals, the ECtHR considered the following:

In a democratic society within the meaning of the Convention, the right to a fair administration of justice holds such a prominent place that a restrictive interpretation of Article 6 para. 1 would not correspond to the aim and the purpose of that provision $[\ldots] .{ }^{55}$

While there are many ways in which Contracting Parties may organise a fair trial, the ECtHR has the final say as to whether that fairness was achieved. In doing so, it will carry out a rigorous scrutiny of the trial as a whole. There is, however, a limitation to the review carried out by the ECtHR: the so-called "fourth instance" doctrine. This essentially means that the ECtHR does not deal with errors of fact and law: it does not get involved with the merits of the case. ${ }^{56}$ Yet, the ECtHR may intervene in respect to "errors of fact and law" in so far as they may have infringed the procedural rights guaranteed by Article 6(1) ${ }^{57}$ Consequently, in recent case law the ECtHR found that Article 6(1) had been violated by decisions that were "arbitrary or manifestly unreasonable". 58

There is also a line of case law dealing with inconsistencies in judicial decisions. Though it is not for the ECtHR to deal with errors of fact and law, and though it acknowledges that irregularities are a necessary element of each justice system, it nevertheless may find a violation if "profound and long-standing differences" exist in the case law of the domestic courts. In such cases it will review "whether the domestic law provides for machinery for overcoming these inconsistencies, whether that machinery has been applied and, if appropriate, to what effect". 59

If Article 6(1) were to become the criterion for deciding on the enforcement or recognition of a judgment, a national court could, quite legitimately, apply the ECtHR's rulings in the aforementioned cases to arrive at the conclusion that recognition or enforcement could be refused. The prohibition against reviewing a judgment as to its substance applies to findings of fact and substantive law and to the exercise of discretion. ${ }^{60}$ It appears that the ECtHR's rulings where it considered that inconsistencies in case law constituted violations may fall foul of this prohibition.

\footnotetext{
${ }^{55}$ ECtHR Delcourt v. Belgium appl. no. 2689/65 ECHR A11 para. 25.

${ }^{56}$ ECtHR Garcia Ruiz v. Spain, appl. no. 30544/96 ECHR 1999-I, para. 48; Harris et al. (2014) p. 18.

${ }^{57}$ See Harris et al. (2014) p. 371.

${ }^{58}$ ECtHR Andelkovic v. Serbia, appl. no. 1401/08, 9 April 2013, para. 27. See further 3.4.2.

${ }^{59}$ ECtHR Albu and others v. Romania, appl. no. 34796/09 and 63 other cases, 10 May 2012; see 3.3.2.

${ }^{60}$ Jenard (1979) para. A1.198.
} 


\subsubsection{The suitability of fair trial as a criterion for recognition and enforcement}

What does all this mean for the suitability of the right to a fair trial as a criterion for the recognition or enforcement of foreign civil judgments within the EU? The advantage of the right to a fair trial as a criterion would be, firstly, that it embodies a principle that is recognised by all EU Member States and by the EU itself as being fundamental. This is also borne out by Member State and CJEU practice. An additional advantage is that it may not be restricted (apart from the requirement of publicity) and is not subject to a margin of appreciation, which reduces confusion and the ability to abuse the provision. Of course, the right to a fair trial is subject to interpretation according to the circumstances of the case: whether a trial has been fair must be assessed on a case-by-case basis. But this is also true for the public policy exception. In fact, the casuistic character of the right to a fair trial may prove to be an advantage. Practice has shown that the judgments whose enforcement is refused under the public policy requirement are extremely diverse. The public policy exception has functioned as a 'catch-all' provision, ${ }^{61}$ which is capable of addressing a diversity of situations. In this sense, it would be undesirable to create - if this were even possible - a 'hard and fast' rule according to which the acceptability of foreign judgments could be assessed. The room for interpretation which the right to a fair trial allows in this regard fulfils the same function as a public policy criterion: it is deliberately open to interpretation, so that cases can be assessed in their entirety, and it remains possible to do justice to the specific circumstances of the case.

It was shown above that what constitutes a fair trial differs according to the circumstances of the case; the elements of the right to a fair trial are subject to interpretation in the light of those circumstances. What must be emphasised however is that the fact that these elements are subject to interpretation in a specific case does not mean that Contracting States can form different opinions on what is a 'fair' trial. It is the circumstances of the case that determine whether a fair trial has been conducted or not, not the Contracting States' interpretation of the notion of fair trial or one of its components. In that sense, the right to a fair trial provides a common standard that is not subject to a margin of appreciation on the part of the Contracting States. This is not diminished by the fact that the right to a fair trial does not prescribe exactly what a fair trial should look like. It seems obvious that, if fair trial became the yardstick, this would considerably reduce Member State's freedom to apply a national definition of fair trial comparable to the public policy exception. Currently, public policy, at least in theory, allows Member States to refuse recognition or enforcement of foreign judgments on the basis of domestic conceptions of a fair trial. It is however doubtful whether this reduction would have considerable practical impact, since the content of procedural public policy is already largely derived from Article 6(1) ECHR and because the CJEU monitors its application. Moreover, this reduction in scope may be beneficial with a view to protecting the right to a fair trial, since it reduces the possibility for EU Member States to apply an overly broad or conclusive

\footnotetext{
${ }^{61}$ It was discussed that public policy performs a residual function with regard to the other, more specific grounds for refusal; see 2.23; CJEU Case 145/86 Hoffman v Krieg ECLI:EU:C:1988:61, para. 21.
} 
conception of public policy. This improves legal certainty for the judgment creditor and therefore potentially helps to protect his right to enforcement.

Using the fair trial as a yardstick to decide whether a foreign judgment should be recognised or enforced may create problems. There are ECtHR judgments where a violation of Article 6(1) ECHR was found, but where application of the public policy exception would have been highly problematic. As Chapter 4 discussed, there is a line of case law dealing with inconsistencies in judicial decisions. Though it is not for the ECtHR to deal with errors of fact and law, and though it acknowledges that irregularities are a necessary element of each justice system, it nevertheless may find a violation if "profound and long-standing differences" exist in the case law of the domestic courts. In such cases it will review "whether the domestic law provides for machinery for overcoming these inconsistencies, whether that machinery has been applied and, if appropriate, to what effect". ${ }^{62}$ If a fair trial were to become the criterion for deciding on the enforcement or recognition of a judgment, a national court could, quite legitimately, apply the ECtHR's rulings in the aforementioned cases to arrive at the conclusion that recognition or enforcement could be refused.

Although the ECtHR may consider itself well placed to carry out such a review, to allow a national court, asked to enforce a judgment from another EU Member State, to perform such a review, would be fundamentally at odds with the prohibition on review as to the substance which is one of the guiding principles of EU law on recognition and enforcement and private international law more generally. The national court would certainly not be allowed to apply the public policy exception of one of the existing instruments in such a way as to allow a review of the merits of the kind conducted in the aforementioned cases. ${ }^{63}$ This is therefore an example of a situation which would fall within the remit of Article 6(1) ECHR, but that should arguably not lead to refusal of recognition or enforcement. This highlights a risk of incorporating Article 6(1) ECHR as a ground for refusal into the Regulations: Article 6, like all articles of the ECHR, is not static, but subject to evolving interpretation by the ECHR (the so-called 'living instrument' doctrine). If judgments can be refused enforcement because of their incompatibility with Article 6(1) ECHR, it is possible that an evolving interpretation of that article by the ECHR may widen the scope of that refusal ground in ways that cannot be foreseen at the time of adoption of the relevant regulation. It can however be asked if this is not preferable to the many potential and unpredictable interpretations that national courts may give to the public policy exception. ${ }^{64}$ More generally, the ECHR is a living instrument whose interpretation will evolve. While this is a good thing in the context of the ECtHR's monitoring mechanism, where changes in society need to be taken into consideration, it potentially creates risks in the context of cross-border recognition and enforcement, where legal certainty is essential.

From the perspective of the creditor, replacing procedural public policy with fair trial may have a considerable advantage. The next section shows that, though rare, there are examples of cases where EU Member States employed a conception of public policy that goes beyond the remit

\footnotetext{
${ }^{62}$ ECtHR Albu and others v. Romania, para. 21.

${ }^{63}$ Article 52, Brussels I Regulation; Article 26 Brussels IIbis Regulation; Article 41 Succession Regulation.

${ }^{64}$ Some examples are discussed under 7.2.4.
} 
of fair trial. For a creditor, this creates a risk of being confronted with overly inclusive national conceptions of public policy. Replacing procedural public policy with fair trial grounds may increase foreseeability and reduce this risk, contributing to better protection of the creditor's right to enforcement by restricting the scope of public policy.

Another potential benefit of replacing procedural public policy with fair trial grounds is that it would guarantee that violations of the fair trial would be remedied through the application of this refusal ground. Currently, recognition or enforcement may only be refused if such recognition or enforcement would be contrary to the public policy of the Member State addressed. In principle, therefore, refusal is only possible where the violation of procedural rights that occurred in the Member State of origin could not occur under the law of the Member State addressed. If that Member State's law would also allow the violation, there would be no ground to refuse enforcement to the foreign judgment on the basis of public policy, because the judgment would not be contrary to the public policy of the Member State addressed. ${ }^{65}$ Since the CJEU held that the right to a fair trial is part of Member State's public policy, ${ }^{66}$ and Member States in practice derive the content of public policy from the right to a fair trial, ${ }^{67}$ the problem should not occur. Enforcement or recognition should, as a matter of EU law, be refused to judgments from other Member States if those judgments result from procedures that are incompatible with a fair trial, even if the procedure in question would be compatible with the addressed Member State's own law. Still, replacing procedural public policy with fair trial grounds would have the advantage of clarifying the status of a fair trial as a precondition for recognition and enforcement and removing the condition of incompatibility of the judgment with the national law and practice of the Member State addressed.

\subsubsection{Are procedural public policy and fair trial identical in scope?}

Replacing procedural public policy with fair trial grounds may have advantages from the perspective of foreseeability. Compared to the national concept of public policy, the fair trial is a common norm defined at the European level. Replacing public policy with fair trial grounds would also create benefits from the perspective of fundamental rights protection. The question remains as to what consequences such a replacement would have for the scope of the emergency brake; the types of cases that would come within its remit. It is discussed in this section that some cases that fall within the scope of public policy would fall outside the scope of a fair trial refusal ground, and vice versa. The question is whether this difference in respective coverage would be problematic.

The previous paragraphs showed that fundamental rights are often used to shape the public policy exception. Of course there are also cases where public policy is applied to protect

\footnotetext{
${ }^{65}$ Corthaut (2012) p. 186-187.

${ }^{66}$ CJEU Krombach v. Bamberski, para. 37.

${ }^{67}$ Hess and Pfeiffer (2011) p. 57-59; see the discussion under 7.2.3.
} 
national values which, though certainly fundamental within their own legal order, are arguably not commensurate with the right to a fair trial. There are also elements of public policy which, though they are not covered by fair trial, nevertheless do touch on the fairness of the trial. An example is procedural fraud committed by one of the parties, rather than by the judge. These elements are discussed in turn.

\subsubsection{The inherent threshold of the public policy exception}

The preceding sections showed that the right to a fair trial largely overlaps with procedural public policy. This observation may justify the conclusion that fair trial grounds may adequately replace procedural public policy. Even so, do all violations of the right to a fair trial justify the application of the public policy exception, or should a distinction be made between violations, for instance on the basis of their seriousness, or according to the element of fair trial that was harmed?

Case law shows that not all procedural irregularities are sufficient grounds for a refusal of recognition or enforcement. This is for two different reasons: firstly, because public policy may not be applied to refuse recognition or enforcement simply because the outcome of the case would have been different under national law of the Member State addressed. Secondly, the public policy exception may only be applied in the most serious of cases, where a manifest infringement of a fundamental principle has occurred. Practice shows that courts often reject an appeal to public policy where irregularities occurred in the original proceedings but were insufficiently serious, or where remedies were still available in the state of origin. This is reasonable, because application of a refusal ground has serious consequences: it completely prevents the judgment creditor from exercising his right to enforcement.

In the literature on public policy, it is accepted that not all norms that are deemed part of public policy in a certain legal order are also sufficiently fundamental to be considered part of external public policy. ${ }^{68}$ External public policy (ordre public externe) only consists of those norms that are deemed fundamental to that legal order to the extent that they prevent foreign judgments or foreign law from taking effect. ${ }^{69}$ The requirements that the legal order imposes on domestic procedures therefore only have a reduced effect to foreign law or foreign judgments: ${ }^{70}$ foreign judgments cannot be required to comply with each specific rule that would apply in a domestic procedure. This does not mean, however, that all rules that apply in the state addressed are to be given a 'reduced effect'. As Schilling argues, the right to a fair trial is itself already a more general and more fundamental version of domestic procedural norms. ${ }^{71}$ Such a fundamental norm should therefore not be accorded only a reduced effect in the context of cross-border

${ }^{68}$ Corthaut (2012) p. 23.

${ }^{69}$ Chapter 3.2.1.

${ }^{70}$ Schilling (2012) p. 569.

${ }^{71}$ Schilling (2012) p. 569. 
recognition and enforcement. In principle, therefore, all violations of the right to a fair trial should be considered grounds for refusing recognition or enforcement.

The CJEU's case law does not provide an indication that only qualified, i.e., sufficiently serious, violations of fundamental principles should lead to refusal or recognition of enforcement. The CJEU has consistently ruled that only 'manifest' breaches of fundamental rights should lead to the application of the public policy exception. ${ }^{72}$ However, as Chapter 3 discussed, the qualification 'manifest' relates to the visibility or obviousness of the violation, as it is connected to the prohibition of review on the substance of the judgment. ${ }^{73}$ 'Manifest' does not refer to the seriousness of a violation (though it seems reasonable to expect that a very serious violation is also obvious and therefore manifest). According to the CJEU, what is required for the application of the public policy exception is a "manifest breach of a rule of law regarded as essential in the legal order of the State in which enforcement is sought or of a right recognised as being fundamental within that legal order". ${ }^{74}$ Since the right to a fair trial is regarded as a fundamental right, any manifest (i.e., obvious) violation should in principle lead to application of procedural public policy.

Practice shows that EU Member State courts are indeed restrained in the application of public policy, and cases can be found where there were certainly concerns as to the fairness of the proceedings, but an appeal to public policy was nevertheless refused. However, court practice does not appear to support a reduced application of the right to a fair trial; the restrictiveness is rather found in a high evidentiary standard or in the availability of remedies in the state of origin. It does not seem to be the case that an appeal to public policy is refused in cases where there is an obvious violation of the right to a fair trial on the basis that that violation is not sufficiently serious. Rather, the violation had not been demonstrated, or remedies were available in the Member State of origin.

Layton and Mercer, for instance, cite a French judgment which ruled that it was not contrary to French public policy to enforce a German judgment ordering maintenance on the basis of a finding of paternity, even though that finding had not been based on procedural safeguards which would have been available in France. ${ }^{75}$ They also cite a case where it was not considered contrary to French public policy to enforce an Italian judgment where the defendant had been precluded by Italian procedural law from raising a ground of defence on appeal which he had failed, by reason of his non-appearance, to raise in first instance. ${ }^{76}$ More examples can be found in the Hess/Pfeiffer Report. For example, a Dutch court considered an appeal to public policy unfounded, as the fact that the defendant was not adequately informed of the proceedings, as

\footnotetext{
72 CJEU Krombach v. Bamberski, para. 37.

${ }^{73}$ Chapter 3.2.5.

${ }^{74}$ CJEU Krombach v. Bamberski, para. 37.

75 Layton and Mercer (2004) no. 26.021; Theillol v Office de la Jeunesse de Fribourg, Journal de Droit International 1979, p. 383.

${ }^{76}$ Layton and Mercer (2004) no. 26.021; Cozzi v Dame Capurro et autres, Bull. Cass. 1979, Part I, no. 286.
} 
she claimed, not necessarily meant that the procedure had been unfair. ${ }^{77}$ Similarly, the Dutch Supreme Court rejected an appeal to public policy by a defendant who claimed that he had not been heard in the proceedings resulting in a default judgment, because he had - albeit unsuccessfully - been able to invoke a remedy against this default judgment. ${ }^{78}$ In an earlier judgment, the Dutch Supreme Court had already made clear that recourse to public policy is only possible when no remedies were available against procedural defects in the country of origin. ${ }^{79}$ There are also three cases in which the Dutch Supreme Court overturned decisions from the lower courts in which public policy had been applied to refuse enforcement of judgments that did not contain any reasoning. The Supreme Court ruled in all three cases that the judgments indeed contained no reasoning, but that this could not be considered contrary to public policy, because the claims had been acknowledged by the defendant as correct. ${ }^{80}$ Another interesting example is a Lithuanian case, where a defendant argued that he had not received a fair trial, because he had not been provided with legal aid; the Lithuanian court however ruled that free legal aid is not awarded to everyone and that it cannot therefore constitute part of public policy. ${ }^{81}$

The question remains however whether all elements of the right to a fair trial should come within the scope of public policy, i.e., their violation should lead to refusal of recognition or enforcement. Neither the right to a fair trial itself nor the ECtHR's case law provides a basis for concluding that certain elements are less important than others, or that certain procedural irregularities are in every case more likely to lead to a finding of a violation than others. All elements of the right to a fair trial, whether explicit or implicit, contribute towards the fairness of the trial. Against this background, the reference in the Commission's 2010 Proposal for the recast Brussels I Regulation to "fundamental principles underlying the right to a fair trial" somewhat puzzling, because Article 6(1), the most commonly accepted incarnation of the right to a fair trial in Europe, does not make a distinction between fundamental and non-fundamental principles. In fact, it could be argued that "the right to a fair trial" itself is the fundamental principle underlying the elements of Article 6(1). It was shown that when applying such elements as the right to a reasoned judgment, the principle of an adversarial trial, or one of the other elements, the guiding principle is always what is fair or just in a specific case. In that sense, the 'fair trial' is the fundamental principle underlying its separate elements. Those elements can be seen as specific requirements that serve to operationalise the notion of a fair trial, but in whose interpretation the fair trial still serves as a guiding principle. In principle, therefore, there seems to be no reason to distinguish between more and less fundamental elements of the right to a fair trial. If a fair trial became the yardstick for review of foreign judgments, in principle all violations of that right could be grounds for refusal of recognition or enforcement. It can however be debated whether refusal of enforcement is indeed an

\footnotetext{
${ }^{77}$ Rb Middelburg 23 September 2009, ECLI:NL:RBMID:2009:BK9209

${ }^{78}$ HR 27-6-2008, ECLI:NL:PHR:2008:BD2007

${ }^{79}$ HR 5 April 2002, ECLI:NL:HR:2002:AD9145.

${ }^{80}$ Hoge Raad 18 March 2011, ECLI:NL:HR:2011:BP0003.

${ }^{81}$ Hess and Pfeiffer (2011) p. 55.

822010 Proposal, Article 46(1) p. 42.
} 
appropriate remedy for all violations. For example, if the proceedings took an unreasonable length of time within the meaning of Articles 6(1) ECHR/47 EU CFR, will refusing enforcement adequately remedy that violation? This question is considered for each element of fair trial in Section 7.3, below.

\subsubsection{Antisuit- or Mareva-injunctions}

Conversely, there are examples ${ }^{83}$ of the application of public policy that would fall outside the scope of fair trial were this to become a ground for enforcement. An example that was recently discussed in the literature ${ }^{84}$ is the application of public policy against so-called 'Mareva' or antisuit-injunctions. Such injunctions, which were developed and are predominantly used in England, ${ }^{85}$ may be requested by one of the parties to a conflict in order to prevent the other party from commencing or continuing the proceedings in another forum. The CJEU in Turner v. Grovit ${ }^{86}$ settled the debate by declaring such injunctions incompatible with the Brussels Convention/Regulation, because injunctions prohibiting one party from bringing an action before the courts of a Member State interfere with the jurisdiction allocated to that Member State by the Regulation. Since such injunctions are contrary to a fundamental principle underlying judicial cooperation under the EU Regulations, it can be argued that Member States may legitimately refuse to recognise such an injunction on the basis of the public policy exception. ${ }^{87}$ Here, the principle that would be protected by the public policy exception would be the allocation of jurisdiction in cross-border cases, which is one of the foundations of the Brussels regime. While certainly of fundamental importance to the functioning of that regime, this principle appears to be more about the effective functioning of the Brussels regime and about legal certainty, rather than the protection of fundamental individual rights.

\subsubsection{Procedural fraud}

\footnotetext{
${ }^{83}$ More examples can be found than the ones discussed in these sections. One possible example is a Hungarian judgment referred to in the 2011 Report on the application of public policy, where enforcement was refused because the judgment contravened the Hungarian principle that one should be able to litigate in one's native language (Hess and Pfeiffer 2011, p. 53-54). Though the right to a fair trial may include a right of the defendant to translation of the document instituting the proceedings into a language he understands, it arguably does not include a right to litigate in one's native language before a foreign court. See Ontanu and Pannebakker (2012) p. 171-172, European Commission of Human Rights $X$ and $Y$ v. Austria 9099/80 DR 27, p. 209.

${ }^{84}$ Ortolani (2015).

${ }^{85}$ Hartley (2014) p. 9; Hess and Pfeiffer (2011) p. 67, shows the UK view on this matter.

${ }^{86}$ CJEU Case C-159/02 Turner v Grovit ECLI:EU:C:2004:228.

${ }^{87}$ See also Ortolani (2015) p. 17. He raises the interesting question whether the principle of mutual trust as such has public policy status in the EU.
} 
A more problematic issue is the question of procedural fraud committed by one of the parties. Fraud may constitute, for example, lying to the court, ${ }^{88}$ or forging a signature. ${ }^{89}$ Procedural fraud is a separate ground for refusal for recognition under English law, ${ }^{90}$ but in many EU Member States, and in the European context, fraud can be considered to be subsumed by public policy, provided that no means for redress were available in the Member State of origin. ${ }^{91}$ The Heidelberg Report (2007) finds a considerable number of judgments where fraud was found to have occurred and whose enforcement was refused on the basis of public policy. ${ }^{92}$ It cannot be doubted that where a judgment has been obtained by fraud committed by one of the parties (provided that this can be proven by their opponent), the proceedings have not been fair. Yet fraud committed by the parties, as opposed to fraud committed by the judge (for example by accepting a bribe), does not appear to be covered by Article 6(1). This article is, in principle, ${ }^{93}$ not horizontally applicable. It confers an obligation on the state rather than on individuals. It cannot therefore be used to remedy instances of procedural fraud by one of the parties.

This is confirmed by the ECtHR's McDonald judgment, discussed in Chapter 4. In this judgment, the ECtHR accepted that a refusal to enforce a foreign judgment could result in a violation, but not where that refusal was based on procedural fraud. According to ECtHR case law, no one can complain about a situation to which they themselves had contributed. ${ }^{94}$ The fraudulent party cannot invoke his right to enforcement of a judgment if that judgment was fraudulently achieved. McDonald concerned a case in which the applicant, the party who sought enforcement, had himself committed fraud. Whether Article 6(1) is of any help where the person against whom enforcement is sought was the victim of fraud, and whether it confers on Contracting States a positive obligation to identify fraud or remedy it if the fraud only becomes apparent after the delivery of a judgment, is unclear. So far, there appears to be no

\footnotetext{
${ }^{88}$ Hartley (2015) p. 410.

${ }^{89}$ For example, in a Dutch case under The Hague Child Abduction Convention, the child's habitual residence was said to be Portugal on the basis of an agreement between the parents on which the mother's signature was allegedly forged. See Rechtbank Den Haag 6 March 2009, ECLI:NL:RBSGR:2009:BJ0317.

${ }^{90}$ Hartley (2015) p. 410. French law also recognises the separate refusal ground of fraude à la loi, which involves parties manipulating certain connecting factors in order to ensure the application of certain law to their dispute. It may also encompass the misrepresentation of facts that touches upon the rights of the defendant. See Rosner (2004) p. 249.

${ }^{91}$ Franq (2016) p. 888-889; p. 27; Schlosser Report on Brussels Convention (1979) para. 192. In the Netherlands, for instance, public policy encompasses procedural fraud as well; see Rosner (2004) p. 44, who cites a judgment of the Rechtbank Alkmaar, 7 June 1984, in which the claimant in the original proceedings had wrongfully claimed that it had been impossible to reach the defendant.

${ }^{92}$ Hess, Pfeiffer and Schlosser (2007) paras. 548-558.

${ }^{93}$ Article 1 ECHR creates an obligation to respect human rights, but only for States; furthermore, Article 34 of the ECHR only allows applications to be brought against States, not individuals. The ECtHR has accepted a kind of horizontal application of the ECHR by ruling that States may have a positive obligation to prevent or interfere in certain horizontal situations (see Gerards (2011) p. 264 onwards). Thus far, there does not however appear to be an obligation for States to protect litigants from fraud by their counterparties, if these allegations of fraud were not raised during the proceedings.

${ }^{94}$ ECtHR McDonald v. France [dec.], appl. no. 18648/04, 29 April 2008. See also ECtHR Avotins v. Latvia, appl. no. 17502/07, 25 February 2014.
} 
indication of a positive obligation for Contracting States to prevent or remedy fraud, unless it was alleged during the proceedings.

A ground for refusal that refers only to Article 6(1) ECHR therefore runs the risk of excluding judgments obtained by fraud. This is an undesirable outcome that runs counter to the idea of a European area of justice. In contrast to abuse of procedural rights, which results in a delay, procedural fraud may in fact influence the outcome of the case. Procedural fraud may lead to judgements that are simply wrong as they are based on an incorrect presentation of the facts. Such judgemtns should not be allowed to circulate freely.

\subsubsection{Excessive procedural costs}

Another example of a use of procedural public policy that would probably not overlap with Article 6(1) ECtHR is the practice of Greek courts refusing the enforcement of orders for costs deemed to be 'excessive' according to national standards. This practice appears to follow from a 2006 judgment from the Greek Areios Pagos, in which it ruled that 'excessive' procedural costs should be considered against public policy. ${ }^{95}$ The Areios Pagos based this conclusion on the Greek constitution and on Article 6(1) ECHR. This judgment appears to have been followed by lower courts: in 2013 it was reported ${ }^{96}$ that a Greek Court of Appeal refused enforcement a cost order granted in the United Kingdom. In that case, costs of more than $£ 80,000$ had been awarded for a claim not exceeding $£ 17,000$. The Court of Appeal of Corfu in Greece deemed these costs excessive in proportion to the amount of the original claim by domestic standards. Accordingly, the cost order contravened Greek public policy standards and enforcement was refused for part of the cost order.

It is questionable whether such an application of procedural public policy is indeed supported by Article 6(1). Though the ECtHR has ruled that high costs of civil litigation may be incompatible with Article 6(1) as they restrict the right to access to a court that Article 6(1) contains, ${ }^{97}$ it has also ruled that the right to access to a court may be subject to (financial) limitations and that states enjoy a margin of appreciation in this regard. ${ }^{98}$ Where the ECtHR has found violations of Article 6(1) in relation to excessively high costs, it has consistently ruled that costs can only be excessive if they would effectively prevent the litigants from pursuing their case based on their individual circumstances. ${ }^{99}$ The ECtHR's case law does not appear to support a general rule that a certain proportion of costs to the amount claimed results in an unacceptable restriction of the right to access. Such an assessment can only be made in an individual case on the basis of evidence regarding the litigant's financial situation.

\footnotetext{
95 Areios Pagos Court decision number 1829/2006, 25 October 2006.

${ }^{96}$ Anthimos, A. 'Excessive English Costs Orders and Greek Public Policy', http://conflictoflaws.net/, 5 March 2013.

${ }^{97}$ ECtHR Golder v. the United Kingdom, $\$ 36$.

${ }^{98}$ ECtHR Tolstoy Miloslavski v. UK, appl. no. 18139/91 20 February 1992, para. 61 et seq.

${ }^{99}$ ECtHR Kreuz v. Poland, appl. no. 28249/95 ECHR 2001-VI, para. 63; ECtHR Podbielski and PPU Polpure v. Poland, appl. no. 39199/98 26 July 2005, paras. 67-68; ECtHR Weissman and Others v. Romania, appl. no. 63945/00 ECHR 2006-VII para. 39.
} 
Moreover, the enforcing court would need to take into account the margin of appreciation of the state of origin in this instance. For this reason, the Greek practice of applying the public policy exception to costs orders in the way the Areios Pagos has advocated does not seem to be supported by Article 6(1). Such an application of procedural public policy would therefore likely fall outside the scope of Article 6(1) and would no longer be possible if the right to a fair trial were to be made the framework for refusing enforcement or recognition.

\subsubsection{Varying interpretations of elements of Article 6(1)}

Apart from the right to access to a court, there are more elements of Article 6(1) that may legitimately be applied differently by the Contracting States. An example is the right to a reasoned judgment. It has been discussed in literature that states have varying practices concerning the degree to which judgments must be motivated and that they have applied their national standards to foreign judgments as part of procedural public policy. Most commentators refer to France, where it was the practice of the Cour de Cassation to refuse enforcement of judgments that were, by French standards, insufficiently motivated, or to request additional documents to make up for this lack of motivation. ${ }^{100}$ It should be asked whether replacing procedural public policy with a reference to "the right to a fair trial" would curtail such differences in standards. Perhaps it would not, because the ECtHR itself has accorded Contracting States a degree of margin of appreciation in this regard. The ECtHR has taken into account that various practices exist between the Contracting States regarding the degree to which judgments are motivated. This means that a judgment that contains little motivation may be compatible with Article 6(1) if it is consistent with the usual practice of courts in the state concerned, provided that the objectives served by providing reasons have been met. ${ }^{101}$ This is relevant to the present discussion, because procedural public policy has been used to apply national standards concerning the motivation of judgments to foreign decisions.

The problem of differing interpretations of common principles is therefore unlikely to be solved by incorporating a common norm into EU legislation instead of a public policy exception. It is submitted that such differences should not be applied excessively in order to safeguard creditor's rights to enforcement, but that this limitation on their application should lie in a proportionality test rather than in a restriction of the scope of the refusal ground.

\subsubsection{Substantive public policy and fundamental rights other than fair trial}

This research explicitly does not concern substantive public policy, but since procedural and substantive issues can in practice be closely interwoven, ${ }^{102}$ it is necessary to briefly review the

\footnotetext{
100 Cuniberti (2008).

${ }^{101}$ E.g. ECtHR Lhermitte v. Belgium, appl. no. 34238/09 26 May 2015, para. 27.

102 See for instance Case C 681/13 Diageo Brands v Simiramida-04 EOOD ECLI:EU:C:2015:471, discussed in Chapter 3.2.4. See Hazelhorst (2016).
} 
relationship between fundamental rights and substantive public policy and to consider whether the observations about suitability of fundamental rights as a yardstick also apply in this context.

It is certain that if the right to a fair trial were to become a refusal ground, this would prevent judges from refusing enforcement or recognition because of substantive elements. In the field of civil justice, a likely casualty of such a curtailment would be the issue of punitive damages, where a court awards damages to a claimant over and above the amount of damage he suffered, as a kind of penalty for the party who caused the damage. This type of penalty is generally not recognised in civil law systems, where the starting point is the reparation of damage that was actually suffered. ${ }^{103}$ Punitive damages are in some jurisdictions therefore considered to be contrary to public policy. Here also, the public policy exception is used to bridge the gap between two legal systems that are based on incompatible principles, rather than on a concern for individual rights. The problem of punitive damages however primarily arises in the context of judgments from the United States, since not only do very few EU Member States allow for their imposition, punitive damages are also most excessive in the United States. ${ }^{104}$

In the examples cited, the public policy exception is clearly very valuable as a tool for ensuring the smooth interaction of legal systems that may be based on very different principles. Whether this function is still necessary within the EU may be debated; some authors posit that situations of incompatibility between legal systems within the EU will become ever scarcer. ${ }^{105}$ For the purposes of the protection of fundamental rights however it may be concluded that the "bridging" function of public policy is not the most important. For the purposes of fundamental rights protection, it would be possible to replace the public policy exception with a fundamental rights reference.

During the negotiations on the recast Brussels I Regulation, two fields of civil justice were singled out as requiring a substantive public policy exception: defamation and collective redress procedures. ${ }^{106}$ Especially with regard to defamation cases, the link with various fundamental rights is apparent. As the European Commission wrote in its 2010 Proposal,

The proposal retains the exequatur procedure with regard to defamation cases in which an individual claims that rights relating to his personality or privacy have been violated by the media. These cases are particularly sensitive and Member States have adopted diverging approaches on how to ensure compliance with the various fundamental rights affected, such as human dignity, respect for private and family life, protection of personal data, freedom of expression and information. ${ }^{107}$

\footnotetext{
${ }^{103}$ Vanleenhove (2016); Hazelhorst (2010).

${ }^{104}$ Nagy (2012) p. 4.

${ }^{105}$ Franq (2016) p. 883.

1062010 Proposal, Explanatory Memorandum, p. 8-9.

1072010 Proposal, Explanatory Memorandum, p. 7-8.
} 
According to the Commission, the lack of consensus among the Member States on how to balance fundamental principles such as privacy and freedom of expression is sufficient to justify a restricted application of mutual recognition in these matters. In the subsequent discussion, commentators argued that this divergence required the retention of a substantive public policy exception in the Brussels I bis Regulation. ${ }^{108}$ There seems to be a consensus that a substantive public policy exception remains necessary.

Could substantive public policy be replaced with a reference to 'fundamental rights', in the same way that procedural public policy might be replaced by the right to a fair trial? The potential consequences of such a choice are impossible to oversee within the limits of this research. It should however be observed that the variation amongst Member States' principles is likely to be far larger with regard to substantive issues, for example with regard to the balance between free speech and privacy as illustrated above, than it is with regard to fair trial. As explained, the right to a fair trial's fundamental status is not contested, and it has been interpreted extensively by the ECtHR. This means that, though there are many ways of conducting a fair trial, EU Member States at least agree that a trial should be fair, and the same standard applies in all Member States. For these reasons, and considering that the content of procedural public policy is already largely derived from the right to a fair trial, replacing the former with the latter would have the advantage of increasing clarity and legal certainty.

By contrast, the matters covered by substantive public policy are far more varied, as illustrated by Dickinson: as examples of matters on which Member States disagree, he mentions questions of medical ethics, the use of gene technology, or the operation of nuclear installations. ${ }^{109}$ Many of these matters are arguably not covered by fundamental rights, or only tangentially.

Even where fundamental rights overlap with the principles encompassed by substantive public policy, there would still be considerable differences between Member States. The field of family law reveals a considerable divergence of views among Member States on such matters as same-sex marriage and adoption. With regard to same-sex marriage, the ECtHR itself has ruled that the lack of consensus among the Contracting States on this issue meant that the decision whether to allow same-sex couples to marry is part of the States' margin of appreciation. ${ }^{110}$ Here, as well, replacing public policy with fundamental rights is unlikely to reduce uncertainty for litigants or, conversely, improve fundamental rights protection; both options leave a considerable margin of appreciation to the states.

\subsubsection{Interim conclusion}

This Chapter set out to answer the question whether, with a view to remedying fundamental rights violations in the context of cross-border enforcement of judgments, the procedural public

\footnotetext{
${ }^{108}$ Dickinson (2011) p. 8; Layton (2011) p. 4.

${ }^{109}$ Dickinson (2011) p.8.

${ }^{110}$ ECtHR Schalk and Kopf v Austria, appl. no. 30141/04 ECHR 2010 para. 105.
} 
policy exception could be replaced with a reference to fair trial, as was proposed by the European Commission in its 2010 Proposal.

Section 7.2.2 showed that the fundamental status of a fair trial is uncontested. Currently, but also historically, states consider a fair trial a fundamental principle underlying their legal order. CJEU and Member State case law also bears out that procedural public policy and fair trial are more or less synonymous.

There are some advantages to replacing procedural public policy with fair trial grounds from the perspective of fundamental rights protection. For the judgment creditor, applying a common norm such as fair trial reduces the possibility of enforcement being refused on the basis of national conceptions of public policy that are outside the scope of fair trial (such as in the Greek case discussed above). For the judgment debtor, a replacement would increase legal certainty because it would be clear that recognition or enforcement should be refused if a violation of fair trial had occurred; currently, application of the public policy exception at least in theory still requires that the procedural irregularity would be considered contrary to the law of the Member State addressed.

Another considerable advantage from a legal-political point of view is that the refusal grounds would become truly 'Europeanised'. Replacing (national) public policy with a common fundamental principle would reinforce this refusal ground's role in the protection of fundamental rights; the argument against public policy that it was an example of 'obsolete nationalism' could no longer be made. ${ }^{111}$ Refusal of recognition or enforcement to a foreign judgment would cease to be a conflict of national principles with European ones (mutual trust), but rather an application of a common European fundamental rights norm, which would be in line with the EU's commitment to fundamental rights as discussed in Chapter 6.

There are however also disadvantages. One is that certain situations that would currently fall within the scope of public policy would fall outside the scope of fair trial, such as procedural fraud. This problem could be resolved by adding a separate refusal ground for dealing with cases of fraud (committed by one of the parties).

A more fundamental problem is the question whether all violations of fair trial should be capable of triggering refusal of recognition or enforcement. Currently, in order to trigger the application of the public policy exception cases must show a 'manifest breach' of a 'right considered as fundamental'. It cannot be said on the basis of Article 6(1) itself that there is a hierarchy between its elements and that one can consequently be seen as more fundamental than the other. One could also ask whether all violations of Article 6(1) would constitute a manifest breach of one of those fundamental principles: is the threshold for finding a violation that the ECtHR applies more stringent, or more lenient, than the one applied by courts when they consider the application of the public policy exception? This question is very difficult to answer in abstracto. The examination of cases in which public policy was applied in Section 7.2.4 did not yield evidence to suggest that national courts are more lenient in their application

${ }^{111}$ As described by Oberhammer (2010) p. 201-202. 
of public policy than they would be if they applied Article 6(1); practice suggests that they consider these provisions to be one and the same for the purposes of denying enforcement. This also follows from the Krombach judgment in which the CJEU applied the ECtHR's case law to deduce that public policy should be considered applicable. ${ }^{112}$ This gives a clear signal that when Article 6(1) is not observed, public policy may be applied. However, some violations of fair trial should arguably not lead to refusal of recognition or enforcement, such as violations of the right to a trial within a reasonable time. It is questionable whether this problem could be solved by incorporating a requirement that only 'flagrant' or 'manifest' violations should lead to refusal of enforcement, since the problem is not so much the seriousness of the violation, but the appropriateness of refusal of enforcement as a remedy for these types of situations.

Finally, a fundamental problem is that, as Section 7.2.5 showed, there is clearly still a need for a substantive public policy exception. Theoretically, replacement of procedural public policy with fair trial could be combined with a separate substantive public policy exception. However, it has been observed that the distinction between substantive and procedural public policy is primarily an academic one and potentially difficult to make in practice ${ }^{113}$ substantive and procedural issues are often intertwined. Though they are difficult to oversee, an artificial distinction between substantive and procedural issues may create considerable problems of interpretation.

Considering these potential problems that may be caused by 'the right to a fair trial' as a ground for refusal of recognition or enforcement, perhaps the wiser option would be to maintain a public policy exception. Public policy has been a standard feature of EU legislation on civil justice matters for a long time, and remains included in a number of important Regulations. ${ }^{114}$ Practice shows that its application is rare and that its interpretation does not seem to cause national courts any problems. It is universally accepted that public policy must only be applied in very serious cases; the Reports on its application (the 2007 and 2011 Reports) did not point into the direction of an excessive or unacceptable use of this provision by the national courts. Furthermore, the application of the concept is closely supervised by the CJEU. In its Krombach judgment, it gave a highly authoritative and universally accepted (it appears from the 2011 Report) definition of the outer limits of the principle, in which it also affirmed the concept's link with the rights protected by the ECHR and their interpretation by the ECtHR. Arguably the CJEU's influence provides a guarantee that the rights of the ECHR will be protected within the context of the public policy exception; it would be very difficult to argue against the background of Krombach that a situation which would clearly amount to a violation of Article $6(1)$ or one of the other more absolute provisions could not result in the application of public policy.

${ }^{112}$ Case C-7/98 Dieter Krombach v André Bamberski ECLI:EU:C:2000:164, paras. 39-40.

${ }^{113}$ Dickinson (2011) p. 8; see also the discussion of CJEU Diageo/Simiramida under 3.2.4.

114 Apart from the Regulations on recognition and enforcement discussed in this research, the Rome I and Rome II Regulations on applicable law also contain a public policy exception. Public policy is also one of the grounds for limitation of the free movement of capital, workers, services and goods under the TFEU. 
On the basis of these considerations, this research proposes that the public policy exception still provides an effective and workable means of remedying violations of the right to a fair trial in the cross-border context. It is therefore submitted that the public policy exception of (currently) Article 45(1)(a) of the Brussels I bis Regulation be (re)adopted for all Regulations that cover recognition and enforcement of judgments in civil matters.

\subsection{The conflict between debtor's and creditor's rights}

Having concluded that the European Regulations on recognition and enforcement should retain a public policy exception, this section now considers in what cases this refusal ground should be applied. The aim of this exploration is to provide guidance to courts tasked with interpreting the provision; it may also serve to clarify, from a fundamental rights perspective, the essential conflict that refusal of recognition or enforcement entails, and how it should be resolved. This section explores the conflict that is created by the possibility of refusing recognition and enforcement between the creditor's right to enforcement, and the debtor's right to a fair trial. It is shown that this conflict is essentially one of proportionality: neither of these rights can in all cases override the other, but when they inevitably clash, a solution must be found that does not disproportionally disadvantage the 'losing' party.

It was discussed above that the public policy exception as it currently exists does not explicitly allow for a proportionality assessment. On the basis of the CJEU's guideline as provided in Krombach v. Bamberski, all violations of an "essential principle" or a "fundamental right" should, in principle, be grounds for application of the public policy exception. However, it is clear that the CJEU requires Member State courts to examine whether the violation suffered by the defendant or judgment debtor is sufficiently serious to justify refusal of enforcement. In Gambazzi, it ruled that,

It should $[\ldots]$ be borne in mind that fundamental rights, such as respect for the rights of the defence, do not constitute unfettered prerogatives and may be subject to restrictions. However, such restrictions must in fact correspond to the objectives of public interest pursued by the measure in question and must not constitute, with regard to the aim pursued, a manifest or disproportionate breach of the rights thus guaranteed. ${ }^{115}$

According to the CJEU in Gambazzi, the court of the Member State where enforcement is sought should, inter alia, take into account the reasons for the (perceived) infringement of the right to a fair trial. ${ }^{116}$ This interpretation of public policy leaves a certain margin of appreciation to the Member State addressed to assess the degree of infringement of the right to be heard that was in fact suffered. ${ }^{117}$

${ }^{115}$ Case C-394/07 Marco Gambazzi v. DaimlerChrysler Canada Inc. and CIBC Mellon Trust Company, ECLI:EU:C:2009:219, para. 29.

116 CJEU Gambazzi, paras. 30 and 49.

${ }^{117}$ Franq (2016) p. 894. 
Application of the public policy exception therefore always involves an examination of the proportionality of that application vis-à-vis the infringement that occurred. Consequently, the application of an 'emergency brake' must primarily be seen as a conflict between two equal interests: the rights of the creditor and of the debtor, which, both being derived from the right to a fair trial, are in principle equal in weight. Perhaps therefore the answer can be found by applying the theories surrounding the conflict between fundamental rights as it has been developed in legal theory and case law.

\subsubsection{Guidance of the ECtHR for solving conflicts}

Could an infringement of the right to enforcement be justified by the fact that to grant enforcement would result in the violation of another person's rights to fair trial? Kiestra, in his study of the impact of the ECHR on private international law, shows that the right to enforcement can be restricted and what matters is the proportionality of that restriction. ${ }^{118}$ While the ECtHR has not yet ruled on a case where refusal of enforcement was allowed on fundamental rights grounds, it has certainly provided an opening for such considerations to be taken into account. In Négrépontis-Giannisis the ECtHR ruled that the right to enforcement of a foreign judgment could be restricted on the basis of a public policy exception, though it found a violation because the application of that exception had in fact failed to respect the applicant's right to family life. ${ }^{119}$ In Avotins v. Latvia, the ECtHR ruled that the disadvantage suffered by the judgment debtor was of his own doing and could therefore not constitute a reason to request refusal of enforcement. ${ }^{120}$

The ECtHR does therefore acknowledge that a refusal of enforcement or recognition can be justified, but it has not had the chance to set out the conditions in which that might happen. An exploration of the possible factors that could be taken into account is therefore still necessary.

\subsubsection{Methods for resolving conflicts between fundamental rights}

A great deal has been written on the appropriate method for resolving conflicts between fundamental rights. ${ }^{121}$ The ECtHR itself has employed various techniques. It is said to generally favour a solution in which a balance is found between the two rights at issue by applying the principle of proportionality (also referred to as 'practical concordance'). ${ }^{122}$ The benefit of this approach is that it avoids having to find a hierarchy between the rights at issue; hierarchy as a technique for resolving conflicts between fundamental rights is said to have become a 'taboo'. ${ }^{123}$ Yet for a judge asked to rule on an appeal to refuse enforcement of a foreign judgment, it is impossible to balance the rights of both debtor and creditor, since he is faced

\footnotetext{
${ }^{118}$ Kiestra (2014) p. 241. See also the discussion in Chapter 4.3.6.

${ }^{119}$ ECtHR Négrépontis-Giannisis (merits) appl. no. 56759/08, 3 May 2011.

${ }^{120}$ ECtHR Avotins v. Latvia, appl. no. 17502/07, 25 February 2014 (currently under consideration of the Grand Chamber).

${ }^{121}$ See for example the volume edited by Brems (2008).

${ }^{122}$ Gerards (2011) p. 171. See on this method De Schutter and Tulkens (2008) p. 203 onwards.

${ }^{123}$ Ducoulombier (2008) p. 234.
} 
with a binary choice. He can either allow enforcement, thus giving precedence to the creditor's right to enforcement over the debtor's right to a fair trial; or refuse enforcement, thereby doing the opposite. It is impossible in this situation to achieve a solution that 'balances' both interests, as one must necessarily prevail over the other, and both outcomes are mutually exclusive. The judge in this situation cannot therefore avoid having to choose between two rights, implicitly creating a hierarchy: the creditor's right to enforcement and whatever aspect of the debtor's right to a fair trial appears to have been violated.

It should therefore be examined how the ECtHR has resolved conflicts between elements of the right to a fair trial in its case law. It is of course impossible to provide a definitive guidance that is capable of solving all possible future conflicts, but this analysis may at least provide national judges with useful viewpoints to apply in such cases.

Conflicts between fundamental rights are often conflicts between two different fundamental rights, for example the right to privacy versus the right to freedom of expression, ${ }^{124}$ or the right to equal treatment with the right to freely practice one's religion. ${ }^{125}$ For these types of problems, a solution can sometimes be found in the (implicit) hierarchy that exists in the ECHR between rights that are absolute and notstandsfest, rights that are absolute but not notstandsfest, rights that have specific grounds for limitation, rights that have general grounds for limitation and are subject to a margin of appreciation, and so on. ${ }^{126}$ This approach does not usually provide a solution for cases where both parties invoke the same Convention right - unless certain elements of that right are subject to limitation clauses where others are not. In the case of Article $6(1)$, the element of publicity is the only element that may be limited, though such limitations must comply with the conditions laid down in this Article. ${ }^{127}$ Chapter 3 and Chapter 6.2.3 in particular also discussed that some elements of fair trial, including the right to access to a court, are subject to inherent limitations.

Some useful guidance is provided by Brems in a 2005 article on how to resolve conflicts in the context of the right to a fair trial. In this article, she references criteria that have been developed by Sullivan in her work on gender equality and religious freedom. ${ }^{128}$ The criteria to be applied in order to resolve conflicts are as follows. Firstly, one has to examine each of the rights involved and how important the aspect of the right that is at issue in the concrete case is for the protection of the human right as such. ${ }^{129}$ As Chapter 4 already discussed, this comes down to distinguishing a 'core' and a 'periphery' within the right in question. ${ }^{130}$ The question of conflicts between fundamental rights therefore becomes, in essence, a test of proportionality,

\footnotetext{
${ }^{124}$ See for instance ECtHR Von Hannover v. Germany, appl. no. 59320/00 ECHR 2004-VI.

125 Sullivan (1991-1992).

${ }^{126}$ De Lange (2008) p. 72-74.

${ }^{127}$ See 4.3.3, and 7.2.3.

${ }^{128}$ Sullivan (1991-1992).

${ }^{129}$ Brems (2005) p. 303.

${ }^{130}$ Chapter 4.4.
} 
which is only limited by the assertion that the enjoyment of a right may not be made absolutely impossible: the 'core' of the right in question may not be harmed. ${ }^{131}$ Chapter 4 already concluded that it is difficult to distinguish in abstracto a core and a periphery within the right to a fair trial, because different elements may be a 'core' with regard to certain objectives of the fair trial, but 'peripheral' to others. ${ }^{132}$ This Chapter proposes that it may be possible to distinguish between the various elements according to different criteria, including the margin of appreciation that is accorded to the state, and the remedy that the ECtHR has found to be appropriate. The next section discusses this further.

The second criteria developed by Sullivan is the severity of the interference. If the exercise of one right is rendered utterly impossible, this will carry more weight than if it is merely made more difficult. ${ }^{133}$ This is especially important in the context of cross-border enforcement: a refusal of recognition or enforcement will make the exercise of the creditor's right to enforcement completely impossible. This means that the interference with the debtor's right must have been very serious to justify this interference with the creditor's right. It should be stated here that it is difficult to speak, in the context of the fair trial, of 'exercising' this right. The right to a fair trial is not one that litigants can exercise without active interference of the state: in fact it provides a positive obligation for the state to facilitate a fair trial for the litigant. This in contrast to, for example, the right to family life (Art. 8 ECHR), which is something that people can indeed exercise and where the state has a negative obligation not to interfere. ${ }^{134}$ Perhaps it is therefore not appropriate to ask whether the violation has made the 'exercise' of the right to a fair trial utterly impossible. One should rather ask whether the violation has made it completely impossible for the objectives of the fair trial to be achieved. What objective that is depends on the element at issue: Chapter 4 explained that some elements of Article 6(1) mostly serve the objective of a fair outcome, while others mostly serve to ensure fair proceedings. ${ }^{135}$

Thirdly, it needs to be examined whether, apart from the two rights that are in direct conflict, other rights are also implicated. The restriction of a human right carries more weight if it results in practice in the additional restriction of another right. Because the right to a fair trial provides auxiliary protection to other fundamental rights, this will nearly always be the case. ${ }^{136}$ In the context of this research, one might think in particular about family cases in which procedures are started to enforce one of the parties' right to family life under Article 8 ECHR. Many commercial and consumer cases can however be seen as enforcing, for example, the right to

\footnotetext{
${ }^{131}$ Brems (2005) p. 304.

132 Chapter 4.4.4.

133 Brems (2005) p. 304.

${ }^{134}$ Harris et al. (2014) p. 531 onwards.

${ }^{135}$ See 4.4.

${ }^{136}$ Brems (2005) p. 304.
} 
property (Art. 1 of the First Protocol to the ECHR), ${ }^{137}$ or the right to privacy (Art. 8 ECHR). It is questionable whether this criterion is of much use when dealing with conflicts between elements of a fair trial, given its auxiliary nature; but it is certainly something than can be taken into account if the exercise of the other implicated rights would be made excessively difficult.

The final criterion developed by Sullivan is the cumulative effect of the restrictions of the human right in question. Restrictive measures should not be viewed in isolation but should also be seen in their larger context. For the right to a fair trial this means that a judge should take into account not only the impact of a refusal to enforce on the parties, but also the impact on the rule of law and the interests of justice. ${ }^{138}$

This section considers to what extent the criteria proposed by Sullivan, and developed by Brems, could be applied to the conflict between a creditor's right to enforcement and another element of fair trial. The preceding section already pointed out some difficulties with applying the method to this type of conflict. For that reason, the following proposes how the framework could be amended or interpreted in the context of the fair trial.

\subsubsection{Distinguishing a 'core' and a 'periphery' in the elements of Article 6(1)}

Chapter 2 already concluded that it is very difficult to distinguish, in abstracto, a 'core' and a 'periphery' within the elements of fair trial. All elements of that article contribute equally to the trial's fairness, at least in principle. It was however suggested that there are other factors that may, in a concrete case, allow a judge to distinguish between the elements of Article 6(1) and to decide whether non-enforcement or non-recognition is an appropriate remedy for their violation. It must be stressed that this is not to suggest that some elements are more 'important' or 'essential' than others. The following merely suggests that, in the specific context of a conflict with the right to enforcement, and considering that the only option would be to make the exercise of that right by the creditor utterly impossible (see below), certain factors could be taken into account.

\subsubsection{The objective of the fair trial the element intends to protect}

The first of these factors is the goal that the element that was violated was intended to protect. Chapter 4 concluded that the fair trial serves, essentially, two objectives: to facilitate a fair outcome, and to provide a fair process. ${ }^{139}$ Some elements of fair trial primarily serve the outcome, while others serve the process; though some of course contribute to both. In the

\footnotetext{
${ }^{137}$ According to the ECtHR the right to free enjoyment of property includes a positive obligation by the State to "ensure in its domestic legal system that property rights are sufficiently protected by law and that adequate remedies are provided whereby the victim of an interference can seek to vindicate his rights". Article 1 of Protocol 1 therefore includes a right for individuals to effective protection of their property rights (arising out of contract or tort) against interference by other individuals. ECtHR Kotov v Russia, appl. no. 54522/00, 3 March 2012 para. 113-114; ECtHR Blumberga v. Latvia, appl. no. 70930/01, 14 October 2008, para. 67; Harris et al. (2014) p. 871. 138 Brems (2005) p. 304.

${ }^{139}$ Chapters 4.4.2 and 4.4.3.
} 
ECtHR's case law, both objectives normally weigh equally heavily, in the sense that all elements of fair trial are equally important, and all elements may trigger a finding of a violation if they are not observed.

It could be argued however that in the specific context of conflicts with the right to enforcement, outcome-related violations should outweigh process-related violations. As Chapter 3 explained, the reason why refusal of enforcement or recognition is allowed, and the reason why it is effective, is because it prevents the consequences of an unfair trial from taking place. Is it appropriate if enforcement is refused, so that the outcome of the judgment is prevented from taking effect, even if that outcome would have been the same either way? It should be emphasized that this should not be seen as permission for a judge to review the fairness of the outcome (which would be incompatible with the prohibition on review on the substance). ${ }^{140}$ Rather it allows the judge to take into account whether the violation that occurred completely removed the prerequisites for achieving a fair outcome, so that the outcome cannot have been fair. It is submitted that refusal of recognition or enforcement is more likely to be an appropriate sanction when the outcome of the trial is likely to be unfair than when it is only the procedure that was unfair. Arguably, in the latter situation, a remedy such as the finding of a violation by the ECtHR may address the violation; see further the discussion on whether the exercise of the right is made utterly impossible, below.

This consideration would be important primarily in those cases in which the principle of equality of arms was not observed, but where the object of the inequality was not of consequence for the outcome of the trial. Likewise, procedural irregularities such as a failure to communicate certain information of evidence to one of the parties, which may in themselves constitute a violation of Articles 6(1) or 47, should for not trigger the application of the public policy exception if a fair outcome could still have been achieved. Section 7.3.7 (below) elaborates further on the consequences of this conclusion for a concrete case.

\subsubsection{Margin of appreciation}

A second factor that could be taken into consideration is whether the element at issue is subject to a margin of appreciation. ${ }^{141}$ This is appropriate for two separate reasons. The first is that, where a margin of appreciation exists, it is simply less obvious whether the observed irregularity in the procedure would also amount to a violation before the ECtHR. If the element at issue were subject to a margin of appreciation, it cannot be obvious whether such interference would immediately amount to a violation. Since the public policy exception should only be applied to 'manifest', which means obvious and serious, violations, this would exclude situations where it is doubtful whether a violation would in fact be found. The second reason lies in the principle that the public policy exception should not be used where the problem is

\footnotetext{
${ }^{140}$ Chapter 2.3.1.1; see for a discussion of its implications in specific situations 7.3.7, particularly in the context of the right to an oral hearing.

${ }^{141}$ Section 7.3.2, showed that certain elements of the right to a fair trial are subject to a margin of appreciation: notably the admissibility of evidence and the right to a public trial and public pronouncement of the judgment.
} 
simply a difference between the legal system of the state of origin and that of the state of enforcement. It cannot be a valid reason for refusal of enforcement that, for example, under the law of the state of enforcement, a judgment would have had to be more extensively motivated. The question the judge should ask himself is whether the judgment constitutes a clear violation of fair trial as interpreted by the ECtHR, not whether it constitutes a violation of the interpretation of that provision in his state.

\subsubsection{The remedies that are considered appropriate for addressing violations}

Finally, a factor that could be weighed is what remedies are generally considered appropriate for a violation of the element at issue. Chapter 4 extensively discussed what remedies the ECtHR and CJEU have considered appropriate for specific violations. ${ }^{142}$ It was shown that violations of the reasonable time requirement are generally treated differently than violations of other elements of Article 6(1). Contrary to, for example, a violation of the right to a fair hearing, an excessively long procedure cannot be adequately remedied with for example a right to appeal or other remedies that protract the proceedings even further. Rather, excessively lengthy proceedings should be addressed by either a preventative remedy, aimed at acceleration of the proceedings, or by compensation. ${ }^{143}$ The consensus appears to be that remedies for excessively long proceedings should not influence the outcome of the proceedings. ${ }^{144}$ It is proposed that this is appropriate because, in most cases, ${ }^{145}$ the length of the proceedings has no impact on the outcome of the proceedings, contrary to, for example, a violation of the right to a fair hearing. If one party has not been given a chance to present his or her views during the trial at first instance, the outcome of that trial is also questionable, and it is therefore correct that it can be subject to an appeal, during which the mistakes made during the first stage of the proceedings can be rectified.

By contrast, a violation of the reasonable time requirement does not in itself invalidate the outcome of the trial. What has been harmed is not so much the correctness of the outcome or the procedural justice of the parties, but their interest in an efficient and effective trial. Of course, a trial that lasts overly long is not effective; but this is not a problem that a retrial or appeal can solve; and neither can a refusal of enforcement. What purpose does it serve when, after having waited for a judgment for an excessively long period, the judgment creditor is then denied enforcement of that judgment because the debtor suffered a violation of his right to a reasonable time? This would be especially inappropriate because the two parties are, from the viewpoint of the ECHR, both victims of one and the same violation of fair trial. In accordance with the ECtHR's and CJEU's stance, in such a case enforcement should not be refused, but parties should invoke the remedies available in the state of origin of the judgment. This might only be different in cases where a failure to conclude the proceedings within a reasonable time

\footnotetext{
142 See 4.3.7.

${ }^{143}$ See 4.3.7.2.

${ }^{144}$ Chapter 4.3.7.2; Smits (2008) p. 253.

${ }^{145}$ See further under 7.3.7.
} 
can impact the decision; though as Section 7.3.7 (below) argues, it is questionable whether refusal of recognition or enforcement is an adequate sanction even where that is the case.

\subsubsection{Whether the exercise of the right is made utterly impossible}

This section considers the second element of Sullivan's method for solving conflicts: whether the exercise of the right is made utterly impossible. This means that when one of the parties to the conflict is prevented completely from exercising his or her right, than the violation suffered by the other party should be very severe to justify this interference. As Brems states,

The hardest cases are obviously those in which the exercise or protection of each of the rights involved excludes the exercise or protection of the other. ${ }^{146}$

It can be questioned whether this is always the case in situations where refusal of enforcement is considered. Of course, it is clear that refusal of enforcement - thereby giving precedence to the debtor's right to a fair trial - excludes the exercise of the creditor's right to enforcement, at least in the Member State where enforcement is refused. But in the opposite situation, where enforcement is allowed, one could question whether it has become entirely impossible to protect the debtor's right to a fair trial. One could argue that it is still possible for a debtor who has suffered an unfair trial to appeal to the ECtHR and obtain compensation that way, so that the protection of their rights has not become entirely impossible. The counterargument is that an application to the ECtHR cannot be considered a sufficient remedy for certain very serious violations. ${ }^{147}$ It was argued that it seems hardly sufficient when a judgment has been handed down in clear violation of fair trial, whose outcome is very questionable, for the creditor to profit from its enforcement while the judgment debtor has no choice but to undertake a lengthy and costly procedure before the ECtHR. More importantly, an application to the ECtHR can only result in a violation being found: it will not prevent the effects of the judgment from taking place.

A judge asked to rule on the judgment's enforceability should therefore ask himself whether the violation suffered by the debtor can be adequately remedied by an application to the ECtHR, or whether the only effective sanction is to prohibit the judgment's enforcement. In assessing this, the outcome/process dichotomy becomes relevant again. It could, for instance, be considered which of these two objectives the element concerned contributes to, and whether its violation has made achieving that goal utterly impossible. For example, one could argue that refusal of enforcement of the judgment ordering Mr Krombach to pay compensation was appropriate, because Mr Krombach's right to a fair hearing had been violated to such an extent that both objectives, obtaining a fair outcome and conducting a fair procedure, had become entirely impossible. Arguably, the only way of preventing an entirely unfair outcome from taking effect is to prohibit enforcement. For violations which concern only the procedure but

\footnotetext{
146 Brems (2005) p. 304.

${ }^{147}$ Cuniberti and Rueda (2011) p. 295
} 
which would not have influenced the outcome, it is perhaps still possible to restore the litigant's trust through compensation or a finding of a violation by the ECtHR, thereby making the achievement of this goal not entirely impossible. In any case, refusing enforcement would not repair a violation of this kind.

To ascertain whether attainment of the objectives of the fair trial has become utterly impossible, judges should ask what objective each of the elements of fair trial serves and whether it has been rendered utterly impossible. Section 7.3.7 provides concrete examples, but some idea should be given here of the implications of this factor for the judges' consideration.

\subsubsection{Whether other rights are also implicated}

The third element of Sullivan's proposed method is the question whether other rights are also implicated in the conflict. This is a difficult criterion to apply to cases involving the right to a fair trial, since they arguably by definition involve other rights; a fair trial is an auxiliary right necessary to protect or acquire subjective rights. However it may be possible to distinguish between cases in which the link with other rights is particularly strong. Within the context of this research, cases involving the right to family life (Art. 8) immediately come to mind, though in cases involving access to or the return of a child, this will likely not help solve the conflict because both parties will have equal claims under that right. Another example might be a case such as K.H. and others v. Slovakia, ${ }^{148}$ in which the ECtHR found a violation of Article 6(1) because a group of Roma women were denied access to their medical files. They needed these files to substantiate a claim against a hospital where, it was suspected, a sterilisation procedure had been performed on them without their consent, leading to their infertility. Being denied access to this information concerning their health also amounted to a violation of their right to private and family life, protected under Article 8.

\subsubsection{Cumulative effect}

As the final factor in Sullivan's approach, the question of 'cumulative effect' pertains to the wider repercussions of the restrictions imposed on the rights in question. It means that judges should consider the general interest that many fundamental rights embody. In the context of the right to a fair trial, this could perhaps lead judges to attach more weight to a violation of the requirement of independence of the judge which is shown to be systemic and widespread, since allowing such violations to go unchecked does not only have repercussions for the individual litigant. One could think of situations where a widely reported and serious problem exists concerning a lack of independence or the prevalence of corruption within the judiciary. It can, however, be questioned whether judges are really in a position to take such factors into account within the context of one particular case.

${ }^{148}$ ECtHR K.H. and others v. Slovakia, appl. no. 32881/04 ECHR 2009-II. 


\subsubsection{Other factors to consider}

In addition to the criteria developed by Sullivan, judges should take into account the principles underlying the recognition and enforcement regime of the European Regulations. One such principle, which was discussed in Chapter 2, is the prohibition of review on the merits. This principle, laid down in Article 52 of the Brussels I bis Regulation, requires judges to assume that the court in the Member State of origin lawfully reached a legally correct decision ${ }^{149}$. The finding of facts and legal qualification of those facts by the court of origin must be regarded as correct. What constitutes the 'substance' of the judgment should be interpreted broadly. ${ }^{150}$ According to the CJEU, this prohibition justifies a narrow interpretation of the grounds of refusal.

What implications does this have for the judge's consideration whether the judgment debtor's violation outweighs the refusal of enforcement to the creditor? Arguably, the prohibition of review on the substance prohibits a judge from refusing enforcement where the assessment whether a violation has taken place requires him to delve too deeply into the substantive assessment of the foreign court (it may be remembered that only 'manifest' or obvious violations should lead to refusal of enforcement). This problem could arise for example where the complaint of the judgment debtor pertains to him having been denied an oral hearing in the state of origin (see Section 7.3.7, below). The same might apply to a complaint that the judgment was not sufficiently motivated, since this also depends on such factors as the nature of the decision and the submissions that were made by the parties and whether those were or could have been decisive. ${ }^{151}$ The prohibition would most likely prevent a court from refusing enforcement on the basis of inconsistencies or irregularities in the Member State of origin's case law, even though such inconsistencies may lead to a finding of a violation according to the ECtHR. ${ }^{152}$ At the same time, any appeal to one of the refusal grounds may require a thorough review of the procedure before the court of origin, which may make it necessary to gain an overview of the arguments and evidence that were put forward. The scope of the prohibition on review on the substance is not entirely clear.

It must be clarified that the suggestion made above, that violations which affect the outcome of the trial should weigh heavier than violations that only affected the fairness of the process, should not be interpreted as permitting the judge in the relevant Member State to rule on the fairness of the outcome. Rather, it means that the complete absence of the prerequisites for achieving a fair outcome, among which a fair hearing, should weigh heavily towards a finding that refusal of enforcement is justified. The judge's consideration should therefore not concern the fairness of the outcome in the particular case, but the existence of violations of the elements of Article 6(1), which mean that the outcome cannot possibly have been fair.

\footnotetext{
${ }^{149}$ Fitchen (2015) p. 497.

${ }^{150}$ Ibid.

${ }^{151}$ See under 7.3.7.

${ }^{152}$ See 4.3.2.8.
} 
Arguably, judges may therefore only refuse recognition or enforcement if the violation in the underlying procedure is not only sufficiently serious but also obvious. This coincides with the qualification of Article 45(1)(a) of the Brussels I bis Regulation that the enforcement should be 'manifestly' incompatible with public policy for refusal to be justified. It is of course difficult to provide a criterion that allows a judge do distinguish between manifest and nonmanifest violations in every case. The next section aims to illustrate the difference with a number of examples.

Another factor to consider is the burden of proof, which lies with the party who appeals for a refusal of recognition or enforcement. Contrary to the ECtHR, a judge asked to rule on an application for refusal of enforcement should rely on the evidence provided by the applicant.

Though Article 47 of the Brussels I bis Regulation is silent on the matter of the burden of proof, it is clear that the refusal grounds must be actively invoked by an interested party. As discussed in Chapter 2, the requirement that refusal of enforcement or recognition may only be done on application by one of the interested parties is aimed at preventing courts from applying the refusal grounds ex officio. According to Article 47, which governs the procedure for requesting refusal of enforcement, requires the applicant to submit a copy of the judgment as well as a translation or transliteration where necessary. It does not refer to the possibility of submitting additional documentation to support the application for refusal. The article therefore does not exclude this possibility. Most likely the law of the Member State where enforcement is sought governs the matter of evidence according to as Article 47(2). This is important, because not all violations of the right to a fair trial may be obvious from the judgment on its own.

Yet even if the law of that Member State allows the submission of evidence in addition to the judgment, the system of the Regulation is clearly intended to avoid an extensive investigation at the enforcement stage of everything that may have gone wrong in an earlier phase of the proceedings. This is shown by the requirement that only 'manifest' violations of public policy may lead to refusal, and by the prohibition of review on the substance. Moreover, contrary to the ECtHR, a judge deciding on an application for refusal of enforcement does not have the authority to request documentation from the responsible government. For that reason, it seems clear that while a party who applies for refusal of enforcement is in principle free to submit evidence supporting that application, the judge deciding on that application should only take it into consideration in so far as it shows that an obvious violation has taken place.

A further factor that should be taken into account is whether the judgment debtor was capable of invoking remedies in the Member State of origin. This is not to say that enforcement should only be refused if no remedy remains in the Member State of origin, because as Layton states, it is precisely in cases where such remedies proved to be inadequate that refusal grounds are needed ${ }^{153}$ however, as the CJEU has consistently held, most recently in Diageo/Simiramida,

${ }^{153}$ Layton (2011) p. 6-7. 
they should only be applied "where specific circumstances make it too difficult or impossible to make use of the legal remedies in the Member State of origin". ${ }^{154}$ It is not sufficient for the debtor to merely state that the available remedies were likely to be ineffective.

Finally, and quite obviously, it should be considered whether the judgment debtor indeed suffered a disadvantage as a result of the violation. In this regard it should be observed that the rights that fair trial guarantees can be voluntarily waived, explicitly or implicitly. ${ }^{155}$

\subsubsection{Application to conflicts between specific elements of fair trial}

This section applies the factors identified in the preceding section to concrete cases. Examples are taken from the existing case law of the ECtHR and the CJEU to show how the rather abstract approach developed above could be applied to a concrete situation. In each of the following examples, the right to enforcement of the creditor is contrasted with one of the elements of fair trial, and it is considered how serious a violation of that element should be to outweigh the disadvantage suffered by the creditor. To this end, it is first examined to what extent a refusal of enforcement constitutes a violation of the creditor's right to enforcement, and how heavy such a violation should weigh in a conflict with another element of fair trial.

\subsubsection{Right to enforcement}

As Chapter 4.3.6 explained, the right to a fair trial encompasses a right to enforcement. According to the ECtHR, the right to enforcement requires states to take all necessary measures required to effect enforcement, though there may be limitations such as limitation periods, ${ }^{156}$ and states cannot be held accountable for circumstances beyond their control. ${ }^{157}$ In McDonald v. France, the ECtHR acknowledged that a denial of permission for enforcement of a foreign judgment could potentially constitute a violation of Article 6(1). ${ }^{158}$ At the same time, in Négrépontis-Giannisis the ECtHR acknowledged that states could apply a public policy condition to foreign judgments, provided it was not applied disproportionately and arbitrarily. ${ }^{159}$

Applying the principles developed above, it is clear that a refusal of enforcement would certainly preclude the objectives of a fair trial from being obtained, given that the ECtHR itself ruled that "that right would be illusory if a Contracting State's domestic legal system allowed

\footnotetext{
${ }^{154}$ CJEU Diageo/Simiramida, para. 64.

${ }^{155}$ ECtHR Deweer v. Belgium, appl. no. 6903/75, ECHR A35.

${ }^{156}$ ECtHR Vrbica v. Croatia appl. no. 32540/05, 1 April 2014, para. 66; ECtHR Scollo v. Italy, appl. no. $19133 / 91$ ECHR A315-C, para. 44; ECtHR Fuklev v. Ukraine appl. no. 71186/01, 7 June 2005; ECtHR Sanglier v. France, appl. no. 50342/99 27 May 2003, para. 39.

${ }^{157}$ ECtHR Sanglier v. France para. 39.

${ }^{158}$ ECtHR McDonald v. France.

${ }^{159}$ ECtHR Négrépontis-Giannisis, see also ECtHR Avotins v. Latvia.
} 
a final, binding judicial decision to remain inoperative to the detriment of one party". ${ }^{160} \mathrm{~A}$ refusal of enforcement would likely also mean that the exercise of this right would be rendered utterly impossible, since a refusal completely prohibits a judgment creditor from taking enforcement measures (at least in the Member State that refuses enforcement), or where recognition is concerned from invoking the judgment in any way. It is also possible, and in fact likely, that this has consequences for his ability to exercise other fundamental rights: the obvious example is a parent being prevented from having access to his or her children, as would follow from Article 8. ${ }^{161}$

A refusal to recognise or enforce a foreign judgment would therefore certainly amount to an interference with the creditor's rights under Article 6(1), though as Chapter 4.3.6 explained, the ECtHR has ruled that such an interference may be justified and therefore does not have to amount to a violation. A restriction does have to be proportional, according to the ECtHR. The following therefore essentially explores when a restriction of the creditor's right to enforcement would be disproportional to the violation suffered by the debtor.

\subsubsection{Right to a fair hearing versus the right to enforcement}

Under what circumstances can a violation of the right to a fair hearing outweigh the right to enforcement? Applying the principles developed above, the violation of the right to a fair hearing would first need to be such as to violate the 'core' of fair trial. It was proposed that what is the 'core' of fair trial depends on the objective that the element is intended to achieve, and that the objective of obtaining a fair outcome outweighs the objective of achieving a fair process. The right to a fair hearing does not appear to be subject to a margin of appreciation to any considerable degree. Furthermore, the violation would need to have been sufficiently serious to make the fulfilment of the objectives of the fair trial utterly impossible.

It seems to be quite clear that a case such as Krombach v. Bamberski ${ }^{162}$ would fulfil these criteria. In this case the defendant was entirely excluded from the trial and prevented from commenting on the claims and evidence presented by the claimant. Under such circumstances it seems clear that both the outcome and the process cannot have been fair. As Chapter 4 explained, the fair trial relies on an exchange of views between the parties in order to provide an accurate depiction of the facts of the case; if the facts have not been accurately established, it is impossible to apply the law to the facts and achieve a fair outcome. It seems clear that excluding a defendant from the trial entirely casts doubt on the veracity and fairness of the outcome. Furthermore, it seems clear that a rule of national law, which entirely precludes a

\footnotetext{
${ }^{160}$ ECtHR Hornsby v. Greece appl. no. 18357/91 ECHR 1997-II para. 40; see also ECtHR Marinkovic v Serbia, appl. no. 5353/11, 22 October 2013.

${ }^{161}$ Kiestra discusses to what extent a right to enforcement can be derived from ECHR rights other than fair trial: Kiestra (2014), p. 216-241.

${ }^{162}$ CJEU Krombach v. Bamberski, as discussed in Chapter 3.2.5.
} 
person from taking part in the trial, renders the exercise of his right to be heard utterly impossible. Moreover, the existence of such a rule makes it very simple for a judge to ascertain that a violation occurred. The prohibition of reviewing a judgment on its substance should not pose an obstacle in this context, and neither should the burden of proof. ${ }^{163}$ Along the same lines, a case in which no service took place or the defendant was otherwise not informed for reasons outside his control, such as Beer v. Austria or Maronier v. Larmer, could also justify refusal of enforcement. ${ }^{164}$

The application of the criteria is more difficult when it comes to violations that do not affect the outcome of the proceedings, or where their impact is difficult to ascertain. In a case such as Nideröst-Huber, a violation of the right to adversarial proceedings was found because the defendant had not been allowed to comment on observations submitted by a lower court to the court that was to decide on the case. ${ }^{165}$ This amounted to a violation, even though the observations had not influenced the decision, because according to the ECtHR it is for the parties to decide whether they wish to comment on any observations submitted, and because the observations were clearly aimed at influencing the decision. Though these circumstances may lead to a finding of a violation by the ECtHR, it is questionable whether refusal of enforcement would be proportional in such a case. Firstly, given that the lack of an adversarial trial did not have any consequences for the outcome of the trial, refusal of enforcement would not seem to be able to remedy such a violation. Arguably, what has been harmed is, as the ECtHR puts it, "the litigant's trust in the workings of justice", which may be remedied by a finding of the ECtHR that a violation has been committed. ${ }^{166}$ This reasoning would also apply to violations of the right to equality of arms that did not influence the outcome of the trial.

By contrast, a case such as Feldbrugge, ${ }^{167}$ where the defendant was prevented from commenting on evidence which was decisive for the outcome of the proceedings, could trigger the refusal of enforcement provided it can be shown, without the judge having to review the entire procedure, that such evidence was indeed decisive for the outcome. The trouble here would most likely lie in the prohibition to review the judgment as to its substance: it would be very difficult for a judge to make an assessment of what evidence was presented during the trial and whether or not it was decisive for the outcome. Perhaps for this reason the application of the remedy of refusing recognition or enforcement should be restricted to cases in which the defendant was entirely and unfairly excluded from the trial or prevented from commenting on any submissions. A possible example would be the case of A.B. v. Slovakia, in which a litigant was prevented from effectively taking part in the trial due to the court's failure to respond to

\footnotetext{
163 The same reasoning applies to the Gambazzi case, discussed under 3.2.5. See also Andrews (2007) p. 43.

${ }^{164}$ ECtHR Beer v. Austria, appl. no. 30428/96, 6 February 2001; Court of Appeal, 29 March 2002, Unanimous opinion by Lord Philips MR - Maronier v. Larmer; see under 3.2.6.

${ }^{165}$ ECtHR Nideröst-Huber v. Switzerland appl. no. 18990/91 ECHR 1997-I,

${ }^{166}$ ECtHR Nideröst-Huber v. Switzerland para. 30.

${ }^{167}$ ECtHR Feldbrugge $v$ Netherlands (merits) appl. No 8562/79, ECHR A99.
} 
her request that a lawyer be appointed. ${ }^{168}$ In such cases, it would be almost impossible for the right to an adversarial trial to be respected; and such an exclusion from the trial would be immediately obvious to the judge who decides on the appeal for refusal of enforcement.

It can therefore be concluded that violations of the right to an adversarial trial and the principle of equality of arms are likely to fall foul of the prohibition on reviewing a judgment as to its substance. The ECtHR's case law offers many examples of violations that would not justify a refusal of enforcement for this reason. One example is Cepekv. Czech Republic, ${ }^{169}$ in which the court failed to inform the litigant that it would apply a very specific derogation of a rule of civil procedure concerning procedural costs. Another is Zagrebacka banka v. Croatia, ${ }^{170}$ in which a litigant did not have sufficient time to react to an estimate of the legal interest to be paid over the principal sum, which also amounted to a violation. In such cases, a refusal to enforce only those parts of the judgment affected by the violation may offer a solution.

Finally, a clear reason for refusal would be if the courts in the Member State of origin failed to request a preliminary ruling from the CJEU if they were under an obligation to do so; the CJEU's ruling in, for instance, Diageo/Simiramida makes quite clear that preliminary ruling is an essential part of safeguarding a fair trial. ${ }^{171}$ The ECtHR also considers it a violation of Article 6(1) if a domestic court failed to request a preliminary ruling if it was under an obligation to do so. ${ }^{172}$

\subsubsection{Right to a reasoned judgment versus the right to enforcement}

The right to a reasoned judgment is one of the more complex elements of Article 6(1) to which to apply the criteria developed above. It is true that an adequate reasoning is essential for the parties to understand the reasons why a decision was taken and to enable them to decide whether or not to appeal against it. It ensures that the judge is accountable to both the parties and to the wider society for his decisions; it allows the fairness and veracity of his decisions to be scrutinised. A complete absence of any kind of reasoning therefore certainly casts legitimate doubt on the fairness of the outcome of the proceedings and therefore arguably affects the very core of the right to a fair trial. ${ }^{173}$

At the same time, it was repeatedly mentioned that the right to a reasoned judgment is not only subject to a certain discretion, but that it also entirely depends on the circumstances of the case.

${ }^{168}$ ECtHR A.B. v. Slovakia, appl. no. 41784/98 4 March 2003.

${ }^{169}$ ECtHR Cepek v. Czech Republic, appl. no. 9815/10, 5 September 2013.

${ }^{170}$ ECtHR Zagrebacka banka v. Croatia appl. no. 39544/05 12 December 2013.

${ }^{171}$ Case C 681/13 Diageo Brands v Simiramida-04 EOOD ECLI:EU:C:2015:471, para. 49; Hazelhorst (2016) p. 13.

${ }^{172}$ ECtHR Dhahbi v. Italy, appl. no. 17120/09, 8 April 2014.

${ }^{173}$ See also Cuniberti (2008) p. 29. 
On the subject of the discretion, the ECtHR has consistently paid attention to "the differences existing in the Contracting States with regard to statutory provisions, customary rules, legal opinion and the drafting and presentation of judgments." 174 This seems to imply that alongside the objective circumstances of the case, consideration may also be given to what is customary under national law when it comes to the motivation of judgments. Contracting States therefore enjoy a certain margin of discretion in this regard. ${ }^{175}$ From this it can be inferred that differences in national practices with regard to the motivation of judgments are in principle acceptable in light of the right to a fair trial, as long as the manner of reasoning meets the other criteria developed in the Court's case law. ${ }^{176}$ As was explained above, the existence of such a margin of appreciation renders the assessment whether or not the judgment was sufficiently reasoned more difficult. The judge would need to take into account the standard of reasoning that is generally required in the state where the judgment was rendered, and not apply the standard that would be expected for domestic judgments.

Even more problematic is, again, the prohibition on reviewing the judgment on the substance. As was explained in Chapter 4, assessing whether a judgment was sufficiently motivated involves an examination of the arguments and evidence that were at issue during the proceedings. The ECtHR has found violations of this element where the applicant was awarded only a partial disability pension, even though he had earlier received a full pension; according to the Court the 'confusion' this caused for the defendant required the judgment to be more extensively motivated. ${ }^{177}$ To arrive at this conclusion the ECtHR therefore had to establish what was at stake in the case, what questions were raised, and what factors would influence the outcome of the proceedings. Another example is Tatishvili v. Russia, in which the ECtHR found a violation in the failure of the courts to take into account evidence produced at the trial, and to verify whether the treaty on which they based their conclusions in fact existed. ${ }^{178}$ Though such omissions undoubtedly amount to a violation of the right to a fair trial, it is submitted that for a judge deciding on a refusal of enforcement such a conclusion would veer too closely to a review of the evidence submitted and of the legal basis for the foreign court's decision. This seems hardly compatible with the prohibition on review as to the judgment's substance.

\footnotetext{
${ }^{174}$ ECtHR Ruiz Torija v. Spain, appl. no. 18390/91 ECHR A303-A, para. 27; ECtHR Hiro Balani v. Spain, appl. no. 18064/91 A303-B, para. 29.

175 Smits (2008) p. 148. It would not be correct to call this a margin of appreciation, because the ECtHR still reviews fully whether the right to a reasoned judgment has been respected in each case: see under 3.3.2.

${ }^{176}$ Cuniberti has questioned in this regard whether English default judgments, in which a claim is simply awarded without further examination if the defendant fails to file a defence or an acknowledgement of service, are compatible with Article 6(1). A definitive answer cannot be given, because such a case has never come before the ECtHR; possibly, as Cuniberti points out, because the ECtHR only has jurisdiction when all remedies at the national level have been exhausted, while default judgments are usually rendered at the first instance level. Cuniberti (2008) p. 29.

${ }^{177}$ ECtHR Hirvisaari v. Finland, appl. no. 49684/99 27 September 2001, para. 31.

${ }^{178}$ ECtHR Tatishvili v. Russia appl. no. 1509/02 ECHR 2007-I, para. 60-61.
} 
It is concluded that a lack of reasoning should only lead to refusal of enforcement if it is obvious, for example when a judgment has not been motivated at all. In this assessment, the judge must keep in mind whether the objective of providing clarity and accountability have indeed been rendered entirely impossible to achieve by the lack of reasoning. Arguably, a default judgment which contains no reasons but which is based on a rule of law which says that a claim shall be awarded if it is not opposed, is not incompatible with these objectives. ${ }^{179}$

\subsubsection{Right to an oral hearing versus the right to enforcement}

The right to an oral hearing may be essential to both objectives of the fair trial depending on the circumstances of the case; yet a right to an oral hearing does not exist in each case. As the ECtHR clarified in Jussila v. Finland, whether an oral hearing is required comes down to the nature of the issues to be decided; ${ }^{180}$ it also ruled that regard may be had to considerations of "efficiency and economy"181 in the decision whether to allow an oral hearing. This margin of discretion means that it would be difficult to review at the enforcement stage whether an oral hearing should have been held. It may be remembered that in Jussila the ECtHR explicitly renounced the idea that there is a right to an oral hearing in at least one instance unless 'exceptional circumstances' allow the court to dispense with it, ${ }^{182}$ and that it is not the case that an oral hearing should be refused only in rare cases. It is submitted that considering this leeway that is accorded to the national judge of the state where the procedure took place, it would be difficult for a judge in the state of enforcement to review whether the oral hearing was rightfully refused.

This is compounded by the fact that the decision to hold an oral hearing is highly influenced by the facts of the case. The prohibition on review as to the substance likely forms an obstacle here as well. Whether a refusal to hold an oral hearing constitutes a violation comes down, according to the ECtHR, to whether it is possible to resolve the case only on the basis of written observations or whether there were circumstances that could only be verified at an oral hearing. An oral hearing may be necessary where the "personal character and manner of life" of the party concerned are relevant for the decision, ${ }^{183}$ or where the case involves an assessment of the applicant's conduct. ${ }^{184}$ Again, deciding whether an oral hearing was necessary therefore requires the judge to review whether the judge that delivered the judgment adequately assessed

\footnotetext{
${ }^{179}$ Cuniberti (2008).

${ }^{180}$ ECtHR Jussila v. Finland (merits) appl. no. 73053/01 ECHR 2006-XIV.

${ }^{181}$ ECtHR Schuler-Zgraggen v. Austria, appl. no. 14518/89, 31 January 1995.

182 As was the ECtHR's approach in ECtHR Fischer v Austria, appl. no. 33382/96, 17 January 2002; ECtHR Salomonsson v Sweden, appl. no. 38978/97, 12 November 2002; ECtHR Martinie v France [GC], 58675/00, ECHR 2006-VI, ECtHR Miller $v$ Sweden appl. no. 55853/00 para. 29; see 3.3.2.

${ }^{183}$ ECtHR $X$. v. Sweden. The presence of the litigant has also been required in child access cases $(X v$. Sweden) and in some commercial cases (X. v. Germany). European Commission for Human Rights X. v. Germany (dec.) appl. no. 1169/61 24 September 1963; and X. v. Sweden (dec.) appl. no. 434/58 30 June 1959.

${ }^{184}$ ECtHR Muyldermans v. Belgium, appl. no., 12217/86 ECHR A214-A.
} 
the facts and arguments presented and what was needed to either prove or disprove them. Arguably, such a review would be incompatible with the prohibition on review as to the substance. As an example, refusal of enforcement or recognition would likely not be justified in a case such as Helmers. In that case, the ECtHR concluded that an oral hearing should have been held due to the nature of the case (defamation), what was at stake for the applicant (his professional reputation and career). It also considered what questions were at issue: the points raised "went to the merits of the case and, [...] raised serious questions as to which facts were relevant [and] which facts had been proved." According to the ECtHR, such matters could only be settled by means of an oral hearing. ${ }^{185}$ It is submitted that if a court, asked to decide on an application for refusal of enforcement, were to carry out such a thorough review, this would come close to substituting its own discretion for that of the court of origin, which the EU regime for recognition and enforcement does not allow. ${ }^{186}$

Given the degree of discretion attached to the decision to hold an oral hearing, a decision not to do so is unlikely to be able to justify refusal of recognition or enforcement. This may be different where the oral hearing was refused because of a rule of law that completely prohibits oral hearings from being held for an entire category of cases, where it was impossible to plead that exceptional circumstances nevertheless justified a hearing, and where there was no possibility of remedying this during an appeal.

\subsubsection{Right to a public trial versus the right to enforcement}

As explained in Chapter 4, publicity is important to a fair trial. As the ECtHR put it, given the possible detrimental effects that the lack of a public hearing could have on the fairness of the proceedings, the absence of publicity could not in any event be remedied by anything other than a complete re-hearing before the appellate court. ${ }^{187}$ Article 6(1) exhaustively lists a number of grounds for limitation of the right to a public hearing.

On one hand, the right to a public hearing is therefore in most cases 'essential' to the fairness of the trial. This is borne out by the fact that it can only be limited under very specific circumstances, which Article 6(1) lists exhaustively. At the same time, the application of these limitation grounds leaves a degree of discretion to the national court. Establishing whether or not, for example, the young age of those involved, or the sensitivity of the issues discussed, could justify a restriction of the right to a hearing held in public, is a consideration which really only the judge deciding on the dispute could have made.

On the other hand, if there was a rule that required that all hearings should be held in private, without the litigant being able to request a public hearing on the ground that his case presents

\footnotetext{
${ }^{185}$ ECtHR Helmers v. Sweden, appl. no. 1826/85 ECHR A212-A para 38-39.

${ }^{186}$ Mankowski (2016) p. 964.

${ }^{187}$ ECtHR Riepan v. Austria, appl. no. 35115/97, ECHR 2000-XII, para. 40.
} 
special features, this could perhaps be considered ground for refusing enforcement or recognition. As the ECtHR ruled in Martinie v. France, such rules "cannot in principle be regarded as compatible with Article $6 \S 1$ of the Convention". ${ }^{188}$ In that case it ruled that "other than in wholly exceptional circumstances, litigants must at least have the opportunity of requesting a public hearing, though the court may refuse the request and hold the hearing in private on account of the circumstances of the case and for pertinent reasons". ${ }^{189}$ If, therefore, the hearing was held in private, without any possibility of requesting that it be held in public, this might justify a refusal of enforcement or recognition. The existence of such a rule would be immediately obvious, so the prohibition of review on the substance would not be an issue; also, it might be considered what wider repercussions for the credibility of the justice system it would have if all hearings were held in private. Such a rule would affect the transparency and accountability of the justice system and therefore cast doubt on the fairness of both the outcome and the proceedings.

7.3.7.6 The right to adjudication by an impartial and independent tribunal versus the right to enforcement

The absence of independence or impartiality of the judge imparts the fairness of the outcome and destroys both the parties' and the public's confidence in the judiciary. This is exemplified by the ECtHR's judgment in Micallef v. Malta, where the Court held that even when deciding on a request for interim measures (such as injunctions), where speed is of the essence, the right to an impartial and independent tribunal must always be respected, even if other elements of Article 6(1) may only apply in so far as compatible with the nature and purpose of interim proceedings. ${ }^{190}$ In such cases, the right to an impartial and independent tribunal remains an indispensable and inalienable safeguard, according to the Court. ${ }^{191}$ A clear case of corruption, for example, should therefore probably lead to refusal of enforcement. In such cases, the deciding judge may take into account the 'cumulative effect' of the violation, and the effects it has on society.

The problem with this assessment will most likely lie in the burden of proof. It was previously concluded that while a party who applies for refusal of enforcement is in principle free to submit evidence supporting that application, the judge deciding on that application should only consider it as far as it shows that an obvious violation has taken place. An application for refusal of enforcement should not result in a complete review of the procedure in the Member State of origin. Yet with regard to the problem of independence or impartiality, additional evidence may be necessary, considering that a lack of impartiality is most likely not immediately obvious from the judgment alone.

${ }^{188}$ ECtHR Martinie v France [GC], paras. 41-42.

${ }^{189}$ ECtHR Martinie v France [GC], para. 42.

${ }^{190}$ ECtHR Micallef v. Malta [GC], appl. no. 17056/06 ECHR 2009-V, para. 86.

${ }^{191}$ ECtHR Micallef v. Malta [GC], para. 86. 
In particular, it may be difficult to prove personal bias on the part of the judge. For this reason, the ECtHR has also allowed objective factors that give rise to legitimate doubt as to the judge's impartiality as evidence of a violation. A case such as Micallef $v$. Malta provides a clear indication of a personal bias of the judge: in that case the judge was a family member of the opponent of an applicant. Such a personal connection is likely to lead to personal bias, and is often simple to prove. A case such as Aslaner v. Turkey is more difficult, because in that case a violation was found in the fact that three judges out of thirty-one had been previously involved with the case. Though such factors are in principle objectively verifiable, the ECtHR has ruled that the 'degree of the involvement' should be taken into account; the fact that a judge was previously involved at all does not necessarily amount to a lack of impartiality. To establish whether a violation took place, a judge should look very closely at the decisions previously taken by the judges suspected of bias and to what extent those decisions concerned the substance of the judgment whose enforcement is requested. In Aslaner, that assessment included reviewing the exact questions on which the judges suspected of bias had been asked to rule in a previous stage of the proceedings. Though such factors are still relatively easy to discern objectively, and might therefore amount to an 'obvious' violation, such an assessment comes close to a review on the substance and requires detailed information about the proceedings. More problematic are cases that require a review of the internal rules of the judiciary in the Member State of origin. According to the ECtHR, the absence of procedures for requesting the withdrawal of judges suspected of bias may amount to an objective factor giving rise to legitimate doubt about the judges' impartiality. ${ }^{192}$ Likewise, an absence of independence may be derived from deficiencies in the judicial organisation, such as guarantees for a random assignment of cases ${ }^{193}$ and to prevent interference from the executive powers. ${ }^{194}$ It is questionable to what extent such factors can really be assessed adequately in an enforcement dispute, as they would require thorough knowledge of the procedural law and judicial organisation of the state of origin. For example, the ECtHR found a violation in DMD Group v Slovakia because there was no system in place to guarantee the random assignment of cases to a judge, but it only came to this conclusion after an extensive discussion of the mechanism for awarding cases and the criteria used in that regard. ${ }^{195}$ Such information is most likely not publicly available; in its judgment, the ECtHR referred to administrative rules on the assignment of cases, ${ }^{196}$ but also to the work schedules made pursuant to those rules ${ }^{197}$ and the number of modifications made to those schedules. ${ }^{198}$ It is submitted that such an assessment could not be expected from a judge ruling on refusal of enforcement.

\footnotetext{
${ }^{192}$ ECtHR Piersack v. Belgium (merits) appl. no. 8692/79, ECHR A53.

${ }^{193}$ ECtHR DMD Group v. Slovakia, appl. no. 19334/03 5 October 2010.

${ }^{194}$ ECtHR Agrokompleks v. Ukraine (merits) appl. no. 23465/03, 6 October 2011.

195 ECtHR DMD Group v. Slovakia.

${ }^{196}$ ECtHR DMD Group v. Slovakia, paras. 34-39.

${ }^{197}$ ECtHR DMD Group v. Slovakia, para. 16.

${ }^{198}$ ECtHR DMD Group v. Slovakia, paras. 18-21.
} 
By contrast, in some cases, it is comparatively easy to assess the degree of independence of the judge without having to go into details. As an example, in the case of Brudnicka v. Poland, ${ }^{199}$ a violation was found in a maritime dispute, because of the fact that the judges who decided were immediately accountable to the executive, and that their appointment and removal was also decided on by the executive. This hierarchy was immediately obvious from the legislation governing the procedure. In such a case, the deciding judge should only have to look at legislation, which is usually publicly available, to establish a lack of independence. Another clear indication may be the presence of submissions by members of the executive in the case file. ${ }^{200}$ In Agrokompleks v. Ukraine, there were letters in the case file from the applicant's opponent to members of the Parliament, letters with 'instructions' from those members of parliament to the court, and letters of thanks from that party to the members of parliament for their intervention. ${ }^{201}$ The ECtHR therefore concluded that the authorities "blatantly interfered in the court proceedings, which is unacceptable". ${ }^{202}$ It is submitted that such cases, where there is evidence in the case file of an interference that by its nature is incompatible with the principle of independence, should lead to refusal of enforcement or recognition. Most likely such cases where evidence of blatant interference is available are rare; presumably, in most cases the interference of the executive or other actors happens more covertly. It is submitted that in such cases courts should be able to take into account generally available and objective information as to, for example, the presence of corruption in the judiciary. This was the approach of the Dutch Court of Appeal on the recognition of arbitral awards in the Yukos Oil v. Rosneft case. These arbitral awards were annulled by a Russian court. Despite this annulment, the Yukos Oil shareholders sought enforcement of the arbitral awards, stating that the trial in which they had been annulled was tainted by corruption. ${ }^{203}$ The Dutch Court of Appeal, relying on diversity sources, ruled that it was sufficiently likely that the courts who decided on the annulment had been partial and dependent, and that therefore this decision should be ignored in the proceedings on recognition. ${ }^{204}$ It is submitted that, extreme though this example is, this approach is correct given that it is impossible to require the parties affected by corruption or partiality to provide evidence thereof. In this context, one may also think of reorganisations of the judiciary that give rise to severe doubt as to the independence of the judiciary from the executive. For example, in 2011, Hungary undertook a reform of its judicial system which involved such measures as an abrupt lowering of the retirement age for judges and the dismissal of the President of the Supreme Court. The former was found by the CJEU to be incompatible with EU legislation on equal treatment, ${ }^{205}$ while the latter led to a finding of a violation of

\footnotetext{
${ }^{199}$ ECtHR Brudnicka and others v. Poland, appl. no. 54723/00, ECHR 2005-II, para. 17.

${ }^{200}$ ECtHR Agrokompleks v. Ukraine (merits).

${ }^{201}$ ECtHR Agrokompleks v. Ukraine (merits) para. 130.

202 ECtHR Agrokompleks v. Ukraine (merits) para. 135.

${ }^{203}$ Kramer (2012) p. 136.

${ }^{204}$ Gerechtshof Amsterdam 28 April 2009, ECLI:NL:GHAMS:2009:BI2451, Yukos Capital v. Rosneft, para, 3.10.

${ }^{205}$ CJEU Case C-286/12 European Commission v. Hungary, ECLI:EU:C:2012:687.
} 
Articles 6(1) and 10 ECHR by the ECtHR. ${ }^{206}$ The reforms were also widely condemned politically. ${ }^{207}$ Such widespread, well-documented and profound concerns about the independence of the judiciary in a Member State may arguably provide a basis for applying the public policy exception.

7.3.7.7 The right to a decision within a reasonable time versus the right to enforcement

The right to a decision within a reasonable time is certainly essential to the fairness of the trial, given that excessive delays undermine the credibility and effectiveness of the trial. However, it is questionable whether a failure to observe this requirement should result in nonenforcement. Firstly, the argument made in the preceding sections was that it is arguably fair for the creditor to be denied enforcement of a judgment if it is doubtful that the judgment itself is fair or based on a correct understanding of the facts. If the reasonable time has been exceeded, the fairness of the outcome is however in principle not affected (though this may be different for cases where speed is of the essence: see below). Moreover, if a court has failed to deliver its judgment within a reasonable time, this constitutes a violation of Article 6(1) vis-à-vis both parties, not just the judgment debtor. It does not seem proportionate if a court were to refuse enforcement in order to remedy a violation of the reasonable time requirement suffered by the debtor, if the creditor is also a victim of that violation.

Secondly, the ECtHR's own case law offers up examples of cases where the reasonable time requirement was found not to outweigh violations of other elements of the fair trial. In Wynen v. Belgium, ${ }^{208}$ a criminal case, the ECtHR found a violation of the principle of equality of arms because the applicant was limited in the number of memorandums or documents he could submit, while the defendant in the same case was not subjected to such a time limit. According to the respondent government, this limitation had been imposed in order to expedite the proceedings and make them more efficient by limiting the number of exchanges that parties could have between themselves, thus reducing the burden on the deciding court. Though the ECtHR acknowledged the importance of guaranteeing a trial within a reasonable time, it ruled that the applicant's right to equality of arms should not have been sacrificed to achieve that goal. It stated that other ways could have been found to ensure expeditious proceedings which

${ }^{206}$ ECtHR Baka v. Hungary (merits) appl. no. 20261/12 27 May 2014 (referred to the Grand Chamber on 15 December 2014). The applicant, former President of the Hungarian Supreme Court Baka, argued that critical opinions about the reforms submitted by him in his official capacity had led to his dismissal. The ECtHR considered this a violation of Article 10 (the right to free expression) rather than of judicial independence, though it has been argued that this would have been the better option: Sillen (2014).

207 The European Commission launched accelerated infringement proceedings against Hungary as a result of the reforms: European Commission, Press Release: European Commission - Press release

European Commission launches accelerated infringement proceedings against Hungary over the independence of its central bank and data protection authorities as well as over measures affecting the judiciary, Strasbourg: 17 January 2012.

${ }^{208}$ ECtHR Wynen v Belgium appl. no. 32576/96 ECHR 2002-VIII. See for a discussion Brems 2005, p. 306. 
did not put one of the parties at a disadvantage vis-à-vis the other, for example by limiting the time during which submissions could be made for both parties equally. ${ }^{209}$

Another important case is Goç v. Turkey, ${ }^{210}$ in which the applicant had claimed compensation from the state for his wrongful arrest and deprivation of liberty. During the proceedings the applicant had not been allowed to present his views during an oral hearing. The ECtHR ruled that this constituted a violation of Article 6(1), because the applicant had been wrongly imprisoned, and an oral hearing was necessary to allow the applicant to communicate effectively the extent of his suffering and how this had influenced him and his family. ${ }^{211}$ The respondent government argued that holding an oral hearing was not necessary in this case and would have impaired the procedure's speed and efficiency. The ECtHR however considered that the applicant's "right to explain his personal situation in a hearing before the domestic court subject to public scrutiny [...] outweighs the considerations of speed and efficiency" 212 .

In both these judgments, the ECtHR therefore prioritised other elements of the fair trial over the right to a decision within a reasonable time. The underlying idea appears to be that there are many ways of ensuring a speedy and efficient procedure, which do not impact on the litigant's other rights under Article 6(1). Along the same lines, and in addition to the argument presented above, it can be argued that it would also be disproportionate to prioritise the reasonable time requirement over the right to enforcement. It is important to all parties involved that procedures are conducted within a reasonable time, but according to the ECtHR, this can never be a reason to disregard other elements of the fair trial.

Finally, as has been discussed, there appears to be a consensus that excessively long proceedings should not be addressed by a remedy that affects the outcome of the proceedings. Chapter 4 referred to the ECtHR's judgment in Kudla v. Poland, and the CJEU's judgment in Der Grüne Punkt, both of which proscribed either remedies aimed at acceleration of the proceedings, or pecuniary compensation, for violations of the reasonable time requirement. Contrary to violations of other elements of Articles 6(1) and 47, appeals or other procedural remedies appear not to be seen as effective for addressing violations of the reasonable time requirement, since additional procedures only extend the proceedings even further. Apart from that practical consideration, there may also be an argument of principle behind this rule. Contrary to such elements as the right to a fair hearing, the reasonable time requirement arguably does not contribute to the fairness of the outcome of the proceedings. It would perhaps be inappropriate if, as a sanction for exceeding the reasonable time, the decision that was taken would again be made subject to discussion, even though there are no reasons to doubt its fairness. In line with the ECtHR's judgment in Kudla v. Poland, it would be too burdensome

${ }^{209}$ ECtHR Wynen v. Belgium para. 32.

${ }^{210}$ ECtHR Goç v. Turkey, appl. no. 36590/97 ECHR 2002-V.

${ }^{211}$ ECtHR Goç v Turkey para. 51.

${ }^{212}$ ECtHR Goç v Turkey para. 51. 
to expect the litigants to endure additional procedural steps if the decision was not unfair in the first place. A refusal of enforcement or recognition, or another remedy which influences the outcome of the proceedings, therefore cannot adequately address the damage suffered by the litigants as a result of an exceedance of the reasonable time.

This could be different in cases where the lack of speed either disproportionally disadvantaged one of the parties, or where it had a demonstrable impact on the outcome of the proceedings. Both may be an issue in family law matters, especially in cases concerning child custody, where the passage of time may have irreversible consequences for the parent-child relationship. ${ }^{213}$ It has also been accepted that, even when a child has been wrongfully removed, the passage of time may eventually render a return of the child to the country where he or she originally resided contrary to his or her best interests. ${ }^{214}$ It would thus be possible for litigants to apply delaying tactics to such an extent that it affects the outcome of the proceedings. Such delays, especially where they are partly caused by the courts that delivered the judgment, should arguably be considered contrary to public policy. The inherent risk of this approach is that the abducting or removing parent could argue that a return order handed down after an excessively long period should not be enforced, thereby profiting from both the abduction and the inactivity of the courts in the country of habitual residence. This risk is well documented in literature on international child abduction, which is why speed is one of the concepts underlying both Regulation 2201/2003 and the Hague Child Abduction Convention, ${ }^{215}$ so that excessively long proceedings are avoided. The other inherent risk is that refusal of enforcement of, for example, a return order, may only exacerbate the damage done to the relationship between the child and its parent. It is therefore very unlikely that refusal of recognition or enforcement on the basis of a violation of the reasonable time requirement is an adequate remedy for that violation and in the interests of the parties involved. ${ }^{216}$

\subsubsection{The right to consistency and legal certainty versus the right to enforcement}

Finally, it was previously discussed that a violation of fair trial may also occur where there are considerable inconsistencies in court decisions. ${ }^{217}$ In such cases, the violation is found in the outcome of the proceedings and the application of the law by the court of origin, not in the

\footnotetext{
${ }^{213}$ ECtHR Tsikakis v. Germany, appl. no. 1521/06 10 February 2011. There may be more examples of cases where the length of proceedings is elementary to their fairness, for instance in personal injury cases.

${ }^{214}$ Chapter 8.6.

${ }^{215}$ Recital 17 Regulation 2201/2003; the Recitals of the Convention of 25 October 1980 on the Civil Aspects of International Child Abduction (Hague Child Abduction Convention) cite achieving a prompt return of the child as an aim of the Convention.

${ }^{216}$ See also the discussion under 7.5.

${ }^{217}$ Chapter 4.3.2.8.
} 
procedure itself. It is submitted that such an application of fair trial does not sit well with the general prohibition on reviewing judgments on the merits.

This may be different in cases where the decision of the court is 'arbitrary or manifestly unreasonable', as it was in the cases of Khamidov and Andelkovic. ${ }^{218}$ Even though in those cases the violation also concerns the outcome of the proceedings, it is submitted that the prohibition on review as to the substance should not be an obstacle. These judgments emanate from cases in which the unfairness of the trial was apparent from the outcome of the case: he or she may have been given an opportunity to be heard, but clearly their submissions or any evidence in favour of their claim was nevertheless disregarded. This points to extreme carelessness, or perhaps a lack of impartiality, on the part of the court. The problem is that this procedural unfairness is only apparent in the outcome of the case, and that a review of the substance, including the available evidence and how it was appreciated, needs to be carried out in order to arrive at this conclusion. However, these are extreme examples of cases where only a superficial reading of the judgment would show that the trial cannot have been fair. In Khamidov v. Russia, it was apparent from the judgment that the courts had completely and without justification ignored all evidence submitted by the applicant, while in Andelkovic the court failed to refer to the applicable law and the facts of the case, rendering the judgment wholly arbitrary. Such defects should be immediately obvious from looking at the judgment and the case file.

Along the same lines, it would be possible for a court to refuse enforcement on the basis that legal certainty was not respected, for example in a case such as Brumarescu. In this case a violation was found in the fact that a final judicial decision was overturned without a justification. Provided that there no possible justification could be found, such violations could be considered contrary to public policy. The ECtHR's line of case law pertaining to consistency however is more problematic. While the ECtHR may find that inconsistencies are incompatible with the right to a fair trial, for a judge to refuse enforcement on this basis would most likely clash with the prohibition on review as to the substance of the judgment. A case such as Borovska and Ferrai v. Slovakia should therefore probably not lead to refusal of recognition or enforcement. ${ }^{219}$

\subsubsection{Conclusion: the threshold for refusing recognition or enforcement}

Refusal of recognition or enforcement is only justified when the violation suffered by the judgment debtor outweighs the violation suffered by the creditor of his right to enforcement. The following factors should be taken into consideration in such an assessment.

a. Refusal of recognition or enforcement is more likely to be justified where the debtor suffered a violation of an element of Article 6(1) that serves the objective of achieving a fair outcome; if this is so, the violation has given rise to severe doubts

\footnotetext{
${ }^{218}$ ECtHR Khamidov v. Russia; ECtHR Andelkovic v Serbia.

${ }^{219}$ ECtHR Borovská and Ferrai v. Slovakia, appl. no. 48554/10, 25 November 2014.
} 
as to the fairness and veracity of the outcome, and refusal of enforcement if that outcome may be an appropriate sanction. Refusal of enforcement or recognition is likely not an appropriate sanction for violations of elements that only inform the procedure and have no impact on the outcome, or for which specific sanctions have been proscribed.

b. Refusal of recognition or enforcement is less likely to be appropriate if the element that was violated leaves a degree of appreciation to the Contracting States.

c. Refusal of recognition or enforcement is more likely to be justified where the violation suffered by the debtor must made the exercise of the element of Article 6(1) utterly impossible. The deciding judge must consider whether a remedy in the state of origin or before the ECtHR may offer an adequate solution. If so, refusal of enforcement or recognition is not appropriate.

d. When fundamental rights other than Article 6(1) are also violated or interfered with by the violation of Article 6(1), this provides an additional reason for refusing enforcement or recognition. The judge should have regard to the immediacy and severity of the interference.

e. The judge may consider the wider repercussions of the violation suffered by the debtor on underlying principles such as the rule of law or the credibility of the justice system.

f. Refusal of recognition or enforcement is inappropriate if the assessment whether a violation took place requires a review of the procedure in the state of origin, to such an extent that it essentially amounts to a review of the judgment on its substance.

g. Judges should, when necessary, take into account the difficulties the applicant may encounter in providing evidence, and correct for them.

h. Refusal is unlikely to be appropriate if a remedy was available in the Member State of origin, unless the specific circumstances made it too difficult or impossible to make use of the legal remedies in the Member State of origin.

i. Refusal is only appropriate if the person who requests refusal has in fact suffered a disadvantage as a result of the violation. It should be considered whether he himself contributed to the violation and whether he (implicitly) waived his right to fair trial.

j. A judge must consider whether partial refusal of enforcement is possible and adequate as a sanction, if the violation suffered by the debtor affects only one distinct aspect of the procedure.

\subsection{Protection of the defaulting defendant and the special jurisdiction grounds}

The previous sections discussed in detail the need for a public policy exception in the European Regulations on recognition and enforcement. This Chapter does not discuss in detail the need for a specific refusal ground to protect defendants, such as Article 45(1)(b) of Brussels I bis. The reason for this is that the arguments in favour of retaining a refusal ground capable of addressing violations of fair trial apply equally to this refusal ground as they do to the public 
policy exception. As Chapter 3 discussed, this refusal ground has proved practically important in remedying fundamental rights violations; for that reason, it should be retained. ${ }^{220}$ If public policy were replaced with a reference to fair trial, there would arguably be little use for the refusal ground of Article 45(1)(b), since it was considered a lex specialis compared to public policy. ${ }^{221}$ However, since this research concludes that such a replacement is likely to create problems, and therefore advises the retention of public policy, there would be clear added value to retaining the refusal ground of Article 45(1)(b) alongside public policy. It has been shown that this refusal ground has proved practically important. ${ }^{222}$ As Chapter 3 showed, some of the most important CJEU judgments that concern the rights of defendants, such as Trade Agency and $A S M L$, relate to the application of this refusal ground. ${ }^{223}$

In the 2010 Proposal for a recast of the Brussels I Regulation, a proposal was made to replace the refusal ground with a review procedure in the Member State of origin of the judgment. A similar arrangement was included in the Maintenance Regulation (Art. 19), the ESCP Regulation (Art. 18), the EOP Regulation (Art. 20) and the EEO Regulation (Art. 19). As is discussed in more detail in Chapter 8, such an arrangement increases the burden on the defendant, since he not only has to actively invoke the protection of the review mechanism, but to do so in a Member State where he is not domiciled. Considering that the application of this refusal ground was already strictly circumscribed by the CJEU, it is submitted that this further restriction places a disproportionate burden on the defendant. Furthermore, it is submitted that, as shown with regard to the public policy exception, it is difficult to expect Member States to be sufficiently critical of their own law and practice within such a review mechanism. ${ }^{224}$ An example is a case like Hendrikman, where the German court of origin was of the opinion that the defendants had technically 'appeared' because the court had appointed lawyers on their behalf, even though they were unable to instruct these lawyers. Though this standpoint was defended by the German government during the preliminary reference procedure, the CJEU robustly dismissed this argument. ${ }^{225}$ The Hendrikman case shows that, as with the public policy exception, it is unwise to rely on self-examination by the Member State of origin when it comes to reviewing whether the rights of the defaulting defendant were respected. This may be different where the rules on service are harmonised. ${ }^{226}$

${ }^{220}$ Chapter 3.3.1.

221 Cuniberti and Rueda (2011) p. 298; Franq (2015) p. 882; CJEU Case 145/86 Hoffman v Krieg, ECLI:EU:C:1988:61, para. 21; Case C -78/95 Hendrikman and Feyen / Magenta Druck \& Verlag, ECLI:EU:C:1996:380, para. 23.

222 Chapter 3.3.1.

223 CJEU Case C-283/05 ASML Netherlands BV v Semiconductor Industry Services GmbH (SEMIS) ECLI:EU:C:2006:787; Case C-619/10 Trade Agency Ltd v Seramico Investments Ltd ECLI:EU:C:2012:531. Chapter 3.3.2.

${ }^{224}$ Chapter 3.4.

${ }^{225}$ Case C -78/95 Hendrikman and Feyen / Magenta Druck \& Verlag ECLI:EU:C:1996:380, para. 18. See also Case C-112/13 A v B and Others ECLI:EU:C:2014:2195, para. 60.

${ }^{226}$ See Chapter 8.5.3, on the EOP and ESCP Regulations. 
The same applies to the jurisdiction defences of Article 45(1)(e) Brussels I bis. The correct application of the special and exclusive jurisdiction grounds protected by this Article is essential to a proper functioning of the Regulation as such. The protection afforded by these special jurisdiction grounds, especially that afforded to consumers, would be illusory if it could only be invoked by challenging jurisdiction in the Member State where the opposing party commenced proceedings. ${ }^{227}$

\subsection{The need for an 'emergency brake' for return and access orders}

\subsubsection{Refusal of enforcement of return orders}

This Chapter proposes that EU Regulations that facilitate the cross-border enforcement of civil judgments should contain an emergency brake mechanism, in the form of a ground for refusal of recognition or enforcement that should be applied restrictively and in only the most serious of cases. The question considered here is whether such a mechanism is appropriate for child abduction cases. The main argument in favour of an emergency brake put forward in this Chapter was that refusal of enforcement was proven to be the only way, in some cases, of addressing fundamental rights violations that had been committed in the Member State of origin of the judgment. It is certainly possible that a return order from one Member State constitutes a violation, either because one of the parties' rights to be heard under Article 6(1) ECHR was violated in achieving it, or because its enforcement will violate one of the parties' rights under Article $8 \mathrm{ECHR}$. The question remains as to whether there are instances in which a refusal of enforcement is the only way of remedying such a violation, and whether the potential impact on the other parties' fundamental rights and interests can ever be justified.

When it comes to the parties' rights to a fair trial, it first needs to be pointed out that it is only the parents or guardians that derive any rights from Articles 6(1)/47 in the context of return proceedings, because they are the parties to the proceedings. The child is not a party, but rather the object of the proceedings; his or her rights are protected by the system of the Brussels II bis Regulation as such, and by specific rules such as the requirement that the child is given an opportunity to be heard as a prerequisite for enforcement (Art. 42(1)). The child's right to be heard is however not derived from the right to a fair trial, but from the child's right to participate in proceedings that affect him or her, introduced by the Convention on the Rights of the Child. ${ }^{228}$ Any violations of the right to a fair trial in the context of return proceedings can therefore only directly concern one of the parties to the proceedings, though they may of course adversely affect the child's right to participate and his or her interests more generally.

${ }^{227}$ Chapter 3.3.2; Dickinson (2011) p. 10.

${ }^{228}$ United Nations Convention on the Rights of the Child, Article 9. 
Essentially, the question is therefore whether a violation of a party's right to a fair trial should lead to a refusal of enforcement. Clearly, a refusal of enforcement may adversely affect the child's best interest. It is submitted that allowing courts to refuse enforcement of return orders as a remedy for a violation of a party's right to a fair trial is almost by definition disproportionate if any harm to the child's health and development occurs as a result of that refusal. In Sahin v. Germany, the ECtHR ruled that in matters such as rights of access, parents have independent rights to respect for their family life, but that particular importance should be attached to the best interests of the child, which, depending on their nature and seriousness, may override those of the parents. According to the ECtHR, a parent cannot be entitled under Article 8 to have measures taken that would harm the child's health and development. ${ }^{229}$ It seems improbable that the ECtHR would come to a different conclusion with regard to Article 6 ECHR. Refusal of enforcement of a return order cannot be an appropriate remedy for a violation of a guardian's rights under Article 6(1) if it adversely affects the child's interests.

Even if there is no, or no considerable, risk of harm to the child as a result of the refusal to enforce, it is questionable whether a violation of Article 6(1) can ever in itself be a sufficient reason for such a refusal. While of course parents, as parties to those proceedings, have a right to be heard in return proceedings, the main purpose of those proceedings is the protection of the parents' and the child's rights under Article 8 ECHR. The parents' right to be heard is one of the ways to achieve effective protection of those rights, as this right enables him or her to voice any views or concerns as to where the child should live. Under the Brussels II bis Regulation, the parties' right to be heard is expressly protected by Article 42(2). If one of the parents suffers a violation of this right, or another element of Article 6(1), this therefore also affects the extent to which he can effectively invoke his rights under Article 8. A violation of Article 6(1) is therefore clearly of consequence for the fairness of the return proceedings and its outcome.

However, the right to a fair trial is also of independent importance in child abduction cases. It is possible that one of the parties to the proceedings is an organisation such as a child protection agency, which may have custody or act as an agent for the left-behind parent or guardian. ${ }^{230} \mathrm{In}$ such a case, the organisation does not have a right to family life, but does enjoy a right to be heard; in this case, the right to be heard should be seen as conducive to protecting the child's best interests. Again, the right to be heard is therefore essential to guarantee a fair outcome to the proceedings.

The question is now whether refusal of enforcement can be an appropriate sanction, if it does not adversely affect the child's interests, or in fact aligns with those interests. It was proposed

\footnotetext{
${ }^{229}$ ECtHR Sahin v. Germany appl. no. 30943/96 2003-VIII, para. 66.

${ }^{230}$ It should be noted that perhaps not all guardians enjoy an independent right to a relationship with the child under Article 8; for example, while the relationship between children and foster/adoptive parents has been found to fall within the scope of Article 8, the relationship between a child and a protective agency or organisation has not; see European Commission for Human Rights X. v. Switzerland, appl. no. 8257/78, DR 13, p. 248.
} 
that refusal of enforcement may be a proportionate remedy for a violation that makes the exercise of the right utterly impossible. ${ }^{231}$ In this context, it is important to consider that a judgment ordering return may not be the final decision in a child abduction case. The purpose of a return order is to ensure the swift return of a child to his or her state of habitual residence, in order to allow the courts of that state to subsequently make an informed decision on where the child should live. Enforcement of a return order is not necessarily the last step in a child abduction case: any views the abducting parent may have as to where the child should live he or he may voice during later custody proceedings, which are better suited to consider such arguments. However, the automatic enforcement regime of Brussels II bis applies to all judgments requiring return; such a judgment may well be a final judgment on custody from the Member State of the child's habitual residence. ${ }^{232}$ Unless a right to appeal is available against that judgment, the abducting parent who was not heard may have no recourse other than to oppose its enforcement. Again, such a remedy can only be appropriate if the child's interests are not at risk.

It is possible to conclude on the basis of the factors identified in this Chapter that refusal of enforcement of a judgment requiring return may sometimes be the only way to remedy a violation of one of the parties' right to a fair trial, especially it that violation also affects the parent's right to family life. However it is only appropriate if it does not endanger the child's health or safety or otherwise affect his or her interests; according to the ECtHR, a parent should not be able to request measures that would harm the child's health or development. Rightfully, under the 1980 Convention refusal of enforcement is only possible if the child is at a "grave risk" of physical or psychological harm. ${ }^{233}$ Article 11(4) of the Brussels II bis Regulation provides that this refusal ground cannot be used if 'adequate arrangements' have been made to ensure the child's safety, but the 2015 Study shows that courts are often unclear on what this entails and whether any measures will be sufficient, resulting in a higher number of refusals. ${ }^{234}$

It is also accepted that providing a possibility to oppose the enforcement of a return order may have wider repercussions: it may encourage abductions, ${ }^{235}$ and remove the left-behind parent's advantage of being able to conduct proceedings in his or her own Member State. Again, it goes beyond the remit of this research to conclude whether or not this is a sufficient reason to have enforcement of return orders be completely automatic within the EU. The matter of returning abducted children involves primarily a balancing act between all the parties' rights under Article 8 ECHR and the child's best interests as an independent factor. To determine how these factors should influence the availability and application of a refusal mechanism is beyond the scope of this research.

\subsubsection{Automatic enforcement of judgments granting rights of access}

${ }^{231}$ Chapter 7.3.

${ }^{232}$ Article 11(8) Brussels IIbis Regulation.

${ }^{233}$ Chapter 8.6.1.

${ }^{234}$ Study on the assessment of the Brussels IIbis Regulation (2015) p. 47.

${ }^{235}$ McEleavy (2005); Pérez-Vera (1982) p. 22. 
Under the Brussels II bis Regulation, judgments granting rights of access also benefit from the automatic enforcement regime (Art. 41(1)). Access rights may include the right take a child for a limited period of time to a place other than the child's habitual residence (Art. 5(b) 1980 Convention). The 1980 Convention only provides with regard to these rights that states should have in place Central Authorities, to which parties may present "an application to make arrangements for organising or securing the effective exercise of rights of access" (Art. 21). The Authorities should then, in conformity with the obligations of co-operation under the Convention, "take steps to remove, as far as possible, all obstacles to the exercise of such rights. ${ }^{236}$ It appears that a legislative initiative to which was intended only to simplify the enforcement of access rights in the $\mathrm{EU}^{237}$ in fact triggered the reform of the enforcement of return orders as well. ${ }^{238}$ The introduction of automatic enforcement for access rights however proved less controversial, presumably because it did not attempt to extensively reform an already existing mechanism.

It is submitted that, in principle, the same arguments apply to the automatic enforcement of access rights as to return orders. It is possible that a judgment that grants a right of access is rendered in violation of one of the parties' rights to be heard, and that it may, as a consequence or additionally, violate that parties' rights under Article 8 ECHR or the child's interests. The enforcement of access rights may require the use of force or the imposition of penalty fees for a failure to deliver the child at the agreed time and place. Such enforcement may have considerable consequences for the parties involved.

On the other hand, it is questionable whether this is always the case and whether the effects created by enforcement are irreversible. This Chapter proposes that refusal of enforcement should only be considered if it is impossible to address violations in another way. It is clear that a right of access is essential to realising the parent's right to a relationship with his child, whereas it does not render the exercise of the other parent's right with his child utterly impossible. When it comes to the child's best interests, the risks mostly appear to lie in the manner of enforcement. As with return orders, the best interests of the child may outweigh the rights of the parents. ${ }^{239}$ The enforcement of these rights can be organised in many ways; the Regulation does not proscribe the manner of enforcement. Article 48 of the Brussels II bis Regulation authorises courts in the Member State of enforcement to "make practical arrangements for organising the exercise of rights of access, if the necessary arrangements have not or have not sufficiently been made in the judgment delivered by the courts of the Member State having jurisdiction as to the substance of the matter and provided the essential elements of this judgment are respected." It may be possible to widen this competence, so that the court may not refuse enforcement altogether but may alter the manner in which the access rights are

\footnotetext{
${ }^{236}$ Article 21, 1980 Convention.

${ }^{237}$ Initiative of the French Republic with the view to adopting a Council Regulation on the mutual enforcement of judgments on rights of access to children, OJ C 234/7.

${ }^{238}$ Proposal for a Council Regulation concerning jurisdiction and the recognition and enforcement of judgments in matrimonial matters an in matters of parental responsibility repealing Regulation (EC) No 1347/2000 and amending Regulation (EC) No 44/2001 in matters relating to maintenance, COM (2002) 222 final/2, p. 2.

${ }^{239}$ ECtHR Sahin v. Germany, para. 66.
} 
enforced in such a way as to avoid any harm to the child, provided that the essential elements of the judgment are respected. In this way, a lack of consideration of the 'unheard' parent's and the child's interests and rights can be compensated, without having to resort to a complete refusal of enforcement. A refusal of enforcement would disproportionately affect the rights of the parent to whom access was granted, whereas there are alternative ways of protecting the other parent's rights and the best interests of the child.

\subsection{Conclusion}

This Chapter proposes that an 'emergency brake' should be retained for all categories of civil judgments whose cross-border recognition and enforcement is facilitated by EU regulations. The purpose of this Chapter is to explore what such a refusal ground should look like. It was concluded that it seems more appropriate to retain the public policy exception rather than to replace it with a reference to fundamental rights. The primary problem with such a replacement is that a somewhat artificial distinction would have to be made between procedural and substantive public policy. This distinction is primarily academic and may prove difficult to apply in practice. This is because in practice substantive and procedural problems are closely interlinked. A distinction in legislation between substantive and procedural public policy may create more problems than it solves. Further research would be needed to see whether this issue can be resolved.

Nevertheless, there are advantages to replacing the procedural element of public policy with a reference to fair trial. The primary advantage is that it would ensure that defendants could rely on violations of their right to a fair trial being remedied at the enforcement stage, whereas currently the contested practice would (in theory) be contrary to the practice of the Member State addressed as well. Conversely, the claimant would not be confronted with an application of public policy that goes outside what is allowed by the right to a fair trial, thus improving the protection of his right to enforcement. Combined, these changes would have the advantage of solidifying the link between fundamental rights and the cross-border recognition and enforcement of judgments and further entrenching fair trial in EU legislation on this matter.

Finally, this Chapter concludes that in each case, a careful balancing needs to take place between the right to enforcement of the creditor and the element of the debtor's fair trial that was violated. In this respect, the judge should always ask himself whether refusal of recognition or enforcement is an appropriate remedy to the debtor's violation and whether it is proportional to the disadvantage suffered by the creditor. 


\section{Facilitating enforcement of civil judgments across European Union Member States}

\subsection{Introduction}

The previous Chapter argued that European Union (EU) regulations concerning the enforcement of civil judgments across borders should contain a mechanism for judgment inspection in the Member State of enforcement, allowing that Member State to refuse enforcement or recognition on the basis of a limited number of grounds for refusal. This Chapter discusses how the second element of cross-border enforcement, judgment import, should be organized to protect the parties' right to a fair trial adequately. Like the previous Chapter, it discusses how to balance the judgment creditors' right to enforcement with safeguards that should ensure that judgment debtors' rights are respected. As the previous Chapter concluded, this thesis rejects the idea of complete abolition of cross-border checks on enforcement of judgments in civil cases. Instead, it argues that refusal grounds in the State of enforcement should be combined with an effective procedure for obtaining, in the Member State of origin, permission for cross-border enforcement. This Chapter explores what that procedure should look like in order to ensure conformity with the right to a fair trial for all parties concerned.

This Chapter has as its starting point that both the EU fundamental rights framework and the European Convention on Human Rights (ECHR) require that EU legislation respects fundamental rights and that EU legislation should contain effective safeguards to that end. Chapter 5 concluded that though the European Court of Human Rights (ECtHR) in principle allows the abolition of cross-border checks on the enforcement of judgments in civil cases, it does so on the basis of a premise that the EU is, as an organization, able to effectively protect fundamental rights within its legal framework. ${ }^{1}$ This means that it is for the European legislature to formulate effective safeguards in legislation and to provide the machinery capable of enforcing those safeguards. ${ }^{2}$ In conformity with the ECtHR's judgment in Avotins ${ }^{3}$ and the CJEU's in Lindqvist ${ }^{4}$ Member States are ultimately responsible for applying these safeguards. Because the CJEU ruled in Melloni ${ }^{5}$ that fundamental rights standards in EU secondary law are, by dint of the principle of effectiveness, maximum standards, these standards will need to be carefully calibrated. They will also need to be clear, so that problems of interpretation are kept to a minimum.

\footnotetext{
${ }^{1}$ Conclusion to Part II.

${ }^{2}$ Conclusion to Part II.

${ }^{3}$ ECtHR Avotins v. Latvia, appl. no. 17502/07, 25 February 2014.

${ }^{4}$ CJEU Case C-101/01 Criminal proceedings against Bodil Lindqvist ECLI:EU:C:2003:596.

${ }^{5}$ CJEU Case C-399/11 Stefano Melloni v. Ministerio Fiscal ECLI:EU:C:2013:107.
} 
The structure of this Chapter is as follows. Section 8.2 discusses the requirements that a procedure for obtaining permission for enforcement should fulfil. It looks at this procedure from both the perspective of the creditor and that of the debtor. It also considers whether these requirements are best fulfilled by a procedure in the Member State of origin of the judgment or one in the Member State of enforcement, and whether this aspect makes any difference for the design of the procedure. Specifically, it considers whether the instrument of certification, as implemented in the Brussels I bis Regulation, can adequately fulfil the identified requirements.

Section 8.3 discusses the Maintenance Regulation, which completely abolished all intermediate steps for cross-border enforcement and the refusal grounds. Next, Section 8.4 discusses the European Enforcement Order (EEO). This instrument merits a detailed discussion, because it introduced a mechanism for enforcing a judgment across borders that combines both judgment import (or rather: export) and judgment inspection with the court of origin of the judgment, abolishing any role for the Member State of enforcement. It is considered whether this mechanism is capable of protecting the right to a fair trial effectively.

Section 8.5 deals with the uniform European procedures, the European Order for Payment Procedure (EOP) and the European Small Claims Procedure (ESCP). These procedures should of course conform to the right to a fair trial in their entirety, not just on the matter of crossborder enforcement. Recent CJEU case law and empirical data are analysed to determine what problems there are in the design and implementation of these procedures and how these could be resolved.

Finally, Section 8.6 discusses the specific context of child abduction and access to children. This field of European civil justice cooperation merits specific attention, because practice has made clear that the protection of the rights of both children and parents in the cross-border context is a sensitive issue, which cannot be done justice by merely looking at the enforcement stage. Without aiming to be exhaustive on the subject, this section highlights a number of the most problematic aspects and explains why these cannot be adequately addressed by merely looking at the enforcement stage.

\subsection{How to organize judgment import in European Union Regulations}

The preceding Chapter argued that EU regulations that concern cross-border enforcement of judgments within the EU should contain grounds for refusal of recognition and enforcement in the Member State where enforcement is sought. This section discusses the other element of cross-border enforcement: judgment import, the formal means by which a judgment gains the status of an enforceable title in a state other than where it was handed down. It explains how judgment import should be organized, taking into account the requirements that the right to a fair trial imposes on enforcement proceedings. This section presumes, as the preceding Chapter proposed, that judgment inspection consists of a limited number of grounds of refusal for 
enforcement that the Member State of enforcement may apply. This section therefore only considers how judgment import should be organized when the person against whom enforcement is sought has the possibility of later invoking grounds for refusal in the Member State of enforcement. An effective mechanism for judgment import is essential with a view to guaranteeing the creditor's right to enforcement.

Currently, the Brussels I bis Regulation contains a mechanism for cross-border enforcement that fulfils these characteristics: it combines a simple procedure for obtaining a certificate in the Member State of origin, which constitutes an enforceable title, with grounds for refusal in the Member State of enforcement. It is therefore appropriate to review this mechanism for its expediency and its conformity with the right to a fair trial. The following briefly sketches the mechanism. The next sections then discuss what demands the right to a fair trial makes of the procedure for achieving enforcement; they relate to both ECHR and Court of Justice of the European Union (CJEU) case law (8.2.1) and other recommendations, such as those of CEPEJ (8.2.3). These are then applied to the example of Brussels I bis in order to assess whether its mechanism meets the demands. Recent literature on the Regulation is also used to assess its practical application.

The current Brussels I bis Regulation requires the party who wishes to enforce a judgment in another Member State to request a certificate from the court that rendered the judgment (Art. 42(1)). In accordance with Article 53, the court shall issue the certificate on application, using the form in Annex 1 to the Regulation. This form consists of a number of questions that partly concern very formal aspects of the judgment, such as contact details of the court and the parties and the date on which it was given, and some more substantive aspects. For the purposes of the protection of fair trial rights, the questions under 4.3 and 4.5 of Annex 1 are most relevant. Question 4.3 requires the court to check whether the judgment was delivered by default, and if so, when the document instituting the proceedings was served on the defendant. Question 4.5 asks whether the judgment was served on the defendant prior to the certificate being issued. It does not specify how service should have been effected, but leaves this to the interpretation of the court that issues the certificate. Most likely courts will apply the requirement in conformity with the way Article 45(1)(b) and its predecessor have been interpreted by the CJEU. ${ }^{6}$

Essentially, the certification procedure can be characterized as a form of judgment export: it facilitates the enforcement of a domestic judgment in other EU Member States. The certificate of the Brussels I bis Regulation serves to aid communication between the courts and to certify that the judgment constitutes an enforceable title. ${ }^{7}$ In this sense, it has the same function as the declaration of enforceability of Brussels I (though contrary to that declaration the certificate has no independent function as an enforceable title). It is therefore possible to speak of 'judgment export'; this distinguishes the procedure from the judgment inspection stage, and makes clear that it fulfils the same function, but is different from, judgment import (exequatur).

\footnotetext{
6 CJEU Case C-283/05 ASML Netherlands BV v Semiconductor Industry Services GmbH (SEMIS) ECLI:EU:C:2006:787; Fitchen (2015) p. 459-460.

${ }^{7}$ Chapter 2.3.3.1, in relation to the Brussels Ibis Regulation.
} 
Both judgment import and judgment export are mechanisms for obtaining permission for enforcement in another Member State from where the judgment was given. The following discussion concerns both these mechanisms.

\subsubsection{Requirements that can be derived from ECtHR case law}

This section discusses what requirements the ECtHR has set out in its case law concerning the procedure for obtaining permission for enforcement. It discusses both ECtHR case law on cases concerning exequatur, meaning the procedure for obtaining permission in one state for enforcement of a judgment obtained in another state, as case law on purely internal situations concerning enforcement. Both strands of case law are relevant, because obtaining permission for enforcement in another state is only part of the wider issue of achieving effective enforcement.

Chapter 4 showed that ECtHR case law provides a right to enforcement of judgments obtained in civil cases, because according to the Court the right to a fair trial would be 'illusory' if states were to allow judgments to remain inoperative. ${ }^{8}$ It was also concluded that proceedings necessary to obtain enforcement should fulfil the requirements of the right to a fair trial; this also applies also to exequatur proceedings in states where enforcement of a foreign judgment was sought.

So which requirements can be derived from ECtHR case law with regard to procedures that allow judgment creditors to obtain permission for enforcement? The most relevant ECtHR judgment in this regard is Saccoccia ${ }^{9}$, which concerned the question whether a hearing should have been held during exequatur proceedings. The case concerned the enforcement in Austria of a judgment obtained in the United States. The applicant before the ECtHR, Mr Saccoccia (a United States national), was suspected in the United States of having laundered money. The Rhode Island District Court in the United States issued a forfeiture order in respect of assets (cash, a bank account and bearer bonds) held in Austrian banks, which were deemed to be the proceeds of money laundering. The Vienna Regional Criminal Court allowed the forfeiture order to be enforced. Before the ECtHR, the applicant complained that the Austrian exequatur proceedings did not comply with Article 6(1) of the ECHR, since the enforcing court had not held a public hearing to allow him to explain why the assets had been lawfully acquired.

The ECtHR established the applicability of Article 6(1) by ruling that the forfeiture order involved a determination of the applicant's civil rights and obligations. ${ }^{10}$ It then cited its case law in Hornsby v. Greece and other cases to establish that exequatur proceedings also come

\footnotetext{
${ }^{8}$ ECtHR Hornsby v. Greece appl. no. 18357/91 ECHR 1997-II.

${ }^{9}$ ECtHR Saccoccia v. Austria, appl. no. 69917/01, 18 December 2008.

${ }^{10}$ ECtHR Hornsby v. Greece, para. 57.
} 
within the scope of Article 6(1), given that this "is the moment when the right asserted actually becomes effective". ${ }^{11}$ It also acknowledged, however, that exequatur proceedings do not require the court to decide anew on the merits of the case, but only to "examine whether the conditions for granting execution are met". ${ }^{12}$ The Court then used this characteristic of exequatur proceedings to determine whether the refusal to hold a public hearing constituted a violation of Article 6(1). The Court cited its settled case law concerning the right to an oral hearing to establish that that right is not absolute, and that the nature of the issues to be decided is decisive. ${ }^{13}$ An oral hearing may not be necessary when there are no "issues of credibility or contested facts" 14 or where the proceedings concern merely "legal issues of a limited nature" or of "no particular complexity". ${ }^{15}$

The Court applied these criteria to the case at hand. According to the relevant treaties between the United States and Austria, the questions to be examined were the following: reciprocity; whether the acts committed by the applicant were punishable by Austrian law at the time of their commission; whether statutory time-limits were complied with; and whether the proceedings before the court of origin "had been in conformity with the standards of Article 6 of the ECHR" $"$. The Court found that the exequatur procedure conducted before the Austrian courts only involved "rather technical issues of inter-State cooperation in combating moneylaundering through the enforcement of a foreign forfeiture order" and that "they raised exclusively legal issues of a limited nature" 17 . The proceedings did not require the hearing of witnesses or the taking of evidence, nor did they require a hearing of the applicant in person because his credibility or personal conduct were not at issue. The Austrian courts could therefore fairly and reasonably decide the case on the basis of written materials, and a hearing did not need to be held.

In Saccoccia, the ECtHR therefore provided an important assessment of the characteristics of the exequatur proceedings and what requirements Article 6(1) imposes on them. It appears, as is in line with the settled case law on the right to an oral hearing, that the limited review conducted at this stage justifies that no oral hearing needs to be held. This finding is also relevant to other elements of Article 6(1), such as the right to a reasoned judgment, because their applicability is also determined by the extent and complexity of the review conducted

\footnotetext{
${ }^{11}$ ECtHR Hornsby v. Greece, para. 61-2.

${ }^{12}$ ECtHR Hornsby v. Greece, para. 63.

${ }^{13}$ ECtHR Hornsby v. Greece, para. 73-76; see for a discussion 4.3 .6 of this thesis.

${ }^{14}$ ECtHR Hornsby v. Greece, para. 76; the Court cites ECtHR Jacobsson v. Sweden (no. 2) appl. no. $16970 / 90$ ECHR 1998-I and ECtHR Valová and others v. Slovakia, appl. no. 44925/98.

15 The Court cites ECtHR Varela Assalino v. Portugal (dec.) appl. no. 64336/01 and ECtHR Speil v. Austria (dec.) appl. no. 42057/98.

${ }^{16}$ ECtHR Saccoccia v. Austria, para. 77.

${ }^{17}$ ECtHR Saccoccia v. Austria, para. 78.
} 
during the proceedings. ${ }^{18}$ The next section considers how this influences the way other elements of the right to a fair trial apply in this context.

Saccoccia provides guidance on the protection that should be provided to the person against whom enforcement is sought during the procedure itself (other than the protection afforded by a potential refusal of enforcement). Of course, the ECtHR's case law on the right to enforcement is relevant to the creditor.

In such cases as Romanczyk, ${ }^{19}$ and Matrakas and others, ${ }^{20}$ the ECtHR examined whether Contracting States had violated the applicants' right to enforcement of maintenance orders on the basis of the New York Convention. ${ }^{21}$ The Court is not prescriptive in this regard, but reviews whether the authorities acted with sufficient diligence in their assistance of the creditor. In Matrakas, the ECtHR found a violation on the part of Greece because it had not acted diligently in the enforcement of maintenance orders. The Greek authorities were found to have failed to provide the necessary information, to summon the debtor, or otherwise take measures to ensure the enforcement of these orders, which led to unacceptable delays in the enforcement. In Romanczyk, the violation lay in the failure of authorities in the state where enforcement was sought to follow up when they were informed that the debtor had not honoured his obligations. In Jovanovski, and Vrbica, the ECtHR also found violations in the authorities' failures to act diligently and within a reasonable time period.

Though these judgments make clear that a failure to provide assistance in the enforcement of a (foreign) judgment may constitute a violation of fair trial, they do not prescribe what an effective enforcement procedure should look like. The ECtHR rather reviews what obligations the relevant international treaty or domestic law created and whether the authorities carried out those obligations in a diligent manner and within a reasonable time. In order to guarantee the creditor's right to enforcement it therefore does not matter what exactly the enforcement procedure looks like, as long as it is effective in obtaining enforcement (with the important caveat that the state's authorities are not responsible when enforcement is impossible due to the debtor's lack of funds). Any procedure for obtaining enforcement included in EU Regulations must therefore contain clear obligations for both states involved in the enforcement, and guarantees for ensuring that they fulfil these obligations diligently and within due time.

\subsubsection{Implications for the design of the procedure for obtaining permission for enforcement}

The preceding section leads to the conclusion that any procedure for obtaining permission for enforcement is a balance between the creditor's right to (and the general public's interest in) speedy and effective enforcement, and the debtor's right to a fair trial in general. The latter

\footnotetext{
${ }^{18}$ Chapter 4.3.2.7.

${ }^{19}$ ECtHR Matrakas and others v. Poland and Greece, appl. no. 47268/06.

${ }^{20}$ ECtHR Romanczyk v. France appl. no. 7618/05.

${ }^{21}$ New York Convention of 20 June 1956 on the Recovery Abroad of Maintenance.
} 
may manifest itself differently depending to how the procedure is designed: as Saccoccia provides, various elements of the right to a fair trial may merit more or less extensive protection depending on what actually happens during the procedure. If the questions examined at the stage where permission for enforcement is granted are merely 'legal issues of a technical nature' and of 'no real complexity', the procedural safeguards may be less extensive. The following discusses the implications of this case law for the design of a procedure for obtaining permission for enforcement.

As Chapter 7 extensively discussed, this thesis proposes that EU regulations should retain a possibility for Member States where enforcement is sought to refuse enforcement or recognition when the judgment constitutes a sufficiently serious violation of the right to a fair trial. This means that another check at the stage where permission for enforcement is granted would probably not be justified, because it would add little additional protection in return for the added procedural burden of an additional administrative step. A simple and effective procedure for obtaining permission for enforcement, during which only the judgment's compliance with relatively formal requirements are checked, would likely be the best option for combining effectiveness with protection of the rights of the debtor. This would allow the creditor to quickly and effectively obtain permission for enforcement, while the debtor would retain the possibility of applying for refusal of enforcement in the Member State where enforcement is sought (likely his own domicile) if serious violations were suspected.

One reservation that should be clearly stated is that specific safeguards may be needed in the context of family law, specifically pertaining to child abduction cases. Refusal of enforcement may not be an appropriate remedy for miscarriages of justice in this context, due to the sensitivity of the issues. Section 8.6 therefore discusses what specific safeguards may be needed for these types of cases.

For judgments outside this category, the question is essentially what requirements the judge (or authority) who decides whether a judgment may be enforced should check at that stage, keeping in mind that refusal grounds may still be invoked in the Member State of enforcement. In order to form a picture of the type of requirements that may be checked, this Chapter looks at the requirements that are included in the regulations that are discussed in this thesis. The regulations that have abolished exequatur in the Member State of enforcement all contain some requirements that the court of origin must check prior to allowing it to be enforced across borders. $^{22}$

${ }^{22}$ The European Order for Payment (EOP) and judgments resulting from a European Small Claims Procedure (ESCP) may only be enforced when all procedural guarantees contained in those Regulations are complied with (CJEU Joined cases C-119/13 and C-120/13 eco cosmetics GmbH \& Co. KG v Virginie Laetitia Barbara Dupuy and Raiffeisenbank St. Georgen reg. Gen. mbH v Tetyana Bonchyk, ECLI:EU:C:2014:2144). Because these guarantees apply to the entire procedure, and are not simply prerequisites for enforcement, they are discussed separately, in Section 8.5 of this Chapter. 


\subsubsection{Other recommendations for the design of an effective enforcement procedure}

Further to the ECHR and the ECtHR's case law, the Committee of Ministers of the Council of Europe has adopted a Recommendation on enforcement. ${ }^{23}$ The Council of Europe's Commission on the Efficiency of Justice (CEPEJ) later adopted Guidelines on the implementation of this Recommendation (2009). ${ }^{24}$ Both documents are not binding, but should be seen as authoritative advice on the proper implementation of the right to enforcement of judgment that Article 6(1) ECHR encompasses.

The Recommendation advises that the member states of the Council of Europe implement enforcement procedures that are "efficient and cost-effective". In order to achieve this, according to the Recommendation the following conditions should be fulfilled (paraphrased):

i. Enforcement should be defined and underpinned by a clear legal framework which delineates the powers, rights and responsibilities of all actors involved;

ii. Enforcement should be carried out in accordance with the existing law and judicial interpretation thereof, in order to guarantee legal certainty, transparency and foreseeability;

iii. Parties have a duty to cooperate;

iv. Defendants should provide up-to-date information on their income, assets and other relevant matters;

v. There should be no postponement of the enforcement process unless there are reasons prescribed by law;

vi. A proper balance should be struck between interests of both parties (especially with regard to Articles 6 and $8 \mathrm{ECHR}$ );

vii. Certain essential assets and income of the defendant should be protected.

Furthermore, the Committee recommends that enforcement procedures provide for the most effective and appropriate means for serving documents, provide for measures to deter or prevent procedural abuses, proscribe a right for parties to suspend enforcement to ensure protection of their rights, and provide for judicial review (where necessary) of decisions made during the enforcement process. These recommendations all inform the actual enforcement proceedings in the state where enforcement is carried out, and are only to a limited extent

\footnotetext{
${ }^{23}$ Council of Europe, Commission of Ministers, Recommendation Rec(2003)17of the Committee of Ministers to member states on enforcement (adopted by the Committee of Ministers on 9 September 2003 at the 851st meeting of the Ministers' Deputies) Rec(2003)17.

${ }^{24}$ European Commission on the Efficiency of Justice (CEPEJ) Guidelines for a better implementation of the existing Council of Europe's Recommendation on Enforcement, adopted by the CEPEJ at its 14th plenary meeting, (Strasbourg, 9 - 10 December 2009) CEPEJ(2009)11REV2.
} 
applicable to the mechanism for cross-border enforcement of the EU regulations. Still, they are a relevant source of information as to what constitutes an effective right to enforcement.

The 2009 CEPEJ Guidelines further contain the following advice (in so far as relevant to the cross-border aspect of enforcement) (paraphrased):

i. There should be sufficient information on the enforcement process and the activities of the court and the enforcement agent should be transparent; enforcement authorities should bear responsibility for effecting service ${ }^{25}$

ii. Parties should be able to understand and participate effectively in the enforcement proceedings: to that end, information should be communicated as clearly and comprehensibly as possible; ${ }^{26}$

iii. Parties should be notified effectively of the enforcement measures taken against them, including any possibilities for challenging enforcement and the consequences of failing to comply; ${ }^{27}$

iv. Member states should ensure that enforcement is not unnecessarily prolonged; defendants should be given the right to challenge enforcement measures within reasonable time, but this should not unjustifiably halt or delay the enforcement. ${ }^{28}$

\subsubsection{Assessment: how should judgment import or export be organized?}

It was concluded that, where grounds of refusal are available in the Member State of enforcement, the procedure for achieving judgment import should be kept as simple as possible. This is likely the best way to reconcile the creditor's right to speedy and effective enforcement with the protection of the rights of the debtor.

The certification procedure of the Brussels I bis Regulation appears to fit these requirements reasonably well. During the recast process, it was pointed out that the judgment import phase of the enforcement mechanism of Brussels I had only a formal function that could be greatly simplified or even abolished without adverse consequences for the protection of fundamental rights, as long as grounds for refusal were available. ${ }^{29}$ This does not however mean that the import function is of no importance to the protection of the parties' rights. An effective harmonized mechanism for obtaining an enforceable title that is easily identifiable by enforcement authorities throughout the EU can greatly contribute to the realization of the

\footnotetext{
25 No. 9-12.

${ }^{26}$ No. 15.

${ }^{27}$ No. 17-22.

${ }^{28}$ No. 66-71.

${ }^{29}$ Oberhammer (2010) p. 198; Arenas Garcia (2010) p. 359.
} 
creditor's right to enforcement. A uniform certificate, such as that required for enforcement under the Brussels I bis Regulation, could be a very effective way of achieving this.

\subsubsection{Creditor's right to enforcement}

It has been questioned whether a certificate provided by the court of origin of the judgment would be equally effective as an exequatur in the Member State of enforcement. Some commentators welcomed the replacement of the exequatur with the certificate as it simplified the procedure for the creditor. ${ }^{30}$ It was however also observed that the exequatur provided a link between the judgment and the Member State where enforcement is sought, while the current certification procedure places the burden on national enforcement authorities. ${ }^{31}$ Not everyone sees this as a justified concern. According to Hovaguimian, in most Member States enforcement agents are highly qualified individuals, and there is little reason "at least for a major part of the EU" to fear that they would be confronted with legal questions beyond their qualifications. $^{32}$

Another issue is the matter of adaptation of enforcement measures that are unknown in the Member State of enforcement to measures that are available in that State. ${ }^{33}$ It has been stated ${ }^{34}$ that problems may occur as Brussels I bis allows Member States to leave such decisions to nonjudicial enforcement authorities, who may not accurately assess the need for adaptation or for an examination by a court on this matter. The (lack of) adaptation may be challenged by the parties (Art. 52(2)), but this may cause delays. Hovaguimian however points out that complex questions of adaptation are rare and that, as previously stated, enforcement authorities should be sufficiently skilled to address them. ${ }^{35}$

Likewise, there is disagreement as to whether the fact that a certificate is issued by the court of origin, as opposed to an exequatur by the court of enforcement, constitutes an advantage to the creditor in terms of speed, costs and expediency. Potential advantages are that the court of origin is better informed of the proceedings, which enables him to quickly and efficiently decide on a request for a certificate. Another potential advantage is that nothing precludes the creditor from requesting the certificate before the judgment has been handed down, for example, in the summons. ${ }^{36}$ This eliminates the need for a separate exequatur from a court in the Member State of enforcement and thus reduces costs and increases speed and efficiency. There are doubts, however, as to the actual size of this cost reduction, since according to the

\footnotetext{
${ }^{30}$ Hess (2012) p. 1102; Oberhammer (2010) p. 199.

${ }^{31}$ Kramer (2014) p. 368.

${ }^{32}$ Hovaguimian (2015) p. 229.

${ }^{33}$ Art. 51(1) Brussels Ibis.

${ }^{34}$ Kramer (2014) p. 356, Hovaguimian (2015) p. 231.

${ }^{35}$ Hovaguimian (2015) p. 231.

${ }^{36}$ This is indeed what happens in Dutch first instance courts, for example District Court Rotterdam 25 March 2015, ECLI:NL:RBROT:2015:2487.
} 
CSES Report, only a small proportion of the costs associated with cross-border enforcement is spent on court fees. ${ }^{37}$ It is possible that lawyer's fees may also be reduced by the removal of the need for a court-issued exequatur, but it was rightly pointed out that creditors are still unlikely to approach enforcement authorities in a Member State they are unfamiliar with without the aid of a lawyer. ${ }^{38}$

It also needs to be pointed out that the disparity in enforcement costs among Member States, which was an important rationale for the reform of the enforcement mechanism of the EU Regulations ${ }^{39}$ has not been solved with the abolition of exequatur in favour of a certification procedure. The court fees Member States may charge for issuing the certificate have not been harmonised, nor have the fees charged by the enforcement authorities.

On the matter of delays, it should be stressed that in so far as they are caused by a lack of efficiency of the enforcement authorities in the Member States, Brussels I bis does not provide a solution. National enforcement law and practice will always remain the bottleneck of any cross-border enforcement mechanism, unless it is harmonised.

It can be expected that the possibility of requesting the certificate during the proceedings on the merits allows enforcement to happen faster. On the other hand, it has been pointed out that Brussels I bis allows courts addressed with refusal applications or appeals thereof to automatically stay or limit enforcement on the basis of Article $44 .{ }^{40}$ Such a stay or limitation may span three separate proceedings, depending on whether the Member State addressed allows a second appeal against a decision on refusal of enforcement (Art. 50). It has been suggested that such delays could be prevented by imposing some restriction on the discretion to allow a stay of enforcement, and that Brussels I bis constitutes a missed opportunity on this matter. ${ }^{41}$ Such automatic stay or limitation of enforcement could also be considered contrary to nos. 66 and 67 of the CEPEJ Guidelines, which provide that states should not unnecessarily prolong enforcement proceedings and that any action by the defendant to challenge enforcement does not unjustifiably halt or delay these proceedings. ${ }^{42}$

Another possible cause for delay is the lack of a time period within which an application for refusal of enforcement should be submitted. Whereas Brussels I limited this to one month or

${ }^{37}$ According to CSES (2010) p. 147, of the EUR 2.208 average costs of cross-border enforcement in simple cases, EUR 53 constituted court fees.

${ }^{38}$ Hovaguimian (2015) p. 243; according to the CSES Report, EUR 1205 of the total cost of EUR 2.208 are lawyer's fees; CSES (2010) p. 147.

${ }^{39}$ Hess, Pfeiffer and Schlosser (2007) para. 525; Proposal for a Regulation of the European Parliament and of the Council on jurisdiction and the recognition and enforcement of judgments in civil and commercial matters (Recast) $\operatorname{COM(2010)} 748$ final, p. 4; European Commission, Action Plan Implementing the Stockholm Programme, COM(2010)171 final, p. 5.

${ }^{40}$ Hovaguimian (2015) p. 238; Cuniberti and Rueda (2011) p. 315.

${ }^{41}$ Cuniberti and Rueda (2011) p. 315.

${ }^{42}$ CEPEJ Guidelines, Nos. 66-67. 
two months (depending on the debtor's domicile) after the moment of service of the declaration of enforceability (Art. 43(5)), Brussels I bis leaves this to the law of the Member State of enforcement (Art. 47(2)). It will therefore depend on the law of the Member State addressed whether this constitutes an improvement over Brussels I.

Without any statistical evidence on the application of Brussels I bis currently available (at the time of writing, about one year after entry into force) it is impossible to say whether the proposed gains in terms of costs, speed and efficiency have been achieved, and whether they will prove to be significant. However, despite some reservations, there do not seem to be any reasons to suspect that Brussels I bis' certification procedure is significantly less efficient than its predecessor, the exequatur. Since the exequatur was found by the Heidelberg Report to function quite effectively, ${ }^{43}$ it can be concluded that the Brussels I bis mechanism for crossborder enforcement is likely to effectively protect the creditor's right to enforcement, though there is certainly room for improvement.

\subsubsection{Protection of the debtor}

From the debtor's perspective, it should be noted that the certificate, which in accordance with Article 43(1) should be served on the defendant prior to enforcement measures being taken, does not contain information on how and where to apply for refusal of enforcement, and on what grounds this is possible. Member States are free to provide such additional information (Art. 47(2)), but this is not required. Since the CEPEJ Guidelines advise that parties should be informed of any possibilities to challenge enforcement, it is recommended that this information be included in the certificate or otherwise provided to the debtor.

It should also be noted, as Kramer points out, that service on the defendant of the certificate and the judgment does not suffice to inform him where in the EU and at what point in time the creditor will actually seek enforcement. ${ }^{44}$ It may therefore be necessary for the debtor to apply for refusal of enforcement in all EU Member States where targetable assets exist or may exist. Moreover, Article 53 does not provide for a time period between the service of the certificate and the taking of the first enforcement measure; this is left to the Member States. ${ }^{45}$ Domestic time limits may not however be sufficient to enable a debtor in a cross-border case, who may be completely unaware of the case before the certificate is served, to take measures against its enforcement. Kramer is correct to conclude that this lack of uniformity does not contribute to legal certainty and transparency, and that the protection offered by the service of the certificate is incomplete. ${ }^{46}$

\footnotetext{
${ }^{43}$ Hess, Pfeiffer and Schlosser (2007) para. 52; Chapter 2.2.4.1.

${ }_{44}^{44}$ Kramer (2015) p. 427.

${ }^{45}$ Ibid., p. 428.

${ }^{46}$ Ibid., p. 428.
} 
From the debtor's perspective, the protection of his right to a translation of the judgment is also relevant. Article 43(2) of Brussels I bis allows him to request a translation of the judgment if it is not in a language that he understands. This right to translation ensures that the debtor can make an informed decision whether or not to oppose enforcement. For that reason, when a translation has been requested, no enforcement measures other than provisional measures may be taken. This means that enforcement cannot proceed until the translation has been provided and a reasonable time has elapsed to allow the debtor to decide whether to challenge the enforcement. ${ }^{47}$ This rule is based on Article 8 of the EU Service Regulation. This article has rightly been criticized because it is unclear what it means to understand a language sufficiently well to accept the judgment, and who should determine whether that is the case. ${ }^{48}$ The burden of ensuring that the debtor receives the judgment in a language he understands lies with the debtor, who must take active measures to ensure that this happens.

\subsubsection{Effectiveness of a check of service of the documents instituting the proceedings}

Considering that the ECtHR does not provide explicit guidelines to establish what requirements are to be checked before enforcement is permitted, perhaps practice may provide some insight into which requirements are effective.

All regulations discussed require the judge to review, in cases where the judgment was delivered by default, whether the defendant was appropriately notified of the proceedings. Does this check indeed ensure that no judgments are enforced against defaulting defendants who were not properly informed of the proceedings? In this regard it should be observed that though the Brussels I bis Regulation requires judges to check whether the defendant was properly informed before issuing a certificate, this check is not the only way the Regulation protects the rights of the defaulting defendant. Like its predecessor, Brussels I bis contains a double review of this matter, in the form of both a pre-enforcement check by the court of origin and a ground for refusal of enforcement in the Member State where enforcement is sought. As the CJEU ruled in Trade Agency, ${ }^{49}$ the existence of a certificate that indicates that the defendant was adequately served with the document instituting the proceedings can constitute only prima facie evidence of service having been effected. The Court gave three reasons for this conclusion. Firstly, it pointed out that the Brussels I Regulation did not in any way prohibit such a double review. Secondly, the certificate only required the issuing judge to state a date of service, but no other information. Thirdly, the judge who issued the certificate was not necessarily the same as the one who rendered the judgment. The judge in the state of enforcement therefore retains the authority to review whether service was indeed performed. It

\footnotetext{
${ }^{47}$ See Recital 32; Kramer (2015) p. 429.

${ }^{48}$ Stadler (2012).

${ }^{49}$ CJEU Case C-619/10 Trade Agency Ltd v Seramico Investments Ltd ECLI:EU:C:2012:531.
} 
is likely that this interpretation also applies to Brussels I bis, since the certification procedure contained in that Regulation has the same characteristics. ${ }^{50}$ This means that the check of service prior to the issuance of the certificate is not intended to prevent all cases where service was not effected properly from being enforced; there is always the additional insurance of the possibility of refusal of enforcement on the basis of Article 45(1)(b).

If the preliminary check (in the State of origin) whether service was effected is not the only way of safeguarding this essential requirement, then there is also no reason to make it more extensive than it already is. A more precise check prior to certification (for example like the one included in the EEO Regulation, to be discussed further on) would not be necessary and therefore only cause unnecessary delay for the creditor.

\subsubsection{Conclusion on judgment export in Brussels I bis}

From the creditor's perspective, judgment export under Brussels I bis appears to function relatively well, though it needs to be stressed that no quantitative data on its application are available yet. It can however be assumed that the possibility of requesting a certificate from the same judge who issues the judgment is easier to achieve than requesting a declaration of enforceability in the Member State of enforcement. The practical bottleneck remains the accessibility of foreign enforcement authorities and differing enforcement practices, though this problem is not unique to the Brussels I bis Regulation. It was discussed that the concerns that were envisaged with regard to enforcement authorities becoming responsible for adaptation, amongst others, may prove to be unfounded. In terms of costs, certification has unfortunately not resulted in a great reduction when compared to Brussels I.

All in all, it is concluded that thought the efficiency (in particular in terms of cost) gains of the certification mechanism of Brussels I bis over Brussels I's exequatur may be modest, this still means that the certification may turn out to be relatively effective, simply because exequatur was also found to be relatively effective, and certification is not such a radical change. There is some disagreement on the question whether the certificate can adequately replace exequatur as a connection between the judgment and the state of enforcement, clarifying its status, but as of yet, there appears to be no reason to conclude that the certificate is less well received and understood by enforcement authorities. Time will tell; in the meantime, it is concluded that on the face of it, Brussels I bis' combination of a simple and effective certification procedure combined with grounds for refusal combines debtor's and creditor's rights relatively well. Certification allows the creditor to simply and quickly obtain permission for enforcement, whereas refusal grounds provide the necessary flexibility to remedy violations of the debtor's rights when appropriate.

\footnotetext{
${ }^{50}$ Fitchen (2015) p. 504.
} 


\subsection{The Maintenance Regulation}

As discussed in Chapter 2, the Maintenance Regulation ${ }^{51}$ is the only Regulation that abolished exequatur entirely for Member States that have adopted the 2007 Hague Protocol to the Maintenance Convention. ${ }^{52}$ No procedural steps or checks are necessary to obtain enforcement of a maintenance decision falling within the scope of this Regulation. The refusal grounds have also been abolished. As the previous Chapter proposed, the abolition of refusal grounds creates a risk of fundamental rights violations going unchecked; it is therefore recommended that a public policy exception be reintroduced. This seems especially important with regard to maintenance decisions since, as Chapter 3 concluded, most cases in which public policy was invoked concerned maintenance decisions. ${ }^{53}$

The abolition of the exequatur as such can in principle be commended for simplifying crossborder enforcement. However, it is currently difficult to say whether the abolition of exequatur constitutes a real improvement, since the Regulation has not yet been evaluated and no other statistics seem yet to be available regarding its functioning. Whether abolition of exequatur constitutes a real gain from the perspective of facilitating enforcement therefore remains to be seen. From the debtor's perspective, it may be problematic that the Regulation does not contain a mechanism which allows him to be informed of the enforcement before enforcement measures are taken (though service of the judgment itself prior to enforcement is required by most Member States' domestic law). ${ }^{54}$ A lack of service of the EEO however deprives the debtor from the possibility to seek review of the decision in the Member State of origin (as provided by Article 19 of the Regulation) before enforcement has commenced, and from the possibility to invoke domestic remedies against enforcement. As to the (likely) effectiveness of this mechanism, see the discussion of the similar mechanism under the EEO Regulation (8.5.1, below).

\subsection{The European Enforcement Order}

The previous section discussed the 'judgment export' mechanism of the Brussels I bis Regulation. It concluded that though some improvements are possible, the mechanism is capable, in conjunction with refusal grounds to be applied in the Member State of enforcement, of balancing effective enforcement with adequate protection of the debtor's rights.

51 Council Regulation (EC) 4/2009 of 18 December 2009 on jurisdiction, applicable law, recognition and enforcement of decisions and cooperation in matters relating to maintenance obligations, OJ L7/1.

${ }^{52}$ Chapter 2.3.4.

${ }^{53}$ Chapter 3.2.6.1.

${ }^{54}$ For instance, in the Netherlands Article 430(3) of the Code of Civil Procedure requires that judgments are served on the person against whom enforcement is sought prior to enforcement measures being taken, 
This section now discusses the EEO, which offers a very different mechanism for achieving cross-border enforcement. ${ }^{55}$ It combines judgment export and judgment inspection in one procedure, replacing grounds for refusal with a pre-certification check of minimum standards. The following discusses whether that mechanism can satisfy the requirements of the right to a fair trial. It should be noted that there does not appear to be any great political interest in the EEO any longer ${ }^{56}$ and it is questionable whether the EEO has much added value after Brussels I bis abolished exequatur. The point of this discussion is therefore not just to discuss the EEO, but to determine whether it is at all possible to organize effective judgment inspection (through a check of minimum standards) in the Member State of origin, as opposed to in the Member State of enforcement. The discussion is therefore not only about the EEO as such, but about the question whether grounds for refusal can be replaced with a check of minimum requirements in the Member State of origin at all. It will be shown that the conclusions from this section are also highly relevant with regard to the certification of return orders under the Brussels II bis Regulation (Section 8.6, below) while the conclusions with regard to the service requirements are important with regard to the similar arrangements in the EOP and ESCP Regulations (Section 8.5, below).

\subsubsection{Service of the document instituting the proceedings}

The question is whether a check of minimum standards of service by the court of origin is as effective a protection of the debtor's right to be heard as the mechanism provided by the Brussels I bis Regulation. Whereas Brussels I bis contains a dual review on the matter of service to the defendant in default cases, supplementing a check prior to the issuing of the certificate with grounds for refusal in the Member State of origin, the EEO relies solely on the check performed by the court of origin. If that court is convinced that the minimum requirements have been complied with, the judgment may be certified as an EEO. This means that it can be enforced throughout the EU without any appeal against enforcement being possible. It is therefore important that the minimum requirements on service are sufficient to ensure that the debtor was adequately informed of the proceedings, given that he has no recourse in the form of an appeal against the issuing of an EEO or against enforcement (though he may apply for withdrawal if it was "clearly wrongly granted"). ${ }^{57}$ This section asks whether the minimum

\footnotetext{
55 See for a discussion of the instrument Bittman (2008); Zilinsky (2005); Zilinsky (2006).

${ }^{56}$ No evaluation of the EEO Regulation has yet been announced, despite this being required, despite it having entered into force in 2004. No other legislative developments (such as proposals for amendment) have yet occurred.

${ }^{57}$ Additionally, Article 19 provides that debtors should have the right, under national law, to apply for a review of the judgment itself in exceptional situations. Such exceptional situations may arise where 1) service was effected in accordance with Article 14 (without proof of receipt) but not in sufficient time to enable the debtor to arrange for his defence, or b) where the debtor was unable to object to the claim by reason of force majeure or due to extraordinary circumstances without any fault on his part. This Article concerns a right to review of the judgment, not of the certificate; and it does not in itself create a right to review, but merely requires that national law does. The remedies of Articles 10 and 19 are discussed further on in this section.
} 
requirements on service are sufficient to ensure that the debtor's right to be heard was respected. Effective service is especially important in the context of uncontested judgments, because proof that the defendant knew about the proceedings instituted against him, and was in a position to challenge the claims, yet chose not to, justifies the delivery of a default judgment against him. For the automatic enforcement of such a judgment to be justified the rules on service, and the manner in which they are checked, ${ }^{58}$ should be watertight.

Chapter III of the EEO Regulation exhaustively lists a number of ways in which service of the document instituting the proceedings may have been effected to the debtor. The methods of service are alternative: there is no hierarchy between them. The permitted methods of service of the document instituting the proceedings are:

i) Personal service attested by proof of receipt signed by the debtor (Art. 13(1)(a));

ii) Personal service attested by a document signed by the competent person who effected the service stating that the debtor has received the document or refused to receive it 'without any legal justification' (Art. 13(1)(b));

iii) Postal service attested by an acknowledgement of receipt which is signed and returned by the debtor (Art. 13(1)(c));

iv) Service by electronic means such as fax or e-mail attested by an acknowledgement of receipt which is signed and returned by the debtor (Art. 13(1)(d));

v) Personal service at the debtor's address on persons living or employed there (Art. 14(1)(a));

vi) In the case of a self-employed debtor or a legal person, personal service at the debtor's business premises or on persons employed by him (Art. 14(1)(b));

vii) Deposit of the document in the debtor's mailbox (Art. 14(1)(c));

viii) Deposit of the document at a post office or with competent public authorities and the placing in the debtor's mailbox of a notification of that deposit, provided that the notification contains certain information (Art. 14(1)(d)):

ix) Postal service without proof pursuant to the method mentioned under vii "where the debtor has his address in the Member State of origin" (Art. 14(1)(e);

$\mathrm{x}$ Electronic means attested by an automatic confirmation of delivery, provided that the debtor has expressly accepted this method of service in advance (Art. 14(1)(f)).

Article 14(2) further provides that the methods of Article 14 may not be used "if the debtor's address is not known with certainty". The Regulation also requires that document instituting proceedings contained information concerning the amount of the claim, the reasons for it and any interest (Art. 16) and with due information about the procedural steps necessary to contest the claim (Art. 17). Furthermore, if service was effected in conformity with Article 14 (so without proof of receipt by the debtor), but not in sufficient time to enable the debtor to arrange

\footnotetext{
58 The matter of impartiality of the judge who checks the minimum requirements for enforceability is discussed
} further on in this section. 
for his defence, Article 19 provides additional protection to the debtor. In such cases a judgment may only be certified as an EEO if the debtor is allowed, under the law of the Member State of origin, to apply for a review of the judgment. Article 19 also applies where the debtor was prevented from objecting to the claim "by reason of force majeure or due to extraordinary circumstances without any fault on his part." Finally, if service of documents in another EU Member State is required, the EU Service Regulation may be applied. ${ }^{59}$

Are these methods of service sufficient to guarantee the debtor's right to be heard? It may be recalled that Article 6(1) ECHR does not proscribe one method of service. The question is rather whether an individual's right to access to justice has been denied in a specific case. The ECtHR's case law provides that authorities must show that they acted with diligence in ensuring that persons are informed of any court proceedings against them. The Court has consistently reviewed whether authorities took all the necessary steps to ensure the documents reached the person concerned. This may involve searching for his address, ${ }^{60}$ or publishing a notification in mass media. ${ }^{61}$ Sending a letter to the debtor without proof of delivery has not been considered sufficient. ${ }^{62}$

In theory, therefore, all methods of service provided in the Regulation are compatible with the ECHR. It may however be called questionable that the Regulation provides no hierarchy between them. ${ }^{63}$ While the ECHR does not proscribe one manner of service, it can be inferred from the ECtHR's case law that the authorities must apply the method that appears most likely to ensure that the person concerned indeed receives the requisite documents: in this regard the Court has observed that only personal service is conclusive. ${ }^{64}$ The European Court of Justice has likewise observed, in a case concerning Article 26(2) of the Brussels I Regulation, that courts should satisfy itself that "all necessary steps are have been taken to ensure that the defendant can defend his interests. To that end, the court seised of the matter must be satisfied that all investigations required by the principles of diligence and good faith have been undertaken to trace the defendant." 65

\footnotetext{
${ }^{59}$ Regulation (EC) No 1393/2007 of the European Parliament and of the Council of 13 November 2007 on the service in the Member States of judicial and extrajudicial documents in civil or commercial matters (service of documents) and repealing Council Regulation (EC) No 1348/2000, OJ L 324/79.

${ }^{60}$ ECtHR Dilipak and Karakaya v. Turkey Application nos. 7942/05 24838/05 ECHR 2014, para. 83.

${ }^{61}$ ECtHR Zavodnik v. Slovenia appl. no. 36261/08 ECHR 2013, paras. 79-81.

${ }^{62}$ ECtHR Godorozea v. Moldova appl. no. 17023/05 ECHR 2009, para. 31, and Russu v. Moldova appl. no. 7413/05 13 November 2008.

${ }^{63}$ It may be noted that an earlier proposal did include a hierarchy between methods of service (Zilinsky (2005) p. 159); this appears to have been replaced with the implied hierarchy of Article 19. It may be mentioned that hierarchy between service methods is common in domestic civil procedure law, such as Dutch law (Articles 45 and 46 of the Civil Procedure Code, respectively) and Germany (Sections 176-178 ZPO).

${ }^{64}$ ECtHR F.C.B. v. Italy appl, no. 12151/86 ECHR A208-B para. 32.

${ }^{65}$ CJEU Case C-292/10 Gv Cornelius de Visser ECLI:EU:C:2012:142, para. 55. Article 26(2) of Brussels I allows a court to stay proceedings "so long as it is not shown that the defendant has been able to receive the document instituting the proceedings or an equivalent document in sufficient time to enable him to arrange for his defence, or that all necessary steps have been taken to this end".
} 
It is reasonable to expect that a defendant is more likely to receive the documents if they are served on him personally with proof of receipt (Art. 13(1)(a)) than when they are left in his mailbox (Art. 14(1)(c)). Leaving the documents in the debtor's mailbox may be compatible with Article 6(1) ECHR if this was the most effective method for serving the documents, but perhaps not if it was also possible to serve them in person or by registered mail. The problem with a non-hierarchical list of acceptable methods of service is that it precludes any kind of review whether the method of service that was used was also, in light of the circumstances of the case, most likely to ensure that the debtor indeed received the information he needed. The ECtHR's approach with regard to service is not to assess whether the method of service is as such acceptable, but whether the authorities took the action that could "legitimately and reasonably be expected" of them. The EEO Regulation does not afford judges any discretion in their appraisal of the methods of service used, even though especially in the context of default judgments it is essential that they can safely assume that the debtor was informed. This can be contrasted with the approach of the Brussels I bis Regulation, which, as discussed, allows judges to assess whether in the circumstances of the case service was effected in such a way "as to allow [the defendant] to arrange for his defence". This lack of flexibility combined with the absence of hierarchy in methods of service is what causes tension with the defendant's right to be heard.

Further, it has been pointed out that some elements of the minimum standards for service are unclear. The first element is Article 14(2), which provides that the alternative methods for service are not permitted "if the debtor's address is not known with certainty". Commentators have asked, rightly, how 'certain' the creditor must be of the debtor's address for service by one of these methods to be allowed. ${ }^{66}$ To that may be added the question to whom the address must be known: is it sufficient that the creditor states that he knows the debtor's address for certain? Or must the court that decides on the claim, or the authorities that served the document, satisfy themselves that the address provided indeed belongs to the debtor? It is certainly not unknown for creditors to act in bad faith in this regard. The ECtHR does expect authorities to make all reasonable efforts to establish a person's address. ${ }^{67}$ If this has not happened, and the court that rendered the judgment relied only on the creditor's information, is this sufficient for certification as an EEO?

A second element that has been criticised is Article 14(1)(c), which allows the document instituting the proceedings to be left "in the debtor's mailbox". The original proposal allowed service by means of a deposit in a mailbox only if that mailbox was "suitable for the safe keeping of mail". The Regulation omits this qualification. Stadler and Ptak have pointed out that this may allow service in a common mailbox that is freely accessible to all inhabitants of

${ }^{66}$ Zilinsky (2006) p. 483. See for an interpretation Ptak (2014) p. 130-131.

${ }^{67}$ ECtHR Dilipak and Karakaya v. Turkey para. 85. 
a larger apartment building or business premises, or one that is otherwise insecure, thus increasing the possibilities for error. ${ }^{68}$

Thirdly, Article 13(1)(b) which requires the person who effected the service to attest that the debtor "refused to receive [the document] without any legal justification". The question is on what basis this person (who may be a court bailiff, but also a postman or someone else) should decide whether the refusal to accept the document was legally justified. ${ }^{69}$ The proposal did not contain this possibility and therefore also does not provide any clarification. The provision therefore creates room for error.

A further questionable element is Article 14(1)(e), which allows service without any kind of proof (neither an attestation by the person who effected the service or proof of receipt by the debtor) if the debtor has his address in the Member State of origin (of the judgment). Stadler has pointed out that this section refers to the debtor's address, not his domicile. It is not required that the debtor lives at the address or even spends time there. In the case of a default judgment, a court cannot check whether the debtor has indeed himself provided the address or whether the creditor has invented it. ${ }^{70}$ In such cases, according to Stadler, the review mechanism of Article 19 would not benefit the debtor. Stadler's criticism coincides with the point made above that it is unclear who should verify the debtor's address and what degree of certainty they should have.

A more general criticism of the EEO's minimum requirements is that they require courts to assess their own methods of service for conformity with these requirements. The EEO Regulation does not proscribe how service should be effected, but only provides minimum requirements that the method of service applied should fulfil. All Member States have methods of service that are incompatible with these minimum requirements. ${ }^{71}$ Courts will therefore need to be vigilant when it comes to the conformity of their own rules on service with the Regulation. It has been doubted whether courts can effectively exercise such self-control. ${ }^{72}$ The matter of impartiality is discussed in detail further on in this section.

To conclude, the problem with the minimum requirements on service of the EEO Regulation does not lie so much in the minimum requirements themselves (though some criticism is certainly possible). It lies in the fact that, unlike the refusal ground of Article 45(1)(b) of Brussels I bis, the minimum requirements leave the judge no room for deliberation on the

\footnotetext{
${ }^{68}$ Stadler (2004a) p. 806; also Ptak (2014) p. 122.

${ }^{69}$ Stadler (2004a) p. 806 makes the comparison with Article 8 of the Service Regulation, which requires the person who affects the service to ascertain whether the person on whom the document is served 'understands the language' of the document. According to Stadler, both requirements are equally impracticable.

${ }^{70}$ See also Ptak (2014) p. 126-127.

71 Zilinsky (2006) p. 482.

${ }^{72}$ Stadler (2004a) p. 805.
} 
question whether service was effected in the most effective way possible. ${ }^{73}$ If service was effected in one of the ways allowed by the Regulation, then there is no reason to refuse certification as an EEO. This is problematic for two reasons. Firstly, because as the CJEU itself confirmed in the context of the Service Regulation, it is important that that the addressee of a document actually receives the document in question, but also that he is able to know and understand effectively and completely the meaning and scope of the action brought against him abroad, so as to be able effectively to assert his rights in the Member State of transmission. ${ }^{74}$ The simple 'checklist' procedure of the EEO Regulation removes any possibility to review whether this was the case. Secondly, the problem lies in a potential lack of vigilance and impartiality of judges when it comes to the conformity of their national rules on service with the Regulation. This is discussed in more detail further on.

It is further questionable if the available remedies of Articles 10 and 19 can really provide the debtor with an effective possibility to dispute the manner in which service was effected. These remedies are discussed further on in this section. ${ }^{75}$

Unfortunately, because the EEO Regulation has not been reviewed by the European Commission as of yet, there is no empirical evidence which would enable us to conclude whether the mechanism it created is sufficient to protect debtors' rights. A survey of Dutch case law on this point suggests that courts appear to apply the minimum requirements on service and the protection of consumer debtors strictly. ${ }^{76}$ That said, the number of instances in which an EEO was requested is low, ${ }^{77}$ and in the majority of cases the request for an EEO was rejected because the judgment fell outside the scope of the Regulation or because the claim in question was not uncontested. ${ }^{78}$ Because of these low numbers, it seems too soon to conclude that the EEO protects debtor's rights adequately.

\subsubsection{Impartiality of the judge who issues the EEO certificate}

All European instruments that require a judgment to be certified in the Member State of origin specify that the certificate should be issued by the 'court of origin' of the judgment. ${ }^{79}$ This

\footnotetext{
${ }^{73}$ See also Ptak (2014) p. 239.

${ }^{74}$ CJEU Case C-519/13 Alpha Bank Cyprus Ltd ECLI:EU:C:2015:603, para. 32; CJEU Case C-325/11 Alder ECLI:EU:C:2012:824, paras. 35 and 41.

75 Section 8.5.2.6.

${ }^{76}$ E.g. Rechtbank Haarlem 15 December 2009, ECLI:NL:RBHAA:2009:BK6667; Rechtbank 's Hertogenbosch 9 September 2009, ECLI:NL:RBSHE:2009:BJ7558; Gerechtshof Amsterdam 10 April 2012, ECLI:NL:GHAMS:2012:BW1284.

${ }^{77}$ On 31 March 2016, a search in the Dutch case law database http://www.rechtspraak.nl for the European Enforcement Order Regulation yielded 60 results.

${ }^{78}$ A survey of judgments concerning the EEO Regulation published in the case law database shows that, since the EEO became available 40 out of 57 requests for an EEO were rejected.

${ }^{79}$ Art. 53 Brussels Ibis, Art. 6(1) EEO Regulation.
} 
section discusses how this relates to the right to adjudication by an independent judge that Articles 6(1) ECHR and Article 47 of the Charter guarantee.

The literature on the EEO and on the Brussels I bis Regulation shows that the question of independence has provoked debate. The fact that the Regulations specify that the certificate should be issued by the same court that handed down the judgment, but not necessarily by the same judge, was considered potentially problematic from two different perspectives.

On the one hand, in relation to the Brussels I bis Regulation, it was considered that it is likely that it may not always be feasible to have the judge that handed down the judgment also be the one to later declare it enforceable. This means that the judge who eventually issues the certificate of Annex 1 to the Regulation may not be the judge who decided on the case. It also means that the judge who issues the certificate may not be as well informed of the proceedings, including the manner of service to the defendant, as the judge who decided the case. It has been questioned whether it may not be preferable to specify that these tasks should be performed by one and the same judge in order to avoid confusion and disinformation. ${ }^{80}$

The opposite argument has also been made that the relative complexity of the minimum standards of the EEO Regulation may require greater independence of the judge who decides on enforceability in relation to the judge who delivered the judgment. Stadler has argued that judges cannot be expected to be sufficiently critical at the certification stage of their own conduct in an earlier stage of the proceedings to guarantee that the minimum requirements are adequately observed. ${ }^{81}$ She points out that though the original Commission Proposal required the certificate to be issued by the same judge who delivered the judgment, the Regulation only requires this to be done by the same court, and therefore allows Member States to organize their procedures in such a way as to divide these tasks among different judges. ${ }^{82}$ According to her, in particular the questions of jurisdiction and proper service are too important to rely on the self-discipline of the deciding judge.

These differing views may be explained by the differing purposes that the certification process serves in each Regulation. Within the Brussels I bis Regulation, the certificate fulfils a mostly formal function and provides only prima facie evidence of service having been effected, with Article 45(1)(b) providing complementary protection. However, within the EEO Regulation, the checks at the certification stage are the only way of safeguarding the debtor's rights. The need for independence may therefore be greater. This section considers this question in the context of the ECtHR's case law on independence and impartiality.

\footnotetext{
${ }^{80}$ Fitchen (2015) p. 504; Zilinsky recommends for these reasons that Member States implement the Regulation in such a way as to ensure that these tasks are indeed performed by the same judge; Zilinsky (2005) p. 155.

${ }^{81}$ Stadler (2004a) p. 805.

${ }^{82}$ Ptak reaches the same conclusion based on an analysis of Article 6 ECHR: Ptak (2014) p. 238.
} 
Chapter 4 explained that the principle of impartiality may prohibit a judge's involvement in a case at multiple stages of the proceedings, depending on the degree of their involvement. Impartiality denotes the absence of bias on the part of the judge, and it has been acknowledged that involvement of the judge in pre-trial decisions may give rise to a suspicion of such bias. The question is therefore whether a judge who issues a certificate of enforceability can be considered partial if he is also the judge who delivered the original judgment.

There is no doubt that the principle of impartiality applies in the enforcement stages of the proceedings as well, considering that the ECtHR has ruled that enforcement proceedings fall within the scope of Article 6(1) ${ }^{83}$ So what does the requirement of impartiality imply for the certification mechanism, whereby a judge checks whether the decision he himself handed down earlier conforms to certain requirements?

There is a substantial body of case law from the ECtHR on the question of whether a judge can be considered impartial if he is involved in several stages of the proceedings. This case law mostly concerns criminal cases in which judges often take both pre-trial decisions, for example ordering the pre-trial detention of the accused, and the decision on the merits in the same case. This may be compatible with the right to an impartial judge, depending on the 'scope and nature' of the decisions taken at the earlier stage. ${ }^{84}$ Though the case law on the interpretation of this concept is fairly casuistic, some general guidelines have been identified in the Court's case law. ${ }^{85}$

Before these can be applied to the mechanism of certification of judgments, a preliminary question needs to be addressed: is the certification, in the Member State of origin, a separate 'stage' of the proceedings? As an example, in a civil case the ECtHR found a violation of the principle of impartiality where a judge who decided on the applicant's dismissal from her job later also decided, in separate proceedings, whether she should be rehabilitated. ${ }^{86}$ The principle of impartiality also prevents a judge from hearing an appeal to his own decision. ${ }^{87}$

It may be recalled that it was shown that in Dutch courts, the decision on the merits and the certification of that decision as an EEO are usually given in one and the same judgment; judges therefore likely do not regard these procedural stages as separate. It is however very well possible that the certification of a judgment as an EEO is a procedural step separate from the delivery of the judgment; Article 6 provides that certification can be done "at any time upon application". This allows for the possibility that an EEO may be requested separately some time after the judgment has been handed down, so that it is truly a different 'stage' of the

\footnotetext{
${ }^{83}$ See 4.3.6.

${ }^{84}$ ECtHR Morel v. France appl. no. 34130/96 ECHR 2000-VI; ECtHR Nortier v. the Netherlands appl. no. 13924/88 ECHR A267; ECtHR Saraiva de Carvalho v. Portugal appl. no. 15651/89 ECHR A286-B; ECtHR Fey v. Austria appl. no. 14396/88 ECHR A255-A.

${ }^{85}$ Kuijer (2004) p. 347.

${ }^{86}$ ECtHR Indra v. Slovakia appl. no. 46845/99.

${ }^{87}$ ECtHR De Haan v. The Netherlands appl. no. 22839/93 ECHR 1997-IV.
} 
proceedings. The conclusion that the certification as an EEO is a separate stage is also supported by the fact that the certification is not integral to the civil procedure: it is an additional, and optional, step that may be taken if the judgment creditor considers it desirable. Certification as an EEO is not an essential part of the civil procedure as such.

It is also necessary to look at the function of the certification mechanism in relation to the decision on the merits. The EEO Regulation is aimed to replace the control mechanism previously provided by the application of refusal grounds ${ }^{88}$ and requires courts to exercise 'scrutiny' to satisfy themselves that the minimum requirements have been complied with. Only then may they issue an EEO. ${ }^{89}$ The delivery of an EEO is therefore not merely a formality, but is intended to act as a control mechanism: it requires judges to inspect the judgment and the facts of the case in order to verify whether the minimum requirements have been complied with. The expectation is that judges will refrain from issuing an EEO if, for example, they conclude that service was not effected in accordance with one of the methods proscribed by the Regulation, or that the debtor is a consumer and the judgment was not delivered in the Member State of his domicile..$^{90}$ It is submitted that this control function of the EEO provides that it should be regarded as, functionally, a separate stage of the proceedings, because it serves a different function from the decision on the merits. Its purpose is to allow a judge to ascertain whether the judgment fulfils the requirements for enforceability, which is a separate question from the merits of the applicant's claim.

For both these reasons, it is concluded that certification as an EEO is intended to be a separate stage in the proceedings to the decision of the merits. The question is now whether it is problematic when the same judge (by which is meant the same person, not a different judge in the same court) is involved in both stages.

The ECtHR appreciates that procedural efficiency may justify the involvement of one and the same judge in various stages of the proceedings, and this practice is therefore not necessarily incompatible with Article 6(1). What matters is the 'scope and nature' of the issues examined. From the case law it transpires that a lack of impartiality may occur where the two stages of the proceedings concern different legal questions, but there is nevertheless a 'close link' between the issues examined. Such a close link may be present where the stages both concern the same set of facts, ${ }^{91}$ and where the second stage may to some degree entail reconsideration of the decision taken at the first stage. ${ }^{92}$

These two factors, the substantive overlap in the issues addressed and the element of reconsideration, are both relevant with regard to the mechanism of certification. The issues that

\footnotetext{
${ }^{88}$ Recital 10.

${ }^{89}$ Recital 17.

${ }^{90}$ It is not always self-evident when a party acts in his capacity as a consumer or within his trade or profession. The CJEU has ruled that the same criteria should be applied under the EEO Regulation as under the Brussels Ibis Regulation to ascertain whether a person acts as a consumer: CJEU C-508/12 Walter Vapenik $v$ Josef Thurner ECLI:EU:C:2013:790.

${ }^{91}$ ECtHR Indra v. Slovakia, para. 52.

${ }^{92}$ Ibid.
} 
are considered before a judgment is certified as an EEO are numerous, but they can be summed up as follows:

i) Whether the judgment falls within the material scope of the Regulation (Art. 2);

ii) Whether the claim is indeed uncontested (Art. 3);

iii) Whether the judgment is enforceable in the Member State of origin (Art. 6(1)(a));

iv) Whether the jurisdiction rules of sections 3 and 6 of Chapter II the Brussels I Regulation, which protect consumers, were complied with (Art. 6(1)(b));

v) Whether the minimum standards on service of Chapter III of the EEO Regulation were observed (Art. 6(1)(c);

vi) Whether the judgment was delivered in the Member State where the debtor has his domicile, if the debtor is a consumer and he did not expressly agree to the debt in a settlement or an authentic instrument (Art. 6(1)(d)).

It is submitted that there may be a close link between the issues addressed in a decision on the merits and some of the issues set out above. This applies for example to the requirement that a claim is uncontested, in conjunction with the question whether the standards of service were observed. Under Dutch law, for example, a default judgment may only be delivered if the defendant has not appeared (which means he did not appear in person or has not at any stage been represented by an attorney), provided that the summons was properly served on him. ${ }^{93}$ This coincides with Article 3(1)(b) of the Regulation, which provides that a claim shall be regarded as uncontested if "the debtor has never objected to it, in compliance with the relevant procedural requirements under the law of the Member State of origin, in the course of the court proceedings". The question whether he was adequately served with the summons also overlaps: most methods of service proscribed by the Regulation are also allowed under Dutch law. The primary method of service under Dutch law is personal service on the defendant or a person present at his address who can be expected to ensure that the defendant indeed receives the document ${ }^{94}$ If neither of these are possible, the document may be left at the defendant's address or sent by mail. ${ }^{95}$ In all cases, service is attested by a written confirmation signed by the bailiff.

The question is now whether judges are likely to come to a different conclusion on these matters in the certification phase than they are in the decision stage. If a judge has previously decided that a default judgment is appropriate, because the defendant did not appear according to national procedural law, is he then in a position to effectively scrutinise this decision before certifying it as an EEO? The analysis of the Dutch courts' application of the EEO Regulation shows that there is sometimes confusion as to its interpretation and the requirements that it imposes. One court concluded that certification as an EEO in all cases requires that the decision

\footnotetext{
93 Art. 139 Wetboek van Burgerlijke Rechtsvordering (Rv).

${ }^{94}$ Article $46 \mathrm{Rv}$.

95 Article 47(1) Rv).
} 
has been served on the debtor, which it does not. ${ }^{96}$ Another refused certification on the basis that the case did not concern a consumer, even though the EEO is not limited to consumer cases. ${ }^{97}$ These are only a few examples, but they show that the EEO Regulation is a complicated piece of legislation, which moreover is little used and may not be familiar to all judges. It does not seem unreasonable to assume that judges may not always apply the conditions for certification correctly, perhaps especially so if they have already taken a correct, according to them, decision on some of those conditions already. It is submitted that the correction mechanism of certification is unlikely to function effectively if it is carried out by the same judge who issued the decision.

Would this also amount to a violation of Article 6(1) ECHR, based on the ECtHR's case law on impartiality? Certification and the decision on the merits certainly concern, to an extent, the same questions. Certification does not however provide any kind of review of the decision on the merits; it merely concerns the conditions in which that decision was delivered. It is no appeal or review of the decision itself. The ECtHR's judgments concerning situations in which the same judge was involved in both the first instance and the appeal (or review) procedure can therefore not be seen as precedents. The overlap in the issues considered in the certification stage and in the decision stage are clearly not as large as the overlap between stages where the merits are (at least partly) reconsidered.

The question is whether it is the extent of the overlap that is decisive, or the nature of the reconsideration that the second stage is intended to achieve. It was concluded that the purpose of the certification procedure is to prevent decisions that were handed down in violation of one of the minimum requirements from being certified as an EEO. Does this specific function have any bearing on the matter of impartiality?

In its judgment in San Leonard Band Club v. Malta,${ }^{98}$ the ECtHR does appear to suggest that judges can hardly be expected to correct their own errors when it comes to an interpretation or application of the law. The facts of the case were as follows. The Maltese Housing Secretary had issued a requisition order with respect to a property, which had the effect of protecting the occupation of that property by a tenant (The San Leonard Band Club). The owners of the property sought to have the order declared null and void and to regain possession of the property. The first instance court rejected their claim, but the Court of Appeals subsequently reversed that decision and declared the order null and void. San Leonard Band Club then applied for a retrial of the case: this was the only remedy available to them, because no third level of jurisdiction existed for these types of cases. Under Maltese law, a request for a retrial is allowed on limited grounds, which include 'a wrong application of the law'. According to San Leonard Band Club, the law had been applied wrongly, because the requisition order was a matter of public interest, and decisions of the Housing Secretary were not subject to judicial review. The request for a retrial on this ground was considered, and rejected, by the same three-

\footnotetext{
${ }^{96}$ Rb Groningen, ECLI:NL:RBGRO:2006:AZ7764.

${ }^{97}$ Rb Middelburg, ECLI:NL:RBMID:2010:BN9802.

${ }^{98}$ ECtHR San Leonard Band Club v. Malta appl. no. 77562/01 ECHR 2004-IX.
} 
judge panel that took the original decision to declare the requisition order null and void. San Leonard Band Club then applied first to the domestic courts, and then to the ECtHR, with the complaint that the panel could not have been impartial in its examination of the request for a retrial, because it required them to assess whether their own conclusions in the decision on the merits may have been incorrect.

The ECtHR indeed found that the principle of impartiality had not been respected and found a violation of Article 6(1) ECHR. It accepted that the fact that the same panel of judges was involved in both phases of the proceedings could give rise to doubts in the applicant's mind as to its impartiality (the objective aspect of impartiality). ${ }^{99}$ It then ruled that these doubts could be objectively justified. The ECtHR considered that the same judges were called upon to decide whether or not they themselves had committed an error of legal interpretation or application in their previous decision, being in fact requested to judge themselves and their ability to apply the law. There was no new information available to them, nor did the evaluation concern a new question: they were simply called upon to reassess and evaluate their own earlier decisions as to the application of the law. This, according to the ECtHR, provided an objective justification for the applicant's doubts as to the panel's impartiality. ${ }^{100}$

The lack of impartiality was thus found in the fact that judges were required to reassess their own earlier decisions on the application of the law. This case clearly did not concern an appeal or another kind of reconsideration of the merits of the case (which distinguishes it from the cases cited above); it concerned an evaluation of only one aspect of the decision. What was important to the Court was that this same matter had already been decided upon by the same judges once before. Therefore, even though the overlap between the matters examined at both stages was limited to this one issue, the question the judges had to answer on the issue was identical.

This judgment appears to provide that a mechanism that requires a judge to reconsider an issue he decided on earlier may give rise to objectively justified doubts as to his impartiality. It does not appear to matter that the reconsideration only concerns one aspect of his earlier decision. Application of this finding to the EEO mechanism leads to the conclusion that a judge can hardly be expected to be impartial with regard to questions such as the uncontested nature of the claim and the correct application of minimum standards, in so far as those were part of his decision on the merits as well. The consideration of the question whether the claim is uncontested or whether the defendant was served with the documents instituting the proceedings in the proper manner may require a judge to admit that he was wrong to deliver a default judgment. A judge may also be required to conclude that he wrongly assumed jurisdiction, in violation of the (exclusive) jurisdiction rules of sections 3 and 6 of Chapter III of the Brussels I Regulation. It is submitted that, based on the ECtHR's case law, legitimate doubts may arise as to a judge's impartiality when he has to reassess his own earlier findings in this manner.

\footnotetext{
99 Paras. 61-62.

100 Paras. 63-65.
} 


\subsubsection{Right to a fair hearing before a judgment is declared enforceable}

The discussion of Saccoccia above yielded the conclusion that it is likely not necessary to hold an oral hearing during enforcement proceedings if the questions considered during those proceedings are 'legal issues of a limited nature'. Chapter 4 discussed the European courts' case law on this point, which provides that an oral hearing only needs to be held when there are 'issues of credibility or contested facts'; ${ }^{101}$ it may not be necessary where the proceedings concern merely 'legal issues of a limited nature' or of 'no particular complexity' ${ }^{102}$

If we look at the way the certification procedure of Brussels II bis and the EEO Regulation is currently organized, it appears that an oral hearing would likely not be required. The examination at this stage concerns only the compatibility of the proceedings with a number of narrowly defined requirements which are fairly technical in nature and do not, as they are currently formulated, require an examination of the debtor's credibility. There is also not much room for contestation due to the lack of room for interpretation in the minimum requirements. This can be contrasted with the examination of grounds for refusal in the Member State of enforcement. When the question is whether enforcement should be refused because it would be 'manifestly contrary to public policy' or because the debtor was not served 'in sufficient time to enable him to arrange for his defence', these questions cannot be called simple or technical and are likely to be subject to contestation.

\subsubsection{The right to appeal (non-)certification}

What seems most problematic from the perspective of the right to a fair trial is the lack of enforceability of the minimum standards on service contained in the Regulation. This problem concerns the core of the EEO's innovation, which is the concentration of all checks on enforcement with the courts in the Member State of origin. It was concluded above that the minimum requirements on service of the EEO Regulation are in principle compatible with the ECHR, though it may be problematic that there is no requirement that the most likely effective method was attempted first.

The question is what happens when the minimum requirements have not been observed, yet the court of origin nevertheless certifies the judgment as an EEO. Even if a judgment debtor is then able to request withdrawal of the certificate on the basis of Article 10 of the Regulation, this is no remedy for the lack of effective service in the first place. Presumably, the creditor should then seek enforcement through the Brussels I bis Regulation, which then contains the double review procedure for lack of effective service as described above. If withdrawal turns out not to be the appropriate remedy for a failure to observe the minimum requirements (for

${ }^{101}$ Judgment, para. 76; the Court cites ECtHR Jacobsson (no. 2) and ECtHR Valová and others v. Slovakia.

102 The Court cites Varela Assalino v. Portugal and Speil v. Austria. 
one, when will an EEO be considered to have been 'clearly' wrongly issued?), the Regulation does not appear to provide a remedy to the debtor at all. In either case, it is questionable whether the Regulation provides effective protection to the debtor with regard to his right to be effectively informed of the proceedings. Since the presumption that service has been properly effected forms the cornerstone of the Regulation as a whole, and because the Regulation contains no other way of remedying a failure to observe the debtor's right to a hearing, this casts serious doubt on the Regulation's conformity with the right to a fair trial. It is also questionable whether it provides any real advantage to the creditor, since he may have to return to the Brussels I bis Regulation in certain cases. However, since - as previously shown - in Dutch procedural practice no additional steps need to be taken to obtain an EEO after the judgment is issued, the loss of time and money spent on obtaining an EEO is likely to be negligible. ${ }^{103}$ In Member States where this is not the case, it is to be expected that the EEO will fall out of favour in comparison with the Brussels I bis Regulation.

The possibility for review that Article 19 requires may provide relief to a debtor who was not adequately served, though Article 19 in itself does not create a remedy, it merely requires that one should be available if one of the service methods of Article 14 was used. It is important to stress however that this remedy, as well as that of Article 10, requires the judgment debtor to take action in the Member State of origin of the judgment. This is clearly less favourable to him then a request for refusal of enforcement in his own Member State, where enforcement is sought. This may not be such an obstacle for a professional party who has access to legal advice and information on the procedural steps to take. But what if the court of origin of the judgment certifies a judgment against a consumer as an EEO, even though the court of origin is not in the Member State of the debtor's domicile (as required by Article 6(1)(d) of the Regulation)? Then the debtor (the consumer) would need to take action in the Member State where the judgment was given, not his own Member State, to have it withdrawn. This is arguably precisely the kind of situation the EEO Regulation was intended to avoid by including Article $6(1)(d)$ in the first place.

Section 4 of Article 10 of the EEO Regulation provides that "no appeal shall lie against the issuing of a European Enforcement Order certificate". This section does not appear to prohibit an appeal against a refusal to issue an EEO certificate. The Dutch and German courts certainly interpret it that way. This does not seem to conflict with the aim and purpose of the Regulation. Zilinsky argues that "any appeal against the decision to issue or not to issue an EEO conflicts with the aim of the EEO Regulation" because it creates delays. ${ }^{104}$ But surely this is only a problem when judgment debtors aim to forestall enforcement by appealing against the issuing of a certificate. Where a certificate is refused, the delay created by the creditor's appeal against

103 The Dutch case law repository offers one judgment involving an EEO requested after the entry into force of Brussels Ibis, though considering the low numbers of usage of the EEO prior to that development, this is perhaps not statistically significant. See the Annex.

104 Zilinsky (2005) p. 168. 
that decision affects only himself, and it is up to him to evaluate whether a delay is preferable to seeking enforcement through the Brussels I bis Regulation instead.

The matter of remedies against the (wrongful) certification of an EEO is one where a careful balance needs to be struck between the creditor's interest in speed and efficiency and the debtor's right to observance of his right to effective service. On the one hand, an appeal by the debtor against the certification as an EEO would probably provide too much scope for abuse and therefore adversely affect the creditor. On the other hand, it is problematic that there are no effective possibilities for review after enforcement has commenced (or after the certificate and the judgment have been served) when the minimum standards have been misapplied.

It should be noted that debtors may have the possibility to contest the enforcement of a judgment certified as an EEO in the Member State of enforcement. Under Dutch law, there is the possibility of starting an enforcement dispute, on the grounds that enforcement amounts to abuse of the right to enforcement. This would occur when, for example, the debtor can show that the debt was already paid. The EEO Regulation does not grant the Member State of enforcement a possibility to refuse enforcement on such grounds (or on any grounds other than irreconcilability, as provided by Article 21(1)). Yet it is possible that the CJEU's judgment in Prism Investments ${ }^{105}$ may be applicable here. In that judgment, the CJEU ruled that the enforceability of a judgment in its Member State of origin is a precondition for its enforceability in other Member States. If the judgment has become unenforceable in its Member State of origin due to the debt already having been paid, this also means that enforcement in another Member State is no longer possible. It is very well possible that this reasoning would also apply to a judgment certified as an EEO, since Article 11 of the EEO Regulation provides that the certificate "shall take effect only within the limits of the enforceability of the judgment." The French Cour de Cassation recently relied on this Article to declare unlawful the enforcement of a judgment certified as an EEO where that judgment had been overturned in its Member State of origin. ${ }^{106}$ It therefore appears that withdrawal in the Member State of origin of the EEO is not the only way for the debtor to prevent enforcement of a judgment that is no longer enforceable in its country of origin.

Finally, it seems plausible that a judgment that has been certified as an EEO in violation of one of the minimum requirements cannot benefit from the Regulation's enforcement regime at all. In this judgment, which is discussed in detail in the next section, the CJEU ruled that if an application for an EOP was not served on the defendant in conformity with the Regulation's minimum requirements, the defendant was not able to make an informed decision whether or not to oppose the claim. According to the CJEU, this meant that an EOP granted without the minimum requirements having been complied with "cannot benefit from the application of the

105 Case C-139/10Prism Investments v. Jaap Anne van der Meer ECLI:EU:C:2011:653.

${ }^{106}$ Cour de cassation, chambre civile 2, Audience publique du vendredi 6 janvier $2012 \mathrm{~N}^{\circ}$ de pourvoi: 10-23518 
enforcement procedure laid down in Article 18 [of the Regulation]. It follows that the declaration of enforceability of such an order for payment must be regarded as invalid."107 Since the EEO Regulation contains a similar mechanism of minimum requirements followed by automatic enforceability, it could be concluded that an EEO issued in violation of these minimum requirements should be regarded as invalid. According to the CJEU, such an invalid title should not therefore benefit from the automatic enforcement regime.

This leads to the conclusion that a certificate issued in violation of the EEO's minimum standards should be considered invalid. It is clear that the CJEU's reasons for considering an EOP invalid (the lack of opportunity for the defendant to defend himself) also apply in the context of an EEO: the purpose of the minimum requirements in both Regulations is exactly the same. The CJEU's conclusion regarding the EOP should therefore also be considered applicable to the EEO Regulation. Even without the certificate having been withdrawn, it can therefore not be enforced if issued in violation of the minimum requirements. The question is now what should happen in the Member State of enforcement if invalidity is alleged by the debtor. Presumably he would have to apply for a stay of enforcement (Art. 23) while a request for withdrawal under Article 10(1)(a) is considered by the court of origin.

\subsubsection{Conclusion on the European Enforcement Order}

This section aimed to establish whether the EEO could adequately replace the mechanism of Brussels I and I bis, concentrating both judgment export and judgment inspection with one and the same court in the Member State of enforcement. The preceding Chapter gave reasons why EU Regulations should maintain a possibility for cross-border judgment inspection. Since the EEO does not offer such a possibility, it is incapable of addressing some fundamental rights violations effectively. As Chapter 7.1 posited, certain types of violations, particularly but not only a lack of impartiality on the part of the judge, cannot be adequately addressed by a procedure that is confined to the Member State where the judgment was rendered. The EEO, which relies on self-control, cannot function as effectively as a cross-border remedy in this regard.

Apart from this argument, which applies to all EU Regulations, the EEO can also be criticised on its own terms. Its combination of unclear and potentially ineffective minimum standards on service, the impossibility of impartiality of the judge in the certification procedure, and the lack of possibilities for review and appeal, means that the Regulation fails to protect the debtor's right to a fair hearing adequately. ${ }^{108}$

${ }^{107}$ CJEU Joined cases C-119/13 and C-120/13 eco cosmetics GmbH \& Co. KG v Virginie Laetitia Barbara Dupuy and Raiffeisenbank St. Georgen reg. Gen. mbH v Tetyana Bonchyk, ECLI:EU:C:2014:2144, discussed below.

${ }^{108}$ See also Ptak (2014) p. 241. 


\subsection{The uniform European procedures}

This section discusses the uniform European procedures, the ESCP and the EOP Procedure. In contrast to the instruments that were previously discussed, the right to a fair trial is relevant to these procedures in their entirety, because aside from facilitating cross-border enforcement, they aim to provide a complete procedure resulting in an enforceable decision. The following therefore discusses the conformity of these procedures with all aspects of the right to a fair trial as far as they are relevant. However, the protection these procedures give to the rights of the parties involved should be discussed in light of the fact that these procedures allow no refusal of recognition or enforcement. Like the EEO, these procedures rely on checks in the Member State of origin. An EOP or a judgment resulting from an ESCP can be enforced automatically throughout the EU, with no possibilities to oppose enforcement. Possibilities for review of these decisions are very limited. It is therefore essential that the procedural guarantees of these Regulations are sufficient and effective, because the remedies in cases where something goes wrong are very limited.

The discussion touches, for each of the instruments, on the following aspects of the right to a fair trial: access to justice; the creditor's right to enforcement; the right to a fair hearing; service of documents, the right to a trial within a reasonable time, and the effectiveness of procedural safeguards and the right to appeal.

\subsubsection{The European Order for Payment Procedure}

In 2015, the European Commission published a (rather succinct) report on the functioning of the EOP Procedure. ${ }^{109}$ There are some national reports on its functioning which contain some empirical data. ${ }^{110}$ A conclusion that appears to be supported by all national research is that the EOP is very rarely used, both in absolute terms as compared to national orders for payment. ${ }^{111}$

\footnotetext{
${ }^{109}$ Report from the European Commission to the European Parliament, the Council and the European Economic and Social Committee on the Application of Regulation (EC) 1896/2006 of the European Parliament and the Council creating a European Order for Payment Procedure, COM(2015) 495 final.

${ }^{110}$ Rylski (2012) p. 145-190 ("Polish Report"); The Baltic States Report (note 126); for the Netherlands, see Kramer, Tuil and Tillema (2012) p. 112 onwards. The 2015 European Commission Report was prepared on the basis of a number of Member State reports, but these mostly concern the implementation into legislation of the procedure, along with some case law; see http://www.acj.si/en/project-results, last accessed 04/12/2015.

${ }^{111}$ European Commission Report, 2015, p. 3; see references to the Polish report and experiences in Sweden, Austria and Denmark in Mánko (2013) (p. 5); this shows that 35 applications for an EOP were made in Sweden, and 94 in the UK; see also the Baltic States Report, which reports that Latvian courts had issued 9 EOPs until 2012 (p. 325) the Estonian courts 'carried out' (what this means is unclear) 94 decisions on the basis of the EOP Regulation (p. 694) and that Lithuanian figures ranged between 3 EOPs issued (in 2006) to 19 in 2011 (p. 382 ).
} 
On the whole, awareness of the procedure in the Member States appears quite low. ${ }^{112}$ In terms of access to justice, this lack of awareness is a clear problem.

The number of EOP's that are contested varies greatly among Member States. In the 2013 European Parliament Research Briefing, Polish figures were cited, which showed that $93 \%$ of EOPs remained uncontested. ${ }^{113}$ The 2015 European Commission Report however shows that the number of uncontested EOPs may be as low as 5\% (in Greece). Dutch research showed that the percentage of cases in which a statement of opposition was lodged lay around $24 \%{ }^{114}$ When an EOP is issued, it is therefore likely to be quite an effective means of debt collection, but reports also show that it may take a long time before the EOP is issued ${ }^{115}$ and costs are not transparent. ${ }^{116}$ This forms a problem with regard to the creditor's right to enforcement, but also with regard to the debtor's right to a fair hearing: the reports show that debtors were sometimes hesitant to oppose EOPs served on them for fear that this would incur costs, ${ }^{117}$ or unsure of the status of the document. It is essential, particularly in a one-sided procedure such as the EOP, that defendants are aware of the implications of an Order for Payment being issued against them and the possibilities of opposition in order to safeguard their right to a fair hearing.

The 2015 Report states that 'no major problem concerning the service of documents has been reported in the specific context of the European Order for Payment Procedure'. ${ }^{118}$ At the same time, the Report cites the eco cosmetics/Raiffeisenbank case, which resulted from a failure to serve an EOP on the defendant, so some problems are clearly experienced. Moreover, this case shows that in such cases the EOP Regulation does not provide for a remedy, making the potential problems with service especially concerning. This case is discussed below (Section 8.5.1).

The experiences with the ESCP have shown that the uniform European procedures are not very well known and their complexities not well understood, neither by litigants nor by courts. It has been shown that service is not always effected in the way prescribed by the Regulations; it has also been pointed out that defendants may be unaware of what is being served on them, or afraid that lodging a statement of opposition may incur costs.

The 2013 European Parliament Research Briefing also stated that

The analysis revealed that the rules of the Regulation are interpreted and applied in divergent ways, often contrary to the purposes of the Regulation. For instance, in several cases courts required the claimant to pay in advance for the costs of translation,

\footnotetext{
1122010 Eurobarometer.

${ }^{113}$ European Commission Report, 2015, p. 8-9.

${ }^{114}$ Kramer, Tuil, Tillema (2012) p. 114.

${ }^{115}$ European Commission Report, 2015, p. 7.

${ }^{116}$ European Commission Report, 2015, p. 8.

${ }^{117}$ Chainais (2010) p. 647.

${ }^{118}$ European Commission Report, 2015, p. 7.
} 
without checking first whether it was really necessary. In some cases courts demanded that the claimant provide the documents supporting the claim, although the Regulation does not require this. Polish courts usually sent the EOP abroad by post, without checking if this method is acceptable in a specific MS. ${ }^{119}$

While the latter sentence is clearly also worrying in view of the rights of the defence, perhaps a greater problem appears to be that, rather than being motivated by a perceived injustice, courts are - once again - simply not very familiar with the rules of the EOP Regulation. This conclusion seems to be supported by the Baltic experience. ${ }^{120}$

Even though the rules contained in the EOP Regulation have themselves been criticized for not protecting procedural rights effectively, surely a situation in which they are applied inconsistently across the different Member States, and even between courts within one Member State, is in any case unsatisfactory. In cross-border litigation especially parties are greatly benefited by clarity and consistency of legal rules. Given that uniform European procedures like the EOP and ESCP are designed to offer greater simplicity and coherence in cross-border litigation, the fact that they are not succeeding is worrisome with a view to protecting fundamental rights. Otherwise, there is of yet too little empirical evidence to draw a conclusion either way.

\subsubsection{Effectiveness of procedural safeguards and right to appeal}

Like the ESCP, the EOP procedure affords the defendant a right to apply for a review of the Order under limited circumstances (Art. 20(1)). A review may only be granted if: a) service was effected in accordance with one of the methods of Article 14 (service without proof of receipt by the debtor), but not in sufficient time to enable him to arrange for his defence, without any fault on his part, or b) the defendant was prevented from objecting to the claim by reason of force majeure or due to extraordinary circumstances without any fault on his part. In both cases the defendant should act promptly. The review procedure is therefore not available in cases where service was not effected in conformity with any of the methods of the Regulation, for instance where it was served on a business address where the defendant is no longer located. This happened in the case of eco cosmetics/Raiffeisenbank, ${ }^{121}$ where the CJEU indeed concluded that the review procedure of the EOP did not apply.

At issue was the question of what happens when an EOP was issued against a defendant, but the defendant claims that the EOP was not properly served on them. The EOP Regulation (like the ESCP Regulation) ${ }^{122}$ exhaustively proscribes the ways in which service can be effected. ${ }^{123}$ However, the Regulation does not say what happens when an EOP is not served in accordance

\footnotetext{
${ }^{119}$ Mankó (2013) p. 5.

${ }^{120}$ Baltic States Report (2012) p. 425 concerning Lithuania especially.

${ }^{121}$ CJEU Joined cases C-119/13 and C-120/13 eco cosmetics GmbH \& Co. KG v Virginie Laetitia Barbara Dupuy and Raiffeisenbank St. Georgen reg. Gen. mbH v Tetyana Bonchyk, ECLI:EU:C:2014:2144.

${ }^{122}$ Article 13, ESCP Regulation.

${ }^{123}$ See also Kramer (2010) p. 25, citing Hess and Bittman (2008) and Storme (2009).
} 
with these rules. A German court asked whether the review procedure could be used in such a case. The existing review procedure and the grounds for review could legitimately be seen as exhaustively laying down the situations in which a decision could be can be reviewed. The referring court asked whether it could nevertheless apply the review procedure in a case where service had not been effected at all.

The CJEU held that it could not, since Article 20(1) exhaustively listed the situations in which the review procedure could be applied, and failure to effect service is not one of them. However, it then ruled that the national court should find such a remedy under national law. EOP's that were declared enforceable despite not having been served in the appropriate manner could not, the CJEU held, "benefit from the application of the enforcement procedure", and should therefore be considered 'invalid'.

This outcome is certainly correct, as it would be unacceptable if there was nothing a debtor could do against an EOP that was issued against him without it having been served on him properly. The manner in which the CJEU reaches it is a little ambiguous: it states that Article 20 cannot be applied because this is only applicable in the situations that it exhaustively enumerates, "a failure to effect service not being one of them". Article 20 does however allow review when service has been performed but in insufficient time, so it is not true that this Article does not concern service. It appears however that the CJEU on this point followed AdvocateGeneral (A-G) Bot, who points out that review would be an inappropriate remedy in cases where service was not effected, ${ }^{124}$ since for review to be possible the EOP should have become enforceable in the first place. For an EOP to become enforceable even though the debtor was never in a position to contest it is contrary to the rights of the defence. According to the A-G and the CJEU the consequence of a failure to serve the EOP effectively should therefore be that the EOP is regarded as invalid.

However, in the words of the A-G, the absence of a remedy for such situations in the EOP Regulation means that a legal vacuum exists on this point. ${ }^{125}$ It is left up to national procedural law to provide an adequate remedy, which could result in inequality between the Member States on this important point. Instead of simplifying cross-border litigation, it requires parties to familiarize themselves with the procedural law of the Member State that has jurisdiction, which could be any of 27 (at the time of writing) different legal systems. Such a fragmented system of judicial protection against failures to observe the EOP Regulation's minimum standards is contrary to the EOP's intentions and should be addressed in a future proposal. ${ }^{126}$

\footnotetext{
${ }^{124}$ View of Advocate General Bot, delivered on 9 April 2014, Joined Cases C 119/13 to C 121/13 eco cosmetics GmbH \& Co. KG (C 119/13) v Virginie Laetitia Barbara Dupuy, Raiffeisenbank St. Georgen reg. Gen. mbH (C 120/13) v Tetyana Bonchyk and Rechtsanwaltskanzlei CMS Hasche Sigle, Partnerschaftsgesellschaft (C 121/13) $v$ Xceed Holding Ltd, ECLI:EU:C:2014:248, para. 45.

${ }^{125}$ Ibid., para. 27.

${ }^{126}$ See also Hess and Raffelsieper (2015) p. 402.
} 
The Commission concluded in its 2015 Report on the EOP that the conditions for application of Article 20 need 'clarification'. ${ }^{127}$ No amendments have yet been proposed. ${ }^{128}$

Apart from the review procedure provided for in Article 20(1), Article 20(2) of the EOP Regulation allows a defendant to apply for a review in cases where the order was "clearly wrongly issued, having regard to the requirements laid down in this Regulation, or due to other exceptional circumstances". The CJEU has ruled that wrong information in the claim form does not constitute an exceptional circumstance, ${ }^{129}$ nor does a failure to observe the time limits. ${ }^{130}$ The latter raises the question if there are any, and if so what, consequences attached to a failure to observe time limits under the EOP Regulation. If there are none, this is contrary to ECtHR case law requiring that effective measures are available against failures to observe the reasonable time requirement. ${ }^{131}$

\subsubsection{The European Small Claims Procedure}

This section looks at the experiences with the ESCP, which was introduced in 2009 and amended in 2015 (taking effect in 2017). ${ }^{132}$ Chapter 2 explained ${ }^{133}$ that the ESCP is one of two harmonized European procedures that remove the need for exequatur by providing an opportunity to obtain a decision that is immediately enforceable throughout the EU. Numerous evaluations show that the functioning of this procedure has not been free of problems as far as the protection of procedural rights is concerned. Of course, any problems with the ESCP are not immediately comparable with a situation in which exequatur previously existed, but has been abolished, as under the Brussels II bis Regulation. The objective of the ESCP and EOP is more ambitious than a simple abolition of exequatur. Instead of only simplifying cross-border recognition and enforcement, they aim to replace the traditional path of obtaining a judgment under national procedural rules followed by an exequatur entirely. Any problems concerning fundamental rights protection under these instruments can therefore not be blamed entirely on the absence of exequatur. However, it is clear that if an ESCP or EOP results in a judgment that infringes procedural rights, through a malfunctioning of the procedural guarantees

\footnotetext{
${ }^{127}$ Report from the European Commission to the European Parliament, the Council and the European Economic and Social Committee on the Application of Regulation (EC) 1896/2006 of the European Parliament and the Council creating a European Order for Payment Procedure, COM(2015) 495 final, p. 9.

${ }^{128}$ As section 8.5.2.6, discusses, the 2015 Regulation amending the ESCP and EOP Regulations does address this problem for the ESCP Regulation by widening the scope of the review procedure.

${ }^{129}$ Case C-245/14 Thomas Cook Belgium NV v Thurner Hotel GmbH, ECLI:EU:C:2015:715.

${ }^{130}$ Case C-324/12 Novontech-Zala ECLI:EU:C:2013:205.

${ }^{131}$ Chapter 4.3.7.2.

132 Regulation (EU) 2015/2421 of the European Parliament and of the Council of 16 December 2015 amending Regulation (EC) No 861/2007 establishing a European Small Claims Procedure and Regulation (EC) No 1896/2006 creating a European order for payment procedure, OJ L 341/1.

${ }^{133}$ Chapter 2.3.7.
} 
contained in either of these Regulations or for other reasons, the added protection of the exequatur is lacking, magnifying the potential effects of such a faulty judgment.

In order to determine what problems have been encountered in the implementation of the ESCP, it is worth looking at some of the empirical studies that have been done on the functioning of the ESCP. The following also discusses some of the experiences of Dutch courts with the ESCP as evidenced by case law. There is as of yet no CJEU case law on the ESCP.

The most comprehensive study on the functioning of the ESCP to date is the 2013 Assessment of the socio-economic impacts of the policy options for the future of the European Small Claims Regulation, prepared by Deloitte (the "Deloitte Report") for the European Commission. ${ }^{134}$ This study evaluated the effectiveness of the ESCP and provided policy recommendations for the future. The European Commission also published two Eurobarometer reports that are relevant: Eurobarometer 395 on the ESCP from April 2013 ("Eurobarometer 395") "135 and Eurobarometer 351 on Civil Justice from October 2010 ("Eurobarometer 351"). ${ }^{136}$

There are also the reports prepared by consumer networks: the 2012 European Small Claims Procedure Report of the Network of European Consumer Centres (ECC-Net) ${ }^{137}$ and the 2011 Report of the French and German European Consumer Centres (CEC-ZEV). ${ }^{138}$ Empirical research into the conduct of Dutch courts has also been carried out. ${ }^{139}$ The Baltic States published a report on the implementation of and experiences with the ESCP as well as the EOP and EEO in those three states. ${ }^{140}$

Furthermore, a public consultation was launched in early 2013, whose results were published on a website; a number of individual responses were also submitted. ${ }^{141}$ In November 2013 the European Commission published a Proposal for amendment of the ESCP and the EOP, ${ }^{142}$

\footnotetext{
${ }^{134}$ Assessment of the socio-economic impacts of the policy options for the future of the European Small Claims Regulation. Final Report, European Commission - Directorate-General for Justice, July 2013 ("Deloitte Report 2013”) available at http://ec.europa.eu/justice/civil/document/index_en.htm (last accessed 29 April 2016). Note that this Report consists of 2 parts: I: "Evaluation of the Small Claims Procedure", and II: "Assessment of the socio-economic impacts of the policy options for the future of the Small Claims Regulation". These parts are referenced as "Part I: Evaluation" and "Part 2: Assessment of the policy options", respectively.

${ }^{135}$ European Commission - Directorate-General for Justice, Special Eurobarometer 395: The European Small Claims Procedure, April 2013, available at http://ec.europa.eu/public_opinion/archives/ebs/ebs_395_en.pdf (last accessed 29 April 2016).

${ }^{136}$ European Commission - Directorate-General for Justice, Special Eurobarometer 351: Civil Justice, October 2010, available at http://ec.europa.eu/public_opinion/archives/ebs/ebs_351_en.pdf (last accessed 29 April 2016).

${ }^{137}$ ECC-Net (2012).

138 CEC-ZEV (2011).

${ }^{139}$ Kramer and Ontanu (2013); Kramer (2014).

${ }^{140}$ Baltic States Report (2012).

${ }^{141}$ See http://ec.europa.eu/justice/newsroom/civil/opinion/130318_en.htm (last accessed 29 April 2016).

142 European Commission, Proposal for a Regulation amending Regulation (EC) No 861/2007 of the European Parliament and the Council of 11 July 2007 establishing a European Small Claims Procedure and Regulation (EC) No 1896/2006 of the European Parliament and of the Council of 12 December 2006 creating a European Order for Payment Procedure, COM (2013) 794 final.
} 
which addressed the problems detected by the various evaluations. An amended ESCP Regulation was adopted on 16 December 2015. ${ }^{143}$ An important feature of this amendment is that it raised the ceiling of EUR 2,000 to EUR 5,000. Originally, the Commission proposed extending the scope of the ESCP to claims up to EUR 10,000, which was considered too high. ${ }^{144}$

The original proposal also entailed a substantial widening of the definition of cross-border cases be substantially widened: instead of only applying to cases where one of the parties is habitually domiciled in another Member State than the one whose courts have jurisdiction, application can now also be based on the place of performance of a contract, the place where the facts on which the claim is based arose, or the place where the judgment is to be enforced. The 2015 Regulation does not include this extension of the definition of cross-border.

With regard to fundamental rights protection, the following issues were identified as potentially problematic. They are discussed for their relevance to certain elements of the right to a fair trial.

\subsubsection{Access to justice}

First of all, the ESCP was evaluated as to its effect in improving access to justice in crossborder cases, which is one of its main objectives. The Deloitte Report concluded that the total number of ESCP applications in 2012 was around 3500, which was "low compared to the theoretical scope of the Regulation of 5 million claims". ${ }^{145}$ It identified three obstacles to the effective use of the procedure. First of all, the costs and time associated with cross-border litigation were considered "disproportionate", because cross-border litigation often includes translation costs, court fees, costs for serving documents and the costs associated with oral hearings. The ESCP had not resulted in a reduction of these costs as opposed to traditional cross-border litigation. A second obstacle was the lack of transparency concerning the costs of

${ }^{143}$ Regulation (EU) 2015/2421 of the European Parliament and of the Council of 16 December 2015 amending Regulation (EC) No 861/2007 establishing a European Small Claims Procedure and Regulation (EC) No 1896/2006 creating a European order for payment procedure, OJ L 341/1.

${ }^{144}$ Opinion of the European Economic and Social Committee on the 'Proposal for a Regulation of the European Parliament and of the Council amending Regulation (EC) No 861/2007 of the European Parliament and the Council of 11 July 2007 establishing a European Small Claims Procedure and Regulation (EC) No 1896/2006 of the European Parliament and of the Council of 12 December 2006 creating a European order for payment procedure' COM(2013) 794 final - 2013/0403 (COD) OJ C 226/08, p. 45.

${ }^{145}$ Deloitte Report, Part I: Evaluation, p. v. Data concerning the Dutch experience corroborate these findings: see Kramer and Ontanu (2013) p. 324. As does the Baltic States Report (2012): this shows the following numbers: 6 cases in Latvia (which is "comparatively rarely" according to the researchers; p. 327); 1 case in Estonia (p. 676); and none for Lithuania, because no data were collected on the use of the ESCP (though the answers to the questionnaires show that 1 judge answered "yes" to the question whether he had experience with the ESCP (p. 386)). The Lithuanian reports stated that they "intended to receive a lot more statistical information on Lithuanian court activities regarding the application of Regulations, yet this was not the case"(p. 383). 
litigation, ${ }^{146}$ while a third was simply that relevant actors were not aware of the availability of the procedure. The Report concluded therefore, "while there is evidence that the Regulation has improved the access to justice since it entered into force, it may be relevant to consider making some amendments to the Regulation in order to further contribute to the improvement to the access to justice". One proposed amendment to the Regulation was a cap on court fees of $10 \%$ of the value of the claim, which would improve transparency but proved controversial. ${ }^{147}$ It was not adopted in the new Regulation.

Another problem, identified in all reports, is the complexity of forms. Both the Deloitte and ECC-Net Reports noted that the main obstacle to the effective application of the ESCP is the complexity of the forms. ${ }^{148}$ The Special Eurobarometer indicated that $16 \%$ of the respondents found it difficult to fill in the application forms, against $62 \%$ who found it easy. The complexity of the forms, along with the limited assistance available through the courts or other responsible authorities at the Member State level (despite Article 11 ESCP requiring Member States to provide assistance), lead consumers to approach lawyers; this greatly adds to the cost of an ESCP. In particular, forms are seen as too rigid, applicants have difficulties formulating the legal basis of the claim, and the question of international jurisdiction poses a problem. ${ }^{149}$ It is notable that various respondents to the Commission survey observed that legal assistance proved necessary for the effective use of the procedure, and recommended that consumers be made aware of the risk of attempting a procedure without professional advice or that this be made available free of charge. ${ }^{150}$

Finally, according to the ECC-Net survey, language issues are the largest problem encountered by consumers using the ESCP. First of all, while the forms are available online and can be automatically translated, they need to be filled in in the language of the competent court. This may incur high translation costs. ${ }^{151}$ Furthermore, the Dutch experience shows that courts do not know what to do with Dutch forms that are to be sent to a foreign defendant, though one would send the answer form in the language of the defendant. Also, the Service Regulation requires that a notice be sent that the defendant can refuse the documents, but it was found that most courts do not do this. ${ }^{152}$

\footnotetext{
${ }^{146}$ Also observed in submissions to the public consultation, e.g. BEUC (2013) p. 6; Lawyer Ireland (2013) p. 12; the Law Society (2013) proposes that claim forms be standardized and automatically translated (p. 3).

${ }^{147}$ Article 15a, Proposal for amendment of the ESCP Regulation, 2013. See for example the Opinion of the European Economic and Social Committee, point 4.4 and 4.5, which pointed out that court fees are calculated differently across Member States, and that a cap of $10 \%$ of the claim may actually have negative consequences in Member States where fees do not reach this level. See also Kramer (2014) p. 108.

${ }^{148}$ Deloitte Report, Part I: Evaluation, p. 82.

${ }^{149}$ Kramer and Ontanu (2013) p. 325.

${ }^{150}$ CBBE (2013) p. 5; Bar Council England \& Wales (2013) p. 2; BEUC (2013) p. 5; Business Europe (2013) p. 2.

${ }^{151}$ Deloitte Report, Part I: Evaluation, p. 83

${ }^{152}$ Kramer and Ontanu (2013) p. 326.
} 
Lastly, there was confusion over who is responsible for translating form $\mathrm{D}$, which is the certificate that needs to accompany the decision to be enforced in another Member State. Since this will often need to be translated into the language of the Member State of enforcement, costs will be incurred; but it is currently unclear whether the courts can recover these costs from one of the parties.

\subsubsection{The creditor's right to enforcement}

A second problem, mostly concerning access to justice, is the enforcement of judgments resulting from the ESCP. The ECC-Net Report concluded that while it is difficult to obtain data on enforcement, ${ }^{153}$

as the enforcement procedures are very different from one Member State to another, it is hard to get advice on who to turn to and what it may cost, furthermore, considering that an enforcement procedure, to be started in the country of the defendant with necessary legal assistance, can cost even more than the value of the claim itself, all the Small Claims Procedure benefits can be nullified. ${ }^{154}$

The fact that differences in enforcement procedures between Member States are seen as a problem has been identified before, ${ }^{155}$ and it is not directly attributable to the ESCP. However it is regrettable that an instrument designed to make cross-border litigation simpler has not succeeded in addressing these problems.

The amended Regulation also aims to make the procedure more transparent and accessible by clarifying Member States' obligations to provide assistance to creditors. Whereas previously the Regulation only required Member States to 'ensure that parties can receive practical assistance', the amended Regulation clarifies on what topics parties should be able to receive assistance. These include the matter of jurisdiction and the question whether the ESCP is appropriate for resolving their conflict. In principle, this amendment should create an incentive for Member States to be more diligent in providing information, but as always the question is whether it will be duly implemented. ${ }^{156}$

\subsubsection{The right to a fair hearing}

Of the identified obstacles, the high costs, both financially and in terms of time and effort, associated with oral hearings is especially concerning with a view to protecting fair trial rights, as an oral hearing may be essential to protecting the right to a fair trial of both parties. In the

\footnotetext{
${ }^{153}$ A problem that was also encountered by the Dutch researchers: Kramer and Ontanu (2013) p. 326.

${ }^{154}$ ECC-Net (2012); see also BEUC (2013) p. 8.

155 Eurobarometer 351 (2010) p. 38-43.

${ }^{156}$ ESCP Regulation, as amended by Regulation 2015/2421, Article 11. Experiences with the ESCP show that even though it contains a provision requiring Member States to provide assistance, many Member States simply do not provide the required information. See for example BEUC (2013) p. 3.
} 
context of cross-border litigation, however, requiring both parties to attend an oral hearing in the court that has jurisdiction, which may well be far away in another Member State, can also form an impediment to fair trial. The court seized must therefore carefully consider whether an oral hearing is necessary.

A solution to this problem may be to conduct a hearing with the aid of audiovisual communication technology, such as videoconferencing). Article 8 of the ESCP Regulation explicitly provides for this possibility. However, the Deloitte Report was very critical of the degree to which an oral hearing through distance communication means is made possible in the various Member States. It concluded that in 11 of the 21 Member States included in the research, videoconferencing was not available, but that even in those jurisdictions where it was in theory available, it was often not used in practice. Accordingly, the Deloitte Report concluded that "parties may at present face unnecessarily high costs in order to physically turn up in court for oral hearings" and that "these costs could at least partly be saved by parties each time a videoconference is organized, instead of an actual physical meeting". ${ }^{157}$ The ECC-Net Report corroborated the findings on the matter of the availability of videoconferencing. ${ }^{158}$ Accordingly, the Deloitte Report recommended amending the Regulation to oblige Member States to make videoconferencing available in a selected number of courts. ${ }^{159}$ Additionally, the Report recommended limiting the discretion of the court in deciding whether an oral hearing would be organized, so that it should be organized if both parties so request; this was seen as a necessary complement to its other recommendation that the threshold for claims be extended to EUR 10,000. The Report stated that "additional procedural safeguards may be needed for cases with a higher value than 2,000 euro". ${ }^{160}$ The 2013 Proposal for amendment of the Regulation addressed this suggestion by providing a right to request an oral hearing, which may not be refused when the value of the claim exceeds EUR 2,000 (though this was not adopted, see below).

It is submitted that the inclination of courts to refuse an oral hearing through distance communication means is problematic with a view to protecting both parties' procedural rights. Offering the possibility of conducting an oral hearing in this way would provide an appropriate balance between the right to be heard in person on one hand, and on the other hand, the need to reduce costs - and to limit the potential for 'tactical' requests, which only seek to frustrate the procedure and create difficulties for the opponent. The fact that the use of audiovisual technology is so often either refused or altogether impossible is therefore undeniably

${ }^{157}$ Deloitte Report (2013) Part I: Evaluation, p. 80.

${ }^{158}$ ECC-Net (2012) p. 22. See also the submissions to the public consultation, among others BEUC (2013) p. 7 , Business Europe (2013) p. 2; ECC-Portugal (2013) p. 4 proposes that videoconferencing should be made available whenever its costs are lower than the travel costs.

${ }^{159}$ Deloitte Report (2013) Part II: Assessment of the policy options, p. 116.

${ }^{160}$ Deloitte Report (2013) Part II: Assessment of the policy options, p. xxii. Submissions to the Public Consultation also suggested that procedural safeguards, in particular the right to an oral hearing or a right to appeal, should be more 'robust' if the maximum amount was raised: Bar Council England \& Wales (2013) p. 3. 
problematic. National court practices whereby an oral hearing is required as a rule should also be discouraged. ${ }^{161}$

The Regulation amending the ESCP Regulation, adopted in December 2015, addresses some these problems. Concerning oral hearings, it imposes an obligation on courts and tribunals to use distance means of communication such as videoconference or teleconference whenever an oral hearing is held (Art. 8(1)). In order to safeguard the rights of the parties, an exception will be made for the party who expressly requests to be present in court (Art. 8). It has been pointed out that the increased reliance on digital means of communication may not be easily implemented in all courts. ${ }^{162}$

To compensate for the increased value of claims to be regarded as 'small' under the Regulation, the 2013 Proposal aimed to increase procedural protection by clarifying when an oral hearing should be held. It proposed that courts may not refuse a request for an oral hearing if (a) the value of the claim exceeds EUR 2,000, or (b) both parties indicate their willingness to conclude a court settlement and request a court hearing for that purpose. ${ }^{163}$ This clarification is commendable, because it increases legal certainty and strengthens the protection of the right to an oral hearing. It was however not included in the 2015 Regulation amending the ESCP Regulation. The ESCP Regulation retains an efficiency-based approach to oral hearings, where the judge in each case decides whether or not to hold an oral hearing. Article 5(1) of the 2015 Regulation provides that the court shall hold an oral hearing only if it considers that it is not possible to give the judgment on the basis of the written evidence. The parties may request an oral hearing, but the court may refuse this request if it considers that, with regard to the circumstances of the case, an oral hearing is not necessary for the fair conduct of the proceedings. The 2015 Regulation is therefore stricter than the original ESCP Regulation, which only provided that "the court or tribunal may hold an oral hearing" (Art. 8). The 2013 Proposal shows that the ESCP aims to strike a balance between fairness of the procedure on one hand and the accessibility on the other hand. It is commendable that the European legislature acknowledged that oral hearings in cross-border cases may incur disproportionate costs, especially where the presence of the parties in person is required. Such costs can be reduced when hearings are held through distance communication means, but while the 2015 Regulation's emphasis on the use of such technology is to be welcomed, it seems rather premature to expect courts in all Member States to be able to deliver it, as the European Economic and Social Committee pointed out. If not all courts can guarantee the availability of such technology, it seems unwise to grant parties an absolute right to an oral hearing, as parties

\footnotetext{
${ }^{161}$ BEUC (2013) p. 7.

${ }^{162}$ EESC Opinion, no. 5.1.

${ }^{163}$ Article 5(1) European Commission, Proposal for a Regulation amending Regulation (EC) No 861/2007 of the European Parliament and the Council of 11 July 2007 establishing a European Small Claims Procedure and Regulation (EC) No 1896/2006 of the European Parliament and of the Council of 12 December 2006 creating a European Order for Payment Procedure, COM (2013) 794 final.
} 
may abuse this right to increase their opponent's costs. Keeping in mind that the ECtHR does not confer an absolute right to an oral hearing, but allows the judge to decide in each case whether an oral hearing is necessary ${ }^{164}$, the ESCP's arrangement seems to strike an appropriate balance between fairness and accessibility. The only problem is that there seems to be no remedy when the court wrongfully denies an oral hearing where one is necessary (see 8.5.2.6, below).

\subsubsection{Service of documents on the defendant/debtor}

Another problematic element is identified by the Deloitte Report, as well as Kramer and Ontanu: the service of documents to defendants. The Deloitte Report concludes that while electronic means of effecting service are available in most Member States, the Regulation restricts their use; postal service is the main means of servicing documents. ${ }^{165}$ Allowing documents to be served electronically would save both times and costs. That practices concerning service are sometimes unsatisfactory is shown by the research among Dutch courts done by Kramer and Ontanu. According to them, most courts remarked during interviews that in the majority of cases they did not receive acknowledgement of receipt of the documents by the defendant. ${ }^{166}$ Service then becomes a problem for the courts, and they deal with it in different ways:

Some extend the period for answering if no acknowledgement of receipt is received in time, while others make another attempt to send the documents. One court remarked that it does hand down judgment, even if an acknowledgment of receipt is not received; it assumes that the addressee received the documents. Another court explained that it simply sends the documents by ordinary postal mail without acknowledgment of receipt.

It does not need explaining that the latter two solutions are undesirable if the right of the defendant to offer his views is taken seriously. At the same time, the courts cannot be blamed for lack of procedural means of effecting service, as the Deloitte Report shows that this problem is widely experienced.

The 2015 Regulation widens the possibilities for electronic service (Art. 13). Whether this change will make service easier is questionable, because it provides that service may be effected through electronic means only if both parties agree. This seems of little use in cases where no reaction of the defendant is received at all, as the Dutch courts experienced. Concerning language, there are no new measures to address these issues.

\footnotetext{
${ }^{164}$ See Chapter 4.3.2.6.

${ }^{165}$ Deloitte Report (2013) Part II: Assessment of the policy options, p. xii.

166 Kramer and Ontanu (2013) p. 326.
} 


\subsubsection{The right to a trial within a reasonable time}

The ESCP Regulation contains relatively short time limits for all stages of the procedure. A decision in an ESCP should be obtainable within 74 days: 14 days for the court to serve the claim form on the defendant (Art. 5(2)); 30 days for the defendant to reply (Art. 5(3)); and 30 days for the court to give its decision after the defendant's reply has been received (Art. 7(1)). The procedure may be longer when the defendant lodges a counterclaim (Art. 5(6)), where a translation is requested (Arts. 6(2) or 6(3)), where the court demands further details (Art. 7(1)(a)), takes evidence (Art. 7(1)(b)), or decides to hold an oral hearing (Art. 7(2)(c)).

If the ESCP was indeed always concluded within this time period, it would likely satisfy the requirements of the right to a trial within a reasonable time. The problem is however, as observed by one submission to the Public Consultation, ${ }^{167}$ that courts do not always abide by the time limits. It may be remembered that the ECtHR requires states to make available effective measures for addressing excessively long proceedings. It is evident that Member States are responsible for addressing delays in concluding procedures under EU law such as the ESCP in the same way as they are responsible for delays in ordinary national civil procedures. Any delays should therefore be effectively addressed. In this regard, it is interesting to note, as another submission to the Public Consultation did, that the ESCP Regulation contains no provision for delivering default judgments in case of an unresponsive defendant; this is left to the Member States. The submission recommended that this be harmonised. ${ }^{168}$ The 2015 Regulation did not take up this suggestion or otherwise addressed delays.

\subsubsection{Effectiveness of procedural safeguards and right to appeal}

Even if, in principle, the defendant's procedural rights are adequately protected by the ESCP Regulation, the question is what happens if something goes wrong; for example, if the claim form was not served on him in such a way as to enable him to arrange for his defence, or where an oral hearing was wrongly refused. Article 18 of the ESCP Regulation provides for a review procedure under very narrowly defined circumstances. Under this Article, the defendant may apply for a review of the judgment if either a) the claim form has been served on him in one of the ways provided for in Article 14 of the EEO Regulation, but not in sufficient time as to enable him to arrange for his defence; or b) if the defendant was prevented from objecting to the claim by reason of force majeure or due to extraordinary circumstances without any fault on his part. It should also be noted that the ESCP Regulation does not provide for a right to appeal, but leaves this to the Member States (Art. 17(1)).

\footnotetext{
${ }^{167}$ BEUC (2013) p. 5.

${ }^{168}$ ECC-Poland (2013) p. 5.
} 
The question is now what a defendant can do if the claim form was not served on him in an appropriate manner at all, for example when it was served on a business address where the defendant is no longer located, yet a judgment was handed down against him regardless (Art. 7(3)). This happened in the eco cosmetics/Raiffeisenbank case, ${ }^{169}$ which dealt with the EOP Regulation and is discussed in detail below. In that case, the CJEU ruled that if an EOP is not served on the defendant in accordance with one of the methods of service permitted by the Regulation, the defendant will not be able to oppose the Order if he so wishes. Since, according to the CJEU, this is incompatible with the rights of the defence, such an Order cannot benefit from the enforcement regime provided for by the Regulation. Equally importantly, the CJEU ruled that the review procedure of Article 20 EOP Regulation (the equivalent of the ESCP's Article 18) cannot then be applied, since a failure to effect service is not one of the grounds for review provided for in that Article. The Regulation does not provide for a remedy in such cases, which leads to the conclusion that a remedy should be provided by national law.

It is submitted that the CJEU's findings in eco cosmetics/Raiffeisenbank also create issues for the ESCP. Under the ESCP Regulation, as under the EOP Regulation, service is essential to allow the defendant to decide whether to respond to the claim, respectively oppose it. When service has not been effected in the appropriate manner, he cannot make effective use of his right to be heard, which is incompatible with the scheme and purpose of the Regulation. However, unlike under the ESCP, the claim is not automatically awarded if the defendant does not oppose it. According to Article 7(3) of the ESCP Regulation, when the defendant does not respond the judge 'shall give a judgment on the claim'. It does not however provide that the claim shall be awarded; it is presumed that the extent of the examination of the claim shall be governed by the law of the Member State of the court in accordance with Article 19. If a default judgment is given, it is presumably then also a matter of national law whether or not the defendant is able to oppose that default judgment. A failure to effect service may not be as problematic as it is under the EOP, in which it would mean that the claim cannot be regarded as uncontested and essentially fall outside the EOP Regulation's scope. However, it is clearly incompatible with the defendant's rights if a judgment resulting from an ESCP procedure could be declared enforceable and be enforced without the defendant having been informed of the proceedings.

It also seems clear that the review procedure of Article 18 would not be applicable in case of a failure to effect service, since, like its counterpart in the EOP Regulation, it does not encompass such cases. National law (of the Member State of origin) should thus provide for a remedy. This lack of a harmonised remedy can be called unsatisfactory. The ESCP, like the EOP, can only be an effective method for resolving cross-border disputes if the procedural rights of both parties are protected effectively and if any remedies are foreseeable and uniformly applied. Yet

${ }^{169}$ CJEU Joined Cases C-119/13 and C-120/13, eco cosmetics \& Co. KG v Virginie Laetitia Barbara Dupuy and Raiffeisenbank St. Georgen reg. Gen. mbH v Tetyana Bonchyk ECLI:EU:C:2014:2144. 
again, the defendant is expected to find his way among 27 different national procedural laws to find redress if a judgment is enforced against him without him having been served, while his counterpart who has been served is allowed to make use of the review procedure of Article 18.

Fortunately, the 2015 Regulation amending the ESCP Regulation widens the scope of the review procedure to include all cases where "the defendant was not served with the claim form in sufficient time and in such a way as to enable him for a defence". ${ }^{170}$ The limitation of the availability of review to only certain methods of service will therefore be repaired. Review however still takes place in the Member State of origin, and it can be questioned whether this does not place a disproportionate burden on the defendant; see Section 8.5.3, below.

However, the review procedure it still only available in situations where the defendant did not appear and where service was not effected properly (essentially the situation covered by Article 45(1)(b) of Brussels I bis). There are no remedies where, for instance, the right to an oral hearing was wrongly refused (unless an appeal is available). It is therefore recommended that Member States allow ESCP decisions to be appealed, so that such problems can be addressed in the Member State of origin. The ESCP Regulation could also be amended to make such an appeal mandatory.

\subsubsection{Other elements of the right to a fair trial}

A number of elements of the right to a fair trial have not yet been discussed. Firstly, the right to a fair trial includes a right to adjudication by an independent and impartial tribunal. ${ }^{171}$ It also requires that a trial be held in public. ${ }^{172}$ It goes without saying that in their conduct of a ESCP, Member State courts should comply with these requirements. None of the empirical evidence however appears to assert that compliance with these requirements is lacking in relation to the ESCP (though of course the risk of them being violated exists in any procedure). The same goes for the right to a reasoned judgment. ${ }^{173}$

\subsubsection{The uniform procedures and the need for grounds for refusal}

The previous Chapter proposed that refusal of enforcement should be possible under all EU Regulations that facilitate cross-border enforcement of civil judgments. It is submitted that all arguments put forward in favour of that position in the previous Chapter apply equally to the ESCP and EOP procedures. There is no reason to presume that these procedures are immune to the problems for which refusal of enforcement has proven to be a solution. A lack of

\footnotetext{
${ }^{170}$ ESCP Regulation as amended by Regulation 2015/2421, Article 18.

${ }^{171}$ Chapter 4.3.4.

172 Chapter 4.3.3.

${ }^{173}$ Chapter 4.3.2.7.
} 
impartiality such as corruption, procedural fraud, or any serious mistakes that result in a violation of the parties' right to a fair trial are equally possible under these procedures as they are under ordinary national civil procedures.

It is therefore proposed that the ESCP and EOP procedures also include grounds for refusal. The difficulty is however that the Regulations already contain a multitude of possibilities for opposition, review, appeal or refusal of recognition (in case of irreconcilability), some of which are governed by the Regulations themselves, some by national law. The question is now how these will interact with the remedies already available under the Regulations and whether they will not overcomplicate the procedures.

It is important to emphasize that a mechanism for refusing recognition or enforcement should be a measure of last resort, as it always has been. The availability of such a mechanism in the Member State of enforcement does not diminish the need for remedies at the earlier stages of the proceedings, such as appeal or review. In fact, inactive defendants could be discouraged from relying on the possibility to oppose recognition or enforcement by making such opposition dependent on them having exercised any available possibilities for review or appeal in the Member State of origin.

For the EOP Procedure, it is submitted that a remedy should be made available, in the Regulation, for a failure to effect service, in order to address the problem identified by the CJEU in the eco cosmetics case. Because increasing the scope of the review procedure would be unsuitable as a remedy for such cases, ${ }^{174}$ this should take the form of a possibility to oppose the Order for Payment after it has been issued and once the defendant becomes aware of its existence, which may be at the moment enforcement measures are taken. This guarantees that the rights of the defense are respected fully. The burden of proof that the order was not served on him should lie with the defendant in order to discourage abuse. In order to prevent such situations from occurring in the first place, the rules on service, especially those of Article 14, should be reformed in order to ascertain that service is effected. ${ }^{175}$ The period for opposition should also be clarified.

As for the review procedure, it is submitted that the review procedure of the EOP Regulation is amended to coincide with Article 18(1) of the ESCP Regulation, as amended. ${ }^{176}$ This would

\footnotetext{
${ }^{174}$ As the CJEU ruled in eco cosmetics/Raiffeisenbank, review would not be suitable for such cases because the EOP should not have been issued to begin with. See the discussion under 8.5.1.1 above.

${ }^{175}$ See 8.4.1 for a discussion on how the permitted methods of service could be improved.

176 The difference with the extended possibility for opposition in case of ineffective service, as proposed, is of course that opposition offers the defendant all procedural rights provided for in Article 16 of the EOP Regulation, and that he is allowed to contest the claim in its entirety. Recital 25 to the EOP Regulation provides that the review mechanism should not entail a second opportunity for the defendant to contest the claim (Kramer (2014) p.101, shows that Dutch courts indeed interpret the provision strictly). As A-G Bot concluded in eco cosmetics/Raiffeisenbank, the consequence of a failure to effect service of an EOP should be that the EOP is considered invalid; opposition where service was not effected should avoid this consequence. See View of A-G Bot in eco cosmetics/Raiffeisenbank, paras. 51-52.
} 
make review possible in all situations where service was ineffectual. Review would be possible where the defendant was not served with a claim form or EOP, in sufficient time and in such a way as to enable him to arrange for his defence; or where he was prevented from contesting the claim by reason of force majeure or due to extraordinary circumstances without any fault on his part. ${ }^{177}$

The question remains however who should carry out such a review: the Member State of origin, or the Member State of enforcement. The review procedure essentially performs the function of Article 45(1)(b) of the Brussels I bis Regulation in remedying ineffective service, but through review in the Member State of origin instead of refusal of recognition or enforcement. It entails a thorough review of the methods of service applied. In its current form, it also relies on a self-examination by the courts of the Member State of origin of the judgment. Chapter 3 posited that experience with the public policy exception shows that Member States can hardly be expected to exercise self-examination. ${ }^{178}$ Such self-examination may be possible, however, when the methods of service are harmonized, as they are under the ESCP and EOP procedures, provided that the impartiality of the court that carries out the review is guaranteed (see Section 8.4.2, above). Yet it remains the case that a review procedure in the Member State of origin places a disproportionate burden on the defendant. The EOP and ESCP Regulations already greatly benefit creditors by providing them with a simplified procedure that abolishes exequatur. The defendant is now not only required to actively invoke the possibility for review, but to do so in a Member State that is not his own. It is submitted that this constitutes a disproportionate disadvantage. It is however considered that review is in principle preferable to refusal of enforcement, being less radical as a remedy, and allowing for a reconsideration of the judgment as such. For that reason, it is proposed that the EOP and ESCP Regulations retain a review procedure (though with a scope widened to include all possible defects in service), but that the mechanism for requesting a review is made more accessible. As a first step, a standardized form should be included in the Regulations; the possibilities for making such a form available online should be examined. It is submitted that it be clarified what the scope of the review in exceptional cases should be, in order to ensure that it does not amount to a second opportunity for appeal or opposition.

As for the ESCP regulation, much could be gained by harmonizing the possibilities for opposition (currently presumably governed by national law), review, and appeal. Appeal and opposition (to a default judgment) are currently entirely governed by national law. Availability of such remedies and clarity on their interrelation could go far towards ensuring that mistakes, such as a refusal to hold an oral hearing where one was necessary, are avoided and if necessary

\footnotetext{
177 This would have the additional advantage of harmonising the requirements for review as contained in the ESCP and EOP Regulations with Article 19(1) of the Maintenance Regulation. As the European Commission states in its 2013 Proposal for amendment of the ESCP and EOP Regulations, There is no reason why these provisions on review, which pursue exactly the same objective, are formulated differently in the various European regulations" (p. 9).

${ }^{178}$ Chapter 3.4.1.
} 
addressed within the procedure itself. Refusal of enforcement or recognition will then remain a measure of last resort.

To conclude, it is proposed that the ESCP and EOP Regulations retain a procedure for review in cases where service was ineffective, to be carried out in the Member State of origin. The ESCP procedure should guarantee a right to appeal to address procedural irregularities before a final judgment is obtained. Finally, the procedures should include a public policy exception to be applied by the Member State of enforcement for exceptional cases, for instance in cases of corruption.

It is submitted that adding a mechanism for refusal of enforcement to the Regulations should not diminish their effectiveness to such an extent as to nullify their accessibility and efficacy. It transpires from the reports referred to above that, to a large extent, the attractiveness of the uniform procedures lies in the fact that they are harmonized and reduce the need to familiarize oneself with foreign civil procedural law. The availability of refusal grounds does not diminish this accessibility, nor does it affect the immediate cross-border enforceability of decisions resulting from these procedures. As stated above, effective remedies within the procedures themselves will in most cases reduce or abolish the need for refusal grounds. It is important that a failure to invoke such remedies is taken into consideration in an application for refusal of enforcement, either by the judge on their own motion or by incorporating it into legislation, in the model of Article 45(1)(b) of the Brussels I bis Regulation.

\subsection{Enforcement of return orders and access rights under Brussels II bis}

This section discusses the automatic enforcement of judgments under the Brussels II bis Regulation. ${ }^{179}$ The enforcement of judgments in family law matters, specifically those in child abduction cases, is of a different character than the enforcement of civil or commercial judgments, due to the sensitivity of the issue and the variety of interests involved. Decisions in cases involving children have an impact not just on the rights and responsibilities of the parents, who are usually the parties to the return proceedings, ${ }^{180}$ but also on those of the child itself.

\footnotetext{
179 This section does not discuss the (non-)recognition of judgments relating to divorce, legal separation or marriage annulment (Article 22) or judgments relating to parental responsibility (Article 23). The reason is that the grounds for refusal of recognition of these categories of judgments are identical to those of the Brussels Ibis Regulation, which is discussed in detail in 2.3.2. Though this does not mean that the interpretation of those grounds will be identical in the context of Brussels IIbis, and that these grounds are sufficient or necessary to protect fundamental rights in that context, the lack of reforms and controversy on this point renders an in-depth discussion rather superfluous. See for a discussion of the grounds for refusal Borrás (1998) paras. 67-73; Siehr (2012) p. 261286. See for a recent view of their application in the Netherlands Curry-Sumner (2014).

180 Though this section refers to 'parents', it is of course possible that other persons or organisations exercise custody rights over the child. In such a case, this person of organisation will be the party to the abduction proceedings. 1980 Hague Child Abduction Convention, Article 3(a); Brussels IIbis Regulation, Article 11(1).
} 
While speed and efficiency are essential, the child's safety and well-being are of paramount importance.

For these reasons, international and EU instruments in the field of family law have sought to achieve a balance between these interests. Effective enforcement, and any possibility to refuse enforcement, are only one element of the complex of rules that are intended to achieve this balance. It is difficult to argue for or against the free movement of judgments in this field without considering what impact this will have on all the factors involved. Even more than in civil and commercial cases, it needs to be carefully considered whether refusal of enforcement can ever be an appropriate remedy for violations of the rights of the interested parties. Refusal of enforcement of a judgment ordering the return of the child may remedy a violation committed in the Member State of origin of the judgment, but at the same time be contrary to the best interests of the child by further delaying a final decision on where he or she should live.

This section aims to provide insight into the complexities of enforcement in the context of family law matters and some viewpoints for future developments in this field. The following concentrates on the two types of judgments which require enforcement, and for which Brussels IIbis abolished exequatur and the possibility of refusal of enforcement: judgments requiring the return of a child (Art. 42(1)), and those providing a parent with a right to access to his child (Art. 41(1)). It is shown that the first category of judgments, which are given in child abduction cases, is most controversial. Much of the discussion below therefore focuses on this type of case.

\subsubsection{Introduction: the 1980 Hague Convention}

International child abduction refers to situations in which a child is removed ${ }^{181}$ from the state where he or she is habitually resident to another, in breach of rights of custody. The typical abduction situation envisaged by international instruments is one where one parent has custody and the non-custodial parent abducts a child across borders to pre-empt an unfavourable custody decision or out of frustration over losing custody. ${ }^{182}$ Removal of a child is also considered wrongful if the parents share custody but one of the parents removes a child without the other parent's consent. ${ }^{183}$ Abduction may consist of wrongful removal, in which a child is taken from one state to another, or of wrongful retention, in which the non-custodial parent

\footnotetext{
${ }^{181}$ Neither the Brussels IIbis Regulation nor the 1980 Hague Convention distinguish between categories of persons who may wrongfully remove a child; the abductor may therefore equally be a grandparent, aunt, uncle, or a person unrelated to the child.

182 Dyer (1978) para. 19-20.

${ }^{183}$ Pérez-Vera (1982) p. 35.
} 
fails to return the child to the custodial parent after a visit. ${ }^{184}$ For clarity's sake, this section uses the term 'abduction' to refer to both types of situations.

Chapter 2 discussed that child abduction cases are covered by several international instruments. ${ }^{185}$ The primary instrument is the 1980 Hague Convention on the Civil Aspects of International Child Abduction ${ }^{186}$ (hereinafter: the 1980 Convention), which applies in the EU alongside Brussels II bis. ${ }^{187}$ Article 12 of the 1980 Convention requires the state to which the child was abducted to order the return of the child 'forthwith', unless one of the grounds for refusal applies. The defences, especially the 'grave risk defence', should be interpreted restrictively, ${ }^{188}$ in order to discourage abductors from claiming it too freely simply to gain time. Empirical research suggests that courts have indeed interpreted Article 13(1)(b) in a restrictive fashion. ${ }^{189}$

Another important element of international legislation on child abduction is the principle that the Member State where the child was habitually resident before the abduction retains jurisdiction (perpetuatio fori); this prevents the abductor from profiting from the abduction by taking the child to a state that has a more favourable custody regime. The underlying principle is that the courts in the state where the child was habitually resident is best placed to decide where the child should live and how the dispute between the parents should be resolved. ${ }^{190}$

This principle is laid down in Articles 5(2) and 7 of the 1996 Hague Child Protection Convention as well as in Article 10 of Brussels II bis. It is important to note that according to these instruments jurisdiction lies with the state where the child is 'habitually resident'. This concept is of a factual nature: it refers to the child's actual residence, not to his legal domicile. Due to its factual nature and the lack of an internationally accepted definition, it is one of the most litigated issues under the Conventions. ${ }^{191}$ However, for the purposes of this section it is merely important to note that a child's habitual residence may change: importantly, even if a child is wrongfully removed, the state to where he is taken may eventually become his state of habitual residence and therefore gain jurisdiction. The 1996 Child Protection Convention explicitly allows for this possibility. ${ }^{192}$ Even though Article 7 of this Convention aims to

\footnotetext{
${ }^{184}$ Pérez-Vera (1982) p. 16-17.

${ }^{185}$ See for a discussion of all instruments relevant in Europe Kruger (2011) p. 111-130.

${ }^{186}$ Convention of 25 October 1980 on the Civil Aspects of International Child Abduction.

${ }^{187}$ Because the 1980 Convention remains in force within the EU, the following discussion on the child abduction regime in the EU refers where relevant also to that Convention. See also Article 62(2) of Brussels IIbis that provides that "The conventions mentioned in Article 60, in particular the 1980 Hague Convention, continue to produce effects between the Member States which are party thereto" unless the Brussels IIbis Regulation takes precedence.

188 Perez-Vera (1982) para. 34.

189 Schuz (2013) p. 273.

${ }^{190}$ Vlaardingerbroek (2014) p. 13.

${ }^{191}$ Schuz (2013) p. 175. The 2015 European Commission Study on the assessment of the Brussels IIbis Regulation shows that habitual residence is a problematic issue under that Regulation as well (p. 42).

192 Article 7(1).
} 
prevent jurisdiction from being transferred onto the state to where the child was abducted simply because of the abduction, this transfer may eventually happen because the child's habitual residence has changed. If the parent and/or authorities in the state from where the child was abducted acquiesce in the removal, or if no action is taken to have the child returned and the child has settled in his or her new environment, this together with the change of habitual residence may cause jurisdiction to be transferred. In order to prevent this, the courts of the state where the child was habitually resident prior to his abduction must take timely action. The Brussels II bis Regulation contains the same rule, with some additional specifications. ${ }^{193}$ Time is therefore of the essence; however, the safety of the child may trump the need for a speedy return: a state may refuse to return a child to the state from where he or she was abducted if this constitutes a grave risk to his or her safety. To prevent this defence from being abused it should be interpreted restrictively.

\subsubsection{Interpretation by the ECtHR}

The ECtHR has repeatedly been asked to determine whether states adequately performed their obligations under the Conventions. The ECtHR has consistently found that Article 8 ECHR confers on states positive obligations to effectively cooperate to ensure the speedy return of children to their state of habitual residence. ${ }^{194}$ Ordering the return of an abducted child need not be automatic: courts are allowed to refuse to order a child's return of one of the defences of Article 13 of the 1980 Convention applies. In the ECtHR's case law, there are some inconsistencies concerning the extent of the review that courts are obliged to carry out to establish whether return of the child would constitute a 'grave risk' to his or her safety. In the much-discussed case of Neulinger $v$. Shuruk, ${ }^{195}$ the ECtHR appeared to require courts to make an 'in-depth' examination of the entire family situation in the context of the grave risk defence. Some commentators were of the opinion that such an in-depth examination would be incompatible with the effective functioning of the return mechanism and would almost equate them to custody proceedings, which is explicitly not the purpose of the provision. ${ }^{196}$ In a later case, $X$. v. Latvia, the ECtHR however stated that Neulinger had not been intended to create a universal principle. In that case, the ECtHR clarified that what it expects of courts that are to decide on the return of an abducted child, is to "genuinely take into account [...] the factors capable of constituting an exception to the child's immediate return in application of Articles 12,13 and 20" of the 1980 Convention, "particularly where they are raised by one of the parties to the proceedings"197. The court must then "take a decision that is sufficiently reasoned on this point, in order to enable the [ECtHR] to verify that those questions have been effectively

\footnotetext{
193 Article 10.

${ }^{194}$ For instance ECtHR X. v. Latvia, appl. no. 27853/09, ECHR 2013; see Beaumont and Walker (2013).

${ }^{195}$ ECtHR Neulinger and Shuruk v. Switzerland, appl. no. 41615/07, ECHR 2010.

${ }^{196}$ Keller and Heri (2015) p. 284; Beaumont and Walker (2013) p. 17-30; see Vlaardingerbroek (2014) p. 15.

${ }^{197}$ ECtHR X. v. Latvia, para. 106.
} 
examined"198. Secondly, the factors "must be evaluated in the light of Article 8 of the Convention". ${ }^{199}$ An 'in-depth examination' of the 'entire family situation' is therefore not necessary. X. v. Latvia is seen as having achieved an appropriate balance between the aims of the 1980 Convention and the requirements of the ECHR. ${ }^{200}$

To conclude, Article 8 ECHR imposes on states positive obligations to effectively cooperate in order to ensure the return of abducted children; in this regard the ECtHR has shown itself to be sensitive to the requirements of the international framework on child abduction.

\subsubsection{Reforms achieved by the Brussels II bis Regulation and controversy}

The preceding section having described the state of international child abduction law outside of Brussels II bis, this section now concerns the reforms introduced by that Regulation and their reception. It is shown that much of the criticism levelled at the reforms concerned the perceived disturbance of the balance that had been achieved by the 1980 Convention. ${ }^{201}$

The Brussels II bis Regulation applies alongside the 1980 Convention, with some of the more specific rules of the Regulation taking precedence over those of the Convention. With regard to child abduction, the Regulation retains the perpetuation fori rule (Art. 10), with some specifications. ${ }^{202}$ Most importantly, Article 11(8) of Brussels II bis provides that a refusal by a state on the basis of Article 131980 Convention can be trumped by a subsequent judgment requiring the return of a child from the Member State with jurisdiction (i.e., the state of habitual residence of the child prior to the abduction). Finally, the exequatur was abolished for return orders. This system of automatic enforcement was considered a "valuable improvement", according to the 2015 Study on the assessment of the Regulation, ${ }^{203}$ though enforcement still proved difficult and time-consuming in practice, sometimes taking as long as a year. ${ }^{204}$

However, the system whereby the Member State of habitual residence retains ultimate control and may issue judgments which trump earlier non-return orders of other states has been criticised by some commentators. Some believe that it is at odds with the principles of international cooperation in child abduction cases to allow one Member State to trump another's findings; this is believed to potentially cause ill-feeling and resentment between States in a context in which harmonious cooperation is essential. ${ }^{205}$ It is also considered that

\footnotetext{
198 Ibid.

${ }^{199}$ ECtHR X. v. Latvia para. 106. See Beaumont, Trimmings et al. (2015) p. 43.

${ }^{200}$ Keller and Heri (2015) p. 287; Beaumont, Trimmings et al. (2015) p. 43.

${ }^{201}$ Beaumont and Walker (2011) argue that there is an increasing discrepancy in the interpretation of the 1980 Convention between the CJEU and the ECtHR, with the CJEU placing too much confidence mutual trust whereas the ECtHR overemphasizes the child's best interests (p. 231). See for the CJEU's view Lenaerts (2013).

202 See Section 8.6.1.

${ }^{203}$ Study on the assessment of the Brussels IIbis Regulation (2015) p. 33.

${ }^{204}$ Study on the assessment of the Brussels IIbis Regulation (2015) p. 31.

${ }^{205}$ McEleavy (2004) p. 510.
} 
the absence of refusal grounds removes any possibilities to correct mistakes such as a failure to hear a child even though it has a right thereto, and may simply create new problems without addressing the problems associated with cross-border enforcement of return orders. ${ }^{206}$

On the other hand, it has been acknowledged that it is very costly and time-consuming for the left-behind parent to apply to the courts in another state from where he or she is located and request a return order there. The absence of exequatur also allows return proceedings to be concluded faster and may therefore reduce any harm to the relationship between the child and the parents. ${ }^{207}$ Concentrating the proceedings in the state of habitual residence is commendable from that perspective. In Povse, the ECtHR effectively sanctioned this strict division of responsibilities. ${ }^{208}$

The question is now whether this concentration of powers in the Member State of habitual residence, and the absence of refusal grounds, is the best way of balancing the rights of the parties concerned. It is important to realise that, from the perspective of fundamental rights protection, at least eight factors ${ }^{209}$ should be considered:

i. The best interests of the child (Art. 24(2) CFR, Art. 31980 Convention); 210

ii. The child's right to participate in the proceedings, including his or her right to be heard (Art. 24 CFR, Recital 19 and Art. 42(2) Brussels II bis);

iii. The child's right to a relationship with the abducting parent (Art. 8 ECHR);

iv. The child's right to a relationship with the left-behind parent (Art. 8 ECHR);

v. The right of the abducting parent to a relationship with his or her child (Art. 8 ECHR);

vi. The right of the left-behind parent to a relationship with his or her child (Art. 8 ECHR); 211

vii. The abducting parent's right to a fair trial in the context of the return proceedings (Art. 6(1) ECHR/47 CFR, Art. 42(2) Brussels II bis);

\footnotetext{
${ }^{206} \operatorname{Scott}(2015)$ p. $28-29$.

${ }^{207}$ Scott (2015) p. 28.

208 See Chapter 4.

${ }^{209}$ Other rights or interests could be identified. For example, although it is not expressly recognised by the Brussels IIbis Regulation, the 1980 Convention, or the United Nations Convention on the Rights of the Child (CRC) it has been argued that the child additionally enjoys a 'right to identity'. This right is relevant to child abduction since the removal of certain (family) ties meaningful to the child affects his or her identity. See Ronen (2004) p. 160.

${ }^{210}$ In literature on international child abduction, there is a discussion on the question whether the best interests standard of the child should be seen as an expression of the independent rights of the child. The recognition of children's rights, and the idea of children as independent rights holders, is in a state of development. See Schuz (2013) p. 112.

${ }^{211}$ When the party that applies for a child's return is not a parent, but for instance a child protection agency, this factor changes, as these types of organisations' relationship with the child has not been found to be protected by Article 8 ECHR; however, the rights of foster or adoptive parents have been found to come within the scope of this Article. ECtHR Jolie and Lebrun v. Belgium appl. no. 11418/85, 14 May 1986; European Commission on Human Rights $X$ v. France, appl. no. 9993/82 DR 31, p. 241; Kilkelly (2003) p. 18.
} 
viii. The left-behind parent's right to a fair trial in the context of the return proceedings, including their right to enforcement of a decision ordering return (Art. 6(1) ECHR/47 CFR, Art. 42(2) Brussels II bis).

Considering that this research is restricted to the implications of the right to a fair trial for the organisation of cross-border enforcement, it is difficult to do justice to the added complexities of the right to family life (Art. 8 ECHR). The question whether automatic enforcement of return orders is or is not the best way of safeguarding the parties' rights under these provisions goes beyond the remit of this research. However, it is also impossible to treat the enforcement of return orders in the same way as other civil or commercial judgments, due to this special characteristic. Chapter 7 for this reason concluded that refusal of enforcement of return orders may only be justified if it is not contrary to the child's best interests. It also showed that suppression of refusal grounds may be justified on the grounds that the possibility of invoking refusal grounds may encourage abductions and remove from the left-behind parent the advantage of going to court in their own Member State. ${ }^{212}$ Given that there may be good arguments for automatic enforcement of return orders (i.e., against allowing the Member State to where the child was abducted to refuse enforcement), it is worth considering how the procedure for enforcement of such orders can protect the parties' rights as effectively as possible in the absence of refusal grounds.

\subsubsection{How should enforcement of return orders be organized?}

Section 8.2 of this Chapter argued that for judgments within the scope of Brussels I bis, where grounds for refusal apply, the procedure for obtaining permission for cross-border enforcement (certification) should be as simple and effective as possible. Any comprehensive checks, for instance whether service was effected, can be kept to a minimum because grounds for refusal in the Member State of enforcement will act as a safety net. It follows that if there are no refusal grounds for return judgments, safeguards at the 'judgment export' stage should be more extensive.

Brussels II bis contains a certification procedure, which requires the judge who issues the certificate to check whether: ${ }^{213}$

(a) the child was given an opportunity to be heard, unless a hearing was considered inappropriate having regard to his or her age or degree of maturity;

(b) the parties were given an opportunity to be heard; and,

${ }^{212}$ Chapter 7.5.

${ }^{213}$ Article 42(2) Brussels IIbis Regulation. 
(c) the court has taken into account in issuing its judgment the reasons for and evidence underlying the order issued pursuant to Article 13 of the 1980 Hague Convention.

The first two requirements clearly have as their purpose to protect the child's and the parents' rights to be heard, respectively. The question is whether such a pre-certification check is likely to be effective.

\subsubsection{Impartiality of the judge who issues the certificate}

Firstly, the mechanism as such can be criticized on the same grounds as that of the EEO: the risk of a lack of impartiality on the part of the judge who issues the certificate. Section 8.4.2 of this Chapter concluded that it is unlikely that a judge who has previously decided on the merits of a case is unlikely to critically evaluate his or her own findings at the certification stage. This risk applies a fortiori to the mechanism of Article 42 of Brussels II bis, because it expressly requires that the certificate is issued by the same judge who delivered the judgment. The EEO Regulation only requires that this be done by "the same court", which allows Member States some leeway that, it is suggested, Member States should use to divide tasks among different judges to safeguard impartiality. ${ }^{214}$

It is to be expected that there is a similar risk of bias with regard to certification under Article 42 of Brussels II bis. As discussed above, certification may be seen as a stage of the proceedings separate from the proceedings leading to a return order, as it is both formally and functionally separate from that examination. ${ }^{215}$ As was also explained, involvement of the same judge in two stages of the proceedings may be incompatible with fair trial depending on the 'scope and nature' of the issues examined. From the ECtHR's case law it transpires that a lack of impartiality may occur where the two stages of the proceedings concern different legal questions, but there is nevertheless a 'close link' between the issues examined. Such a close link may be present where the stages both concern the same set of facts ${ }^{216}$ and where the second stage may to some degree entail reconsideration of the decision taken at the first stage. ${ }^{217}$ In San Leonard Band Club, discussed above, the ECtHR ruled that when there is an overlap in the questions judges are required to examine, even if it is limited, at separate stages of the proceedings, this may give rise to concerns as to the judge's impartiality. ${ }^{218}$ As to the EEO Regulation, it was concluded that the overlap between certain requirements of the EEO Regulation and the proceedings on the merits may be of such a nature that impartiality concerns arise. A judge can hardly be expected to come to a different conclusion on a matter such as jurisdiction in the certification phase than he did in the merits phase.

With the Article 42 procedure, all three requirements cited above may overlap with questions that were already examined during the examination on the merits. It was, after all, the judge

\footnotetext{
${ }^{214}$ Section 8.4.2 of this Chapter; Stadler (2004a) p. 805.

${ }^{215}$ Section 8.4.2.

${ }^{216}$ ECtHR Indra v. Slovakia, para. 52.

${ }^{217}$ Ibid.

${ }^{218}$ ECtHR San Leonard Band Club.
} 
who decided on the merits who also provided the parties and the child (if appropriate) with 'an opportunity to be heard'. Article 42(2)(c) likely provides the most extensive overlap, since this requires the court to check whether it adequately considered the factors which may be used as grounds for refusal under the 1980 Convention. It may be recalled that these concern a) whether the party who requests the child's return indeed exercised custody prior to the abduction, and b) whether return would expose the child to physical or psychological harm or otherwise place the child in an intolerable situation. ${ }^{219}$ It is submitted that it is unrealistic to expect a judge to come to a different conclusion on these matters when he issues a certificate than he did when deciding on the return as such. This is especially so for the third requirement (Art. 42(2)(c)), considering its overlap with the decision on the merits.

The problems with the concentration of these two tasks in one and the same judge is illustrated by the Zarraga case, discussed previously. ${ }^{220}$ It may be recalled that in that case the Spanish court certified its own judgment as enforceable, considering that the child in question (nine years of age) had been given an opportunity to be heard. However, in that case the 'opportunity to be heard' had consisted of an invitation to the mother and child to return to Spain, with no guarantee that they would be allowed to leave together; a request for a hearing through videoconferencing was refused. The courts of Germany, to where the child had been abducted, considered this insufficient, but were not allowed to refuse enforcement on this basis. It was submitted that the opportunity to be heard provided to the child in the Zarraga case was not effective and that the Spanish court should have done more. Indeed, it is difficult to see how a simple invitation to the child to return to the state of previous habitual residence for a hearing, without any guarantees as to being allowed to leave, can ever be effective: if it were so simple to get a child to return, return orders would not be necessary. In this case, the court that issued the certificate clearly did not consider the opportunity to be heard that it had earlier granted to the child to be ineffective. It is submitted that it could hardly have been expected to find otherwise, because that would have required the court to come to a different conclusion with regard to the same question and on the basis of the same facts. It is proposed that the Brussels II bis Regulation be amended to require Member States to divide the decision on the merits and the certification among different judges, in order to safeguard impartiality. Without an impartial and critical examination of the requirements for certification, these requirements have no practical value to the parties to the proceedings or the child.

\subsubsection{The right of the child to participate in the proceedings}

A related issue is the divergence among states on the question whether children should be heard at all; states have different interpretations as to when a hearing is appropriate having regard to the child's age and maturity. Under the Convention on the Rights of the Child and the EU Charter of Fundamental Rights children have a right to express their views and have them taken into consideration in matters that concern them in accordance with their age and maturity.

\footnotetext{
${ }^{219}$ Article 13, 1980 Convention; see also section 8.6.1 of this Chapter.

${ }^{220}$ Chapter 3.5.
} 
However, some argue that hearing a child is difficult, as a child may be manipulated, may feel put under pressure, or forced to choose between his or her parents. In abduction cases, an abducted child often has not seen the left-behind parent for a considerable length of time, and cannot therefore be expected to have a realistic impression of that parent. It is also hard to explain to children that the return proceedings are not decisive as to where the child will live, as that decision remains with the judge in the state of the child's habitual residence. ${ }^{221}$

It was foreseen when the Brussels II bis Regulation was adopted that these divergences would create problems at the enforcement stage. ${ }^{22}$ The 2015 Study on the assessment of the Brussels II bis Regulation shows that such divergences have indeed created problems at the enforcement stage: distrust between Member States on this matter has led to refusals of enforcement where the Regulation allows it. ${ }^{223}$ It has proven especially difficult to organise a hearing of the child if the abducting parent does not cooperate. ${ }^{224}$ Given that such divergences exist, it can be doubted whether the condition that the child be heard prior to issuing the certificate of Article 42(2)(a) is at all effective. Unfortunately, the 2015 Study does not provide conclusions as to whether the requirement of Article 42(2)(a) serves its purpose.

It has therefore been suggested that the requirement that the child be given an opportunity to be heard should be harmonised in order to avoid diverging approaches: Scott proposes harmonisation of the age at which children may be heard and the ways in which this could be done. ${ }^{225}$ Explicit and harmonised rules on this matter could certainly increase the effectiveness of the certification mechanism: they would both ensure that the rights of the child are respected, and reduce the scope for mistrust and uncertainty at the enforcement stage. More research is needed to ascertain whether such harmonisation is feasible.

\subsubsection{Right to appeal against (non)-certification}

Finally, it needs to be considered what consequences should be attached to a failure to correctly apply the requirements for certification. Currently, the only potential recourse of parties to return proceedings against the wrongful issuing of a certificate is Article 43(1) Brussels II bis, which provides that "the law of the Member State of origin shall be applicable to any rectification of the certificate". The wording of this provision makes clear that Member States are not obligated to allow for rectification. Moreover, Article 43(2) provides that no appeal shall lie against the issuing of a certificate. This leaves open the possibility that a party may appeal against a decision not to issue a certificate, but clearly excludes any appeal against its issuing on the grounds that the preconditions of Article 42(2) were not observed. It can be questioned what the purpose of requirements for certification is, if a failure to observe them can remain without consequences. Perhaps a mechanism such as that of Article 10 of the EEO Regulation, whereby a debtor can apply for withdrawal of the certificate in the Member State

${ }^{221}$ Kruger (2011) p. 37-39.

${ }^{222}$ Kruger (2011) p. 37.

${ }^{223}$ Study on the assessment of the Brussels IIbis Regulation (2015) p. 43.

${ }^{224}$ Study on the assessment of the Brussels IIbis Regulation (2015) p. 48.

${ }^{225}$ Scott (2015) p. 32. 
of origin if it was clearly wrongly issued with regard to the requirements of the Regulation, should be introduced. In that way, the burden of opposing the certification lies with the abducting parent, and the fact that this remedy should be invoked in the Member State of origin may act as a deterrent for invoking it too lightly and causing unnecessary delays. Combined with a more precise and harmonised set of requirements for certification, such as suggested by Scott, ${ }^{226}$ so that possibilities for abuse are minimised, such a mechanism may provide a more equitable balance between the rights of both parties.

\subsubsection{Conclusion: cross-border enforcement of return order and access rights}

The simple answer given to the question posed above, whether refusal of enforcement is ever an appropriate sanction for fair trial violations in cases concerning access rights, is no. It was shown that the primary interests that return proceedings should protect are those of the child. Since it is only the parents (or other authorities) that can hold a right to a fair trial in the context of return proceedings, a violation of those rights cannot outweigh the child's interests. If refusal of enforcement leads to a risk to the child's safety, health or well-being, this cannot be an appropriate remedy. It is possible that the parent's right to a fair trial and the child's best interests may align; in those cases, refusal of enforcement may be appropriate, but it is still the child's interests that are decisive. Whether it is necessary for the safeguarding of the best interests of the child to have a possibility for refusal of enforcement in the Brussels II bis Regulation is a question that is outside the remit of this research.

\subsection{Conclusion}

This Chapter showed that judgment import, or export as the case may be, is by no means irrelevant for the protection of the parties' fair trial rights. An effective mechanism for crossborder enforcement is essential for guaranteeing the creditor's right to enforcement. In this regard, the Brussels I bis Regulation's certification mechanism appears to function quite well, since it abolishes the need for a declaration for enforceability and is easily obtainable. Though the debtor's rights should be adequately protected by the availability of refusal grounds, some improvements to the certification procedure are necessary to ensure that the debtor is aware of his rights.

It may be clear that this research rejects the mechanism of the EEO. Not only does it abolish the possibility for refusing enforcement or recognition, it also relies too much on self-control by the judge who issues an EEO on the matter of adequate service. The overreliance on nonhierarchical and possibly ineffective service methods is a problem that plagues the EOP Procedure as well. The combination of potentially ineffective minimum standards on service, 
combined with the reliance on self-control by the judge and the lack of effective remedies for the debtor, is incapable of replacing the grounds for refusal. Most problematic may be cases in which a judgment against a consumer is wrongfully certified as an EEO despite it not having been issued in his own Member State, for example because it was not clear that the debtor was acting as a consumer. To expect a debtor in such a case to request withdrawal of the certificate in a foreign court is impracticable and at odds with the principles of the Regulation itself.

It should also be pointed out that there exists now a remarkable inequality between debtors against whom enforcement is sought under the EEO Regulation, and those who fall within the regime of Brussels I bis. It is submitted that since the EEO Regulation was intended as a first step towards complete free movement of judgments across the EU, which was clearly rejected by the Member States, the European legislature should question whether it should remain in force. It should also be emphasized that as of now, there appears to be no evidence that the EEO has resulted in a significant improvement for creditors.

As for the uniform procedures, a number of improvements are possible and necessary. It is suggested that the methods of service, in particular, are evaluated carefully. The interplay between cross-border service, standards of examination pertaining to default judgments, and enforcement is a complicated one, which Member States resolve in different ways. In this regard, initiatives such as the ELI-Unidroit project 'From Transnational Principles to European Rules of Civil Procedure', ${ }^{227}$ which includes a Working Group on service, are to be welcomed, and its conclusions should be taken into consideration. Apart from service, there are many elements of the uniform procedures that could be improved. One area where great gains could be made is in the digitalization of procedures: improving possibilities for, for example, videoconferencing could greatly improve the accessibility and fairness of the ESCP. It is commendable that the evaluation project of the ESCP and EOP Regulations that was commissioned by the European Commission gives a great deal of attention to this topic;.228 there are many other initiatives in this field. ${ }^{229}$ Cross-border service and the impact of digitalization are just examples of the great potential for improvement in the field of crossborder civil litigation.

$227 \mathrm{http}: / / \mathrm{www}$. europeanlawinstitute.eu/projects/current-projects/ (last accessed 04/12/2015).

228 See the reports of Kezmah and Bostjan, published as part of the Access to Justice Project at http://www.acj.si/en/project-results (last accessed 04/12/2015).

${ }^{229}$ As one of many examples, see the e-Codex project, http://www.e-codex.eu/home.html (last accessed 04/12/2015). 


\section{Conclusion}

\subsection{Introduction}

The motivation for this research is to achieve the policy objective of complete free movement of civil judgments across the European Union (EU), which entails the abolition of grounds for refusal of recognition or enforcement. Because this development has profound implications for the protection of litigants' right to a fair trial, this research set itself the goal of identifying the requirements imposed by the right to a fair trial on the regulation of free movement of civil judgments across borders within the EU. It was shown that the right to a fair trial in particular, and the fundamental rights framework more generally, are relevant to the cross-border recognition and enforcement of civil judgments in different ways.

Firstly, the right to a fair trial includes a right to enforcement of the judgment resulting from the trial. Facilitating enforcement in cross-border cases is therefore important to safeguarding this aspect of fair trial. It also serves the societal interest in the reliability and efficacy of the civil justice system.

Secondly, mechanisms for cross-border recognition and enforcement can also act as a 'shield' against violations of the right to a fair trial. A refusal to recognize or enforce a foreign judgment is a very effective, though radical, way of ensuring the foreign judgment does not take effect, thereby avoiding a violation in the Member State of enforcement. A limitation on free movement in the shape of a possibility to refuse recognition or enforcement to a judgment that is the result of an unfair procedure can thus provide protection to judgment debtors.

These two observations show how the right to a fair trial informs free movement of judgments from an individual perspective. The research question should however also be answered from a constitutional perspective. The right to a fair trial is protected, in the EU, by the European Convention on Human Rights (ECHR) and the EU Charter of Fundamental Rights (EU CFR). These instruments form the fundamental rights framework of the EU as an organization and of its Member States when they apply EU legislation. From the constitutional perspective, the question is how fundamental rights can be most effectively protected in this constellation, and which institution is responsible for checking the compatibility of judicial decisions with the right to a fair trial. More to the point, the question is whether EU Member States can legitimately be obligated to rely on the presumption that judgments from other Member States conform to the right to a fair trial. This research analysed this question from the perspective of both the ECHR and the EU CFR.

This conclusion summarises the findings of this research for each Chapter, providing succinct answers to each of the research questions. It delineates the implications of these answers for legislation, policy and practice. Finally, a number of avenues for further research are explored.

\subsection{The research}




\subsubsection{The research questions}

As was elaborated upon in the Introduction to this thesis, this research set out to answer the following research question:

Which are the requirements imposed by the right to a fair trial (as laid down in Article 6(1) ECHR and Article 47 CFR) on the free movement of civil judgments in cross-border cases within the $\mathrm{EU}$, and how can the right to a fair trial be effectively safeguarded in this context?

This research question was divided into the following sub questions, which were answered in each consecutive Chapter, as summarized below.

1. How does the (previously) existing mechanism for recognition and enforcement protect, and what consequences will its abolition or simplification have for the protection of, the right to a fair trial in cross-border cases?

2. Which requirements can be derived from Article 6(1) ECHR and Article 47 CFR that are relevant to the civil trial, including the enforcement stage?

3. To what extent does the ECHR require a mechanism that allows the Member State where enforcement is sought to refuse such recognition or enforcement in case of a violation of the right to a fair trial, and what preconditions does it impose on its abolition?

4. To what extent does the EU legal order require a mechanism that allows the Member State where enforcement is sought to refuse such recognition or enforcement in case of a violation of the right to a fair trial, and what preconditions does it impose on its abolition?

5. If a mechanism for the refusal of recognition and enforcement is found to be necessary, what criterion should national judges apply?

6. Which procedural safeguards should EU legislation concerning the recognition and enforcement contain in order to guarantee the effective protection of right to a fair trial in cross-border cases?

\subsubsection{Summary of the findings and answers to the research questions}

This research consists of three parts. The first part consists of Chapters 2 and 3 .

Chapter 2 discussed the evolution of free movement of judgments in the EU. It showed that, because of their importance to the functioning of the internal market, recognition and enforcement of foreign judgments has been on the EU's legislative agenda since the first founding Treaty. For a long time, civil judgments were recognized automatically, while for enforcement a declaration of enforceability (exequatur) was required in the Member State where enforcement was sought. Both recognition and enforcement could be refused by the Member State addressed on the basis of a limited number of narrowly formulated refusal grounds. The introduction of mutual recognition as a legislative concept in 1999 however, fundamentally changed the basis of cooperation in the field of civil justice. In its most absolute 
form, mutual recognition requires Member States to recognize or execute judicial decisions from other EU Member States without any discretion to review or refuse the decision. Mutual recognition is based on mutual trust between the Member States, though whether it in fact exists or whether it is merely assumed to exists remains a question. Chapter 2 showed that the introduction of mutual recognition in the field of civil justice took the shape of the abolition of exequatur and of the refusal grounds, though the various regulations achieved this in different ways.

Chapter 3 showed why and how this development has an impact on the protection of the right to a fair trial. The most controversial of the reforms proved to be the abolition of the public policy exception. This provision, which was a standard feature of EU (but also domestic and international) instruments, allows states to refuse recognition or enforcement to a judgment if that recognition or enforcement would be contrary to the public policy of that state. Since public policy encompasses fundamental rights, including the right to a fair trial, the exception enables states to refuse recognition or enforcement to judgments that result from a procedure that does not conform to the requirements of a fair trial. The Chapter discussed a number of cases where the public policy exception was used in this way. Apart from public policy, there are other refusal grounds capable of addressing fair trial violations, notably the protection afforded to the defaulting defendant and the review of jurisdiction under the Brussels I Regulation. Chapter 3 also showed that the cross-border element of refusal provides protection in and of itself, since it provides an 'outsider view' that may identify violations that would go unchecked in the Member State of origin. The abolition of refusal grounds is therefore problematic from the perspective of fundamental rights protection.

Together, these two Chapters (Part I of this research) answered sub-question 1. They showed that serious problems simply sometimes occur, and that application of the refusal grounds has proved a very effective remedy in those cases. The abolition of refusal grounds in particular, and the reforms in European civil procedure law more generally, therefore raise questions as to their conformity with the right to a fair trial.

Part II of this research (Chapters 4, 5 and 6) explored different ways in which the right to a fair trial circumscribes cross-border recognition and enforcement of civil judgments.

Chapter 4 answered sub-question 2. It showed that the right to a fair trial holds a prominent place within the ECHR, because of its importance in a democratic society and as a central element of the rule of law. The CJEU has long acknowledged the existence of the right to a fair trial within the EU legal order. The Charter explicitly links the interpretation of the right to a fair trial in the EU context to that provided in the European Court of Human Rights' (ECtHR) case law. The CJEU's interpretation of the right to a fair trial is in some respects more specific and extensive than that provided by the ECtHR. It was also shown that the right to a fair trial applies to the enforcement stage of civil proceedings, and guarantees a right to enforcement to the judgment creditor. The Chapter further discussed whether some kind of hierarchy could be discerned within the right to a fair trial. While in principle all aspects of the fair trial are equally deserving of protection, it was shown that a useful distinction can be made between them according to their function in achieving a fair trial and according to how a failure to observe them could be remedied. 
Chapter 5 concluded - in an answer to sub question 3 - that in principle, the ECtHR allows discretion to refuse enforcement to be removed from the Member State where enforcement is sought under EU legislation. However, this results from the ECtHR's reduced level of scrutiny in situations where Contracting Parties act as agents of the EU and therefore have no discretion. Chapter 4 discussed that the ECtHR developed the Bosphorus doctrine for addressing potential fundamental rights violations that occurred due to the application of EU law. The Bosphorus line of case law is based on the premise that the EU provides fundamental rights protection that is equivalent to that provided by the ECHR. In Povse, the ECtHR applied this reasoning to the free movement of civil judgments. Chapter 5 argued that Povse suffers from twisted logic due to the ECtHR not being well placed to deal with a violation involving several states. The marginal scrutiny by the ECtHR of the application of EU law is especially problematic in the context of mutual recognition, since the ECtHR essentially sanctioned the concentration of decision-making power in the Member State of origin, which, it was submitted, may at times produce results that are highly problematic with regard to the protection of fair trial. The ECtHR ruled in MSS v. Belgium and Greece, where it ruled that exceptions to mutual recognition should be made if the state where the decision originates does not fulfil its obligations under the ECHR.

Chapter 6 analysed the role of fundamental rights in the EU's constitutional framework, answering sub-question 4 . It showed that the EU has committed itself to protecting fundamental rights, which constitute part of its founding principles. Through the CJEU's case law, and most explicitly through the EU CFR, the EU and its Member States are bound to respect fundamental rights in the creation and application of EU legislation. However, Chapter 6 showed that fundamental rights standards in EU legislation can also act as maximum standards where a high level of harmonisation is intended, reducing or removing Member States' discretion to apply higher national conceptions of certain fundamental rights. It is therefore especially important that fundamental rights standards laid down in secondary EU legislation provide sufficient protection, also because Member States have few or no possibilities to correct the application of EU law without disregarding their obligations. The CJEU itself has accepted that the protection of fundamental rights may at times require an exception to absolute mutual recognition. Sub question 4 is therefore answered to the effect that the EU fundamental rights framework requires a mechanism for refusing recognition or enforcement in order to ensure that the EU does not fall foul of its commitment to respect fundamental rights.

Part II concluded that what the right to a fair trial, as protected by the ECHR and the EU CFR, requires, is that violations are prevented or, if not, addressed effectively in the domestic procedure. Whatever the division of tasks between the EU's Member States in the context of cross-border recognition and enforcement, there remains an obligation on the EU and its Member States to protect fundamental rights effectively. The question is therefore how EU legislation on recognition and enforcement can most effectively protect the right to a fair trial.

Part III (Chapters 7 and 8) presented recommendations as to how effective protection of fair trial is best achieved.

Chapter 7 proposed - answering sub question 5 - that the EU instruments should retain an emergency brake in the shape of a public policy exception (and other grounds for refusal) which should be applied by the Member State addressed. The Chapter analysed to what extent procedural public policy and the right to a fair trial overlap, with the purpose of exploring 
whether procedural public policy could be replaced with a more narrow reference to fair trial. While the Chapter concluded that such a replacement would have several advantages, it considered that the disadvantage of having to create an artificial distinction between procedural and substantive public policy could not (within the limits of this research) be overcome. The Chapter also explored how in certain concrete cases the conflict between creditors' and debtors' rights to fair trial could be resolved. It concluded that the judge should always ask himself whether refusal of recognition or enforcement is an appropriate remedy to the debtor's violation and whether it is proportional to the disadvantage suffered by the creditor. The Chapter made a reservation with regard to the enforcement of decisions ordering the return of a child, which involves a more complicated balancing act between the rights of the parents and the interests of the child.

Chapter 8 answers sub question 6. It examined how the procedure for cross-border recognition and enforcement should be designed to safeguard both creditors' and debtors' fair trial rights effectively. To that end it analysed the existing instruments, with special attention to the more innovative instruments. It concluded that a simple, speedy and effective mechanism to achieve cross-border enforcement is essential with respect to realising the creditor's right to enforcement. It also showed that the self-control required by the European Enforcement Order, the Brussels II bis Regulation and the uniform European procedures is likely to be ineffective and may be incompatible with the right to a fair trial because it does not guarantee an impartial examination of the prerequisites (minimum standards) for enforcement. The Chapter also highlighted a number of particular deficiencies in the various instruments, such as the lack of information provided to the debtor by the certificate of the Brussels I bis Regulation. It also pointed out the inequality that exists between debtors depending on which mechanism the creditor chooses to enforce the judgment he obtained. A number of recommendations for improvement of the existing Regulations were made.

\subsubsection{Limitations of the research}

This research has as its explicit aim to discuss the cross-border recognition and enforcement of civil judgments from the perspective of fundamental rights. It does not explore whether free movement of civil judgments is feasible or desirable politically or economically. This limitation is of special significance with regard to the retention of the public policy exception. Public policy is still at least in theory a national concept, since all Regulations that contain this concept refer to the public policy 'of the Member State addressed', although its outer limits are defined by the European Court of Justice, and its content partly consists of common European norms. The value of public policy has often been found in its capacity to 'bridge gaps' between different procedural systems, which makes free movement of judgments more feasible politically. This function of public policy is not analysed in this research, nor is the question whether this function is an argument for the retention of public policy.

Another limitation is that this research does not consider whether it is legitimately possible to weigh the protection of fundamental rights against considerations of efficiency, such as the potential costs and benefits of the abolition of certain safeguards, or against other considerations of societal interest. This research has as its starting point that the right to a fair trial should be protected effectively in all proceedings falling within its scope. Since both the 
EU and its Member States have committed themselves to protecting fundamental rights, limitations on that protection are only allowed in so far as the fundamental rights framework allows for those limitations. Whereas, for example, the right to privacy (Art. 8(1) ECHR) can be legitimately limited provided certain conditions are fulfilled, the right to a fair trial does not contain an explicit limitation clause. ${ }^{1}$ It is therefore not possible to legitimately discuss in what cases interferences with the right to a fair trial should be allowed. Whether such an outcome is acceptable as 'collateral damage' of the abolition of safeguards that may be seen as obstacles to enforcement is a political question; but this research would maintain that even politically, such a trade-off could not legitimately be considered, given that within the EU's political framework, fundamental rights are considered to be among its founding principles.

\subsection{Implications of the findings and recommendations}

\subsubsection{Implications for academic and political debate}

The findings of this research have several implications for academic and political discourse.

This research entails a fundamental consideration of the mode of cooperation between EU Member States on the basis of EU legislation. During the discussions on the abolition of exequatur in the Brussels I regime, commentators opposed this development for various reasons. Some argued that the abolition of exequatur, and in particular the abolition of the public policy exception, was unacceptable because it would be incompatible with national sovereignty. In this paradigm, which is the basis of classical private international law, recognition of a foreign judgment is, in essence, a favour one state bestows on another out of comity (literally: courtesy). It is the exception to the rule that judicial decisions have no legal force outside of the jurisdiction where they were rendered, and that states at all times retain the authority to protect their legal order against dubious foreign influences. This language of 'protection' of the legal order is still influential in classical private international law. In this paradigm, the refusal of recognition or enforcement to a foreign judgment can perhaps with some legitimacy be seen as expressing a lack of trust.

This research however proposes that refusing recognition or enforcement need not be seen as a denial of mutual trust if it is considered that the protection of fundamental rights is a common goal of the EU and its Member States. It is not a denial of mutual trust to review a foreign judgment on the basis of a commonly accepted norm such as the right to a fair trial. In fact, a possibility to refuse recognition or enforcement can work in synergy with mutual trust. The implication of this conclusion for the field of EU civil procedure is therefore that effective cross-border recognition and enforcement with appropriate safeguards should be seen as a common goal of the EU and its Member States. In this paradigm the retention of a possibility for refusal is not a matter of 'obsolete nationalism' but rather an acknowledgement of the fact that review by a second Member State is sometimes the most effective way of safeguarding common fundamental principles.

\footnotetext{
${ }^{1}$ See for a general overview of the topic Koch (2008).
} 
This research proposes a reconsideration of the function of mutual recognition, in the sense that it rejects the notion that mutual recognition can only be an effective mode of cooperation if it is absolute. This research has shown that the effective protection of procedural rights is very difficult to combine with absolute mutual recognition, i.e., the abolition of grounds for refusal to recognise or enforce a foreign decision. If there are clear indications that fundamental rights are not adequately protected in the Member State whose decision is to be recognised, it should be possible to refuse such recognition. In the context of the recognition or enforcement of civil judgments it does however always need to be considered whether refusal would constitute a disproportionate interference with the debtor's right to enforcement. Refusal cannot therefore be automatic; it needs to be carefully considered in each case whether refusal is an effective and proportional remedy to the violation suffered by the judgment debtor.

Harmonisation of civil procedure, or the formulation of common minimum standards of civil procedure, may help to reduce uncertainty as to the acceptability of foreign judgments (see below), but it can never sufficiently replace the protection provided by cross-border checks. For this reason, 'building' mutual trust by formulating common minimum standards, in so far as this is possible, should not be seen as a panacea.

This also implies a reconsideration of the relationship between the EU and its Member States when it comes to fundamental rights protection. It has been shown that effective protection of fundamental rights is a common task of the EU and its Member States. Given that EU Member States are able to benefit from a presumption of Convention compliance under the ECHR when they act in the implementation of EU law, the EU legislature should take its responsibility to afford 'equivalent protection' to the ECHR seriously. This may involve, as this Chapter argues, giving back some discretion to the Member States when they implement EU legislation, rather than aiming to curtail their discretion by adopting narrowly formulated common norms in secondary legislation. Respect for fundamental rights binds the EU and its Member States, so instead of viewing fundamental rights protection as a potential source of conflict and aiming to restrict Member States' discretion, the European legislature should trust Member States' judges to combine fundamental rights protection with a faithful application of EU legislation.

\subsubsection{Implications for legislation}

For the purpose of legislation, the implications of this research are the following.

Firstly, all the instruments that are discussed in this research are Regulations. While Regulations have the advantage of needing, in principle, no implementation, practice has shown that they should be properly embedded into national procedural law for them to function effectively. To achieve this, it is especially important to gather information regarding the functioning of the instruments in the Member States and to take seriously the concerns and problems that practitioners, national legislatures and litigants experience. This is not only a task for the European institutions, but also one for the Member States.

This connects to a second recommendation. The field of civil justice cooperation has seen a great deal of legislative innovation over the past decade. Together, the instruments discussed in this research comprise a plethora of enforcement regimes, some of which are even alternatives. After this period of innovation, time has come for the critical evaluation of the functioning of the various instruments and to draw lessons from the practical experiences with 
them. Consolidation, coherence, and effective implementation are now more important than innovation, and it is commendable that the European legislature and policy maker increasingly shows evidence of its awareness of this fact. ${ }^{2}$

Specifically, this research recommends the following changes to existing legislation. Firstly, this research recommends the retention, or where necessary the reintroduction, of a public policy exception in instruments the European Order for Payment (EOP), European Small Claims Procedure (ESCP) and Maintenance Regulations. For the EOP and ESCP Regulations, this implies that the 'review procedure' be widened in scope and that its use is closely circumscribed. For the EOP Regulation, this refusal ground would have to be reformulated so as to remove the requirement that the judgment was delivered by default, since the EOP by its nature does not require the defendant to enter an appearance. The EOP Regulation also requires a remedy for the defendant who was unable to oppose the Order for reasons outside his control.

For the Brussels II bis Regulation, specifically return orders, this research reserves a conclusion as to whether refusal grounds should be reintroduced, since it has found that the best interests of the child, a topic that falls outside the scope of this research, should always be paramount in these procedures.

For the Brussels I bis Regulation, this research concludes that the certification procedure, combined with refusal grounds, appears, 'on paper', to combine protection of both debtors' and creditors' rights reasonably well. A number of specific recommendations are made, such as the introduction of a harmonised period of time between service of the certificate on the debtor and the taking of enforcement measures, as well as on the provision of information to the debtor as to the possibility to invoke grounds for refusal. It should also be clarified in what circumstances a debtor is allowed to request translation of the judgment. The cost, and especially the disparity in costs, of enforcing a judgment across borders remains a bottleneck.

For the EOP Regulation, it was recommended that it be clarified when an EOP would be considered to have been 'clearly wrongly issued' for the purposes of a review under its Article 20(2). It should however be considered whether the review procedure would still be needed if grounds for refusal are available in the Member State of enforcement, especially given that the authority to apply the grounds for review or refusal of the EOP would be divided across two Member States.

For the ESCP Regulation, the amendment that use of distance communication technology is now obligatory for oral hearings is welcomed. Regarding the possibilities for review of Article 18(1), the recommendations are the same as for the EOP; it should be carefully considered whether a review mechanism remains necessary when the recommended grounds for refusal have been reintroduced.

Finally, this research recommends that the added value of the European Enforcement Order Regulation be reconsidered. Since this research rejects the idea that the checks necessary for judgment inspection can be effectively carried out in the Member State of origin, refusal grounds should have to be reintroduced; but this would negate any advantages of using the

\footnotetext{
${ }^{2}$ See on the need to develop a coherent approach also Stadler (2005) and Tulibacka (2009). A comprehensive overview of the field is provided by Strorskrubb (2008).
} 
EEO in comparison to the Brussels I bis Regulation. Given that there does not appear to be a great deal of political interest in the instrument, since it has not been evaluated or amended since its introduction, it is recommended that the European legislature consider its withdrawal.

\subsection{Avenues for further research}

\subsubsection{Convergence of civil procedure}

One important and potentially fruitful avenue for research is the identification of common (minimum) standards of civil procedure. A great deal of research on these matters has already been conducted, going back to the work of the Storme Commission ${ }^{3}$ in the 1990s, but a number of recent projects also deserve mentioning. ${ }^{4}$

One such project is 'From Transnational Principles to European Rules of Civil Procedure', a joint initiative of the European Law Institute and Unidroit, the International Institute for the Unification of Private Law. This project aims at adapting the Principles of Transnational Civil Procedure adopted by the American Law Association and Unidroit. These Principles are an optional model for reform and approximation of domestic private law. The European Law Institute-Unidroit project aims to adopt more specific principles for European civil procedure. In 2014, five working groups of international experts were formed, which respectively address (1) Service and Due Notice of Proceedings; (2) Provisional and Protective Measures; (3) Access to Information and Evidence; (4) Lis Pendens and Res Judicata; and, (5) Obligations of the Parties and Lawyers. At the end of 2015, it was decided to form three more working groups, addressing (6) Costs, (7) Judgments, and an overarching working group on (8) Structure of Civil Proceedings. While it has been reported that the comparative research carried out by these groups is of a high quality, some matters are unclear, including whether the principles would apply only to disputes involving a cross-border element and what the precise goal of the project is. In any case, the Principles are intended to be used as soft law for the European legal community.

The European Commission has also commissioned a number of comparative studies, ${ }^{5}$ including a Study on the service of documents in EU Member States, with the stated aim of "understanding the existing disparities between the national regimes on service of documents that might constitute an obstacle to the proper functioning of Regulation 1393/2007 on the service of documents" ${ }^{6}$. This knowledge will then be employed to put forward reasoned and circumstantiated suggestions enhancing the existing regime of service of documents, including by setting minimum standards or highlighting best practices that could be proposed to all

\footnotetext{
${ }^{3}$ Storme (1993).

${ }^{4}$ A comprehensive overview is provided by Kramer (2016).

5 Among others J Albert, Study on the Transparency of Costs of Civil Proceedings in the EU: Final Report, December 2007, available at https://e-justice.europa.eu/content_costs_of_proceedings-37-en.do (last accessed 17 April 2016).

${ }^{6}$ https://euservicestudy2015.wordpress.com/ (Accessed 29 April 2016).
} 
national authorities. ${ }^{7}$ Secondly, a Study recently started on the functioning of national civil procedure law on the context of the enforcement of European consumer rights. ${ }^{8}$

Furthermore, the European Parliament is undertaking a project ${ }^{9}$ on establishing common minimum standards of civil procedure. A recent Research Briefing identifies ${ }^{10}$ three legislative options for implementing the common procedural principles: (1) optional instruments, that are available as an alternative to national procedures; (2) common (minimum) standards in Directives, either sector-specific or addressing a specific element of civil procedure (such as the existing Mediation Directive ${ }^{11}$ and Legal Aid Directive ${ }^{12}$ ); or (3) a horizontal approach that, due to the limitations of Article 81 of the Treaty on the Functioning of the European Union (TFEU), would apply only to cases involving a cross-border element.

All these initiatives have the potential to facilitate convergence of civil procedure law. This convergence may take different forms, from optional soft law instruments to binding sectoral legislation. The degree of convergence will also differ depending on whether the instrument aims to identify common principles or minimum standards (such as the European Parliament project) or to develop or amend directly applicable legislation (such as the projected amendment of the Service Regulation by the European Commission).

All these projects are to be commended for their attention to procedural rights and the actual functioning in practice of the instruments. The European Parliament project in particular has as its goal to "establish a balance between the fundamental rights of litigants in the interest of full mutual trust between the Member States"13. As this research recommends a more coherent and integrated approach to protecting fundamental rights in the context of civil justice cooperation, it welcomes these initiatives. It is to be hoped that they will lead to legislation that achieves a better balance between efficiency and fundamental rights protection and that addresses the practical problems that are experienced in the implementation of EU legislation.

\footnotetext{
${ }^{7}$ https://euservicestudy2015.wordpress.com/description-of-the-project/.

${ }^{8} \mathrm{http}: / /$ conflictoflaws.net/2016/study-on-the-laws-of-national-civil-procedure-of-the-28-member-states-and-theenforcement-of-european-union-law/.

9 European Parliament, Committee on Legal Affairs, Working Document on establishing common minimum standards for civil procedure in the European Union. The legal basis, 21 December 2015.

${ }^{10}$ Mankó (2015) p. 4.

${ }^{11}$ Directive 2008/52/EC of the European Parliament and of the Council of 21 May 2008 on certain aspects of mediation in civil and commercial matters, OJ L 136/3. According to its Recital 7, this Directive aims to 'promote further the use of mediation and ensure that parties having recourse to mediation can rely on a predictable legal framework' by introducing 'framework legislation addressing, in particular, key aspects of civil procedure' for cross-border disputes.

12 Council Directive 2002/8/EC of 27 January 2003 to improve access to justice in cross-border disputes by establishing minimum common rules relating to legal aid for such disputes, OJ L 026/41. This Directive seeks to promote the application of legal aid in cross-border disputes for persons who lack sufficient resources where aid is necessary to secure effective access to justice (Recital 5). Another example is the Directive on Consumer ADR: Directive 2013/11/EU of the European Parliament and of the Council of 21 May 2013 on alternative dispute resolution for consumer disputes and amending Regulation (EC) No 2006/2004 and Directive 2009/22/EC (Directive on consumer ADR) OJ L 165/ 63.

${ }^{13}$ European Parliament, Committee on Legal Affairs, Working Document on establishing common minimum standards for civil procedure in the European Union. The legal basis, 21 December 2015, p. 2.
} 
If EU legislation is better adapted to national practice this will increase the efficacy of the safeguards contained in that legislation.

The European Parliament also has as its aim to create a sufficient level of mutual trust between the Member States. The presumption is that trust in the functioning of other Member States' legal systems will encourage Member States to accept foreign decisions more readily. It is certainly in the interest of litigants if judicial decisions are not met with distrust in Member States other than where they were rendered and enforced smoothly and efficiently. Building mutual trust is therefore a laudable goal, and if common minimum standards are likely to help achieve that goal, it is worth the effort to identify and implement them. Common minimum standards may also help Member State courts to interpret and apply EU legislation, increasing the chance that this legislation is applied in conformity with fundamental rights. Coherence in the drafting, interpretation and application of EU civil procedure legislation is greatly needed. ${ }^{14}$

However, it is very important to emphasise that mutual trust should always remain a rebuttable presumption. Even if common rules or minimum standards exist this of course never guarantees that they will always be observed in practice. Building mutual trust by identifying common principles is commendable, but it can only ever lead to a strong working presumption that decisions from other Member States conform to those principles. Common principles are not an alternative to cross-border checks because, as this research shows, such checks may sometimes be the only way to ensure the observance of the principles.

\subsubsection{Best practices in the application of EU civil procedure law}

Particularly where it comes to the uniform European procedures, much can be gained by making courts, practitioners and litigants more familiar with the intricacies of the procedures. It is therefore commendable that the European Commission's study on service aims at highlighting best practices that could be proposed to all national authorities. For the uniform procedures to fulfil their potential to improve access to justice effectively, they need to be understandable and well integrated into their domestic legal 'surroundings'. This does not only mean that they should be implemented effectively, but also that they should become part of domestic procedural culture.

One field where promising research is already taking place is that of usability of civil procedure. User-friendliness may be achieved in various ways. One way is to improve accessibility and availability of information, for instance through the European E-justice Portal, which is intended to be a "future one-stop-shop in the area of practical information concerning judicial cooperation in civil matters". ${ }^{15}$ Another recent initiative is the Online Dispute Resolution Platform, ${ }^{16}$ which aims to serve as a single point of entry for consumers and

\footnotetext{
${ }^{14}$ A comprehensive exposé of the need for coherence in EU instruments is provided by Von Hein and Rühl (2016).

15 https://e-justice.europa.eu/content_european_judicial_atlas_in_civil_matters-321-en.do, last accessed $12 / 04 / 2016$.

${ }^{16}$ http://ec.europa.eu/odr, last accessed 12/04/2016.
} 
professionals seeking to settle a dispute out of court. ${ }^{17} \mathrm{~A}$ great deal of research into the possibilities of procedural innovation is also taking place, for instance that carried out by IRSIG-CNR, ${ }^{18}$ and by the Hague Institute for Innovation in Law. ${ }^{19}$ Digitalization of civil procedures may take many forms, from the simple possibility to communicate with the court via e-mail (which is already possible in some EU Member States ${ }^{20}$ ) to divorce dispute settlement modules which are conducted entirely online. ${ }^{21}$

These initiatives are all very different, but they all aim to increase the accessibility and usability of civil procedure, some explicitly for cross-border cases. It is commendable that cross-border online dispute resolution or other forms of alternative dispute resolution are being facilitated. These initiatives have the potential to increase access to justice and help businesses and consumers enforce claims in cross-border situations. It will always have to remain a priority to ensure that the rights of claimants and defendants are properly balanced, and that there is no information disparity between professional and private litigants.

\subsection{Final remarks}

How to protect of the right to a fair trial of two parties in the context of recognition and enforcement is a perennial topic for discussion, ${ }^{22}$ not just in the Europe but also around the world. ${ }^{23}$ This research is an attempt to provide guidance on the delicate balance between debtor's and creditor's rights, and the societal values underlying those rights, this involves. This research showed that this balance has been struck in different ways according to time and place. Within the EU, mutual trust (even before the term was applied) has spurred on an evolution from inter-State cooperation based on comity, to automatic recognition paired with exequatur and refusal grounds, to complete free movement of judgments with no possibility of refusing recognition and enforcement. The concept of public policy has likewise evolved from a purely national concept to one whose limits are defined by the Court of Justice of the European Union. Its content evolved to include the right to a fair trial as defined by Article 6(1) ECHR. These changes are inevitable and even desirable, as public policy is intended to reflect society's fundamental values at a given moment. The right to a fair trial is likewise constantly adapting to changing circumstances: see for instance the ECtHR's recent judgment that the right to adversarial proceedings includes a right to submit documents digitally to the court. ${ }^{24}$

This is a long way of saying that the proposals submitted in this research should not be seen as definitive. The guidelines for the application of the public policy exception developed in

\footnotetext{
${ }^{17}$ European Commission, Press release. Solving disputes online: New platform for consumers and traders, Brussels, 15 February 2016.

${ }^{18}$ http://www.irsig.cnr.it/index.php?lang=en, last accessed 12/04/2016.

19 http://www.hiil.org/, last accessed 12/04/2016.

20 See for instance the project 'Quality and Innovation in the administration of justice' (KEI) of the Dutch government, which allows civil procedures to be conducted fully digitally.

${ }^{21}$ The HiiL project 'Rechtwijzer 2.0': see http://www.hiil.org/project/rechtwijzer, last accessed 12/04/2016.

${ }^{22}$ See for a historical view Berglund (2009) and Lopez de Tejada (2013).

${ }^{23}$ See for instance on the United States Von Mehren (1981) and on China Zhang (2013).

${ }^{24}$ ECtHR Lawyers Partners A.S. v. Slovakia, appl. no. 54252/07 ECHR 2009; Chapter 4.3.2.4.
} 
Chapter 7 should always be adapted to the circumstances of the case. This research proposes that absolute mutual trust cannot be justified, since deficiencies in fundamental rights protection can 'never' be ruled out; but while that conclusion may be definitive, a different solution than cross-border refusal of enforcement may be available in future, such as recourse to a supranational European enforcement court or authority. Likewise, common minimum standards may enable even further reduction of prerequisites for enforcement. 


\section{Nederlandstalige samenvatting}

De aanleiding voor dit onderzoek is het het recente beleidsdoel van de Europese wetgever om volledig vrij verkeer van civiele vonnissen tussen Lidstaten in de Europese Unie (EU) mogelijk te maken. Dit beleid omvat het versimpelen of afschaffen van de mogelijkheid om erkenning of tenuitvoerlegging van een vonnis afkomstig uit een andere Lidstaat te weigeren. Zo heeft de herschikte Brussel I of Brussel Ibis-Verordening de uitvoerbaarverklaring (exequatur) afgeschaft, waarmee vonnissen die binnen de reikwijdte van deze Verordening vallen automatisch in alle EU-Lidstaten uitvoerbaar zijn. Een aantal Verordeningen gaat echter verder. Zo heeft de Alimentatieverordening zowel het exequatur als de gronden voor weigering van erkenning of tenuitvoerlegging, waaronder de openbare orde-exceptie, afgeschaft. De Europese Executoriale Titel makt automatische tenuitvoerlegging mogelijk van vonnissen inzake niet-betwiste geldvorderingen, waarbij geen weigering van tenuitvoerlegging mogelijk is. De Brussel IIbis-Verordening heeft de weigeringsgronden afgeschaft voor vonnissen die de terugkeer van een kind bevelen en vonnissen die het omgangsrecht betreffen. Tenslotte bestaan er sinds enkele jaren twee uniforme Europese procedures, die als alternatief kunnen worden gebruikt voor nationale burgerlijke procedures: de Europese Betalingsbevelprocedure en de Europese Procedure voor Geringe Vorderingen. Beide procedures resulteren in een beslissing die automatisch uitvoerbaar is in alle EU-Lidstaten zonder dat weigering daarvan mogelijk is. De implementatie van het beleid om erkenning en tenuitvoerlegging ingrijpend te vereenvoudigen is daarmee al ver gevorderd.

Omdat deze ontwikkeling potentieel ingrijpende gevolgen heeft voor de bescherming van de rechten van de verdediging, heeft dit onderzoek als doel om te onderzoeken welke eisen de bescherming van het recht op een eerlijk proces stelt aan de verwezenlijking van het vrij verkeer van vonnissen binnen de EU. Dit onderzoek toont aan dat het recht op een eerlijk proces in het bijzonder, maar ook het Europese grondrechtenkader in het algemeen, op verschillende manieren van belang zijn voor de grensoverschrijdende erkenning en tenuitvoerlegging.

Ten eerste omvat het recht op een eerlijk proces een recht op tenuitvoerlegging van het vonnis dat uit dat proces voortkomt. Het faciliteren van tenuitvoerlegging van vonnissen in grensoverschrijdende zaken is daarom belangrijk om dit aspect van het eerlijk proces te garanderen. Effectieve grensoverschrijdende tenuitvoerlegging dient bovendien het maatschappelijk belang door de effectiviteit en betrouwbaarheid van het gerechtelijk systeem te bevorderen.

Ten tweede kan het mechanisme voor grensoverschrijdende erkenning en tenuitvoerlegging van vonnissen ook schendingen van het recht op een eerlijk proces opsporen en remediëren. Een weigering om een buitenlands vonnis te erkennen of ten uitvoer te leggen is een zeer effectieve, doch ingrijpende, manier om te voorkomen dat het vonnis geen werking heeft, waarmee een schending van het eerlijk proces in de Lidstaat van tenuitvoerlegging voorkomen kan worden. Een beperking van het vrij verkeer van vonnissen in de vorm van een mogelijkheid om erkenning of tenuitvoerlegging te weigeren van een vonnis dat resulteert uit een oneerlijk proces kan daarmee bescherming bieden aan de schuldenaar.

Deze twee observaties laten zien hoe, bezien vanuit de individuele procespartij, het recht op een eerlijk proces een rol speelt bij het vrij verkeer van vonnissen. Deze vraag kan echter ook 
worden beschouwd vanuit een constitutioneel perspectief. In de Europese Unie wordt het recht op een eerlijk proces beschermd door zowel het Europees Verdrag voor de Rechten van de Mens (EVRM) en het Grondrechtenhandvest van de Europese Unie (het Handvest). Deze instrumenten vormen het grondrechtenkader van de Europese Unie als organisatie én van haar Lidstaten wanneer deze EU-recht toepassen. Vanuit constitutioneel perspectief is de vraag hoe grondrechten het meest effectief kunnen worden beschermd in de bevoegdheidsverdeling tussen de EU en haar Lidstaten en de Lidstaten onderling, en welke organisatie verantwoordelijk is voor het opsporen en remediëren van grondrechtenschendingen. Meer specifiek is de vraag of EU-Lidstaten kunnen worden verplicht om erop te vertrouwen dat rechterlijke beslissingen uit andere Lidstaten in overeenstemming zijn met het recht op een eerlijk proces, of dat zij de verantwoordelijkheid behouden om deze beslissingen hierop te controleren. Dit onderzoek analyseert deze vragen vanuit het perspectief van zowel het EVRM en het EU-grondrechtenkader.

Het onderzoek bestaat uit drie delen. Het eerste deel bestaat uit hoofdstukken 2 en 3 .

Hoofdstuk 2 bespreekt de ontwikkeling van het vrij verkeer van civiele vonnissen in de EU vanuit politiek en historisch perspectief. Het laat zien dat, vanwege hun belang voor het functioneren van de interne markt, erkenning en tenuitvoerlegging van vonnissen sinds het eerste EU-Verdrag binnen de EU is gereguleerd. Lange tijd werden civiele vonnissen automatisch erkend, wat betekent dat hun rechtskracht kon worden ingeroepen. Voor tenuitvoerlegging, het nemen van (dwang)maatregelen om nakoming van het vonnis te verzekeren, was een uitvoerbaarverklaring (exequatur) in de Lidstaat van tenuitvoerlegging vereist. Zowel erkenning als tenuitvoerlegging konden worden geweigerd in de Lidstaat waar erkenning of tenuitvoerlegging werden verzocht, op basis van een beperkt aantal eng geformuleerde en uitgelegde weigeringsgronden. De introductie van wederzijdse erkenning als uitgangspunt voor wetgeving in 1999 veranderde de basis voor justitiële samenwerking in civiele zaken echter ingrijpend. In zijn meest absolute vorm vereist wederzijdse erkenning dat Lidstaten buitenlandse vonnissen erkennen of ten uitvoer leggen zonder enige discretionaire ruimte om dit te weigeren. Wederzijdse erkenning is gebaseerd op wederzijds vertrouwen tussen de Lidstaten, hoewel het de vraag is in hoeverre wederzijds vertrouwen in de praktijk bestaat of moet bestaan. Hoofdstuk 2 toont aan dat de introductie van wederzijdse erkenning op het terrein van het civiele procesrecht de vorm aannam van de afschaffing van exequatir en de weigeringsgronden, hoewel verschillende Verordeningen dit op verschillende manieren hebben vormgegegeven.

Hoofdstuk 3 laat zien hoe en waarom deze ontwikkeling invloed heeft op de bescherming van het recht op een eerlijk proces. De meest controversiële ontwikkeling betrof de afschaffing van de openbare-orde exceptie, die traditioneel een onderdeel is van (EU-)wetgeving met betrekking tot justitiële samenwerking in civiele zaken. Deze exceptie staat Lidstaten toe om erkenning of tenuitvoerlegging van een vonnis te weigeren wanneer deze erkenning of tenuitvoerlegging in strijd zou komen met de openbare orde van de aangezochte Lidstaat. Omdat openbare orde grondrechten omvat, waaronder ook het recht op een eerlijk proces, maakt de exceptie het mogelijk om erkenning of tenuitvoerlegging te weigeren van een vonnis dat het resultaat is van een procedure die niet aan de eisen van een eerlijk proces voldoet. Het Hoofdstuk bespreekt een aantal zaken waarin de openbare orde-exceptie op deze wijze werd gebruikt. Naast openbare orde zijn er andere weigeringsgronden die schendingen van het recht op een eerlijk proces kunnen remediëren, waaronder de bescherming van de bij verstek 
veroordeelde gedaagde en de controle op de naleving van bepaalde bevoegdheidsgronden onder de Brussel I-Verordening. Hoofdstuk 3 toont ook aan dat het grensoverschrijdende element van de controle van deze weigeringsgronden ook op zichzelf bescherming biedt tegen schendingen van het eerlijk proces, omdat de toepassing van weigeringsgronden een onafhankelijke controle biedt die schendingen kan idenficeren die anders in de Lidstaat van oorsprong onopgemerkt waren gebleven. De afschaffing van weigeringsgronden is daarmee problematisch vanuit het perspectief van grondrechtenbescherming.

Samen laten deze twee hoofdstukken (deel I van dit onderzoek) zien dat ernstige schendingen van het eerlijk proces zich simpelweg soms voordoen, en dat weigering van erkenning of tenuitvoerlegging een zeer effectief middel kan zijn om deze op te sporen. De afschaffing van weigeringsgronden in het bijzonder, maar de hervormingen op het gebied van Europese justitiële samenwerking in civiele zaken in het algemeen, roepen daarom vragen op met betrekking tot hun verenigbaarheid met het recht op een eerlijk proces.

Deel II van dit onderzoek, hoofdstukken 4, 5 en 6, onderzoekt verschillende wijzen waarop het recht op een eerlijk proces van invloed is op grensoverschrijdende erkenning en tenuitvoerlegging van vonnissen in burgerlijke en handelszaken.

Hoofdstuk 4 laat zien dat het recht op een eerlijk proces een prominente plaats inneemt binnen het EVRM, vanwege het belang van een eerlijk proces binnen een democratische samenleving en als essentieel element van de rechtsstaat. Het Hof van Justitie van de Europese Unie (HvJ EU) erkent al lange tijd het bestaan van een recht op een eerlijk proces binnen de EU rechtsorde. Het Handvest legt een expliciet verband tussen de toepassing van het recht op een eerlijk proces binnen de EU-context en de toepassing door het EHRM in zijn jurisprudentie. De interpretatie van het recht op een eerlijk proces door het HvJ is in sommige opzichten meer specifiek en daarmee uitgebreider dan tot nu toe door het EHRM wordt geboden. Hoofdstuk 4 laat ook zien dat het recht op een eerlijk proces een recht op tenuitvoerlegging van het vonnis omvat, en eisen stelt aan de tenuitvoerleggingsfase van het burgerlijk proces. Hoofdstuk 4 bespreekt ook of het mogelijk is om een zekere hiërarchie te ontdekken tussen de elementen van het recht op een eerlijk proces. Terwijl in beginsel alle elementen in gelijke mate bijdragen aan een eerlijk proces, kan er wel een onderscheid worden gemaakt aan de hand van hun functie die zij vervullen en de manier waarop een schending kan worden geremedieerd.

Hoofdstuk 5 concludeert dat het EVRM in beginsel niet vereist dat EU-Lidstaten de mogelijkheid hebben om erkenning of tenuitvoerlegging van een vonnis uit een andere Lidstaat te weigeren, mits EU-wetgeving deze bevoegdheid uitsluit. Dit is echter een gevolg van het feit dat het EHRM geen rechtsmacht heeft om te oordelen over situaties waarin Lidstaten handelen in de uitvoering van EU-wetgeving. Hoofdstuk 4 bespreekt dat het EHRM de zogenoemde Bosphorus-doctrine heeft ontwikkeld om eventuele grondrechtenschendingen die voortkomen uit de toepassing van EU-recht te beoordelen. De Bosphorus-doctrine is gebaseerd op het uitgangspunt dat de EU grondrechten beschermt op een wijze die gelijkwaardig is aan de bescherming geboden door het EVRM. In zijn beslissing in Povse paste het EHRM deze doctrine toe op de tenuitvoerlegging van vonnissen in burgerlijke zaken op basis van EUwetgeving. Hoofdstuk 5 betoogt dat Povse een weinig logische toepassing van de doctrine inhoudt, omdat de doctrine slecht toepasbaar is op een situatie waarin twee Lidstaten bij een eventuele schending betrokken zijn. De beperkte rechtsmacht van het EHRM in zaken 
betreffende de toepassing van EU recht is problematisch in de context van wederzijdse erkenning, omdat het EHRM hiermee toestaat dat discretie om erkenning of tenuitvoerlegging te weigeren wordt weggenomen, terwijl dit soms tot onacceptabele resultaten kan leiden. Het EHRM liet zien dat dit het geval kan zijn in zijn arrest in M.S.S. t. België en Griekenland, waarin het oordeelde dat een uitzondering op wederzijdse erkenning moet worden gemaakt als de Lidstaat waar de beslissing vandaan komt niet voldoet aan haar verplichtingen onder het EVRM.

Hoofdstuk 6 analyseert de rol van grondrechten in de constitutionele structuur van de Europese Unie. Het laat zien dat de Europese Unie zich heeft verbonden om grondrechten te beschermen, en dat grondrechten deel uitmaken van de algemene beginsele van de Unie. Door de jurisprudentie van het HvJ EU, en expliciet door het Handvest, zijn de EU en haar Lidstaten gehouden om grondrechten te respecteren wanneer zij EU-wetgeving creëren of implementeren. Hoofdstuk 6 laat ook zien dat grondrechtenbepalingen in secundaire EUwetgeving ook als maximumeisen kunnen gelden, waarbij zij de discretionaire ruimte van Lidstaten om hogere nationale eisen aan grondrechtenbescherming te stellen. Het is daarom belangrijk dat grondrechtenbepalingen en secundaire wetgeving voldoende bescherming bieden, ook omdat Lidstaten geen mogelijkheden hebben om de toepassing van EU-wetgeving te corrigeren zonder hun verplichtingen onder het EU-recht te veronachtzamen. Het HvJ EU heeft geoordeeld dat in sommige gevallen een uitzondering op absolute wederzijdse erkenning mogelijk moet zijn om grondrechtenbescherming te waarborgen.

Deel II concludeert dat het recht op een eerlijk proces, zoals beschermd door het EVRM en het Handvest, vereist dat schendingen van dat recht worden voorkomen of, zo niet, op effectieve wijze in de nationale procedure worden geremedieerd. Hoe de verdeling van verantwoordelijkheden tussen de EU en haar Lidstaten, en de Lidstaten onderling, ook word verdeeld, deze verantwoordelijkheid om effectieve bescherming te bieden geldt onverkort. De vraag is dus hoe EU-wetgeving met betrekking tot erkenning en tenuitvoerlegging het recht op een eerlijk proces zo effectief mogelijk kan beschermen.

Deel III, hoofdstukken 7 en 8, doet aanbevelingen over de effectieve bescherming van het eerlijk proces in EU-wetgeving op dit terrein.

Hoofdstuk 7 beveelt aan dat de EU-Verordeningen een 'noodrem' zouden moeten behouden in de vorm van een openbare orde-exceptie (of andere weigeringsgronden) die in de Lidstaat waar erkenning of tenuitvoerlegging wordt gezocht kan worden toegepast. Dit hoofdstuk analyseert in hoeverre procedurele openbare orde en het recht op een eerlijk proces overlappen, met als doel om te verkennen of het mogelijk is om openbare orde te vervangen door een verwijzing naar het eerlijk proces. Hoewel het hoofdstuk concludeerde dat een dergelijke vervanging meerdere voordelen zou hebben, overwoog het dat het nadeel dat daarmee een kunstmatige scheiding zou ontstaan tussen materiële en procedurele openbare orde een probleem oplevert dat niet (binnen de reikwijdte van dit onderzoek) kan worden opgelost. Het hoofdstuk verkent ook hoe in concrete gevallen het conflict tussen de rechten van de schuldeiser en schuldenaar kan worden opgelost. Het concludeerde dat de rechter zich altijd moet afvragen of erkenning of tenuitvoerlegging een geschikte remedie is voor de schending van de rechten van de schuldenaar, en of deze remedie geen disproportionele inbreuk maakt op de rechten van de 
schuldeiser. Het hoofdstuk concludeert ook dat deze redenering niet onverkort kan worden toegepast op de tenuitvoerlegging van beslissingen die de terugkeer van een kind bevelen, om dat hierbij een meer gecompliceerde afweging moet worden gemaakt tussen de rechten van de ouders en het belang van het kind.

Hoofdstuk 8 onderzoekt hoe de procedure waarmee grensoverschrijdende erkenning of tenuitvoerlegging kan worden bereikt moet worden vormgegeven om zowel de procedurele rechten van schuldeisers als schuldenaars te beschermen. Daartoe analyseerde het de bestaande instrumenten, met bijzondere aandacht voor de meer innovatieve instrumenten. Het concludeerde dat een eenvoudige, snelle en effectieve procedure om tenuitvoerlegging in een andere Lidstaat te bewerkstelligen essentieel is voor de bescherming van het recht op tenuitvoerlegging van de schuldeiser. Het liet ook zien dat de zelfcontrole waarop de Europese Executoriale Titel, de Brussel IIbis-Verordening en de uniforme Europese procedures vertrouwen waarschijnlijk niet effectief is. Dit mechanisme kan zelfs in strijd komen met het recht op een eerlijk proces omdat het geen onafhankelijk onderzoek van de minimumeisen voor grensoverschrijdende tenuitvoerlegging garandeert. Het hoofdstuk bespreekt ook een aantal tekortkomingen van de bestaande Verordeningen, waaronder de gebrekkige informatievoorziening aan de schuldenaar door middel van het door de Brussel IbisVerordening voorgeschreven certificaat. Het wijst ook op de ongelijkheid tussen schuldenaars afhankelijk van welk tenuitvoerleggingsregime de schuldeiser kiest. Het hoofdstuk bevat een aantal aanbevelingen ter verbetering van de bestaande Verordeningen. 


\section{Bibliography}

A

Albi (2010)

Amerasinghe

(2004)

Alexy (2002)

Andenas, Hess and Oberhammer (2005)

Andersson

(2005)

Andrews (2007)

Arai (2001)

Arenas Garcia

(2010)

B

Bar Council England \& Wales (2013)

Barents (2010)
Albi, A., (2010). From the Banana Saga to a Sugar Saga and Beyond: Could the Post-Communist Constitutional Courts Teach the EU a Lesson in the Rule of Law?. Common Market Law Review 47:791-829.

Amerasinghe C.F., (2004) Local Remedies in International Law. Cambridge University Press, Cambridge.

Rivers, J. (tr), Alexy, R., (2002). A Theory of Constitutional Rights. Oxford University Press, Oxford.

Andenas, M., B. Hess and P. Oberhammer (eds) (2005). Enforcement Agency Practice in Europe. British Institute of International and Comparative Law, London.

Andersson, T., (2005). Harmonization and Mutual Recognition: How to Handle Mutual Distrust. In: Andenas, M., B. Hess and P. Oberhammer (eds), Enforcement Agency Practice in Europe. British Institute of International and Comparative Law, London, pp. 245-251.

Andrews, N. (2007). 'PARERE DEL PROF. NEIL ANDREWS, University of Cambridge, del 23.11.2007 (Legal Opinion of Prof. Neil Andrews)'. Problemi di diritto processuale internazionane Italiano, .

Arai, Y., (2001). The Margin of Appreciation Doctrine and the Principle of Proportionality in the Jurisprudence of the ECHR. Intersentia, Antwerpen - Oxford - New York.

Arenas Garcia, R., (2010). Abolition of exequatur: problems and solutions. Mutual recognition, mutual trust and recognition of foreign judgments: too many words in the sea. Yearbook of Private International Law 12:351-375.

General Council of the Bar of England and Wales (2013). Bar Council response to the European Commission's consultation on the European Small Claims Procedure. http://ec.europa.eu/justice/newsroom/civil/opinion/130318_en.htm.

Accessed 29 April 2016.

Barents, R. (2010). The Court of Justice after the Treaty of Lisbon. Common Market Law Review 47:710-728. 
Bariatti (2009) Bariatti, S. (2009). Recent Case-Law Concerning Jurisdiction and the Recognition and Enforcement of Judgments under the European Insolvency Regulation. Rabels Zeitschrift für ausländisches und internationales Privatrecht 73:629-659.

Barlowski (2012) Barlowski, M. (2012). Public Policy exception under the EC Regulation on Insolvency Proceedings: is it fit for purpose?. Corporate Rescue and Insolvency 5:166-168.

Battjes et al. Battjes, H. and others (2011). The Principle of Mutual Trust in European (2011)

Beale (2006) Beale, S. (2006). The Judgment in Eurofood: the European Court of Justice gives Guidance on the EC Insolvency Regulation. Journal of International Banking Law and Regulation 21:487-492.

Beaumont and Beaumont, P. and E. Johnston (2010). Abolition of Exequatur in Brussels Johnston (2010a) I: Is a Public Policy Defence Necessary for the Protection of Human Rights?. Praxis der Internationalen Privat- und Verfahrenrechts (IPRax) 30:105-110.

Beaumont and Beaumont, P. and E. Johnston (2010). Can exequatur be abolished in Johnston (2010b) Brussels I whilst retaining a public policy defence?. Journal of Private International Law 6:249-279.

Beaumont, Beaumont, P., Trimmings, K., Walker, L., Holliday, J. (2015). Child Trimmings et al abduction: recent jurisprudence of the European Court of Human Rights. (2015)

Beaumont and Beaumont, P. and L. Walker (2013). 'Post Neulinger Case Law of the Walker (2013) European Court of Human Rights on the Child Abduction Convention. In: The Permanent Bureau of the Hague Conference on Private International Law (ed) (2013). A Commitment to Private International Law. Essays in honour of Hans van Loon. Intersentia, Cambridge, pp. 17-32.

Beaumont and Beaumont, P. and L. Walker (2011). Shifting the Balance Achieved by the Walker (2011) Abduction Convention: the Contrasting Approaches of the European Court of Human Rights and the European Court of Justice. Journal of Private International Law 7:231-249.

Beraudo (2013) Beraudo, J. P. (2013). Regards sur le nouveau règlement Bruxelles I sur la compétence judiciaire, la reconaissance et l'execution des décisions en matière civile et commercial. Journal du Droit International 140:741-763.

Berglund (2009) Berglund, M. (2009). Cross-Border Enforcement of Claims in the EU. History, Present Time, and Future. Kluwer Law International, Alphen aan den Rijn. 
Bernitz,

Nergelius and

Cardner (2008)

Besselink (2014) Besselink, L. (2014). Parameters of Constitutional Conflict after Melloni. European Law Review 39:531-552.

Besselink (2008) Besselink, L. (2008). The European Union and the European Convention on Human Rights: from sovereign immunity in Bosphorus to full scrutiny under the Reform Treaty?. In: Boerefijn, I., Goldschmidt, J.E. (2008). Changing Perceptions of Sovereignty and Human Rights: Essays in Honour of Cees Flinterman. Intersentia Antwerpen, pp. 295-309.

Besselink (2001) Besselink, L. (2001). 'The Member States, the National Constitutions and the Scope of the Charter. Maastricht Journal of European and Comparative Law 8:68-80.

BEUC (2013) Bureau Européen des Unions de Consommateurs AISBL (BEUC) (2013). European Small Claims. BEUC Response to European Commission Consultation.

http://ec.europa.eu/justice/newsroom/civil/opinion/130318_en.htm.

Accessed 29 April 2016).

Billing (2012) Billing, F. (2012). The Parallel Between Non-Removal of Asylum Seekers and Non-execution of a European Arrest Warrant on Human RIghts Grounds: the CJEU Case of N.S. v. Secretary of State for the Home Department. European Criminal Law Review 2:77-91.

Bittman (2008) Bittman, D. (2008). Vom Exequatur zum qualifizierten Klausererteilungsverfahren. Die Implementierung des Europäischen Vollstreckungstitels für unbestrittene Forderungen in den nationalen Zivilprozessordnungen. Nomos, Baden-Baden.

Boele-Woelki Boele-Woelki, K. and C. Gonzàlez Beilfuss (eds) (2007). Brussels II bis: and Gonzàlez Its Impact and Application in the Member States. Intersentia, Antwerpen Beilfuss (2007) - Oxford.

Borowski (2012) Borowski, M. (2012). The Charter of Fundamental Rights in the Treaty on European Union. In :Trybus, M. and L. Rubini (eds) (2012) The Treaty of Lisbon and the future of European law and policy. Edward Elgar: Cheltenham.

Borràs (1998) Borràs, A. (1998). Explanatory Report on the Convention, drawn up on the basis of Article K.3 of the Treaty on European Union, on Jurisdiction and the Recognition and Enforcement of Judgments in Matrimonial Matters (approved by the Council on 28 May 1998).

Bossuyt (2011) Bossuyt, M. (2011). Belgium Condemned for Inhuman or Degrading Treatment Due to Violations by Greece of EU Asylum Law: M.S.S. v Belgium and Greece, Grand Chamber, European Court of Human Rights, January 21, 2011. European Human Rights Law Review 15:582-597. 
Brems (2008) Brems, E. (ed.) (2008). Conflicts between fundamental rights. Hart Publishing, Antwerp/Oxford/Portland.

Brems (2005) Brems, E. (2005). Conflicting Human Rights: An Exploration in the Context of the Right to a Fair Trial in the European Convention for the Protection of Human Rights and Fundamental Freedoms. Human Rights Quarterly 27:294-326.

Briggs (2005) Briggs, A. (2005). Foreign Judgments and Human Rights. The Law Quarterly Review 121:185-189.

Brouwer (2013) Brouwer, E. (2013). Mutual Trust and the Dublin Regulation: Protection of Fundamental Rights in the EU and the Burden of Proof. Utrecht Law Review 9:135-147.

Business Europe Business Europe (2013). Reaction to the consultation on the European (2013) Small Claims Procedure. http://ec.europa.eu/justice/newsroom/civil/opinion/130318_en.htm. Accessed 29 April 2016.

C

Cadet (2013) Cadet, F. (2013). Le nouveau règlement Bruxelles I ou l'itinéraire d'un enfant gâté. Journal du Droit International 140:765-790.

Van Caenegem (1995)

Callewaert (2009)

Van Caenegem, R.C. (1995). An historical introduction to Western constitutional law. Cambridge University Press, Cambridge.

Callewaert, J. (2009). The European Convention on Human Rights and European Union Law: a Long Way to Harmony. European Human Rights Law Review 2009 768-783.

Callsen (2011) Callsen, R. (2011). Human rights and the public policy exception in private international law. In: Alleweldt, R., R. Callsen and J. Dupendant (eds), Human Rights Abuses in the Contemporary World. Peter Lang, Bern, pp. 125-144.

CEC-ZEV Centre Européen de Consommation/Zentrum für Europäische (2011) Verbraucherschutz e.V. (2011). Procedure de Règlement des petits litiges et injonction de payer Européenne. Des procédures simplifiées pas si simples dans la pratique. http://www.europe-consommateurs.eu. Accessed 29 April 2016.

CBBE (2013) Conseil des barreaux Européens (2013). Response to the public consultation on the European Small Claims Procedure. http://ec.europa.eu/justice/newsroom/civil/opinion/130318_en.htm Accessed 29 April 2016. 
Chainais (2010) Chainais, C. (2010). L'injonction de payer francaise, modèle d'une protection juridictionelle monitoire. De l'art de concilier légalisme procédural et humanisme processual. In: Guinchard, S. (ed) (2010). Justices et droit du procès. Du légalisme procédural à l'humanisme processual. Dalloz, Paris, pp. 621-650.

Chainais (2009) Chainais, C. (2009). L'injonction de payer: maniemant et remaniements. Recueil Dalloz 2009:860-862.

Chalmers and Chalmers, D. and Trotter, S. (2016). Fundamental Rights and Legal Trotter (2016) Wrongs: the Two Sides of the Same EU Coin. European Law Journal 22:939.

Christians (2004) Christians, L. L. (2004). Cour européenne des droits de l'homme. - 20 juillet 2001. Revue Critique de Droit International Privé 93:106-124.

Clayton (2011) Clayton, G. (2011). Asylum Seekers in Europe: M.S.S. v. Belgium and Greece. Human Rights Law Review 11:758-773.

Corthaut (2012) Corthaut, T. (2012). EU Ordre Public. Kluwer Law International, Alphen aan den Rijn.

Costa (2002) Costa, J-P (2002). Le Tribunal de La Rote et l'article 6 de la Convention européenne des droits de l'homme. Revue trimestrielle des droits de l'homme 13:470-476.

Costello (2012) Costello, C. (2012). Dublin Case NS/ME: Finally, an end to blind trust across the EU?. Asiel \& Migrantenrecht 2012 2:83-92.

Costello (2006) Costello, C. (2006). The Bosphorus ruling of the European Court of Human Rights: Fundamental Rights and Blurred Boundaries in Europe. Human Rights Law Review 6:87-130.

Craig (2012) Craig, P. (2012). EU Administrative Law. Oxford University Press, Oxford.

Craig and de Craig, P. and G. De Búrca (2015). EU Law. Text, cases, and materials. Bùrca (2015) Oxford University Press, Oxford.

CSES (2010) Centre for Strategy \& Evaluation Services (CSES) (2010). Data Collection and Impact Analysis, Certain Aspects of a Possible Revision of Council Regulation No 44/2001 on Jurisdiction and the Recognition and Enforcement of Judgments in Civil and Commercial Matters, Final Report. http://ec.europa.eu/justice/civil/files/study_cses_ brussels_i_final_17_12_10_en.pdf. Accessed 29 April 2016.

Cuniberti (2014) Cuniberti, G., (2014). Abolition de l'exequatur et présomption de protection des droits fondamentaux. A propos de l' affaire Povse c/ Autriche. Revue Critique de Droit International Privé 103:303-327. 
Cuniberti (2008) Cuniberti, G. (2008). The Recognition of foreign judgments lacking reasons in Europe: access to justice, foreign court avoidance, and efficiency. International and Comparative Law Quarterly 57:25-52.

Cuniberti (2007- Cuniberti, G. (2007-2008). The first stage of the abolition of the exequatur 2008) in the European Union. Columbia Journal of European Law 14:371-376.

Cuniberti (2012) Cuniberti, G. (2012). Some Remarks on the Efficiency of Exequatur, Paper Number 2012-01. Law Working Paper Series, University of Luxembourg, available at http://ssrn.com/abstract=1998030.

Cuniberti and Cuniberti, G. and I. Rueda (2011). Abolition of Exequatur: Addressing the Rueda (2011) Commission's Concerns. Rabels Zeitschrift für ausländisches und internationales Privatrecht 75:286-316.

Cuniberti (2010) Cuniberti, G. (2010). Debarment from defending, default judgments and public policy in Europe. A case note on Gambazzi. Praxis der Internationalen Privat- und Verfahrenrechts (IPRax) 30:148-153, accessed via http://ssrn.com/abstract=1515363.

Curry-Sumner Curry-Sumner, I. (2014). Rules on the recognition of parental (2014) responsibility decisions: a view from the Netherlands. Nederlands Internationaal Privaatrecht 32:545-558.

D

Rendtorff and Dahl Rendtorff, J. and P. Kemp (2000). Basic Ethical Principles in Kemp (2000) European bioethics and biolaw. Vol I: Autonomy, dignity, integrity and vulnerability. Report to the European Commission of the BIOMED-II Project. Centre for Ethics and Law/Borja de Bioètica, Copenhagen/Barcelona

De Bock (2011) De Bock, R. H. (2011). Tussen waarheid en onzekerheid: over het vaststellen van feiten in de civiele procedure. Kluwer, Deventer.

De Boer, N. De Boer, N. (2013). Addressing rights divergences under the Charter: (2013) Melloni. Case C-399/11, Stefano Melloni v. Ministerio Fiscal, Judgment of the Court (Grand Chamber) of 26 February 2009, nyr. Common Market Law Review 50:1083-1104.

De Boer, Th. M. De Boer, Th M. (2015). What we should not expect from a Recast of the (2015)

Brussels IIbis Regulation. Nederlands Internationaal Privaatrecht 33 1:1019.

De Boer, Th. M. De Boer, Th M. (2011). Zaaknr. C-491/10 PPU, LJN BP0409: [Joseba (2011)

Andoni Aquirre Zarraga/Simone Pelz]. Nederlandse Jurisprudentie 43:4635-4644. 
De Cristofaro (2011)

De Lange (2008) De Lange, R. (2008). Botsing van grondrechten. In: Brems, E., Henrard, K., De Lange, R. (2008). Botsing van grondrechten. Boom Juridische Uitgevers, Den Haag, pp. 63-84.

De Schutter and Tulkens (2008)

De Schutter (2006)

De Visser (2014) De Visser, M. (2014). National Constitutional Courts, the Court of Justice and the Protection of Fundamental Rights in a post-Charter landscape. 15 ERA Forum 15:39-51.

De Visser (2013) De Visser, M. (2013). 113. Hof van Justitie EU (Grote Kamer) 26 februari 2013, zaak C-399/11 (case note). European Human Rights Cases 2013: 1239-1249.

De Vries, Bernitz, Weatherill (eds.) (2013)

Den Heijer (2012)

Di Federico (ed.) (2011)

Dickinson (2012) Brussels I Review Proposal Uncovered. The British
International and Comparative Law, London, pp. 135-164.

Dickinson (2011) Dickinson, A. (2011). The Proposal for a Regulation of the European Parliament and of the Council on Jurisdiction and the Recognition and Enforcement of Judgments in Civil and Commercial Matters (Recast) ("Brussels I bis" Regulation), Note. European Parliament. 
Dickinson (2010) Dickinson, A. (2010). The Revision of the Brussels I Regulation. Surveying the proposed Brussels I Bis Regulation - solid foundations but renovation needed. Yearbook of Private International Law 12:247-309.

D'Oliveira D'Oliveira, U. (2014). The Public Policy Exception in EEX Regulation (2014) 44/2001: is "Union Public Policy" included? A Constitutional Conundrum. In: Piers, M., Storme, S., Verhellen, J.(eds.) (2014). Liber Amicorum Johan Erauw. Intersentia, Antwerpen/Cambridge, pp. 15-34.

D’Oliveira

D’Oliveira, U. (2015). Inlijving van de openbare orde van de EU in die (2015) van de lidstaten?. Nederlands Juristenblad 2015, 90: 2350-2357.

Douglas-Scott (2006a)

Douglas-Scott, S. (2006). Bosphorus Hava Yollari Turizm Ve Ticaret Anonim Sirketi v. Ireland, application No. 45036/98, judgment of the European Court of Human Rights (Grand Chamber) if 30 June 2005, (2006) E.H.R.R. 1.. Common Market Law Review 43:243-254.

Douglas-Scott (2006b)

Ducoulombier (2008)

Douglas-Scott, S. (2006). A Tale of Two Courts: Luxembourg, Strasbourg and the growing European human rights acquis. Common Market Law Review 43:629-664.

Dyer (1978) Dyer, A. (1978). Report on international child abduction by one parent', Prelim. Doc. No. 1 of August 1978. In: Hague Conference on Private International Law. Actes et Documents de 14ième Session (Child Abduction) 3:312.

$\mathbf{E}$

ECC-Net (2013) ECC-Net (2013). European Small Claims Procedure Report. http://ec.europa.eu/consumers/ecc/docs/small_claims_210992012_en.pdf . Accessed 29 April 2016.

ECC-Portugal (2013)

Centro Europeu do Consumidor/European Consumer Centre - Portugal (2013). Public Consultation on the European Small Claims Procedure. http://ec.europa.eu/justice/newsroom/civil/opinion/130318_en.htm. Accessed 29 April 2016).

ECC-Poland European Consumer Centre Poland (2013). Response to the public (2013) consultation on the European Small Claims Procedure. http://ec.europa.eu/justice/newsroom/civil/opinion/130318_en.htm. Accessed 29 April 2016. 
Eckes (2007) Eckes, C. (2007). Does the European Court of Human Rights provide Protection from the European Community? - the Case of Bosphorus Airways. European Public Law 13:47-67.

Édel (2007) Édel. F. (2007). The length of civil and criminal proceedings in the case law of the European Court of Human Rights. Council of Europe Publishing, Strasbourg.

Ehlers (2007) Ehlers, D. (ed) (2007). European Fundamental Rights and Freedoms. De Gruyter, Berlin.

Esplugues Mota Esplugues Mota, C. and Palao Moreno, G. (2016). Section 5: Jurisdiction and Palao

Moreno (2016) over individual contracts of employment. In: U. and Mankowski, P. (eds) (2016). The Brussels Ibis Regulation. Sellier European Law Publishers, Munich, pp. 534-558.

\section{$\mathbf{F}$}

Fawcett (2007) Fawcett, J. J. (2007). The Impact of Article 6(1) of the ECHR on Private International Law'. International and Comparative Law Quarterly 56:1-48.

Fierstra (2014) Fierstra, M. A. (2014). Akerberg Fransson: ruim toepassingsgebied van Handvest op handelingen van lidstaten. Nederlands Tijdschrift voor Europees Recht 2014 6:197-205.

Fitchen (2015) Fitchen, J. (2015). The Recognition and Enforcement of Member State judgments - Arts 45-57. In: Dickinson, A., Lein, E. (2015). The Brussels I Regulation Recast. Oxford University Press, Oxford, pp. 432-519.

Fontanelli (2013) Fontanelli, F. (2013). Hic Sunt Nationes: The Elusive Limits of the EU Charter and the European Constitutional Watchdog: Court of Justice of the European Union: Judgment of 26 February 2013, Case C-617/10 Aklagaren vs. Hans Akerberg Fransson. European Consitutional Law Review 9:315-334.

Francioni (2007) Francioni, F. (ed) (2007). Access to Justice as a Human Right. Oxford University Press, New York 2007.

Frąckowiak- $\quad$ Frąckowiak-Adamska, A. (2015). Time for a European "Full Faith and Adamska (2015) Credit Clause”. Common Market Law Review 52:1-28.

Franq (2016) Franq, S. (2016). Article 45. In: Magnus, U. and Mankowski, P., (eds) (2016). Brussels Ibis Regulation. Sellier European Law Publishers, Munich, pp. 863-928.

Franq (2012) Franq, S. (2012). Art. 34. In Magnus, U. and Mankowski, P., (eds) (2012). Brussels I Regulation, Sellier European Law Publishers, Munich, pp. 644697.

Franzosi (1997) Franzosi, M. (1997). Worldwide Patent Litigation and the Italian Torpedo. European Intellectual Property Review 19:382-385. 
Freudenthal

(2004)

\section{G}

Gattinara (2015) Gattinara, G. (2015). Fundamental rights in European Union civil service law. ERA Forum 16:1-17.

Gebauer (2007) Gebauer, M., (2007). Ordre public (public policy). In: Max Planck Encyclopedia of Public International Law (MPEPIL). http://opil.ouplaw.com/home/EPIL. Oxford University Press, Oxford.

Gerards (2014) Gerards, J. (2014). Inadmissibility decisions of the European Court of Human Rights: A Critique of the Lack of Reasoning. Human Rights Law Review 14:1-11.

Gerards (2011) Gerards, J. (2011). EVRM - algemene beginselen. Sdu Uitgevers, Den Haag.

Gragl (2014) Gragl, P. (2014). A giant leap for European human rights? The final agreement on the European Union's accession to the European Convention on Human Rights. Common Market Law Review 51:13-58.

Grotian (1994) Grotian (1994). Article 6 of the European Convention on Human Rights: the Right to a Fair Trial. Council of Europe Human Rights File No 13.

Gundel (2007) Gundel, J. (2007). Judicial and Procedural Fundamental Rights. In Ehlers, D. (ed) (2007). European Fundamental Rights and Freedoms. De Gruyter, Berlin, pp. 490-517.

\section{$\mathbf{H}$}

Hancox (2013) Hancox, E. (2013). The meaning of "implementing" EU law under Article 51(1) of the Charter: Akerberg Fransson. Common Market Law Review 50:1411-1432.

Harris et al. Harris, D. and others (2014). Law of the European Convention on Human (2014)

Hartley (2015) Hartley, T. C. (2015). International Commercial Litigation: Text, Cases and Materials on Private International Law. Cambridge University Press, Cambridge.

Hartley (2014) Hartley, T.C. (2014). The Brussels I Regulation and arbitration. International and Comparative Law Quarterly 63:1-24.

Hazelhorst and Hazelhorst, M. and X. E. Kramer (2013). Afschaffing van het exequatur Kramer (2013) in Brussel I: daadwerkelijke verbetering of politiek gebaar?. Tijdschrift voor Civiele Rechtspleging 21:37-46. 
Hazelhorst

(2016)

Hazelhorst

(2014)

Hazelhorst

(2010)

Heiss (2016)

Heringa and

Verhey (2001)

Hess (2012)

Hess (2001)

Hess,

Oberhammer and

Schlosser (2013)

Hess and Pfeiffer (2011)

Hess, Pfeiffer and Schlosser (2008)

Hess, Pfeiffer and Schlosser (2007)
Hazelhorst, M.I. (2016). Onjuiste toepassing van het Unierecht als grond voor toepassing van de openbare orde-exceptie. Hof van Justitie EU 16 juli 2015, zaak C-681/13, ECLI:EU:C:2015:471 (Diageo Brands BV tegen Simiramida-05 EOOD). Nederlands Internationaal Privaatrecht 34 1:1117.

Hazelhorst, M. I. (2014). The ECtHR's decision in Povse: guidance for the future of the abolition of exequatur for civil judgments in the European Union. Nederlands Internationaal Privaatrecht 2014 27-33.

Hazelhorst, M.I. (2010). Private enforcement of competition law: why punitive damages are a step too far. European Review of Private Law 18:757-773.

Heiss, H. (2016). Section 3: Jurisdiction in matters relating to insurance. In: Magnus, U. and Mankowski, P. (eds) (2016). Brussels Ibis Regulation. Sellier European Law Publishers, Munich, pp. 407-437.

Heringa, A. and L. Verhey (2001). The EU Charter: Text and Structure. Maastricht Journal of European and Comparative Law 8:11-32.

Hess, B. (2012). The Brussels I Regulation: recent case law of the Court of Justice and the Commission's proposed recast. Common Market Law Review 48:1075-1112.

Hess, B. (2001). Die Integrationsfunktion des Europäischen Zivilverfahrensrechts. Praxis der Internationalen Privat- und Verfahrenrechts (IPRax) 21:389-396.

Hess and Bittman Hess, B. and D. Bittman (2008). Die Verordnungen zur Einführung eines Europäischen Mahnverfahrens und eines Europäischen Verfahrens für geringfügige Forderungen - ein substantieller Integrationsschritt im Europäischen Zivilprozessrecht. Praxis des Internationalen Privat- und Verfahrensrecht (IPRax) 28:305-313.

Hess, B., P. Oberhammer and P. Schlosser (2013). External Evaluation of Regulation 1346/2000/EC on Insolvency Proceedings. Ruprecht-KarlsUniversität Heidelberg; Universität Wien.

B. Hess and T. Pfeiffer (2011). Interpretation of the Public Policy Exception as referred to in EU Instruments of Private International and Procedural Law. Study for the European Parliament. European Parliament, Brussels.

Hess, B., T. Pfeiffer and P. Schlosser (2008). The Brussels I Regulation 44/2001. Application and Enforcement in the EU. C.H. Beck, München.

B. Hess, T. Pfeiffer and P. Schlosser (2007). Report on the Application of Regulation Brussels I in the Member States. Ruprecht-Karls-Universität Heidelberg. 
Hess and

Raffelsieper

(2015)

Hinarejos Parga

(2006)

Hodgkin and

Newell (2007)

Holliday (2012)

Hovaguimian

(2015)

\section{I}

Iglesias Sanchez (2012)

\section{J}

Jacqué (2011)

Janis et al. (2008)

Janssens (2013)

Jänterä-Jareborg (2003)

Jenard (1979)
Hess, B. and K. Raffelsieper (2015). Schuldnerschutz bei fehlender Zustellung eines EU-Mahnbescheids: Regelungslücken der EuMahnVO. Praxis der Internationalen Privat- und Verfahrenrechts (IPRax) 35:401403.

Hinarejos Parga, A. (2006). Bosphorus v Ireland and the protection of fundamental rights in Europe. European Law Review 31:251-259.

Hodgkin, R. and P. Newell (2007). Implementation Handbook for the Convention on the Rights of the Child (prepared for the United Nations Children's Fund). UNICEF.

Holliday, J. (2012). Case Comment: Aguirre Zarraga v Simone Pelz. Aberdeen Student Law Review 3:126-135.

Hovaguimian, P. (2015). The enforcement of foreign judgments under Brussels I bis: false alarms and real concerns. Journal of Private International Law 11:212-251.

Iglesias Sanchez, S. (2012). The Court and the Charter: The Impact of the Entry into Force of the Lisbon Treaty on the ECJ's approach to Fundamental Rights. 49 Common Market Law Review 49:1565-1611.

Jacqué, J. P. (2011). The accession of the European Union to the European Convention on Human Rights and Fundamental Freedoms. Common Market Law Review 48:995-1023.

Janis, M., R. Kay and A. Bradley (2008). European Human Rights Law. Text and Materials. Oxford University Press Oxford.

Janssens, C. (2013). The principle of mutual recognition in EU Law. Oxford University Press, Oxford.

Jänterä-Jareborg, M. (2003). Unification of international family law in Europe - a critical perspective. In: Boele-Woelki, K. (ed) (2003). Perspectives for the Unification and Harmonisation of Family Law in Europe. Intersentia, Antwerp - Oxford - New York, pp.194-216.

P. Jenard (1979). Report on the Convention on jurisdiction and the enforcement of judgments in civil and commercial matters (Signed at Brussels, 27 September 1968), OJ C 59/1. 
Kacevska et al. I. Kacevska, B. Rudevska, V. Mizaras, A. Brazdeikis and M. Torga (2012) (2012). Practical Application of European Union Regulations relating to European Union Level Procedure in Civil Cases: the Experience in Baltic States (Riga, Vilnius, Tallinn). TM 2012/04/EK. http://www.just.ee. Accessed 4 April 2014.

Keller and Heri Keller, H. and C. Heri (2015). Protecting the Best Interests of the Child: (2015)

Kessedjian (2007)

Kiestra (2014) Kiestra, L. (2014). The impact of the ECHR on private international law. An analysis of Strasbourg and selected national case law. TMC Asser Press, The Hague.

Kilkelly (2003) Kilkelly, U. (2003). The right to respect for private and family life. A guide to the implementation of Article 8 of the European Convention on Human Rights. Council of Europe, Strasbourg.

Kinsch (2014) Kinsch, P. (2014). Enforcement as a fundamental right. Nederlands Internationaal Privaatrecht 32 4:540-544.

Kinsch (2011) Kinsch, P. (2011). Private International Law topics before the European Court of Human Rights. Selected judgments and decisions (2010-2011). Yearbook of Private International Law 13: 37-49.

Kinsch (2004) Kinsch, P. (2004). 'The impact of Human Rights on the Application of Foreign Law and on the Recognition of Foreign Judgments - A Survey of the Cases Decided by the European Human Rights Institutions. In: Einhorn, T. and K. Siehr (eds) (2004). Intercontinental Cooperation Through Private International Law - Essays in Memory of Peter E. Nygh. T.M.C. Asser Press, The Hague, pp. 197-228.

Klaming and Klaming, L., Giesen, I. (2008). Access to Justice: the quality of the Giesen (2008) procedure. TISCO Working Paper Series on Civil Law and Conflict Resolution Systems, No. 002/2008. http://ssrn.com/abstract=1091105. Accessed 8 July 2016.

Koch (2008) Koch, I. E. (2008). Human Rights: A conflict between positive individual and collective democratic interests? (Erasmus Law Lectures no. 12). Boom Juridische Uitgevers, The Hague.

Kodek (2005) Kodek, G. (2005). The Impact of the European Convention on Human Rights and Fundamental Liberties on Enforcement Practices. In: Andenas, M., B. Hess and P. Oberhammer (eds) (2005). Enforcement Agency Practice in Europe. British Institute for International and Comparative Law, London, pp. 303-333. 
Kowalyk-

Bańczyk (2015)

Kramberger

Skerl (2011)

Kramer (2016)

Kramer (2015)

Kramer (2014)

Kramer (2013).

Kramer (2012)

Kramer (2011a)

Kramer (2011b)

Kramer (2010)

Kramer (2009)
Kowalyk-Bańczyk, K. (2015). An elusive convergence - rights of defence in competition matters in the jurisprudence of the CJEU. In: Nihoul, P., Skoczny, T. (2015). Procedural Fairness in Competition Proceedings. Edward Elgar Publishing, Cheltenham, p. 182-208.

Kramberger Skerl, J. (2011). European Public Policy (with an emphasis on exequatur proceedings). Journal of Private International Law 7:461490.

Kramer, X.E. (2016). Europees procesrecht in de lift: het ELI-Unidroit project en andere Europese initiatieven. Nederlands Internationaal Privaatrecht 34 1:1-2.

Kramer, X. (2015). The Recognition and Enforcement of Member State judgments - Arts 39-44. In: Dickinson, A., Lein, E. (2015). The Brussels I Regulation Recast. Oxford University Press, Oxford, pp. 403-432.

Kramer, X.E. (2014). Ervaringen met Europese civiele procedures in Nederland: een terugblik en wenkend toekomstperspectief. Nederlands tijdschrift voor Europees recht 2014 4:99-108.

Kramer, X. E. (2013). Cross-Border Enforcement and the Brussels I-Bis Regulation: Towards A New Balance Between Mutual Trust and National Control over Fundamental Rights. Netherlands International Law Review 60:343-373.

Kramer, X.E. (2012). Private International Law responses to corruption approaches to jurisdiction and foreign judgments and the international fight against corruption. Mededelingen van de Koninklijke Nederlandse Vereniging voor Internationaal Recht 139:99-142.

Kramer, X. E. (2011a). Abolition of exequatur under the Brussels I Regulation: effecting and protecting rights in the European judicial area. Nederlands Internationaal Privaatrecht 29 4:633-641.

Kramer, X. E. (2011b). Cross-Border Enforcement in the EU: Mutual Trust versus Fair Trial? Towards Principles of European Civil Procedure. International Journal of Procedural Law 1:202-230.

Kramer, X. E. (2010). Enhancing Enforcement in the European Union. The European Order for Payment Procudure and Its Implementation in the Member States, Particularly in Germany, The Netherlands and England. In: Van Rhee, C. H. and A. Uzelac (eds) (2010). Enforcement and Enforceability. Tradition and Reform. Antwerp-Oxford-Portland Intersentia, pp. 17-39.

Kramer, X.E. (2009). Het IPR voorbij: de invoering van eenvormige Europese procedures. De Europese betalingsbevelprocedure en de Europese procedure voor de inning van geringe vorderingen. In: Erauw, J. 
Kramer (2008a) Kramer, X. E. (2008). The European Small Claims Procedure: Striking the Balance between Simplicity and Fairness in European Litigation. Zeitschrift für europäisches Privatrecht 16:355-373.

Kramer (2008b) Kramer, X. E. (2008). A Major Step in the Harmonization of Procedural Law in Europe: the European Small Claims Procedure. Accomplishments, New Features and Some Fundamental Questions of European Harmonization. In Jongbloed, A. W. (ed) (2008). The XIIIth World Congress of Procedural Law: The Belgian and Dutch Report. Intersentia, Antwerpen, pp. 253-283.

Kramer (2007) Kramer, X. E. (2007). Eenvormige Europese procedures voor de inning van vorderingen. De Europese betalingsbevelprocedure en de Europese procedure voor geringe vorderingen. Kluwer, Deventer.

Kramer and Kramer, X. E. and E. A. Ontanu (2013). The Functioning of the European Ontanu (2013) Small Claims Procedure in the Netherlands: normative and empirical reflections. Nederlands Internationaal Privaatrecht 31:319-328.

Kramer, Tuil and Kramer, X. E., M. L. Tuil and I. Tillema (2012). Verkrijging van een Tillema (2012) executoriale titel in incassozaken (study for the Ministry of Security and Justice). WODC, The Hague.

Kramer (2003) Kramer. X.E. (2003). Enforcement under the Brussels Convention: Procedural public policy and the influence of Article 6 ECHR. Int'l Lis 2003:16-20.

Krans (2013) Krans, H. B. (2013). EBB-Verordening. Europese Betalingsbevelprocedure. Verzoek om betalingsbevel dat niet voldoet aan formele voorwaarden van nationale wettelijke regeling. Nederlandse Jurisprudentie 2013:335.

Krans (2005) Krans, H. B. (2005). Een Europese Executoriale Titel. Maandblad voor Vermogensrecht 2005:187-190.

Krommendijk, Krommendijk, J., Beijer, M., Van Rossem, J.W.C. (2015). EHRC 2015/65

Beijer and Van HvJ EU, 18-12-2014, Advies 2/13. European Human Rights Cases 2015 Rossem (2015) no. 65.

Kropholler Kropholler, J. (2005). Europäisches Zivilprozessrecht. 8th edn Beck, (2005)

Kruger (2011) Kruger, T. (2011). International Child Abduction. The Inadequacies of the Law. Hart Publishing, Oxford and Portland, Oregon.

Kuipers (2010) Kuipers, J-J. (2010). The right to a fair trial and the free movement of civil judgments. Croatian Yearbook of European Law and Policy 6:23-51. 
Kuijer (2004) Kuijer, M. (2004). The blindfold of Lady Justice. Judicial Independence and Impartiality in Light of the Requirements of Article 6 ECHR. E.M. Meijers Institute of Legal Studies of Leiden University, Leiden.

$\mathbf{L}$

Law Society (2013)

The Law Society of England and Wales (2013). European Small Claims Procedure. Reponse to public consultation. http://ec.europa.eu/justice/newsroom/civil/opinion/130318_en.htm. Accessed 29 April 2016).

Lawson (2010) Lawson, R. (2010). Jurisdictional issues: Bosphorus Airlines v. Ireland. Irish Human Rights Law Review 2010:227-236.

Lawson (2005) Lawson, R. (2005). The contribution of the Agency to the Implementation in the EU of International and European Human Rights Instruments. In: Alston, P., De Schutter, O. (eds.) (2005). Monitoring Fundamental Rights in the EU. The Contribution of the Fundamental Rights Agency. Hart Publishing, Oxford and Portland, Oregon, pp. 229-251.

Lawson and Lawson, R., Teuben, K. 92004). De redelijke termijn in het Nederlandse Teuben (2004) burgerlijk procesrecht. In: Hoogervorst, E. et al (eds.). Termijnen. BWKrant Jaarboek 20. Kluwer, Deventer.

Lawyer Ireland Lawyer Ireland (2013). Submission on European Small Claims Procedure. (2013)

Layton (2011) Layton, A. (2011). The Proposal for a Regulation of the European Parliament and of the Council on Jurisdiction and the Recognition and Enforcement of Judgments in Civil and Commercial Matters (Recast). European Parliament.

Layton and Layton, A. and H. Mercer (2004). European Civil Practice. Mercer (2004) Thomson/Sweet and Maxwell, London.

Leanza and Leanza, P. and O. Pridal (2014). The Right to a Fair Trial. Article 6 of the Pridal (2014) European Convention on Human Rights. Kluwer Law International, Alphen aan den Rijn.

Leczykiewicz Leczykiewicz, D. (2010). "Effective judicial protection" of human rights (2010)

Legg (2012) Legg, A. (2012). The Margin of Appreciation in International Human Rights Law. Oxford University Press, Oxford.

Leible, Leible, S., Mankowski, P. and A. Staudinger (2006). Verordnung (EG) Nr Mankowski and 44/2001 des Rates vom 22.12.2000 über die gerichtliche Zuständigkeit und die Anerkennung und Vollstreckung von Entscheidungen in Zivil- und 
Staudinger

(2006)

Lenaerts (2013) Lenaerts, K. (2013). The Best Interests of the Child Always Come First: The Brussels II Bis Regulation and the European Court of Justice. Jurisprudence (Jurisprudencija) 20:1302-1328.

Lenaerts (2000) Lenaerts, K. (2000). Fundamental Rights in the European Union. European Law Review 25:575-581.

Lock (2012) Lock, T. (2012). End of an epic? The draft agreement on the EU's accession to the ECHR. Yearbook of European Law 31:162-197.

Lock (2010a) Lock, T. (2010). Beyond Bosphorus: The European Court of Human Rights' Case Law on the Responsibility of Member States of International Organisations under the European Convention on Human Rights. Human Rights Law Review 10:529-545.

Lock (2010b) Lock, T. (2010). EU accession to the ECHR: implications for the judicial review in Strasbourg. European Law Review 35:777-798.

Lopez de Tejada Lopez de Tejada, M. (2013). La Disparation de l'exequatur dans l' espace (2013)

Luban (2009) Luban, D. (2009). Legal Ethics and Human Dignity. 4th edn Cambridge University Press, Cambridge.

Luban (1988) Luban, D. (1988). Lawyers and Justice. An Ethical Study. Princeton University Press, Princeton.

Lush (1993) Lush, C. (1993). The Territorial Application of the European Convention on Human Rights: Recent Case Law. The International and Comparative Law Quarterly 42:897-906.

\section{M}

Mankowski (2016)

Mankowski and Nielsen (2016)

Mankó (2015)

Mankó (2013)
Mankowski, P. (2016). Section 4: Common Provisions'. In: Magnus, U. and Mankowski, P. (eds) (2016). Brussels Ibis Regulation. Sellier European Law Publishers, Munich, pp. 963-969.

Mankowski, P. and Nielsen, P. (2016). Section 4: Jurisdiction over consumer contracts. In: Magnus, U. and Mankowski, P. (eds). Brussels Ibis Regulation. Sellier European Law Publishers, Munich, pp. 437-534.

Mankó, R. (2015). Europeanisation of civil procedure - Towards common minimum standards?. European Parliament Research Service. http://www.europarl.europa.eu/thinktank/en/home.html.

Mankó, R. (2013). Research briefing: Orders for payment in the EU. National procedures and the European order for payment. European Parliament Research Service. 
McEleavy (2005) McEleavy, P. (2005). The New Child Abduction Regime in the European Union: Symbiotic Relationship or Forced Partnership?. Journal of Private International Law 5:5-34.

McEleavy (2004) McEleavy, P. (2004). CURRENT DEVELOPMENTS: 1. Brussels IIbis: Matrimonial Matters, Parental Responsibility, Child Abduction and Mutual Recognition. International and Comparative Law Quarterly 53:503-512.

Michaels (2009) Michaels, R. (2009). Recognition and Enforcement of Foreign Judgments. In: Wolfram, R. (ed) (2009). Max Planck Encyclopedia of Public International Law Online Edition [www.mpepil.com], Oxford University Press.

Mitsilegas (2006) Mitsilegas, V. (2006). The constitutional implications of mutual recognition in criminal matters in the EU. Common Market Law Review 43:1277-1311.

Mole (2016) Mole, N. (2016). Can Bosphorus be maintained?. ERA Forum 16:467-480.

Mole and Harby Mole, N. and C. Harby (2006). The right to a fair trial. A guide to the (2006) implementation of Article 6 of the European Convention on Human Rights, Human Rights Handbooks, no. 3. Council of Europe.

Muir Watt (2001) Muir Watt, H. (2001). Evidence of an Emergent European Legal Culture: Public Policy Requirements of Procedural Fairness under the Brussels and Lugano Conventions. Texas International Law Journal 36:539-554.

Muller and Muller, M. and G. Cuniberti (2013). 'Une étude empirique sur la pratique Cuniberti (2013) de l'exequatur dans la Grande Région. Journal du Droit International 140:83-104.

$\mathbf{N}$

Nagy (2012) Nagy, C. I. (2012). Recognition and enforcement of US judgments involving punitive damages in continental Europe. Nederlands Internationaal Privaatrecht 30:4-11.

Nielsen (2013) Nielsen, P. A. (2013). The New Brussels I Regulation. Common Market Law Review 50:503-528.

Nielsen (2012) Nielsen, P. A. (2012). The State of Play of the Recast of the Brussels I Regulation' Nordic Journal of International Law 81:585-603.

\section{$\mathbf{O}$}

Oberhammer

Oberhammer, P. (2010). The abolition of exequatur. Praxis der (2010) 
O'Brien and

Koltermann

(2013)

Ontanu and

Pannebakker

(2012)

Ortolani (2015)

Oster (2015)

Ouwerkerk

(2011)

\section{$\mathbf{P}$}

Peers, Hervey et al (2014)

Peers (2011)

Peers (2006)

Pérez-Vera (1982)

Popper (1963)

Ptak (2014)

\section{$\mathbf{R}$}

Raba (2013)
O'Brien, K. and B. Koltermann, (2013). The Charter of Fundamental Rights of the EU in practice. ERA Forum 14:457-461.

Ontanu, E.A. and Pannebakker, E. (2012). Tackling language obstacles in cross-border litigation: the European Order for Payment and the European Small Claims Procedure approach. Erasmus Law Review 5:169-186.

Ortolani, P. (2015). Anti-suit injunctions in support of arbitration under the recast Brussels I Regulation. MPILux Working Paper. http://www.mpi.lu/research/working-paper-series/. Accessed 8 July 2016.

Oster, J. (2015). Public policy and human rights. Journal of Private International Law p. 11:542-567.

Ouwerkerk, J. (2011). Quid Pro Quo? A comparative perspective on the mutual recognition of judicial decisions in criminal matters. Intersentia, Antwerp.

Peers, S., Hervey, T., Kenner, J., Ward, A. (eds.) (2014). The EU Charter of Fundamental Rights. A Commentary. Nomos/C.H. Beck/Hart Publishing, Baden Baden/Munich/Oxford.

Peers, S., (2011). Mission accomplished? EU Justice and Home Affairs after the Treaty of Lisbon. Common Market Law Review 48:661-693.

Peers, S., (2006). Bosphorus. European Court of Human Rights. Limited responsibility of European Union Member States for actions within the scope of Community law. Judgment of 30 June 2005, Bosphorus Airways v. Ireland, Application No. 45036/98. European Constitutional Law Review 2:443-456.

Pérez-Vera, E. (1982). Explanatory Report on the 1980 Hague Child Abduction Convention'. Acts and Documents of the Fourteenth Session (1980), tome III, Child abduction.

Popper, K. (1963). Conjectures and refutations: the growth of scientific knowledge. Harper and Row, New York.

Ptak, P. (2014). Der Europäische Vollstreckungstitel und das rechtliche Gehör des Schuldners. Mohr Siebeck, Tübingen.

Raba, K. (2013). The accession of the European Union to the European Convention on Human Rights - overview of the Accession Agreement'. ERA Forum 14:557. 
Rainey et al. Rainey, B., E. Wicks and C. Ovey (2014). The European Convention on (2014) Human Rights. Oxford University Press, Oxford.

Requejo Isidro Requejo Isidro, M. (2015). On Exequatur and the ECHR: Brussels I (2015)

Raulus (2012) Raulus, H. (2012). The Charter of Fundamental Rights as a set of constitutional principles' in Trybus, M. and L. Rubini (eds) (2012). The Treaty of Lisbon and the future of European law and policy. Edward Elgar, Cheltenham, pp.181-199.

Ronen (2004) Ronen, Y. (2004). Redifining the child's right to identity. International Journal of Law, Policy and the Family 18:147-177.

Rosner (2004) Rosner, N. (2004). Cross-Border Recognition and Enforcement of Foreign Money Judgments in Civil and Commercial Matters. Ulrik Huber Institute for Private International Law, Groningen.

Rozakis (2004) Rozakis, C. (2004). The Right to a Fair Trial in Civil Cases. Judicial Studies Institute Journal 4:96-106.

Rylski (2012) Rylski, P. (2012). Europejski nakaz zaplaty w praktyce sadowej (European order for payment in court practice). Prawo w Dzialaniu - Sprawy Cywilne 12:145-190.

$\mathbf{S}$

Sanna (2011) Sanna, G. (2011). Article 47 of the EU Charter of Fundamental Rights and Its Impact on Judicial Cooperation in Civil and Commercial Matters. In: Di Federico, G. (ed) (2011). The EU Charter of Fundamental Rights: from Declaration to Binding Instrument. Springer, Dordrecht/Heidelberg/London/New York.

Sarmiento, R. Sarmiento, R., (2013). Who's afraid of the Charter? The Court of Justice, (2013) national courts and the new framework of fundamental rights protection in Europe. Common Market Law Review 50:1267-1304.

Sarmiento, D. Sarmiento, D. (2008). European Union: the European arrest warrant and (2008)

Schack (2011) Schack, H. (2011). The misguided abolition of exequatur proceedings in the European Union. In: Gudowski, J. and K. Weitz (eds) (2011). Festschrift für Tadeusz Erecinski. LexisNexis Polska, Warsaw.

Schilling (2012) Schilling, T. (2012). The Enforcement of Foreign Judgments in the Jurisprudence of the European Court of Human Rights. Rivista di diritto internazionale privato e processuale 48:545-572. 
Schilling (2011) Schilling, T. (2011). Das Exequatur und die EMRK. Praxis der Internationalen Privat- und Verfahrenrechts (IPRax) 31:31-40.

Schlosser (2010) Schlosser, P. (2010). The Abolition of Exequatur Proceedings - Including Public Policy Review?. Praxis der Internationalen Privat- und Verfahrenrechts (IPRax) 30:101-104.

Schlosser (1979) Schlosser, P. (1979). Report on the Convention of 9 October 1978 on the Association of the Kingdom of Denmark, Ireland and the United Kingdom of Great Britain and Northern Ireland to the Convention on jurisdiction and the enforcement of judgments in civil and commercial matters and to the Protocol on its interpretation by the Court of Justice, OJ C 59, 5.3.1979, p. $71-151$.

Schuz (2013) Schuz, R. (2013). The Hague Child Abduction Convention. A Critical Analysis. Hart Publishing: Oxford and Portland, Oregon, 2013.

Scott (2015) Scott, J. (2015). A question of trust? Recognition and enforcement of judgments'. Nederlands Internationaal Privaatrecht 33 1:27-35.

Siehr (2013) Siehr, K. (2013). The EU Maintenance Regulation and the Hague Maintenance Protocol of 2007: Recognition of Foreign Judgments and the Public Policy Defence. In: Permanent Bureau of the Hague Conference on Private International Law (ed) (2013). A commitment to private international law: essays in honour of Hans van Loon. Intersentia, Cambridge, pp. 529-540.

Siehr (2012) Siehr, K. (2012). Article 22 and Article 23. In: Magnus, U., Mankowski, P. Brussels IIbis Regulation. Sellier European Law Publishers, Munich, pp. 256-292.

Sillen (2014) Sillen, J. (2014). 2014/177 EHRM, 27-05-2014, 20261/12. European Human Rights Cases 2014 no. 8.

Smits (2008) Smits, P. (2008). Artikel 6 EVRM en de civiele procedure. Kluwer, Deventer.

Stadler (2005) Stadler, A. (2005). From the Brussels Convention to Regulation 44/2001: Cornerstones of a European Law of Civil Procedure. Common Market Law Review 42:1637-1661.

Stadler (2012) Stadler, A. (2012). Practical Obstacles in Cross-Border Litigation and Communication between (EU) Courts. Erasmus Law Review 5:151-168.

Stadler (2004b) Stadler, A. (2004). Das Europäische Zivilprozessrecht - Wie viel Beschleunigung verträgt Europa? Kritisches zur Verordnung über den Europäischen Vollstreckungstitel und ihrer Grundidee. Praxis der Internationalen Privat- und Verfahrenrechts (IPRax) 24:2-11.

Stadler (2004a) Stadler, A. (2004). Kritische Anmerkungen zur Europäischen Vollstreckungstitel. Recht der Internationalen Wirtschaft 12:801-808. 
Stein (2004) Stein, A. (2004). Der Europäische Vollstreckungstitle für unbestrittene Forderungen tritt in Kraft - Aufruf zu einer nüchternen Betrachtung. Praxis der Internationalen Privat- und Verfahrenrechts (IPRax) 24:181-191.

Stone (2006) Stone, P. (2006). EU Private International Law. Harmonization of Laws. Edward Elgar, Cheltenham.

Storme (2009) Storme, H. (2009). Europese betalingsbevelprocedure. Nieuw Juridisch Weekblad 98.

Storme (1993) Storme, M., (1993). Final Report of the Working-Group for the Approximation of Civil Procedural Law.

Storskrubb Storskrubb, E. (2016). Mutual Recognition as a Governance Strategy for Civil (2016)

Storskrubb (2008) Justice', in: Hess, B., Bergström, M., Storskrubb, B., (eds.) (2016). EU Civil Justice. Current Issues and Future Outlook. Hart Publishing, Oxford pp. 299-317.

Sullivan (1991- Sullivan, D. (1992). Gender Equality and Religious Freedom: Toward a 1992)

Storskrubb, E. (2008). Civil Procedure and EU Law: A Policy Area Uncovered. Oxford University Press, Oxford.

Framework for Conflict Resolution. NYU Journal of International Law and Politics. 24:795-856.

Swarcz (2014). Swarcz, M. (2014). Application of the Charter of Fundamental Rights in the Context of Sanctions Imposed by Member States for Infringements of EU law: Comment on Fransson case. European Public Law 20:229-246.

$\mathbf{T}$

Ten Kate (1983) Ten Kate, Th. B. (1983). Procesregels naar de kern genomen. In: Heemskerk, W.H. et al (eds.) (1983). Een goede procesorde (HaardtBundel). Kluwer: Deventer, pp. 71-82.

Thomas (2013) Thomas, J. (2013). The principle of mutual recognition - success or failure?. ERA Forum 13:585-588.

Thunberg Thunberg Schunke, M. (2013). Whose Responsibility? A Study of Schunke (2013) Transnational Defence Rights and Mutual Recognition of Judicial Decisions within the EU. Intersentia, Antwerp.

Timmer (2013) Timmer, L. J. E. (2013). Abolition of Exequatur under the Brussels I Regulation: Ill Conceived and Premature?. Journal of Private International Law 9:129-147.

Torres Pérez Torres Pérez, A. (2012). Spanish Constitutional Court, Constitutional (2012) Dialogue on the European Arrest Warrant: the Spanish Constitutional Court Knocking on Luxembourg's Door; Spanish Constitutional Court, Order of 9 June 2011, ATC 86/2011. European Constitutional Law Review 8:105-127. 
Tridimas (2006) Tridimas, T. (2006).The general principles of EU law. Oxford University Press, Oxford.

Trybus and Rubini (eds.) (2012)

Tulibacka (2009)

V

Vanleenhove (2016)

Van Bochove (2009)

Van Bochove (2007)

Van Bochove and Ontanu (2013)

Van Calster (2013)

Van der Grinten (2006)

Van Dijk and Viering (2006)

Van Dijk et al. (2006)

Van Hoecke (2011)
Trybus, M. and L. Rubini (eds) (2012). The Treaty of Lisbon and the Future of European Law and Policy. Edward Elgar Publishing Limited, Cheltenham.

Tulibacka, M. (2009). Europeanization of civil procedures: in search of a coherent approach. Common Market Law Review 46:1527-1565.

Vanleenhove, C. (2016). Punitive Damages in Private International Law: Lessons for the European Union. Dissertation University of Ghent.

Van Bochove, L. (2009). Een onwillige gedaagde uitsluiten van het proces: weigeringsgrond voor tenuitvoerlegging onder het EEX? Hof van Justitie EG 2 april 2009 (Marco Gambazzi/Daimler Chrysler Canada Inc. c.s.). Nederlands Internationaal Privaatrecht 27 3:295-301.

Van Bochove, L. (2007). Het ontbreken van de openbare orde-exceptie in de nieuwe generatie Europese procesrechtelijke verordeningen in het licht van artikel 6 lid 1 EVRM. Nederlands Internationaal Privaatrecht 25 4:331-339.

Van Bochove, L. and E. A. Ontanu (2013). Noot bij Hof van Justitie 13 December 2012. Tijdschrift voor Consumentenrecht en Handelspraktijken 2013:285-293.

Van Calster, G. (2013). European Private International law. Hart Publishing, Oxford and Portland, Oregon.

Van der Grinten, P. (2006). Abolishing Exequatur in the European Union: An Alternative. In: Van der Grinten, P. and T. Heukels (eds) (2006). Crossing Borders. Essays in European and Private International Law, Nationality Law and Islamic Law in Honour of Frans van der Velden. Kluwer, Deventer, pp.71-83.

Van Dijk, P. and M. Viering (2006). Right to a fair and public hearing (Article 6)' In: Van Dijk, P. and others (eds). Theory and Practice of the European Convention on Human Rights. Intersentia, Antwerpen/Oxford, pp. 511-650.

Van Dijk, P. and others (eds) (2006). Theory and Practice of the European Convention on Human Rights. Intersentia, Antwerpen/Oxford.

Van Hoecke, M., (2011). Legal Doctrine: Which Method(s) for What Kind of Discipline?. In: Van Hoecke, M. (ed) (2011). Methodologies of Legal 
Research. Which Kind of Method for What Kind of Discipline?. Hart Publishing, Oxford and Portland, Oregon, pp. 1-18.

Van Hoek (2000) Van Hoek, A. (2000). Case C7-98, D. Krombach v. A. Bamberski, Judgment of the Full Court of 28 March 2000. [2000] ECR I-1395. Common Market Law Review 38:1011-1027.

Van Kempen Van Kempen, P.H.P.H.M.C. (2008). Repression through fundamental (2008) rights, inaugural lecture Radboud Universiteit Nijmegen.

Veenbrink and de Veenbrink, J. M. and H. C. F. J. A. De Waele (2013). 58. Hof van Justitie Waele (2013) EU 26 febrauri 2013, nr. C-617/10 (case note). Jurisprudentie Bestuursrecht 2013 4:305-318.

Veldt-Foglia (2013)

Veldt-Foglia, M. I. (2013). Stefano Melloni: grenzen aan de nationale grondwettelijke grondrechtenbescherming bij uitvoering van een EAB. Nederlands Tijdschrift voor Europees Recht 2013 10:399-345.

Venice

Commission

(2007)

Vitkausas and European Commission for Democracy through Law (Venice Commission) Dikov (2012)

Vlaardingerbroek (2014) (2007). Can excessive length of proceedings be remedied?. Council of Europe Publishing, Strasbourg.

Vlas (2013)

Vitkausas, D. and G. Dikov (2012). Protecting the right to a fair trial under the European Convention on Human Rights. Council of Europe, Strasbourg.

Vlaardingerbroek, P. (2014). Internationale Kinderontvoering en het EHRM. Nederlands Internationaal Privaatrecht 32 1:12-19.

Vlas, P. (2013). Public policy in private international law and its continuing importance. In: The Permanent Bureau of the Hague Conference on Private International Law (ed) (2013). A Commitment to Private International Law. Essays in honour of Hans van Loon. Intersentia, Cambridge, p. 621-629.

Vlas (2003) Vlas, P. (2003). (Case note on CJEU Case Case C-38/98 Régie nationale des usines Renault SA $v$ Maxicar SpA and Orazio Formento, ECLI:EU:C:2000:225). Nederlandse Jurisprudentie 2003 no. 627.

Von Hein and Von Hein, J., Rühl, G., (eds.) (2016). Kohärenz im Internationalen PrivatRühl (2016) und Verfahrensrecht der Europäischen Union, Mohr Siebeck, Tübingen, 2016.

Vonken (1993) Vonken, A.P.M.J (1993). De reflexwerking van de mensenrechten op het IPR. In: Cliteur, P.B., Vonken, A.P.M.J, (eds.) (1993). Doorwerking van mensenrechten. Wolters-Noordhoff, Groningen, pp. 153-185.

Von Mehren Von Mehren, A. T. (1981). Recognition and Enforcement of Sister-State (1981) Judgments: Reflections on General Theory and Current Practice in the European Economic Community and the United States. Columbia Law Review 81:1044-1060. 
Weller (2015) Weller, M. (2015). Mutual trust: in search of the future of European Union private international law. Journal of Private International Law 11:64-102.

Wurmnest (2016) Wurmnest, W. (2016). Ordre public (public policy). In: Leible, S. (ed.), General Principles of European Private International Law. Wolters Kluwer, The Netherlands, pp. 305-329.

\section{$\mathbf{Z}$}

Zilinsky (2014) Zilinsky, M., (2014). De herschikte EEX-Verordening: een overzicht en de gevolgen voor de Nederlandse rechtspraktijk. Nederlands Internationaal Privaatrecht 32 1:3-11.

Zilinsky (2011) Zilinsky, M. (2011). Afschaffing van het exequatur onder het voorstel tot herschikking van de EEX-Verordening: een hybride tussenvorm?. Weekblad voor Privaatrecht, Notariaat en Registratie 2011:544-546.

Zilinsky (2006) Zilinsky, M. (2006). Abolishing exequatur in the European Union: the European Enforcement Order. Netherlands International Law Review 53:471-492.

Zilinsky (2005) Zilinsky, M. (2005). De Europese Executoriale Titel: Tijdige tenuitvoerlegging van vermogensrechtelijke beslissingen in de Europese Unie bezien vanuit verschillende internationale instrumenten. Kluwer, Deventer.

Zhang (2013) Zhang, W. (2013). Recognition and Enforcement of Foreign Judgments in China: A Call for Special Attention to Both the "Due Service Requirement" and the "Principle of Reciprocity". Chinese Journal of International Law 12:143-174. 


\title{
List of cases
}

\section{Judgments of the Court of Justice of the European Union}

\author{
Case number Parties \\ ECLI number \\ Case C-112/13 AvB and Others \\ Case C-303/05 Advocaten voor de Wereld VZWv Leden van \\ ECLI:EU:C:2014:2195 \\ de Ministerraad \\ Case C-617/10 ̊klagaren v Hans Åkerberg Fransson \\ ECLI:EU:C:2007:261 \\ Case C-325/11 Alder \\ Case C-519/13 Alpha Bank Cyprus Ltd \\ ECLI:EU:C:2013:280 \\ ECLI:EU:C:2012:824 \\ Case C-420/07 Apostolides v. Orams \\ ECLI:EU:C:2015:603 \\ Case C-283/05 ASML Netherlands BV v Semiconductor \\ ECLI:EU:C:2009:271 \\ Industry Services GmbH (SEMIS) \\ Case C-236/09 Association Belge de Consommateurs Test- \\ Achats \\ Case C-618/10 Banco Español de Crédito SA v Joaquín \\ Calderón Camino \\ Case 185/95 P Baustahlgewebe \\ ECLI:EU:C:2006:787 \\ Case C-84/95 Bosphorus Hava Yollari Turizm ve Ticaret AS \\ $v$ Minister for Transport, Energy and \\ Communications and others \\ Joined Cases C- Brasserie du Pecheur and Factortame \\ $46 / 93$ and C- \\ $48 / 93$ \\ Case 258/83 Brennero v Wendel \\ ECLI:EU:C:1984:363 \\ Case C-562/13 Centre public d'action sociale d'Ottignies- \\ ECLI:EU:C:2014:2453 \\ Louvain-La-Neuve v Moussa Abdida \\ Joined Cases Chronopost and La Poste v UFEX and Others \\ ECLI:EU:C:2008:375 \\ $\mathrm{C}-341 / 06 \mathrm{P}$ and \\ C-342/06 P \\ Case $77 / 83$ \\ CILFIT \\ Joined cases T- \\ Cimenteries CBR and others v. Commission \\ ECLI:EU:C:1984:91 \\ 10/92, T-11/92, \\ ECLI:EU:T:1992:123 \\ $\mathrm{T}-12 / 92$ and $\mathrm{T}-$ \\ $15 / 92$ \\ Case C-396/11 \\ Ciprian Vasile Radu \\ Case C-473/00 Cofidis SA v Jean-Louis Fredout \\ ECLI:EU:C:1998:608 \\ ECLI:EU:C:1996:312 \\ ECLI:EU:C:1996:79 \\ Case C-584/10 \\ Commission v Kadi \\ ECLI:EU:C:2013:39. \\ Case C-101/01 Criminal proceedings against Bodil Lindqvist \\ ECLI:EU:C:2002:705 \\ ECLI:EU:C:2013:518 \\ ECLI:EU:C:2003:596.
}


Case C-309/96 Daniele Annibaldi v Sindaco del Comune di Guidonia and Presidente Regione Lazio

Case C-279/09 DEB

Case 43-75 Defrenne

Case 125/79 Denilauler v SNC Couchet Frères

Case C-385/07 Der Grüne Punkt-Duales System Deutschland $\mathrm{P}$

GmbH $v$ Commission of the European Communities

Case C-681/13 Diageo Brands v Simiramida-04 EOOD

Case C-7/98 Dieter Krombach v André Bamberski

Joined Cases C- Digital Rights Ireland and Seitlinger and 293/12 and C- Others

$594 / 12$

Case C-211/10 Doris Povse v Mauro Alpago

PPU

Joined cases C- eco cosmetics GmbH \& Co. KG v Virginie 119/13 and C- Laetitia Barbara Dupuy and Raiffeisenbank St. $120 / 13$

Georgen reg. Gen. mbH v Tetyana Bonchyk

Case C-126/97 Eco Swiss China Time Ltd vs Benetton International $N \mathrm{~V}$

Case C-260/89 Elliniki Radiophonia Tiléorassi AE and Panellinia Omospondia Syllogon Prossopikou $\checkmark$ Dimotiki Etairia Pliroforissis and Sotirios Kouvelas and Nicolaos Avdellas and others (ERT v DEP)

Case C-341/04 Eurofood IFSC Ltd

Case C-286/12 European Commission v. Hungary

Case C-135/92 Fiskano

Case 314/85 Foto-Frost

Case C-292/10 Gv Cornelius de Visser

Case T-146/04 Gorostiaga Atxandalabaso v. European Parliament

Case C-443/03 Götz Leffler v Berlin Chemie AG

Case C-78/95 Hendrikman and Feyen / Magenta Druck \& Verlag

Case 222/86 Heylens

Joined Cases Hoechst

$46 / 87$ and

$227 / 88$

Case 145/86

Hoffman v Krieg

Hoffman-la Roche
ECLI:EU:C:2015:471

ECLI:EU:C:1997:631

ECLI:EU:C:2010:811

ECLI:EU:C:1976:56

ECLI:EU:C:1980:130

ECLI:EU:C:2009:456

ECLI:EU:C:2000:164

ECLI:EU:C:2014:238

ECLI:EU:C:2010:400

ECLI:EU:C:2014:2144

ECLI:EU:C:1999:269

ECLI:EU:C:1991:254

ECLI:EU:C:2006:281

ECLI:EU:C:2012:687

ECLI:EU:C:1994:267

ECLI:EU:C:1987:452

ECLI:EU:C:2012:142

ECLI:EU:T:2005:584.

ECLI:EU:C:2005:665

ECLI:EU:C:1996:380

ECLI:EU:C:1987:442

ECLI:EU:C:1989:337

ECLI:EU:C:1988:61

ECLI:EU:C:1977:89 
Case C-5/88

Hubert Wachauf v Bundesamt für Ernährung und Forstwirtschaft

Case C-327/10 Hypoteční banka a.s. v Udo Mike Lindner

Case 195/08 Inga Rinau

PPU

Case C-14/07 Ingenieurbüro Michael Weiss und Partner GbR v Industrie- und Handelskammer Berlin

Case T-286/09 Intel Corp. V. Commission

Case 11-70 Internationale Handelsgesellschaft mbH v Einfuhr- und Vorratsstelle für Getreide und Futtermittel

Case C-215/11 Iwona Szyrocka v SiGer Technologie GmbH

Case 222/84 Johnston.

Case C-491/10 Joseba Andoni Aguirre Zarraga v Simone Pelz PPU

Joined Cases C- Kadi and Al Barakaat International 402/05 P and C- Foundation v Council and Commission $415 / 05 \mathrm{P}$

Case T-85/09 Kadiv Commission and Council

Case C-25/02 Katharina Rinke $v$ Ärztekammer Hamburg

Case C-249/13 Khaled Boudjlida v Préfet des PyrénéesAtlantiques

Case 294/83 Les Verts

Case C-44/79 Liselotte Hauer v Land Rheinland-Pfalz

Case C-32/95 P Lisrestal

Case T-23/99 LR af

Case C-394/07 Marco Gambazzi v. DaimlerChrysler Canada Inc. and CIBC Mellon Trust Company.

Case C-362/14 Maximillian Schrems $v$ Data Protection Commissioner

Case 322-81 Michelin

Case C-123/91 Minalmet GmbH v Brandeis Ltd

Joined Cases N.S. and M.E. and others

C-411/10 and

C- $493 / 10$

Case $4 / 73$

Nold v Commission

Case C-324/12 Novontech-Zala

Case C-36/02 Omega Spielhallen

Case C-305/05 Ordre des barreaux francophones et germanophone and Others $v$. Conseil des Ministres

Case C-374/87 Orkem

Otis
ECLI:EU:C:1989:321

ECLI:EU:C:2011:745, ECLI:EU:C:1998:608

ECLI:EU:C:2008:264

ECLI:EU:T:2014:547

ECLI:EU:C:1970:114

ECLI:EU:C:2012:794

ECLI:EU:C:1986:206

ECLI:EU:C:2010:828

ECLI:EU:C:2008:461

ECLI:EU:T:2010:418

ECLI:EU:C:2003:435

ECLI:EU:C:2014:2431

ECLI:EU:C:1986:166

ECLI:EU:C:1979:290

ECLI:EU:C:1996:402

ECLI:EU:T:2002:75

ECLI:EU:C:2009:219

ECLI:EU:C:2015:650

ECLI:EU:C:1983:313

ECLI:EU:C:1992:432

ECLI:EU:C:2011:865

ECLI:EU:C:1974:51

ECLI:EU:C:2013:205

ECLI:EU:C:2004:614

ECLI:EU:C:2007:383

ECLI:EU:C:1989:387

ECLI:EU:C:2012:684 
$404 / 15$ and C-

659/15 PPU

Case 228/81 Pendy Plastic Products BV v Pluspunkt ECLI:EU:C:1982:276

$\begin{array}{ll} & \text { Handelsgesllschaft GmbH } \\ \text { Case 166/80 } & \text { Peter Klomps v Karl Michel }\end{array}$

ECLI:EU:C:1981:137

Case C-473/04 Plumex V Young Sports NV

ECLI:EU:C:2006:96

Case C-139/10 Prism Investments v. Jaap Anne van der Meer

ECLI:EU:C:2011:653

Joined Cases C- Rechnungshof (C-465/00) v Österreichischer

465/00, C-

Rundfunk and Others and Christa Neukomm

ECLI:EU:C:2003:294

138/01 and C- (C-138/01) and Joseph Lauermann (C-139/01)

139/01 v Österreichischer Rundfunk

Case C-38/98 Régie nationale des usines Renault SA v

ECLI:EU:C:2000:225 Maxicar SpA and Orazio Formento

Case 30/77 Regina v. Pierre Bouchereau

ECLI:EU:C:1977:172

Case $120 / 78$

Rewe-Zentral $A G$

$v$

Bundesmonopolverwaltung für Branntwein

Case C-94/00

Roquette Frères

ECLI:EU:C:1979:42

Case 36-75 Rutili

Case C-414/92 Solo Kleinmotoren GmbH v Emilio Boch

ECLI:EU:C:2002:603

ECLI:EU:C:1975:137

ECLI:EU:C:1994:221

Case 29-69 Stauder

Case C-399/11 Stefano Melloni v. Ministerio Fiscal

ECLI:EU:C:1969:57

Case C-235/99 The Queen v Secretary of State for the Home

ECLI:EU:C:2013:107.

ECLI:EU:C:2001:489

Department, ex parte Eleanora Ivanova

Kondova

Case C-245/14 Thomas Cook Belgium NV v Thurner Hotel $\mathrm{GmbH}$

Case C-619/10 Trade Agency Ltd v Seramico Investments Ltd

Case 17-74 Transoceanic Marine Paint Association

Case C-159/02 Turnerv Grovit

Case C-437/13 Unitrading

Case C-450/06 Varec SA v Belgian State

Case C-172/91 Volker Sonntag v Hans Waidmann

Joined Cases C- Volker und Schecke

92/09 and C-

93/09

Case C-508/12 Walter Vapenik v Josef Thurner

Cases C-402 Yassin Abdullah Kadi and Al Barakaat

ECLI:EU:C:2013:790

and 415/05 P International Foundation $v$ Council and

ECLI:EU:C:2008:461

Commission

Joined Cases C- Zuckerfabrik

ECLI:EU:C:1991:65

$134 / 88$ and C-

$92 / 89$ 


\section{Opinions of the Court of Justice of the European Union}

Opinion 2/13 of the Court (Full Court) of 18 December 2014, ECLI:EU:C:2014:2454.

\section{Judgments of the Civil Service Tribunal}

Case F-40/05, Marta Andreasen v Commission of the European Communities, ECLI:EU:F:2007:189.

\section{Judgments of the General Court}

Case T-17/08 P, Marta Andreasen v European Commission, ECLI:EU:T:2010:374.

\section{Advocate Generals' Opinions}

View of Advocate General Bot, delivered on 7 December 2010, Case C-491/10 PPU, Joseba Andoni Aguirre Zarraga v. Simone Pelz.

View of Advocate General Bot, delivered on 9 April 2014, Joined Cases C-119/13 to C-121/13 eco cosmetics GmbH \& Co. KG (C-119/13) v Virginie Laetitia Barbara Dupuy, Raiffeisenbank St. Georgen reg. Gen. mbH (C-120/13) v Tetyana Bonchyk and Rechtsanwaltskanzlei CMS Hasche Sigle, Partnerschaftsgesellschaft (C-121/13) v Xceed Holding Ltd, ECLI:EU:C:2014:248.

\section{Judgments and decisions of the European Court of Human Rights}

Name

Baka v. Hungary (merits)

Deweer v. Belgium

A. Menarini Diagnostics S.R.L. v. Italy

A.B. v. Slovakia

Agrokompleks v. Ukraine (merits)

Airey v. Ireland

Alaverdyan v. Armenia (dec.)

Albu and others v. Romania

Andelkovic v. Serbia

$\begin{aligned} & \text { Application } \\ & \text { number }\end{aligned}$
$20261 / 12$
$6903 / 75$
$43509 / 08$
$41784 / 98$
$23465 / 03$
$6289 / 73$
$4523 / 04$
$34796 / 09$ and 63
other cases
$1401 / 08$

Reported

27 May 2014

ECHR A35

27 September 2011

4 March 2003

6 October 2011

ECHR A32

24 August 2010

$10 / 05 / 2012$

9 April 2013 
Andreasen v. the United Kingdom and 26 other Member States of the European

Union (dec).

Ankerl v. Switzerland

Apeh Uldozotteinek Szovetsege and others $v$. Hungary

Ashingdane v. UK

Aslaner v. Turkey

Avotins v. Latvia

Avotins v. Latvia [GC]

Axen v. Germany

$B$ and $P$ v. UK

Barberà, Messegué and Jabardo v.

Spain

Beaumartin v.France

Beer v. Austria

Benthem v. Netherlands

Biryukov v. Russia

Blumberga v. Latvia

Borovská and Ferrai v. Slovakia

Bosphorus Hava Yollari Turizm ve

Ticaret Anonim Sirketi v. Ireland

Brudnicka and others v. Poland

Brumarescu v. Romania [GC]

Bucuria v. Moldova

Burdov v. Russia

Buscemi v. Italy

Campbell and Fell v. UK

Cantoni v. France [GC]

Centro Europa 7 S.R.L. and Di Stefano

v. Italy [GC]

Cepek v. Czech Republic

Clinique des Acacias and others $v$.

France

Colozza v. Italy

Comingersol S.A. v Portugal [GC]

Coöperatieve Producentenorganisatie

van de Nederlandse kokkelvisserij e.a. v.

Netherlands [dec.]

Cooperative des Agriculteurs de

Mayenne et la Cooperative Laitière

Maine-Anjou v. France [dec.]

D. v. Ireland [dec.]

De Cubber v. Belgium (merits)
17748/91

28827/11

31 March 2015

$32367 / 96$

ECHR 1996-V

ECHR 2000-X

$8225 / 78$

ECHR A93

36073/04

4 March 2014

17502/07

25 February 2014

17502/07

23 May 2016

$8273 / 78$

ECHR A72

$36337 / 9735974 / 97$

ECHR 2001-III

10590/83

ECHR A146

$15287 / 89$

ECHR A296-B

$30428 / 96$

6 February 2001

$5548 / 80$

ECHR A97

14810/02

70930/01

ECHR 2008-I

14 October 2008

$48554 / 10$

$45036 / 98$

$54723 / 00$

28342/95

10758/05

59498/00

29569/95

7819/77 7878/77

17862/91

38433/09

25 November 2014

ECHR 2005-VI

ECHR 2005-II

ECHR 2001-I

5 January 2010

ECHR 2002-III

ECHR 1999-VI

ECHR A80

ECHR 1996-V

ECHR 2012

9815/10

5 September 2013

65399/01 65405/01

$65407 / 01$ 65406/01

9024/80

13 October 2005

$35382 / 97$

$65542 / 12$

ECHR A89

ECHR 2000-IV

ECHR 2009-I

16931/04

ECHR 2006-XV

26499/02

27 June 2006

$9186 / 80$

ECHR A124-B 
De Haan v. The Netherlands

Delcourt v. Belgium

Delcourt v. Belgium

Demicoli v. Malta

Dhahbi v. Italy

Dilipak and Karakaya v. Turkey

Dilipak and Karakaya v. Turkey

DMD Group v. Slovakia

Dombo Beheer B.V. v. the Netherlands

Döry v Sweden

Drozd and Janousek $v$ France and Spain

[GC]

Edwards and Lewis v. UK

Eliazer v. the Netherlands

Engel $v$ Netherlands (merits)

Erkner and Hofauer v. Austria

Esertas v. Lithuania

F.C.B. v. Italy

F.C.B. v. Italy

Feldbrugge $v$ the Netherlands (merits)

Fey v. Austria

Findlay v. UK

Fischer $v$ Austria

Frydlender v France

Fuklev v. Ukraine

Garcia Mateos v. Spain

Garcia Ruiz v. Spain

Gautrin and Others v. France

Georgiadis v Greece

Georgiadis v Greece

Gerasimov v. Russia

Göç v. Turkey

Godlevskiy v Russia

Godorozea v. Moldova

Godorozea v. Moldova

Golder v. UK

Guincho v. Portugal

H. v France
$22839 / 93$

$2689 / 65$

$2689 / 65$

$13057 / 87$

17120/09

7942/05 24838/05

$7942 / 05$ 24838/05

$19334 / 03$

$14448 / 88$

28394/95

$12747 / 87$

$39647 / 9840461 / 98$

$38055 / 97$

$5100 / 715101 / 71$

$5102 / 715354 / 72$

$5370 / 72$

9616/81

50208/06

$12151 / 86$

$12151 / 86$

$8562 / 79$

$14396 / 88$

$22107 / 93$

$33382 / 96$

30979/96

$71186 / 01$

38285/09

30544/96

21257/93 21258/93

21259/93 21260/93

21522/93

21522/93

29920/05 and 10

other cases

36590/97

14888/03

17023/05

17023/05

$4451 / 70$

$8990 / 80$

$10073 / 82$
ECHR 1997-IV

ECHR A11

ECHR A11

ECHR A210

8 April 2014

ECHR 2014

ECHR 2014

5 October 2010

ECHR A274

12 November 2002

ECHR 1992

ECHR 2004-X

ECHR 2001-X

ECHR A22

ECHR A117

31 May 2012

ECHR A208-B

ECHR A208-B

ECHR A99

ECHR A255-A

ECHR 1997-I

17 January 2002

ECHR 2000-VII

7 June 2005

19 February 2013

ECHR 1999-I

ECHR 1998-III

ECHR 1997-III

ECHR 1997-III

1 July 2014

ECHR 2002-V

23 October 2008

ECHR 2009

ECHR 2009

ECHR A18

ECHR A81

ECHR A162-A 


\begin{tabular}{|c|c|c|}
\hline H. v. Belgium & $8950 / 80$ & ECHR A127-B \\
\hline H. v. the United Kingdom & $9580 / 81$ & ECHR A120 \\
\hline Hadjanastassiou v. Greece & $12945 / 87$ & ECHR A252 \\
\hline Hadjianastassiou v Greece & & ECHR A252 \\
\hline Handyside v. UK & $5493 / 72$ & ECHR A24 \\
\hline Helmers v. Sweden & $11826 / 85$ & ECHR A212-A \\
\hline Hennings v. Germany & $12129 / 86$ & ECHR A251-A \\
\hline Hermi v. Italy & $18114 / 02$ & ECHR 2006-XII \\
\hline Hiro Balani v. Spain & $18064 / 91$ & A303-B \\
\hline Hirvisaari v. Finland & $49684 / 99$ & 27 September 2001 \\
\hline Hokkanen v. Finland & $19823 / 92$ & ECHR A299-A \\
\hline Hornsby v. Greece & $18357 / 91$ & ECHR 1997-II \\
\hline Hornsby v. Greece & $18357 / 91$ & ECHR 1997-II \\
\hline Humen v. Poland [GC] & $26614 / 95$ & 15 September 1999 \\
\hline Immeuble Groupe Kosser v. France & $38748 / 97$ & 21 March 2002 \\
\hline Indra v. Slovakia & $46845 / 99$ & \\
\hline Jacobsson v. Sweden (no. 2) & $16970 / 90$ & ECHR 1998-I \\
\hline Jahnke and Lenoble v. France [déc.] & $40490 / 98$ & ECHR 2000-IX \\
\hline Jolie and Lebrun v. Belgium & $11418 / 85$ & 14 May 1986 \\
\hline Jussila v. Finland (merits) & $73053 / 01$ & ECHR 2006-XIV \\
\hline K.H. and others v. Slovakia & $32881 / 04$ & ECHR 2009-II \\
\hline K.R.S. v. United Kingdom & $32733 / 08$ & $02 / 12 / 2008$ \\
\hline Katte Klitsche de la Grange v. Italy & $12539 / 86$ & ECHR A293-B \\
\hline $\begin{array}{l}\text { Kenzie Global Limited Ltd. B. Republic } \\
\text { of Moldova }\end{array}$ & $287 / 07$ & 8 April 2014 \\
\hline Kerojärvi v. Finland & $17506 / 90$ & ECHR A322 \\
\hline Kerojärvi v. Finland & $17506 / 90$ & ECHR A322 \\
\hline Khamidov v. Russia & $72118 / 01$ & 15 November 2007 \\
\hline Khuzhin v. Russia & $13470 / 02$ & 23 October 2008 \\
\hline Kienast v. Austria & $23379 / 94$ & 23 January 2003 \\
\hline König v. Germany & $6232 / 73$ & ECHR A27 \\
\hline Kostovski v. The Netherlands (merits) & $11454 / 85$ & A166 \\
\hline Kotov v Russia & $54522 / 00$ & 3 March 2012 \\
\hline Kraska v. Switzerland & $13942 / 88$ & ECHR A254-B \\
\hline Krcmar and others $v$ Czech Republic & $35376 / 97$ & 3 March 2000 \\
\hline Kreuz v. Poland & $28249 / 95$ & ECHR 2001-VI \\
\hline Kudla v. Poland & $30210 / 96$ & ECHR 2000-XI \\
\hline Kyprianou v. Cyprus & $73797 / 01$ & ECHR 2005-XIII \\
\hline La Société Établissements Biret et Cie & $13762 / 04$ & 9 December 2008 \\
\hline
\end{tabular}




\begin{tabular}{|c|c|c|}
\hline Lawyers Partners A.S v. Slovakia & $54252 / 07$ & ECHR 2009 \\
\hline $\begin{array}{l}\text { Le Compte, Van Leuven and De Meyere } \\
\text { v. Belgium [merits] }\end{array}$ & $6878 / 757238 / 75$ & ECHR A43 \\
\hline Lhermitte v. Belgium & $34238 / 09$ & 26 May 2015 \\
\hline Lindberg v. Sweden [dec.] & $48198 / 99$ & 15 January 2004 \\
\hline $\begin{array}{l}\text { Loizidou v. Turkey (preliminary } \\
\text { objections) }\end{array}$ & $15318 / 89$ & ECHR 1995. \\
\hline Lorenzetti v Italy & $32075 / 09$ & 10 April 2012 \\
\hline M.S.S. v. Belgium and Greece & $30696 / 09$ & ECHR 2011-I \\
\hline Malhous v. Czech Republic [GC] & $33071 / 96$ & ECHR 2000-XII \\
\hline Malmberg and Others v. Russia & $\begin{array}{l}23045 / 0521236 / 09 \\
17759 / 1048402 / 10\end{array}$ & 15 January 2015 \\
\hline Marinkovic v Serbia & $5353 / 11$ & 22 October 2013 \\
\hline Martinie v France [GC] & $58675 / 00$ & ECHR 2006-VI \\
\hline $\begin{array}{l}\text { Matrakas and others v. Poland and } \\
\text { Greece }\end{array}$ & $47268 / 06$ & 7 November 2013 \\
\hline Matthews v. United Kingdom [GC] & $24833 / 94$ & ECHR 1999-I \\
\hline McDonald v. France [dec.] & $18648 / 04$ & 29 April 2008 \\
\hline McMichael v. UK & $16424 / 90$ & ECHR A307-B \\
\hline Micallef v. Malta $[\mathrm{GC}]$ & $17056 / 06$ & ECHR 2009-V \\
\hline Michaud v. France & $12323 / 11$ & ECHR 2012-VI \\
\hline Mifsud [dec.] & $57220 / 00$ & ECHR 2002-VIII \\
\hline Miller v Sweden & $55853 / 00$ & 8 February 2005 \\
\hline Mincheva v. Bulgaria & $21558 / 03$ & 2 September 2010 \\
\hline Mizzi v. Malta & $26111 / 02$ & ECHR 2006-I \\
\hline Morel v. France & $34130 / 96$ & ECHR 2000-VI \\
\hline Morel v. France & $34130 / 96$ & ECHR 2000-VI \\
\hline Moser v. Austria & $12643 / 02$ & 21 September 2006 \\
\hline Muyldermans v. Belgium & $12217 / 86$ & ECHR A214-A \\
\hline Négrépontis-Giannisis (merits) & $56759 / 08$ & 3 May 2011 \\
\hline Nesevski v. FYR Macedonia & $14438 / 03$ & 24 April 2008 \\
\hline Neulinger and Shuruk v. Switzerland & $41615 / 07$ & ECHR 2010 \\
\hline Nideröst-Huber v. Switzerland & $18990 / 91$ & ECHR 1997-I \\
\hline Niederböster v. Germany & $39547 / 98$ & ECHR 2003-IV \\
\hline Niemietz v. Germany & $13710 / 88$ & ECHR A251-B \\
\hline Nikitin v. Russia & $50178 / 99$ & ECHR 2004-VIII \\
\hline Nortier $v$. the Netherlands & $13924 / 88$ & ECHR A267 \\
\hline Nosov v. Russia & $9117 / 0410441 / 04$ & 20 February 2014 \\
\hline Ökten v. Turkey [dec.] & $22347 / 07$ & 3 November 2011 \\
\hline Pafitis and Others v. Greece & $20323 / 93$ & ECHR 1998-I \\
\hline
\end{tabular}




\begin{tabular}{|c|c|c|}
\hline Papachelas v. Greece & $31423 / 96$ & ECHR 1999-II \\
\hline Pellegrini v. Italy & $30882 / 96$ & ECHR 2001-VIII \\
\hline Perezv. France & $47287 / 99$ & ECHR 2004-I \\
\hline Perez v. France $[\mathrm{GC}]$ & $47287 / 99$ & ECHR 2004-I \\
\hline Perez v. Germany & $15521 / 08$ & 6 January 2015 \\
\hline Petroff v. Finland & $31021 / 06$ & 3 November 2009 \\
\hline Piersack v. Belgium (merits) & $8692 / 79$ & ECHR A53 \\
\hline Platakou v. Greece & $38460 / 97$ & ECHR 2001-I \\
\hline Podbielski and PPU Polpure v. Poland & $39199 / 98$ & 26 July 2005 \\
\hline Poiss v. Austria & $9816 / 82$ & ECHR A117 \\
\hline Poitromol v. France & $14032 / 88$ & ECHR A277-A \\
\hline Povse v. Austria [dec.] & $3890 / 11$ & ECHR 2013 \\
\hline Pravednaya v. Russia & $69529 / 01$ & 18 November 2004 \\
\hline Pretto v. Italy & $7984 / 77$ & ECHR A71 \\
\hline Procola v. Luxembourg & $14570 / 89$ & ECHR A326 \\
\hline Riepan v. Austria & $35115 / 97$ & ECHR 2000-XII \\
\hline Ringeisen v. Austria & $2614 / 65$ & ECHR A13 \\
\hline Romanczyk v. France & $7618 / 05$ & 18 November 2010 \\
\hline Rowe and Davis $v$ The United Kingdom & $28901 / 95$ & ECHR 2000-II \\
\hline Ruiz Torija v. Spain & $18390 / 91$ & ECHR A303-A \\
\hline Ruiz-Mateos v. Spain & $12952 / 87$ & ECHR A262 \\
\hline Russu v. Moldova & $7413 / 05$ & 13 November 2008 \\
\hline Saccoccia v. Austria & $69917 / 01$ & 18 December 2008 \\
\hline Sahin v. Germany & $30943 / 96$ & ECHR 2003-VIII \\
\hline Salomonsson v Sweden & $38978 / 97$ & 12 November 2002 \\
\hline San Leonard Band Club v. Malta & $77562 / 01$ & ECHR 2004-IX \\
\hline Sanglier v. France & $50342 / 99$ & 27 May 2003 \\
\hline Saraiva de Carvalho v. Portugal & $15651 / 89$ & ECHR A286-B \\
\hline Saunders v. United Kingdom & $19187 / 91$ & ECHR 1996-VI \\
\hline Schalk and Kopf v Austria & $30141 / 04$ & ECHR 2010 \\
\hline Schenk v. Switzerland & $10862 / 84$ & ECHR A140 \\
\hline Schuler-Zgraggen v. Austria & $14518 / 89$ & 31 January 1995 \\
\hline Scollo v. Italy & $19133 / 91$ & ECHR A315-C \\
\hline Sejdovic v Italy & $56581 / 00$ & ECHR 2006-II \\
\hline Sergey Smirnov v. Russia & $14085 / 04$ & 22 December 2009 \\
\hline Sigurdsson v. Iceland & $39731 / 98$ & ECHR 2003-IV \\
\hline Šneersone and Kampanella v. Italy & $14737 / 09$ & 12 July 2011 \\
\hline Société Cofinfo v. France & $23516 / 08$ & 12 October 2010 \\
\hline Soering v. United Kingdom $[\mathrm{GC}]$ & $14038 / 88$ & ECHR 1989 \\
\hline
\end{tabular}




\begin{tabular}{|c|c|c|}
\hline Speil v. Austria [dec.] & $42057 / 98$ & 5 September 2002 \\
\hline Sramek v.Austria & $8790 / 79$ & ECHR A84 \\
\hline Steel and Morris v. UK & $68416 / 01$ & ECHR 2005-II \\
\hline Stögmüller v Austria & $1602 / 62$ & ECHR A9 \\
\hline Sud Est Réalisations v. France & $6722 / 05$ & 2 December 2010 \\
\hline Suominen v. Finland & $37801 / 97$ & 1 July 2003 \\
\hline Sürmerli v. Germany & $75529 / 01$ & ECHR 2006-VII \\
\hline T.I. v. United Kingdom [dec.] & $43844 / 98$ & ECHR 2000-III \\
\hline Tarakhel v. Switzerland [GC] & $29217 / 12$ & ECHR 2014 \\
\hline Tatishvili v. Russia & $1509 / 02$ & ECHR 2007-I \\
\hline Tolstoy Miloslavski v. UK & $18139 / 91$ & 20 February 1992 \\
\hline Tsikakis v. Germany & $1521 / 06$ & 10 February 2011 \\
\hline Unión Alimentaria Sanders S.A. v. Spain & $11681 / 85$ & ECHR A157 \\
\hline$V v$ Finland & $40412 / 98$ & 24 April 2007 \\
\hline V. v. United Kingdom $[\mathrm{GC}]$ & $24888 / 94$ & 1999-IX \\
\hline Vallauri v. Italy & $39128 / 05$ & 20 October 2009 \\
\hline Valová and others v. Slovakia. & $44925 / 98$ & 1 June 2004 \\
\hline Van der Hurk v. Netherlands & $16034 / 90$ & ECHR A288 \\
\hline Van Marle v. The Netherlands & 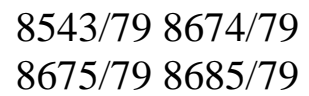 & ECHR A101 \\
\hline Varela Assalino v. Portugal [dec.] & $64336 / 01$ & 25 April 2002 \\
\hline Vergauwen and others v. Belgium & $4832 / 04$ & 10 April 2012 \\
\hline Vernillo v. France & $11889 / 85$ & ECHR A198 \\
\hline Vocaturo v. Italy & $11891 / 85$ & ECHR A206-C \\
\hline Von Hannover v. Germany & $59320 / 00$ & ECHR 2004-VI \\
\hline Vrbica v. Croatia & $32540 / 05$ & \\
\hline Weissman and Others v. Romania & $63945 / 00$ & ECHR 2006-VII \\
\hline Weissman v. Romania & $63945 / 00$ & ECHR 2006-VII \\
\hline Wiesinger v. Austria & $11796 / 85$ & ECHR A213 \\
\hline Wynen v Belgium & $32576 / 96$ & ECHR 2002-VIII \\
\hline$X v . U K$ & $7366 / 76$ & 2 Digest 452 (1977) \\
\hline X. v. Latvia & 27853/09 & ECHR 2013 \\
\hline Yakovlev v. Russia & $72701 / 01$ & 15 March 2005 \\
\hline Yvon v. France & $44962 / 98$ & ECHR 2003-V \\
\hline Zagrebacka banka v. Croatia & $39544 / 05$ & 12 December 2013 \\
\hline Zavodnik v. Slovenia & $36261 / 08$ & ECHR 2013 \\
\hline Zavodnik v. Slovenia & $36261 / 08$ & ECHR 2013 \\
\hline
\end{tabular}

Decisions of the European Commission of Human Rights 


\begin{tabular}{|c|c|c|}
\hline Bricmont v. Belgium & $9938 / 82$ & D.R. 48 p. 28 \\
\hline Guenoun v. France [dec.] & $13562 / 88$ & D.R. No. 66 p. 184 \\
\hline Imberechts v. Belgium [dec.] & $15561 / 89$ & D.R. No 69, p. 314 \\
\hline $\begin{array}{l}M \& \text { Co. v. Federal Republic of Germany } \\
\text { [dec.] }\end{array}$ & $13258 / 87$ & D.R. No. 64 , p. 138 \\
\hline Procola v. Luxembourg [dec.] & $14570 / 89$ & 28 September 1995 \\
\hline$X v$. Belgium & $7450 / 46$ & D.R. 9 p. 108 \\
\hline X. v. Germany (dec.) & $1169 / 61$ & 24 September 1963 \\
\hline X.v. Sweden (dec.) & $434 / 58$ & 30 June 1959 \\
\hline$X$ and $Y v$. Austria & $9099 / 80$ & DR 27, p. 209 \\
\hline$X v$. France & $9993 / 82$ & DR 31, p. 241 \\
\hline X.v. Switzerland & $8257 / 78$ & DR 13, p. 248 \\
\hline
\end{tabular}

\section{National case law}

\section{The Netherlands}

Hoge Raad 22 April 1983, Ritzen v. Hoekstra, ECLI:NL:HR:1983:AG4575.

Hoge Raad 5 April 2002, ECLI:NL:HR:2002:AD9145.

Hoge Raad 3 March 2006, ECLI:NL:HR:2006:AU8179.

Hoge Raad 27 June 2008, ECLI:NL:PHR:2008:BD2007.

Hoge Raad 18 March 2011, ECLI:NL:HR:2011:BP0003.

Rechtbank Alkmaar, 7 June 1984, Nederlands Internationaal Privaatrecht 1984, 282.

Rechtbank Groningen, 3 November 2006, ECLI:NL:RBGRO:2006:AZ7764.

Rechtbank Dordrecht 24 May 2006, ECLI:NL:RBDOR:2006:AX2008.

Rechtbank Den Haag 23 December 2008, ECLI:NL:RBSGR:2008:BG9144.

Rechtbank Haarlem 25 April 2008, ECLI:NL:RBHAA:2008:BD0602.

Rechtbank Middelburg 23 September 2009, ECLI:NL:RBMID:2009:BK9209.

Rechtbank Den Haag 6 March 2009, ECLI:NL:RBSGR:2009:BJ0317.

Rechtbank Den Haag 10 April 2009, ECLI:NL:RBSGR:2009:BJ1995.

Rechtbank 's Hertogenbosch 9 September 2009, ECLI:NL:RBSHE:2009:BJ7558

Rechtbank Haarlem 15 December 2009, ECLI:NL:RBHAA:2009:BK6667

Rechtbank Middelburg 1 September 2010, ECLI:NL:RBMID:2010:BN9802.

Rechtbank Haarlem, 7 September 2010, Nr. F. 172470.

Gerechtshof Amsterdam 10 April 2012, ECLI:NL:GHAMS:2012:BW1284. 
Gerechtshof Amsterdam 28 April 2009, ECLI:NL:GHAMS:2009:BI2451, Yukos Capital v. Rosneft.

Rechtbank Rotterdam 25 March 2015, ECLI:NL:RBROT:2015:2487.

England and Wales

Court of Appeal, 29 March 2002, Unanimous opinion by Lord Philips MR - Maronier v. Larmer.

Re Stojevic v Official Receiver, [2007] BPIR 141.

\section{France}

Cour de cassation, chambre civile 2, Audience publique du vendredi 6 janvier 2012 No 10/23518.

Cour d'appel Colmar 25 March 2004, No 02/04955.

Cour d'appel Versailles, 5 July 2006, No 05/04718.

Cour d'appel Versailles, 21 december 2006, No 06/03801.

Cour d'appel Reims, 7 May 2007, No 06/01161.

Theillol v Office de la Jeunesse de Fribourg, Journal de Droit International 1979, p. 383.

Cozzi v Dame Capurro et autres, Bull. Cass. 1979, Part I, no. 286

\section{Germany}

Bundesgerichtshof 12 December 2007, XII ZB 240/05

Oberlandesgericht Zweibrücken 10.05.2005, 3 W 165/04.

Bundesgerichtshof 26 August 2009, XII ZB 169/07.

Oberlandesgericht Celle, 30 September 2010, 18 UF 67/10.

Amtsgericht Düsseldorf 07 April 2004, 502 IN 124/03.

Amtsgericht Nürnberg 15 August 2006, 8004 IN 1326.

Amtsgericht Düsseldorf 12 March 2004, 502 IN 126/03.

Amtsgericht Deggendorf 12 February 2007, 1 IK 255/03.

Amtsgericht Düsseldorf 6 June 2003, 502 IN 126/03.

Landesarbeitsgericht Hessen 14 December 2010, 13 Sa 969/10.

Italy

Corte d'appello di Milano, September 29, 1978, Jure id: 38703.

Corte d'Appello di Napoli, February 20, 1982, Trans-Atlantica s.p.a./Soc. Vertom Shipping and Trading Corporation B.V.

Corte d'appello di Milano, Section I, 14 December 2010, Gambazzi. 


\section{Portugal}

Suprema Tribunal de Justica, Ac STJ pf 22 September 2005.

Lisbon Court of Appeal, 20 January 2009, RP 10097/2008-7, N. 4-6.

Finland

Helsinki Court of Appeal 13-05-2009 S 09/357.

Sweden

Göta Hovrätt case Ö 3222-07.

Svea Hovrätt case Ö 4988-08.

Greece

Areios Pagos Court decision number 1829/2006, 25 October 2006.

Spain

Tribunal Constitucional, judgment of 28 September 2009, STC 199/2009. 


\section{Overview of legislation}

\section{Treaties}

Charter of Fundamental Rights of the European Union, OJ C 326/391, 2012.

Consolidated version of the Treaty on European Union, OJ C 326/13.

Consolidated version of the Treaty on the Functioning of the European Union, OJ C $83 / 47$.

Convention of 25 October 1980 on the Civil Aspects of International Child Abduction (Hague Child Abduction Convention).

Convention of 27 September 1968 on Jurisdiction and the Recognition and Enforcement of Judgments in Civil and Commercial Matters, done at Brussels on 27 September 1968.

Convention on jurisdiction and the enforcement of judgments in civil and commercial matters, done at Lugano on 16 September 1988.

Convention on the Rights of the Child, Adopted and opened for signature, ratification and accession by General Assembly resolution 44/25 of 20 November 1989 entry into force 2 September 1990, in accordance with article 49 (United Nations Convention on the Rights of the Child).

New York Convention of 20 June 1956 on the Recovery Abroad of Maintenance (New York Convention).

Protocol of 23 November 2007 on the Law Applicable to Maintenance Obligations.

Treaty Establishing the European Community (Amsterdam consolidated version), OJ C340/173, 1997.

Treaty Establishing the European Economic Community, Rome 1957, OJ 25 March 1957.

Convention for the Protection of Human Rights and Fundamental Freedoms, done at Rome on 4 November 1950.

Protocol to the Convention for the Protection of Human Rights and Fundamental Freedoms, done at Paris, 20 March 1952 (First Protocol).

Agreement between the European Community and the Kingdom of Denmark on jurisdiction and the recognition and enforcement of judgments in civil and commercial matters, OJ L 79/4, 31 March 2013. 


\section{European Union Regulations}

Council Regulation (EC) 2201/2003 of 27 November 2003 concerning jurisdiction and recognition and enforcement of judgments in matrimonial matters and matters of parental responsibility, OJ L 338/1 ('Brussels IIbis Regulation').

Council Regulation (EC) 4/2009 of 18 December 2009 on jurisdiction, applicable law, recognition and enforcement of decisions and cooperation in matters relating to maintenance obligations, OJ L7/1 ('Maintenance Regulation').

Council Regulation (EC) No 1206/2001 of 28 May 2001 on cooperation between the courts of the Member States in the taking of evidence in civil or commercial matters ('Evidence Regulation').

Council Regulation (EC) No 1346/2000 of 29 May 2000 on insolvency proceedings ('Insolvency Regulation').

Council Regulation (EC) No 1347/2000 of 29 May 2000 on jurisdiction and the recognition and enforcement of judgments in matrimonial matters and in matters of parental responsibility for children of both spouses, OJ L 160/19 (Brussels II Regulation').

Council Regulation (EC) No 44/2001 of 22 December 2000 on Jurisdiction and the Recognition and Enforcement of Judgments, OJ L 12/1 ('Brussels I Regulation').

Council Regulation (EC) No. 343/2003 of 18 February 2003 establishing the criteria and mechanisms for determining the Member State responsible for examining an asylum application lodged in one of the Member States by a third-country national, OJ L 50/01 (the "Dublin II Regulation").

Regulation (EU) No 604/2013 of the European Parliament and of the Council of 26 June 2013 establishing the criteria and mechanisms for determining the Member State responsible for examining an application for international protection lodged in one of the Member States by a third-country national or a stateless person, OJ L 180/31 (the 'Dublin III Regulation').

Council Regulation (EU) 1215/2012 of 12 December 2012 on jurisdiction and the recognition and enforcement of judgments in civil and commercial matters (recast), OJ L 351/1 ('Brussels Ibis Regulation').

Regulation (EC) No 1393/2007 of the European Parliament and of the Council of 13 November 2007 on the service in the Member States of judicial and extrajudicial documents in civil or commercial matters (service of documents), and repealing Council Regulation (EC) No 1348/2000, OJ L 324/79 ('Service Regulation').

Regulation (EC) No 1896/2006 of the European Parliament and the Council of 12 December 2006 creating a European Order for Payment Procedure, OJ L 399/1 ('EOP Regulation').

Regulation (EC) No 593/2008 of the European Parliament and of the Council of 17 June 2008 on the law applicable to contractual obligations (Rome I) OJ L 177/6 ('Rome I Regulation').

Regulation (EC) No 805/2004 of the European Parliament and of the Council of 21 April 2004 creating a European Enforcement Order for uncontested claims, OJ L 134/15 (the 'EEO Regulation'). 
Regulation (EC) No 861/2007 of the European Parliament and the Council of 11 July 2007 establishing a European Small Claims Procedure, OJ L 199/1 (the 'ESCP Regulation').

Regulation (EC) No 864/2007 of the European Parliament and of the Council of 11 July 2007 on the law applicable to non-contractual obligations ('Rome II Regulation'), OJ L $199 / 40$.

Regulation (EU) 2015/... of the European Parliament and of the Council of 20 May 2015 on insolvency proceedings (recast), 2012/0360 (COD) LEX 1607, PE-CONS 31/15 (not yet published in the Official Journal) ('recast Insolvency Regulation').

Regulation (EU) 2015/2421 of the European Parliament and of the Council of 16 December 2015 amending Regulation (EC) No 861/2007 establishing a European Small Claims Procedure and Regulation (EC) No 1896/2006 creating a European order for payment procedure, OJ L 341/1.

Regulation (EU) No 655/2014 of the European Parliament and of the Council of 15 May 2014 establishing a European Account Preservation Order procedure to facilitate crossborder debt recovery in civil and commercial matters, OJ L 189/59 ('EAPO Regulation').

\section{European Union Directives}

Directive 2008/52/EC of the European Parliament and of the Council of 21 May 2008 on certain aspects of mediation in civil and commercial matters, OJ L 136/3.

Council Directive 2002/8/EC of 27 January 2003 to improve access to justice in cross-border disputes by establishing minimum common rules relating to legal aid for such disputes, OJ L 026/41.

Directive 2013/11/EU of the European Parliament and of the Council of 21 May 2013 on alternative dispute resolution for consumer disputes and amending Regulation (EC) No 2006/2004 and Directive 2009/22/EC (Directive on consumer ADR), OJ L 165/ 63

Directive 2010/64/EU of the European Parliament and of the Council of 20 October 2010 on the right to interpretation and translation in criminal proceedings, OJ L 280/1.

Directive 2012/13/EU of the European Parliament and of the Council of 22 May 2012 on the right to information in criminal proceedings, OJ L 142/1.

\section{European Union Framework decisions}

Council Framework Decision 2009/299/JHA of 26 February 2009 amending Framework Decisions 2002/584/JHA, 2005/214/JHA, 2006/783/JHA, 2008/909/JHA and $2008 / 947 / \mathrm{JHA}$, thereby enhancing the procedural rights of persons and fostering the application of the principle of mutual recognition to decisions rendered in the absence of the person concerned at the trial, OJ L 81/24. 
Council Framework Decision 2002/584/JHA on the European arrest warrant and the surrender procedures between Member States, OJ L 190/001.

\section{European Commission preparatory documents, proposals, green papers, reports}

J Albert, Study on the Transparency of Costs of Civil Proceedings in the EU: Final Report, December 2007, available at https://e-justice.europa.eu/content_costs_of_proceedings-37en.do

Deloitte and Coffey, Study on the assessment of Regulation (EC) 2201/2003 and the policy options for its amendment. Final Report - Evaluation, Study for the European Commission, 2015.

Deloitte, Assessment of the socio-economic impacts of the policy options for the future of the European Small Claims Regulation. Final Report, study commissioned by the European Commission, 19 July 2013, available at http://ec.europa.eu/justice/civil/files/small_claims_report_ia_en.pdf (last accessed 29/04/2016) ('Deloitte Report 2013').

European Commission - Directorate-General for Justice, Special Eurobarometer 395: The European Small Claims Procedure, April 2013, available at http://ec.europa.eu/public_opinion/archives/ebs/ebs_395_en.pdf (last accessed 29 April 2016).

European Commission - Directorate-General for Justice, Special Eurobarometer 351: Civil Justice, October 2010, available at http://ec.europa.eu/public_opinion/archives/ebs/ebs_351_en.pdf (last accessed 29 April 2016).

European Commission, Action Plan Implementing the Stockholm Programme, $\operatorname{COM}(2010) 171$ final.

European Commission, EU Anti-Corruption Report 2014, COM(2014) 38 final.

European Commission, Green Paper on the Review of Council Regulation (EC) No $44 / 2001$ on jurisdiction and the recognition and enforcement of judgments in civil and commercial matters, COM(2009) 175 final.

European Commission, Proposal for a Council Decision authorising enhanced cooperation in the area of jurisdiction, applicable law and the recognition and enforcement of decisions on the property regimes of international couples, covering both matters of matrimonial property regimes and the property consequences of registered partnerships, $\operatorname{COM}(2016)$ 108 final.

European Commission, Proposal for a Council Framework Decision on certain procedural rights in criminal proceedings throughout the European Union, COM(2004) 328 final. 
European Commission, Proposal for a Council Regulation concerning jurisdiction and the recognition and enforcement of judgments in matrimonial matters an in matters of parental responsibility repealing Regulation (EC) No 1347/2000 and amending Regulation (EC) No $44 / 2001$ in matters relating to maintenance, COM (2002) 222 final/2.

European Commission, Proposal for a Council Regulation on jurisdiction, applicable law, recognition and enforcement of decisions and cooperation in matters relating to maintenance obligations, $\operatorname{COM}(2005) 649$ final.

European Commission, Proposal for a Council Regulation on jurisdiction, applicable law, recognition and enforcement of decisions in matters of matrimonial property regimes, COM (2011) 126 final.

European Commission, Proposal for a Council Regulation on jurisdiction, applicable law, recognition and enforcement of decisions regarding the property consequences of registered partnerships, COM (2011) 127 final.

European Commission, Proposal for a Regulation amending Regulation (EC) No 861/2007 of the European Parliament and the Council of 11 July 2007 establishing a European Small Claims Procedure and Regulation (EC) No 1896/2006 of the European Parliament and of the Council of 12 December 2006 creating a European Enforcement Order, COM (2013) 794 final.

European Commission, Proposal for a Regulation of the European Parliament and of the Council on jurisdiction and the recognition and enforcement of judgments in civil and commercial matters (Recast), COM (2010) 148 final of 14 December 2010.

European Commission, Proposal for a Regulation of the European Parliament and of the Council on jurisdiction and the recognition and enforcement of judgments in civil and commercial matters (Recast), COM(2010) 748 final.

European Commission, Proposal for a Council Regulation (EC) on jurisdiction and the recognition and enforcement of judgments in civil and commercial matters, COM(1999) 348 final.

European Commission, Report from the Commission to the European Parliament, the Council and the European Economic and Social Committee on the application of Council Regulation (EC) No 2201/2003 concerning jurisdiction and the recognition and enforcement of judgements in matrimonial matters and the matters of parental responsibility, repealing Regulation (EC) No 1347/2000, COM(2014) 225 final.

European Commission, Report from the European Commission to the European Parliament, the Council and the European Economic and Social Committee on the Application of Regulation (EC) 1896/2006 of the European Parliament and the Council creating a European Order for Payment Procedure, COM(2015) 495 final.

European Commission, Report on the application of the EU Charter of Fundamental Rights, 2012, COM/2013/0271 final.

European Commission, The EU Justice Scoreboard, COM(2013) 160 final. 
Explanatory Memorandum, Proposal for a Regulation of the European Parliament and of the Council on jurisdiction and the recognition and enforcement of judgments in civil and commercial matters (Recast), $\operatorname{COM}(2010) 748$ final.

Reasoned Opinion by the Senate and House of Representatives of the Kingdom of the Netherlands on the proposal for a Regulation of the European Parliament and of the Council on jurisdiction and the recognition and enforcement of judgments in civil and commercial matters (recast), 17 February 2011 in.

Réponse de le Délegation Belge au la Livre Vert préparé par la Commission sur la Révision du Règlement (CE) n* 44/2001 concernant la compétence judiciaire, la reconnaissance et lexecution des décisions au matière civile (Bruxelles I).

Revision der europäischen Gerichtsstands- und Vollstreckungsverordnung $\mathrm{Nr}$ 44/2001 vom 22. Dezember 2000. Stellungnahme des Bundesministeriums für Justiz der Republik Österreich zu Bericht und Grünbuch der Europäischen Kommission vom 27. April 2009.

\section{European Council proposals and policy programmes}

European Council, Tampere European Council, 15-16 October 1999, Presidency Conclusions.

European Council, The Hague Programme, Strengthening freedom, security and justice in the European Union, OJ C/53/01, 2005.

European Council, The Stockholm Programme - an open and secure Europe serving and protecting citizens, OJ C/115/10, 2010. (2010).

European Council, Council Programme of measures to implement the principle of mutual recognition of decisions in civil and commercial matters, OJ 2001, C 12/1.

European Council, Draft programme of measures for implementation of the principle of mutual recognition of decisions in civil and commercial matters, OJ C 12/01, 2001.

European Council, Proposal for a Regulation of the European Parliament and of the Council on Jurisdiction and recognition and enforcement of judicial decisions in civil and commercial cases (Recast), 2010/0383, 1 June 2012.

\section{European Parliament reports}

European Parliament, Draft Report on the proposal for a regulation of the European Parliament and of the Council on jurisdiction and the recognition and enforcement of judgments in civil and commercial matters (recast) (COM(2010)0748 - C7-0433/2010 2010/0383(COD)), 28 June 2011. 
European Parliament, Report on the proposal for a Council Regulation on jurisdiction, applicable law and the recognition and enforcement of decisions in matters of matrimonial property regimes (COM(2011)0126 - C7-0093/2011 - 2011/0059(CNS)), Committee on Legal Affairs, rapporteur: Alexandra Thein.

European Parliament, Report on the proposal for a regulation of the European Parliament and of the Council on jurisdiction and the recognition and enforcement of judgments in civil and commercial matters (recast) (COM(2010)0748 - C7-0433/2010 - 2010/0383(COD)), Committee on Legal Affairs, Rapporteur: Tadeusz Zwiefka, 15 October 2012.

\section{European Economic and Social Committee Opinions}

Opinion of the European Economic and Social Committee on the 'Proposal for a Regulation of the European Parliament and of the Council amending Regulation (EC) No 861/2007 of the European Parliament and the Council of 11 July 2007 establishing a European Small Claims Procedure and Regulation (EC) No 1896/2006 of the European Parliament and of the Council of 12 December 2006 creating a European order for payment procedure' COM(2013) 794 final — 2013/0403 (COD), C 226/08.

\section{Other European Union legislative documents}

Draft revised agreement on the accession of the European Union to the Convention for the Protection of Fundamental Rights and Freedoms, 47+1(2013)008rev2, available at http://www.coe.int/t/dghl/standardsetting/hrpolicy/Accession/Working_documents_en.asp

Explanations relating to the Charter of Fundamental Rights, OJ C 303/17, 2007.

Initiative of the French Republic with the view to adopting a Council Regulation on the mutual enforcement of judgments on rights of access to children, OJ C 234/7.

\section{Council of Europe recommendations and guidelines}

European Commission on the Efficiency of Justice (CEPEJ), Guidelines for a better implementation of the existing Council of Europe's Recommendation on Enforcement, adopted by the CEPEJ at its 14th plenary meeting, (Strasbourg, 9 - 10 December 2009), CEPEJ(2009)11REV2.

Council of Europe, Commission of Ministers, Recommendation Rec(2003)17of the Committee of Ministers to member states on enforcement (adopted by the Committee of Ministers on 9 September 2003 at the 851st meeting of the Ministers' Deputies), $\operatorname{Rec}(2003) 17$. 
Council of Europe/European Court of Human Rights, Guide to Article 6. Right to a fair trial (civil limb), Council of Europe 2013, available at http://www.echr.coe.int.

Council of Europe/European Court of Human Rights, Practical Guide on Admissibility Criteria, Council of Europe 2011, available at http://www.echr.coe.int.

\section{United Nations recommendations and guidelines}

United Nations Committee on the Rights of the Child, Convention on the Rights of the Child. General Comment No. 12: the right of the child to be heard (2009). 


\section{Acknowledgements}

First and foremost, I thank my supervisors, Professor Xandra Kramer and Professor Kristin Henrard, at Erasmus School of Law, for their support and comments on earlier versions. This thesis is part of the research project 'Securing Quality in Cross-Border Enforcement: Towards European Principles of Civil Procedure?', based on a VIDI grant by the Dutch Organization for Scientific Research, and led by Professor Kramer. I am very grateful to Professor Kramer for introducing me to the rich field of European civil procedure.

Next, I would like to thank the members of my doctoral committee for their invaluable comments: Professor Fabian Amtenbrink at Erasmus School of Law; Professor Rick Lawson at Leiden University; and Professor Marta Requejo Isidro, Professor at the University of Santiago de Compostela and Senior Research Fellow at the Max Planck Institute for Procedural Law in Luxembourg.

In Luxembourg, I would like to thank Professor Hess for the opportunity to spend two months as a guest researcher at the Max Planck Institute for Procedural Law. The Institute provided an inspiring work environment. Its research fellows made me feel very welcome: I would like to name Katharina Raffelsieper in particular, though all became good friends in the short time I was there. I also thank International Officer Christiane Göbel for her practical help in getting settled. During my time in Luxembourg, Professor Gilles Cuniberti at the University of Luxembourg agreed to meet me and discuss my work, for which I am thankful.

In Rotterdam, I would like to thank Professor Wibren van der Burg, Professor Sanne Taekema and Professor Elaine Mak for valuable help and comments on earlier versions of some of the chapters of this book. Dr. Karin van Wingerde provided essential practical advice during the final stages of this research. My fellow PhD candidates not only provided support but were also prepared to discuss my ideas with me; I mention in particular Stefan Philipsen, Thomas Riesthuis and Anna Sting. I am also grateful to Professor Roel de Lange and Professor Janneke Gerards (at Utrecht University) for letting me participate in their reading group on fundamental rights, where I had the opportunity to explore this rich and ever-changing topic in more depth.

I also wish to thank my fellow (ex-)PhDs from the department of private international law, Laura, Alina, Ekaterina, Piotr, Erlis, and Marta: the latter two deserve special thanks for putting up with me as their office-mate in the stressful final months.

Ryan Gauthier took on the tremendous task of correcting the manuscript, which he did superbly, despite being on a different continent.

In Utrecht, I would like to thank those who gave me the opportunity to start, and complete, the Master's Programme in Legal Research, which proved an invaluable springboard for $\mathrm{PhD}$ research: Professor Leonard Besselink, professor Ewoud Hondius and doctor Ton van den Brink, my tutor during the Programme, who was always good at making me put things into perspective. I would also very much like to thank dr. Tony Marguery for being prepared to review earlier versions of my work.

My friends from the LRM Programme, most of whom have also completed PhDs themselves, also deserve thanks for being there for me during the process and even as paranymphs at the defence. Melissa, Frank, Marja-Liisa, Eduardo, Jurriën: I could not have done it without you. 
A special word of thanks goes out to Nik de Boer, who not only reviewed some of my work, but who also organized highly inspiring reading groups on EU law and political philosophy.

I am grateful to my colleagues at Denkkracht Utrecht; participating in its activities gave me the opportunity to use my legal knowledge for different purposes than my research every once in a while, which proved very refreshing. In particular I would like to thank Marije Louisse for always being prepared to listen to my lectures on my $\mathrm{PhD}$ topic: I hope to be able to do the same for you.

Last but not least, my family and friends gave me the confidence I needed to start the project in the first place. So I thank my mother Francisca, my father Willem-Otto, and my sister Leonie; and especially my grandmother, Mariëtte Louise Hoogendijk-van Holst Pellekaan, who practiced law in the 50s and from whom I inherited the 'legal gene'. I thank my parents-, brothers- and sisters-in-law for welcoming me into their family and for always being interested. My friends Sophie and Sjoerd were always there when I needed them, even if they were not geographically close. Finally: dear Wouter, you helped me immensely, not just by being there for me, but also by understanding so well why I wanted to do this. The fact that it's now finished to me proves we can do anything as long as we're together. 